Luiz Cláudio de Lima

(organizador)

\section{Tópicos em Gestão de Pessoas Volume 3}

$1^{\text {a }}$ Edição

Belo Horizonte

Poisson

2018 
Editor Chefe: Dr. Darly Fernando Andrade

Conselho Editorial

Dra. Cacilda Nacur Lorentz - Universidade do Estado de Minas Gerais

Dr. José Eduardo Ferreira Lopes - Universidade Federal de Uberlândia

Dr. Otaviano Francisco Neves - Pontifícia Universidade Católica de Minas Gerais

Dr. Luiz Cláudio de Lima - Universidade FUMEC

Dr. Nelson Ferreira Filho - Faculdades Kennedy

Dados Internacionais de Catalogação na Publicação (CIP)

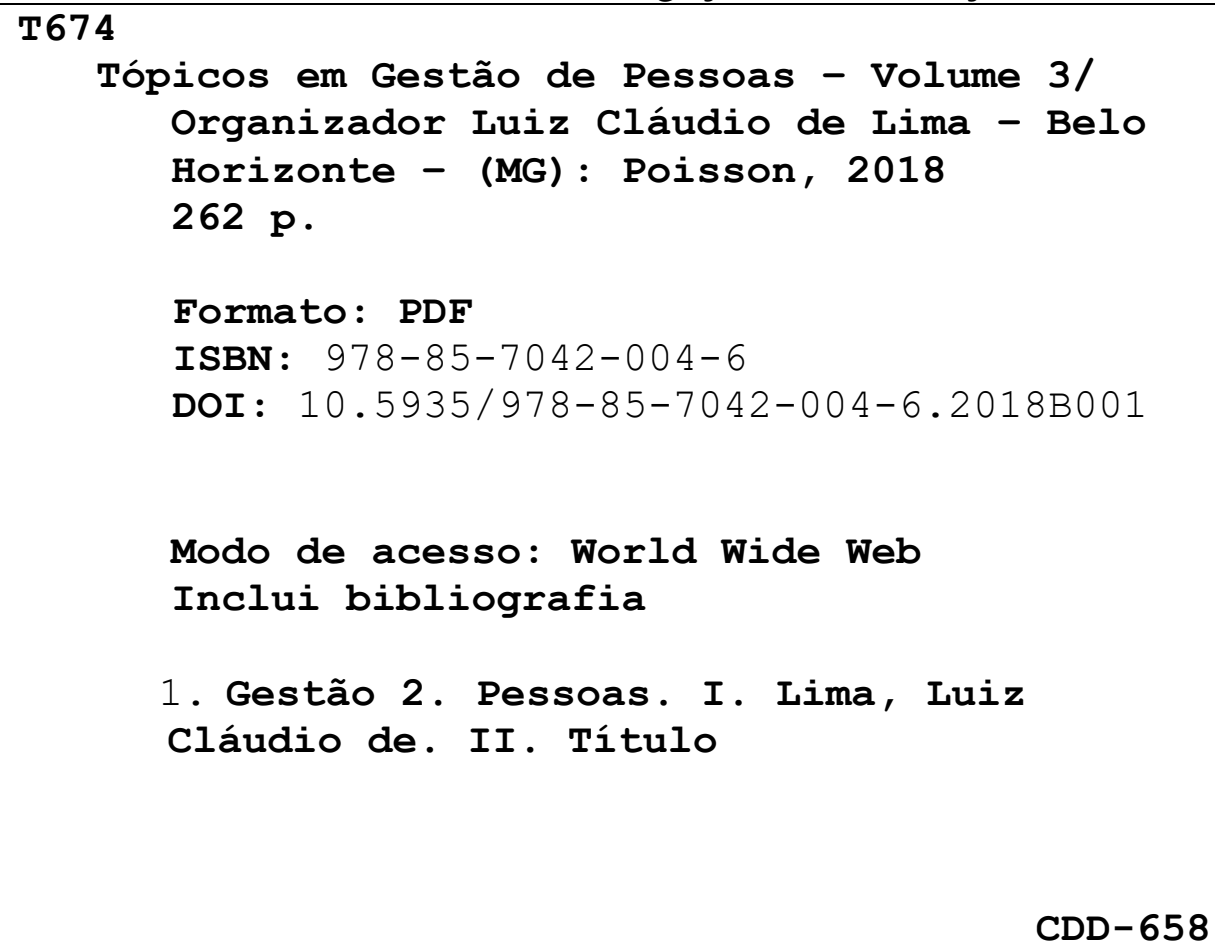

O conteúdo dos artigos e seus dados em sua forma, correção e confiabilidade são de responsabilidade exclusiva dos seus respectivos autores.

www.poisson.com.br

contato@poisson.com.br 


\section{Apresentação}

A gestão da força de trabalho sempre foi um grande desfio para as organizações, pois uma parcela significativa do seu sucesso ou de seu fracasso, pode ser atribuída às pessoas que realizam as suas atividades. Desde os tempos da primeira revolução industrial até hoje, as pessoas são, para a maioria das organizações, o seu principal ativo, ou seja, o principal elemento de geração de valor. E essa importância só se acentuou nos dias de hoje, nos quais que vivemos em uma sociedade do conhecimento.

Desta forma, é de extrema importância que o foco das organizações se volte para a gestão das pessoas, o que amplia o papel e a responsabilidade da área de Gestão de Pessoas. Neste contexto, torna-se importante que a gestão de pessoas seja capaz de oferecer uma contribuição eficiente e eficaz para a organização, possibilitando que ela atinja os seus objetivos e os resultados desejados.

Em uma sociedade do conhecimento, onde a competitividade e a velocidade das mudanças se acentuam a cada dia, a área de Gestão de Pessoas deve ser capaz de atuar em consonância com a estratégia e os objetivos organizacionais, proporcionando condições adequadas para o atingimento dos resultados individuais, grupais e organizacionais. Cabe também a essa área atuar em sintonia com as principais demandas das pessoas, proporcionando oportunidades de crescimento e desenvolvimento pessoal e profissional, respeitando e incorporando a diversidade da força de trabalho em suas similaridades e particularidades.

Este livro apresenta trabalhos que estão orientados para uma análise e reflexão sobre a Gestão de Pessoas nas organizações, abordando inúmeros aspectos e questões relativas ao tema, de forma ampla e diversificada, buscando oferecer contribuições para a melhor compressão e desenvolvimento do tema tanto no âmbito acadêmico quanto empresarial.

Boa leitura a todos!
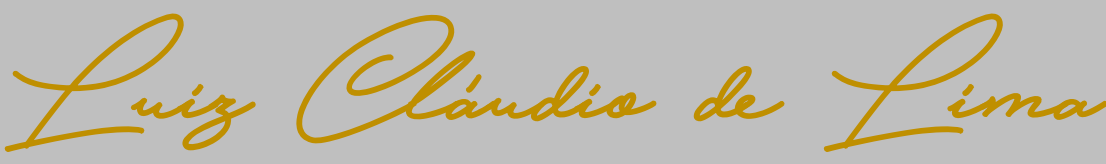


\section{Sumárīo}

Capítulo 1: A relação entre transtornos mentais e a percepção de risco dos empregados no ambiente de trabalho

Mauricio Soares do Vale, André Faes Oliveira, Diego Alexsander Moreira Pires

Capítulo 2: Acessibilidade com tecnologia assistida aos portadores de mobilidade reduzida em Nova Iguaçu: uma proposta empreendedora e socialmente responsável de sistemas de transporte.....

Máyra Gabriel dos Santos, Neide Lúcia de O. Almeida

Capítulo 3: Uma análise da qualidade de vida no ambiente de trabalho por meio da espiritualidade corporativa

Randes de Faria Enes

Capítulo 4: Gestão de equipes e resultados: uma análise da motivação, comprometimento e clima, em um hospital regional e público de São José/SC

Samara Passig, Helio Alves da Cruz

Capítulo 5: O clima organizacional em uma instituição de ensino federal um estudo de caso.

Dennis Hanson Costa

Capítulo 6: Rotatividade de pessoal: uma análise do clima organizacional e fatores que influenciam o turnover na área operacional da uma clínica de saúde em Florianópolis/SC

Geórgia Gonçalves, Helio Alves da Cruz

Capítulo 7: Relações de confiança na gestão empresarial: Um estudo na empresa Doces Dyana Nordestino na Cidade de Pombal-PB.

Raphaela Mota Lacerda, Simone Costa Silva, Dante Flávio Oliveira Passos, Érika Campos Marinho de Góes Pires, Eunice Ferreira Carvalho

Capítulo 8: O endomarketing como uma ferramenta para a humanização no serviço de Saúde: um estudo de caso no Hospital da FAP 


\section{Sumárīio}

Capítulo 9: Fatores estressores no ambiente educacional - um estudo em um CMEl.

Flavio Mudesto;, Eduarda De Biase Ferrari Gomes, Simone de Souza Christo, Virgínia de Paula Batista Carvalho

Capítulo 10: Uma análise crítica da construção da escala de envolvimento com o trabalho

Bárbara Helena Giovannini Pinto, Eric David Cohen

Capítulo 11: Profissionais de saúde: Fenômeno bullying

Amanda Raquel Franca Filgueiras D'Amorim, Ramon Schnayder de França Filgueiras D`Amorim, Luciene Laranjeira Diniz, Angélica Carina de Andrade Farias, Adriana Costa Cavalcanti, Carlos Rubens Moreira da Silva

Capítulo 12: A avaliação de desempenho individual por múltiplas fontes, um estudo sob o viés das racionalidades instrumental e substantiva. . .

Getulio de Azevedo Ramos Junior, Fernando de Oliveira Vieira

Capítulo 13: A "co-opetição" na capacitação profissional: exemplos da indústria de petróleo no Brasil

Renata Pereira Gonçalves Ribeiro, Júlio César de Faria Alvim Wasserman, Evandro La Macchia

Capítulo 14: Análise da contribuição da capacitação do fiscal de contrato na administração pública.

Juliana Cristina da Silva de França Barboza, Marcelo Gonçalves do Amaral, Sheila Serafim da Silva

Capítulo 15: Programação Neurolinguística - PNL: um diferencial para formação de gestores

Henrique Martins Galvão, Hilquias Gabriel Capucho, Luciani Vieira Gomes Alvareli

Capítulo 16: O papel da gestão de pessoas mediante a urgência de qualificação da mão de obra utilizada no turismo e a oportunidade oferecida pelos megaeventos 


\section{Sumárīio}

Capítulo 17: Impactos da crise econômica brasileira na gestão de recursos humanos: um estudo em hospitais do interior de Minas Gerais

Matheus Toledo Cupertino, Junio Vasconcelos Soares, Patrícia Souza Luz Fritz

Capítulo 18: Gestão de pessoas em unidades escolares do município de Júlio de Castilhos-RS: estudo de caso comparativo entre escolas pública e privada

Ana Paula Fernandes, Katia da Motta Fronquetti, Camila Coletto, Siomara Cristina Broch

Capítulo 19: Plano de Ação para minimizar o absenteísmo na atenção ambulatorial de um hospital universitário da região Metropolitana II, na cidade Niterói - RJ.....

Waldir Viana das Neves Junior, Christina Souto Nicolau das Neves

Capítulo 20: Cultura e mudança organizacional: um estudo no hospital de Trauma-PB

Amanda Raquel Franca Filgueiras D'Amorim, Ramon Schnayder de França Filgueiras D`Amorim, Luciene Laranjeira Diniz, Angélica Carina de Andrade Farias, Adriana Costa Cavalcanti, Odaelson Antônio Clementino da Silva

Capítulo 21: Estudo sobre a gestão sucessória na administração pública estadual com base no capital intelectual/humano

Thiago Couto Lage, Branca Regina Cantisano dos Santos e Silva Riscado Terra, Ricardo Miyashita, Dércio Santiago da Silva Junior

Capítulo 22: Autonomia financeira no contexto do mercado de trabalho em crise: Expectativas de universitários da Geração $Y$

Thaís Andrade Damasceno, Maria de Lurdes Costa Domingos, Helenna Barreto Magdalena, Luana Camargo Carrilho

Autores:: 


\section{Gapítulo 1}

\section{A RELAÇÃO ENTRE TRANSTORNOS MENTAIS E A PERCEPCAOO DE RISCO DOS EMPREGADOS NO AMBIENTE DE TRABALHO}

\section{Mauricio Soares do Vale \\ André Faes Oliveira \\ Diego Alexsander Moreira Pires}

Resumo: A constante busca pela qualidade tem acirrado a competitividade entre as empresas visando atender às demandas do mercado. O conceito de qualidade ainda é comummente dissociado de uma cultura de segurança, apesar de acidentes de trabalho influírem negativamente nesse quesito. Os transtornos mentais são a principal causa de perda de dias de trabalho. Diante, o presente trabalho buscou traçar uma relação, através de uma busca referencial bibliográfica na literatura, entre transtornos mentais, com enfoque no Transtorno de Estresse Pós-Traumático (TEPT), e a percepção de risco dos trabalhadores. Transtornos mentais, incluindo o TEPT, são de difícil diagnóstico. Esse último é divido em a) Reexperiência traumática; b) Esquiva e distanciamento emocional e c) Hiperexcitabilidade psíquica. A percepção de risco por parte dos trabalhadores não pareceu estar norteada por princípios científicos, mas se mostrou demasiadamente pessoal. Trabalhadores que passaram por transtornos mentais apresentaram distintas evoluções no percepção ao risco: enquanto uns foram afetados positivamente, adquirindo resiliência, outros foram afetados negativamente. O TEPT pode desencadear uma hipersensibilização da percepção de risco do trabalhador. Apesar disso, transtornos mentais de qualquer sorte não se mostraram preponderantes para estabelecer uma melhora na percepção de risco.

Palavras-chave: Qualidade; Segurança do Trabalho; Percepção de risco; Transtornos Mentais. 


\section{INTRODUÇÃO}

Sabe-se que atualmente o mercado demanda um alto nível de exigência por parte das organizações. Estas estão cada vez mais buscando serem criativas para inovarem e, consequentemente, atenderem as necessidades dos consumidores. Para isso, é necessário elevar o padrão da qualidade, de forma a se obter vantagem competitiva frente aos concorrentes.

O que vem acontecendo nas empresas é a completa separação dos conceitos de segurança e qualidade, enquanto os processos de segurança de reforçam os de qualidade (KRAUSE, THOMAS R., 1994). Essa dissociação leva aos gerentes preterirem a segurança em relação à segurança, encarando esta segunda como uma mera obrigação e, na melhor das hipóteses se limitando a cumprir as normas estabelecidas pelas agências reguladoras. No Brasil, quem regulamenta a prevenção de doenças e acidentes do trabalho é a Norma Regulamentadora 29 (FUNDACENTRO, 1998).

Contudo, para se conseguir uma cultura de segurança, onde todos os funcionários sintamse parte responsável pela segurança, é preciso encarar a segurança como parte essencial de um sistema organizacional eficiente. O termo cultura de segurança, trata de um conjunto coletivo de conhecimentos adquirido e construído, levando assim a uma maior estabilidade (AREZES, PEDRO MIGUEL F. M., 2002).

Os acidentes são os grandes responsáveis pela ausências de trabalhadores nos postos de serviços. As consequências desse fato são as mais diversas: pagamento de indenizações, contratação de funcionários temporários, pagamento de salário e encargos ao funcionário acidentado sem este estar produzindo, interrupção da produção, atraso em entregas, insegurança por parte dos funcionários que presenciaram acidentes e etc. Todas essas consequências convergem para o aumento dos custos e consequente diminuição nos lucros.

Segundo Arezes (2002), perigo como sendo qualquer coisa que possa originar dano (por exemplo produtos químicos, eletricidade, etc.) e o risco como sendo a probabilidade, alta ou baixa, de alguém sofrer um dano através do perigo. A percepção de riscos, então, é fundamental para que o empregado não se envolva em acidentes. Wiedemann (1993) define percepção de riscos como a "habilidade de interpretar uma situação de potencial dano à saúde ou à vida da pessoa, ou de terceiros, baseada em experiências anteriores e sua extrapolação para um momento futuro, habilidade esta que varia de uma vaga opinião a uma firme convicção". A percepção de riscos, segundo este, é baseada em crenças e tem raízes em experiências anteriores. A percepção de riscos da população é, geralmente, bastante distinta daquela dos especialistas, sobretudo cientistas (SLOVIC, P ET AL, 1979).

Os transtornos mentais estão entre as principais causas de perdas de dias no trabalho, podendo causar em média até 200 dias/ano de afastamento (DEMYTTENAERE et al., 2004). Timms (2006) sinaliza que o transtornos mentais comprometem o rendimento no trabalho, levando à elevação do quadro de absenteísmo por doença, acidentes de trabalho e rotatividade de pessoal. O empregado deprimido, por exemplo, tende a apresentar, segundo o autor, elevada taxa de erros nas tarefas, dificuldade de concentração, incapacidade de delegar tarefas, lentidão, execução das atividades com intenso sofrimento psíquico, atrasos em compromissos, diminuindo sua eficácia.

Frente à importância para qualquer organização destes dois fatores: transtornos mentais como doença ocupacional e percepção de riscos, este trabalho buscou construir uma ponte entre esses temas e checar se existe relação entre eles.

\section{TRANSTORNOS MENTAIS}

Os transtornos mentais comuns (TMC), como definidos por Goldberg \& Huxley (1993), são designados por sintomas como insônia, ansiedade, depressão, irritabilidade, dificuldade de concentração, esquecimento, fadiga e queixas somáticas. Ainda segundo os autores, os TMC, frequentemente encontrados nas cidades, representam alto custo social e econômico, pois incapacitam o trabalhador, fazendo-o perder dias de trabalho, além de pesarem a demanda do setor de saúde.

De acordo com Campos (2006), os transtornos mentais e comportamentais associados ao trabalho não são facilmente diagnosticados no momento da avaliação clínica, visto que seus sintomas se confundem com sintomas físicos (insônia, distúrbios alimentares, distúrbios gástricos. 
Como especificado por Seligman (1994) e Warr (1987), no processo de trabalho existem alguns fatores que podem prejudicar a saúde mental do trabalhador, como estresse no ambiente, instabilidade, controle autoritário e rígido, instabilidade e remuneração por produtividade ou baixa. São também relevantes, de acordo com Souza, Carvalho, Araújo e Porto (2010), fatores psicossociais do trabalho como sobrecarga, subcarga, falta de controle sobre o trabalho, distanciamento entre grupo de mandos e de subordinados, isolamento social no ambiente de trabalho, conflitos de papéis, conflitos interpessoais e falta de apoio social.

Segundo dados provenientes da Previdência Social os transtornos mentais estão na terceira posição entre as causas de concessão de benefícios previdenciários. Ainda, Uma pesquisa da Universidade de Brasília (UnB) em parceria com a Previdência Social mostrou que o número de trabalhadores com problemas mentais vem aumentando nos últimos anos.48,8\% dos trabalhadores que se afastam por mais de 15 dias do serviço sofrem algum tipo de doença mental. (Anadergh Barbosa Branco, coordenadora do Laboratório de Saúde do Trabalhador da Faculdade de Ciências da Saúde da UnB)

De modo mais oficial, o Ministério da Saúde do Brasil e a Organização Pan-Americana da Saúde (2001), através da criação da portaria no 1339, de 18 de Novembro de 1999, reconhecem e apresentam uma lista de 12 transtornos mentais e do comportamento que tem relação com o trabalho e que podem afetar os trabalhadores, são eles:

a) Demência e outras doenças específicas classificadas em outros locais;

b) Delirium, não-sobreposto à demência, como descrita;

c) Transtorno cognitivo leve;

d) Transtorno orgânico de personalidade;

e) Transtorno mental orgânico ou sintomático não especificado;

f) Alcoolismo crônico;

g) Episódios depressivos;

h) Estado de estresse pós-traumático; j) Outros transtornos neuróticos especificados;

k) Transtorno do ciclo vigília-sono devido a fatores não orgânicos;

I) Síndrome de burnout ou síndrome do esgotamento profissional;

Dentre todos esses, o presente trabalho buscará focar no Estado de estresse póstraumático ou Transtorno de estresse póstraumático (TEPT). Este é definido um transtorno prevalente, crônico, incapacitante, resistente ao tratamento e pouco diagnosticado. Está associado ao alcoolismo, suicídio, insatisfação no trabalho, absenteísmo e aposentadoria precoce. (BUCASIO; ERIKA ET. AL., 2004).

\subsection{TRANSTORNO DE ESTRESSE PÓS- TRAUMÁTICO (TEPT)}

TO transtorno de estresse pós-traumático (TEPT) pode ser considerado relacionado ao trabalho quando o trauma que o causou é considerado um acidente de trabalho. O ministério da previdência e Assistência Social (MPAS), de acordo com o regulamento dos benefícios da previdência social, decreto no 2172 de 05/03/1997, caracteriza como acidente do trabalho como "(...) o que ocorre pelo exercício do trabalho a serviço da empresa (...), provocando lesão corporal ou perturbação funcional que cause a morte, a perda ou redução da capacidade para o trabalho, permanente ou temporária"; "(...) sofrido pelo segurado no local e no horário de trabalho, em consequência de ato de agressão, sabotagem ou terrorismo praticado por terceiro ou companheiro de trabalho".

Trauma, fundamental na concepção do TEPT, é definido como uma situação experimentada, testemunhada ou confrontada pelo indivíduo, na qual houve ameaça à vida ou à integridade física de si próprio ou de pessoas a ele afetivamente ligadas (CÂMARA FILHO; JWS, SOUGEY; EB, 1999).

Este, segundo Filho e Sougey (2001), pode ser organizado em 3 grupos:

i) Neurastenia; 


\section{a) Reexperiência traumática:}

Como diz Herman (1997), mesmo que o perigo não esteja mais presente e confinado ao passado, a pessoa que sofre de TEPT revive o ocorrido de forma contínua, vivencia a experiência de forma contemporânea em vez de aceitar o fato de que faz parte do passado.

\section{b) Esquiva e distanciamento emocional}

Essa repetição da experiência causam grande sofrimento à quem sofre de TEPT, e o faz se esquivar e distanciar emocionalmente de qualquer coisa que possa desencadear lembranças, pode se esquivar pelo uso de drogas, ou dedicação excessiva e compulsiva à determinadas atividades e outros vícios, como jogo e sexo.

\section{c) Hiperexcitabilidade psíquica}

Câmara Filho e Sougey (2001) definem como sintoma a hiperexcitabilidade psíquica, como o humor ansioso, taquicardia, respiração curta ou suspirosa, constrição precordial,

"formigamentos, parestesias, sudorese, extremidades frias ou também cefaleias, tonturas, sensação de "oco na cabeça", "peso no estômago", insônia, irritabilidade, explosividade, hipervigilância, entre outros.

\section{PERCEPÇÃO E CONDUTA PÓS-ACIDENTE}

Rossi et al (2003) em seu estudo sobre a percepção de pacientes envolvidos em acidentes que levaram à queimaduras e de seus familiares, através de entrevistas, 44\% não identificou situações de risco no ambiente de trabalho ou doméstico.

Em um estudo publicado por Oliveira e Gonçalves (2010) em um grupo de profissionais de saúde de um centro cirúrgico sobre acidentes por material perfurocortante, constatou-se que a percepção pós acidente neste grupo não era ideal ao se constatar a baixa procura por atendimento médico (30\%) e realização de exames (26.7\%), isso indica que as pessoas que sofreram o acidente não levam suficientemente a sério os riscos pósacidente.

Em um outro estudo publicado por Almeida e Benatti (2007), observou-se que há $7.3 \%$ de recusa à quimio-profilaxia contra o vírus da imunodeficiência humana por meio de antiretroviral, e dos que aceitam, 40.6\% não termina o tratamento.
Damasceno et al (2006) apresentaram em seu estudo com 382 profissionais da área de saúde onde metade dos entrevistados declarou que o acidente não the trouxe nenhuma consequência, enquanto apenas a outra metade acabou servindo como um alerta em suas vidas para a mudança de postura profissional.

Mafra et al (2008), estudando profissionais de enfermagem concluiu que os enfermeiros têm consciência da importância do uso de EPI's, porém não os utilizam com a devida frequência na prática de seu cotidiano laboral. Acreditase que estes profissionais conheçam os fatores de risco a que se expõe, as medidas protetoras para evitar acidentes ou enfermidades profissionais, ainda que isto não implique diretamente a adoção por parte dele de medidas de precauções.

Por outro lado, Balsamo e Felli (2006) argumentam que trabalhadores não percebem ou desconhecem o risco de exposição associados aos procedimentos em que existe a probabilidade de acidente por contato com sangue.

Semelhantemente, Azap (2005) et al confirma essa percepção reduzida em seu estudo: Após o acidente de trabalho houve baixa procura pelo atendimento médico (30\%) e realização de exames laboratoriais pós-acidente (26,7\%). Isso demonstra que os profissionais de saúde apresentam uma conduta de descuido consigo mesmos frente às exposições a materiais perfurocortantes com sangue e/ou fluídos corporais.

Saindo da área de saúde para a área agrícola, propões que os agricultores têm a percepção de que os agrotóxicos são venenos, com potencial real de intoxicação alguns agricultores, porém, não se consideravam afetados diretamente pela ação desses produtos, sempre referindo aos eventos de intoxicação a outros trabalhadores, associando-os a indivíduos "fracos" para esses produtos. Em relação ao uso de equipamentos de proteção individual (EPI), muitos agricultores afirmaram não usar luvas, máscaras ou roupas impermeáveis, embora conhecessem esses equipamentos e considerassem que deveriam usá-los.

Recena e Caldas (2008), em outro estudo, acrescenta que os principais aspectos relacionados à percepção de riscos no trabalho rural são a minimização de riscos e negação do perigo: o agrotóxico é chamado de defensivo e a dor de cabeça vira uma 
"dorzinha". Desta forma, torna-se possível a permanência num processo de trabalho reconhecidamente injurioso. Fica claro que não há uma clara associação, por parte do trabalhador, entre as condições de trabalho e a percepção de riscos.

Sabemos, entretanto, que esses eventos não acontecem exclusivamente com trabalhadores da área de saúde ou trabalhadores do campo. Pelo contrário, é uma situação generalizada. Por exemplo, o estudo proposto por Dorigo e Lima (2007), traz o caso de João (nome fictício), segurança de uma estação de metrô, que após sofrer os três assaltos, começou a apresentar alterações em seu comportamento, passando a não sentir-se bem no seu posto de trabalho e a desconfiar de que havia mesmo alguém o perseguindo. Sofria com delírios (Em outro momento, achou que a lagoa da Pampulha secava por sua causa), se isolava em casa e não mantinha convívio com amigos ou vizinhos do prédio onde morava. não conseguia exercer adequadamente suas atividades. Ele passou a sentir medo de realizar algumas tarefas, como conferir a presença de metais em bolsas ou pastas de clientes. Sua percepção após o trauma se comprometeu totalmente.

Cabe ainda citar o trabalho de Bucasio et al (2004), que apresenta a situação de J. que há três anos, sofreu um assalto na agência bancária onde era gerente administrativo. Ele passou a sentir-se em permanente estado de alerta. Nos dias subsequentes, para conseguir trabalhar, passava na roleta da agência e voltava várias vezes, muito sobressaltado, tremia e sentia calafrios. Não consegue passar perto de carros-fortes ou agências bancárias.

Concluindo, Garcia e Blank (2008) apontam que fica evidente a divergência entre o conhecimento possuído e comportamento adotado pelos pesquisados. Fica subentendido que a percepção do risco e o conjunto de medidas para se evitar o acidente não melhora com a ocorrência acidente. Essa conclusão foi tomada após analisar os dois grupos estudados em seu trabalho:

O grupo que não havia sofrido acidente afirma que tomaria as medidas de segurança frente à situação de iminente acidente, enquanto o grupo acidentado não as tomou.

\section{DISCUSSÃO E CONCLUSÃO}

Diante das explanações teóricas até aqui descritas, com importantes estudiosos do tema, resta-nos a intenção de tecer algumas considerações que possam expressar nosso posicionamento frente à questão até então tratada.

A percepção de risco do ser-humano comumente não é baseada em dados científicos. Para ilustrar essa afirmação, propomos um exemplo: estatisticamente falando é muito mais provável que uma pessoa morra em um acidente de carro do que em um acidente de avião. Porém, é mais comum que as pessoas tenham medo de voar do que de dirigir. Isso se dá pois um acidente de avião, quando acontece, costuma ser algo muito mais sério, e tem como resultado um alto número de vítimas e frequentemente com nenhum sobrevivente. Já em um acidente de carro, frequentemente não é um evento que leve a morte de tantas pessoas como o de avião, em um só acidente, e em muitos acidentes a vítima sobrevive. De certa forma podemos dizer que a empatia com catástrofes de centenas de mortos gera um certo "trauma" que leva a pessoa a ficar mais preocupada com o menos provável, ou seja, altera a sua percepção do risco.

Apesar de cada trabalhador possuiu uma percepção individual dos riscos, este possui grande responsabilidade em relação à sua própria segurança e em relação à segurança daqueles que o cercam, podendo alterar o seu ambiente para mais ou menos seguro.

Pessoas são diferentes, podendo ser mais ou menos tolerantes ao risco, podem ter maior ou menor motivação para o trabalho. Cada indivíduo tem necessidades diferentes que Ihes trazem mais ou menos satisfações no ambiente profissional. A forma com que o profissional está inserido em seu meio também é relevante, e podemos dizer que um mesmo trabalho, embora supra as necessidades de realizações do trabalhador, pode trazer desgaste e diminuir sua qualidade de vida, dependendo de sua tolerância à problemas e até de sua positividade. Uma jornada dupla ou tripla de trabalho, por exemplo, propicia um grande desgaste físico e emocional, levando a uma maior possibilidade de acidente.

Enquanto um indivíduo é afetado negativamente por um acidente de trabalho ou pelo trauma causado, outro indivíduo pode encontrar nas dificuldades motivo para crescimento pessoal e redescoberta, de forma 
a posteriormente demonstrar maior competência, autoestima e resiliência. É o que Cavalcante et. al (2009) chama de "crescimento pós-traumático", que vem com mudança de valores, atitudes e maior valorização da vida. Devido a esse fato, inicialmente era esperado que transtornos póstraumáticos e acidentes de forma geral pudessem contribuir para a formação de uma melhor percepção de risco, expectativa que não veio a se concretizar.

Se é danoso ao trabalhador ser negligente subestimar os riscos do trabalho, o TEPT nos traz um outro lado igualmente danoso, uma espécie de hipersensibilidade aos riscos inerentes ao trabalho. O trabalhador passa a se comportar como se o incidente fosse ocorrer novamente em qualquer situação. Esse estado leva a incapacitação, perda de rendimento e autoestima.

Diante de um quadro de transtorno mental, incluindo o TEPT e o TMC, a pessoa pode se tornar constantemente cansada devido à insônias e níveis altos de estresse, isto por si só é um risco para o indivíduo que trabalha nestas condições e para outros que possam depender de suas atividades, visto que sua percepção dos riscos é bem menor, assim como sua reação será mais lenta, o que poderia ser a diferença entre a ocorrência ou não de um acidente. O transtorno também pode tornar a pessoa mais irritável ou agressiva, gerando risco aos seus companheiros de jornada e a si mesmo, além de também gerarem muitas vezes pensamentos de morte e suicídio.

O presente trabalho presenciou que a maioria dos trabalhadores não apresentou a devida conduta, mesmo após o acidente, subestimando os riscos. O risco é ainda mais subestimado quando este passa a fazer parte do dia-a-dia do trabalhador: o tempo de serviço e as habilidades técnicas acabam proporcionando uma sensação protetiva, de forma que ele enxergue a possibilidade de acidente como um evento distante, possível de

\section{REFERÊNCIAS}

[1]. ALMEIDA, Clara A. F., BENATTI, Maria Cecília C. Exposições ocupacionais por fluidos corpóreos entre trabalhadores da saúde e sua adesão à quimioterapia. Rev Esc Enfermgem USP, 2007; 41(1):120-6. acontecer apenas com outros trabalhadores e nunca consigo próprio; superestimando sua capacidade de evitar o acidente, sem precisar usar equipamentos de proteção ou medidas protetivas e levando à desatenção, que é uma grande causadora de acidentes.

Profissionais de diversas áreas, como mostrado, demonstram dificuldade em tomar as devidas medidas de prevenção. Essa afirmação pode ser confirmada através da análise de como os trabalhadores se utilizam dos EPI: corriqueiramente é visto apenas como uma obrigação e até como um estorvo, chegando em casos extremos onde os trabalhadores costumam classificar os outros, aqueles que seguem à risca as normas de segurança e saúde no trabalho, como "afeminados", "mocinhas", "delicados" e "fracos", conforme cita Peres (2005).

Em outros casos observamos que os trabalhadores têm a percepção do risco no que se relaciona com a importância de usar os EPIs, porém não o usam ou o usam de maneira incorreta. Em outras palavras, não há relação entre conhecer os fatores de risco e adotar medidas protetoras. É raro encontrar trabalhadores que transformam seu know-how profissional em práticas seguras. Por outro lado, ao se deparar com o perigo eminente, o trabalhador sempre responderá de acordo com sua experiência de vida.

Concluímos então que, em linhas gerais, a ocorrência de acidentes e transtornos mentais com os trabalhadores, incluindo TEPT, não são preponderantes para estabelecer uma percepção de risco alinhada à atividade que o trabalhador exerce. É necessário, sobretudo, que a organização instaure uma cultura de segurança na empresa. Entende-se por cultura de segurança, segundo Cooper (2000), o conjunto coletivo de conhecimentos adquirido e construído, e assim, caracterizado por uma maior estabilidade, onde a cultura organizacional uma partilha de valores que afetam e influenciam as atitudes e comportamentos dos seus membros.

[2]. AREZES, Pedro Miguel F. M. Percepção do Risco de Exposição Ocupacional ao Ruído. Braga: Universidade do Minho, 2002. 269 p. Tese (Doutorado) - Escola de Engenharia da Universidade do Minho, Curso de Doutorado, Universidade do Minho, Braga, Portugal, 2002. 
[3]. AZAP, A, ERGNUL O, KO, YESXILKAYA, A, ALTUNSOY, A. Occupational exposure to blood and body fluids among health care workers in Ankara, Turkey. Am J Infect Control. 2005;33 (1):48-51.

[4]. BALSAMO, Ana Cristina, FELLI, Vanda Elisa A. Estudo sobre os acidentes de trabalho com exposição aos líquidos corporais humanos em trabalhadores da saúde de um hospital universitário. Rev Latino-am Enfermagem 2006 maio-junho; 14(3):346-53.

[5]. BUCASIO, Erika et. al. Transtorno de estresse pós-traumático como acidente de trabalho em um bancário: relato de um caso. Rio de Janeiro: UFRJ, 2004.

[6]. BRASIL, Ministério da Previdência e Assistência Social. Decreto no 2172, de 05 de Março de 1997

[7]. BRASIL, Ministério da Saúde do Brasil, Portaria no 1339, de 18 de Novembro de 1999.

[8]. CÂMARA FILHO, JWS, SOUGEY, EB. Estupro e transtorno de estresse pós-traumático: aspectos epidemiológicos e clínicos. J Bras Psiquiatr 1999; 48:547-53.

[9]. CÂMARA FILHO, JWS, SOUGEY, EB. Transtorno de estresse pós-traumático: formulação diagnóstica e questões sobre comorbidade. Rev Bras Psiquiatr 2001; 23(4):221-8.

[10]. CAMPOS, Izabel Carolina Martins. Diagnóstico de Transtornos Mentais e Comportamentais e Relação com o Trabalho de Servidores Públicos Estaduais. Florianópolis: UFSC, 2006. 185 p. Tese (Mestrado) - Programa de PósGraduação em Psicologia, Curso de Mestrado, Universidade Federal de Santa Catarina, Florianópolis, 2006.

[11]. CAVALCANTE, Fátima $G$ et al. Sequelas invisíveis dos acidentes de trânsito: o transtorno de estresse pós-traumático como problema de saúde pública. Ciência \& Saúde Coletiva, 14(5):1763-1772, 2009.

[12]. COOPER, M. (2000) Towards a model of safety culture. Safety Science, vol. 36(2), pp. 111136.

[13]. DAMASCENO, Ariadna P et al. Acidentes ocupacionais com material biológico: a percepção do profissional acidentado. Rev Bras Enferm, 2006 jan-fev; 59(1):72-7.

[14]. DEMYTTENAERE, K. et. al. Prevalence, severity, and unmet need for treatment of mental disorders in the World Health Organization World Mental Health Surveys. JAMA: The journal of the American Medical Association, United States, v. 291, n. 21, p. 2581-2590, Junho, 2004.

[15]. DORIGO, Júlia N., LIMA, Maria Elizabeth A. O transtorno de estresse pós-traumático nos contextos de trabalho: reflexões em torno de um caso clínico. Cadernos de Psicologia Social do Trabalho, 2007, 10(1):55-73.
[16]. FUNDACENTRO, Fundação Jorge Duprat Figueiredo de Segurança e Medicina do Trabalho. Norma Regulamentadora 29: segurança e saúde no trabalho portuário. São Paulo: Fundação Jorge Duprat Figueiredo de Segurança e Medicina do Trabalho; 1998.

[17]. GARCIA, Leila P., BLANK, Vera Lúcia G. Condutas pós-exposição ocupacional a material biológico na odontologia. Rev Saúde Pública 2008; 42(2):279-86.

[18]. GOLDBERG, David P., HUXLEY, Peter. Common Mental Disorders: a Bio-Social Model. London: Tavistock/Routledge, 1993.

[19]. HERMAN, Judith. Trauma and recovery. New York: Basic Books; 1997

[20]. KRAUSE, Thomas R. Segurança e Qualidade: Os dois Lados da Mesma Moeda. Quality Progress, 1994.

[21]. MAFRA, Denise A. L. et al. Percepção dos Enfermeiros sobre a importância do uso dos Equipamentos de Proteção Individual para Riscos Biológicos em um Serviço de Atendimento Móvel de Urgência. O Mundo da Saúde São Paulo: 2008: jan/mar 32(1):31-38.

[22]. OLIVEIRA, Adriana C., GONÇALVES, Jacqueline de A. Acidente ocupacional por material perfurocortante entre profissionais de saúde de um Centro Cirúrgico. Rev Esc Enferm USP, 2010; 44(2):482-7

[23]. PERES, Frederico et al. Percepção de riscos no trabalho rural em uma região agrícola do Estado do Rio de Janeiro, Brasil: agrotóxicos, saúde e ambiente. Cad. Saúde Pública, Rio de Janeiro, 21(6):1836-1844, nov-dez, 2005.

[24]. RECENA, Maria C. P., CALDAS, Eloisa D. Percepção de risco, atitudes e práticas no uso de agrotóxicos entre agricultores de Culturama. MS. Rev Saúde Pública 2008;42(2):294-301.

[25]. ROSSI, Lídia A., et al. Prevenção de queimaduras: percepção de pacientes e de seus familiares. Rev Latino-americana Enfermagem 2003 janeiro- fevereiro; 11(1):36-42

[26]. SELIGMANN, Silva E. Desgaste Mental no Trabalho Dominado. Rio de Janeiro: Cortez Editora, 1994.

[27]. SILVA, Glauco et al. Considerações sobre transtorno depressivo no trabalho. Rev. Bras. Saúde ocup., São Paulo, 34(119):79-87, 2009.

[28]. SLOVIC, P, FISCHHOFF, B, LIECHTEISNTEIN, S. Rating the risks. Environment $1979 ; 21: 36-9$.

[29]. SOUZA, Suerda F. de, CARVALHO, Fernando M., ARAÚJO, Tânia M. de, PORTO, Laura A. Fatores psicossociais do trabalho e transtornos mentais comuns em eletriciários. Salvador: UFBA, FMB, UEFS, 2010. 717 p. Programa de PósGraduação em Saúde, Ambiente e Trabalho, Universidade Federal da Bahia, Faculdade de 
Medicina da Bahia, Universidade Estadual de Feira Santana, Bahia, 2010

[30]. TIMMS, P. Depression in the workplace. The Royal College of Psychiatrists, 2006. Disponível em:

$<$ http://www.rcpsych.ac.uk/mentalhealthinformation /mentalhealthproblems/depression/depressioninthe workplace.aspx>. Acesso em: 14 jun. 2008.
[31]. WARR, Peter Bryan. Unemployment and Mental Health. Oxford: Clarendon Press, 1987.

[32]. WIEDEMANN, PM. Introduction risk perception and risk communication. Jülich: Programme Group Humans; Environment, Technology (MUT), Research Centre Jülich; 1993. (Arbeiten zur Risko Kommunikation 38). 


\section{Capítulo 2}

ACESSIBILIDADE COM TECNOLOGIA ASSISTIDA AOS PORTADORES DE MOBILIDADE REDUZIDA EM NOVA IGUACU: UMA PROPOSTA EMPREENDEDORA E SOCIALMENTE RESPONSÁVEL DE SISTEMAS DE TRANSPORTE

\section{Máyra Gabriel dos Santos}

Neide Lúcia de O. Almeida

Resumo: O crescimento das cidades e a necessidade de deslocamento da população para áreas de interesse (como o centro, por exemplo), faz com que o sistema de transporte coletivo urbano seja um serviço imprescindível a ser oferecido para toda população. Os problemas para atingir a acessibilidade nestes sistemas podem ser reduzidos e até eliminados quando os elementos a eles relacionados forem pensados em atender a todos. O artigo apresenta-se como uma proposta de projeto empreendedor com viés social no tocante da acessibilidade aos portadores de mobilidade reduzida pela adaptação do transporte urbano para atender à demanda na cidade de Nova Iguaçu, região metropolitana do estado do Rio de Janeiro. 


\section{INTRODUÇÃO}

Todos os dias, muitos brasileiros confrontamse com os mais diversos tipos de impedimentos nos espaços públicos urbanos. Como exemplo, as pessoas com deficiência estão entre as mais afetadas, seguidas das que possuem restrições temporárias, geradas por fatores decorrentes da idade, gravidez, uso de próteses ou aparelhos ortopédicos. Em 2011, a Organização Mundial da Saúde publicou o Relatório Mundial sobre a Deficiência, que divulgou existir cerca de 30 milhões de pessoas com deficiências no Brasil.

Um dos objetivos centrais da acessibilidade é garantir aos cidadãos a possibilidade de uso dos espaços da cidade, permitindo transportarem-se de um lugar para outro. As possibilidades de deslocamento nas áreas públicas, através do uso dos sistemas de transporte, devem garantir o direito de ir e vir de todos os cidadãos, preconizado pela Constituição Federal de 1988. A reunião de fatores como o crescimento urbano e a dificuldade na gestão da circulação, quando confrontados com a crescente necessidade por deslocamentos, faz da acessibilidade um componente fundamental para o equacionamento dos problemas urbanos.

Em 2006, numa análise feita pelo Plano Diretor de Transporte Urbano da Região Metropolitana do Rio de Janeiro, o transporte público representa $65 \%$ dos deslocamentos na cidade do Rio de Janeiro, enquanto 25\% são realizados por veículos particulares. Apesar do número expressivo de deslocamentos por transporte público, a população não é atendida adequadamente uma vez que a oferta é feita por um transporte padronizado e limitador que desconsidera as especificidades da demanda, se o considerarmos sob o ponto de vista da acessibilidade. (SILVA, 2011)

A acessibilidade em estudo neste trabalho trata das coisas materiais, especificamente dos meios de transportes utilizados para deslocamento, no caso a modalidade de transporte adaptado para uso individual às pessoas com mobilidade reduzida. A cidade de Nova Iguaçu, localizada na região metropolitana do estado do Rio de Janeiro, foi selecionada como estudo de caso para análise pela falta de acessibilidade no transporte e as razões serão apresentadas ao longo do artigo.

\section{OBJETIVO}

Com o intuito de compreender a situação- problema, este artigo tem como objetivo conhecer a atual conjuntura do transporte urbano na cidade de Nova Iguaçu, no estado do Rio de Janeiro, e as possíveis alternativas de locomoção com foco na acessibilidade aos portadores de necessidades especiais.

\section{METODOLOGIA}

O presente trabalho partiu de uma pesquisa bibliográfica para coleta de informações e dados, previamente coletados quando da apresentação deste estudo para conclusão de um curso de extensão, na Universidade Federal Fluminense.

\section{ACESSIBILIDADE E MOBILIDADE NOS TRANSPORTES URBANOS}

Na Lei Federal n. 10.098 (Brasil, 2000), a acessibilidade é definida como a "possibilidade e condição de alcance para utilização, com segurança e autonomia, dos espaços, mobiliário e equipamentos urbanos, das edificações, dos transportes e dos sistemas e meios de comunicação, por pessoa portadora de deficiência ou com mobilidade reduzida". Apesar da grande utilização do transporte coletivo, da imposição legislativa e da crescente solicitação dos usuários com deficiência, apenas recentemente gestores e operadores passaram a se preocupar com a acessibilidade ao transporte coletivo e em como atender essa demanda.

O crescimento das cidades e a necessidade de deslocamento da população para áreas de interesse (como aos centros das cidades, por exemplo), faz com que o sistema de transporte coletivo seja um serviço imprescindível a ser oferecido para toda população.

Para chegar aos destinos desejados, as pessoas utilizam diversos modos de transportes, sendo os mais comuns, no Brasil, - modo a pé, de bicicleta, motocicleta, automóvel (transportes individuais) e de ônibus (transporte coletivo).

Os problemas para atingir a acessibilidade nos sistemas de transporte derivam de muitos âmbitos. Por exemplo, os ônibus apresentam, em sua grande maioria, degraus como forma de acesso, o que dificulta o acesso de todos, principalmente daqueles com mobilidade reduzida e impedindo o acesso de pessoas em cadeira de rodas.

Além do acesso, outras barreiras também são 
observadas, como a disposição interna de corrimãos, de assentos e de mecanismos de controle de passageiros. Essas barreiras podem ser reduzidas e até eliminadas quando os elementos do sistema de transporte forem pensados em atender a todos.

Todavia, a acessibilidade ao transporte público não se restringe apenas em dar condições físicas de acesso ao ônibus. Para abranger todo sistema de transporte coletivo, devem-se considerar terminais, abrigos de ônibus e calçadas tão acessíveis quanto os próprios veículos. Da mesma forma, para torná-lo acessível é necessário promover informação sobre o sistema de transporte ao usuário, para poder orientar-se e posteriormente, deslocar-se, utilizar e comunicar-se em todos os elementos que englobam o sistema. A informação deve ser considerada como um dos principais fatores a serem providos aos usuários, uma vez que "um dos fatores decisivos na caracterização da acessibilidade ao ambiente é a possibilidade de os indivíduos perceberem e compreenderem o espaço, e as informações nele contidas" (BINS ELY; DISCHINGER; MATTOS, 2002).

Basicamente, acessibilidade deriva de duas palavras, "acesso" e "habilidade" e está mais ligada à facilidade com que se chega ou se estabelece comunicação com alguma atividade ou lugar específico do que com a facilidade de transitar pela rede, que se pode assumir como mobilidade. Deste modo, se um indivíduo tivesse acesso pleno à rede de transportes, mas através dela só conseguisse acessar uma pequena parte das atividades existentes na localidade, não teria, conceitualmente, problemas de mobilidade, uma vez que trafega sem problemas pela rede. No entanto, teria um baixo índice de acessibilidade, pois a partir de sua localidade, não conseguiria alcançar um grupo significativo de atividades disponíveis.

Segundo Silva (2010), no Brasil este conceito está associado mais diretamente às pessoas com deficiência. De forma mais ampla, acessibilidade significa "a condição do indivíduo se movimentar, locomover e atingir, um destino desejado, dentro de suas capacidades individuais, isto é realizar qualquer movimentação ou deslocamento por seus próprios meios, com total autonomia e em condições seguras". Outra forma de definir acessibilidade é a "facilidade em distância, tempo e custo, de se alcançar, com autonomia, os destinos desejados na cidade", o que adiciona a esse conceito dois novos componentes fundamentais: o tempo e o custo dos deslocamentos (MINISTÉRIO DAS CIDADES, 2007).

Conforme o Social Exclusion Unit (2002), força tarefa do gabinete do Governo do Reino Unido responsável por discutir ações de inclusão social, a ideia de acessibilidade leva à esta questão: as pessoas podem chegar às atividades desejadas a um custo, tempo e facilidade razoáveis? Existe transporte entre as pessoas e a atividade-destino? As pessoas sabem sobre os meios de transportes, confiam nele e se sentem seguras para utilizá-los? As pessoas podem fisicamente e financeiramente acessar os meios de transportes? Acessibilidade não é só sobre transportes, mas sobre localizar e prover acesso às atividades-destino como forma de ajudar as pessoas a alcançá-las.

Em sua análise, Kruger (2012) aponta que as práticas do planejamento de transporte convencional foram desenvolvidas para tomar decisões relativamente simples como desenho e rotas das vias e rodovias, oferta de estacionamento, mas são inadequadas para decisões mais complexas que envolvam acessibilidade, uso do solo, impactos econômicos, ambientais e sociais. O planejamento de transporte mais abrangente além de priorizar o transporte público, deveria apoiar os meios de transporte alternativos e estratégias de gestão da mobilidade.

Silva (2010) ainda cita a Política Nacional de Mobilidade Urbana Sustentável, que define mobilidade como: "um atributo associado às pessoas e aos bens; corresponde às diferentes respostas dadas por indivíduos e agentes econômicos às suas necessidades de deslocamento, considerando as dimensões do espaço urbano e a complexidade das atividades nele desenvolvidas", de maneira mais específica mobilidade é a facilidade de pessoas e bens se deslocarem no espaço urbano (MINISTÉRIO DAS CIDADES, 2004b).

Porto (2001) defende que a mobilidade estaria então relacionada à união entre a necessidade ou desejo de realização da viagem e a possibilidade de realizá-la, como um papel de necessidade e acessibilidade, traduzida pela equação:

\section{NECESSIDADE $\cup$ ACESSIBILIDADE = MOBILIDADE}

Convencionalmente, a mobilidade urbana é 
possível por diferentes meios de transporte: a caminhada, bicicleta, automóvel, transporte coletivo, etc. Em um único deslocamento, uma mesma pessoa pode desempenhar vários papéis, pedestre, motorista, passageiro. São inúmeros os fatores que influenciam, restringem ou até mesmo condicionam sua preferência por um destes modos, como por exemplo, sexo, idade, renda, capacidade motora reduzida e/ou comprometida (MINISTÉRIO DAS CIDADES, 2007). Cada meio de transporte propicia diferentes níveis de mobilidade, devendo ser considerada a importância de cada um deles para a mobilidade da população.

Nos últimos quinze anos houve uma evolução de conceitos, definições e avanços na organização social das pessoas com deficiência, que resultaram no respeito aos seus direitos fundamentais. Foram aprovadas as Leis Federais 10.048/00 e 10.098/00, a NBR 9050 foi revisada e o Decreto 5296/04, que regulamentou essas duas leis federais, possibilita um extraordinário avanço nos próximos anos, fruto de uma preocupação emergente para a inclusão social desta parcela da sociedade que carece de tantos esforços de acessibilidade.

\section{ESTUDO DE CASO}

Nos últimos anos, em todo o mundo, houve um crescimento significativo no tocante às questões relacionadas à preocupação da sociedade com a inclusão social e a conscientização das pessoas sobre essa necessidade. Aumenta a cada dia o número de pessoas que se preocupam com questões referentes à responsabilidade social e ao meio ambiente.

Em âmbito nacional, o transporte adaptado à locomoção de pessoas com necessidades especiais ainda carece de maior atuação no mercado. São poucas as cidades que oferecem essa facilidade e, quando oferecem, a prestação do serviço aliada à inclusão social é precariamente desempenhada.

O mercado de cadeirantes foi o $3^{\circ}$ mais rentável em 2010, segundo informações da Macroplan (2010). Os mercados homossexual e religioso ocuparam os $1^{\circ}$ e $2^{\circ}$ lugares, respectivamente. De acordo com dados do Grupo Cipa Fiera Milano (2014), organizador da Reatech, uma das maiores feiras internacionais envolvendo as áreas de reabilitação, inclusão, acessibilidade e paradesporto, o mercado tem movimentado anualmente $R \$ 1,5$ bilhão, sendo $R \$ 200$ milhões somente em vendas de cadeira de rodas e mais de $\mathrm{R} \$ 800$ milhões no comércio de automóveis com isenções de impostos e adaptações veiculares.

Somente no Estado do Rio de Janeiro, são 3,9 milhões de pessoas com algum tipo de deficiência, o que representa $24,4 \%$ da população estadual, segundo dados do último Censo realizado no Brasil em 2010. A deficiência mais frequente é a visual, seguida da motora, auditiva e mental.

Apesar desses indicadores cada vez mais crescentes, o mercado voltado ao público com necessidades especiais é pouco valorizado. Em muitos casos, pode-se considerar que essa valorização ocorre sazonalmente, isto é, em períodos de maior interesse para o comércio ou para a indústria.

No estado do Rio de Janeiro, somente em algumas cidades a oferta do serviço de transporte adaptado é percebida. A capital fluminense foi a primeira a oferecer esse serviço, que inovou na conjectura atual e permitiu que outras cidades vislumbrassem a oportunidade de atuação nesse mercado. Em seguida, Niterói e São Gonçalo, ofertaram esta inovação através de táxis e linhas de ônibus (transporte público) adaptadas, respectivamente.

Nova Iguaçu, cidade fluminense, foco deste estudo, possui 801.746 habitantes distribuídos em 523,82 km², correspondente a 1.530 habitantes por $\mathrm{km}^{2}$, o que a torna o maior município da Baixada Fluminense, segundo dados apresentados pelo Instituto Brasileiro de Geografia e Estatística - IBGE (2010). Ainda segundos dados do IBGE (2010), Nova Iguaçu possui cerca de 264 mil pessoas com deficiência, representando 33\% da população da cidade.

Outro dado importante de se destacar quanto à escolha desta cidade para o estudo de viabilidade de um projeto empreendedor para implementação de uma frota de táxis adaptados, é a localização da Associação de Assistência à Criança Deficiente - AACD, como a única filial da instituição no Estado do Rio de Janeiro.

A AACD é uma entidade sem fins lucrativos. Inaugurada em 28 de setembro de 2004, com os recursos do VII Teleton, a unidade do Estado do Rio Janeiro da AACD está instalada em um terreno de $9.000 \mathrm{~m}^{2}$, cedido pela 
prefeitura de Nova Iguaçu. O prédio da unidade ocupa quase $2.000 \mathrm{~m}^{2}$.

Conforme informações na página web da instituição, atualmente a AACD - Rio de Janeiro está apta para realizar 470 atendimentos por dia. Diversas patologias são atendidas. Para isso, conta com atendimentos nas áreas de Fisioterapia, Terapia Ocupacional, Hidroterapia, Pedagogia, Fonoaudiologia, Psicologia, Musicoterapia e outras especialidades médicas. Além disso, a AACD Rio de Janeiro possui uma fábrica de aparelhos ortopédicos que produz vários modelos de órteses e próteses para membros superiores e inferiores, coletes para tratamento de deformidades e outros tipos de acessórios para reabilitação.

A instituição foi credenciada e habilitada pelo Ministério da Saúde como um Centro de Reabilitação de Alta Complexidade, de acordo com a Portaria n- 204 de 19 de junho de 2009.

Em geral, poucas pessoas atendidas na AACD chegam de carro próprio ou de terceiros. A maioria dos atendimentos realizados é feito em pessoas (crianças e, em menor número, adultos) que chegam até à filial do Rio de Janeiro por meio do escasso transporte público. Próximo ao local, passa apenas uma linha de ônibus, com frequência irregular e sem adaptação para cadeirantes, o que torna a locomoção dos pacientes muito complicada, demorada e, muitas vezes, constrangedora.

A cidade de Nova Iguaçu possui esparsa oferta de ônibus adaptado. O transporte público convencional é precário, as frotas de ônibus existentes são escassas e insuficientes para atender ao município, o quarto maior e mais populoso do Estado do Rio de Janeiro, conforme dados do último censo (IBGE, 2010).

Para atender a demanda por transporte no local, a população utiliza o transporte ilegal de Vans e Kombis, que oferecem o serviço ao mesmo preço cobrado pelos ônibus, mas que não possuem equipamentos de segurança e conforto para todos os passageiros. Muitas vezes a lotação do veículo é máxima e é mínima a fiscalização dos setores responsáveis para circulação desse transporte nas vias municipais. O único diferencial dessa alternativa é uma oferta mais diversificada.

Com relação ao transporte adaptado, a oferta torna-se nula: o transporte público é falho e os serviços de transporte privados não contemplam adaptações nos veículos. Relatos da população local e frequentadora da AACD (entrevistados pela autora em 2011), que utiliza os ônibus das linhas oferecidas na cidade, informam casos de descompromisso quanto ao fornecimento do serviço. Abaixo, duas constatações de relatos significantes:

i) em alguns ônibus, são aplicados selos que indicam a adaptação dos veículos quando, na verdade, eles não são adaptados; e

ii) alguns motoristas sequer param para os passageiros quando percebem que estes são portadores de necessidades especiais e carecem de um cuidado aprimorado, o que denota o despreparo das frotas convencionais e o descaso dos gestores municipais com este público.

Os empresários responsáveis pela operação do sistema de transportes na cidade guiaram o desenvolvimento e a expansão dos serviços rodoviários segundo suas vontades e objetivos, inibindo/eliminando possíveis ameaças à sua hegemonia. A insatisfação com o sistema criou um cenário propicio para que, por volta dos anos de 1990/1991, se iniciasse um movimento acelerado de iniciativas locais e autônomas de serviço de transporte de passageiros.

A informalidade nos contratos e os elevados índices de acidentes são algum dos problemas que persistem desde o início da circulação dos primeiros carros. Quase diariamente, são publicados na mídia impressa e televisiva, fatos que comprovam a escassez de fiscalização e regulamentação efetiva na operação rodoviária na região Metropolitana do Rio de Janeiro.

O hábito crescente do uso do veículo particular nos deslocamentos diários vem ganhando cada vez mais a atenção de especialistas da área de transportes, saúde e meio ambiente, já que estas são áreas diretamente atingidas pelas externalidades provenientes do atual modelo de deslocamento, baseado nos meios motorizados, implantado e consolidado nos grandes centros.

Silva (2010) ainda aprofunda a análise do transporte relacionado à vida das pessoas no seu cotidiano. A Tabela 1 demonstra a participação significativa dos transportes nos gastos das famílias brasileiras residentes em áreas urbanas, no período de 2008 a 2009. Os gastos com transporte representam cerca de $20 \%$ dos gastos familiares, estando abaixo apenas dos gastos com habitação (36\%). 
Tabela 1: Participação na despesa monetária e não monetária média mensal familiar

\begin{tabular}{|lccc|}
\hline \multirow{2}{*}{$\begin{array}{r}\text { Tipjos de } \\
\text { despesas }\end{array}$} & \multicolumn{3}{r|}{$\begin{array}{c}\text { Participação na despesa média mensal familiar } \\
\text { em área urbana \% }\end{array}$} \\
\cline { 2 - 4 } & 1974-1975 & 2002-2003 & 2008-2009 \\
\hline Alimentação & 30,1 & 19,6 & 19,0 \\
Habitação & 32,7 & 36,1 & 36,4 \\
Transporte & 11,9 & 18,5 & 19,5 \\
Saúde & 4,1 & 6,6 & 7,3 \\
Educação & 2,6 & 4,3 & 3,2 \\
Outros & 18,7 & 14,9 & 14,6 \\
\hline & \multicolumn{4}{|c}{ Fonte: IBGE/POF, (2010) } \\
\hline
\end{tabular}

Na Tabela 2, com dados de 2010, observa-se um gasto mais significativo com o transporte urbano (público) nas famílias com faixa de renda até $R \$ 1.254,00$. A partir desta faixa salarial os gastos passam a ser maiores com a aquisição e manutenção do carro particular.

Tabela 2: Participação dos transportes na despesa média mensal familiar por classe de rendimentos

\begin{tabular}{|c|c|c|c|c|c|c|c|c|}
\hline \multirow{2}{*}{ Tipo de Despesa } & \multicolumn{8}{|c|}{ Distribuição das Despesas \% por Classe de Rendimento RS } \\
\hline & Total & Até 830 & $\begin{array}{l}830 \mathrm{a} \\
1.254\end{array}$ & $\begin{array}{c}1.245 \mathrm{a} \\
2.490\end{array}$ & $\begin{array}{c}2.490 \mathrm{a} \\
4.150\end{array}$ & $\begin{array}{l}4.150 \mathrm{a} \\
6.225\end{array}$ & $\begin{array}{l}6.225 \mathrm{a} \\
10.375\end{array}$ & $\begin{array}{c}\text { Mais de } \\
10.375\end{array}$ \\
\hline Transporte urbano & 2,2 & 3,8 & 4,2 & 3,5 & 2,7 & 1,6 & 1,2 & 0,6 \\
\hline Gasolina veículo próprio & 2,6 & 1,4 & 1,7 & 2,5 & 3,2 & 3,2 & 3 & 2,4 \\
\hline Álcool veículo próprio & 0,5 & 0,1 & 0,2 & 0,3 & 0,5 & 0,7 & 0,7 & 0,5 \\
\hline Manutenção e acessórios & 1,7 & 0,9 & 1 & 1,6 & 2 & 2 & 1,8 & 1,6 \\
\hline Aquisição de veículos & 6,9 & 2,4 & 3 & 4,5 & 6,5 & 8 & 10,3 & 9,4 \\
\hline Viagens esporádicas & 1,2 & 0,8 & 0,8 & 0,8 & 1 & 1,1 & 1,6 & 2 \\
\hline Outras & 0,8 & 0,3 & 0,3 & 0,5 & 0,7 & 0,9 & 1,2 & 1,1 \\
\hline $\begin{array}{l}\text { Participação total dos } \\
\text { Transportes }\end{array}$ & 16,0 & 9,7 & 11,1 & 13,7 & 16,6 & 17,5 & 19,8 & 17,7 \\
\hline
\end{tabular}

O transporte tem por objetivo prover acesso amplo e democrático ao espaço urbano, de forma segura, socialmente inclusiva e sustentável. Muitos autores relacionam a privação do acesso aos serviços de transporte à exclusão social, visto que a indisponibilidade dos serviços ou a dificuldade de arcar com os custos do transporte leva ao agravamento da pobreza. Problemas como desemprego, dificuldade de acesso à educação formal e evasão escolar, estão associados a estes fatores.

A falta de investimentos no transporte público se reflete diretamente nos objetivos sociais. Para ser útil para os propósitos de planejamento prático, uma medida de acessibilidade deve atingir dois requisitos básicos: deve ser coerente com o uso e a percepção dos residentes, trabalhadores e visitantes de uma área e deve ser compreensível para aqueles que fazem parte 
do processo de planejamento (BERTOLINI et al, 2005).

Em virtude do cenário apresentado, pode-se afirmar que o transporte na cidade de Nova Iguaçu carece de um serviço de transporte eficiente e eficaz, que facilite a vida do usuário, prioritariamente às pessoas com mobilidade reduzida.

A expectativa das autoras é a de apresentar um projeto de viabilidade econômica e social, elaborado a partir dos estudos aqui apresentados, a uma empresa da iniciativa privada ou a uma cooperativa de táxi que se interesse em investir em modelos de transporte adaptado para pessoas com mobilidade reduzida, atendendo à demanda de todo o município de Nova Iguaçu, com ampla atuação também nas cidades próximas da Baixada Fluminense, composta por mais de 20 cidades, dentre elas, todas com um contingente populacional bastante representativo, como Duque de Caxias, São João de Meriti, Belford Roxo e Volta Redonda.

\section{CONSIDERAÇÕES FINAIS}

O Brasil está em condições de avançar de forma consistente na implementação de uma política de estado para as pessoas com deficiência, que perdure às mudanças de governo, resultantes do processo democrático. O empenho demonstrado por todos os atores que compõem o setor de transporte público no Brasil, para a elaboração do Decreto 5296/04, resultou em um plano que efetivamente implementa a acessibilidade para as pessoas com deficiência e mobilidade reduzida, pois considera a realidade das cidades, da indústria de veículos e de equipamentos de transporte e dos operadores. Ele representa um grande avanço para um país com as características do Brasil, se for comparado com vários países e seus diferentes graus de acessibilidade obtidos.
Em um levantamento da legislação brasileira sobre pessoas com deficiência, pode-se perceber que tem havido um esforço cada vez maior do poder público para promoção da acessibilidade às pessoas portadoras de deficiência ou mobilidade reduzida. Nos últimos 12 anos, houve uma preocupação em regulamentar o serviço de transporte adaptado para atender às necessidades deste público, vide a tabela 3.

O Brasil Acessível, através de suas várias ações e instrumentos procura contribuir para que todas as cidades incorporem, em seu desenvolvimento urbano, a mobilidade das pessoas com deficiência e dos idosos como componentes de uma nova visão de cidade, que respeite todas as pessoas independentemente do modo de transporte que utilizam, tornando-as lugares mais agradáveis para se viver.

A cidade de Nova Iguaçu foi escolhida como potencial referencial para início de um projeto empreendedor e socialmente responsável pelo fato de ter uma densidade demográfica em níveis altos, com participação em significativos índices de portadores de necessidades especiais, notadamente as pessoas com mobilidade reduzida, além de ser a sede da AACD no Estado e, no entanto, ter oferta bastante precária de transporte público e, em especial, do adaptado às necessidades das pessoas com mobilidade reduzida.

Percebe-se, assim, a oportunidade de se implementar uma iniciativa empreendedora e de viés social, através da oferta de uma proposta de negócio a empresas de transportes privados ou a cooperativas de táxi para o transporte de pessoas com mobilidade reduzida, atendendo à demanda inexplorada na cidade de Nova Iguaçu, até a presente data.: 
Tabela 3: Levantamento legislação brasileira sobre pessoas com deficiencia

\begin{tabular}{|c|c|c|c|}
\hline Regulamento & Número & Data & Disposição \\
\hline Lei Federal & 7.405 & $12 / 11 / 1985$ & $\begin{array}{l}\text { Torna obrigatória a colocação do "Símbolo Internacional de } \\
\text { Acesso" em todos os locais e serviços que permitam sua } \\
\text { utilização por pessoas portadoras de deficiência e dá outras } \\
\text { providências. }\end{array}$ \\
\hline Lei Federal & 8.899 & 29/06/1994 & $\begin{array}{l}\text { Concede passe livre às pessoas portadoras de deficiência no } \\
\text { sistema de transporte coletivo interestadual }\end{array}$ \\
\hline Lei Federal & 8.989 & 24/02/1995 & $\begin{array}{l}\text { Dispõe sobre a isenção do Imposto sobre Produtos } \\
\text { Industrializados (IPI), na aquisição de automóveis para } \\
\text { utilização no transporte autônomo de passageiros, bem como } \\
\text { por pessoas portadoras de deficiência física, e dá outras } \\
\text { providências }\end{array}$ \\
\hline Decreto & 3.691 & 19/12/2000 & $\begin{array}{l}\text { Regulamenta a Lei no } 8.899 \text {, de } 29 \text { de junho de } 1994 \text {, que } \\
\text { dispõe sobre o transporte de pessoas portadoras de deficiência } \\
\text { no sistema de transporte coletivo interestadual }\end{array}$ \\
\hline Lei Federal & 10.098 & 19/12/2000 & $\begin{array}{l}\text { Estabelece normas gerais e critérios básicos para a promoção } \\
\text { da acessibilidade das pessoas portadoras de deficiência ou } \\
\text { com mobilidade reduzida, e dá outras providências }\end{array}$ \\
\hline Decreto & 5.296 & 02/12/2004 & $\begin{array}{l}\text { Regulamenta as Leis nos } 10.048 \text {, de } 8 \text { de novembro de } 2000 \text {, } \\
\text { que dá prioridade de atendimento às pessoas que especifica, e } \\
\text { 10.098, de } 19 \text { de dezembro de } 2000 \text {, que estabelece normas } \\
\text { gerais e critérios básicos para a promoção da acessibilidade } \\
\text { das pessoas portadoras de deficiência ou com mobilidade } \\
\text { reduzida, e dá outras providências }\end{array}$ \\
\hline $\begin{array}{l}\text { Decreto } \\
\text { Municipal }\end{array}$ & 24.934 & 09/12/2004 & $\begin{array}{l}\text { Institui o Serviço de transporte especial de passageiros para } \\
\text { atender as pessoas com necessidades especiais }\end{array}$ \\
\hline $\begin{array}{l}\text { Decreto } \\
\text { Municipal }\end{array}$ & 29.184 & 08/04/2008 & Altera artigo 5 decreto 24934 \\
\hline $\begin{array}{l}\text { Decreto } \\
\text { Legislativo }\end{array}$ & 186 & 09/07/2008 & $\begin{array}{l}\text { Aprova o texto da Convenção sobre os Direitos das Pessoas } \\
\text { com Deficiência e de seu Protocolo Facultativo, assinados em } \\
\text { Nova York, em } 30 \text { de março de } 2007\end{array}$ \\
\hline Lei Federal & 12.587 & $\begin{array}{l}03 / 01 / 201 \\
2\end{array}$ & $\begin{array}{l}\text { Institui as diretrizes da Política Nacional de Mobilidade } \\
\text { Urbana; revoga dispositivos dos Decretos-Leis nos } 3.326 \text {, } \\
\text { de } 3 \text { de junho de 1941, e } 5.405 \text {, de } 13 \text { de abril de } 1943 \text {, } \\
\text { da Consolidação das Leis do Trabalho (CLT), aprovada } \\
\text { pelo Decreto-Lei no } 5.452 \text {, de 1o de maio de 1943, e das } \\
\text { Leis nos } 5.917 \text {, de } 10 \text { de setembro de } 1973 \text {, e } 6.261 \text {, de } \\
14 \text { de novembro de 1975; e dá outras providências }\end{array}$ \\
\hline Lei Federal & 13.146 & $\begin{array}{l}06 / 07 / 201 \\
5\end{array}$ & $\begin{array}{l}\text { Institui a Lei Brasileira de Inclusão da Pessoa com } \\
\text { Deficiência (Estatuto da Pessoa com Deficiência) - } \\
\text { capítulo X direito ao transporte e à mobilidade }\end{array}$ \\
\hline $\begin{array}{l}\text { Decreto } \\
\text { Municipal }\end{array}$ & 40.662 & $\begin{array}{l}21 / 09 / 201 \\
5\end{array}$ & $\begin{array}{l}\text { Aprova o regulamento e o código disciplinar do Serviço } \\
\text { de Transporte Acessível Exclusivo para pessoas com } \\
\text { mobilidade reduzida em veículos de aluguel adaptados - } \\
\text { Serviço Transporte Acessível Exclusivo (STAE }\end{array}$ \\
\hline Resolução SMTR & 2.643 & $\begin{array}{l}25 / 01 / 201 \\
6\end{array}$ & $\begin{array}{l}\text { Estabelece normas relativas a vistoria de veículos para } \\
\text { Serviço de transporte acessível exclusivo (STAE) }\end{array}$ \\
\hline
\end{tabular}




\section{REFERÊNCIAS}

[1] Aacd. Associação de Assistência à Criança com Deficiência. Disponível em: https://aacd.org.br/unidade/nova-iguacu-rj/. Acesso em 14 maio 2016.

[2] Bins Ely, Vera Helena Moro; Dischinger, Marta; Mattos, Melissa Laus. Sistemas de informação ambiental: elementos indispensáveis para a acessibilidade e orientabilidade. Anais do VII Congresso Latino-Americano de Ergonomia. In: XII Congresso Brasileiro de Ergonomia, I Seminário Brasileiro de Acessibilidade Integral, Recife, 2002.

[3] Brasil. Lei no 10.098, de 19 de dezembro de 2000. Estabelece normas gerais e critérios básicos para a promoção da acessibilidade das pessoas portadoras de deficiência ou com mobilidade reduzida, e dá outras providências. Diário Oficial da União, Brasília, DF, 19 dez. 2000

[4] Brasil. Ministério das Cidades. Secretaria Nacional de Transporte e da Mobilidade Urbana. Cadernos do Programa Brasil Acessível.

[5] Krüger, E. T. Padrões de traçado viário urbano e acessibilidade: uma abordagem das relações com o sistema de circulação. 2012. $160 f$. Dissertação (Mestrado) - Programa de PósGraduação em Arquitetura e Urbanismo. Universidade Federal de Pelotas, Pelotas.
[6] Martins, M. de O. Acessibilidade na periferia do transporte: o caso de Santa Cruz. Rio de Janeiro: UFRJ/COPPE, 2011.

[7] Pianucci, M. N. Análise da acessibilidade do sistema de transporte público urbano: estudo de caso na cidade de São Carlos-SP. São Carlos, 2011, 82p. Dissertação (Mestrado) - Escola de Engenharia de São Carlos, Universidade de São Paulo.

[8] Porto, D. Transporte Coletivo na Gestão da Mobilidade: O caso do Shopping Center Rio Sul. Tese de Mestrado do Programa de Engenharia de Transporte, COPPE / UFRJ, Rio de Janeiro, 2001.

[9] São Paulo. Relatório mundial sobre a deficiência. 2012, 334 p.

[10] Social Exclusion Unit. (2003). Making the Connections: Final Report on Transport and Social Exclusion. United Kingdom: Office of The Deputy Prime Minister.

[11] Silva, S. C. T. A dinâmica dos deslocamentos de estudantes do município do Rio de Janeiro, Rio de Janeiro, 2011, 107p. UFRJ/COPPE, 2011. XII.

[12] Silveira, C. S. Acessibilidade espacial no transporte público urbano: estudo do caso em Joinville/SC. Joinville, 2012, 210p. 


\section{Capítulo 3}

\section{UMA ANÁLISE DA QUALIDADE DE VIDA NO AMBIENTE DE TRABALHO POR MEIO DA ESPIRITUALIDADE CORPORATIVA}

\section{Randes de Faria Enes}

Resumo: O relacionamento proporciona ao ser humano a socialização e o seu bemestar. Com a evolução da sociedade, este fato se tornou mais latente fruto de uma sociedade efêmera. A inseparabilidade da vida pessoal e profissional fez com que a organização começasse a ter um olhar para novas estratégias em gestão de pessoas, e trouxe à luz a qualidade de vida no ambiente de trabalho, potencializando a integração funcionário e empresa. Esta correlação, bem-estar e ambiente de trabalho, fez com que esta pesquisa verificasse a importância em utilizar a estratégia de um ambiente espiritualizado para gerar a felicidade no trabalho e ainda levantar quais são as variáveis que possibilitam a transcendência de uma empresa tradicional para uma empresa espiritualizada. A metodologia utilizada foi cedida pelo PROGEGP-FIA, que aplica uma pesquisa quantitativa onde classifica anualmente as Melhores Empresas para Você Trabalhar, por meio de índices de qualidade de vida (IQAT) e gestão de pessoas (IQGP). Também foi possível analisar as variáveis que tornam uma empresa entre as dez Melhores. Baseado nestes resultados houve 0 comparativo entre as dez Melhores e as empresas pertencentes ao segmento de Indústrias Farmacêuticas, de Higiene e Cosméticos, nacional e multinacional, situadas no Estado de São Paulo. Diante disso, as variáveis que tornaram uma empresa entre as dez Melhores não aparecem naquelas que estão fora deste ranking. As conclusões apontam que os principais motivos geradores da felicidade no trabalho estão baseados na construção da cultura organizacional focada no bemestar do indivíduo, denominada neste estudo como espiritualidade corporativa, onde a aplicabilidade desta moção estratégica possibilita melhor qualidade de vida no ambiente de trabalho.

Palavras-chave: Qualidade de Vida. Espiritualidade. Felicidade no Trabalho. Gestão de Pessoas. 


\section{INTRODUÇÃO}

Mediante a evolução da sociedade, o indivíduo do século XXI encontra uma tecnologia estreitando $\mathrm{O}$ espaço-tempo tanto nas informações como também nos relacionamentos com pessoas de qualquer lugar do mundo. Segundo Bauman (2001), esta interação veloz acarretará profundas transformações sociais do estado de bemestar, da família, das relações de trabalho, entre outras, perdendo espaço para o fenômeno de liquefação. Ao analisar essa metáfora, as instituições sociais, por manterem esta estrutura sólida, fundamentada e inabalável, se funde irreversivelmente, tomando, paradoxalmente, a amorfabilidade do estado líquido (PICCHIONI, 2007, p. 2).

Em busca da sinergia da felicidade no ambiente de trabalho, as empresas começam a refletir mais sobre os valores individuais de seus colaboradores, tornando a integração de outros valores, como a sustentabilidade, a igualdade social e a espiritualidade. Esses valores possibilitariam uma transcendência individualista em direção a uma consciência mais coletivista e organizacional, a partir de um novo estilo de gerenciamento e de liderança, voltados ao capital humano (KORACKAKABADSE; KOUZMIN; KAKABADSE, 2002).

Existem caminhos diferentes que levam à felicidade e à sensação de bem-estar da pessoa. O que contribui para a realização é o uso das gratificações para algo maior, ou seja, disponibilizar as forças pessoais em prol de ações que favoreçam outros além de si mesmo (SELIGMAN, 2009).

Segundo Jung et al. (2008, p. 53), "Conheça todas as teorias, domine todas as técnicas, mas ao tocar uma alma humana, seja apenas outra alma humana".

Para Neal (apud BOOG, 2005, p. 1): "Se qualquer organização quiser sobreviver, terá que promover radicais transformações em si mesmas. Essas não se referem à estrutura, mas sim aos valores, essencialmente, aos valores do coração e da alma".

A espiritualidade no trabalho é o reconhecimento de que os colaboradores têm uma vida interior que os alimenta e é alimentada pela realização de trabalho com significado num contexto de comunidade (ASHMOS; DUCHON, 2000).

Marques (2010, p. 13) menciona "onde quer que as pessoas interajam, haverá alguns que têm melhores intenções do que outros; alguns que parecem ser mais favorecidos do que outros; e alguns que são apenas mais fáceis de conviver com e entender do que outros".

Assim, este indivíduo do século XXI passa por momentos transacionais e ao mesmo tempo de uma doença social, oriundos de várias áreas da vida contemporânea, surgindo a experiência do desapego. Bauman (2001, p. 46) menciona o "processo de individualização" como uma das grandes transformações sociais. Segundo ele, quando existe a ruptura dos laços sociais, sugestiona o desapego e a constituição de novas subjetividades. Pode-se dizer que esta constituição inverte o coletivo para o individual e, assim, a subjetividade relacional do "Eu" se sobrepõe ao "Nós": não importa mais o bem comum e, sim, o compromisso com os próprios interesses. "Em suma: o outro lado da individualização parece ser a corrosão e a lenta desintegração da cidadania" (BAUMAN, 2001, p. 46).

Tendo em vista a velocidade das transformações sociais, a busca pelo bemestar, em curto prazo, não permite, muitas vezes, que a razão consiga trazer respostas para esta humanidade que deseja viver momentos intensamente. Vive-se numa sociedade de riqueza de experiências sociais (SANTOS, 2002, p. 238); no entanto, estas devem ser momentâneas. Caso não seja rápida, não há interesse. $A$ imersão na era do "curto prazo" (BERNSTEIN, 1998, p. 88) leva o indivíduo à necessidade da formação permanente. É preciso um aperfeiçoamento constante, pois é exigido, para se sustentar nesta sociedade, que as habilidades estejam em melhoria contínua (BERNSTEIN, 1998, p. 88).

A humanidade necessita dirimir os modelos transacionais e voltar aos modelos relacionais, intensificando no indivíduo os aspectos característicos da maturidade emocional, intelectual e espiritual, onde se destaca, conforme Allport (1963), como sendo a extensão do sentido do eu, isto é, ultrapassar a barreira de sair de si e aumentar a fronteira que existe entre o eu e os outros. Segundo o autor, a maturidade avança na proporção da descentralização, do imediatismo e egocentrismo do corpo.

E, expandindo esta contextualização, o indivíduo deixa de se preocupar somente consigo e começa a preocupar-se com os outros também, aumentando o grau de empatia e proporcionando uma aceitação de reações extremadas e desproporcionais, tanto 
sobre suas próprias reações quanto em relação aos outros.

Desta forma, o indivíduo começa a aprender a viver consigo mesmo sob um ponto de vista real e sensível. Assim, a evolução social sustentável da sociedade do século XXI está ligada à experiência individual, onde a espiritualidade é o caminho para essa experiência acontecer, proporcionando uma abertura na percepção da pessoa sobre o que ela é e o que pode realizar a favor das suas expectativas, possibilitando, assim, o crescimento do grupo a qual está inserida.

\section{REVISÃO DA LITERATURA}

É fundamental, para a contextualização do tema desta pesquisa, o entendimento sobre os conceitos de espiritualidade, religião, espiritualidade no trabalho, e como esta interação pode proporcionar uma qualidade de vida no ambiente de trabalho.

Desta forma, no intuito de promover a elucidação do objeto de estudo, a revisão da literatura aborda livros de pesquisadores e artigos publicados, assim como algumas teses de dissertação, nacionais e internacionais recentes, que se relacionam especialmente aos temas: ambiente espiritualizado, qualidade de vida, felicidade no trabalho e liderança. Também contempla a amostra investigada da base do banco de dados fornecido pela FIA, por meio do PROGEP, responsável pela pesquisa que define anualmente As Melhores Empresas para Você Trabalhar no Brasil, que está detalhada no capítulo 3.

\subsection{A CONTEXTUALIZAÇÃO DE RELIGIÃO E ESPIRITUALIDADE}

Nesta pesquisa, assume-se que a espiritualidade é uma variável complementar que contribui para uma boa vida, surgindo fortes relações entre: Espiritualidade, Felicidade e Qualidade de Vida (QDV).

A associação do termo espiritualidade com o significado de religião é errôneo, pois são distintos, mas se complementam, fazendo com que o entendimento sobre estes dois conceitos se torne necessário para expressar o sentido deste estudo.

\subsection{ESPIRITUALIDADE NO AMBIENTE DE TRABALHO}

Esta pesquisa fomenta a definição de Ashmos e Duchon (2000) de que a espiritualidade corporativa está alicerçada no grau de reconhecimento dos colaboradores como seres humanos, os quais possuem uma vida interior que os alimenta e também é alimentada pelo ambiente de trabalho dentro da comunidade, onde desenvolveu o primeiro instrumento a medir a espiritualidade nas organizações, o qual foi validado no Brasil por Paulino et al. (2010). Ashmos e Duchon (2000) afirmam que o ambiente de trabalho, por ter uma quantidade progressiva de pessoas, é o único laço consistente com outras pessoas. Este escopo demonstra que o ambiente organizacional deve ser encarado como um espaço privilegiado, onde se pode praticar a espiritualidade.

Este tema possibilita a discussão para o novo paradigma surgindo no ambiente de negócios - a espiritualidade no ambiente de trabalho. Atualmente a espiritualidade no ambiente de trabalho é considerada aceitável e reconhecida no universo acadêmico. Temas específicos abordando este assunto entram em cena com maior frequência em paperreviewed, revistas e, em 2001, a Academy of Management criou um grupo de interesse especial para gestão da espiritualidade e religião (POOLE, 2009).

Percebe-se que a espiritualidade se movimenta fortemente no ambiente dos negócios. Com isso, surge um grande número de autores que defende a correlação do tema no cenário corporativo (PAULA; COSTA, 2008).

Há duas décadas, o tema espiritualidade no ambiente de trabalho emerge no cenário corporativo com muitas dificuldades (POOLE, 2009; GOTSIS, KORTEZI, 2008; DRIVER, 2005, 2007; MITROFF, DENTON, 1999; BENEFIEL, 2003, 2007; MARQUES et al., 2007, 2009; NEAL, 1999; HICKS, 2003; CAVANAGH, BANDSUCH, 2002; ASHMOS; DUCHON, 2000; MCCORMICK, 1994).

Resultados de pesquisas anteriores sobre a espiritualidade no trabalho levou à seguinte definição desta tendência:

Espiritualidade no local de trabalho é uma experiência de inter-relação e confiança entre os envolvidos em um processo de trabalho, engendrada pela boa vontade individual. Ela leva à criação coletiva de uma cultura organizacional motivacional, sintetizada pela 
reciprocidade e solidariedade, e resulta em melhor desempenho global, que é, em última análise, traduzida na duração e excelência organizacional (MARQUES, 2010).

Nos dias atuais, a elevada mudança das relações econômicas mundiais acarreta variáveis incontroláveis no ambiente corporativo, pois a globalização impulsiona as incertezas e angústias dentro das organizações. Mais do que nunca, há uma busca por este tema, eleito pelos empresários para dirimir o temor destas tensões, ficando abertos a qualquer possibilidade de mudança. O Capitalismo - determinante para a busca incansável do lucro - leva o dinheiro e o capital a converterem-se em realidades e esse fenômeno favorece a desumanização do homem e a humanização da mercadoria (ARANHA; MARTINS, 1986).

Manz (2006) aponta que a organização que focar os valores de negócio somente nos resultados financeiros pode estar vivendo um profundo paradoxo referente às crenças pessoais e até mesmo espirituais de um indivíduo. Desse modo, quando o indivíduo sacrifica os seus valores pessoais, tais como integridade e honestidade, por essas empresas que levam à busca incessante e impiedosa de lucratividade, faz com que sofra grande pressão pessoal, prejudicando os resultados da organização.

Entender a empresa como ser vivo - empresa orgânica - coloca o indivíduo no centro das atenções, trazendo a luz os valores humanos, o comprometimento organizacional afetivo e o desempenho individual, evidenciando uma empresa viva, onde as pessoas são a pedra angular. Torna-se fundamental, para alcançar os objetivos, esse compartilhamento entre os valores organizacionais e os individuais, possibilitando o envolvimento no trabalho, havendo, assim, maior identificação com a atividade. (DEHLER; WELSH, 1994). A organização, vivendo esse sentido compartilhado, pode fortalecer, na comunidade, um trabalho que permita satisfação e sentido profundos (FOX, 1994; CAVANAGH, 1999), porque a orientação do trabalho pode levar além do senso individual, pois não está focada em si mesmo, surgindo, assim, o sentimento de vocação por aquilo que se faz (ASHAR; LANE-MAHER, 2004). E sob esta ótica, a união do trabalho com a organização potencializa uma importante fonte de desenvolvimento interpessoal e espiritual.
Silva e Siqueira (2004) mencionam a importância do ambiente para potencializar o desenvolvimento pessoal, o autoconhecimento, a intuição e a criatividade. No cenário atual, a sociedade valoriza o indivíduo pelo "ter"; no entanto, a real existência do ser humano busca o "ser", considerando os aspectos humanos - corpo mente - alma. Logo, a organização que valorizar seu funcionário no ambiente de trabalho, proporcionando um aprendizado e conhecimento e um local propício à interação entre as pessoas, poderá ter mais chances de levar o indivíduo à autorrealização e, com isso, reter os talentos na companhia. Quando os funcionários são vistos como indivíduos, os quais possuem suas diferenças pessoais, compostos por suas características biopsicossociais e espirituais, as empresas alcançam o resultado devido à afetividade organizacional que gera o comprometimento e desempenho dos funcionários. Ashmos e Duchon (2000), Matos (2001) e Milliman, Czaplewski e Ferguson. (2003) destacam que esses aspectos podem servir para o incremento da eficiência corporativa, ou seja, denominada aqui neste estudo como espiritualidade corporativa.

Notoriamente pode-se associar a espiritualidade no trabalho como sendo uma boa maneira para lidar com situações de estresse e condições de sobrecarga das atividades. É importante mencionar que a espiritualidade vem apresentando um grande impacto sobre a satisfação dos funcionários no trabalho.

Quando a espiritualidade está inserida na organização, é claramente identificado o interesse em conhecer o colaborador e em humanizar seu ambiente de trabalho, tornando de forma eficaz não somente a competência das pessoas para desenvolver o trabalho, mas constatar aquelas que realmente queiram executar tal atividade. (FERNANDEZ; GUTIERREZ, 1988).

Nesta sinergia empresa - indivíduo, Marques (2010) apresenta as principais diferenças de comportamentos entre a empresa que possui - olhar para a espiritualidade no trabalho e contra a política tradicional de trabalho.

Contudo, o caminho do ambiente espiritualizado abre uma grande possibilidade de oportunidades nos negócios, onde as organizações podem obter resultados significativos, se houver uma verdadeira 
integração e envolvimento do head office corpo diretivo - com seus propósitos.

A integração do ambiente espiritualizado proporciona uma melhor qualidade de vida devido à satisfação no ambiente de trabalho. Segundo Vaill (1989), a organização passa por várias turbulências ao mesmo tempo, oriundas de um cenário competitivo em que recorrem sentimentos nos indivíduos de ausência de liderança, de falta e perda dos valores da empresa. Devido a esse fato, a aprendizagem espiritual inspira o indivíduo para sair desse momento caótico. No entanto, não quer dizer que o lucro não possa fazer parte do negócio, pelo contrário, é mais do que correto ter o lucro, desde que seja dentro de padrões éticos para estar espiritualmente correto (HAWKINS, 1999 apud PAULA; COSTA, 2008). Afirmam Klein e Izzo (2000) que a espiritualidade não pode estar separada do trabalho, onde muitas vezes ela é até ignorada, mas jamais pode ser removida.

Entretanto, Neal (apud BOOG, 2005, p. 1) ressalta que "se qualquer organização quiser sobreviver, terá que promover radicais transformações em si mesmas. Essas não se referem à estrutura, mas sim aos valores, essencialmente aos valores do coração e da alma". Entende-se, então, que a organização é um organismo vivo, pois tem, na sua composição, as pessoas que fazem a sua identidade, ou seja, a sua missão - razão de existir -, ocasionando a transcendência para os seus valores e crenças, os quais validarão suas atitudes internas e externas.

Diante do escopo espiritualidade no ambiente de trabalho, destacam-se algumas pesquisas: Mitroff e Denton (1999) abordaram, em suas pesquisas, a espiritualidade com um propósito; Tischler (1999) relacionou a Teoria das Necessidades de Maslow com o aparecimento da espiritualidade na organização; Dent, Higgins e Wharff (2005) abordaram a Teoria da Complexidade e a espiritualidade no ambiente de trabalho; Ashmos e Duchon (2000), Kriger e Hanson (1999) e Dehler e Welsh (1994) apontaram uma definição para Espiritualidade no Trabalho; Milliman, Czaplewski e Ferguson (2003) fizeram testes para achar o grau das atitudes no trabalho sob as dimensões da espiritualidade; e Rego, Cunha e Souto (2005) criaram um instrumento de medição da espiritualidade em relação ao comprometimento afetivo, normativo e instrumental.
A evidência é clara que espiritualidade no trabalho está dissociada da espiritualidade em si, pois está limitada ao local de trabalho de uma organização. Identifica-se que local de trabalho espiritualizado é proporcionado pelo bem espiritual do estado do indivíduo com as condições do seu trabalho. Podem-se incluir outros fatores distintos influenciadores da satisfação do indivíduo na sua vida no trabalho. Caso estes fatores sejam limitados, pode ocasionar, na sequência, um resultado de insatisfação devido ao ambiente de trabalho, da organização em geral e até chegar a alguns casos pela própria vida (MILLIMAN; CZAPLEWSKI; FERGUSON, 2003).

Um aspecto fundamental da espiritualidade no trabalho implica ter um profundo senso de significado e propósito em seu trabalho. Esta dimensão da espiritualidade no trabalho representa a forma como os funcionários interagem com o seu trabalho do dia a dia, em nível individual. A expressão da espiritualidade no trabalho envolve suposições de que cada pessoa tem suas próprias motivações internas e verdades e deseja estar envolvida em atividades que dão maior significado para sua vida e as vidas de outras pessoas (MILLIMAN, CZAPLEWSKI, FERGUSON, 2003 apud ASHMOS, DUCHON, 2000; HAWLEY, 1993).

Outra dimensão sobre a espiritualidade no trabalho deve incluir a justiça, a honestidade, valores morais, necessidades, desenvolvimento de funcionários, respeito, apoio e encorajamento. Também define a espiritualidade no trabalho usando sete princípios: criatividade, comunicação, respeito, visão de parceria, energia, e flexibilidade.

Marques, Dhiman e King (2005) mencionam 19 temas, que abrangem um efeito sobre a espiritualidade no trabalho. São eles: ética, confiança, crença em Deus ou Poder Superior, respeito, compreensão, honestidade, abertura, Ser, autocriatividade, motivados a incentivar, confiança, bondade, orientação da equipe, poucas barreiras organizacionais, sensação de paz e harmonia, local de trabalho esteticamente agradável, interconexão, estimular a diversidade e aceitação. E, continuando essa relação de espiritualidade no trabalho, Kent Rhodes (EdD) menciona seis efeitos da espiritualidade no ambiente de trabalho: sustentabilidade, valores, premiação criativa, cultiva a inclusão, desenvolve princípios e promove a vocação. 
Um dos aspectos importantes do trabalho espiritualizado é proporcionar aos funcionários a sua realização pessoal, pois se sentem mais engajados e valorizados devido a programas, como o desenvolvimento de carreira e treinamentos que podem ajudá-los a lidar com diferentes situações. Como consequência, a empresa possui um melhor desempenho, melhor tomada de decisão, comunicação assertiva e inovação, pois o funcionário com a espiritualidade no trabalho possibilita 0 desenvolvimento de um sentimento de afeição com a organização, mantendo assim, a retenção dos talentos e fortalecendo a vantagem competitiva, por ter redução de custos na recontratação de funcionários baixo turn over - (ALTAF; AWAN, 2011).

\subsection{QUALIDADE DE VIDA E A ESPIRITUALIDADE NO AMBIENTE DE TRABALHO}

Conforme a Organização Mundial de Saúde (OMS), o conceito de Qualidade de Vida (QDV) está ligado àquilo que o indivíduo sente em relação a sua posição na vida, voltado a sua cultura e aos valores pessoais no qual está imerso, colocando em destaque suas expectativas, objetivos, padrões e preocupações. (ORLEY\& WHOQOL GROUP, 1994).

Conforme citado anteriormente, a psicologia positiva vem confirmar os benefícios do bemestar e das emoções positivas. Na pesquisa empírica realizada por Lyubomirsky e sua equipe, evidenciaram que é possível potencializar o bem-estar do indivíduo em até $40 \%$, devido às ações intencionais de atividades de engajamento, pois expressam um ambiente de otimismo e uma atmosfera de gratidão. (LYUBOMIRSKY, SHELDON, SCHKADE, 2005; SHELDON, LYUBOMIRSKY, 2006, 2007; KURTZ, LYUBOMIRSKY, 2008; LYUBOMIRSKY, 2007; BOEHM, LYUBOMIRSKY, 2009).

Segundo Bolman e Deal (1995), o ambiente de trabalho deve ser mais hospitaleiro, prestando serviços tanto para a organização quanto para a comunidade, e que o espaço de trabalho possa fortalecer o desempenho organizacional. Ainda nesta vertente, Conger (1997) e Dorothy Marcic (1997) reafirmam que as empresas que possuem sucesso, faz parte desse sucesso, principalmente o financeiro, a realização na organização de "valores espirituais na vida".
Segundo K. Koonmee et al. (2010), durante a última década, os efeitos de fatores como o aumento da globalização, tecnologia da informação, a competitividade das empresas no mundo e os recursos naturais limitados mudaram a opinião das pessoas de como uma boa companhia é definida. No passado, os valores financeiros foram o principal fator na definição de "uma boa companhia". Nos últimos anos, a ética, a qualidade de vida no trabalho (QVT) e a satisfação no trabalho são cada vez mais identificadas como indicadores progressivos relacionados com a função e sustentabilidade das organizações empresariais. A crescente complexidade do mundo dos negócios competitivo e complicado e o processo de implementação de leis sociais eficazes fazem com que a ética seja um fator estratégico importante para proteger as empresas contra desastres indesejados (por exemplo, BEAUCHAMP, BOWIE, 2004; CARROLL, BUCHHOLTZ, 2006; FERRELL, FRAEDRICH, FERRELL, 2008). Independentemente disso, pode-se argumentar que a boa ética é simplesmente um bom negócio.

LRN (2006a, p. 1): Culturas éticas criam confiança dentro e fora das organizações. Confiança incentiva à adequada tomada de decisão, o que leva à inovação, o que impulsiona o progresso e, finalmente, a lucratividade.

E sabendo que o trabalho é parte integrante da vida de todos, a contribuição das organizações passa a ser muito importante para o crescimento (mental) espiritual do indivíduo. Assim, o motivo pelo qual existe o interesse na espiritualidade no trabalho é decorrente de dois principais fluxos de desenvolvimento nos negócios, sendo um chamado "imperativo econômico-tecnológico" e o outro identificado como "Pessoas", o qual está centrado na gestão, denominado Teoria YZ (MCLAUGHLIN, 1998). Burack ressalta que o fluxo do "imperativo econômico-tecnológico" foi a força impulsionadora no desenvolvimento das economias de escalas visando a uma maior produtividade. Neste recente cenário, o Downsizing e reengenharia estabelecem um novo modelo de vida. Entretanto, as organizações estão imersas num ambiente competitivo com redução no retorno econômico, onde a tecnologia não é mais segredo devido ao mundo globalizado e avançado em seus processos de informação, possibilitando 0 segundo fluxo de desenvolvimento "Pessoas" como sendo o 
grande diferencial competitivo. Pode-se citar, como exemplo, a Ford Motor Company, a qual realizou uma grande mudança nas abordagens, focando, assim, nas "Pessoas" (BURACK, 1993). Realinharam a empresa para a sobrevivência e sua ação foi o "enxugamento". No início da década de 1980, acumulavam perdas financeiras aproximadamente de U\$ 3 bilhões e reduziu milhares de empregos (BURACK, 1993, capítulo 6). Houve um realinhamento severo na estratégia da empresa permeando entre dez a quinze anos, mudando radicalmente o estilo de gestão da Teoria $X$ - filosofia do fundador Henry Ford. O pensamento em que a pessoa era uma ferramenta integrante do processo foi substituído gradativamente por um novo conceito, elevando o ser humano com um recurso potencial. Esta nova visão desencadeou duas premissas fundamentais: a primeira, sendo a credibilidade corporativa com os colaboradores, clientes e consumidores; e a segunda, sendo o longo prazo, onde o sucesso do negócio seria a consequência do progresso, crescimento sustentável baseado nas pessoas. Foi um modelo praticamente inovador, baseado nas relações de confiança entre a alta administração e os funcionários, questões estas primárias para anteceder a credibilidade no relacionamento interpessoal. Esta nova abordagem de experiência de vida no ambiente de trabalho proporcionou um novo contrato social-psicológico alcançando resultados significativos ao longo dessa trajetória (BURACK, 1999).

Dessa forma, os novos papéis das relações interpessoais e a valorização dos recursos humanos fomentaram uma nova importância, isto é, as pessoas são o centro, e este recurso é construído por capacitação e centrado em atividade de equipe (ULRICH, 1998; JAFFE, SCOTT, TOBE, 1997).

O surgimento de novas formas de gestão orientada para "Pessoas" está sendo muito rentável nos últimos anos, pois visa ao equilíbrio entre negócios e trabalho alcançando alta produtividade e rentabilidade (VAILL, 1989).

A nova abordagem centrada nas "Pessoas" é o princípio para equilibrar alguns elementos, tais como: física (equipamentos, remuneração e segurança); intelectual (aprendizagem, capacitação, treinamentos); emocionais (relações interpessoais, desenvolvimento emocional e comunicação - feedback); proativa (vontade para mudar e boa adaptação às novas exigências ou condições); e espiritual (ética, a empatia para as pessoas, a justiça e a dignidade individual). Estas dimensões são totalmente interdependentes, por isso devem ser balanceadas uniformemente e dinâmicas para obter respostas e rápidas mudanças de estratégias para se chegar ao sucesso da organização (MARCIC, 1997, p, 31-43).

O foco nas pessoas serviu como o princípio de novas práticas na organização na gestão de qualidade no trabalho, nas políticas, nos processos e na cultura. Fundadores e empresários de empresas, tais como: HewlettPackard e Fel-Pro visavam ao comprometimento dessas práticas, nas quais originaram a "Theory $Y Z$ " - reflete as contribuições de Douglas McGregor (1960: Teoria X e Teoria Y) e Bill Ouchi (1980: Teoria $Z$ ). E o legado espiritual: uma visão pessoal "eu acredito que o mundo em que vivemos é regido por várias leis, física, espiritual, biológica e celular, e a bondade essencial de muitas pessoas são exemplos de coisas que não entendemos completamente, mas eu não entendo por que eles estão lá e eles trabalham e formam uma parte essencial de nossas vidas" (MARCIC, 1997, p. 2-44).

Com o surgimento da Teoria YZ, cria uma nova aplicação de espiritualidade no ambiente de trabalho. Focada em quatro diferentes resultados, seu pensamento subdivide-se em:

- Liderança e organização: preocupação voltada para os colaboradores, respeito mútuo, respeito pelos outros, atitudes dignais, leais e maduras.

- Funcionários: habilidade em desenvolver suas competências, promovendo a qualidade de trabalho, conhecimento e alta performance sustentada pela adaptabilidade.

$\begin{array}{llr}\text { - Externo } & \text { (constituintes } & \text { estratégicos): } \\ \text { qualidade, } & \text { consistência, } & \text { consciência }\end{array}$ ambiental.

- Membro responsável da comunidade: mútua confiança e partilha de responsabilidades com benefícios comuns.

Face ao fator espiritualidade a qual proporcionava resultados satisfatórios, houve muitas empresas adeptas a este modelo de gestão, pois perceberam, nas últimas décadas, que considerações da Teoria $X$ (pessoas como instrumentos de trabalho, direção centralizada) não atingem mais os objetivos. Mesmo com a tecnologia, reengenharia de processos, reestruturação, havia na organização suas lacunas e com isso 
emergiu a necessidade da utilização de novas formas de administração estratégica de pessoas. A estratégia foi baseada no empoderamento individual (empowerment), mas este não atingiu sua magnitude, pois estava faltando a autêntica confiança do indivíduo com a organização. Ciente de novos sistemas, capazes de alterar rapidamente as condições de dependência da equipe, o empoderamento possibilitou à organização ganhar um novo prêmio, ou seja, o empregado teve um maior comprometimento no trabalho focado nos objetivos. (CONGER, 1989; MEYER, ALLEN, 1997; SCHUSTER, 1998; WOOD, BANDURA, 1989). Segundo Burack e Mathys (1998), muitas empresas foram classificadas em pesquisas nacionais entre os melhores "lugares para se trabalhar", pois visavam, em longo prazo, aos lucros, tornando um grande sucesso organizacional, tema abordado nesta pesquisa. Mesmo havendo um grande número de empresas ancoradas na Teoria $X$, muitos funcionários exerciam suas opções de escolhas de emprego para aquelas que estavam comprometidas com 0 alto desempenho do empregado (BURACK, 1993; MEYER, ALLEN, 1997).

E seguindo esse pensamento sistêmico, a Hewlett-Packard, pertencente ao pequeno círculo das empresas mais conceituadas nos Estados Unidos, integrou a visão do espírito empreendedor de seus fundadores Bill Hewlett e Dave Packard. Até meados de 1970, a H-P era reconhecida pelo sucesso de uma grande empresa de instrumentos de medição de precisão. Após décadas, houve a necessidade de inovar, chegando à liderança mundial em computadores em 1990. No entanto, desde a sua fundação em 1939, a sua cultura organizacional em nível global, praticou um ambiente de trabalho moldado nas atitudes de relacionamentos, sistemas de compensação, comunicações e iniciativas de funcionários e oportunidades de atendimento. O alicerce deixado pelos fundadores foi a forma de gestão altamente descentralizada, visando objetivos a curto e longo prazos, facilitando novas oportunidades para os funcionários (BURACK, 1999).

Neste cenário, estão surgindo novas organizações assumindo novos papéis, isto é, enfatizando relações colaborativas, como contatos pessoais entre os funcionários e entre funcionários e gerentes, onde eram, muitas vezes, transacionais ou mesmo inexistentes (SHAW, 1997). Contudo, é necessária uma rápida reinvenção da gestão da organização, onde os ambientes de trabalho, que tiverem uma melhor qualidade de vida no trabalho e conscientização dos funcionários, conseguirão o prêmio de enfrentar os problemas com uma resolução destes mais rápidos, uma alta capacidade de adaptação, um veloz processo de melhoria contínua e contará com funcionários dispostos a trabalhar mais horas para 0 desenvolvimento organizacional (BEHLING, 1998, p. 82-4). Pesquisas apontavam, também, que nem sempre é fácil trazer da teoria para a prática, pois menciona que a confiança na gestão está corroída em relação ao funcionário e com isso, a desconfiança cresceu (SHAW, 1997, p. XI). Este sentimento leva a resultados medíocres, surgindo a crítica na comunicação organizacional, nos processos e nos relacionamentos. Tornar superficiais 0 relacionamento e a comunicação faz com que a organização perca tempo em administrar os conflitos, pois merece respostas rápidas para as mudanças ambientais. (SHAW, 1997, p. 1114).

A reflexão de que o indivíduo é um sentido de espiritualidade no trabalho "verdadeiro trabalho, vem de entes do próprio ser" (FOX, 1994). O último pensamento de que a bondade e ser são intercambiáveis (p. 81), onde a cultura da organização ou ambiente é propício para a espiritualidade, também o funcionário assume a expressão da espiritualidade, "Porque desafia os limites do ser e se estende para o [...] espiritual horizonte" (FOX, 1994, p. 82). A percepção por alterações no ambiente de negócios se deve a mudanças dramáticas em andamento nos ambientes de trabalho, forçando as empresas a inovarem radicalmente os seus processos e a sua estrutura organizacional. Esta reinvenção estrutural teve seus impactos externos, como a globalização, a concorrência, o envelhecimento da população, a depredação ambiental, onde houve a necessidade de formatar uma nova arquitetura organizacional (sistemas e processos), manter o foco para a tomada de decisão, o trabalho e as características de estilo de vida dos indivíduos. (BURACK, 1993).

Portanto, o novo contexto das pessoas nas organizações tem estimulado a atração e retenção de pessoas, com o objetivo de desenvolver competências diferenciais em relação aos concorrentes e às necessidades futuras (FLEURY; FLEURY, 2004). 


\section{METODOLOGIA DA PESQUISA}

A estratégia principal desta pesquisa foi utilizar a pesquisa exploratória realizada pela Fundação Instituto de Administração (FIA), onde possibilita a classificação de Melhores Empresas para Você Trabalhar nas principais empresas brasileiras enfatizando a qualidade de vida de trabalho em relação ao Índice de Felicidade no Trabalho (IFT), conforme apontado na revisão da literatura.

Segundo Gil (2010, p. 27), "as pesquisas exploratórias têm como propósito proporcionar maior familiaridade com o problema, com vistas a torná-lo mais explícito ou a construir hipóteses. Seu planejamento tende a ser flexível, pois interessa considerar os mais variados aspectos relativos ao fato ou fenômeno estudado". O autor afirma ainda que "as pesquisas exploratórias têm como principal finalidade desenvolver, esclarecer e modificar conceitos e ideias, tendo em vista a formulação de problemas mais precisos ou hipóteses pesquisáveis para estudos posteriores".

A base do banco de dados foi gentilmente cedida pela Fundação Instituto de Administração (FIA), por meio do Programa de Estudos em Gestão de Pessoas (PROGEP), responsável pela pesquisa que define anualmente As Melhores Empresas para Você Trabalhar no Brasil, a qual aborda quatro pilares de concentração - abrangência / sustentabilidade / consistência / modernidade.
Assim, o objeto da pesquisa é uma estratégia para responder à questão-problema, ou seja, os índices da pesquisa fornecidos pelo PROGEP-FIA apontaram os fatores críticos de sucesso relacionados à espiritualidade corporativa, elencando dois aspectos: a) os geradores potenciais para obter uma melhor qualidade de vida no ambiente de trabalho e b) os impulsionadores por ranquear as empresas entre as 10 Melhores.

O PROGEP-FIA avaliou 446 empresas classificando 383 empresas no programa, conforme apontado neste capítulo. Deste universo, optou-se para analisar as empresas pertencentes ao segmento de Indústrias Farmacêuticas, de Higiene e Cosméticos, nacional e multinacional, situadas no Estado de São Paulo. Segundo a Associação Brasileira da Indústria de Higiene Pessoal, Perfumaria e Cosméticos (ABIHPEC), o Brasil conquistou, em 2012, o segundo maior mercado mundial de cosméticos, e, em 2013, obteve crescimento de 17\%, alcançando US\$ 48,7 bilhões (R\$98,4 bilhões). Assim, optou-se pela escolha deste segmento para análise da amostra e, chegou-se ao resultado de 4.319 colaboradores pesquisados pertencentes às oito empresas que foram selecionadas, conforme a delimitação do estudo pesquisado. No intuito de preservar a confidencialidade dos envolvidos na amostra, segue o ranking: Empresa 046; Empresa 057; Empresa 062; Empresa 176; Empresa 215; Empresa 268; Empresa 298; Empresa 375.

Tabela 1 - O que faz com que eu considere uma empresa um excelente lugar para se trabalhar

\begin{tabular}{|l|c|}
\multicolumn{1}{|c|}{ MOTIVO } & $\begin{array}{c}10 \text { MELHORES } \\
\text { Percentual }\end{array}$ \\
\hline Sentir-me satisfeito e motivado com o trabalho que faço na empresa & $29 \%$ \\
\hline Perceber que estou aprendendo cada vez mais e que tenho oportunidade de crescer & $23 \%$ \\
\hline Concordar com os objetivos da empresa e ter orgulho de trabalhar nela & $19 \%$ \\
\hline Admirar aquilo que a empresa faz para seus clientes, sociedade e comunidade & $9 \%$ \\
\hline Receber a melhor remuneração e melhores benefícios & $7 \%$ \\
\hline Estar em um ambiente de boas relações com os colegas de trabalho & $5 \%$ \\
\hline Ter estabilidade e segurança; & $3 \%$ \\
\hline Ter chefes que eu respeito, confio e que orientam sua equipe de trabalho & $2 \%$ \\
\hline Ser tratado com justiça & $2 \%$ \\
\hline Nenhum dos motivos descritos acima & $1 \%$ \\
\hline \multicolumn{1}{|c|}{ Total } & $100 \%$ \\
\hline
\end{tabular}

Fonte: Relatório de Benchmarking (2013-2014) adaptado pelo autor 


\section{RESULTADOS DA PESQUISA}

O Gráfico 1 relaciona os motivos fundamentais da felicidade no trabalho, ou seja, fatores de espiritualidade que auxiliam a análise do ambiente interno da organização frente à mudança de empresa tradicional $x$ empresa espiritualizada.

Gráfico 1 - O que faz com que eu considere uma empresa um excelente lugar para se trabalhar

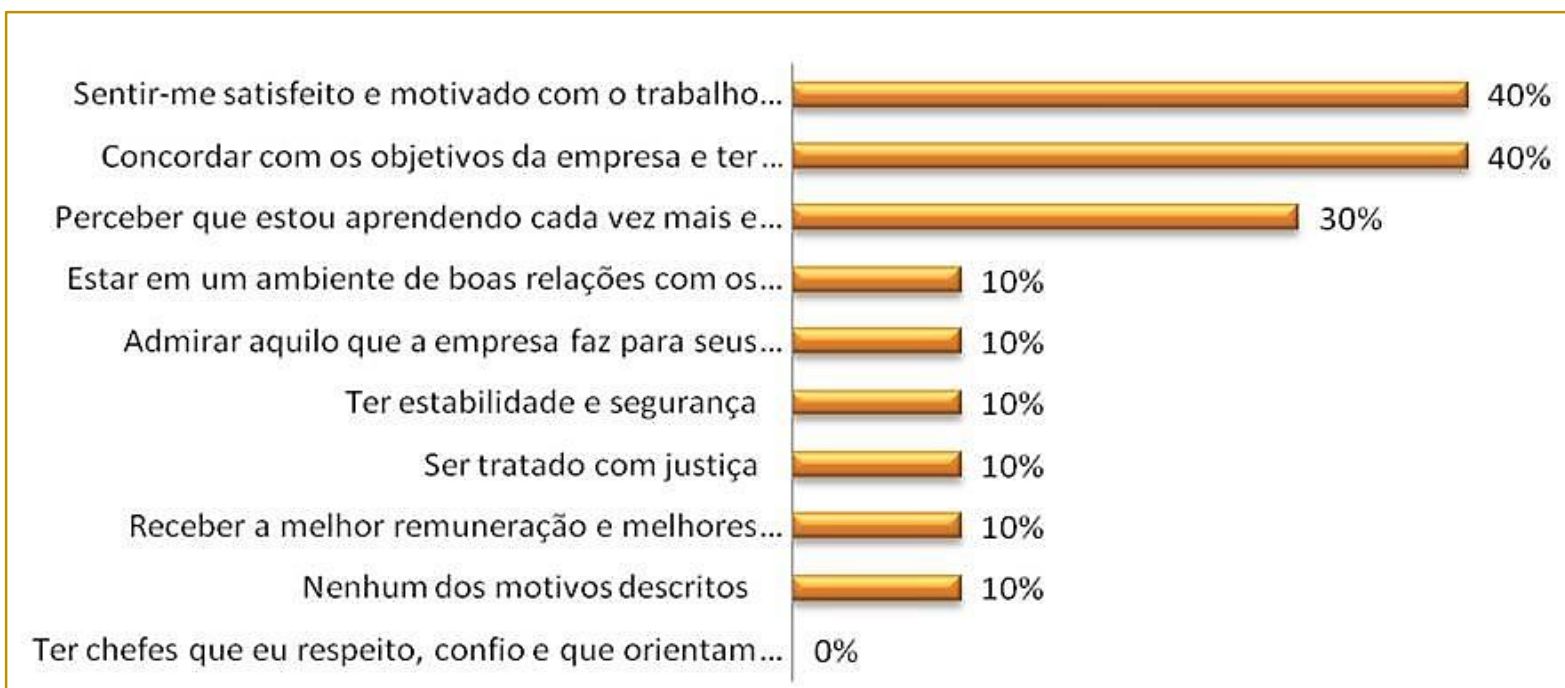

⿶ O que faz com que eu considere uma empresa um excelente lugar para se trabalhar é:

Fonte: Resultado da Pesquisa Quantitativa - FIA (2013-2014) adaptado pelo autor

De acordo com o Gráfico 1, destacam-se três índices que receberam maior percentual favorável entre os funcionários. São eles:

- Concordar com os objetivos da empresa e ter orgulho de trabalhar nela.

- Sentir-me satisfeito e motivado com o trabalho que faço na empresa.

- Estar em um ambiente de boas relações com os colegas de trabalho.

- No entanto, conforme o critério preestabelecido, entre os 10 índices, somente um índice não obteve pontuação:

- Ter chefes que eu respeito, confio e que orientam sua equipe de trabalho.

Estes motivos em destaque reforçam aquilo que Marques (2010) defende como sendo as principais diferenças de comportamentos entre a empresa que possui o olhar para a espiritualidade no trabalho e contra a política tradicional de trabalho. Fernandez e Gutierrez
(1998) destacam que são fatores de uma empresa espiritualizada quando fica claramente identificado o interesse em conhecer o funcionário e humanizar seu ambiente de trabalho, tornando de forma eficaz não somente a competência das pessoas para desenvolver o trabalho, mas constatar aquelas que realmente queiram executar tal atividade.

Conforme a figura 1, estes motivos em destaque reforçam aquilo que Marques (2010) defende como sendo as principais diferenças de comportamentos entre a empresa que possui o olhar para a espiritualidade no trabalho e contra a política tradicional de trabalho. Fernandez e Gutierrez (1998) destacam que são fatores de uma empresa espiritualizada quando fica claramente identificado o interesse em conhecer o funcionário e humanizar seu ambiente de trabalho, tornando de forma eficaz não somente a competência das pessoas para desenvolver o trabalho, mas constatar aquelas que realmente queiram executar tal atividade. 
Figura 1 - Comparativo do IQAT entre as 10 melhores e a amostra da pesquisa

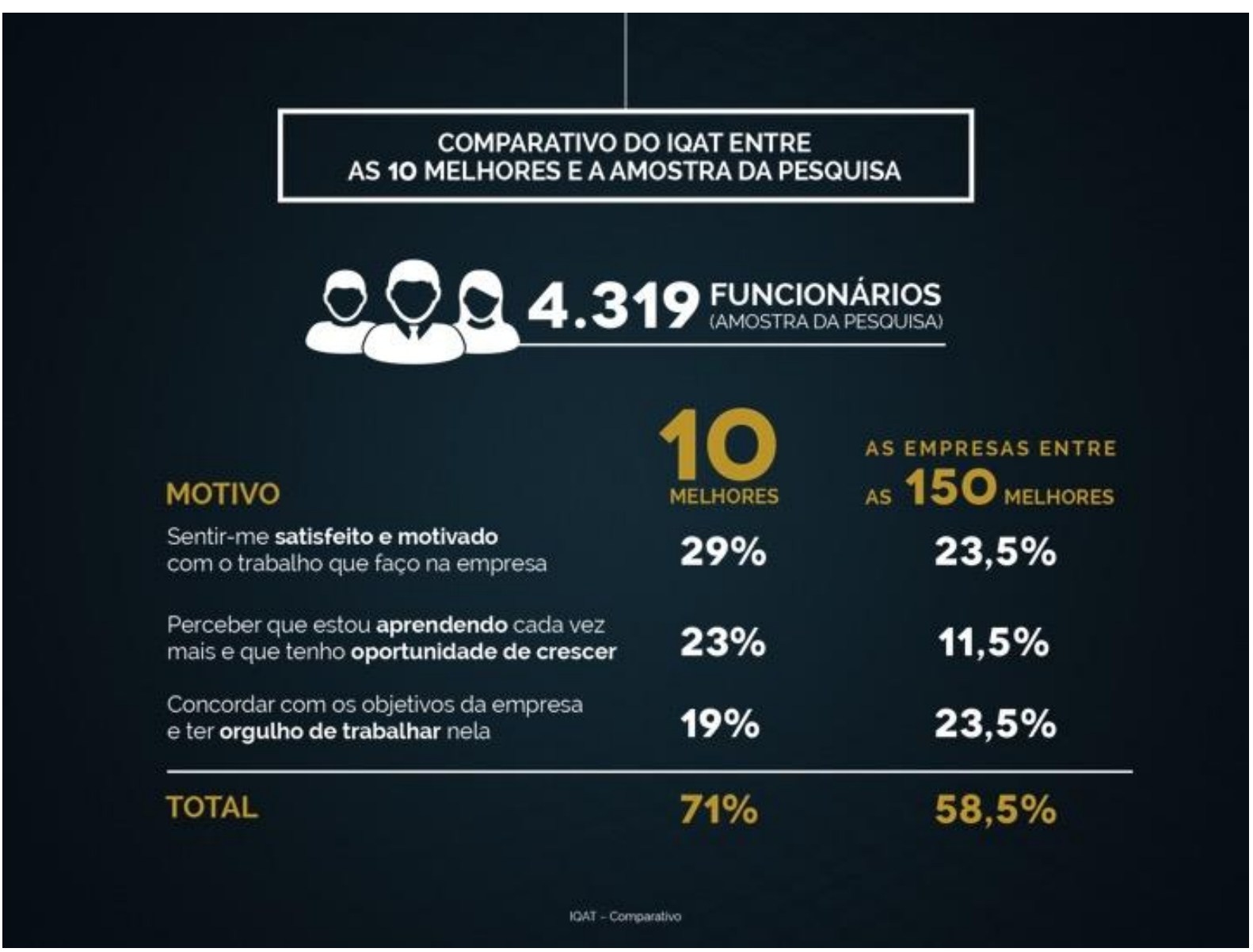

Fonte: Resultado da Pesquisa Quantitativa - FIA (2013-2014) adaptado pelo autor

\section{CONCLUSÕES}

A partir da revisão da literatura da pesquisa quantitativa fornecida pelo PROGEP-FIA e da experiência profissional do pesquisador, neste capítulo serão fornecidas as respostas às questões de estudo formuladas e também serão sugeridas novas pesquisas a serem desenvolvidas.

A primeira questão de estudo, formulada no trabalho, está voltada a identificar se a empresa pode considerar que os motivos de felicidade no trabalho proporcionam um ambiente espiritualizado.

A organização, para desenvolver a espiritualidade no trabalho, necessita desenvolver características particulares moldadas à visão da organização centrada no seu estilo de negócio e a causa de que se pretende chegar. Alguns fatores fundamentais, que influenciam este desenvolvimento, estão alinhados com a tecnologia, a concorrência, tamanho da organização e outros recursos básicos de estrutura e processo e o ambiente de trabalho, fomentando uma permanência feliz do colaborador.

Contudo, as empresas, que começarem a refletir mais sobre os valores individuais de seus colaboradores, implementarão a integração de outros valores como a sustentabilidade, a igualdade social e a espiritualidade. Com isso, para que as empresas busquem a sinergia da felicidade do funcionário no ambiente de trabalho é essencial realizar uma transcendência individualista em direção a uma consciência mais coletivista e organizacional, onde somente será possível a partir de um novo estilo de gerenciamento e de liderança, voltado ao capital humano.

Este desafio está intimamente ligado à cultura organizacional, a qual deve ser atribuída pelos seus líderes em prol da humanização da empresa para tornar resultados sustentáveis e, consequentemente, a retenção dos talentos na organização. 
A segunda questão de estudo levantada direciona-se ao entendimento se a empresa está buscando o sentido humano como fator crítico de sucesso.

É muito importante ressaltar que um ambiente espiritual, associado às atividades de espiritualidade no trabalho, pode resultar em não apenas em um funcionário satisfeito, mas em alta produtividade, alta moral dos empregados e, consequentemente, aumenta a vantagem competitiva por meio das "Pessoas".

Diante disso, as organizações partem para a prática, oferecendo uma ampla gama de sessões, aulas e seminários sobre a conscientização e realização da espiritualidade. Para manter a organização em sintonia com esta nova forma de gestão, basta verificar se está praticando procedimentos ou medidas de bem-estar, justiça ética, incentivo aos funcionários, apoio à diversidade de culturas, acompanhamento à mudança espiritual, valores fundamentados na cultura da empresa e plano de desenvolvimento dos funcionários.

Este sentido humano nas organizações vem reforçar a tendência de espiritualidade no local de trabalho. A experiência de inter-relação e confiança entre os envolvidos em um processo de trabalho, engendrada pela boa vontade individual, levará à criação coletiva de uma cultura organizacional motivacional, sintetizada pela reciprocidade e solidariedade, resultando num melhor desempenho global, que é em última análise, traduzida na duração da excelência organizacional.

A última questão a ser respondida volta-se aos funcionários que, por se sentirem satisfeitos e motivados, proporcionam um bom desempenho com benefícios mútuos.

\section{REFERÊNCIAS}

[1]. ALLPORT, G. Pattern and growth in personallity. London: Holt, Rinehart, and Winston, 1963.

[2]. ALTAF, Amal; AWAN, Mohammad Atif. Moderating Affect of Workplace Spirituality on the Relationship of Job Overload and Job Satisfaction. Journal Bussines Ethics, 104, p. 93-99, 2011.

[3]. ARANHA, M. L. de A.; MARTINS, M. H. P. Filosofando. São Paulo: Moderna, 1986.

[4]. ASHAR, H.; LANE-MAHER, M. Success and spirituality in the new business paradigm. Journal of Management Inquiry, v.13, n. 3, p. 249-260, 2004.
Os resultados obtidos nesta pesquisa trazem à luz os três principais motivos que afetam a qualidade de vida no trabalho - Sentir-me satisfeito e motivado com o trabalho que faço na empresa; Perceber que estou aprendendo cada vez mais e que tenho oportunidade de crescer; Concordar com os objetivos da empresa e ter orgulho de trabalhar nela. Estes motivos demonstraram a integração da espiritualidade baseada nos valores humanos que proporcionam uma melhor qualidade de vida devido à satisfação do funcionário no ambiente de trabalho.

Mediante a essa análise, existem caminhos diferentes que levam à felicidade e à sensação de bem-estar, pois depende das emoções positivas do indivíduo. No entanto, o que contribui para a realização é o uso das gratificações para algo maior, ou seja, disponibilizar as forças pessoais em prol de ações que favoreçam outros além de si mesmo.

Portanto, o indivíduo deve sentir o bem-estar psicológico, ou seja, em relação as suas emoções positivas, experiências positivas e ambientes positivos, onde será valorizado seus pontos fortes e suas virtudes. Este fator faz com que atinja um estado de espírito positivo, isto é, viver bem, florescerá uma vida melhor e mais feliz.

Conclui-se que a espiritualidade não pode estar separada do trabalho, onde muitas vezes ela é até ignorada, mas jamais pode ser removida. Dessa forma, é possível realizar uma empresa espiritualizada por meio da qualidade de vida no ambiente de trabalho obtendo maior produtividade e economicamente sustentável desde que seja fundamentada no indivíduo.
[5]. ASHMOS, D.; DUCHON, D. Sprituality at work; a conceptualization and measure. Journal of Management Inquiry, v. 9, n. 2, p. 134-45, 2000.

[6]. BAUMAN, Zygmunt. Modernidade líquida. Rio de Janeiro: Jorge Zahar Ed., 2001.

[7]. BEAUCHAMP TL, BOWIE NE. Ethical theory and business. Upper Saddle River, $\mathrm{NJ}$ : Pearson Prentice Hall; 2004.

[8]. BERNSTEIN, Basil. A estruturação do discurso pedagógico: classe, códigos e controle. Petrópolis: Vozes, 1996. 
[9]. BOLMAN, L. G.; DEAL, T.E. Leading with Soul, Jossey-Bass, San Francisco, CA, 2001. Original work published 1995.

[10]. BOOG, Gustavo G. Espiritualidade nas empresas. 2005, p. 1. Disponível em: $<$ http://www.empregos.com.br>. Acesso em: 30 nov. 2005.

[11]. BEHLING, O. (1998), “Employee selection: will intelligence and conscientiousness do the job?",Academy of Management Executive, Vol. 12 No. 1, pp. 77-86. BREWER, E. D. C. Life stages and spiritual wellbeing. In MOBERG, D. O. (Ed.). Spiritual Well-Being, Sociological Perspectives. Washington, DC: University Press, p. 99-111, 1979.

[12]. BURACK, E. H. Corporate Resurgence and the New Employment Relationships, Quorum, Westport, CT, 1993.

[13]. Spirituality in the Workplace. Journal of Organizational Change. Management, University of Ilinois, Chicago, Ilinois, USA, v. 12, n. 4 , p. 280-291, 1999.

[14]. CAVANAGH, G. F. Spirituality for managers: context and critique. Journal of Organizational Change Management, v. 12, n. 3, p. 186-199, 1999.

[15]. CONGER, J. A. Leadership: the art of empowering others. Academy of Management, 1989.

[16]. Spirit at Work. São Francisco: Jossey-Bass, 1994.

[17] CA. Jossey-Bass, 1997.

(Ed.). Spirit at Work. San Francisco,

[18]. DEHLER, GORDON E.; WELSH, M. A. Spirituality and Organization Transformation: implications for the new management paradigm. Journal of Management Psychology, v. 9, n. 6, p. 1726, 1994.

[19]. DENT, E. B.; HIGGINS, M. E.; WHARFF, D.MSpirituality and leadership: An empirical review of definitions, distinctions, and embedded assumptions. The Leadership Quarterly, v. 16, n. 5, p. 625-653, out 2005.

[20]. DHIMAN, Satinder; MARQUES, Joan. The role and need of offering workshops and courses on workplace spirituality. Journal of Management Development, v. 30, n. 9, p. 816-835, 2011.

[21]. FERNANDES, E. C.; GUTIERREZ, L. QVT uma experiência brasileira. Revista de Administração, São Paulo, v. 23, n. 4, 1988.

[22]. FLEURY, A.; FLEURY, M. T. L. Alinhando estratégia e competências. Revista de Administração de Empresas - RAE, v. 44, n. 1, p. 4457, jan./mar. 2004

[23]. FOX, M. The Reinvention of Work: A New Vision of Livelihood for Our Time, New York, NY: HarperCollins, 1994.
[24]. _.. The reinvention of work. New York: Harper San Francisco, 1994.

[25]. GIL, Antônio Carlos, Como elaborar projetos de pesquisa. 5. ed. São Paulo: Atlas, 2010.

[26]. JUNG, Carl et al. O Homem e seus símbolos - Concepção e Organização de Carl G. Jung. 2. ed. Ed. Nova Edição - 2a. edição especial brasileira, 2008.

[27]. KALAYANEE KOONMEE A. et al. Ethics institutionalization, quality of work life, and employee job-related outcomes: A survey of human resource managers in Thailand. Journal of Business Research, 63, p. 20-26, 2010.

[28]. KORAC-KAKABADSE, N.; KOUZMIN, A.; KAKABADSE, A. Spirituality and leadership práxis. Journal of Management Psychology, v. 17, n. 3, p. $165-182,2002$.

[29]. LIPMAN-BLUMEN, J. The allure of toxic leaders. New York: Oxford University Press, 2005.

[30]. LRN. New research reveals business impact of ethics, signals the importance of ethical cultures. New York: LRN; 2006 [updated 2006 January 30; cited 2007 October 8]. Available from: http://www.Irn.com/about_Irn/media_room/press_rel eases/146.

[31]. MANZ, C. C. Jesus o maior executivo que já existiu: lições práticas de liderança. Rio de Janeiro: Campus, 2006.

[32]. MARCIC, D. Managing with the Wisdom of Love, San Francisco, CA: Jossey-Bass, 1997.

[33]. MARQUES, J. Spiritually or politically driven behavior: differences in the workplace, Development and Learning in Organizations: An International Journal, v. 24, Iss 6, p. 12 - 16, 2010.

[34]. MATOS, F. G. Empresa com alma: espiritualidade nas organizações. São Paulo: Makron Books, 2001.

[35]. MCLAUGHLIN, C. Spirituality at work, 17 March. 1998.

[36]. MILLIMAN, J.; CZAPLEWSKI, J. A.; \& FERGUSON, J. J. Workplace spirituality and employee work attitudes: An exploratory empirical assessment. Journal of Organizational Change Management, v. 16, n. 4, p. 426-447, 2003;

[37]. MITROFF, I. I; DENTON, E. A. A spiritual audit of corporate America. San Francisco: JosseyBass Inc, 1999

[38]. A study of spirituality in the workplace. SloanManagement Review, v. 40, n. 4, p. 83-93, 1999.

[39]. NEAL, C. A conscious change in the workplace, The Journal of Quality and Participation, v. 22, n. 2, p. 27-30, 1999

[40]. PAULA, R. M de.; COSTA, D. L. A espiritualidade como diferencial competitivo para as 
organizações. In: XII ENCONTRO LATINO AMERICANO DE INICIAÇÃO CIENTÍFICA E VIII ENCONTRO LATINO AMERICANO DE PÓSGRADUAÇÃO - Universidade do Vale do Paraíba, 2008.

[41]. PAULINO, R. D. et al. Validação do questionário "espiritualidade no trabalho" de Ashmos e Duchon para o contexto paraibano. In: XX JORNADAS LUSO ESPANHOLAS DE GESTÃO, Setúbal, 2010. Anais... Setúbal, 2010.

[42]. PICCHIONI, Marta Serra Young Modernidade líquida. Revista ACOALFAplp: acolhendo a alfabetização nos países de língua portuguesa, São Paulo, v. 2, n. 3, 2007. Disponível em: <http://www.mocambras.org> e ou http://www.acoalfaplp.org>. Acesso em: out. 2013.

[43]. POOLE, E. Organizational spirituality - a literature review, Journal of Business Ehtics, v. 84, n. 4, p. 577-88, 2009.

[44]. REGO, A.; CUNHA, M. P.; SOUTO, S. Espiritualidade nas organizações e empenhamento organizacional: um estudo empírico. Área Científica de Gestão. G/nㅇ 6, p. 4-5, 2005. Disponível em: $<$ http//:www.egi.ua.pt/Wp_gestao/Wp6_Espiritual_E mpenhamento.pdf>. Acesso em: 15 set. 2013.
[45]. SANTOS, B. S. Para uma sociologia das ausências e uma sociologia das emergências. Revista

[46]. Crítica de Ciências Sociais. Coimbra, v. 63, p. 237-280, out. 2002.

[47]. SELIGMAN, M. Felicidade Autêntica: usando a Psicologia Positiva para a realização permanente. Rio de Janeiro: Objetiva, 2009. Originalmente publicado em 2002.

[48]. SHAW. Trust in the Balance. San Francisco, CA: Jossey-Bass, 1997.

[49]. SILVA, R. R. da; SIQUEIRA, D. E. Espiritualidade e satisfação no trabalho em organizações religiosas neopentecostais e tradicionais. Dissertação (Mestrado). Instituto de Psicologia da Universidade de Brasília, 2004.

[50]. TISHLER, LEN. The growing interest in spirituality in business. A long-term socio-economic explanation.Journal of Organizational Change Management, v. 12, n. 4, p. 273 - 279, 1999.

[51]. ULRICH, D. Human Resource Champions: The Next Agenda for Adding Value and Delivering Results, San Francisco, CA: Jossey-Bass, 1998.

[52]. VAILL, P. Managing as a Performing Art: New Ideas for a World of Chaotic Change, San Francisco, CA: Jossey- Bass, 1989. 


\section{Capítulo 4}

GESTÃO DE EQUIPES E RESULTADOS: UMA ANÁLISE DA MOTIVAÇAO, COMPROMETIMENTO E CLIMA, EM UM HOSPITAL REGIONAL E PÚBLICO DE SÃO JOSÉSSC

Samara Passig

Helio Alves da Cruz

Resumo: Desenvolver o trabalho em equipe é uma tarefa difícil pra qualquer gestor, mas que deve ser lapidada, a fim de fazer com que os profissionais passam a olhar a empresa como se fossem sua, passem a enxergar os objetivos pretendidos pelo gestor e pela organização, como seus próprios objetivos. E que juntos todos, gestor e demais colaboradores, efetuam suas tarefas com satisfação, qualidade e resolutividade. A motivação desses profissionais é essencial e possui um papel fundamental no processo de implantação e de introdução do trabalho em grupo. 0 profissional desmotivado se vê sem animo pra executar as suas tarefas diárias, aumentando a quantidade de absenteísmo, o que acontece frequentemente em instituições públicas. A importância da existência de uma equipe multidisciplinar de apoio a esses profissionais é de extrema importância pra auxiliar os mesmos, e despertar dentro de cada profissional o sentimento de que possa fazer a diferença no seu ambiente de trabalho. As situações que envolvem esses profissionais, são as mais variadas, e a importância do trabalho em equipe e motivação profissional se tornam mais evidente, a união em todas as esferas, e o respeito mútuo entre os profissionais da área da saúde, auxiliando assim o gestor na tomada de decisões que envolve a sua equipe.

Palavras- chave: Motivação. Equipes. Liderança. Clima. Comprometimento. 


\section{INTRODUÇÃO}

O trabalho por si em muitas áreas já é considerado exaustivo, cansativo, repetitivo e o colaborador muitas vezes se vê desmotivado com sua vida profissional. Isso se torna mais evidente quando se fala em profissionais da área da saúde, médicos enfermeiros, técnicos de enfermagem, vivenciam essa angustia diariamente, muitas vezes sem condições básicas de atendimento, falta frequente de profissionais, superlotação de pacientes, muitos em estado grave em risco eminente de vida. Essa situação é presenciada diariamente com as longas jornadas de trabalho em plantões desgastantes e muitas vezes em situações desumanas.

O processo de trabalho em saúde caracterizase pela complexidade, heterogeneidade e fragmentação. A complexidade é decorrente da diversidade de profissões e profissionais, usuários, relações sociais e interpessoais e as formas de organização do trabalho. A heterogeneidade é dada pela diversidade de muitos processos de trabalho que coexistem nas instituições de saúde e que, forma adequada com os demais processos de trabalho.

A fragmentação abrange as varias dimensões, como fragmentação conceitual, separação entre o pensar e fazer, a fragmentação técnica, caracterizada pela presença de profissionais especializados e a fragmentação social, que estabelece relações rígidas de hierarquia e subordinação, configuradas a divisão social do trabalho no interior entre diversas categorias profissionais.

A sistemática do problema é vivenciada em todas as áreas da saúde e na maioria dos seus profissionais. Os hospitais e unidades básicas de saúde já são lugares de tensão e exaustão diária, mas onde encontraríamos formas para mudar essa situação? Como o gestor poderia amenizar essas tensões e motivar seus profissionais, diminuindo a quantidade de faltas, criando um ambiente de trabalho mais leve, menos tenso, diminuindo a quantidade de absenteísmo para tratamento de saúde.

A Tensão vivenciada por esses profissionais pode ser amenizada com o trabalho em equipe e grupos de estudos para educação continuada. Dividindo as experiências com os demais colegas, poderão junto encontrar formas para solucionar as divergências e angustias diárias dos profissionais, onde os mais experientes auxiliam os mais novos na resolução das problemáticas encontradas no ambiente de trabalho.

Essa interação ira proporcionar uma maior agilidade na resolução dos problemas encontrados pelos profissionais, despertando a atitude de fazer o diferente, de não temer o medo com a mudança.

Quando se trabalha em equipe, os problemas que são vivenciados diariamente se amenizam, as soluções se tornam evidentes e as situações que pareciam difíceis e intrigantes passam a se tornar mais fáceis e compreensivas, facilitando o entendimento e resolução dos mesmos.

A importância da pesquisa nessa área é tornar visível, a pressão vivida por esses profissionais e demonstrar como a união, o trabalho em equipe e a motivação profissional podem fazer a diferença dentro de uma unidade, melhorando o atendimento e principalmente a qualidade de vida do profissional envolvido.

\subsection{OBJETIVO DA PESQUISA}

Verificar junto à unidade de saúde a preocupação com a qualidade e resolutividade, do serviço prestado pelo servidor que este inserido em seu quadro funcional;

Determinar a importância do trabalho em equipe e motivação profissional;

Identificar e conhecer a influencia do gestor sobre a equipe.

\section{FUNDAMENTAÇÃO TEÓRICA DA PESQUISA}

A fundamentação teórica apresentada deve servir de base para a análise e interpretação dos dados coletados na fase de elaboração do relatório final. Dessa forma, os dados apresentados devem ser interpretados à luz das teorias existentes (MELLO, 2006).

\subsection{MOTIVAR, E A ARTE DE LIDERAR}

E disse Deus a Adão: com suor do teu rosto comeras o teu pão, até que tornes a terra, pois dela foste formado: porque tu és pó e ao pó tornaras (GÊNISIS, 3:19, Bíblia Sagrada).

O trabalho surgiu desde o aparecimento dos primeiros seres humanos, com a necessidade de se alimentar, da moradia, de sobrevivência 
fizeram-no estarem presentes em todas as épocas e civilizações da humanidade até os dias atuais. Com o trabalho, também surgiram doenças relacionadas ao mesmo, Dejours (1992) afirma que falar de saúde do trabalhador é sempre difícil. E executar uma tarefa sem envolvimento afetivo, exige o jogo da motivação e desejo.

Mas como motivar os profissionais? Fazê-los acreditar que podemos fazer diferente, tirá-los de sua zona de conforto, sem medo de inovações? Do ponto de vista do trabalhador, um serviço tem significado para si mesmo quando exige sua participação na identificação e solução dos problemas que influem em sua vida. Trata-se, portanto, de trabalho motivador, no sentido de que o trabalhador é fortemente motivado a solucionar os problemas que o atingem pessoalmente (NEIL, 1976).

Já na antiguidade, os filósofos gregos afirmavam que o comportamento humano, baseava-se nos princípios do hedonismo: Macedo (2007, p.92) "minimizar a dor e o desconforto, e por outro lado maximizar o prazer". Assim, o estudo da motivação que é complexo dado à multiplicidade de facetas do ser humano poderá torna-se paradoxalmente simples se o gestor adotar de formas mais flexível os princípios hedonistas segundo os quais o prazer individual e imediato é o único bem possível.

Segundo Bateman e Snell (1998, p. 105), "a motivação refere-se às forças que dirigem e sustentam os esforços das pessoas numa determinada direção". Já para Motta (1995, p.192) "Motivação é a energia oriunda do conjunto de aspirações, desejos valores, desafios e sensibilidades individuais, manifestada através de objetivos e tarefas específicas." Essa definição focaliza a dimensão interna do individuo.

Segundo Bergamini (1980, p.49) "a condição ideal para haver forte motivação é quando as habilidades e energias pessoais são suficientes para atender as expectativas organizacionais e os recursos são também adequados para atender as necessidades individuais".

Schein (1982, p.61) por sua vez afirma que: "para os seres humanos adultos, o motivador é fundamental é a necessidade de manter e desenvolver o autoconceito e autoestima." Fazemos coisas que são coerentes com o modo como nos vemos; evitamos coisas que não coadunam com o modo como nos vemos; procuramos nos sentir bem com nós mesmos e evitar situações que fazem com que nos sintamos mal com nos mesmos.

Os empregados são motivados positivamente por funções que representam um desafio a sua capacidade e proporcionem senso de realização, desenvolvimento, progresso, reconhecimento e satisfação pela própria execução do trabalho. São atingidos negativamente por fatores periféricos, tais como salários, símbolos de status social e benefícios previdenciários. $\mathrm{O}$ trabalhador tende a não tomar conhecimento desses fatores negativos quando seu trabalho the parece motivador, julgando-os, porém desagradáveis, quando suas oportunidades de realização significativas são eliminadas. (MYLES, 1987).

Segundo Rocher (1986, p.33) "o trabalhador motivado pode, geralmente, desempenhar funções administrativas ligadas ao seu serviço; podem participar do planejamento, organização e controle do trabalho que executa.".

O verdadeiro perito na identificação e solução dos problemas ligados ao seu trabalho é o homem que trabalha todos os dias com eles e apesar deles. Esse homem é você, cada um de vocês. Muitas vezes vocês perguntam: "Por que eles não põem ordem esta confusão? Eles não vêem que custa dinheiro para a companhia?" Alias, é possível até que vocês tenham chamado atenção para esses problemas sem que nada fosse feito para resolvê-los. Apresentem-nos novamente; o supervisor os anotará, fará com que vocês participem de sua solução e the informaram depois a respeito dos resultados (MYLES, 1987).

\subsection{TEORIAS MOTIVACIONAIS}

\subsubsection{TEORIAS DE CONTEÚDO}

Segundo Macedo (2007, p. 93) "As chamadas teorias de conteúdo dizem respeito a priorização das necessidades internas das pessoas como fatores capazes de alavancar o processo motivacional." As mais conhecidas são a teoria da hierarquia das necessidades, a teoria dos motivos humanos e a teoria dos dois fatores. 


\subsubsection{TEORIA DA HIERARQUIA DAS NECESSIDADES DE MASLOW}

Considerada uma referência essa teoria explica que a motivação nasce da busca da satisfação de necessidades. Maslow afirmava que existem cinco sistemas responsáveis por grande parte de nosso comportamento. Ele colocou esses sistemas em uma escala hierárquica indo do mais primitivo e imaturo em termos de comportamento que eles promovem para o mais civilizado e maduro (MONTANA, 2000).

Para Maslow, existem cinco níveis de necessidade: sobrevivência; proteção ou segurança; necessidade de pertencer a um grupo; estima ou ego; e finalmente, autorealização. A teoria de Maslow traz importantes contribuições na medida em que permite identificar os grandes grupos de necessidades, o crescimento pessoal e da auto-realização em consonância com os objetivos organizacionais.

\subsubsection{TEORIA DOS MOTIVOS HUMANOS, DE MCCLELLAND}

McClelland também destaca a importância da satisfação das necessidades básicas e identifica três conjuntos que segundo ele, são adquiridos socialmente mediante aprendizagem ao longo da vida.

Realização- busca da excelência, orientação para o sucesso, alcance de metas, assunção de riscos calculados e desejo de reconhecimento. É a necessidade de desenvolver e alcançar o sucesso;

Afiliação- interesse por amizades, compartilhamento e boa convivência. Representa a necessidade de estreitar relacionamentos e de ser aceito por outros;

Poder- interesse pela liderança e pelos sinais de status. È a capacidade de influenciar ou mesmo dominar os outros (MACEDO, 2007).

McClelland concluiu que a maioria dos gestores tem níveis consideráveis de necessidades de poder, razão pela qual tendem a se ajustar melhor as organizações burocráticas.

Aguiar (1981) afirma que as pessoas movidas pela necessidade de realização não encontram as mesmas facilidades para se ajustar nesses ambientes.

\subsubsection{TEORIA DOS DOIS FATORES, DE HERZBERG}

Segundo essa teoria, não basta as pessoas ficarem satisfeitas com o ambiente de trabalho, o relacionamentos, os benefícios ou mesmo os salários percebidos para que haja um estimulo interno capaz de motivar. Herzberg distinguiu dois grupos de fatores que afetam 0 desempenho:

Fatores higiênicos- são os de manutenção, presentes no ambiente da empresa, tais como: remuneração justa, boas relações interpessoais, condições físicas satisfatórias de trabalho, benefícios. Tais fatores representam investimentos elevados e ate podem não causar satisfação, mas se forem suprimidos poderão provocar insatisfação e queda na produtividade.

Fatores motivacionais- são aqueles relacionados ao conteúdo do cargo e do trabalho realizado e que tem o poder de gerar um estado de motivação. Por exemplo, remuneração variável, desafios relacionados com recompensas, reconhecimento, grau de autonomia, auto-realização (MONTANA, 2000).

\subsubsection{TEORIAS DO PROCESSO}

Esse conjunto de teorias apresenta uma visão mais dinâmica dos processos cognitivos que influenciam o comportamento, focalizando desde sua ativação até sua supressão. Neste caso, se destacam a teoria do estabelecimento de objetivos, a teoria da equidade e a teoria da expectativa.

\subsubsection{TEORIA DO ESTABELECIMENTO DE OBJETIVOS, DE LOCKE}

Macedo (apud LOCKE 1999, p. 96) "sustenta que a intenção de trabalhar por algum objetivo constitui grandes fonte de motivação, pois suscita comportamentos proativos." A partir das pesquisas realizadas, as principais conclusões que se aplicam diretamente a gestão de pessoas: Os objetivos considerados mais difíceis conduzem a um melhor desempenho; Os objetivos específicos produzem melhor desempenho do que os objetivos vagos e imprecisos; A participação na definição dos objetivos, aumentam a aceitação pelo colaborador e o seu grau de comprometimento; O monitoramento do próprio progresso motiva mais que o feedback de outra pessoa; Pessoas com elevado grau 
de auto eficácia tendem a vencem muitos desafios. (MACEDO apud LOCKE, apud WAGNER; HOLLENBECK, 1999).

Ainda para Macedo (apud LOCKE 1999), os quatro principais métodos para provocar a motivação nas pessoas são: recompensas financeiras; fixação de metas individuais e de equipe; participação nas decisões sobre assuntos pertinentes; e criação de cargos com tarefas mais amplas.

\subsubsection{TEORIA DA EQUIDADE, DE ADAMS}

Segundo Adams (apud Robbins; Finley, 1997) o sentimento de justiça resulta da comparação de nossa contribuição e de nossas recompensas com as dos outros. Por contribuição deve-se entender o esforço e o tempo empregados, o talento e o nível de desempenho, enquanto as recompensas incluem o reconhecimento, os pagamentos, os benefícios e até as punições.

Se houver igualdade nessa proporção a certeza da equidade e tratamento com a justiça será reforçada. Havendo desigualdade, o processo motivacional será prejudicado pelo sentimento de injustiça. Dai a importância de igualdade nas relações e nas políticas que norteiam o trabalho (ADAMS apud ROBBINS; FINLEY,1997).

Ao perceber uma injustiça, o colaborador procurara reequilibrar a relação: Diminuindo sua contribuição; Pedindo maior recompensa; Solicitando maior esforço dos outros; Modificando a situação, transferindo-se ou deixando a organização.

Em geral as pessoas aceitam receber mais do que julgam merecer, mas não menos. Alguns são mais complacentes com as desigualdades de tratamento, enquanto outros reivindicam imediatamente aquilo que, a seu ver, Ihes é devido. O salário é o quesito principal, mas as comparações podem descer a minúcias tais como nome do cargo, localização da sala, tamanho da mesa e até sorrisos do chefe.

\subsubsection{TEORIA DA EXPECTATIVA, DE VROOM}

Segundo Robbins e Finley (1997, p.355), essa teoria "ajuda a explicar porque muitos trabalhadores não são motivados em seus cargos e fazem apenas o mínimo necessário para não perdê-los."
Vroom pressupõe a existência de três relações: Relações entre quantidade de esforço e o desempenho resultante da expectativa; Relação entre desempenho a mais e uma recompensa; instrumentalidade; Relação entre recompensa e satisfação de metas pessoais; valência.

Essa teoria sugere três expedientes para gerar motivação, os quais podem servir de base para a atuação do líder: Criar um ambiente propício ao bom desempenho, oferecendo treinamento, apoio e estimulo, de modo a aumentar a expectativa; Garantir que o bom desempenho seja recompensado com elogios, avaliações positivas, aumentos de salários ou de cotas de participação nos resultados; Identificar as recompensas com maiores valências (ROBBINS; FINLEY, 1997).

\subsection{A FORMAÇÃO DE UM GRUPO E DESENVOLVIMENTO DE UMA EQUIPE}

Podemos perceber que é claro em qualquer organização a importância do trabalho em equipe, junto podemos reconhecer o problema vivenciado na organização e tentar solucionar. O Ser humano desde os tempos primórdios se viu na necessidade de viver em sociedade, viver em grupos, mas o que podemos entender por grupos.

Grupos - são conjuntos de pessoas em reações coletivas com o mesmo objetivo, mantenham ou não contato entre si. Se há interações, se o individuo mantém contato uns com os outros, os grupos podem influir na personalidade, condicionando-a. Em relações públicas há grupos dum e doutro tipo: uns mantém interações, como é o caso dos funcionários de uma empresa; outros não; como é o caso de clientes de uma empresa. No primeiro caso, o grupo pode agir com esse caráter, no segundo cada individuo age por si, dai os grupos organizados ou não organizados (MAGALHÃES, 1967).

Segundo Moscovici (1994) um grupo transforma-se em equipe quando passa a prestar atenção a sua própria forma de operar e procurar resolver os problemas que afetam o seu funcionamento. Um grupo que se desenvolve como equipe necessariamente incorpora a sua dinâmica as habilidades de diagnose e de resolução de problemas.

Entende-se por equipe um conjunto de pessoas com habilidades complementares, atuando juntas numa mesma atividade, com 
propósito e objetivos comuns, comprometidas umas com as outras e com qualidade dos relacionamentos e dos resultados.

Katzenbach (2000, p.16) a define como, "um pequeno número de pessoas com habilidades complementares comprometidas com 0 mesmo objetivo, as mesmas metas de desempenho e a mesma abordagem, pelos quais elas se consideram responsáveis."

Podemos concluir então que todos nos fizemos parte de algum grupo seja ele organizado ou não. Todos nos possuímos objetivos e buscamos 0 melhor para a nossa sobrevivência, mas será que pensamos no coletivo, pensamos em o que poderia ser melhor para a nossa organização ou pro nosso colega de trabalho? Como poderíamos melhorar as situações vivenciadas em nosso trabalho em nossa organização.

Sabe-se que é uma tarefa muito difícil, mas que existem passos a ser percorridos que exigem o apoio de todas as pessoas envolvidas na ação. Mas como poderíamos fazer com que todos os membros de uma organização se sintam envolvidos.

Segundo Boettinger (1986, p.87) "administrar é dirigir. E para dirigir outras pessoas é necessário suas emoções, a fim de fazê-las participar de uma visão como se fora delas próprias. Se isso não é arte, então nada mais é." Para que um grupo evolua para o desenvolvimento de uma equipe é necessária a presença de um líder, pois como víamos nem todo grupo é uma equipe.

Henry (1986, p.89) "intuição, talento, competência e energia não são suficientes para fazer um bom administrador. Todas essas qualidades precisam ser completadas com o treinamento pessoal."

\subsubsection{PROCESSO MOTIVACIONAL - MOTIVAÇÃO E FRUSTRAÇÃO}

O grande desafio no processo de gerar motivação é descobrir o estimulo mais adequado. Caso esse objetivo seja atingido, as vezes o estimulo não é suficiente para levar ao resultado esperado e pode gerar frustrações. Assim o individuo é levado a preencher esse vazio com mecanismos de defesa.

- Racionalização- desdenhar algo que não pode ter;

- Fantasia- trocar o que se tem pelo o que se sonha:
- Projeção- atribuir a outrem a causa de seus problemas;

- Deslocamento- transferir a emoção de uma situação para outra;

- Sublimação- desviar sensações e emoções para uma condição análoga aquela que não se pode ter;

- Generalização- entender o descontentamento a todas as situações ou pessoas;

- Isolamento- afasta-se dos outros;

Apatia- indiferença a outras oportunidades.

Vergara (2003) aponta outros mecanismos de defesa, além dos psicológicos: mecanismos de defesa sociológicos - compensações no meio social, como por exemplo, o consumismo exagerado; Mecanismo de defesa químico- a satisfação é obtida mediante o uso de drogas e abuso de álcool e fumo; Mecanismos de defesa tecnológicos- por exemplo, utilização excessiva da televisão e internet.

Alguns estudiosos definem a frustração como decorrente de obstáculos físicos, como decorrente do impedimento do alcance de uma meta. O Impedimento pode ser decorrente de obstáculos físico, como distancia, falta de condições ambientais favoráveis (por exemplo, falta de recursos para realizar um trabalho) e aplicação de força física. A frustração pode também estar associada a obstáculos sociais, como normas, regras ou leis que impedem que a pessoa atinja seus objetivos. Como por exemplo, pode-se pensar em um individuo que fica frustrado porque não pode dirigir enquanto não tem carteira de habilitação. Também existem impedimentos emocionais associados ao sentimento de frustração, como aqueles percebidos em pessoas que sofrem fobia social. Essas pessoas, mesmo, tendo aptidões para alcançar certos objetivos que envolvam exposição e desempenho, são impedidos por fazê-los por suas crenças sobre si mesmas e sobre os outros sobre o mundo (MALAGRIS, 2014). 


\subsection{O DESAFIO DE ENVOLVER A EQUIPE COMPROMETENDO-SE COM OS RESULTADOS}

Ao se falar de ralações humanas, é importante falar sobre a relação entre os mesmos. Viver em sociedade não é nada fácil, entender as dificuldades do outro e respeitar seus limites é uma tarefa difícil para qualquer pessoa da nossa família, imagina quando essas diferenças são de pessoas que apenas mantemos relações profissionais e que as atitudes delas influenciam nas nossas decisões.

Vivemos em uma época marcada por grandes desafios econômicos, onde as organizações que não forem extremamente produtivas não sobreviverão. É preciso gerar resultados. As organizações precisam gerar lucros. Os órgãos públicos precisam atender as necessidades dos cidadãos e implantar as políticas governamentais com eficiência, eficácia e efetividade. As organizações não governamentais precisam cumprir fielmente a missão para o qual foram criadas e dar retorno aos investimentos feitos pelas pessoas e instituições que as sustentam (VIANNA, 1997).

O líder deve ser um obstinado por resultados, pela superação de metas, pelo compromisso com a qualidade e a produtividade, especial com o bom atendimento aos clientes. Marco Aurélio Vianna, um dos autores de abordagem mais humanistas dentre outros anteriores citados, lança um claro alerta neste sentido. Conforme ele destaca:

\subsubsection{EM BUSCA DA QUALIDADE}

Nunca se falou tanto em qualidade como nesta ultima década. Em reuniões de dirigentes, seminários de treinamento, em pesquisas de mercado e nos meios acadêmicos o tema qualidade tem sido intensamente explorado e discutido. A palavra qualidade tem vários significados dependendo de como é utilizada. Vejamos a seguir as definições de alguns autores. Podemos entender que qualidade é a capacidade de atender durante todo o tempo as necessidades do cliente, satisfazendo as suas necessidades imediatas e futuras. Segundo Deming (1951) para se ter a qualidade seria necessário seguir alguns passos: Analisar e encontrar as fontes de erros, fazer correções, eliminar defeitos e registrar detalhadamente o que acontece.
O envolvimento dos funcionários na busca de soluções de qualidade constitui um aspecto fundamental nos processos da melhoria da qualidade. A ênfase na melhoria continua reflete a tentativa de manter uma vantagem de qualidade ao longo do tempo sempre buscando novos meios para melhorar incremental mente o desempenho atual.

\subsubsection{RESOLUTIVIDADE}

É a capacidade de dar uma solução aos problemas do usuário do serviço de saúde de forma adequada, no local mais próximo de sua residência ou encaminhando-o aonde suas necessidades possam ser atendidas conforme o nível de complexidade. Segundo Gonçalves (1994) "Atendendo a sua demanda dentro da unidade ou fora dela de forma ágil e eficaz." Obtendo assim a resolutividade do processo.

\section{METODOLOGIA DA PESQUISA}

\subsection{APRESENTAÇÃO DA PESQUISA}

O procedimento técnico adotado a essa pesquisa é a exploratória e as técnicas de coleta de dados será uma entrevista através de um roteiro estruturado com os funcionários lotados na Clinica Médica do Hospital Regional Dr. Homero Miranda Gomes.

\subsubsection{NATUREZA DA PESQUISA}

A natureza da pesquisa é aplicada com objetivos de gerar conhecimento para a aplicação da pratica dirigidos a solução de problemas específicos. Segundo Gil (1999) "A pesquisa aplicada envolve verdades e interesses locais."

$\mathrm{Na}$ mesma linha de pensamento Collise e Hussey (2005) defendem que esse tipo de pesquisa visa a aplicação de suas descobertas a um problema." Segundo Castro (2006, p. 110) "Sob esse rotulo de pesquisa aplicada estariam aquelas investigações que respondessem diretamente as indagações dos que estão envolvidos na formulação da política, planejamento ou coisas do mesmo teor."

\subsubsection{ABORDAGEM QUALITATIVA}

A abordagem do problema será qualitativa, mediante a pretensão de descrever os fenômenos que compõem a interface da equipe de enfermagem. Segundo Gil (1999) "O 
ambiente natural é a fonte direta para a coleta de dados, e o pesquisador é o instrumentochave." Há uma relação dinâmica entre o mundo real e o sujeito, isto é, um vinculo indissociável entre objetivo e a subjetividade do sujeito que não pode ser traduzido em números.

Dentre os principais referenciais teóricos e metodológicos utilizados nos estudos qualitativos, optamos pelo Grounded Theory, conhecida como a Teoria Fundamentada em Dados.

\subsubsection{GRAUNDED THEORY}

Segundo os idealizadores da Grounded Theory, Glaser (1967) " essa metodologia consiste na descoberta e no desenvolvimento de uma teoria a partir das informações obtidas e analisadas sistemática e comparativamente." Para eles, a teoria significa trabalhar com dados em pesquisa, que proporciona modos de conceitualização para descrever e explicar.

Eles apresentam um método de analise comparativa constante, onde o pesquisador, ao comparar incidente com incidente nos dados, estabelece categorias conceituais que servem para explicar o dado. A teoria, então, é gerada por um processo de indução, no qual categorias analíticas emergem dos dados e são elaboradas conforme o trabalho avança, uma vez que as categorias começam a emergir dos dados ( CASAFUS, 2010).

\subsubsection{REALIZAÇÕES DE OBJETIVOS EXPLORATÓRIAS}

A realização dos objetivos será exploratória para Clollis e Hussey (2005) Esse tipo de pesquisa é voltado a pesquisadores que possuem pouco conhecimento sobre 0 assunto pesquisado, pois geralmente, há poucos ou nenhum estudo publicado sobre o tema.

A pesquisa exploratória, realiza descrições precisas da situação e quer descobrir as relações existentes entre seus elementos componentes. Esse tipo de pesquisa requer um planejamento bastante flexível para possibilitar a consideração dos mais diversos aspectos de um problema ou de uma situação (CERVO, 2007).

\subsubsection{PROCEDIMENTO TÉCNICO- EXPERIMENTAL}

O procedimento técnico adotados na pesquisa será de forma Experimental. Segundo Gil (1999) Quando se determina um objeto de estudo, selecionam-se as variáveis que seriam capazes de influenciá-lo, definem-se as formas de controle e de observação dos efeitos que a variável produz no objeto.

A pesquisa experimental caracteriza-se por manipular diretamente as variáveis relacionadas com o objetivo de estudo. Nesse tipo de pesquisa, a manipulação das variáveis proporciona estudo da relação entre as causas e os efeitos de determinado fenômeno. Com a criação de situações de controle, procura-se evitara interferência de variáveis intervenientes. Interfere-se diretamente na realidade, manipulando-se a variável independente a fim de observar o que acontece com a dependente (CERVO, 2007).

\subsubsection{COLETA DE DADOS- ENTREVISTA}

A estratégia escolhida para coleta de dados é a entrevista uma técnica que permite 0 relacionamento estreito entre entrevistado e o entrevistador.

O termo entrevista é construído a partir de duas palavras, entre e vista. Vista refere-se ao ato de ver, ter preocupação com algo. Entre indica relação de lugar ou estado no espaço que separa duas pessoas ou coisas. Portanto, o termo entrevistado refere-se ao ato de perceber o realizado entre duas pessoas (BARROS apud RICHARDSON, 1985).

\subsection{LOCAL DA PESQUISA}

A pesquisa será realizada no Hospital Regional Dr. Homero Miranda Gomes, localizado na cidade de São José, no estado de Santa Catarina. Inaugurado em 25 de fevereiro de 1987, e ativado no dia 02 de março do mesmo ano. O hospital possui 3.600 funcionários divididos em 14 setores, sendo que todos foram admitidos através de concurso publico.

O local escolhido para a pesquisa será o setor de clinica médica onde é atendido as mais diversas patologias dentre a infectologia, pneumologia, endocrinologia, neurologia entre outras. Esta dividida em 34 leitos de enfermaria masculina e feminina. 
A unidade possui 52 funcionários entre eles Enfermeiros, Técnicos de Enfermagens, Auxiliares de Enfermagem, Técnicos Administrativos, Nutricionistas, Fonoaudióloga, Fisioterapeuta, Médicos.

\subsubsection{Missão e visão da instituição}

A missão do Hospital é oferecer serviços de saúde, ensino e pesquisa, com qualidade e resolutividade, de acordo com as necessidades de nossos usuários internos e externos, com princípios de respeito, humanização e principalmente ética. Sua visão busca a excelência em quantidade e qualidade no atendimento das áreas/especialidades em que hoje atuam, focados no futuro, buscando ampliar assegurando eficiência (SANTA CATARINA. 2015).

\section{ANÁLISE DOS DADOS}

A pesquisa foi realizada entre os dias 14 a 21 de março de 2016, no setor de Clinica Médica do Hospital Regional de São José. Foi realizado uma entrevista contendo 16 perguntas objetivas e 2 perguntas Discursivas a 25 funcionários do setor.

O setor possui $64 \%$ dos funcionários do sexo feminino e apenas $36 \%$ do sexo masculino. Por ser uma empresa publica a estabilidade é uma das vantagens do gestor. Sendo que o tempo de trabalho entre os mesmos é de 2 anos a 29 anos de instituição.

Foi questionada a possibilidade de mudarem de área de trabalho e 44\%mostraram interesses por outras áreas como Administração, enfermagem, epidemiologia, nutrição, direito, Assistência social, psiquiatria e centro obstétrico, $56 \%$ preferem manter-se no setor onde trabalham.

Gráfico 1- Área de Trabalho Desejada

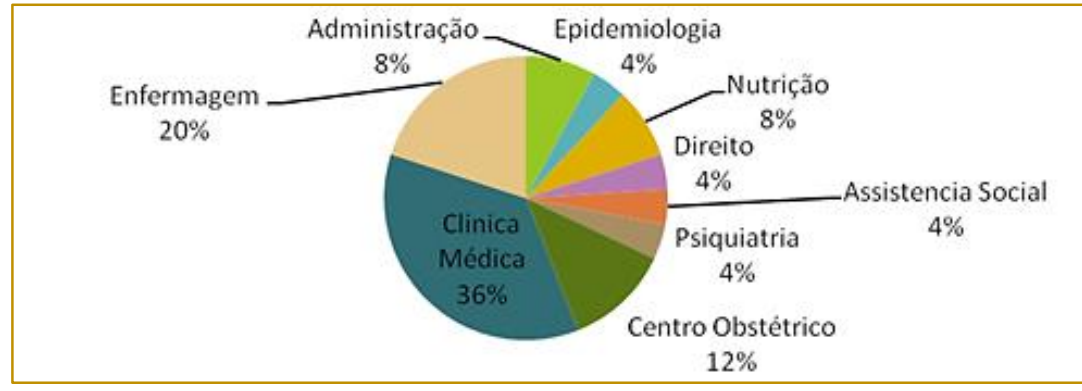

Fonte: Pesquisa Institucional, Hospital Homero Miranda Gomes (2016).

A equipe é formada por diversos profissionais das mais variadas áreas, formando um grupo multiprofissional, $72 \%$ dos profissionais tem 0 nível técnico, $20 \%$ nível superior completo e $8 \%$ estão cursando.
Entende-se por equipe um conjunto de pessoas com habilidades complementares, atuando juntas numa mesma atividade, com propósito e objetivos comuns, comprometidas umas com as outras e com qualidade dos relacionamentos e dos resultados.

Gráfico 2- Nível de Escolaridade dos Profissionais

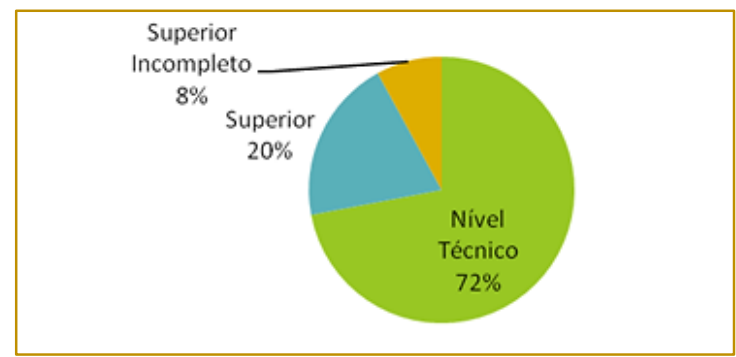

Fonte: Pesquisa Institucional, Hospital Homero Miranda Gomes (2016). 
Segundo o gráfico 1 podemos perceber que a grande interesse da equipe em começar a cursar um nível superior (44\%), apesar de apenas 8\% estarem cursando. É visível o incentivo dos próprios colegas de trabalho, sendo que a principal área desejada é a Enfermagem (20\%).

Katzenbach (2000, p.16) a define equipe como, "Um pequeno número de pessoas com habilidades complementares comprometidas com o mesmo objetivo, as mesmas metas de desempenho e a mesma abordagem, pelos quais elas se consideram responsáveis."

Quando questionado sobre os motivos que podem levar a desmotivação (gráfico 3) observa-se que $42 \%$ dos profissionais responderam que a redução do quadro de funcionários é um dos principais motivos para a desmotivação, pelo fato do sobre carregamento e a tensão vivida diariamente no ambiente de trabalho. Outros motivos também foram citados como 11\% problemas de Saúde, $13 \%$ insatisfação Salarial.

Outra questão levantada pelos profissionais foi a falta de comprometimento com a equipe e a desvalorização profissional. A grande diversidade de valores, necessidades e experiências representam um grande desafio e, como diz Vergara (203, p.42) " lidar com essas diferenças é a arte e a magia do gestor".

Gráfico 3- Motivos que Podem Levar a Desmotivação

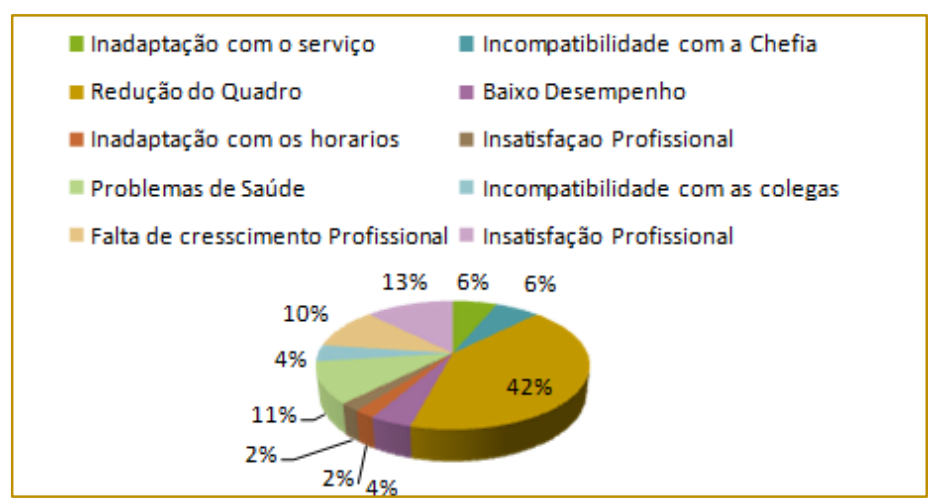

Fonte: Pesquisa Institucional, Hospital Homero Miranda Gomes (2016).

Em relação aos motivos que podem levar a motivação (gráfico 4), 27\% responderam o quadro de funcionários compatível com a necessidade, além de $22 \%$ estrutura física adequada, $6 \%$ Reconhecimento da chefia e $11 \%$ cursos de capacitação.Manter os funcionários motivados diante de uma situação nada motivadora é uma tarefa difícil para qualquer gestor, ainda mais quando envolve o ser humano. Trabalhar com o mesmo é ainda mais desafiador diante da magnitude que o envolve. O que pode ser motivador pra um, pode não ser para o outro.

Além disso, outros fatores são de extrema importância, quando se oferece uma estrutura física adequada de trabalho, cursos de capacitação aos seus funcionários os fazem sentir-se motivados profissionalmente, e serem assim reconhecidos pela chefia. 
Gráfico 4- Motivos que Podem Levar a Motivação

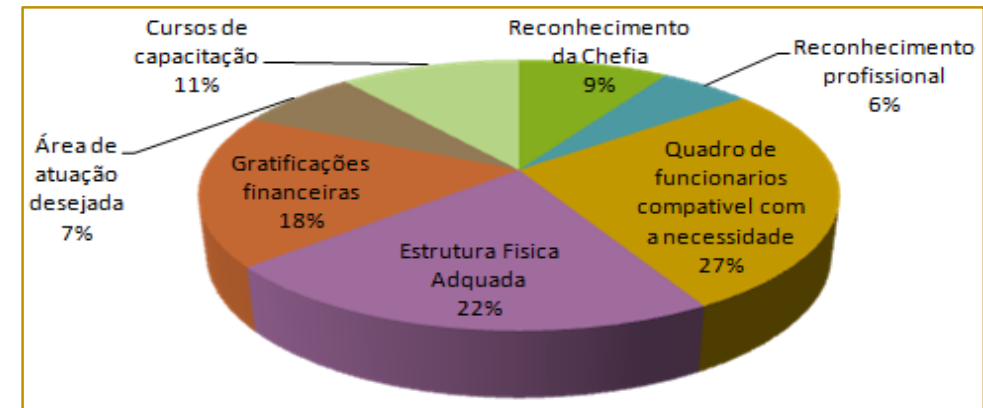

Fonte: Pesquisa Institucional, Hospital Homero Miranda Gomes (2016).

Os empregados são motivados positivamente por funções que representam um desafio a sua capacidade e proporcionem senso de realização, desenvolvimento, progresso, reconhecimento e satisfação pela própria execução do trabalho.

São atingidos negativamente por fatores periféricos, tais como salários, símbolos de status social e benefícios previdenciários. Segundo Myles (1987) O trabalhador tende a não tomar conhecimento desses fatores negativos quando seu trabalho the parece motivador, julgando-os, porém desagradáveis, quando suas oportunidades de realização significativas são eliminadas.

Sobre o ambiente de trabalho (gráfico 5) apenas $7 \%$ consideram um ambiente de trabalho Bom, $78 \%$ consideram regular e 14\% ruim. Em relação as orientações prestadas pelos gerentes e coordenadores $71 \%$ consideram bom , $14 \%$ regular, $14 \%$ ruim, $7 \%$ ótimo.

Quando perguntado sobre a relacionamento com os colegas de trabalho $90 \%$ responderam que é um bom relacionamento, e tentam ajudar o máximo possível para que o trabalho seja realizado da melhor forma.

Segundo Rocher (1986, p.33)"O trabalhador motivado pode, geralmente, desempenhar funções administrativas ligadas ao seu serviço; podem participar do planejamento, organização e controle do trabalho que executa.".

Gráfico 5- Clima Organizacional

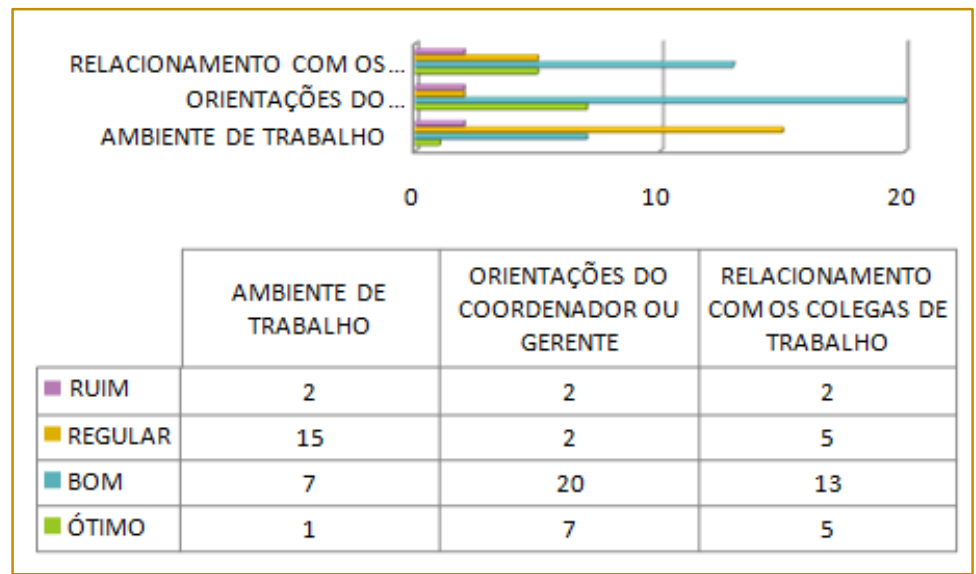

Fonte: Pesquisa Institucional, Hospital Homero Miranda Gomes (2016). 
A remuneração também não é um problema (gráfico 6) sendo que $78 \%$ dos profissionais consideram boa, e $40 \%$ consideram os benefícios regulares. Uma das principais queixas é a falta de infraestrutura física adequada e falta frequente de materiais e medicamentos onde 95\% dos entrevistados consideram ruim, pois atrapalha e muito 0 desempenho de suas atividades diárias.

O verdadeiro perito na identificação e solução dos problemas ligados ao seu trabalho é o homem que trabalha todos os dias com eles e apesar deles. Esse homem é o próprio funcionário, cada um deles. Muitas vezes eles se perguntam: "Por que eles não põem ordem nesta confusão? Para Myles (1987), eles não veem que custa dinheiro para a empresa?" Alias, é possível até que vocês tenham chamado atenção para esses problemas sem que nada fosse feito para resolvê-los. Apresentem-nos novamente; o gestor os anotará, fará com que vocês participem da sua solução e the informarão depois a respeito dos resultados.

Gráfico 6- Estrutura e Benefícios

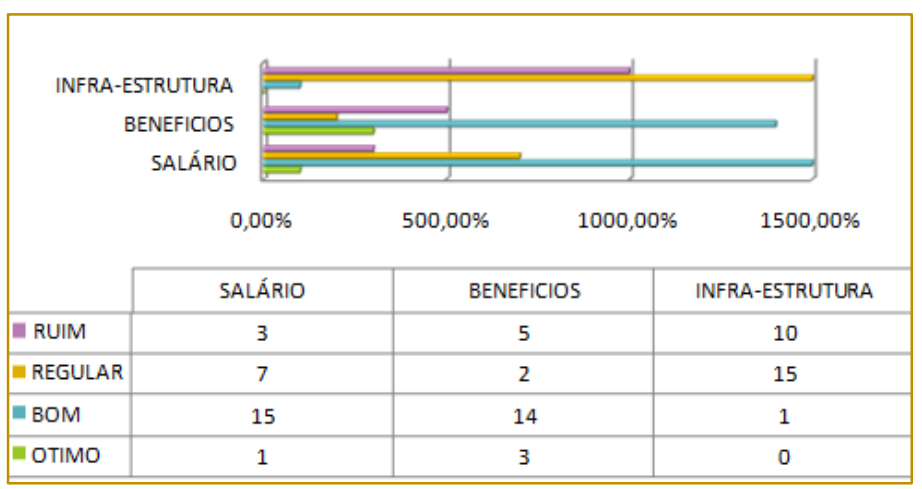

Fonte: Pesquisa Institucional, Hospital Homero Miranda Gomes (2016).

No final da entrevista foi solicitado aos colaboradores que descrevessem pontos positivos e negativos da instituição e citaram que: é visível o interesse dos profissionais em cursos de capacitação, os mais citados foram de PCR- Parada Cardio-Respiratória e de Ulceras. As Chefias se mostraram interessadas e irão realizar os cursos solicitados pelos profissionais.

Viana (1997) "Destaca a necessidade de que - líder esteja buscando continuamente conhecer os fatores de motivação de sua equipe. Deve indagar aos colaboradores quais são seus sonhos e verificar se a organização tem atendido aos mesmos." O escopo de toda chefia é obter de seus auxiliares o rendimento ótimo no trabalho. Para isso o chefe terá de ser como o político: flexível, maleável, avançando aqui, recuando a cola, modificando método e atitudes. É um erro grave permanecer exclusivamente numa forma de comportamento, tomando sempre a mesma atitude face a face com qualquer pessoa.
Outro fato levantado foi a importância do trabalho em equipe e a motivação por parte da chefia. A equipe se mostra com vontade e disposição para ajudar uns aos outros e desenvolver assim um melhor gerenciamento das atividades rotineiras. O que pedem é maior reconhecimento da chefia diante de situações que levam em conta o bem estarem do paciente e dos profissionais envolvido.

\section{CONCLUSÃO}

O presente estudo teve como objetivo principal determinar a importância do trabalho em equipe e motivação profissional, identificar e conhecer as influências do gestor sobre a sua equipe e verificar junto a unidade de saúde a preocupação com a qualidade e resolutividade do serviço prestado pelo servidor que esta inserido em seu quadro funcional.

Com estudo realizado podemos concluir que as pessoas são o maior patrimônio que uma organização pode ter, pois é o trabalho e 
esforço de cada um dos colaboradores que depende a eficiência e eficácia das atividades desempenhadas. Assim valorizar as pessoas e ao mesmo tempo motivá-las a fazer a coisa certa é um desafio que todas as organizações enfrentam nos tempos atuais.

A partir da pesquisa o gestor poderá encontrar o estímulo certo para cada membro da equipe, facilitando assim a tomada de decisão. È de extrema importância que o gestor adote uma das varias teorias motivacionais para envolver a sua equipe. Escolher uma teoria que melhor adapte seu grupo e trabalhar arduamente para que todos se sintam envolvidos com os mesmos objetivos.

Tornou-se claro a necessidade do gestor ouvir seus colaboradores e ajudá-los ou oferecer o

\section{REFERÊNCIAS}

[1] Macedo, Ivanildo Isaias. Aspectos Comportamentais da Gestão de Pessoas. Rio Dejaneiro: FGV, 2007.

[2] Chiavenato, Idalberto. Administração nos novos tempos. 2 edição. Rio de Janeiro: Elsevier, 2004.

[3] Castro, Claudio de Moura. A Prática da Pesquisa. 2 edição. São Paulo: Pearson Prentice Hall, 2006

[4] Cervo, Amado Luiz. Metodologia Cientifica. 6 edição. São Paulo: Pearson Prentice Hall, 2007.

[5] Barros, Aidil Jesus da Silveira. Fundamentos da Metodologia Cientifica. 3 edição. São Paulo: Pearson Prentice Hall, 2007.

[6] Souza, Adriano Dias. Gestão Efetiva: capacitando a equipe a realizar objetivos. Blumenau: Nova Letra, 2007.

[7] Dejours, Christophe. A loucura do Trabalho: estudo de psicopatologia do trabalho. São Paulo: Cortez- Oboré, 1992.

[8] Boettinger, Henry M. Administração é realmente uma arte?.São Paulo: Nova Cultura, 1986.

[9] Magalhães, Celso de. Relações Públicas e Relações Humanas. 3 edição. Rio de Janeiro: Fundação IBGE 1967.

[10] Kotler, Philip. Da Obsessão de Vendas á eficiência de Marketing. São Paulo: nova Cultura, 1986.

[11] Niel, Mackinnon L. Motivação pelo trabalho Significativo. São Paulo: nova Cultura, 1986.

[12] Souza, Cesar. Pensamento Estratégico para lideres de hoje e amanhã. São Paulo: Integrare, 2008. apoio adequado quando necessário. Mostrando-se aberto a ajudar sanar os problemas que podem vir acontecer.

Assim considera-se que os objetivos foram alcançados, tendo em vista que foi possível identificar, tanto na metodologia quanto na pesquisa de campo que a presença do líder é de extrema importância, o líder motivador vai fazer com que sua equipe trabalhe em sintonia e busque alcançar os objetivos da empresa como se fossem seus objetivos.

Administrar é dirigir. E para dirigir outras pessoas é necessário captar suas emoções, a fim de fazê-las participar de uma visão como se fora delas próprias. Se isso não é arte, então nada mais é.

[13] Mills, Ted. Recursos Humanos: Porque toda essa preocupação agora?. São Paulo: nova Cultura, 1986.

[14] Drucker, Peter F. Novos padrões para as organizações de Hoje. São Paulo: nova Cultura, 1986.

[15] Levitt, Theodore. Criatividade é suficiente. São Paulo: nova Cultura, 1986.

[16] Gil, Antonio Carlos. Gestão de Pessoas: enfoque nos papéis profissionais. São Paulo: Atlas, 2001.

[17] Barnes, Louis B. Como Gerar Confiança dos Funcionários na Empresa. São Paulo: nova Cultura, 1986.

[18] Costa, Flavio Rodrigues. Psicologia nas Organizações. Palhoça: UnisulVirtual, 2007.

[19] A Biblia, Anotada. São Paulo: Mundo Cristão, 1994

[20] Carvalho, Geraldo Mota de. Enfermagem do Trabalho. São Paulo: EPU, 2001.

[21] Ludin, Stephen C. Peixe! Como Motivar e Gerar Resultados. Rio de Janeiro: Campus, 2000.

[22] Santa

Catarina. http://portalses.saude.sc.gov.br/index.php?option= com_content\&view=article\&id=3355\&ltemid=525). Data de acesso 01/09/2015.

[23] Motta, Fernando C. Preste. O que é burocracia. 16. Ed. São Paulo: brasiliense, 2000.

[24] Bateman, Thomas; Snell, Scott. Administração: Construindo vantagem competitiva. São Paulo: Atlas, 1998.

[25] Bergamini, Cecilia Whitaker. Desenvolvimento de Recursos humanos: uma 
estratégia de desenvolvimento organizacional. São Paulo: Atlas, 1980.

[26] Schein, Edgar H. Psicologia Organizacional. Rio de Janeiro: Pretince Hall do Brasil, 1982

[27] Myles, Mace L. O Presidente e o planejamento empresarial. São Paulo: Nova Cultura, 1987.

[28] Roche, Willian J. Motivação pelo trabalho significativo. São Paulo: Nova Cultura, 1987.

[29] Montana, Charnov. Administração. São Paulo: Saraiva, 2000.

[30] Aguiar, M. A. E. Psicologia Aplicada a Administração a Psicologia organizacional. São Paulo: Atlas, 1981.

[31] Robbins, H; FINLEY, M. Porque as equipes não funcionam: o que não deu certo e como tornalas criativas e eficientes. Rio de Janeiro: Campus, 1997.

[32] Moscovici, Fela. Desenvolvimento interpessoal. Rio de Janeiro: Atlas, 1991.
[33] Katzenbach, John R. Equipes Campeãs: desenvolvendo o verdadeiro potencial de equipes e lideres. Rio de Janeiro: Campus, 2000.

[34] Vergara, Sylvia. Gestão de pessoas. 3ed. São Paulo: Atlas, 2003

[35] Bennis, Warnen. A invenção de uma vida. Rio de Janeiro: Campus, 1995.

[36] Collis, Jill; Hussey, Roger. Pesquisa em Administração: um guia pratico para alunos de graduação e pós- graduação. 2. Ed. Porto Alegre: Bookman, 2005

[37] Glaser BG, Strauss AL.The discoveryofgroundedtheory. New York (USA):

[38] Aldine; 1967

[39] Casafus, Karen Cristina Urtado. Entre o êxito e a frustação com a operacionalização da SAE; Recursos humanos como componente determinante para a visibilidade do enfermeiro no processo de trabalho. Botucatu, 2010.

[40] Malagris, Lucia Novais. Sentimentos que causam stress. Campinas: Papirus,2014. 


\section{Capítulo 5}

\section{O CLIMA ORGANIZACIONAL EM UMA INSTITUIÇÃO DE ENSINO FEDERAL - UM ESTUDO DE CASO}

\section{Dennis Hanson Costa}

Resumo: O estudo discute os conceitos de clima e cultura organizacionais, aplicando-os ao estudo de caso de uma instituição federal de ensino básico, técnico e tecnológico. A metodologia aplicada é a da observação participativa, buscando compreender como e porquê o clima organizacional é capaz de afetar o desempenho coletivo da organização de forma positiva ou negativa. A conclusão é que as lideranças da organização são responsáveis pelo clima organizacional, permitindo que afetem o desempenho dessa organização - no caso estudado, negativamente.

Palavras-chave: clima organizacional, cultura organizacional, desempenho corporativo, gestão de pessoas 


\section{INTRODUÇÃO}

Enquanto que a cultura organizacional é um conjunto de crenças e valores compartilhados pela maioria dos colaboradores e passados aos membros mais novos pelos mais experientes, o clima organizacional reflete um momento dessa cultura, podendo ou não inserir-se definitivamente na cultura dada a sua aceitação e reprodução pelo grupo.

Optou-se por caracterizar os eventos neste trabalho como pertinentes ao universo do clima organizacional parcialmente na expectativa de que se tratem de situações provisórias, que tendem a desaparecer à medida em que a organização estudada amadureça e que a gestão mude. Espera-se que este seja o destino do caso estudado, dado que reitores e diretores e suas respectivas equipes são eleitos a cada quatro anos.

A questão fundamental que norteia o estudo é o quanto o clima organizacional é capaz de afetar o desempenho coletivo da organização de forma positiva ou negativa.

Para tal, além da base na teoria estabelecida sobre o tema, escolheu-se uma instituição federal de ensino básico, técnico e tecnológico como objeto de um estudo de caso, tendo como metodologia a observação participativa (Richardson, 1999), dado que o autor foi membro efetivo do corpo docente durante pouco mais de dois anos, tendo vivenciado pessoalmente a maioria das situações referidas.

A revisão da literatura, presente na seção a seguir, concentra-se então no que há de estudos sobre clima organizacional e seu impacto no desempenho das equipes afetadas por ele.

\section{REVISÃO DA LITERATURA}

\subsection{DEFINIÇÃO DE CLIMA ORGANIZACIONAL E DE CULTURA ORGANIZACIONAL}

Tem-se, então, que o clima organizacional, ou clima corporativo, é um conjunto de características do ambiente de trabalho, percebidas direta ou indiretamente pelos colaboradores, entendida como uma força importante na influência do comportamento da equipe (IVANCEVICH, KONOPASKE, e MATTESON, 2007).

O clima organizacional pode ser definido como padrões recorrentes de comportamento, atitudes e sentimentos que caracterizam a vida na organização, enquanto que a cultura organizacional tende a ser profunda e estável (ISAKSEN e EKVALL, 2007).

Enquanto a cultura abarca os valores e crenças mais profundos, juntamente com símbolos, rituais e heróis, o clima define um espaço e um momento psicológico e sociológico específico. Mesmo quando se trata de uma organização, rituais como o hastear da bandeira nacional ou mesmo fazer uma prece antes da jornada iniciar-se podem fazer parte de sua cultura, assim como símbolos como um prédio ou até o primeiro veículo de entregas, cuidadosamente preservado, seguindo para o culto a heróis corporativos, como no caso do Comandante Rolim, na empresa aérea TAM e de Steve Jobs, na Apple.

A cultura organizacional pode, ao longo do tempo, absorver aspectos recorrentes do clima organizacional. Mesmo em casos extremos, como situações de competição interna e externa feroz ou climas de medo e insegurança permanentes, tais comportamentos podem incorporar-se à cultura, com as consequências esperadas.

Dallas (2003) ao estudar os fatores legais do escândalo da Enron, empresa americana de energia envolvida em falência fraudulenta, destaca a importância dos fatores culturais que permitiram o comportamento pouco ético de seus dirigentes, dentre eles um entendimento tácito de que regras e leis podiam ser "flexibilizados" se as circunstâncias assim o determinassem. Segundo Dallas (2003), a lei e as regras eram vistas na empresa como empecilhos à inovação, à criatividade e ao espírito empreendedor ao invés de ser o seu alicerce, a ponto de haver o encorajamento por parte do CEO Jeffrey Skilling para que funcionários forçassem as regras, mesmo sem 0 conhecimento de seus superiores.

Depreende-se do exemplo acima que a cultura molda o comportamento da organização como um todo, para o bem ou para o mal.

Como o clima organizacional imprime o passo do dia a dia, seus efeitos também podem ser sentidos também para o bem ou para o mal.

\subsection{ABORDAGENS TEÓRICAS DO CLIMA ORGANIZACIONAL}

Há duas vertentes distintas para o estudo do clima organizacional. No primeiro deles, conhecido como esquema cognitivo, derivado do pensamento do psicólogo, filósofo e 
estudioso da pedagogia Jean Piaget (18961980), entende-se que o clima organizacional seja uma percepção de cada indivíduo a respeito do ambiente que o circunda, os estudos a respeito devendo, portanto, ser conduzidos indivíduo a indivíduo. Os esquemas cognitivos são entendidos como estruturas mentais representativas de aspectos da realidade, organizados em forma de redes associativas na memória de cada pessoa. Destarte, nessas redes associativas esquemas correlatos são agrupados, com um esquema sendo geralmente trazido à mente em conjunto com um ou mais de seus correlatos (DERRY, 1996).

Dois processos se destacam em meio ao conceito de esquema cognitivo: a saliência e a imprimadura. No primeiro caso, quanto mais proeminente, evidente ou saliente um comportamento, mais ele tende a se manifestar, como no caso da falta de ética da Enron, mencionada acima. No que tange à imprimadura, esta se refere a experiências recorrentes na organização, como por exemplo o caso da intolerância a erros. Por mais que haja um discurso explícito de inovação, o entendimento tácito por parte da equipe é o de que erros são punidos. Como decorrência, tem-se que a equipe tende a inovar menos, correndo menos riscos de punição.

A segunda vertente refere-se ao modelo da percepção compartilhada no estudo do clima organizacional. Este arcabouço teórico busca identificar as variáveis que regem ou moderam a capacidade que uma organização tem de mobilizar suas equipes para o atingimento dos objetivos corporativos. Por meio de pesquisas de clima organizacional, uma entidade pode medir os aspectos que impactam no estresse, moral, bem estar, envolvimento, desempenho, qualidade de vida no trabalho, acidentes de trabalho, absenteísmo e turnover (ROSE e GRIFFIN, 2002).

Rose e Griffin (2002) também observam que, embora as lideranças corporativas sejam incapazes de eliminar todos os fatores de estresse do dia-a-dia do trabalho, estudos revelaram uma quantidade de comportamentos de líderes que impactam significativamente no estresse e no moral da equipe.

\subsection{CLIMA ORGANIZACIONAL E DESEMPENHO}

Stetzer, Morgeson e Anderson (1997) realizaram um estudo com 25 equipes de trabalho externo da Bell Atlantic, empresa americana de telecomunicações, correlacionando clima organizacional no nível divisional com eficiência e produtividade ou com o seu oposto, a ineficiência.

Alvarado (1984) propõe uma extensão a uma metáfora corrente que associa uma organização a um organismo humano. Além das usuais associações com a anatomia e a fisiologia, o autor sugere uma visão ligada à patologia - o estudo da doença - para o entendimento de alguns aspectos organizacionais.

Alvarado (1984) cita Ackoff (1974) com a frase: "...essa definição de saúde aplica-se igualmente a organismos e organizações.", convidando ao uso de um paradigma mais amplo para o estudo das organizações. Esse paradigma mais amplo também acrescenta à metáfora: "A organização, como o corpo humano, pode adoecer."

A patologia organizacional, portanto, estaria relacionada à [in]capacidade de um organismo com propósitos de preencher suas necessidades e buscar seus objetivos, ou seja, à diminuição do desempenho da organização comparada a outras entidades semelhantes.

Alvarado (1984) procede a descrever as diversas patologias de um organismo aplicadas a uma organização, incluindo inflamações, degenerações e neoplasias (tumores). Não há dúvidas, portanto, que um mau clima organizacional é um fator de doença organizacional.

Por outro lado, Hellriegel, Slocum e Woodman (2011) explicam que organizações podem tomar medidas para construir um clima positivo, centrado no colaborador, por meio de:

Comunicação - qual a frequência e os meios usados para a informação e a comunicação na organização;

Valores - os princípios que norteiam a organização e se estes são ou não modelados pelos colaboradores, incluindo as lideranças;

Expectativas - tipos de expectativas a respeito de como gerentes se comportam e tomam decisões; 
Normas - os modos normais e rotineiros de comportamento e de tratamento interpessoal na organização;

Políticas e regras - são responsáveis por explicitar o grau de flexibilidade e restrição na organização;

Programas - programação e iniciativas formais auxiliam no apoio e reforço do clima no ambiente de trabalho;

Liderança - líderes que consistentemente apóiam o clima desejado.

Patterson, Warr, e West (2004) descobriram que organizações fabris que enfatizavam um clima organizacional positivo, especificamente a preocupação pelo bem estar dos colaboradores, focando na flexibilidade, aprendizagem e desempenho, mostraram mais produtividade que outras organizações que davam menos ou nenhuma ênfase a esses fatores.

Oswald, Proto e Sgroi (2014), em estudo preliminar conduzido no Departamento de Economia da Universidade de Warwick, Grã Bretanha, fazem uma associação positiva entre a "felicidade", ou bem estar na vida e no trabalho e produtividade. A comprovação da tese proposta se dá por meio de experimentos em ambiente controlado, no qual 713 jovens adultos de ambos os sexos são expostos a situações geradoras de bem estar e geradoras de estresse, seguidas de tarefas nas quais se mede o desempenho dos participantes.

As conclusões são igualmente interessantes: os autores sugerem que economistas e outros cientistas sociais deveriam prestar mais atenção ao bem estar emocional como uma força causal [...] se a felicidade no ambiente de trabalho acarreta em um retorno de produtividade, as conclusões do estudo deveriam ter consequências nas políticas de promoção das empresas e podem ser relevantes para gestores e especialistas em recursos humanos. Finalmente, se o bem estar aumenta o desempenho de indivíduos no trabalho, isso traz a possibilidade, no nível microeconômico e talvez até no macroeconômico, de espirais autossustentáveis entre a produtividade e o bem estar humanos.

Cabe lembrar aqui a famosa experiência Hawthorne, realizada pelo sociólogo Elton Mayo numa fábrica da Western Electric de Hawthorne, perto de Chicago, entre os anos de 1928 e 1933. O experimento, que começou na verdade com outra equipe de pesquisadores em 1924 visando a testar a influência das condições de trabalho na produtividade, acabou mudando de rumo e introduzindo uma nova perspectiva nos estudos organizacionais quando juntou a ela a ciência comportamental criando o que veio a se chamar a escola das relações humanas nos negócios (CAREY, 1967).

\subsection{CLIMA ORGANIZACIONAL E ESCOLA}

Em artigo recente, Babu e Kumari (2013) estudaram 100 professores de escolas elementares do distrito de Koderma em Jharkhand, India. Dos 100 entrevistados, 50 trabalhavam em escolas públicas e os 50 restantes em escolas particulares.

Dentre as observações dos autores, destacase que para que um professor seja eficaz, uma certa autonomia deve ser providenciada de modo que se possa prover as necessidades dos estudantes. Da mesma forma que o estudante requer espaço, liberdade, flexibilidade e respeito, o mesmo pode ser dito sobre o professor. Professores e seus superiores hierárquicos devem compartilhar um relacionamento baseado na igualdade e no respeito mútuo de modo a criar um clima organizacional positivo.

O clima entendido como aberto foi correlacionado aos melhores resultados educacionais, enquanto que o fechado afetava negativamente o desempenho da equipe. As características da liderança no ambiente de clima fechado incluíam a pressão psicológica, - controle excessivo, a obsessão por resultados e a pressão humanizada, resultando em comportamentos da equipe como alienação, não envolvimento e mau humor. Ainda dentro do tema, os autores (2013) descobriram uma maior incidência de síndrome do burnout e exaustão emocional dentre os professores atuando em ambientes de clima fechado.

\subsection{A "GESTÃO PELO TERROR"}

A expressão "Gestão pelo Terror" tem origens no período da revolução francesa no qual dominava Maximilien Robespierre. Foi um período dominado pelo terror da guilhotina, vigilância intensa por parte do Estado, intensa desconfiança de tudo e de todos e indiscriminadas delações. 
Em nossos dias, muitas empresas adotam o terror como instrumento de gestão de pessoas, conforme descrito no caso abaixo:

Fazer parte de uma empresa cotada nas principais bolsas de todo o mundo, com mais de 186 milhões de clientes em 30 países, poderia ser o sonho de qualquer trabalhador. Para o funcionário da France Télécom que, a 28 de Setembro, se atirou de uma ponte, na auto-estrada $A 41$, na região da Alta Sabóia, não foi, todavia, mais que um pesadelo. Antes de pôr fim à própria vida, o homem de 51 anos, casado e pai de dois filhos, que trabalhava num call-center, em Annecy-le-Vieux, deixou no carro uma carta em que atribuía a culpa do seu acto ao ambiente profissional insuportável.

Pouco tempo antes, a 14 de Julho, o testemunho de um colega de Marselha, que também se suicidou, foi ainda mais corrosivo. Especialista em redes móveis e antigo maratonista, deixou claro que "a única causa" por detrás da sua morte foi o emprego na France Télécom.

Longe de serem pequenas ilhas num universo de 187 mil colaboradores (102 mil só em França), estes dois homens fazem parte de um arquipélago de angústia maior que estrangula grande parte dos quadros do terceiro maior operador móvel europeu. À semelhança do que aconteceu na também francesa Renault, os 24 casos verificados desde Fevereiro de 2008 obrigaram a France Télécom a recuar, no braço-de-ferro com os sindicatos, e a reconhecer a urgência de um plano que ponha água na fervura, a curto prazo, e permita fazer diferente, daqui em diante. (Revista VISÃO, 2009)

Sutton (2010), por sua vez, afirma que uma recente pesquisa nacional realizada nos EUA descobriu que $80 \%$ dos empregados sentemse respeitados pelos seus chefes e acreditam que seus chefes valorizam o seu trabalho. Entretanto, também há fortes evidências que a minoria incompetente e sem noção [sic.] causa grandes danos à saúde mental e física de seus subordinados - um estudo longitudinal com trabalhadores suecos descobriu que aqueles com chefes ruins tinham 39\% mais chances de ter um ataque cardíaco do que aqueles com chefes benevolentes.

O autor adiciona que chefes benevolentes não são aqueles permissivos e frouxos, são os que sabem exercer a pressão necessária quando necessária, mas que também têm a sabedoria de ouvir seus subordinados atentamente e os encorajam a desafiar as ideias do chefe de forma civilizada e instrutiva.

\section{O CASO}

\subsection{CARACTERIZAÇÃO - OS INSTITUTOS FEDERAIS DE EDUCAÇÃO, CIÊNCIA E TECNOLOGIA}

Em julho de 2008 a Presidência da República assinou uma lei criando 38 institutos federais de educação, ciência e tecnologia no país, constituídos a partir da integração e reorganização dos CEFETs, ETFs e EAFs vinculados às Universidades Federais nos Estados e DF. Em dezembro do mesmo ano a lei foi aprovada pelo Congresso e sancionada pelo Presidente.

Segundo o projeto, os Institutos Federais são voltados para o desenvolvimento de soluções educacionais nas áreas técnicas e tecnológicas devendo estender seus benefícios à comunidade estendendo-se além das aulas propriamente enveredando por projetos de pesquisa e extensão. Metade das vagas deverá ser destinada à oferta de cursos técnicos de nível médio, em especial cursos de currículo integrado, com o restante voltado para cursos superiores de tecnologia de engenharias e de licenciaturas nas disciplinas de física, química, matemática e biologia. Ainda serão incentivadas as licenciaturas de conteúdos específicos da educação profissional e tecnológica, como a formação de professores de mecânica, eletricidade e informática (IFSULDEMINAS - Reitoria, 2012).

Os institutos federais têm autonomia, nos limites de sua área de atuação territorial, para criar e extinguir cursos, bem como para registrar diplomas dos cursos por eles oferecidos, mediante autorização do seu Conselho Superior. Ainda exercem o papel de instituições acreditadoras e certificadoras de competências profissionais.

Cada instituto federal é organizado em estrutura com vários câmpus, com proposta orçamentária anual identificada para cada câmpus e reitoria, equiparando-se com as universidades federais (Lei 11892/2008).

\subsection{O INSTITUTO FEDERAL DO SUL DE MINAS GERAIS}

Na criação dos 38 primeiros Institutos Federais de educação, o estado de Minas Gerais foi contemplado com cinco instituições, sendo 
que o Instituto Federal do Sul de Minas Gerais foi criado a partir da integração da Escola Agrotécnica Federal de Inconfidentes, Escola Agrotécnica Federal de Machado e Escola Agrotécnica Federal de Muzambinho. Posteriormente, foram criados três novos câmpus, nas cidades de Passos, Poços de Caldas e Pouso Alegre, esta última sediando a Reitoria. O IFSULDEMINAS atua em diversos níveis: médio, técnico, graduação e pósgraduação, em 27 diferentes áreas. O objetivo é ampliar o acesso ao ensino profissionalizante nos 178 municípios de abrangência, beneficiando 3,5 milhões de pessoas, direta ou indiretamente. A rede continua crescendo, com novos câmpus no chamado Circuito das Águas de Minas Gerais (IFSULDEMINAS Reitoria, 2012).

O Câmpus Passos foi criado por meio de um convênio entre a Prefeitura Municipal de Passos e o IFSULDEMINAS - câmpus Muzambinho, mediante contrato de prestação de serviço, estabelecido em 2010. O primeiro processo seletivo de alunos ocorreu em 26 de junho de $2010 \mathrm{com}$ as aulas iniciando em 2 de agosto do mesmo ano. No final de 2010, o Governo Federal adquiriu uma área para ser a sede própria do câmpus de Passos, estendida para uma área que é o dobro da atual em virtude da compra de um terreno e instalações adjacentes no final de 2012. O polo foi transformado em câmpus independente em julho de 2012 (IFSULDEMINAS - Reitoria, 2012).

No momento dos eventos relatados nesse trabalho, os cursos presenciais oferecidos eram os cursos técnicos subsequentes de Informática, Enfermagem, Vestuário e Comunicação Visual e o curso técnico integrado de Informática, com a demanda identificada por meio de consultas públicas em meio à comunidade passense.

\subsection{ASPECTOS RELEVANTES PARA A ANÁLISE DO CASO}

Houve um concurso público para dotar o IFSULDEMINAS do corpo docente e técnico necessário para a realização de seus objetivos no final de 2011. Em dezembro do mesmo ano alguns novos funcionários começaram a tomar posse, com a primeira equipe do câmpus Passos, composta por 17 professores e 14 técnicos, iniciando o ano letivo em fevereiro de 2012.
Em meio à euforia do novo desafio, alguns incidentes prenunciavam o que estava por vir. Segundo instruções da direção, todos os funcionários, incluindo professores, deveriam cumprir as 40 horas contratuais de trabalho dentro do câmpus. Como ainda não havia aulas no mês de janeiro de 2012, cumpria-se o horário das 9 às 18 horas na sala dos professores, sem mesas e cadeiras suficientes, sem ventilador, sem biblioteca, sem computadores, numa sala abafada e exposta ao sol.

O período em questão deveria ser usado para a elaboração do PPC - Projeto Pedagógico de Curso - e dos planos de curso de cada disciplina ministrada. Ninguém sabia, no entanto, que ambos os documentos seriam refeitos dezenas de vezes, não porque estivessem inadequados, mas por razões que incluíam a perda dos originais enviados por membros da secretaria e outros incidentes semelhantes. O retrabalho logo virou norma, com os mesmos formulários, com as mesmas informações, preenchidos diversas vezes para órgãos diferentes da administração, evidenciando a falta de comunicação entre as diversas partes que constituíam o todo.

Um pedido da direção dizendo respeito ao material e equipamento necessário para as aulas de cada docente transformou-se numa corrida para fazer as necessárias licitações, sem apoio, sem informação e com uma decorrente carga de retrabalho.

Os incidentes até agora relatados podem ser considerados normais dadas as condições de inexperiência de todos. O que também ficou evidente foi a falta de apoio da reitoria, que contava com membros mais experientes, na condução dos processos iniciais. A ajuda veio na forma de um curso ministrado pelo responsável pela área de licitações da reitoria, curso este que chegou tarde, isto é, bem depois da documentação pronta ter sido enviada.

Outra surpresa deu-se com a apresentação de uma Normativa Docente, documento para preenchimento semestral online, com as atividades docentes realizadas no período. Tal prática é bastante comum em instituições de ensino, dado que é preciso ter conhecimento da produção docente. A surpresa foi decorrente da necessidade de cumprimento de uma pontuação mínima de 80 pontos, com atividades docentes normais valendo um ponto ou frações. A pontuação por publicações ou participações em congressos e cursos era um 
pouco mais elevada, mas deixando a soma longe do mínimo, a menos que a produção individual beirasse 0 extraordinário. Vale observar que a publicação de livros rendia boa pontuação, como se a publicação de um livro por semestre fosse usual. A maior pontuação vinha das participações nas diversas comissões, o que ensejava uma carga elevada de trabalho adicional e múltiplas reuniões dentro e fora do câmpus. Vale observar que o sistema de preenchimento apresentava problemas frequentes de toda natureza e, até março de 2014, ainda não estava adequado, sendo outra fonte de estresse.

Não era difícil observar-se que havia uma diferença entre discurso e prática: o discurso oficial destacava a importância da aprendizagem, desenvolvimento e inovação e a prática era de abuso, repressão e constrangimento.

Na mesma linha, havia clara preferência pelos funcionários mais cordatos, premiados com coordenações e outras atividades adicionais, enquanto que os mais questionadores eram vítimas de abusos diversos.

Tudo isso somado a um tratamento infantilizado dispensado à equipe. A direção pedagógica não tinha experiência alguma com ensino técnico e superior, imprimindo um ritmo de escola elementar a todo o câmpus, incluindo-se docentes e técnicos. Diversos alunos adultos abandonaram o curso por conta desse tipo de tratamento. A Direção Geral, quando contactada a respeito, ou iniciava um discurso ambíguo, com resultados nulos, ou corroborava a atuação da direção pedagógica. A direção de pessoas da reitoria tinha uma postura hostil e antipática, colaborando em nada para assegurar um bom clima de trabalho.

Como detalhado adiante, havia um grande turnover de colaboradores, com pedidos em massa de transferência. Surpreende que tal fato não tivesse chamado a atenção das instâncias superiores.

\subsection{A "GESTÃO PELO TERROR" APLICADA}

Dentre os muitos casos de gestão equivocada de pessoas, talvez um bastante emblemático ocorreu poucos meses após a chegada da primeira leva de professores concursados. $O$ evento descrito a seguir teve um papel relevante na quebra do moral da equipe e foi determinante para muito do que houve depois.
No início de maio, quando o recesso de julho se avizinhava, a diretora de recursos humanos deslocou-se em veículo oficial, percorrendo os $350 \mathrm{~km}$ que separam a cidade que abriga a Reitoria do câmpus tratado neste trabalho com o único propósito de comunicar aos docentes que, dado que todos tinham apenas alguns meses de empossados, não teriam direito às férias de julho. Ora, a despeito de serem jovens em sua maioria, eram todos adultos, com experiência de trabalho anterior, conhecendo, portanto, a legislação trabalhista. Bastaria um comunicado por email ou, quem sabe para tornar a resolução formal, uma circular assinada por todos, e o fato autoevidente estaria registrado. Entretanto, a viagem de quatro horas foi empreendida com o único propósito de comunicar a todos, em reunião formal, agendada por convocação, o fato de que, embora não havendo alunos durante o recesso, todos teriam que estar presentes no câmpus, 8 horas por dia. A reunião, que levou cerca de 45 minutos, foi encerrada com a frase; "Se não houver o que fazer, vocês podem até dormir. Tragam colchonetes, MAS DURMAM AQUI."

Algumas semanas depois, um novo comunicado, desta vez sem a presença da diretora de pessoas, informava que não haveria expediente para os docentes durante os dez dias de recesso.

A propósito das 8 horas diárias de trabalho, é preciso reiterar o descrito acima que, dado que todos foram empossados no regime de 40 horas, todo o tempo contratado tinha que ser cumprido no câmpus, mesmo que cada professor precisasse estar em sala por, no máximo, 12 horas semanais, com a maioria nem chegando a isso.

Vale salientar novamente que no primeiro ano ainda não havia biblioteca, o acesso à internet era precário e a sala de professores era pequena, abafada e sem mesas e cadeiras suficientes para todos. Preparar aulas nesse ambiente era virtualmente impossível. O resultado prático da exigência eram aulas preparadas nas casas de cada docente, mais do que dobrando as horas semanais. Ainda como agravante, boa parte da equipe era de fora da cidade, precisando de tempo em horário comercial para providenciar moradia. Muitos moraram em hotéis por vários meses até que moradias mais definitivas pudessem ser providenciadas.

A queda no entusiasmo e motivação iniciais foi dramática e os ressentimentos contra a gestão 
só aumentavam. A atitude restritiva e pouco acomodadora tanto da direção geral quanto da direção pedagógica só fazia piorar tudo e diversos casos de assédio moral foram registrados, sem resposta por parte da reitoria.

Um incidente presenciado que demonstra 0 assédio a professores escolhidos foi relatado ao autor, durante uma reunião com a presença de dois prorreitores. Ressalte-se que o autor desse trabalho não presenciou o evento, corroborado por outros professores, por estar em reunião em outro câmpus da rede.

Tomando a palavra, o prorreitor de ensino dirigiu-se a uma professora de fora da cidade, como a maioria do corpo docente, mencionando que esta procurava concentrar suas aulas em poucos dias de modo a poder deslocar-se para o Rio de Janeiro, um grande centro com muitas opções de lazer. Ora, a referida professora é natural de Niterói, no Rio de Janeiro, onde tem marido, também professor da rede pública, e um filho adolescente ainda em idade escolar. Procurar concentrar as aulas para passar parte da semana com a família não só é lícito, como lógico. O autor deste texto também tinha esposa professora da rede pública em outro município. No seu caso, tratava-se de viajar semanalmente dezessete horas para ir e voltar numa viagem de mil quilômetros entre duas cidades pequenas, sem opções atraentes de lazer. Tratava-se, em ambos os casos, de fazer sacrifícios para estar com a família, onde quer que ela estivesse. Ser publicamente criticado por isso é que beira a insensatez.

Outro fator de estresse referia-se à avaliação semestral, com vistas à aprovação do docente (e do técnico administrativo) para ingresso definitivo na carreira pública, após os 3 anos de estágio probatório.

Não há nada de errado com avaliações, dado que são instrumentos necessários à gestão. A questão era como a avaliação era feita: os critérios eram tão subjetivos que o autor desse trabalho, questionando a pontuação alta, porém não total em alguns quesitos, obteve como resposta do diretor que os avaliadores partiam do princípio de que ninguém é perfeito, depreendendo-se daí que a nota máxima seria outorgada apenas a não humanos. Recusando-se a assinar a concordância, dias depois foi informado pelo coordenador de curso que deveria dirigir-se ao departamento de pessoas do câmpus onde foi informado que a assinatura era obrigatória, mas que poderia iniciar um processo administrativo questionando os critérios usados. Naquele ambiente, era mais sensato deixar o problema passar. O caso relatado estava longe de ser único.

\subsection{A QUESTÃO IDEOLÓGICA}

A rede de Institutos Federais de Educação, Ciência e Tecnologia é um projeto da gestão petista na presidência da República. Cabe mencionar que se trata de um projeto de grande mérito porquanto visa a interiorizar e regionalizar um ensino de qualidade, voltado para a potencialização das vocações de cada município ou região atendida.

O projeto teria alcançado maior sucesso não fosse a questão ideológica que permeia a gestão, os projetos pedagógicos e a prática de ensino. Espera-se que ensino e ciência não se misturem a questões de ideologia. A prática, na realidade, evidencia que boa parte do corpo docente e do corpo técnicoadministrativo comunga dos ideais de esquerda, variando de um vago sentimento de que o capitalismo é o mal encarnado, passando pelo pragmatismo cleptocrático e de ética duvidosa do próprio PT e chegando aos extremos de siglas como PSTU e PSOL.

$\mathrm{O}$ destaque dado neste trabalho às questões ideológicas não pretende criticar escolhas pessoais inerentes à democracia. Neste sistema, cabe a cada qual escolher ideologias e partidos que espelhem as suas crenças e aspirações. A crítica se faz no tanto que tais ideologias apresentam de dogmático, com seus adeptos atuando como "evangelizadores", levando a "palavra" a todos que os rodeiam. Assim como a educação brasileira é laica - excetuando-se os casos de escolas pertencentes a alguma denominação religiosa -, facultando a cada um exercer sua religiosidade, ou ausência dela, nos diversos estabelecimentos de ensino disponíveis, inclusive naqueles que professam alguma religião específica, o mesmo deveria vogar para ideologias políticas.

A questão ideológica é tão enraizada que, durante uma reunião pedagógica voltada para a discussão do tratamento a ser dispensado a eventuais alunos com dificuldades de aprendizagem graves, conhecidos como subdotados, o autor deste trabalho ingenuamente perguntou se havia também algum tratamento especial para superdotados, ou seja, aqueles alunos colocados no outro espectro da aprendizagem, com extrema 
facilidade para aprender ou com habilidades inatas que precisassem ser reconhecidas $e$ estimuladas, também com aulas de apoio. Diante da falta de resposta da equipe pedagógica e do grupo presente à reunião, um artigo publicado na revista Época (2011) foi distribuído mais tarde na rede de emails da instituição em pauta, visando a estimular discussões a respeito. A única resposta obtida veio de um professor, bastante respeitado e atuante na instituição, que, fazendo um extenso arrazoado cheio de opiniões pessoais e citações fora de seu contexto original, concluiu dizendo que estatisticamente 0 público-alvo dos Institutos Federais era das classes menos abastadas e que seu problema era de alunos subdotados. Alunos superdotados pertenciam a famílias abastadas que podiam dar conta de suas questões por si mesmas. Poucos meses depois, um aluno pertencente a este último grupo, foi aprovado em concurso vestibular para uma instituição federal de alta tecnologia e o caso foi alardeado com fanfarras, evidenciando a incoerência do pensamento vigente.

Outros exemplos poderiam ser dados, com temática e desfecho semelhantes. Optou-se por omiti-los por questões de redundância e de espaço.

\subsection{LIDERANÇA CONFUSA}

Brewer (2010) descreve em seu artigo os fundamentos teóricos do líder servidor, tornado famoso na mídia pelo livro "O Monge e o Executivo" de James C. Hunter (2004). Seu texto caracteriza o líder servidor como capaz de ouvir, de empatia, de previdência, de servir, de comprometimento com o crescimento e com a construção de comunidades, ecoando Spears (2004).

Há diversos estilos de liderança e, deve-se reconhecer, o líder servidor é um ideal ainda a ser alcançado, mormente em organizações com caráter fortemente competitivo. Entretanto, não há o que discutir que em momentos de crise, nos quais o mundo tem se visto envolvido, o líder com Imperium, no sentido usado pela República romana passa a ser uma necessidade. A capacidade de inspirar e se fazer seguir em meio à tempestade é qualidade rara.

A forte competitividade não é usual nas instituições de ensino, muito menos nas instituições de ensino federais, nas quais impera uma benevolência pachorrenta, com a progressão profissional regulada por decreto e não por mérito.

Por outro lado, Blanding (2013) aponta que líderes agressivos e dominadores tendem a afetar negativamente $\mathrm{o}$ desempenho de equipes. O foco em seu próprio poder e a necessidade de dominar, inclusive dominando o discurso, fecha o espaço para o diálogo, o enriquecimento da experiência coletiva e os consequentes resultados.

Blanding (2013), citando uma pesquisa de outra professora de Harvard, Francesca Gino, ainda em andamento, menciona que o estudo em questão evidencia, em três experimentos diferentes, que o líder muito imbuído de sua força e poder é nocivo no que tange a resultados. Não se discute que uma liderança forte seja benéfica no quesito resultados. Entretanto, a posição dominante que sufoca a discussão e a troca, que tem sempre as soluções prontas, deixa de crescer e se desenvolver, trazendo o mesmo efeito para todo o grupo.

Um aspecto relevante dos experimentos de Gino (em Blanding, 2013) diz respeito a uma posição de poder que só existe na mente do supostamente poderoso, ou o que Gino classifica como possuindo "um sentido subjetivo de poder", quando alguém acredita ter poder, e de fato não o tem, ou o tem em menor escala do que imaginado. Tal fato costuma ocorrer em situações em que não há uma liderança formal, essa liderança pode ser assumida por um indivíduo que creia ter conhecimentos ou habilidades superiores às do resto do grupo. Nesse caso, os efeitos são nulos ou irrelevantes, dado que o grupo tende a ignorar o suposto poder desse indivíduo.

Depreende-se daí que empoderar cada membro do grupo é aumentar os resultados positivos conjuntos.

Outro trabalho, desta vez focando os estilos de liderança especificamente na educação, destaca que o processo educacional depende da liderança exercida por um educador sobre um grupo de educandos.

Segundo a autora, Rajeev (2011), a liderança eficaz se realiza pelo reforço do desempenho dos líderes educacionais, especialmente dos educadores propriamente, de modo a melhorar os resultados dos estudantes.

Ainda segundo Rajeev (2011) não há dúvidas que não há uma única maneira melhor de liderar e inspirar no campo da educação. Cada educador e cada escola enxergam as 
estratégias de liderança de forma diferente. De modo geral, há três estilos de liderança na educação, usadas individualmente ou em combinações entre elas. São eles o hierárquico, o transformacional e o facilitativo.

Resumindo rapidamente cada tipo, o hierárquico baseia-se no método tradicional de educação, com uma abordagem de cima para baixo, com ênfase na autoridade formal, deixando pouco espaço para a participação. Nesse caso, o diretor administrativo tem as atribuições de planejador, supervisor, analista, alocador de recursos, etc. A ênfase é em eficiência, controle e rotinas. O estilo transformacional baseia-se no conceito de trabalho conjunto, com vistas não só a resultados imediatos, mas a benefícios futuros. Embora as decisões continuem sendo tomadas individualmente ou em pequenos grupos, esse estilo de liderança deixa amplo espaço para o exercício intelectual, para a motivação por meio de valores e visão compartilhados e pela participação nas atividades de liderança. A liderança transformacional promove um sentido de propósito e significado na união de pessoas por uma causa comum. Finalmente, o estilo facilitativo de liderança traz estratégias semelhantes 'as da liderança transformacional, embora ainda mais democráticas e interativas na prática. Um líder educacional facilitativo trabalha em conjunto com a gestão, oferecendo parceria na preparação do futuro, promovendo ideias coletivas, fazendo parte do grupo em vez de estar no centro. Empoderar todo o sistema educativo é o objetivo primordial do líder facilitativo.

Cada instituição de ensino e cada grupo de educadores deve buscar um equilíbrio entre os estilos que seja adequado aos objetivos dessa instituição.

O preâmbulo teórico acima visa apenas a evidenciarar a situação da liderança no Instituto estudado. A despeito de um discurso participativo e democrático, a prática era autoritária e nada aberta a contribuições do grupo. Reuniões pedagógicas eram a rotina de todas as tardes de quarta-feira, havendo ou não razão para a sua realização. As reuniões aconteciam apenas para que as diretorias geral e pedagógica comunicassem ao grupo determinações da direção de unidade ou da reitoria. Não havia espaço para discussões ou contribuições.
Apenas para citar um exemplo, houve um incidente em que a diretora pedagógica abriu espaço para a deliberação do grupo a respeito de uma dada prática no câmpus. Como o resultado da votação não foi o esperado pela diretora, uma nova rodada de votos foi feita, com o grupo firmando sua posição contrária à da diretora. Na reunião da semana seguinte, a visão da diretora foi firmada como política institucional.

A sensação geral era de perda de tempo, tempo esse que já era escasso em virtude das múltiplas tarefas a serem realizadas na busca da pontuação da normativa docente, mencionada acima. A despeito da opinião geral a respeito das reuniões, a prorreitoria de ensino e a diretoria de $\mathrm{RH}$ determinaram que faltas a essas reuniões sem justificativa deveriam ser computadas como faltas ao trabalho, sendo passíveis de desconto salarial, independente das muitas horas extras despendidas nas outras tarefas referidas.

Reuniões das múltiplas comissões realizadas em outros câmpus ou na reitoria também eram obrigatórias para seus respectivos integrantes. Como o câmpus Passos ficava a três horas e meia do câmpus mais próximo, reuniões marcadas para as nove horas da manhã demandavam a saída em torno das cinco ou seis da manhã, mesmo que os participantes tivessem trabalhado até as dez horas e quarenta minutos na noite anterior.

Havia um clima perceptível de medo, e esse medo regia as relações profissionais e as tomadas de decisão. A diretoria local temia a reitoria que, por sua vez, temia Brasília. Quando havia algum ponto controverso a respeito de uma regra ou prática, o usual era dizer que se tratava de diretriz da reitoria ou de Brasília. Como no caso mencionado pelo estudo de Gino (em Blanding, 2013), a autoridade da diretoria local era percebida pelo grupo de professores e de técnicos administrativos como sendo do tipo "sentido subjetivo de poder", isto é, embora houvesse uma pressão para a acomodação às normas, por mais absurdas que fossem, havia também uma resistência passiva que continuamente questionava e sabotava essa pressão.

Uma palavra deve ser adicionada a respeito das também periódicas visitas do reitor. Seguindo o mesmo discurso de democracia e participação, o reitor dominava a reunião e, quando diretamente questionado sobre determinado assunto, dava respostas evasivas e rapidamente retomava seu monólogo. 
Com o tempo, o grupo de calouros professores e técnicos administrativos começou a rebelarse, amparando-se na legislação para questionar, levando queixas à reitoria, provocando reuniões em que a reitoria desmentia e desfazia decisões da direção local. O reitor, que tinha como certa a sua reeleição, acabou afastando-se da disputa, deixando que um dos prorreitores, mais simpático à maioria, concorresse à eleição como candidato único, dado que outros pré candidatos desistiram antes da formalização de suas candidaturas.

\subsection{O CLIMA ORGANIZACIONAL RESULTANTE}

Não há dúvidas que a liderança local era vacilante e insegura, isolando-se do grupo num estado de permanente arrogância, disfarçando uma paranóia digna de ditador de filmes ruins. Essa insegurança contaminava o grupo e as reuniões informais, conhecidas como "rádio peão", ou "rádio corredor" eram a regra. Em pouco tempo começou a haver cisões no grupo, desconfiando-se de alguns membros que poderiam ser "colaboradores" ou, pior ainda, "delatores". Havia ainda uma "torcida" pela eventual queda da diretoria local, com boatos circulando a esse respeito. A despeito das sanções pecuniárias, o absenteísmo era grande, com uma profusão de licenças médicas. Cabe registrar que muitos membros da equipe passaram a receber tratamento psicológico e/ou psiquiátrico, alguns com receitas para ansiolíticos e antidepressivos para conseguir lidar com as constantes pressões.

\section{RESULTADOS PRÁTICOS}

Deve-se observar que a literatura sobre o clima organizacional e seus impactos no moral da equipe e no desempenho dessa equipe e da organização como um todo é bastante antiga. A revisão da literatura apresentada trouxe estudos clássicos das décadas de 80 e 90, juntamente com trabalhos mais contemporâneos. Surpreende que, mesmo que a instituição estudada tivesse membros com formação em administração de empresas, tanto na reitoria quanto na unidade estudada, nada era feito para introduzir mudanças. É bem verdade que o clima, conforme descrito ao longo do texto, deixava pouco espaço para sugestões.

Os múltiplos problemas, fossem de desempenho propriamente, fossem de relacionamento com a gestão, ficavam sufocados sob o volume avassalador do trabalho a ser realizado pela equipe. Não se pretende aqui sugerir que o volume de trabalho da gestão também não fosse grande, mas o temperamento inseguro e centralizador tanto do diretor geral quanto da diretora pedagógica os impediam de delegar mais responsabilidades à sua equipe imediata de apoio. Havia uma profusão de cargos de chefia intermediária, muitos deles comissionados, mas também havia um enorme volume de reclamações de tolhimentos e impedimentos diversos.

As comissões acabaram por se tornar o principal instrumento de mudança, dado que os membros dessas comissões que mantinham contato com membros da reitoria, incluindo o próprio reitor, começaram a encaminhar reclamações e algumas ameaças de ações judiciais por assédio moral.

A obrigatoriedade das 40 horas cumpridas no câmpus acabou revogada numa reunião tensa na qual o prorreitor de ensino e a diretora de pessoas desautorizaram a diretora pedagógica do câmpus, definindo que o horário poderia ser cumprido em qualquer local para a preparação de aulas e nos locais apropriados para a supervisão de estágios e projetos de pesquisa.

Sentindo a pressão, a diretora pedagógica pediu transferência para uma das unidades de outro Instituto Federal, numa cidade próxima. Embora o autor do trabalho não estivesse presente em razão de uma reunião fora, a reunião na qual a diretora se despediu foi relatada como reveladora. O discurso de despedida foi respondido com silêncio no lugar dos costumeiros agradecimentos pelo bom trabalho realizado e de votos de sucesso na nova empreitada.

Finalmente, poucas semanas antes das eleições para reitor, o diretor geral foi exonerado, com um membro jovem da equipe docente colocado em seu lugar. A mudança, na realidade, veio tarde, dado que muitos membros da equipe original já haviam pedido transferência ou remoção para outras instituições de ensino, em outras cidades ou mesmo estados.

Nesse sentido, um concurso público levou a esposa do autor deste texto para uma localidade em outro estado, com o dobro da distância da cidade na qual anteriormente atuava, praticamente impedindo as visitas semanais que vinham sendo empreendidas. 
Outro concurso, para a mesma universidade, ainda que em outra área de conhecimento, acabou levando o autor para longe da instituição estudada, sem que pudesse verificar pessoalmente as mudanças introduzidas pelas novas gestões.

Cabe ressaltar que a mudança de instituição veio com prejuízos para o autor, em virtude da nova lei 12.772/2012, que determina que concursados advindos de outras instituições federais retornam ao estágio inicial de carreira, perdendo vantagens e promoções conquistadas. No caso específico, houve uma queda de quatro níveis, com as perdas salariais correspondentes. Retomando um dos incidentes relatados acima, estar com a família, em qualquer lugar que seja, vale qualquer sacrifício.

\section{CONCLUSÕES}

Relembrando, a questão de pesquisa para este estudo é o quanto o clima organizacional é capaz de afetar o desempenho coletivo da organização de forma positiva ou negativa.

Diante da teoria apresentada e dos diversos incidentes relatados no caso, parece razoável afirmar-se que se tratava de um caso de bullying corporativo, institucionalizado por uma gestão omissa e incompetente.

Muito pode e deve ser feito e fazem-se votos que as novas gestões sejam capazes de sanar os males já feitos e impedir que novos males sejam perpetrados. Entretanto, na esfera individual, pouco pode ser feito para remediar os danos feitos à saúde psíquica e física das muitas vítimas.

Diversos comunicados da reitoria elogiavam a produção científica dos docentes, incluindo prêmios ganhos por eles e por alguns de seus alunos. A questão que fica é o quanto mais de produtividade e sucesso poderia ser obtido com uma gestão mais humanizada.

http://links.jstor.org/sici?sici=0003. Acesso em: $18 / 06 / 14$ às 18:20h

[9]. DALLAS, Lynn. A Preliminary Inquiry into the Responsibility of Corporations and Their Directors and Officers for Corporate Climate: The Psychology of Enron's Demise. Rutgers Law Journal, Vol. 35, 2003.

[10]. DERRY, Sharon J. Cognitive Schema Theory in the Constructivist Debate. Educational Psychologist 31 (3/4) 163-174, 1996.

[11]. HELLRIEGEL, D., SLOCUM, J., \& WOODMAN, R. Organizational Behavior. Mason, Ohio : South-Western Cengage Learning, 2011.

[12]. HUNTER, James C. O monge e o Executivo. Rio de Janeiro: Sextante, 2004.

[13]. IFSULDEMINAS - Câmpus Passos - PPC Comunicação Visual, 2012.

[14]. ISAKSEN, S. G.and EKVALL, G.. Assessing the context for change: A technical manual for the Situational Outlook Questionnaire. Orchard Park, NY: The Creative Problem Solving Group, 2007.

[15]. IVANCEVICH, John M.; KONOPASKE, Robert and MATTESON, Michael T.. Organizational Behavior \& Management, Columbus, OH: McGraw Hill Higher Education, 8th Ed., 2007.

[16]. OSWALD, Andrew J.; PROTO, Eugenio e SGROI, Daniel. Happiness and Productivity. Vol. 32 (No.3) 1967. pp. 403-416. Disponível em: 
Ongoing Paper, University of Warwick, UK, and IZA Bonn, Germany, 2014.

[17]. PATTERSON, M.; WARR, P., \& WEST, M. Organizational climate and company productivity: The role of the employee affect and employee level. Journal of Occupational and Organizational Psychology. Volume 77, Issue 2, pages 193-216, June 2004.

[18]. RAJEEV, Loveleena. Types of Leadership Styles in Education. October 10, 2011. Disponível em: $\quad$ http://www.buzzle.com/articles/types-ofleadership-styles-in-education.html. Acesso em 21/06/14 às 23:46h.

[19]. RICHARDSON, R. J. Pesquisa social: métodos e técnicas. 3. ed. São Paulo: Atlas, 1999.

[20]. ROSE. D. M. \& GRIFFIN, M.. High Performance Work Systems, HR practices and high involvement: A group level analysis. Academy of Management, Conference 2002, Denver, USA, 2002.
[21]. SPEARS, L.. Practicing servant-leadership. Leader to Leader - Volume 2004, Issue 34, pages 711, Autumn (Fall) 2004.

[22]. STETZER,Adam; MORGESON Frederick P. e Edward L. ANDERSON. Organizational Climate and Ineffectiveness: Evidence from 25 Outdoor Crew Divisions. Journal of Quality Management. Vol 2 n으 pp 251-265, 1997.

[23]. SUTTON, Robert I., Good Boss, Bad Boss: How to Be the Best... and Learn from the Worst. New York: Business Plus, 2010.

[24]. VISÃO. France Télécom - Chamam-Ihe gestão de terror e suicidam-se por causa dela. Revista VISÃO - 8 de Outubro de 2009. Disponível em: http://citadino.blogspot.com.br/2009/10/francetelecom-chamam-lhe-gestao-de.html. Acesso em 19/06/2014 às 14:32h. 


\section{Bapítulo 6}

\section{ROTATIVIDADE DE PESSOAL: UMA ANÁLISE DO CLIMA ORGANIZACIONAL E FATORES QUE INFLUENCIAMO TURNOVER NA ÁREA OPERACIONAL DA UMA CLINICA DE SAÚDE EM FLORIANÓPOLIS/SC}

\section{Geórgia Gonçalves \\ Helio Alves da Cruz}

Resumo: O objetivo deste trabalho é mostrar sobre uma questão presente nos dia a dia das organizações em diversos ramos de atuação, o "Turnover" que quer dizer, Rotatividade de pessoal. Como a empresa Sonitec lida com esta questão e qual o papel do setor de Recursos Humanos no apoio aos demais setores da organização no intuito de nivelar os índices de rotatividade e garantir que o conhecimento das atividades seja mantido dentro da empresa. Para isso questões como qualidade do ambiente de trabalho e fatores motivacionais serão abordados, bem como, as principais ferramentas disponíveis no gerenciamento das pessoas dentro das empresas, ferramentas como pesquisa de clima, avaliações de desempenho, entrevistas de desligamento, entre outras auxiliam a medir e identificar possíveis pontos de melhoria no corpo funcional da organização, porém, devem ser aplicadas de forma inteligente e perspicaz para buscar o máximo de produtividade e o retorno planejado pela organização sem perder a qualidade de vida das pessoas.

Palavra- chave: Rotatividade. Clima organizacional. Desligamentos. Avaliação. Turnover. 


\section{INTRODUÇÃO}

Uma destas tentativas é o que conhecemos hoje por departamento de gestão de competências ou Recursos Humanos ou Departamento Pessoas como também já foi conhecido, apesar de ser um setor de apoio para as empresas e não gerar lucro direto, a existência deste setor na organização é de vital importância para manter as coisas em ordem e no caminho certo.

O problema evidenciado neste trabalho "Turnover" termo em inglês que quer dizer rotatividade de pessoal é hoje um dos maiores problemas enfrentados no mercado e foco de grande dispêndio de recursos financeiros o que impede o crescimento das organizações. Para a solução desta tão importante questão o setor de gestão de competências ou $\mathrm{RH}$ tem vital importância e responsabilidade.

O fato é que em muitas organizações a falta de qualidade na contratação aliado a perfis de lideranças retrógrados impedem que o setor de $\mathrm{RH}$ ocupe um lugar de destaque no organograma da empresa o que na visão deste estudo é um erro grave.

Por concepção este setor promove o apoio para os demais setores da organização, onde além de tarefas burocráticas e cotidianas pode inclusive participar ativamente na qualidade das pessoas contratadas e no mantimento do recurso principal das organizações reconhecidamente como sendo o capital humano.

Neste trabalho será dado enfoque aos índices de Rotatividade de pessoal no setor operacional da Clínica Sonitec. Mais do que reduzir o índice de rotatividade ou "Turnover" é necessário investir na qualidade de vida das pessoas que fazem parte da empresa melhorando o seu ambiente de trabalho, aumentando sua satisfação, motivação e por conseqüência a qualidade dos serviços prestados ao cliente final.

Os objetivos da pesquisa são:

- Analisar os índices da rotatividade de pessoal ou turnover;

- Pesquisar os fatores que influenciam os índices de rotatividade dentro da organização; - Conhecer os impactos da rotatividade de pessoal dentro da organização;

- Realizar um estudo de clima organizacional definindo e reconhecendo as necessidades dos atuais colaboradores da empresa.
2 TURNOVER - ROTATIVIDADE DE PESSOAL

Um importante índice utilizado dentro de uma empresa é a de rotatividade de pessoal ou turnover que segundo Chiavenato (2010) é o resultado da saída de alguns colaboradores e a entrada de outros para substituí-los.

O termo rotatividade de recursos humanos é usado para definir a flutuação de pessoal entre uma organização e seu ambiente; em outras palavras, o intercâmbio de pessoas entre a organização e o ambiente é definido pelo volume de pessoas que ingressam e que saem da organização (CHIAVENATO 1997).

Morales (2002) define o termo turnover como sendo a flutuação de pessoal entre uma organização e seu ambiente, sendo este intercambio, representado pelo volume de pessoas que ingressam e que saem da organização.

Fernandez (2006) em seu artigo sobre a perda do conhecimento da empresa originada pelo alto turnover, diz que o índice de rotatividade de pessoal é um excelente indicador da saúde da empresa. Quando esse índice está alto, significa que algo não está bem na empresa, mesmo que essa saída seja uma decisão da própria empresa. Precisa-se avaliar com muito cuidado todas as causas que levaram a perda do funcionário.

\subsection{DESLIGAMENTOS DE PROFISSIONAIS}

O desligamento de um profissional ocorre quando uma pessoa deixa de trabalhar na instituição. Sempre quando isso ocorre, devese avaliar como ocorreu esse desligamento, que pode ser: por iniciativa do colaborador ou por iniciativa da empresa.

De acordo com Chiavenato (2010) cada saída ou desligamento corresponde quase sempre à admissão de um substituto como reposição. Isso significa que o fluxo de desligamentos como demissões e aposentadorias deve ser compensado por um fluxo equivalente de admissões ou entradas de pessoas.

Qualquer saída da empresa é traumática, independente se for por opção do trabalhador ou da empresa, segundo Fernandez (2006) quando um membro da equipe sai, toda atividade sofre mudanças em menor ou maior grau. 


\subsection{INDICE DE ROTATIVIDADE DE PESSOAL -}

\section{TURNOVER}

É baseado no volume de entradas e saídas de pessoal em relação aos recursos humanos disponíveis em certa área da empresa, dentro de um período de tempo e em termos percentuais que poderá ser medido, para efeito de planejamento de recursos humanos (MORALES 2002).
Turnover diz respeito ao processo de demissões e admissões ocorridos num certo período de tempo, em relação à quantidade de pessoas em atividade nesse período. Normalmente este índice é realizado mensalmente para permitir comparações e decisões, já que tem caráter preditivo. Para calcular o índice de rotatividade de pessoal ou turnover utiliza-se uma fórmula muito simples:

$$
I R P=\frac{\frac{A+D}{2} X 100}{E M}
$$

Onde:

IRP: Índice de rotatividade de pessoal

A: Admissões de pessoal na área considerada dentro do período considerado (entradas);

D: desligamentos de pessoal (tanto por iniciativa de empresa como por iniciativa dos empregados);

EM: efetivo médio da área considerada dentro do período considerado. Pode ser obtido pela soma dos efetivos existentes no início e no final do período, dividida por dois.

Chiavenato (1997) fala que o turnover exprime um valor percentual de empregados que circula na organização em relação ao número médio de empregados, ele usa como exemplo um percentual de $3 \%$, significando que a empresa só poderá contar com $97 \%$ do seu efetivo, para trabalhar com $100 \%$ do seu efetivo a empresa precisará trabalhar com um excedente de $3 \%$ para compensar o fluxo faltante. Utiliza-se a seguinte fórmula:

$$
I R P=\frac{D}{E M} X 100
$$

\section{Onde:IRP: Índice de reposição de pessoal}

D: Quantidade de demissões

\section{EM: Efetivo médio no mês}

Para Morales (2002) o calculo do índice de rotatividade de pessoal, por ser parcial, ou seja, não considerar o ingresso de recursos humanos que fluem para dentro da organização, poderá mascarar os resultados com alteração no volume de recursos humanos disponíveis.

\subsection{FATORES QUE INFLUENCIAM A ROTATIVIDADE DE PESSOAL}

Toda empresa possui objetivos a serem atingidos e seu sistema torna-se eficaz na medida em que os alcança com um mínimo de recursos, tempo e esforços. $\mathrm{Na}$ administração de um sistema, um dos principais problemas é medir e avaliar seu funcionamento por meio de seus resultados, com a utilização adequada de seus recursos e, conforme for detectada a insatisfação dos resultados de um sistema, a empresa deve replanejar, corrigir as inadequações e ajustar o seu funcionamento (MORALES, 2002). A rotatividade de pessoal não é a causa de um problema, mas sim o efeito de algo interno ou externo que 
afeta a permanência de um funcionário na organização.

Fernandez (2009) cita que no Brasil, além do capitalismo que faz com que os trabalhadores por não serem donos do capital ou de outros recursos além do seu trabalho ficam a mercê da oferta e da demanda de mercado, há também o índice de analfabetismo que afeta a qualidade da força de trabalho disponível, aumentando a oferta da mão de obra não qualificada que tem demanda menor e paga baixos salários restringindo a contratação de mão de obra qualificada, onde percebe-se a quantidade de vagas em aberto.

\subsection{OS IMPACTOS DA ROTATIVIDADE DE PESSOAL NAS ORGANIZAÇÕES}

A rotatividade de pessoal - pelos seus inúmeros e complexos aspectos negativos quando acelerada, torna-se um fator de perturbação. Principalmente quando forçada pelas empresas no sentido de obtenção de falsas vantagens em curto prazo, o certo é que a médios e longos prazos a rotatividade provoca enormes prejuízos à organização, ao mercado e à economia como um todo - e, principalmente, ao empregado tomado individual ou socialmente em relação à sua família (CHIAVENATO, 1997).

Fernandez (2006), em seu artigo explica que os colaboradores de uma empresa detêm os conhecimentos da rotina de trabalho, e após algum tempo eles realizam toda suas tarefas sem dificuldades: quando alguém da equipe sai, as atividades sofrem mudanças que em maior ou menor grau afetam a organização. Assim como um motor que para de funcionar caso alguma engrenagem se deteriore, a empresa também sente essa saída.

\subsection{ENTREVISTAS DE DESLIGAMENTO}

As empresas poderão obter as informações e avaliar os fenômenos internos e externos por meio dos processos de entrevistas de desligamentos realizados com as pessoas que se retiram das organizações, controlando e diagnosticando suas falhas, buscando correções nas causas que provocam a saída do pessoal e entre os fenômenos internos que fazem parte da política de recursos humanos, responsáveis pelos desligamentos (MORALES, 2002).
A entrevista de desligamento é uma grande aliada para verificar a situação de uma empresa e identificar as situações que levam ao índice de rotatividade de pessoal, mas para Fernandez (2009) não se pode contar apenas com a entrevista de desligamento para isso. Ela deve fazer parte de várias avaliações pelas quais o colaborador passou durante toda a sua estada na empresa. Deve-se cruzar com as informações obtidas em avaliações da liderança e dos colegas de trabalho.

\subsection{SOLUÇÕES PARA DIMINUIR O INDICE DE TURNOVER}

Uma empresa com baixo índice de turnover é bem vista no mercado de trabalho e para chegar a essa situação deve-se entender que as pessoas que desenvolvem as atividades dentro da empresa é que são realmente importantes, levando isso em consideração Fernandez (2006) diz que se deve utilizar uma serie de incentivos para manter seus colaboradores enganchados com as metas da empresa.

Para enfrentar o desafio da rotatividade, muitas organizações estão modificando suas políticas de pessoal, redesenhando os cargos para torná-los mais atraentes e desafiadores, redefinindo a gerência para torná-la mais democrática e participativa, repensando a remuneração para transformá-la em ganho variável em função do desempenho e metas a serem superadas estratégias motivadoras (CHIAVENATO, 1997).

\subsection{CLIMA ORGANIZACIONAL}

Knapik (2012) diz que o homem é um ser social que depende de organizações e grupos, e essa relação está sujeita a uma infinidade de variáveis que modelam o comportamento humano. Essas variáveis podem ser externa proveniente do meio ambiente, como a família, a escola, a profissão, a religião, a política, a cultura, etc. - ou internas - decorrentes das diferenças individuais, que são as características de personalidade, desejos, valores, motivações, interesses, etc.

Segundo Russi (2008) diz que entender sobre o comportamento humano das pessoas é muito importante para o sucesso dos negócios nos dias de hoje. Muitas organizações investem maciçamente na área, preocupadas 
em desenvolver o melhor capital intelectual e/ou humano."

O clima organizacional deve ser tratado como um elemento de vital importância estratégica dentro da organização. É ele que muitas vezes causa o impacto maior, positivo ou negativo, sobre a motivação, a capacidade de realização e a satisfação dos colaboradores. Nesse sentido, é preciso compreender os estilos de comportamento dos integrantes de cada equipe e suas atitudes no exercício de cada função, para se identificarem os níveis de motivação e satisfação nesses trabalhadores (RUSSI, 2008).

Para Colossi et al (1998) o tema clima organizacional é bem relevante porque estuda através de variáveis o funcionamento da organização, a analise do clima serve para identificar onde estão as grandes deficiências e mostrar qual caminho poderá ser tomando pelos gestores que virão a favorecer a integração dos colaboradores e a compatibilidade entre as metas individuais e institucionais, traduzindo assim um melhor desempenho dentro da organização.

Para Souza (2014) a avaliação de clima organizacional apresenta com principal vantagem a identificação dos pontos fracos e fortes de uma organização, por meio das opiniões dos clientes internos. Destaca-se ainda que um clima organizacional favorável traz benefícios significativos tanto para organização como para seus funcionários.

Entre as várias vantagens na realização da pesquisa de clima organizacional Souza (2014) cita a melhoria dos processos comunicacionais, a redução dos índices de absenteísmo e rotatividade de pessoal, o resultado da avaliação da pesquisa são instrumentos valiosos para programas voltados a melhoria da qualidade, o aumento da produtividade e a adoção de políticas de recursos humanos.

\section{METODOLOGIA DA PESQUISA}

As atividades práticas serão realizadas na Clinica Sonitec Diagnostico por Imagem, empresa que atua desde 1991no centro da cidade de Florianópolis, e conta hoje com duas unidades e uma equipe de 175 funcionários e menores aprendizes, 10 estagiários, 31 médicos.
O trabalho será realizado através de pesquisa que segundo Gil (2010) pode-se definir como o processo formal e sistemático de desenvolvimento de método científico. O objetivo fundamental da pesquisa é descobrir respostas para problemas mediante 0 emprego de procedimentos científicos.

Nele se organizam as diversas etapas de uma proposta teórica, a ser formulada a respeito de um determinado tema, delimitando em um problema, desenvolvido por meio de passos que se inter-relacionam para solucioná-lo, dentro eles, a metodologia para coleta e analise de dados (DYNIEWICZ, 2007).

O tipo de pesquisa utilizado será a exploratória que consiste em criar uma maior familiaridade com o problema para torná-lo mais claro, e tem como objetivo o aprimoramento de idéias, para Cervo (2007, p. 63) este tipo é normalmente o passo inicial no processo de pesquisa pela experiência e um auxilio que trás a formulação de hipóteses significativas para posteriores pesquisas. As pesquisas exploratórias têm como principal finalidade desenvolver, esclarecer e modificar conceitos e idéias, tendo em vista a formulação de problemas mais precisos ou hipóteses pesquisáveis para posteriores estudos. De todos os tipos de pesquisa, estas são as que apresentam menor rigidez no planejamento. Habitualmente envolvem levantamento bibliográfico e documental, entrevistas não padronizadas e estudo de caso (GIL 2010, p. 27).

Para Dyniewicz (2007) a pesquisa exploratória tem a finalidade de esclarecer e proporcionar uma visão geral em dimensões mais ampliadas acerca de um determinado fato. Devemos saber como o fato se manifesta e quais variáveis se relacionam a ele.

Por pesquisa quantitativa entende-se aquela investigação que se apóia predominantemente em dados estatísticos. Mais do que isso: referidos dados devem pertencer ao universo da estatística inferencial. Não significa não poder incluir dados qualitativos. Também não quer dizer que deva se filiar à tradição teórica - metodológica positivista. Nem que esteja vinculada ao enunciado de hipóteses, ou que se destine à experimentação ou deixe de fazêlo (RODRIGUES, 2007).

$\mathrm{Na}$ quantitativa avaliam-se os fatos que podem ser medidos. Qualitativa é a pesquisa que predominantemente - pondera, sopesa, analisa e interpreta dados relativos à natureza 
dos fenômenos, sem que os aspectos quantitativos sejam a sua preocupação precípua, a lógica que conduz o fio do seu raciocínio, a linguagem que expressa as suas razões. Também não denota filiação teórica metodológica, nem implica o uso de hipótese, de experimentação ou de qualquer outro detalhe. Sintetizando: qualitativa é a denominação dada à pesquisa que se vale da razão discursiva (RODRIGUES, 2007).

Segundo Rodrigues (2007) pesquisa documental é a que se vale, se não unicamente, pelo menos básica ou predominantemente de documentos como fontes de informação. Por documentos entendem-se não apenas papéis oficiais, autenticados ou assemelhados. Para Gil (2010) a pesquisa documental vale-se de materiais que não receberam ainda tratamento analítico, ou que ainda podem ser reelaborados de acordo com os objetivos da pesquisa.

Para aprimorar a teoria realizar-se-á um levantamento dos dados adquiridos nos últimos três anos, reconhecendo os índices de rotatividade de pessoal ou turnover dentro do setor operacional da empresa Sonitec, para avaliar os índices se utilizará dados de entrevista com Gestor do setor, questionário de desligamentos e de clima organizacional.

A entrevista é o tipo mais comum de técnica de coleta de dados em pesquisa. Ela tem por finalidade obter informações verbais de uma parcela representativa de uma população. Seus objetivos são: atender aos propósitos da pesquisa; auxiliar, como roteiro, na coleta de dados; e ajudar a motivar o entrevistado (DYNIEWICZ, 2007).

Rodrigues (2007) diz que entrevista apresenta a vantagem de permitir a interação do pesquisador com a fonte; é compatível com o aprofundamento da investigação. O questionário é uma técnica de coleta de informações constituída por indagações escritas.
Destina-se aos sujeitos eleitos como informantes da pesquisa, seja por conhecerem o assunto sob investigação, por terem testemunhado algum aspecto daquilo que se quer estudar, ou ainda por haver interesse em conhecer a percepção dos ditos sujeitos relativamente a alguma coisa (RODRIGUES, 2007)

\section{COLETA DE DADOS NO SETOR OPERACIONAL}

A pesquisa foi realizada na empresa Sonitec diagnóstico por imagem, mais precisamente na área operacional que conta hoje com 54 funcionários, subdivididos em recepção, agendamento presencial e por telefone. Foi realizado um levantamento documental no setor de recursos humanos sobre o número de funcionários no período de 2013 a 2015, número de colaboradores admitidos e desligamentos a pedido da empresa ou a pedido do colaborador e um estudo nos dados colhidos nas entrevistas de desligamento realizadas pelo setor de recursos humanos também no mesmo período.

Para completar o estudo foi realizada uma entrevista de avaliação institucional com os colaboradores ativos nas áreas estudadas.

\subsection{ROTATIVIDADE DE PESSOAL}

O levantamento dos índices gerados pela rotatividade de funcionários deve ser utilizado como primeiro passo para que as empresas possam reconhecer a realidade dos setores e os fatores que influenciam o desligamento de um profissional. Nesta pesquisa iremos realizar um estudo comparativo anual do índice de rotatividade de pessoal comparando os últimos três anos.

Como podemos verificar na tabela abaixo temos um grande índice de rotatividade de pessoal no setor analisado, neste levantamento está incluído o número de contratação para aumento do quadro funcional. 
Tabela 1: Índice de turnover com aumento de quadro

\begin{tabular}{|c|c|c|c|}
\hline Ano & 2013 & 2014 & 2015 \\
\hline № de funcionários no início do período & 17 & 33 & 35 \\
\hline № de funcionários no final do período & 33 & 35 & 38 \\
\hline Admitidos & 53 & 25 & 43 \\
\hline Demitidos & 39 & 27 & 47 \\
\hline Índice de turnover & $184,00 \%$ & $76,47 \%$ & $123,28 \%$ \\
\hline
\end{tabular}

Fonte: Sonitec (2016)

Um estudo realizado sobre a rotatividade na força de trabalho da rede municipal de saúde de Belo Horizonte, Minas Gerais (Sancho e et

0 a $7 \%$ - esperado

7 a 15\% aceitável

Ainda observando o quadro do índice de rotatividade nota-se a existência de uma queda entre o período de 2013 e 2014, este índice voltou a subir no ano 2015 continuando fora do nível aceitável descrito nas literaturas pesquisadas. Ao avaliar os índices observando o número de colaboradores contratados para aumento de quadro percebese que os valores continuam elevados em um nível crítico.

\subsection{ENTREVISTA DE DESLIGAMENTO}

A entrevista de desligamento é entregue ao colaborador no momento do desligamento independentemente do tipo de rescisão contratual, demissão por parte da empresa ou a pedido do colaborador. O setor de recursos humanos pede para que o colaborador entregue no momento da devolução dos uniformes, não sendo obrigatório responde-la.
2011) estabelece valores para a avaliação dos índices de rotatividade seguindo parâmetros de suas pesquisas:

15 a $25 \%$ - ruim

maior que $25 \%$ - crítico

Realizou-se um estudo das entrevistas do período de 2013 a 2015. Em 2013 foram devolvidas 19 entrevistas, destas 13 foram respondidas e 6 entregues não respondidas, em 2014 foram devolvidas 26 entrevistas com 17 respondidas e 09 não respondida e em 2015 tivemos a devolução de 12 entrevistas com 09 respondidas e 03 não respondidas, como podemos observar obteve-se $37,16 \%$ de entrevistas que podem ser avaliadas para ter uma melhor visão da empresa.

Das questões respondidas pelos funcionários desligados foi constatado que em 2013 e 2014 o maior motivo de afastamento foi pelo recebimento de outra proposta, gerando um percentual de 30\% em 2013 e em 2014 35\%, levando a constatação que a busca por melhores condições de emprego é um fator que impulsiona a saída do funcionário da empresa.

Gráfico 1: Motivo do desligamento em 2013

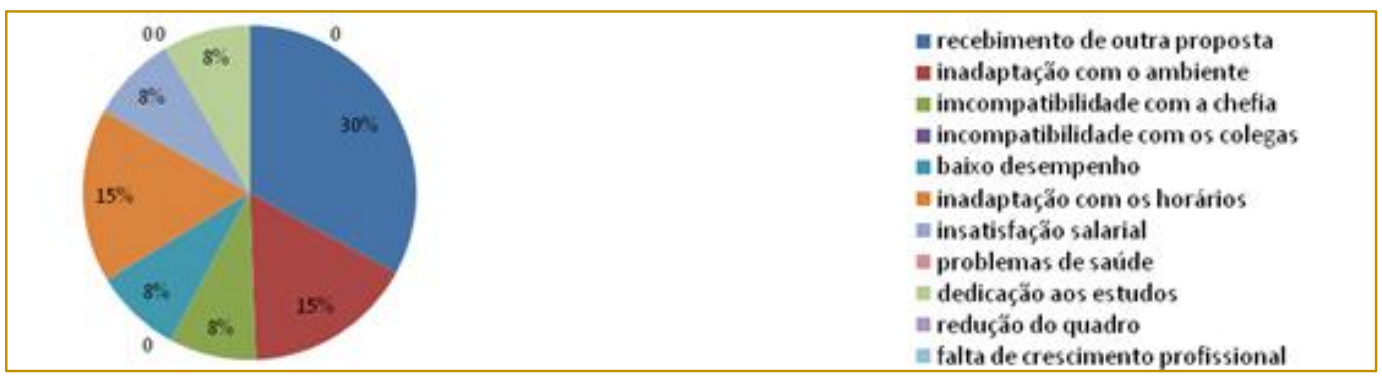

Fonte: Entrevista de desligamento, Sonitec (2016) 
Gráfico 2: Motivo do desligamento em 2014

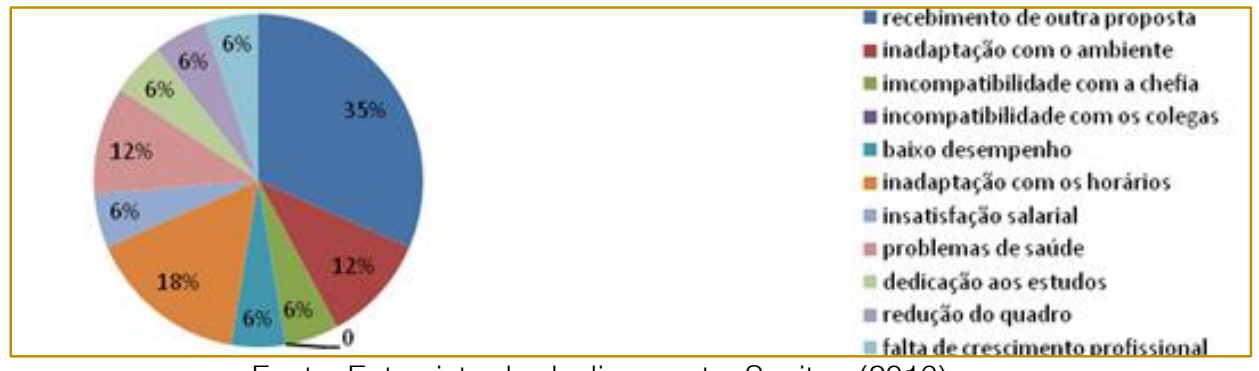

Fonte: Entrevista de desligamento, Sonitec (2016)

Gráfico 3: Motivo do desligamento em 2015

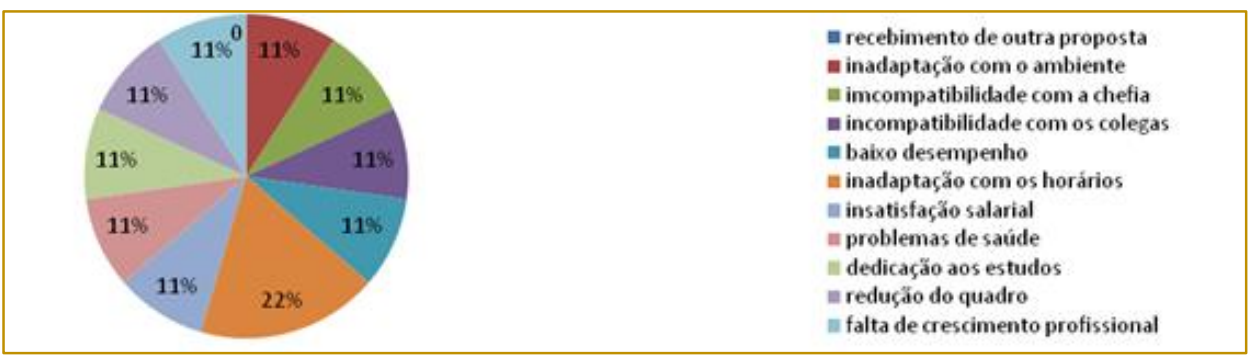

Fonte: Entrevista de desligamento, Sonitec (2016)

Podemos verificar pelos gráficos acima que em 2015 não houve desligamentos por recebimento de outra proposta, e como nos anos anteriores nos outros itens há uma variedade de motivos citados pelos funcionários, dentre os quais podemos eleger como os principais: Inadaptação com o ambiente de trabalho e com os horários.

Para melhor avaliar o motivo do desligamento outras perguntas são realizadas na entrevista como mostrado nos próximos itens:

Gráfico 4: Ambiente de trabalho na sua área

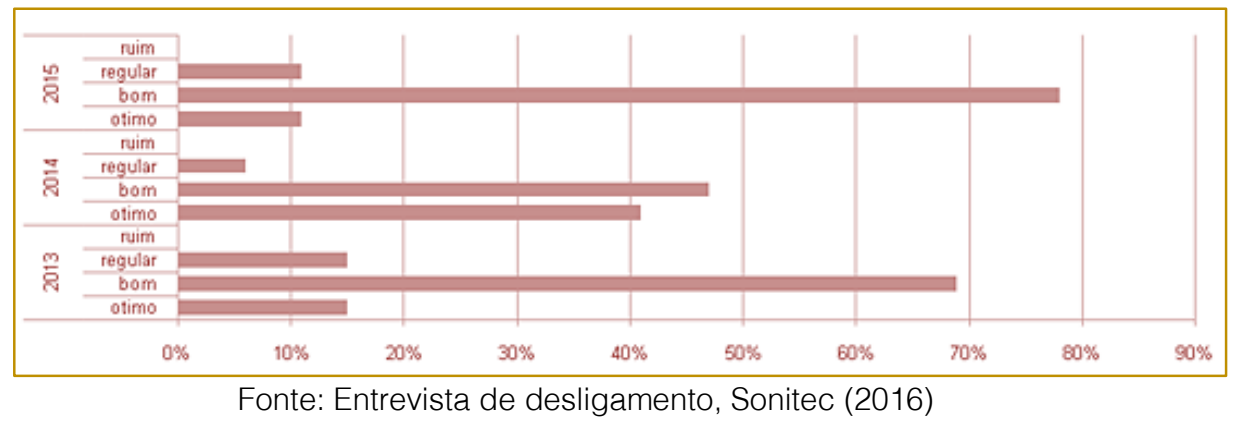

Observa-se que nos três anos as opiniões das pessoas desligadas consideravam ter um bom ambiente de trabalho na sua área (média de $80 \%$ ). 
Gráfico 5: Orientações do seu coordenador ou gerente

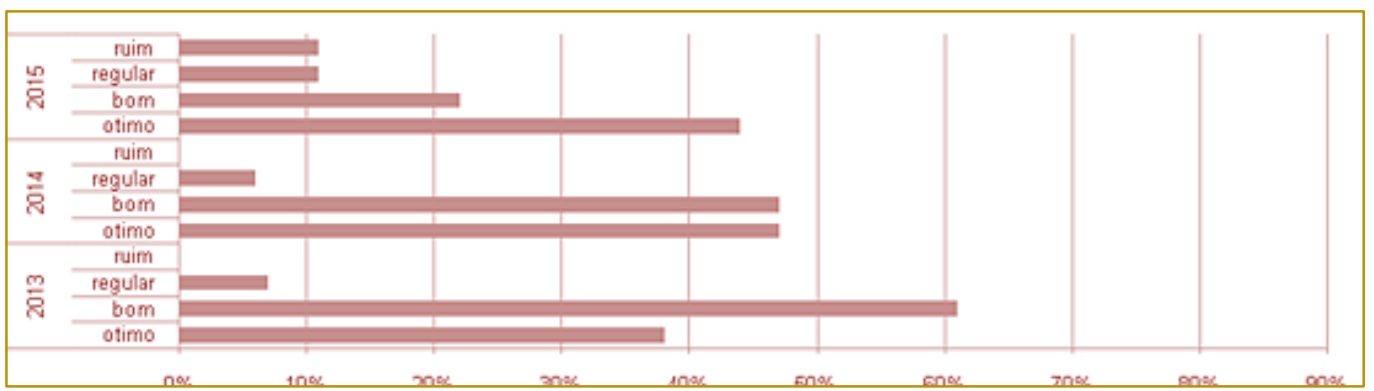

Fonte: Entrevista de desligamento, Sonitec (2016)

Pelo gráfico citado acima se observa que em 2013 e 2014 a maioria dos colaboradores desligados (média de 90\%) achava ótima ou boa a orientação dos coordenadores ou gerentes para seus funcionários, em 2015 esta média caiu para 70\% aumentando o índice de regular e ruim (média de $25 \%$ ).

Gráfico 6: Relacionamento com seu coordenador ou gerente

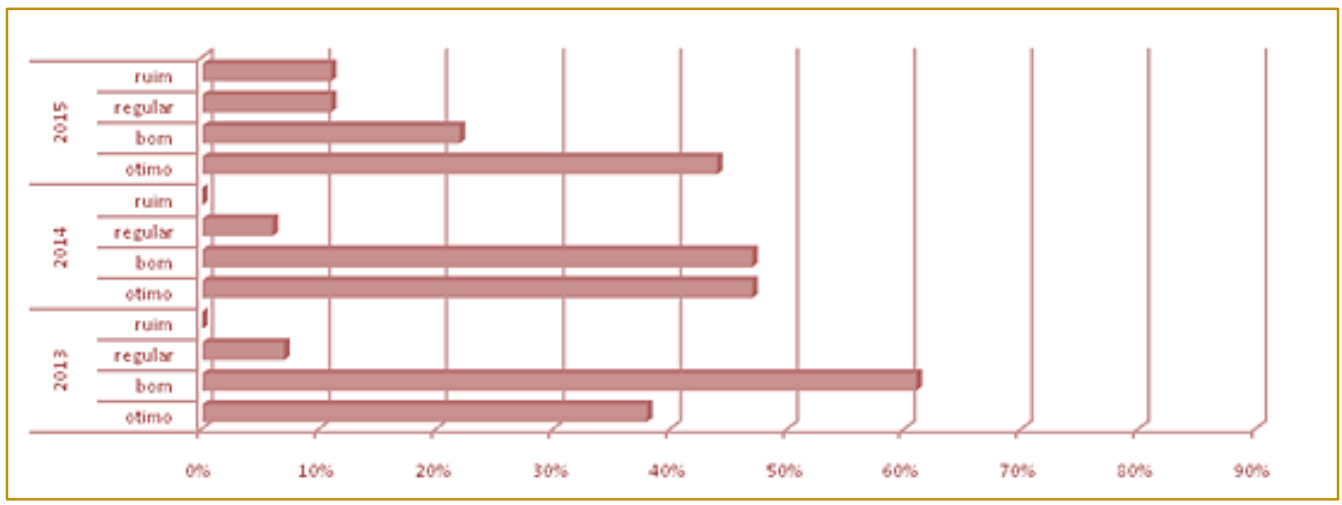

Fonte: Entrevista de desligamento, Sonitec (2016)

Em relação ao relacionamento com os coordenadores ou gerente observa-se que em 2013 e 2014 a média era de 90\% entre ótimo e bom, já em 2015 está média baixou para 65\%, aumentando o índice de insatisfação para $22 \%$ em média. 
Gráfico 7: Relacionamento com os colegas de trabalho

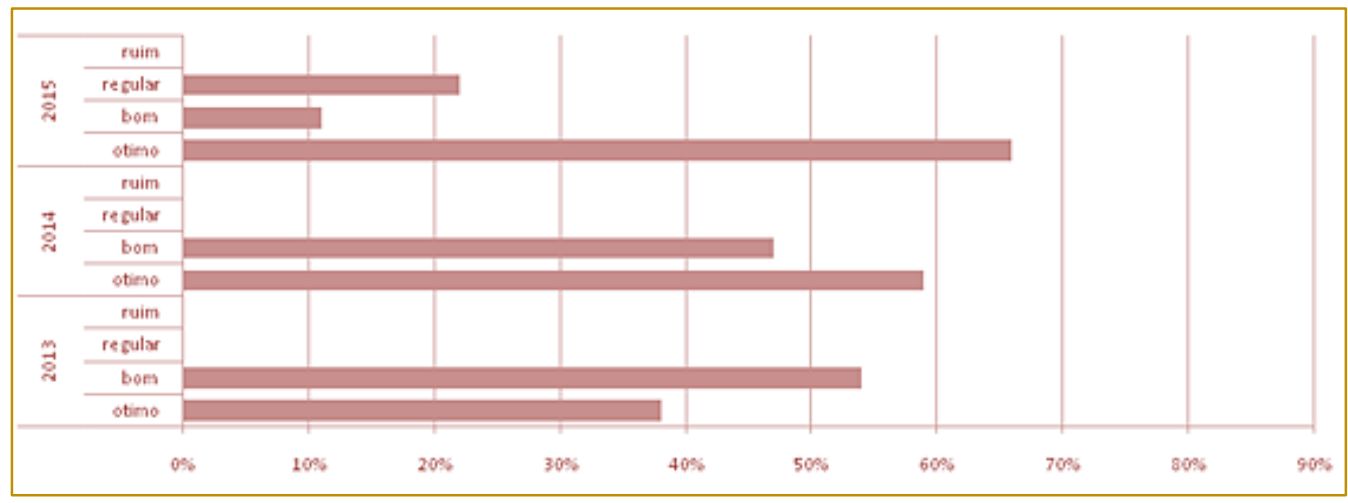

Fonte: Entrevista de desligamento, Sonitec (2016)

Para os funcionários desligados (média de 90\%) em 2013 e 2014 o relacionamento com os colegas era ótimo ou bom. Em 2015 esta média baixou para $75 \%$, aumentando assim o índice de insatisfação (média de 22\%).

Gráfico 8: Salário

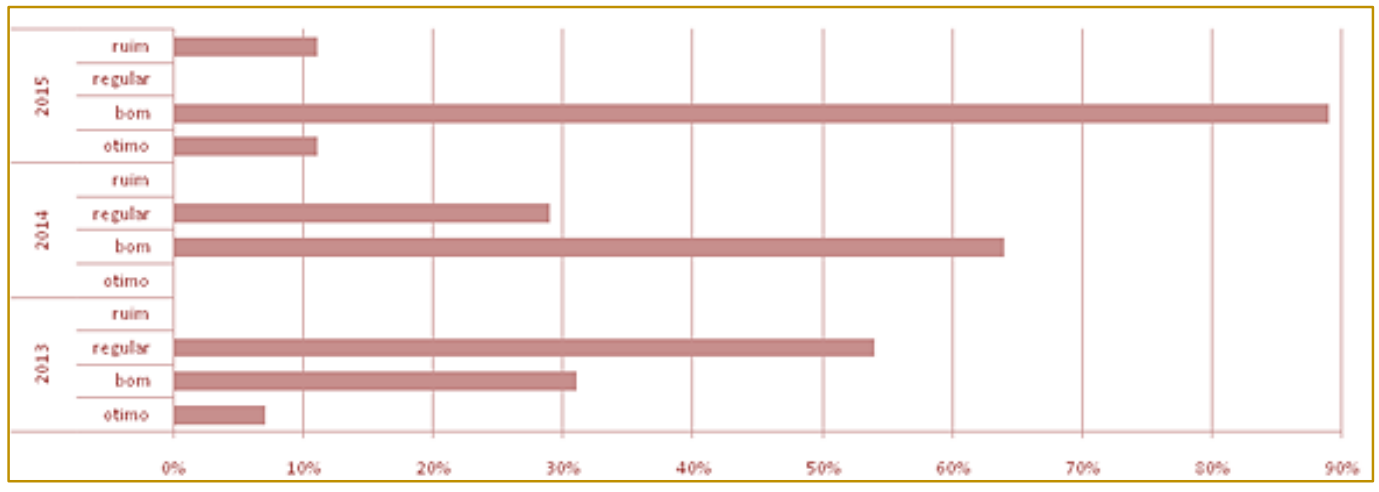

Fonte: Entrevista de desligamento, Sonitec (2016)

Gráfico 9: Benefícios

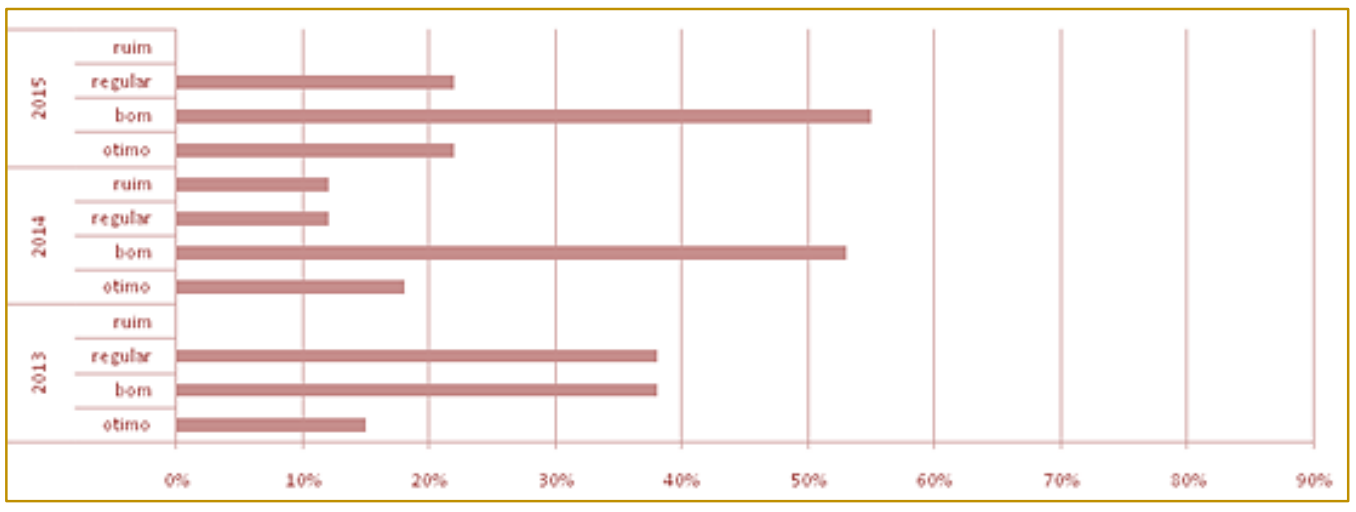

Fonte: Entrevista de desligamento, Sonitec (2016) 
Observa-se comparando o gráfico que houve uma melhora na opinião sobre salário, em 2013 a maioria (cerca de 55\%) achava regular, em 2014 a média para bom aumentou para 65\% diminuindo assim o índice de regular para menos de 30\%, em 2015 o índice de ótimo e bom ficou em cerca de $90 \%$.
Em relação aos benefícios observa-se que houve uma oscilação entre os anos analisados, mas sempre mostrado que a maioria (média de $75 \%$ a $85 \%$ ) achavam satisfatórios os benefícios oferecidos pela empresa.

Gráfico 10: Infra-estrutura (equipamentos de trabalho)

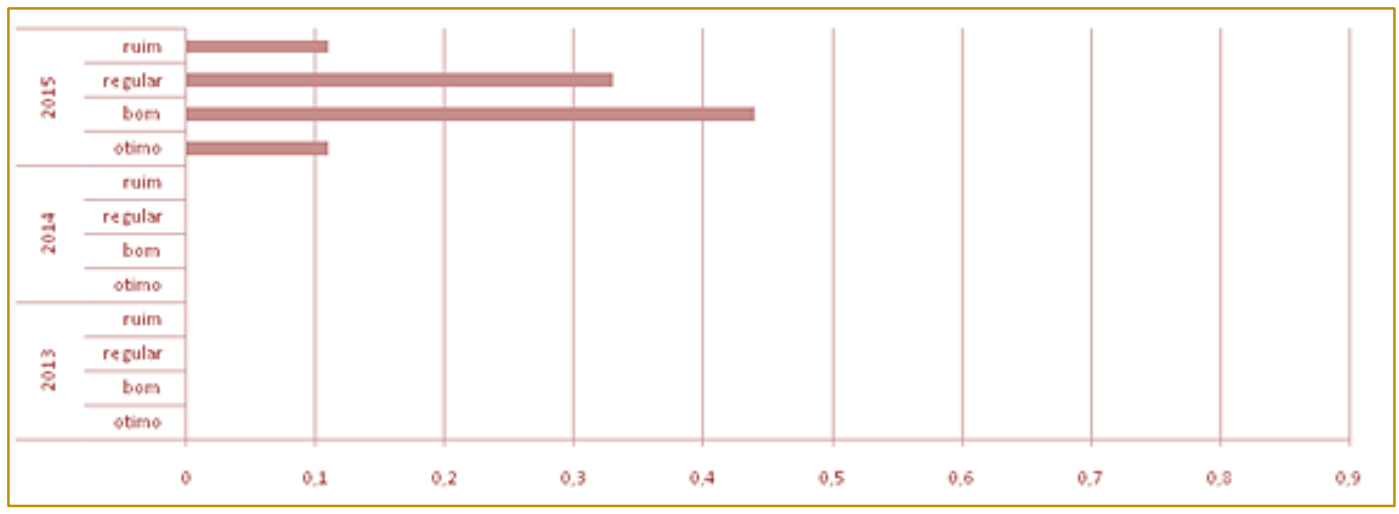

Fonte: Entrevista de desligamento, Sonitec (2016)

Nos anos de 2013 e 2014 esta pergunta não estava incluída na entrevista. Em 2015 esta pergunta dividiu os funcionários sendo que média de 55\% respondeu que era satisfatório, enquanto $45 \%$ responderam que estava insatisfeito com os equipamentos de trabalho.

Gráfico 11: Área de recursos humanos e Departamento Pessoal

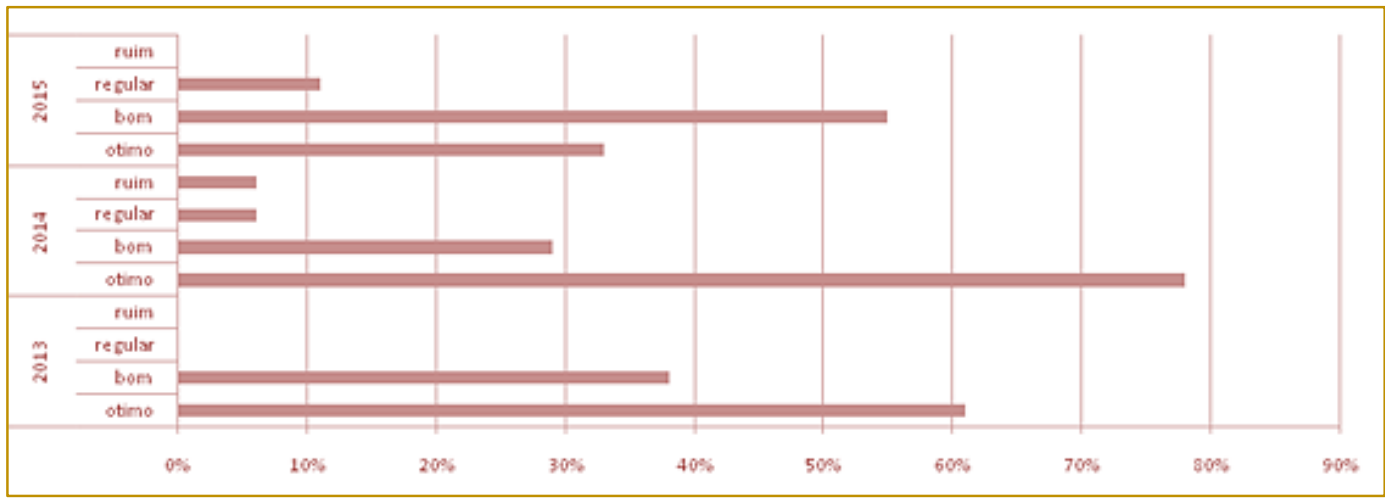

Fonte: Entrevista de desligamento, Sonitec (2016)

Em 2013 percebe-se que a totalidade dos funcionários estava satisfeita com o setor de Recursos humanos e departamento pessoal, em 2014 e 2015 a opinião mudou, sendo que mesmo assim ainda existe um bom índice de satisfação(média de 90\%). 
Gráfico 12: Treinamentos

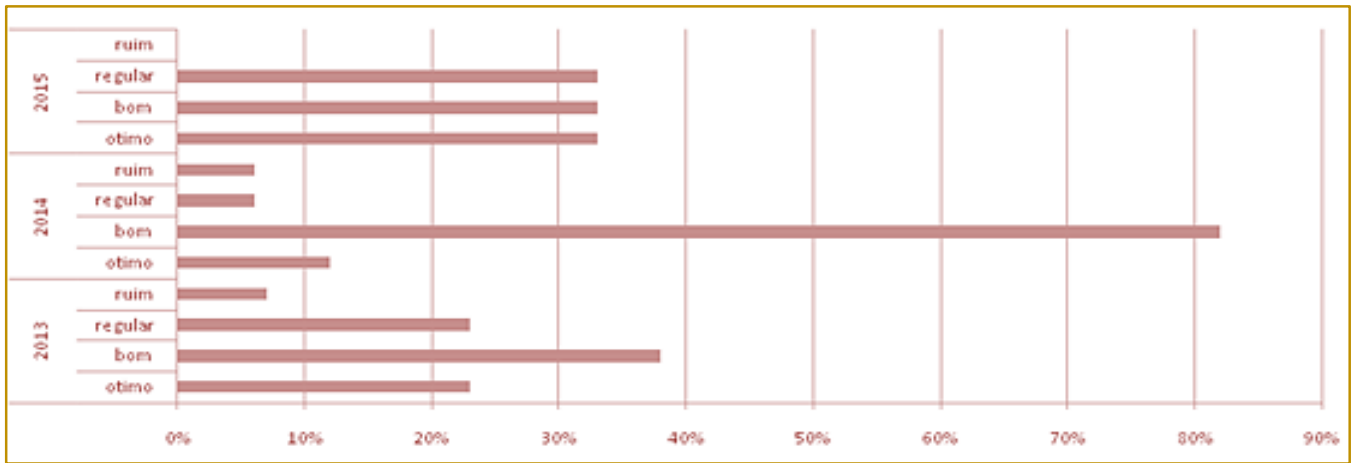

Fonte: Entrevista de desligamento, Sonitec (2016)

Observa-se uma alternância neste item, sendo que em 2013 o índice de satisfação era de 60\% e insatisfação era de 30\%, em 2014 melhorou o índice de satisfação para quase 100\% e em 2015 o índice de satisfação passou para 70\%, aumentando novamente 0 índice de insatisfação (média de 35\%).

\subsection{AVALIAÇÕES INSTITUICIONAIS}

A pesquisa foi realizada no período de 04 a 08 de abril de 2016, sendo aplicada a 37 funcionários, distribuídos nos setores de recepção, agendamento presencial e por telefone, seguindo o mesmo modelo da entrevista de desligamento adaptado para avaliar o clima organizacional. Vejamos as respostas:

Gráfico 13: Motivo da permanência na empresa

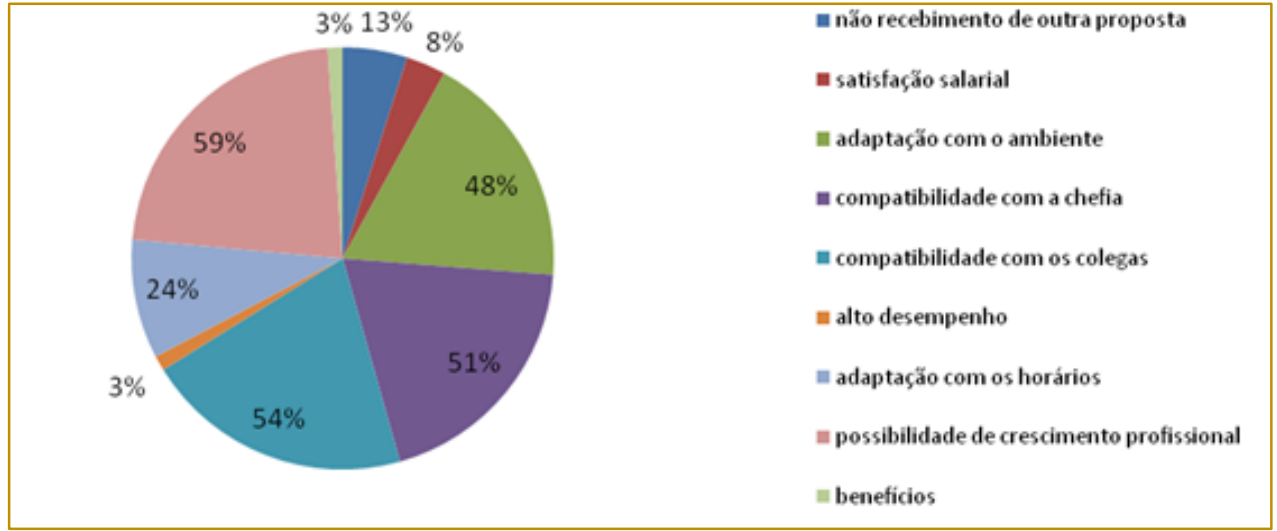

Fonte: Avaliação Institucional, Sonitec (2016)

Como podemos observar no gráfico acima os principais motivos que levam os funcionários a permanecer na empresa atualmente é o relacionamento interpessoal com colegas e chefias e o ambiente de trabalho. A influência dos colegas e chefia, além de um ambiente de trabalho saudável contribui diretamente para redução do índice de turnover nas empresas.

Para se ter uma melhor percepção da opinião dos colaboradores sobre a empresa realizouse outras perguntas obtendo os resultados conforme os gráficos a seguir: 
Gráfico 14: Ambiente de trabalho da sua área

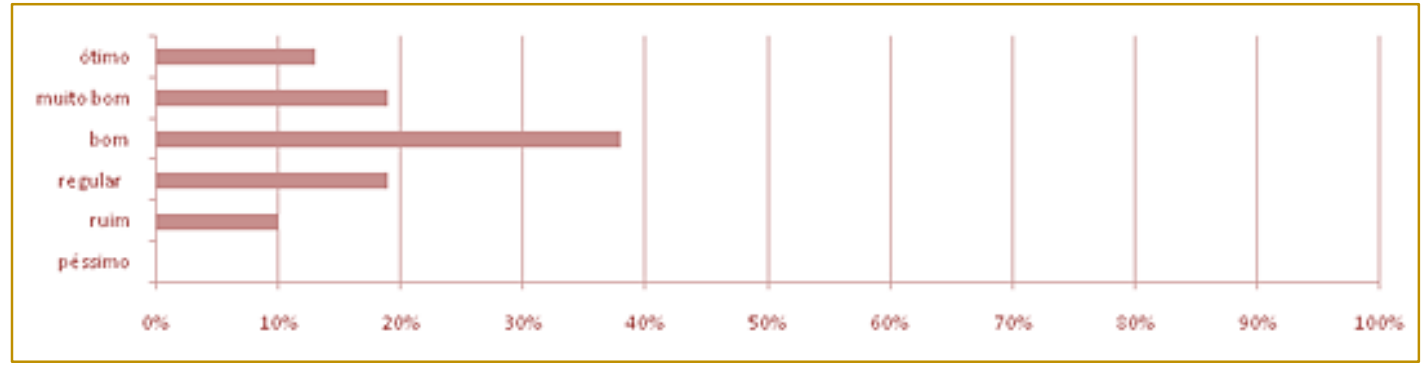

Fonte: Avaliação Institucional, Sonitec (2016)

Como podemos observar em relação ao ambiente de trabalho o nível de satisfação dos funcionários é maior (cerca de 65\%) enquanto o nível de insatisfação girou em torno de 30\%.

Gráfico 15: Orientações do seu coordenador ou gerente

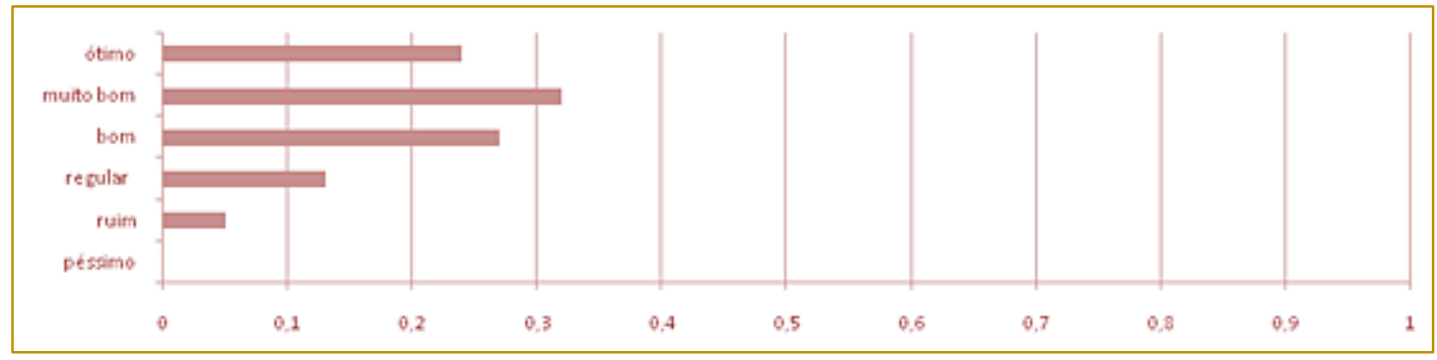

Fonte: Avaliação Institucional, Sonitec (2016)

Sobre este item observamos que são satisfatórias as orientações dos coordenadores ou gerentes.

Gráfico 16: Relacionamento com seu coordenador ou gerente

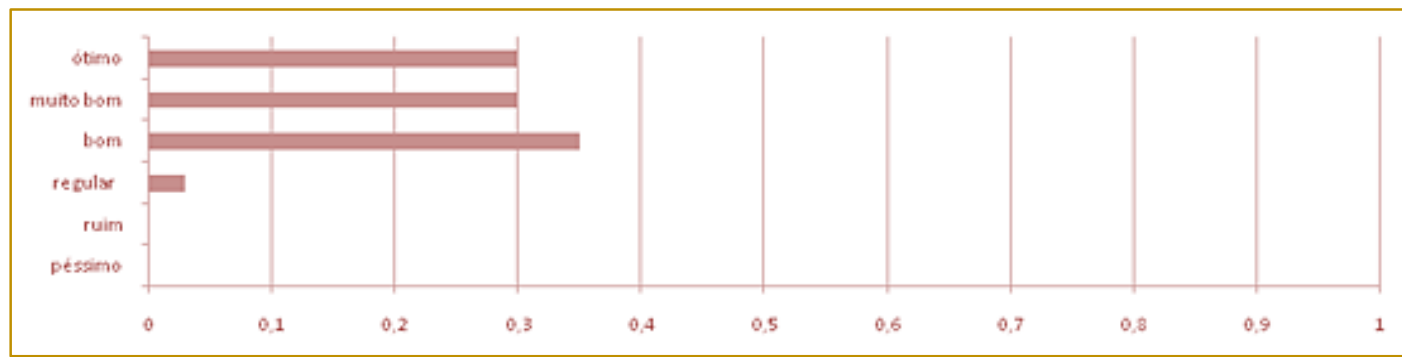

Fonte: Avaliação Institucional, Sonitec (2016)

Para os funcionários do setor operacional o relacionamento com os coordenadores ou gerente é satisfatório (média de 95\%). 
Gráfico 17: Relacionamento com os colegas

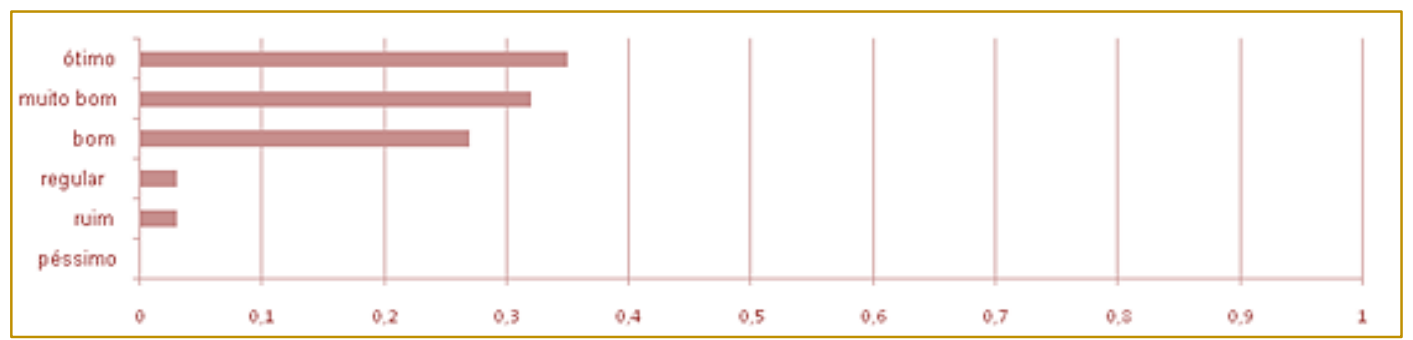

Fonte: Avaliação Institucional, Sonitec (2016)

Observa-se que também o nível de relacionamento com os colegas está em um nível muito bom (média de 95\%).

Gráfico 18: Salário

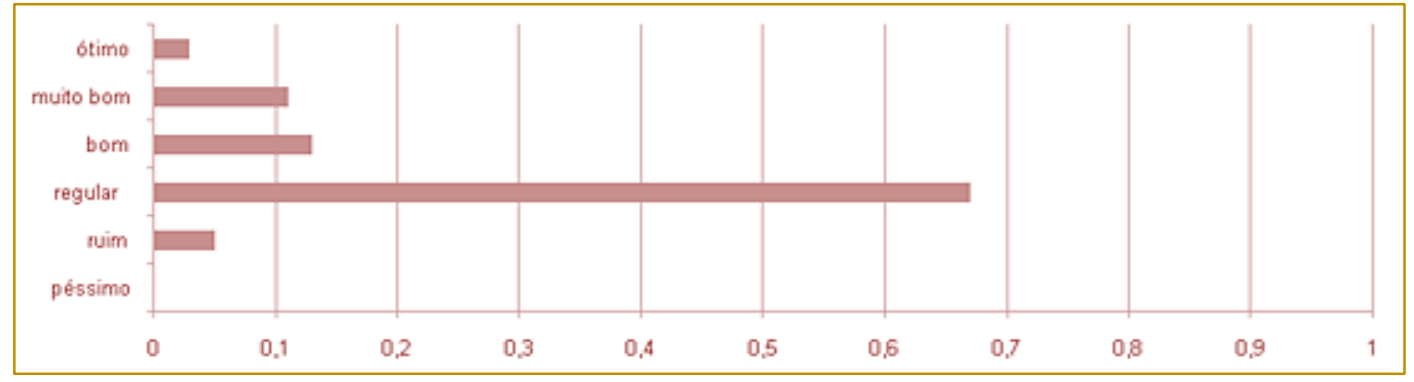

Fonte: Avaliação Institucional, Sonitec (2016)

Quando avaliamos o nível de satisfação em relação aos salários percebe-se que os colaboradores estão insatisfeitos (média de $75 \%$ ) citam como de regular a ruim.

Gráfico 19: Benefícios

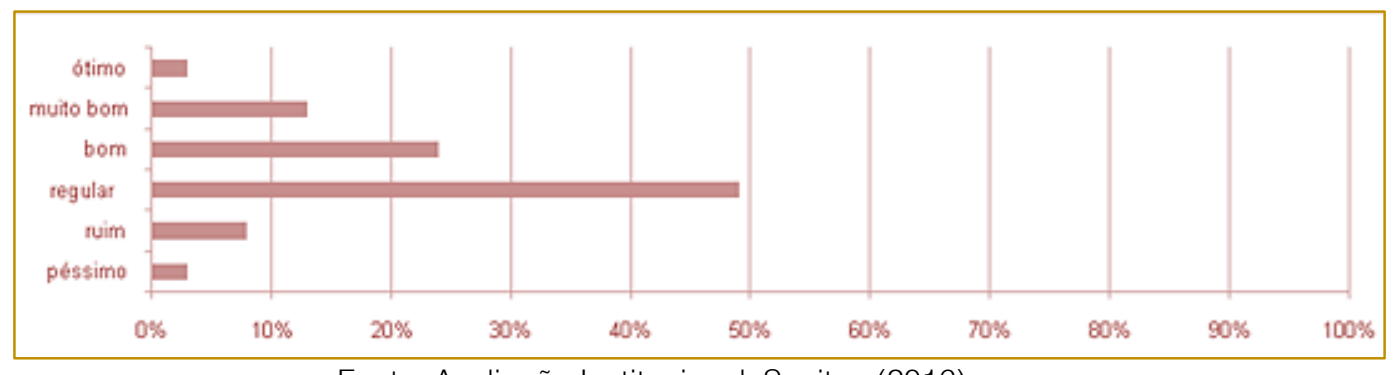

Fonte: Avaliação Institucional, Sonitec (2016) 
Observa-se neste tópico que a maioria dos colaboradores está insatisfeita (média de 68\%) com os benefícios oferecidos pela empresa.

Gráfico 20: Infra estrutura (equipamentos de trabalho)

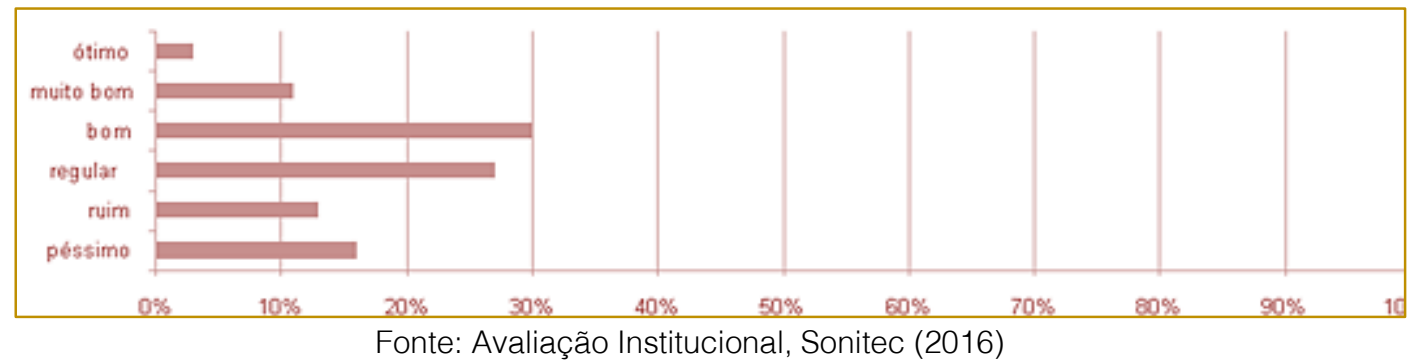

Sobre a infraestrutura houve divisão das opiniões dos colaboradores onde 55\% acham

insatisfatórias, 45\% acham que está de boa a ótima.

Gráfico 21: Área de Recursos Humanos e Departamento Pessoal

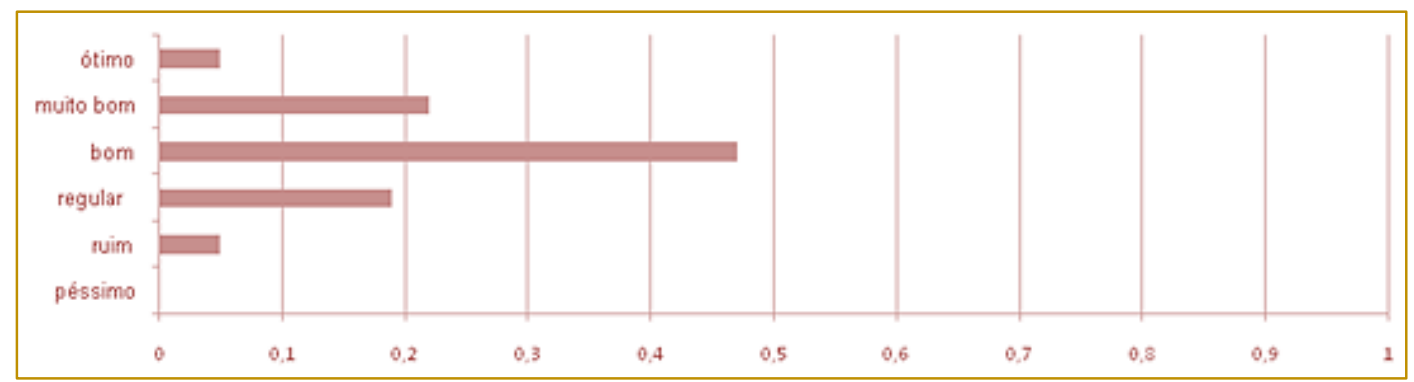

Fonte: Avaliação Institucional, Sonitec (2016)

Quando perguntados sobre a área de os colaboradores opinaram como satisfatória Recursos Humanos e Departamento Pessoal (média de 70\%).

Gráfico 22: Treinamentos

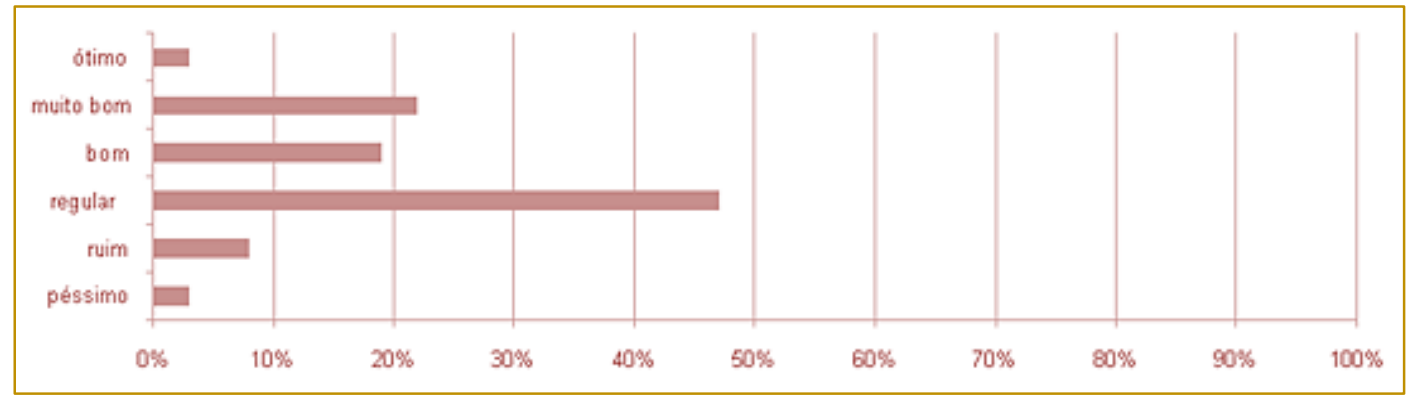

Fonte: Avaliação Institucional, Sonitec (2016) 
Em relação à parte de treinamentos observase que cerca de $60 \%$ está insatisfeita com os treinamentos oferecidos pela empresa.

\section{CONCLUSÃO}

Com base no exposto nesta pesquisa ficam claros pontos importantes para ser trabalhado pela empresa, melhorando assim o bem estar dos trabalhadores. Estratégias e programas voltados à reciclagem e aperfeiçoamento dos colaboradores, benefícios mais atrativos e um planejamento de carreiras setoriais trariam uma redução significativa do índice de turnover descrito na pesquisa.

Neste cenário um processo de recrutamento mais eficaz, desde a abertura do processo seletivo, uma posterior contratação e inserção no ambiente de trabalho, com pessoas melhor capacitadas á vaga que se destina proporciona pessoas mais engajadas em suas atividades e maior qualidade do produto ou serviço entregue pela empresa.

Pontos como estes contribuem para o bem estar dos colaboradores melhorando a infraestrutura e a qualidade do ambiente de trabalho. Com isso, a empresa recebe de

\section{REFERÊNCIAS}

[1] Araújo, LuisCesár G. de. Gestão de pessoas: estratégias e integração organizacional, $2^{2}$ a ed. - São Paulo. Atlas, 2009

[2] Carvalho, Antonio Vieira de. Nascimento, Luiz Paulo do. Serafim, Ozeléa Clen Gomes. Administração de recursos humanos - São Paulo. CengageLearnig, 2012

[3] Cervo, Amado L. Da Silva, Roberto. Bervian, Pedro A. Metodologia Cientifica, 6a ed. São Paulo. Pearson Prentice Hall, 2007.

[4] Chiavenato, Idalberto. Administração de recursos humanos - São Paulo. Atlas, 1979.

[5] Recursos humanos, 4ª ed. - São Paulo. Atlas, 1997.

[6] Administração de recursos Humanos, 2ª ed. - São Paulo. Atlas, 1980.

[7] Dyniewicz, Ana Maria. Metodologia da pesquisa em saúde para iniciantes - São Caetano do Sul. Difusão, 2007.

[8] Fernandez, Henrique Montserrat http://www.bibliotecas.sebrae.com.br/chronus/ARQ UIVOS_CHRONUS/bds/bds.nsf/39FFD559DE73D5 C6832575C700149565/\$File/NT00040F3A.pdf Acesso em 28/08/2015. contra partida maior engajamento e comprometimento dos colaboradores durante a execução de suas atividades laborais no dia a dia.

Outro ponto de vital importância neste processo é o ambiente de trabalho, que deverá ser o mais sadio possível, proporcionando uma relação interpessoal vantajosa onde exista a troca de experiências entre as pessoas, fazendo com que as mesmas aumentem a sua produtividade sempre alinhada aos preceitos definidos na missão e visão da organização.

A aplicabilidade de um programa de melhoria dos pontos críticos descrito na pesquisa não é uma tarefa simples e demanda o engajamento do corpo diretivo da organização uma vez que em tempos de crise econômica, funcionários comprometidos representam uma economia direta de insumos e desperdícios, aumentando também a satisfação do cliente final que por consequência fortalecerá a marca.

É fato que para que este programa de melhoria obtenha êxito, gestores e superiores precisam também se reciclar, assumindo uma postura versátil, dinâmica e comprometida com a excelência do serviço prestado transmitida e implementada por seus liderados.

[9] Fernandez, Henrique Montserrat. http://www.bibliotecas.sebrae.com.br/chronus/ARQ UIVOS_CHRONUS/bds/bds.nsf/B536BA9CA589F2 81032571D70066178A/\$File/NT000321CE.pdf Acesso em 28/08/2015

[10] Gil, Antonio Carlos. Métodos e Técnicas de pesquisasocial, 6 $6^{\underline{a}}$ ed. - São Paulo. Atlas, 2010.

[11] Karkotti, Gilson Riban Gestão de recursos humanos - Curitiba. Camões, 2008.

[12] Knapik, Janete. Gestão de pessoas e talentos - Curitiba. Intersaberes, 2012.

[13] Morales, Mércia. Princípios da administração de recursos humanos: aplicados em cursos técnicos e de qualificação profissional - São Paulo. Textonovo, 2002.

[14] Oliveira, Djalma de Pinho Rebouças de. Teoria geral da administração: umaabordagem prática, $2^{\underline{a}}$ ed. - São Paulo. Atlas, 2010.

[15] Rodrigues, Rui Martinho. Pesquisa acadêmica: como facilitar o processo depreparação de etapas - São Paulo. Atlas, 2007.

[16] Silveira, Amélia. Colossi, Nelson. Sousa, Claudia Gonçalves. Administração Universitária: estudos brasileiros - Florianópolis. Insular, 1998.

[17] Souza, Carla Patrícia da Silva. Cultura e Clima organizacional: Compreendendo aessência das organizações - Curitba. Intersaberes, 2014. 


\section{Capítulo 7}

\section{RELACÕES DE CONFIANCA NA GESTÃO EMPRESARIAL: UM ESTUDO NA EMPRESA DOCES DYANA NORDESTINO NA CIDADE DE POMBAL-PB}

\section{Raphaela Mota Lacerda}

Simone Costa Silva

\section{Dante Flávio Oliveira Passos}

Érika Campos Marinho de Góes Pires

Eunice Ferreira Carvalho

Resumo: Diante das incertezas em que a economia mundial se encontra atualmente, observa-se a necessidade das empresas obterem uma vantagem competitiva em relação às outras. Nessa perspectiva, o presente estudo relata sobre as relações de confiança na gestão empresarial, aprofundando sobre a maneira como essas relações se desenvolvem, abordando, assim, a confiança gerencial, interpessoal e institucional. O objetivo principal deste trabalho é compreender como são desenvolvidas as relações de confiança no ambiente organizacional da empresa Doces Dyana Nordestino, na cidade de Pombal-PB. A pesquisa é um estudo de caso com uma abordagem quantitativa e qualitativa, de caráter descritivo e exploratório. Para obtenção dos resultados, foi aplicado um questionário junto aos colaboradores, a partir do modelo de Zanini, Lusk \& Wolff (2009). A análise dos resultados mostrou que não existem fortes relações de confiança na empresa e que o gestor não estimula para que elas aconteçam. Além disso, a Confiança Institucional apresenta-se como a de menor grau. Conclui-se, portanto, que existe uma forte necessidade na empresa de aumentar as relações de confiança; o que pode ser obtido, como por exemplo, mantendo uma comunicação aberta, sendo justo, falando a verdade, entre outras questões.

Palavra Chave: Relações de Confiança. Vantagem Competitiva. Confiança. 


\section{INTRODUÇÃO}

Considerando o ambiente em que a economia mundial está inserida, caracterizado pela competição acirrada entre as empresas para conseguir uma fatia deste tão sonhado mercado, inovar se tornou não só importante como também essencial para se manterem vivas. Em busca disso, os gestores têm procurado inserir no contexto organizacional uma forma de gestão que agregue valor ao negócio. Os mesmos têm percebido que reside nas pessoas, que fazem a organização, o capital mais precioso e que para inovar é necessário proporcionar um ambiente em que o indivíduo possa deixar todas as suas competências à disposição da empresa e para tal é preciso dar atenção especial às relações de confiança dentro da organização como uma vantagem competitiva para se obter sucesso em relação às outras empresas.

Nos últimos anos, as empresas têm se deparado com vários problemas relacionados com o seu quadro de funcionários, e um que tem se destacado bastante é a falta de confiança entre os membros da organização, seja em relação aos seus pares, ao gestor, seja na organização como um todo, isso não só prejudica os relacionamentos entre eles como também afeta de maneira significativa a produtividade e o andamento da organização. De acordo com Robbins (2009, p. 169), "confiança pode ser definida em termos de uma expectativa positiva de que a outra pessoa não irá reagir de maneira oportunista seja por palavras, ações, comportamentos ou decisões".

Nesta perspectiva, o grande benefício de ambientes de trabalho com uma atmosfera de alta confiança é que o mesmo permite que indivíduos realizem transações sem a necessidade de precaução contra eventuais comportamentos oportunistas dos outros, aceitando assim maiores riscos; já em atmosferas de baixa confiança, as pessoas são mais receosas em realizar investimentos de confiança umas nas outras (MIGUELES \& ZANINI, 2014).

Diante de tudo que foi exposto, o presente artigo se propôs a avançar na seguinte discussão: Como se desenvolvem as relações de confiança na gestão empresarial?

Neste sentido, procurou-se, de modo geral, compreender como são desenvolvidas as relações de confiança no ambiente organizacional da empresa Doces Dyana Nordestino, na cidade de Pombal-PB, tendo como objetivos específicos: - Descrever aspectos das relações de confiança nos âmbitos gerencial, interpessoal e institucional e - Destacar a dimensão da confiança em maior evidência no ambiente estudado.

A escolha do tema a ser investigado reside no fato da escassez de estudos com esta abordagem, podendo-se afirmar que são poucos os trabalhos científicos relacionando a gestão empresarial com as relações de confiança, por esse motivo identificou-se a necessidade de conhecer melhor aspectos envolvidos nesse fenômeno, uma vez que em um ambiente onde há confiança, o medo de expressar as opiniões ou de realizar alguma atividade dentro da empresa diminui. Além disso, a confiança melhora as relações de trabalho e faz com que as atividades da organização funcionem de maneira mais eficiente.

Almejando 0 alcance dos objetivos pretendidos, esse estudo utilizou-se de uma metodologia mista - teórica e prática - que buscou o resumo dos principais conceitos estudados, objetivando a comprovação prática do estudo. Trata-se de uma pesquisa exploratória e descritiva com abordagem quantitativa e qualitativa, usando como método o estudo de caso. O contexto analisado foi a empresa Doces Dyana Nordestino e os participantes da pesquisa foram os colaboradores da empresa. Utilizou-se como instrumentos para coleta de dados a aplicação de um questionário com os colaboradores e a observação simples.

\section{REFERENCIAL TÉORICO}

\subsection{CONFIANÇA: CONCEITOS E ASPECTOS}

Incerteza e instabilidade são as palavras que melhor podem caracterizar o mercado atualmente. $\mathrm{O}$ ambiente tem mudado a dinâmica de mercado em direção a um modelo mais competitivo e com isso as pessoas e as empresas têm enfrentado um dilema relacionado à incerteza ambiental ou incerteza institucional. Para Zanini, Lusk e Wolff (2009, p. 74), "a incerteza institucional pode ser compreendida como a falta de previsibilidade de mudanças do ambiente externo que afetam a organização". Essa incerteza influencia no desenvolvimento da confiança, afetando o comportamento humano consideravelmente, 
restringindo o desenvolvimento de confiança devido ao aumento da incerteza comportamental.

A falta de confiança é generalizada e se estende a estranhos, colegas de trabalho, governo, instituições, empresas, enfim, qualquer coisa que possa representar algum tipo de ameaça à estabilidade ou segurança das pessoas. E assim, a tendência é fazer da desconfiança uma barreira que separa os indivíduos dos perigos do mundo exterior. Enquanto as pessoas desconfiam para não ser passados para trás não conseguem ir adiante. A desconfiança as aconselha a ficar nos limites do conhecido, a evitar riscos e a se fechar para os outros, ao passo que o mundo de hoje requer abertura para o desconhecido, coragem para arriscar e integração com as pessoas (NAVARRO \& GASALLA, 2007).

Diante desse contexto, é perceptível a falta de confiança que existe entre as pessoas com relação a tudo o que envolve o seu cotidiano. Essa desconfiança faz com que se sintam mais seguros, mantendo certa distância das outras pessoas, no entanto, ela também impede que descubram novos horizontes que a falta de confiança as impossibilitam de conhecer.

A definição do termo confiança vem sendo discutido por diversos estudiosos ao longo dos anos. De acordo com Robbins (2009, p. 169) "a confiança é a expectativa positiva de que a outra pessoa não agirá de maneira oportunista - seja por palavras, ações ou decisões". Diante disso, pode-se dizer que a palavra confiança está intimamente relacionada com os sentimentos de familiaridade e risco.

O mesmo autor fala ainda que existem cinco dimensões que fundamentam o conceito de confiança: integridade (baseia-se na honestidade e confiabilidade); competência (tem a ver com as habilidades e conhecimentos técnicos e interpessoais); consistência (está relacionada com a segurança, previsibilidade e julgamento na administração das situações); lealdade (consiste na disposição de proteger e defender outra pessoa); abertura (acreditar que a outra pessoa tem total confiança em você) (Idem).

O significado da palavra confiança possui algumas variâncias, mas seu principal significado está relacionado à crença, seja ela em uma pessoa, organização, em expectativas, capacidades seja em si próprio.
Neste sentido, ela está intimamente ligada a alguns aspectos subjetivos, de difícil descrição, explicação, e quantificação que fazem parte de diversas situações do ser humano (VALENTIM, 2006). Assim, que algo que é confiável para uma pessoa, não necessariamente será confiável para outra pessoa, ou seja, a credibilidade em algo ou alguém depende de um conjunto de aspectos inerentes à cada pessoa.

Confiança também pode ser definida como a aceitação antecipada e voluntária de um investimento de risco através da abdicação de mecanismos contratuais explícitos de segurança e controle contra comportamentos oportunistas, na expectativa de que a outra parte, apesar da abdicação de tais garantias contratuais, não agirá de forma oportunista (RIPPERGER, 1998).

No ambiente organizacional, a convicção na integridade, caráter e habilidade do líder, também pode ser entendida como confiança. Quando os seguidores confiam em um líder, eles não possuem medo de expor as suas ações porque sentem confiança que seus direitos e interesses não serão prejudicados (ROBBINS, 2007). De acordo com Sato (2003, p. 2), "um ambiente em que há confiança, o medo ou temor em agir, em realizar as atividades, em função da incerteza das consequências futuras diminuem".

Ainda segundo a autora, a confiança é definida basicamente através de dois pontos de vista, um que enfatiza o discurso, ou seja, fundamenta-se em valores que são intrínsecos à pessoa e outro que enfatiza um lado prático, que requer experiências e convivências entre as partes. Neste caso, a confiança surge justamente quando, a partir do confronto entre as expectativas e a prática, nota-se que há uma concordância. Ou seja, a ação ou atitude de uma parte atingiu as expectativas de outra (Idem).

Nesse contexto, percebe-se que a incerteza ambiental obrigou as empresas a mudarem a maneira de gerir seus negócios, fazendo com que os gestores dessem maior atenção à confiança dentro das organizações. Seguindo a mesma linha de pensamento, a seguir será discutido a respeito de alguns tipos de relacionamentos existentes dentro das organizações e como a confiança pode ter influência sobre estes. 


\subsection{RELACIONAMENTOS E CONFIANÇA NAS ORGANIZAÇÕES}

Há muito tempo se prega a importância de um clima organizacional favorável, que estimule o bom andamento das atividades nas organizações. Quando o clima organizacional é harmônico, os colaboradores sentem-se mais seguros e, consequentemente, tem um impacto positivo na produtividade, no entanto, o inverso também é perceptível, sendo mensurado com alto nível de absenteísmo e baixa produtividade (BARROSO, 2013).

Mediante isso, pode-se perceber que a confiança interfere diretamente no clima organizacional, fazendo com que as atividades da empresa sejam beneficiadas ou prejudicadas a depender de como se encontra este clima organizacional. Portanto o mesmo deve ser incentivado baseado nos métodos que estimulam a confiança.

Robbins (2009) expõe sobre a confiança baseada no conhecimento e a confiança baseada na identificação. A primeira fundamenta-se na previsibilidade do comportamento que resulta de um histórico de interações. Isso acontece quando temos informações adequadas sobre alguém a ponto de podermos fazer previsões sobre seu comportamento. Já segunda, é quando as partes entendem as intenções uma da outra e concordam com suas vontades e seus desejos; essa confiança mútua desenvolve-se ao ponto de uma parte agir em nome da outra (ROBBINS, 2009).

Sheppard e Sherman (1998) apud Valentim (2006) entendem a confiança como função das relações em três níveis: entre pessoas, entre pessoas e organizações e entre organizações e o contexto institucional em que essas relações se inserem. Já no que se refere ao ambiente de trabalho, pode-se afirmar que é composto por três tipos de relacionamentos interconectados: entre os funcionários e a direção da empresa, entre os funcionários e seu trabalho e entre os funcionários e os outros funcionários.

No que se refere ao ambiente de trabalho, pode-se afirmar que o relacionamento entre os empregados e a direção da organização é o relacionamento mais importante dos três e tem como elemento fundamental a confiança, que é o elemento essencial na criação de um ambiente agradável para se trabalhar. Embora a confiança seja o elemento mais importante na criação deste ambiente, deve-se prestar atenção também na relação do empregado com o próprio trabalho, pois as pessoas desenvolvem o orgulho quando sentem que seu trabalho tem um significado especial e a forma como cada funcionário se relaciona com o outro no trabalho (LEVERING, 1995).

Nesta perspectiva, fala-se em confiança gerencial que se refere aos antecedentes da confiança. O gestor da organização deve ter credibilidade junto aos funcionários, seus colaboradores devem ser percebidos como pessoas competentes, com uma visão clara do estágio para aonde a organização está indo e sabendo como chegar lá (LEVERING, 1995).

De acordo o mesmo autor, as pessoas gostam de trabalhar para pessoas firmes, executivos precisam ser sinceros mesmo em momentos difíceis. Além disso, para ganhar a confiança dos funcionários, os gestores devem estar dispostos a ouvir duras verdades e a não prejudicar aqueles que falam, no entanto, o desejo de ouvir não é suficiente para estabelecer credibilidade, os executivos devem adquirir a reputação de que cumprem o que prometem e demonstrar coerência em seu comportamento, precisam provar a teoria na prática (/dem).

Para que os colaboradores se disponham a seguir alguém, é necessário que eles primeiro se certifiquem de que esse alguém seja uma pessoa merecedora de confiança. De modo geral, pode-se dizer que o gestor que concede maior poder aos seus funcionários e que cria equipes de trabalho autogeridas tem reduzido ou eliminado muitos mecanismos tradicionais utilizados para monitorar os funcionários. Se um grupo de trabalho, por exemplo, é livre para programar seu próprio trabalho, avaliar seu próprio desempenho e até para tomar suas decisões de contratação para a equipe, a confiança se torna crucial (ROBBINS, 2007).

Os colaboradores também precisam sentir que o gestor da empresa é justo com todos os funcionários. No que se refere à remuneração; os mesmos devem perceber que as promoções e remunerações são baseadas em mérito e contribuição e não em manobras políticas. Além disso, se alguém se sentir tratado injustamente, precisa crê que existem meios aos quais poderão recorrer. $\mathrm{E}$, ainda, a confiança gerencial também envolve respeito; os empregados precisam sentir que são respeitados e tratados como indivíduos, parte disso advém da atribuição de maiores 
responsabilidades a eles e do seu envolvimento em decisões que afetem seu trabalho (LEVERING, 1995).

Em relação à confiança interpessoal, pode-se afirmar que esta se refere a uma específica relação de confiança pessoa por pessoa. Segundo Lewis e Weigert (1985) apud Valentim (2006), a confiança pessoal envolve um laço emocional entre indivíduos, e a dor emocional que cada um experimentaria no caso de uma traição eventual, serve de base protetora da confiança contra ganhos de curto prazo.

Almeida e Zanini (2009, p. 315) afirmam que "a confiança interpessoal refere-se à vontade de um indivíduo de se envolver em uma relação de confiança com um indivíduo específico ou com um grupo". As pessoas precisam de aceitação, compreensão, apreciação e diversão em suas interações com os colegas; onde existe confiança interpessoal, os empregados sentem que podem ser eles mesmos, e isso é realmente importante quando a empresa exige muito de seus funcionários (LEVERING, 1995).

A confiança interpessoal pode ter um impacto tremendo na cooperação entre os funcionários. Para Ripperger (1998, p. 93), "existe duas condições independentes que têm de ser satisfeitas a fim de alcançar as ações de cooperação baseadas em confiança interpessoal: a coexistência de uma expectativa de confiança e de uma ação confiante".

Já quando o tema é confiança institucional, para obtê-la é necessário que os empregados acreditem que fazem a diferença pessoalmente; os mesmos devem ter um senso de propriedade em relação ao produto ou serviço que realizam, além disso, precisam perceber que o produto ou serviço tem algum significado para o outro. Os gestores podem promover essa atitude ajudando os empregados a ver como suas tarefas se encaixam no contexto maior ou como os clientes usam o produto (LEVERING, 1995).

Ainda segundo o mesmo autor, os empregados também querem se sentir orgulhosos do papel de sua organização para a população. O fato de as pessoas se sentirem orgulhosas de seu trabalho e de sua empresa proporciona um importante retorno, elas ficam mais dispostas a dar um extra para terminar um trabalho (/dem)
De modo geral, a incerteza ambiental limita o desenvolvimento de confiança gerencial e da confiança interpessoal. Sob os efeitos das incertezas relativas à instabilidade, as empresas enfrentam limitações significativas no desenvolvimento dos elementos estruturantes necessários à criação e manutenção da confiança empresarial e interpessoal (ALMEIDA \& ZANINI, 2009). Por fim, o clima organizacional favorável interfere diretamente no andamento das atividades da organização. Pode-se dizer que as relações de confiança gerencial, interpessoal e institucional afetam esse clima tanto positivamente quanto negativamente, com isso percebe-se a importância das empresas buscarem melhorar esses três tipos de relacionamentos.

\subsection{GESTÃO BASEADA EM CONFIANÇA}

Ao longo dos anos, muitos líderes conseguiram enxergar que investir milhões de dólares em tecnologia e reengenharia de processos não é suficiente para a empresa não ir ao fracasso se não mudar o ambiente de trabalho, ou seja, precisaria criar um local de trabalho onde as pessoas genuinamente quisessem chegar todos os dias e onde todos estivessem ansiosos por ajudar a empresa a ter sucesso (LEVERING, 1995). Sendo assim, observa-se que o tempo em que o sucesso da empresa dependia apenas da quantidade de tecnologia que era empregada passou, e agora as empresas estão cada vez mais percebendo que a chave desse sucesso se encontra nos seus colaboradores.

No mundo corporativo, onde o individualismo se faz presente, não compartilhar tudo o que se tem, não dizer tudo o que se sabe e não acreditar em tudo o que se ouve são estratégias de sobrevivência. Isso acontece devido às próprias organizações darem a entender que não confiam completamente nos seus colaboradores; se confiasse, não haveria tantos controles, regras e procedimentos para serem seguidos (NAVARRO \& GASALLA, 2007).

Porém, a confiança deve ser considerada como um fator fundamental na gestão do ambiente organizacional, por se tratar de um mecanismo a partir do qual os atores sociais reduzem a complexidade do seu sistema de interação pela crença na credibilidade de uma pessoa (GIDDENS, 1991). Ela nasce da 
partilha de valores e capacita as pessoas a trabalharem em conjunto, o que pode gerar mais conhecimento e inovação (ANDRADE; FISCHER; STEFANO, 2011).

Desta forma, o ambiente da nova economia sugere que a confiança pode ser altamente desejável como mecanismo de controle para coordenar tarefas específicas relacionadas com a natureza da produção, sistemas de informação e de conhecimento intensivo (ALMEIDA \& ZANINI, 2009).

Para Robyn (2005, p. 4):

A natureza das relações e a confiança existente entre os profissionais enquanto colegas de trabalho são estudadas visando estabelecer ligações entre o nível de confiança e o clima organizacional e estudar a hipótese de que uma maior confiança entre os colaboradores - e entre esses e seus lideres gera melhores resultados à empresa, incorrendo em aumento da produtividade e da satisfação no nível da organização.

Para alguns autores, a confiança tem um papel importante: o de facilitar as relações de trabalho e as trocas econômicas, possibilitando uma gestão mais efetiva. Confiança é, pois, definida com base em dois fatores: um que enfatiza o discurso (valores intrínsecos à pessoa) e outro que enfatiza a prática (experiências e convivência) (SATO, 2003).

De acordo com Levering (1995, p. 16), "um excelente lugar para se trabalhar é em uma organização onde os funcionários confiam nas pessoas para quem trabalham, têm orgulho do que fazem e gostam das pessoas com quem trabalham".

De modo geral, é com o passar do tempo que uma relação de confiança se estabelece, porém, sempre na racionalidade, ou seja, ao menos dentro de um cenário intraorganizacional, pode ser visualizada uma cooperação prévia estimulada pela própria organização para, só ao longo do tempo, constituir-se ou não uma relação de confiança baseada na racionalidade a partir de tais atitudes de cooperação (SATO, 2003).

A existência de confiança no trabalho melhora o nível de cooperação e, nos negócios de hoje, complicados e mutantes, a cooperação é essencial. O fato de se ter uma força de trabalho com pessoas que cooperam integralmente umas com as outras é uma vantagem competitiva para qualquer empresa (LEVERING, 1995).

Ela também estimula as pessoas a relacionarse de maneira mais aberta e franca, compartilhar experiências e conhecimentos, comprometer-se com objetivos da empresa, engajar-se na solução de problemas e participar dos processos decisórios (NAVARRO \& GASALLA, 2007).

Para Robbins (2007, p. 403):

Os funcionários precisam ter confiança de que a administração os tratará com justiça, e a administração precisa confiar que os trabalhadores cumprirão escrupulosamente suas responsabilidades. A tendência rumo à ampliação das relações não hierárquicas dentro das empresas e entre elas aumenta a necessidade da confiança interpessoal

Sendo assim, um ambiente de alta confiança apresenta diversas vantagens, como o aumento da satisfação e comprometimento dos empregados, melhoria de comunicação entre superior e subordinado, aceitação e delegação de autoridade, exercício de liderança, percepção de justiça nos julgamentos, menor competição interna em negociações e menos conflito, legitimidade das intenções de mudança organizacional, melhor desempenho individual e em equipes de trabalho (ZANINI, 2008).

Ela também pode reduzir a necessidade da aplicação de mecanismos formais contra comportamentos oportunistas entre parceiros de interatividade e, desta forma, reduzir os custos de monitoração formal e controle (RIPPERGER, 1998). E ainda, como já mencionado, a existência de confiança entre os funcionários de uma empresa resulta em cooperação. Com isso, agiliza e facilita as tarefas e o desempenho geral da organização, o que mostra que a confiança funciona como um meio facilitador das atividades diárias dos funcionários e, por tanto, facilita a gestão da organização como um todo (SATO, 2003).

Nesse contexto, as empresas têm percebido a importância que os colaboradores possuem e têm procurado melhorar a gestão dos seus negócios com base em métodos que influenciem favoravelmente o clima organizacional da empresa, para com isso obterem melhores resultados com o aumento da produtividade e da satisfação no nível da organização. 


\section{ASPECTOS METODOLÓGICOS}

A presente pesquisa classifica-se, quanto aos objetivos, em exploratória e descritiva. Exploratória devido à natureza investigativa e de sondagem, além de enfatizar um tema cujas pesquisas são reduzidas. Quanto à pesquisa descritiva, para Vergara (2011, p. 42), "a pesquisa descritiva expõe características de determinada população ou de determinado fenômeno. Não tem compromisso de explicar os fenômenos que descreve, embora sirva de base para tal explicação".

Quanto à abordagem, essa pesquisa se caracterizou como uma pesquisa quantitativa e qualitativa. Quantitativa, devido à utilização de dados estatísticos capaz de mensurar as relações entre variáveis e sua relação de causa e efeito (ROESCH, 2006). Qualitativa por sua característica de dar poder ou dar voz às pessoas, em vez de tratá-las como objetos, cujo comportamento deve ser quantificado e estaticamente modelado (BAUER \& GASKELL, 2012).

O método utilizado foi o estudo de caso, pois se trata de um caso particular suficiente para análise da pesquisa. Segundo Vergara (2011, p. 44), "estudo de caso é o circunscrito a uma ou poucas unidades, entendidas essas como pessoa, família, produto, empresa, órgão público, comunidade ou mesmo país".

Os sujeitos da pesquisa foram constituídos pelo corpo funcional da empresa, que inclui o gerente e os demais colaboradores, que, na empresa investigada, ocupam cargos de auxiliares de embalagem, totalizando dez pessoas. O número de colaboradores abordados, nove no total, foi escolhido de forma não probabilística, por conveniência.

Os procedimentos utilizados para essa pesquisa foram a aplicação de um questionário fechado para coletar os dados junto aos colaboradores, além da observação simples para melhor descrever situações em que o questionário não era capaz de demonstrar. O referido instrumento foi composto por 27 questões de múltipla escolha, sendo 9 relativas à confiança gerencial, 9 à confiança interpessoal e 9 à confiança institucional. No qual se pretendia analisar o grau de confiança entre os funcionários e seus pares; entre os funcionários e o gestor e entre os funcionários e a instituição. O questionário foi construído com base nos modelos de Zanini; Lusk \& Wolff (2009).

Os dados foram coletados entre os dias 05 e 11 de maio do corrente ano, nas dependências da empresa, onde foi aplicado o questionário com os funcionários, solicitando que os mesmos respondessem de acordo com o grau de confiança que eles possuíam em relação às dimensões da confiança.

Para viabilizar os cálculos de mensuração dos níveis de confiança foi utilizada uma escala tipo Likert para avaliar o grau de confiança em cada assertiva, cujos pontos recebem rótulos específicos: 1- Discordo totalmente; 2Discordo em parte; 3- Neutro; 4- Concordo em parte; 5- Concordo totalmente. Em seguida, os dados fornecidos foram trabalhados a partir de planilhas do Microsoft Excel, objetivando encontrar a média e desvio padrão das respostas produzidas pelos respondentes quanto ao grau de concordância em cada nível de confiança.

\section{RESULTADOS ENCONTRADOS}

Buscando analisar como são construídas e desenvolvidas as relações de confiança no contexto organizacional, foi elaborado um inventário com várias situações relacionadas à confiança, do qual consta a análise do grau de confiança em três dimensões: interpessoal e institucional.

A empresa de razão social Anailton Bezerra Araújo ME e nome fantasia Doces Dyana Nordestino possui 31 funcionários, sendo 24 mulheres, que trabalham no setor de embalagem e 7 são homens e ficam no setor da produção. A estrutura da empresa está dividida em três setores: produção, embalagem e expedição. Como a empresa é de pequeno porte, o empresário, que também é o gerente da mesma, é responsável por gerenciar todos os setores da empresa, desde transações até a expedição final, exceto o setor de embalagem, que é gerenciado por sua esposa.

A empresa foi fundada em 1999 pelo atual empresário, e no começo ele mesmo produzia os doces e comercializava; com o crescimento da empresa, ele passou a ser responsável apenas pela administração da mesma. A participação da empresa no mercado tem se intensificado bastante nos últimos anos, além da Paraíba, ela distribui para os Estados do 
Piauí, Maranhão, Bahia, Sergipe, Pará e Brasília.

Com relação a essa pesquisa, os resultados dos questionários revelam que:

\section{A) NÍVEL DE CONFIANÇA GERENCIAL}

Nesta dimensão da confiança, foram questionados sobre a confiança na capacidade e qualificação do gerente em executar as tarefas, se eles dependiam do gestor para lidar com uma questão importante para eles, se dependiam do mesmo em situações difíceis e se falavam ao gerente sobre como eles se sentiam no trabalho, entre outras questões. Nesta perspectiva, pode-se destacar que os itens que obtiveram os maiores e menores índices foram, respectivamente, se eles confiavam na opinião do gestor sobre o desenvolvimento do trabalho deles, obtendo como resposta uma média de 4,33, o que significa que a maioria dos respondentes confia. Por outro lado, sobre o compartilhamento de sentimentos pessoais com o gerente, obteve-se uma média de 1,67, ou seja, essa não é uma prática usada por eles, uma vez que na escala utilizada significa "1- Discordo totalmente".

A Tabela 01 mostra a média obtida e o desvio padrão para cada assertiva.

Tabela 01: Nível De Confiança Na Gerência

\begin{tabular}{|c|c|c|}
\hline \multicolumn{1}{|c}{ CONFIANÇA } & $\begin{array}{c}\text { RESULTADO } \\
\text { (Escala de 1 a 5) }\end{array}$ & DESVIO PADRÃO \\
\hline Capacidade e qualificação & 3,89 & 0,87 \\
\hline Lidar com uma questão importante & 2,56 & 1,42 \\
\hline Apoio em situações difíceis & 3,00 & 1,05 \\
\hline Opinião a respeito do seu trabalho & 4,33 & 0,66 \\
\hline Compartilhar sentimentos pessoais & 1,67 & 0,94 \\
\hline Falar sobre como se sente no trabalho & 3,00 & 1,63 \\
\hline Defende os interesses dos empregados & 3,56 & 1,34 \\
\hline Sinceridade & 2,89 & 1,29 \\
\hline Comportamento consistente & 2,67 & 1,15 \\
\hline
\end{tabular}

Fonte: Dados da pesquisa (2015)

Portanto, de acordo com as respostas obtidas pelos funcionários a confiança na gerência da empresa obteve uma média geral de 3,06, o que significa que os colaboradores nem concordam nem discordam da confiança em seu gerente. Conclui-se que quanto mais voltada para o trabalho, maior é o índice de confiança e quanto mais voltado para relacionamentos interpessoais pior é esse índice.

\section{B) NÍVEL DE CONFIANÇA INTERPESSOAL}

Esse tópico buscou abordar o nível de relação de confiança entre os membros da organização e seus pares. Para isso, perguntou-se sobre a confiança em outro funcionário para fazer o trabalho deles, se eles eram capazes de confidenciar a outra pessoa questões pessoais que estivessem afetando o trabalho e se são capazes de compartilhar seus sentimentos pessoais com outros funcionários.

Nesta dimensão da confiança receberam a melhor média os itens que tratavam sobre: "se compartilhavam com os outros colaboradores sua opinião em relação ao trabalho" e "se acreditavam que podiam contar com a ajuda de outro colega de trabalho em situações de dificuldade".

O demonstrativo dos resultados dessa dimensão está na Tabela 02. 
Tabela 02: Nível De Confiança Interpessoal

\begin{tabular}{|l|c|c|}
\multicolumn{1}{|c}{ Confiança } & $\begin{array}{c}\text { Resultado } \\
\text { (escala de 1 a 5) }\end{array}$ & Desvio padrão o \\
\hline Outro funcionário realizar o seu trabalho & 2,89 & 1,52 \\
\hline Confidenciar questões pessoais que afetem o trabalho & 2,89 & 1,37 \\
\hline Promessas de outros funcionários & 2,11 & 1,09 \\
\hline Compartilha sua opinião sobre o trabalho & 3,44 & 1,07 \\
\hline Opinião de outros funcionários & 3,22 & 1,13 \\
\hline Ajuda em situações de dificuldade & 3,44 & 1,42 \\
\hline Compartilha sentimentos pessoais & 3,00 & 1,70 \\
\hline $\begin{array}{l}\text { Se tivessem oportunidade, outros funcionários se } \\
\text { aproveitariam de você }\end{array}$ & 3,33 & 1,41 \\
\hline Compartilha ideias novas & 2,11 & 1,37 \\
\hline
\end{tabular}

Fonte: Dados da pesquisa (2015)

A média dessas respostas foi de 3,44, ou seja, eles possuem certa confiança nos outros colaboradores para compartilharem sua opinião em relação ao trabalho e também acreditam que eles os ajudariam em situações de dificuldade. Nas assertivas que expõem sobre "a confiança nas promessas dos outros funcionários" e também, "se contam para os colegas suas ideias novas", a média obtida foi de 2,11 nas duas perguntas, sendo as mais baixas, ou seja, assim como na confiança gerencial esta dimensão obteve os melhores índices quando a questão se referia às atividades voltadas para o trabalho. A média geral de confiança interpessoal obtida na empresa é de 3,00 , ou seja, não é muito intenso esse tipo de confiança, mas também não é fraca.

\section{C) NÍVEL DE CONFIANÇA INSTITUCIONAL}

Esta dimensão buscou-se mostrar como são construídas as relações de confiança no ambiente organizacional, com as respostas obtidas dos colaboradores em relação a aspectos que caracterizam a confiança institucional (Tabela 03). A assertiva melhor avaliada (maior média) foi a que se refere a uma justa remuneração quando se compara aos outros colaboradores, com uma média de 3,56. A assertiva que trata sobre a preocupação da empresa com os sentimentos das pessoas obteve a menor média com 1,77.

Esta dimensão questionava, ainda, assuntos considerados de relevada importância, tais como: Comunicação (média 2,77), tomada de decisão consistente $(3,00)$ e participação dos colaboradores com sugestões $(2,22)$. No entanto, estes não foram bem avaliados. Indicando que são temas a serem melhor trabalhados pela organização.

Uma das maneiras de se obter confiança é através de interações com outras pessoas, com isso, é importante que a empresa possua esse hábito com seus colaboradores para que a confiança institucional seja estimulada. Esta dimensão obteve a média geral de 2,65, ou seja, os colaboradores da empresa concordam em parte com esse tipo de confiança. O resumo das assertivas abordadas nesta dimensão se encontra na Tabela 03.

Tabela 03: Nível de confiança institucional

\begin{tabular}{|l|c|c|}
\multicolumn{1}{c}{ Confiança } & $\begin{array}{c}\text { Resultado } \\
\text { (escala de 1 a 5) }\end{array}$ & Desvio padrão \\
\hline Sinceridade & 3,33 & 1,25 \\
\hline Tratamento justo & 3,00 & 1,15 \\
\hline Remuneração justa & 3,56 & 0,83 \\
\hline Sugestões dos funcionários & 2,22 & 1,23 \\
\hline Preocupação com os sentimentos pessoais & 1,77 & 1,13 \\
\hline Chance de resolver problemas do trabalho & 2,11 & 1,09 \\
\hline Decisões consistentes & 3,00 & 0,82 \\
\hline Comunicação aberta & 2,77 & 0,92 \\
\hline
\end{tabular}

Fonte: Dados da pesquisa (2015) 
Comparando-se as três dimensões estudadas, observa-se que a dimensão melhor avaliada pelos participantes da pesquisa foi o da confiança gerencial (média 3,06) e a pior avaliada na visão dos colaboradores participantes da pesquisa foi a dimensão confiança institucional. O gráfico 01 , a seguir, ilustra os dados detalhadamente que representam a média geral de cada uma das dimensões abordadas e expõe a dimensão em maior evidência:

Gráfico 01:Comparativo das dimensões de confiança

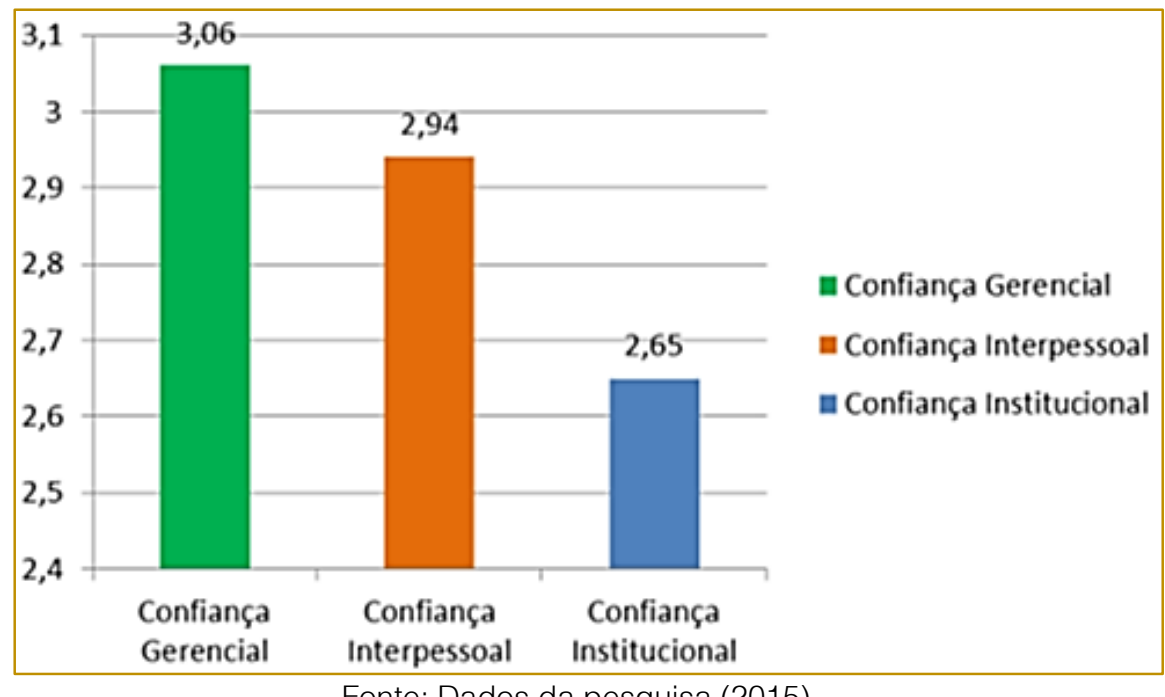

Fonte: Dados da pesquisa (2015)

Os dados mostram que a confiança na gerência possui uma média de 3,06, já a confiança entre os colaboradores e seus pares 2,93; e a confiança dos colaboradores na empresa 2,65. Diante disso, pode-se afirmar que não existem fortes relações de confiança dentro da organização estudada, uma vez que, na escala utilizada, o grau 3 corresponde a "Neutro". Neste caso, torna-se interessante a gestão da empresa buscar mecanismos que possam desenvolver os relacionamentos interpessoais, proporcionando um ambiente de trabalho mais agradável, o que permitirá, ao longo do tempo, transformar a percepção das pessoas a respeito da confiança.

Sobre a confiança institucional, o gestor precisa rever seu modo de conduzir os negócios da organização, sobretudo no que se refere à comunicação, sensibilidade aos interesses dos empregados, abertura às sugestões dos funcionários, preocupação com os sentimentos pessoais, bem como a possibilidade dos indivíduos em resolver problemas relacionados ao trabalho que foram itens mal avaliados pelos participantes da pesquisa.

\section{CONSIDERAÇÕES FINAIS}

Este artigo buscou compreender como são construídas e desenvolvidas as relações de confiança na empresa Doces Dyana Nordestino, com base nas seguintes dimensões: interpessoal e institucional.

Os resultados demonstraram que, em âmbito geral, os colaboradores da empresa não possuem um alto grau de confiança no gestor, porém, eles consideram o gestor qualificado para ocupar essa função e consideram importante a opinião dele a respeito dos seus trabalhos. No entanto, no que se refere a expor os sentimentos pessoais ao gestor, os funcionários não possuem esse hábito, isso quer dizer que com relação às atividades da empresa eles possuem confiança no gestor, mas quando é pra lidar com alguma questão pessoal, não existe muita confiança.

Ficou evidenciado também que a confiança interpessoal entre os colaboradores também não possui um grau elevado, isso foi identificado não somente nas respostas obtidas, como também através da observação 
da pesquisadora; as funcionárias deixaram bem claro, durante a aplicação do questionário, não confiar muito nas colegas de trabalho. Quanto à confiança institucional, esta foi a dimensão em que a média de confiança obtida foi a mais baixa, ou seja, é necessário que a empresa busque estimular principalmente esse tipo de confiança, já que se mostrou em baixa evidência.

Percebe-se ainda que além do nível de confiança da empresa ser baixo, a empresa não busca estimular nenhum desses tipos de confiança, o que faz com que o clima organizacional da mesma esteja sendo prejudicado pela falta de confiança depositada uns nos outros, sendo assim, as atividades da empresa são afetadas e os resultados financeiros também.

Todavia, a maior parte dos funcionários da empresa está trabalhando há um período considerável de tempo, o que significa dizer que, mesmo os resultados dessa pesquisa mostrando um nível baixo de confiança, os empregados permanecem ligados à empresa, talvez pelo fato de existirem poucas oportunidades de emprego na localidade, ou ainda, os mesmos já se acomodaram a trabalhar em um ambiente no qual a confiança não prevaleça.

\section{REFERÊNCIAS}

[1] Almeida, A. L. C.; Zanini, M. T. F. The Impact Of Environmental Uncertainty On Trust Relationships. Revista de Administração, São Paulo, v.44, n.4, p.313-326, out./nov./dez. 2009.

[2] Andrade, S. M.; Fischer, A. L.; Stefano, S. R. Confiança Organizacional e Interpessoal Como Uma Dimensão de Clima Organizacional: um estudo a partir da percepção dos empregados das organizações que pretendem se destacar pela qualidade do ambiente de trabalho. In: Encontro de Gestão de Pessoas e Relações de Trabalho, EnGPR, (3), Anais... João Pessoa, 2011.

[3] Barroso, R. S. Confiança Como um Fator Importante e de Impacto na Organização - FMU. In: Workshop de Pós-Graduação E Pesquisa do Centro Paula Souza, (3). Anais... São Paulo, 2013.

[4] Bauer, W. M.; Gaskell, G. Pesquisa Qualitativa com Texto, Imagem e Som. 10. ed. Petrópolis, RJ : Vozes, 2012. Giddens, A. As Consequências da Modernidade. São Paulo: Unesp, 1991. Levering, R. Confiança e Cooperação: - lucro gerado por um excelente lugar para se trabalhar. Revista de Administração de Empresas RAE - Eletrônica, São Paulo, v. 35, n. 4, jul-ago 1995. Disponível em: <http://www.rae.com.br>. Acesso
De modo geral, cabe ao gestor procurar estímulos que favoreçam as relações de confiança na empresa, buscando conhecer os métodos utilizados por outras empresas em que a confiança predomina e procurando adaptar ao seu contexto, ou seja, buscando melhorar o clima organizacional da empresa através de práticas que incentivam a confiança.

Para tanto, a abordagem do tema não se esgota nesse estudo, nem poderia, uma vez que, a importância do assunto requer a realização de outras pesquisas. Sugere-se, pois, que outros estudos sejam realizados em organizações similares, ou ainda em outros contextos, buscando conhecer outros aspectos que estão presentes neste processo.

As limitações do trabalho residem, sobretudo, na dificuldade para aplicação do questionário junto aos colaboradores, uma vez que nem todos se dispuseram a responder, o que justifica o número limitado de respondentes.

Desta forma, sendo um tema atual e significativo, são inúmeras as possibilidades e espera-se que este artigo contribua tanto para as empresas quanto para os estudiosos na área de recursos humanos.

em: 10 de nov. de 2014. Migueles, C. P.; Zanini, M. T. F. O Papel Mediador Entre Confiança e Desempenho Organizacional. Revista de Administração, São Paulo, v.49, n.1, p.52, jan./fev./mar. 2014. Navarro, L; Gasalla, J. M. Confiança: a chave para o sucesso pessoal e empresarial. São Paulo: Integrare, 2007.

[5] Ripperger, T. Okonomik des Vertauens. Tubingen: Mohr Siebeck Press, 1998.

[6] Robbins, S. P. Fundamentos do Comportamento Organizacional. 8. ed. São Paulo. 2009.

[7] Administração: mudanças perspectivas. 7. ed. São Paulo: Saraiva, 2007.

[8] Robyn, N. Diferenças Individuais e Gestão de Pessoas: um enfoque na confiança. Trabalho de conclusão de curso. Universidade de São Paulo. 2005.

[9] Roesch, S. M. A. Projetos de Estágio e Pesquisa em Administração: guia para estágios, trabalhos de conclusão, dissertações e estudos de caso. 3. ed. - 2. Reimpr - São Paulo: Atlas, 2006.

[10] Sato, C. T. Gestão Baseada em Relações de Confiança. Revista de Administração de 
Empresas - RAE - Eletrônica, v. 2, n. 1, jan/jul 2003. Disponível em: <http://www.rae.com.br>. Acesso em 06 dez. 2014.

[11] Valentim, I. V. L. Confiança Interpessoal: uma análise das relações em uma associação de reciclagem de resíduos sólidos. 2006. Dissertação (Mestrado em Administração) - Programa de PósGraduação em Administração. Universidade Federal do Rio Grande do Sul, Porto Alegre.

[12] Vergara, S. C. Projetos e relatórios de pesquisa em administração. 13. ed. São Paulo: Atlas, 2011.
[13] Zanini, M. T. A Natureza dos Estilos de Gestão: entre o medo e a confiança. 2008. Disponível em: <http://www.adcemg.org.br/artigosver. php?id=9>. Acesso em 20 de abril de 2015.

[14] _ _ Lusk, E. J.; Wolff, B. Confiança Dentro das Organizações da Nova Economia: uma análise empírica sobre as consequências da incerteza institucional. Revista de Administração Contemporânea - RAC, Curitiba, v. 13, n. 1, art. 5, p 72-91, Jan/Mar. 2009. 


\section{Papítulo 8}

\section{O ENDOMARKETING COMO UMA FERRAMENTA PARA A HUMANIZAÇÃO NO SERVIÇO DE SAÚDE: UM ESTUDO DE CASO NO HOSPITAL DA FAP}

\section{Thairo Targino Leopoldino}

Marielza Barbosa Alves

Jussara Palmeira dos Santos

Resumo: A preocupação com uma maior qualidade de vida da população tem feito crescer a exigência por serviços de saúde de qualidade e ambientes mais humano. Diante desta realidade, o Ministério da Saúde do Brasil propôs uma Política Nacional de Humanização visando um atendimento mais humanizado para a população, além de capacitar funcionários para se comprometerem com este objetivo. Portanto, ações de Endomarketing nas instituições de saúde podem ser usadas com a finalidade de envolver e comprometer os funcionários rumo à Humanização, alcançando uma satisfação no trabalho que fazem. A pesquisa teve como objetivo geral diagnosticar a influência das práticas do Endomarketing como incentivo à qualidade e a humanização nos serviços de saúde no hospital da FAP na percepção dos funcionários. Quanto à metodologia, foi realizado estudo de caso, com caráter descritivo e exploratório, aplicando-se um questionário junto aos funcionários como coleta de dados, abordando aspectos quantitativos. Nos resultados obtidos, observa-se que algumas ações concorrem para uma satisfação dos funcionários quanto ao trabalho no hospital, porém com uma tendência a exigirem melhores condições como salários mais justos, cursos de capacitação entre outros que, no caso, a inclusão de outras práticas de Endomarketing iria favorecer tanto aos funcionários quanto ao hospital numa visão holística.

Palavras Chave: Endomarketing - Humanização - Serviços de Saúde 


\section{INTRODUÇÃO}

As organizações, em especial as prestadoras de serviço, estão buscando meios de atingirem a excelência nos serviços como meio de alcançar uma boa qualidade e, assim, fidelizarem seus clientes, além de, consequentemente, manterem-se num mercado cada vez mais competitivo. Para isto, elas têm investido mais nas pessoas, hoje, já se pensa nas pessoas como seres humanos e, dessa forma, o departamento pessoal transforma-se em setor de recursos humanos, gerindo estrategicamente seus recursos para atuar no alcance dos objetivos organizacionais.

Segundo Bekin (2004), as mudanças significativas são geradas pela necessidade, por uma nova fase histórica. Neste sentido, o Endomarketing vem para auxiliar os gestores a valorizarem os recursos humanos de suas empresas, procurando capacitá-los e integrálos com o objetivo geral da instituição. Além disto, pode-se perceber no Brasil que mudanças no setor hospitalar estão exigindo atendimento de saúde humanizado à população. Logo, torna-se interessante a aplicação da ferramenta de Endomarketing para que estas instituições hospitalares se mantenham no mercado, prestando um serviço mais humano, pois cresce a preferência pela qualidade no serviço de saúde, visto que a expectativa de vida da população está aumentando e a mesma está preocupada em investir cada vez mais em saúde.

Sendo a humanização no serviço de saúde uma exigência atual do Ministério da Saúde do Brasil para as instituições hospitalares, com o intuito de buscar cada vez mais um atendimento ético e respeitoso, é coerente para as organizações dessa área trabalhar ações buscando um maior envolvimento e comprometimento dos funcionários com elas e com a humanização na saúde.

A partir deste exposto, questiona-se: pode o Endomarketing ser uma ferramenta utilizada para auxiliar a humanização no serviço de saúde? Buscando responder a este questionamento, foi traçado o seguinte objetivo: Diagnosticar as práticas do Endomarketing que incentivam à qualidade e a humanização nos serviços de saúde no hospital da FAP.

Logo, por ser o hospital uma organização que depende, em grande parte, do seu funcionamento e das pessoas, e por se tratar de uma organização que presta serviço de saúde a clientes (pacientes) que necessitam de cuidado e atenção, a escolha deste tema se deu na importância de que funcionários comprometidos e motivados com a organização buscarão prestar um atendimento mais digno, respeitoso, atencioso e ético, como propõe o Programa Nacional de Humanização da Assistência Hospitalar (PNHAH). Portanto, ainda enfatiza o estudo na prática de Endomarketing, levando a empresa a investir em seus funcionários afim de que eles estejam motivados e estimulados, prestando um serviço mais humano.

\section{FUNDAMENTAÇÃO TEÓRICA}

\subsection{ENDOMARKETING}

"Endo" decorre do grego e quer dizer "ação interior ou movimento para dentro". Portanto, Endomarketing significa de uma forma geral o marketing para dentro, este termo surgiu por volta da década de 70, pelo professor Saul F. Bekin, na época gerente da Johnson e Johnson. Bekin (2004) detectou que a empresa apresentava problemas na comunicação entre os departamentos, os funcionários não conheciam bem a empresa e com isto não conseguiam perceber a dimensão de suas atribuições e responsabilidades.

Apesar de Bekin ser considerado o pai do Endomarketing, os estudos sobre Endomarketing já eram recorrentes na área de administração desde 2002 nas obras de Cerqueira (2002), quando este afirma ser projetos e ações que uma empresa deve empreender para consolidar a base cultural do comprometimento dos seus funcionários com o desenvolvimento adequado das suas diversas tecnologias visando reconhecimento e valorização das pessoas, além de índices satisfatórios em relação à qualidade e produtividade.

O Endomarketing muda a percepção do funcionário sobre seu papel na empresa, que antes se comprometia apenas com o cargo ou função e atualmente se compromete com a empresa numa visão holística.

Percebe-se, entretanto, que antigamente as empresas buscavam lucrar e estarem em dia com as obrigações trabalhistas legais, entretanto, com a evolução do entendimento do Endomarketing, os empresários perceberam que trabalhando com ações voltadas para o publico interno, como a valorização destes e benefícios que poderiam ser concedidos a eles, as empresas tenderiam 
a crescer e se firmarem no mercado competitivo, logo os empresários começaram a introduzir esta ferramenta no planejamento estratégico da organização.

Apresenta-se aqui, três conceitos e autores fundamentais no estudo do Endomarketing. Segundo Brum (2010) Endomarketing é oferecer ao funcionário atenção, educação, carinho, informação tornando-o bem capacitado e preparado a fim de tornar-se uma pessoa criativa e feliz, capaz de surpreender, encantar e entusiasmar o cliente. Portanto, fazse necessário proporcionar ao funcionário um ambiente interno agradável, motivador, capaz de se externalizar essa motivação ao ambiente e aos clientes externos. É valido enfatizar que o Endomarketing procura vender a empresa ao cliente interno fazendo-o conhecer as estratégias e objetivos da empresa, para que ele comprando esta idéia possa passar para o cliente externo um melhor e bem informado atendimento.

Brum (2010) ainda afirma que o endomarketing nada mais é do que a comunicação interna executada com a sofisticação de uma propaganda bem feita, pois, se você passa ao seu funcionário de forma criativa e de forma clara o que a empresa vende e o que ela acredita logo estes procurarão passar isto para o cliente externo.

Para Bekin (2004) o endomarketing consiste em ações de marketing voltadas para o publico interno focando no alinhamento, sintonia e sincronia, visando estabelecer um processo de lealdade no relacionamento com o publico interno da organização. Sendo assim, é preciso haver uma sintonia com todos os departamentos da empresa para que aja uma melhor harmonia com os objetivos dos funcionários e com os objetivos que a empresa queira alcançar.

Sabe-se que os funcionários ao entrarem numa organização possuem objetivos pessoais a serem alcançados por meio de seus trabalhos. Sabe-se também que toda organização possui objetivos a serem alcançados que são definidos já na elaboração de sua estratégia competitiva. Portanto, quando se procura alinhar os dois objetivos (funcionário e empresa) utilizando ações do Endomarketing, encontram-se empresários comprometidos com a melhoria do clima organizacional e funcionários comprometidos e envolvidos com o alcance das metas estabelecidas pela empresa.
Por outro lado, é importante salientar que, segundo Cerqueira (2002) o endomarketing passa a ser projeto e ações voltadas para consolidação da base cultural do comprometimento dos funcionários de uma empresa visando dentre vários aspectos, a administração participativa, melhoria do relacionamento interpessoal, clima ideal de valorização.

Os principais autores que defendem 0 Endomarketing têm visões diferentes ou complementares deste assunto em meio às empresas. Brum procura focar mais na comunicação interna, oferecendo ao funcionário os meios adequados de trabalho e acesso a informação. Já Bekin tende a envolver todos os departamentos da empresa para uma melhor operacionalização dos serviços como também para que aja uma sinergia nas ações que serão percebidas e recebidas pelos clientes. Em contrapartida, Cerqueira já volta os estudos para o clima e a cultura organizacional que é de extrema importância, pois se você trabalha em uma empresa que passa alguns valores para o seu cliente externo diferentes dos que são repassados para o funcionário, este tende a desmotivar-se e em conseqüência acaba não tendo compromisso até mesmo com sua função dentro da organização.

É interessante abordar os vários conceitos de Endomarketing, acreditando que um leva ao outro, pois para se haver comprometimento e envolvimento dos funcionários, é necessário

uma boa comunicação interna e a criação de um clima organizacional agradável. Vale enfatizar que, para que o Endomarketing dê certo em uma empresa é preciso ser aceito e ter suas ações praticadas, primeiramente, pela alta gerencia, pois os funcionários acabam sendo reflexos de seus coordenadores e lideres.

As empresas têm percebido a importância de aplicar o Endomarketing com seus funcionários, pois esta ferramenta ao ser bem aplicada e gerenciada de forma correta e ética, traz a empresa um feedback positivo pois acaba passando uma imagem para o público externo de que a organização possui uma excelência nos serviços prestados a partir do envolvimento dos funcionários com os objetivos gerais da empresa. "Assim o Endomarketing é um instrumento que faz crescer o funcionário como individuo e a empresa como organização" (WEIRICH et al., 2004, p. 756) 
Alguns pressupostos são apontados pelo endomarketing para estimular o processo de motivação o que ressalta a importância desta ferramenta para um melhor envolvimento e comprometimento dos funcionários. Dentre estes pressupostos podemos citar: valorização do individuo no grupo, incentivo a parceria, a cooperação e lealdade, promoção da integração baseada nos valores e objetivos da empresa, reforço contínuo em atitudes e valores compartlihados, envolvimento do funcionário no planejamento e na tomada de decisões, remuneração adequada às pessoas. (WEIRICH et al., 2004, p. 756)

Quando bem aplicado, o Endomarketing traz ao funcionário um comprometimento com a organização levando-o a realizar suas tarefas e obrigações com entusiasmo, ajudando até mesmo quando não faz parte de sua obrigação. É quando Cerqueira (2002) difere de um funcionário envolvido de um comprometido, este é quando ao comprar a idéia da organização ele se empenha a trabalhar para o alcance dos objetivos, já aquele faz o que se é necessário, mas não compra a idéia.

Outro ponto importante para o Endomarketing é a questão da comunicação interna que Brum (2010) relata ser a principal estratégia de aproximação da empresa com o seu público interno. Daí já parte para a idéia de que é preciso uma aceitação já da alta gerencia, pois ao se comunicar com seu público interno proporciona uma abertura para que este venha a expor seus propósitos e até mesmo reclamações e possíveis idéias. A comunicação além de informar as ações da empresa, ajudam também a revelar os potenciais dos funcionários com suas idéias. Como visto anteriormente, o Endormarketing visa vender a imagem e a idéia da empresa primeiramente para seu cliente interno, que é o funcionário. Visto isso, procura-se realizar estratégias e ações para que esta ferramenta seja realmente aceita por cada integrante de uma organização.

A primeira ação de Endomarketing numa organização é a aprovação da alta diretoria para implementar esta ferramenta como estratégia de gestão, alcance e melhoria da qualidade do serviço prestado. Quem primeiro deve comprar a empresa, são os próprios componentes da alta gerencia. Portanto, com a alta administração da empresa envolvida neste objetivo, a metas serão melhores alcançadas, pois haverá comprometimento, uma administração participativa, reconhecimento das pessoas, dentre outros aspectos que favoreçam a mudança da cultura da empresa, por uma cultura baseada em valorização e, no caso deste estudo, humanização na prestação do serviço hospitalar.

Para expor as ações de Endomarketing, é interessante ligá-las ao mix de Endomarketing, denominada por Inkotte (2000 apud Silveira e Tófani, 2007, p.11) como sendo os 4 C's, que são Companhia, Custos, Coordenadores e Comunicação.

A Companhia, segundo os autores, define como será a empresa, que valores guiarão as ações. Com isto, tem-se a implementação ou uma ênfase maior na cultura organizacional voltada para o cliente e voltada para a qualidade do serviço prestado. Cerqueira (2002) afirma que "valor cultural é tudo aquilo que nos incentiva à prática de uma atitude preestabelecida, tendo como base algo que reconhecemos como válido e bom para nós".

O segundo C é Custos, que trata de todos os investimentos financeiros em recursos humanos e as aplicações em instrumentos e ações de Endomarketing. Os investimentos nos recursos humanos se expandem para salários, treinamentos, benefícios, entre outros, e daí é preciso se deter um pouco nestes aspectos, pois é aqui que entra ações do Endomarketing como a motivação que Bekin (2004) define em etapas como estímulo, esforço, desempenho, valorização, recompensa, satisfação e comprometimento.

Partindo para o próximo $\mathrm{C}$, temos a Coordenação que trata de todos aqueles responsáveis por tornar o programa de Endomarketing eficiente, garantindo sua execução. Neste caso da Coordenação tratamos das pessoas que são diretamente responsáveis pela condução do programa de Endomarketing, mas que também são clientes internos e que por isso precisa agir de acordo a também comprar a idéia da empresa. É válido ressaltar também que estas pessoas que estiverem à frente da condução do programa precisam agir de forma coerente, pois de certa forma passaram a serem líderes e consequentemente modelos a serem seguidos pelos demais funcionários.

Por fim, temos o último C - Comunicação. Este é um dos mais importantes, senão o mais, no processo de Endomarketing, pois é através da comunicação que se dará toda a realização na prática do programa. Em se tratando de comunicação faz-se saber que a informação é 
o produto ou serviço trocado neste processo, como afirma Brum (2010) quando diz que a informação é o produto da comunicação interna e o objeto de valor que se estabelece na relação empresa/empregado. É importante nos determos um pouco neste aspecto da comunicação, pois envolve várias questões a serem abordadas.

É na comunicação que haverá uma integração entre empresa e empregado, além de fazer o funcionário deter um melhor conhecimento das estratégias da empresa. Brum (2010, p.107) afirma que "a informação, quando bem trabalhada, acaba se transformando em conhecimento para o público interno. E O conhecimento, por sua vez, pode proporcionar bons níveis de integração."

\subsection{POLÍTICA NACIONAL DE HUMANIZAÇÃO}

Com a crescente demanda nos serviços de saúde e com a preocupação em um atendimento mais humanizado e singular, se deu mais ênfase à política nacional de Humanização, sendo criado em maio de 2000, pelo Ministério da Saúde, o Programa Nacional de Humanização da Assistência Hospitalar. Este programa busca garantir ao cidadão que busca os serviços de saúde, um atendimento de qualidade e mais humano e comprometido com a causa e com a sociedade.

Tal programa foi elaborado mais voltado para - serviço público, entretanto abrange para todas as instituições particulares também. $\mathrm{Na}$ época, o então ministro da Saúde, José Serra, afirmava em sua apresentação do Programa que:

A experiência cotidiana do atendimento da pessoa no serviço de saúde e os resultados de pesquisas de avaliação desses serviços têm demonstrado que a qualidade da atenção ao usuário é uma das questões mais criticas do sistema de saúde brasileiro. Na avaliação do público, a forma do atendimento, a capacidade demonstrada pelos profissionais de saúde para compreender suas demandas e suas expectativas são fatores que chegam a ser mais valorizados que a falta de médicos, a falta de espaço nos hospitais, a falta de medicamentos, etc. (BRASIL, 2001, p. 5)

Sabe-se que o atendimento e a prestação do serviço de saúde envolvem vários fatores como qualidade no atendimento, uma melhor oferta de profissionais, estrutura física satisfatória para realizar os atendimentos, medicamentos básicos que sejam oferecidos no atendimento, entre outros. Contudo, é importante lembrar que também são necessárias melhores condições de trabalho para os profissionais, além de uma educação continuada e mudança de cultura das instituições para que se entenda a deficiência que hoje o sistema de saúde sofre com a desumanização no serviço. Para isto o Programa também surge para oferecer idéias e conceitos para que sejam postos em prática nas instituições.

Neste Programa se mostra o conjunto de ações adotadas pelo Ministério da Saúde visando a melhoria na qualidade do serviço de saúde, que inclui

[...] grandes investimentos para a recuperação das instalações físicas das instituições, a renovação de equipamentos e aparelhagem tecnológica moderna, o barateamento dos medicamentos, a capacitação do quadro de recursos humanos etc. [...] o desenvolvimento de ações que busquem a melhoria do contato humano presente em toda intervenção de atendimento à saúde. (BRASIL, 2001, p. 11)

Embora se tenha alta tecnologia nos hospitais, nada substitui o profissional, o ser humano na prestação do serviço de saúde. Logo, se faz necessário a capacitação dos recursos humanos das instituições de saúde, desenvolvendo entre eles o valor humano no atendimento hospitalar, pois com toda tecnologia o usuário sente a necessidade de um contato humano, principalmente neste meio de saúde, quando ele geralmente busca por estar passando por alguma enfermidade, e esta o deixa carente de uma atenção.

O interessante neste Programa é que ele não é só voltado para o usuário, pois o objetivo é envolver e fortalecer as relações entre profissional de saúde e usuário, dos funcionários entre si e do hospital com a comunidade. Então é um Programa que abrange todas as pessoas envolvidas na prestação do serviço de saúde, acarretando benefícios para todas as partes envolvidas.

\subsection{O ENDOMARKETING COMO FERRAMENTA PARA HUMANIZACAO NO SERVIÇO DE SAÚDE}

Em se tratando de Humanização é possível falar em aplicar a ferramenta de Endomarketing para a Humanização no serviço de saúde, pois os pacientes receberão atendimento humanizado a partir dos funcionários de uma instituição de saúde, que 
vai desde porteiros até mesmo a alta gerencia, passando evidentemente, pelo corpo clínico do hospital nas mais variadas áreas de atuação. Esta ferramenta pode ser aplicada por saber a que se propõe o $\mathrm{PNHAH}$ quando se fala que

Com condições idênticas de trabalho, um hospital consegue melhores resultados que outro se houver compromisso da liderança, qualidade na gestão, competência e criatividade da equipe. Os bons resultados dependem, em grande medida, da capacidade de o hospital oferecer um atendimento humanizado à população. (BRASIL, 2001)

O Endomarketing, visto que é uma ferramenta que se dispõe a realizar ações voltadas para o funcionário para que este se sinta motivado e se envolva e se comprometa com os objetivos da empresa, é uma estratégia que pode ser utilizada pela instituição hospitalar afim de que se alcance o objetivo de um atendimento mais ético, digno e valorizado. Para isto é que se faz necessário o uso de algumas ações do Endomarketing para, em primeiro lugar, mudar a cultura da empresa, pois há funcionários, e até mesmo gestores, que não aceitam mudanças e isto prejudica o trabalho de Humanização dentro de um hospital, visto que este trabalho se dará focado exatamente no recurso humano de uma instituição, sabendose que são fundamentais na prestação de um serviço de saúde.

Assim sendo, irá se analisar as ações de Endomarketing que podem contribuir, ao serem aplicadas para a humanização no serviço de saúde dentro de uma instituição hospitalar. Como citado acima, o primeiro passo é mudar a cultura de um hospital, inserindo nele uma cultura mais humana e não apenas aquela prestação de serviço básica que todo hospital oferece.

Com isto, pode-se realizar ações de conscientização com o público interno do hospital, buscando inseri-los numa cultura mais humana onde o serviço prestado busca valorizar o cliente externo dando a ele dignidade e atendimento respeitoso. Evidentemente que é necessário também, e de forma importante, inserir na cultura a valorização do próprio publico interno que é o funcionário da instituição. Pois funcionário valorizado é funcionário motivado e assim comprometido com a organização no alcance de suas metas.
Após implementar uma cultura humanizada no hospital, realizando ações como campanhas, segue as ações voltadas para a motivação dos funcionários com incentivos, benefícios, capacitações dentre outras formas possíveis para se realizar estas ações motivacionais. $O$ funcionário, antes de tudo, gosta e necessita sentir-se valorizado pela instituição, pois como afirma Silveira e Tófani (2007, p.3):

Falta capacidade para entender que a organização é composta por pessoas, indivíduos e que esses indivíduos merecem respeito e que não admite a exclusão e a indiferença. Mas infelizmente, todos querem lucros, o mundo gira em torno de receitas, lucros, débitos e créditos.

A Humanização propõe este respeito pelo funcionário, e por isto é que se faz interessante e importante, além de ser estratégico à empresa, estas ações motivacionais que o Endomarketing propõe. As ações abrangem reuniões periódicas de avaliação do serviço prestado, a valorização da mão-de-obra proporcionando melhoria nos salários, concedendo benefícios e gratificações, até mesmo concedendo premiações as equipes de trabalho que realizarem um trabalho adequado e de qualidade à população. Outras ações que são válidas para a humanização é a educação continuada para que sempre se mantenha viva a meta e o objetivo da organização em humanizar o atendimento e o serviço hospitalar prestado ao paciente.

Dentro da organização hospitalar é importante também a questão da comunicação interna que parte desde a presidência ou alta gerencia até 0 auxiliar de serviços gerais. A comunicação, antes de tudo, passa pela cordialidade do tratamento entre os colegas de trabalho, as boas maneiras de diálogo que favorece um ambiente de trabalho saudável e agradável de se trabalhar. Entretanto, a comunicação vai além disto, pois precisa ser um meio para passar as informações e decisões tomadas pela empresa que os funcionários precisam compreender e se informarem para passar tudo ao paciente de forma correta e segura. A comunicação é também uma ação que avalia os funcionários e os gestores do hospital para saber se as informações estão sendo realmente comunicadas e estão surtindo o efeito desejado de ambas as partes.

Por fim, o Endomarketing deve trabalhar em todas as partes o que ele tem como meta que é vender a empresa ao próprio funcionário, 
tendo nele o primeiro cliente da organização. Por isto, o funcionário precisa entender que é parte fundamental na organização e que o serviço dele, seja simples ou complexo, é importante, pois caso ele falte com suas obrigações prejudica todo o andamento do serviço a ser prestado. Logo para que o funcionário compreenda, o Endomarketing se vale das ações voltadas para ele para que sentindo-se orgulhosos de suas funções e da empresa onde trabalham, possam trabalhar com motivação, envolvimento e comprometimento, realizando um serviço com qualidade e mais humanizado como propõe o $\mathrm{PNHAH}$.

\section{METODOLOGIA DA PESQUISA}

Este estudo de caso se caracteriza como uma pesquisa exploratória e descritiva com abordagem quantitativa. O universo da pesquisa foram os 388 funcionários do Hospital da Fundação Assistencial da Paraíba (FAP). Sendo a amostra não-probabilística por acessibilidade, composta de 36 funcionários dentre os quais estão técnicos de enfermagem, enfermeiros e pessoas da parte administrativa.

Para a coleta de dados utilizou-se o questionário. Na primeira parte

Devido à amostra ser funcionários de um hospital e ter uma carga de trabalho diferenciada em cada departamento, optou-se por aplicar questionários estruturados com uma questão aberta com essa população amostral, pois no questionário estruturado, segundo Vergara (2003), o respondente faz escolhas, ou pondera, diante e alternativas apresentadas.

Os dados foram trabalhados e transformados em porcentagem, sendo utilizados em gráficos feitos em planilhas de Excel e depois analisados conforme os objetivos deste trabalho.

\section{ANÁLISE DOS RESULTADOS}

\subsection{ENDOMARKETING E HUMANIZAÇÃO}

Em se tratando da questão "Clareza quanto aos objetivos e metas passados ao funcionário", a pesquisa revela que os objetivos e metas do hospital são apresentados ao funcionário, entretanto, a forma como é passada não é tão clara quanto devia, $17,15 \%$ responderam que discordam parcial ou totalmente, o que para a instituição prejudica um pouco, pois sem a informação dos objetivos e metas que o hospital deseja alcançar, fica complicado de o funcionário, sem compreender, realizar ações que ajudem a organização. Em contrapartida, 77,14\% concordam parcial ou totalmente quanto a clareza dos objetivos e metas do hospital, favorecendo ao alcance destas para o engrandecimento do hospital, mostrando que há uma clareza e bom entendimento na apresentação dos objetivos e metas do hospital.

O outro questionamento se refere às "Campanhas desenvolvidas pelo hospital", revela claramente que o hospital não desenvolve com freqüência campanhas para sensibilização da humanização dos serviços prestados, pois $36,11 \%$ discordam parcial ou totalmente desta prática, e 5,56\% não têm opinião, desconhecendo que o hospital possa realizar. Já 30,56\% concordam totalmente sobre o desenvolvimento de campanhas. É interessante ressaltar que os funcionários, muita vezes, confundem as ações voltadas ao público externo, com ações internas.

"Informações do Hospital aos funcionários" foi outra pergunta feita ao público interno e revela que a maior parte dos funcionários concorda totalmente que são bem informados dos serviços oferecidos pelo hospital, 44,44\%, favorecendo assim a um atendimento mais humanizado, já que é importante o funcionário saber sobre o serviço que está prestando, direta ou indiretamente, ao cliente externo.

"Condições estruturais do Hospital" foi a quarta questão e mostrou que $45,71 \%$ dos funcionários concordam totalmente que a organização apresenta estrutura adequada para o atendimento humanizado. Já 14,29\% discordam parcialmente, o que revela que possa existir departamentos dentro do hospital que requeiram melhorias na estrutura física.

No que diz respeito "à realização de reuniões periódicas, para informarem ações planejadas e realizadas pelo hospital", é ausente, pois $34,38 \%$ discordaram total e parcialmente. Portanto é interessante reuniões periódicas, pois os funcionários precisam se manterem informados do que o hospital está realizando para que possam se comprometer a contribuírem e realizarem consequentemente um atendimento que garanta os objetivos.

"Sistema de Comunicação para tomada de decisão" foi a sexta questão e apresentou dados que mostrou que a comunicação interna 
do hospital é falha quanto a troca de informações para a tomada de decisão, 47\% discordam totalmente e 53\% discordam parcialmente, os funcionários que sentem que a tomada de decisão não se baseia tanto na troca de informações, por ser o sistema de comunicação interna falha ou inexistente na organização. Quanto ao "Feedback do trabalho desenvolvido" revela que a maioria dos funcionários, 58,6\%, não concordam totalmente com tal afirmação. É importante ressaltar que este é um aspecto que favorece a organização e ao atendimento humanizado, pois com o feedback o funcionário perceberá se está indo bem ou se pode melhorar ou mudar o trabalho desenvolvido por ele na empresa. Daí vem mais ações de Endomarketing favorecendo para o feedback aos funcionários e aí ações como elogios, reuniões periódicas, conversas informais explicando certas situações, etc. Estes resultados se alinham aos anteriores, pois as reuniões periódicas também são necessárias para se apresentar um feedback aos funcionários.

A questão sobre "abertura de sugestões e reclamações dos funcionários" mostrou que a maioria, 52,78\%, concorda totalmente que se sentem a vontade para comunicar suas opiniões, com isto favorece as práticas de endomarketing, a tomada de decisões e ao atendimento humanizado, já que o hospital é aberto as opiniões dos funcionários.

"Participação do funcionário nas decisões" foi outra pergunta e apresentou que a maior parte dos funcionários não participam das decisões relativas aos seus trabalhos, $63 \%$ dos que discordaram total ou parcialmente. Neste aspecto, dificulta um pouco o atendimento humanizado por os funcionários não terem uma participação nas decisões do seu trabalho, pois quem convive diretamente com o paciente terá mais experiência em tomar algumas decisões necessárias.

Em relação ao "reconhecimento e valorização" a pesquisa mostrou que os funcionários não se sentem valorizados e reconhecidos pelo hospital, pois 30\% discordam totalmente e $20 \%$ discordam parcialmente. Estes dados revelam que a falta de reconhecimento e valorização do funcionário afetam diretamente a prestação do serviço. Diante disto é interessante realizar ações como campanhas de valorização e motivação para que os funcionários se sintam realizados no trabalho que fazem.
A pesquisa revelou a insatisfação dos funcionários com 0 que diz respeito aos salários oferecidos pelo hospital, pois 47,06\% discordam totalmente de que os salários sejam justos e adequados para o cargo. Diante deste fato, é importante refletir se realmente os salários estão inadequados as atividades que os funcionários exercem, se o hospital não pode pagar melhores salários ou se os funcionários estão reivindicando aumento salarial.

Quanto aos "benefícios oferecidos pelo hospital", os dados demonstram que, por $55,56 \%$ concordarem parcialmente que estes benefícios são oferecidos. Na verdade, os que são obrigatórios, como vale-transporte, insalubridade, entre outros. Cabe aqui uma análise mais profunda para que se veja realmente se o hospital oferece benefícios satisfatórios aos funcionários que os façam sentirem motivados a trabalharem na instituição, pois assim o Endomarketing propõe ações voltadas para um programa de benefícios e estímulos.

Já referente aos valores humanizados a pesquisa revela que $66,67 \%$ concordam parcial ou totalmente que os valores do hospital estão voltados para a humanização. Entretanto aqueles que discordam total ou parcialmente somam $13,89 \%$, e os que não têm opinião, 19,44\% o que é significativo, pois a humanização envolve a todos que trabalham no hospital e este precisa passar os valores com eficácia.

Na questão sobre ambiente de trabalho, é perceptível que para os funcionários o ambiente de trabalho é bastante agradável, pois aqueles que concordam total ou parcialmente somam $69,44 \%$ favorecendo assim a um ambiente motivacional e que leva aos funcionários a um atendimento humanizado.

"Consideração das sugestões e reclamações" foi outra questão, e foi mostrado que, em partes, as reclamações e sugestões de clientes e funcionários são levadas em consideração pelo hospital, pois $31,43 \%$ concordam totalmente e 31,43\% concordam parcialmente. Entretanto, 14,29\% discordam totalmente e $14,29 \%$ discordam parcialmente, somando $28,58 \%$ o que é interessante considerar essas respostas, pois reclamações e sugestões são necessárias para um feedback da empresa e para que esta realize ações para envolver o funcionário na 
organização para o alcance dos objetivos e metas.

No que tange ao "relacionamento com colegas de trabalho" foi revelado que $80,56 \%$ concordam totalmente que têm um bom relacionamento com os colegas de trabalho, favorecendo assim a um ambiente de trabalho agradável além de o atendimento ser mais humanizado e em equipe.

Já no "relacionamento com o chefe ou coordenador" foi notório perceber que o relacionamento entre o funcionário e seu chefe ou coordenador é bom, pois $80,56 \%$ concordam totalmente como revela a pesquisa. Portanto é importante ressaltar que este relacionamento colabora para a valorização e reconhecimento do funcionário, por saber que o chefe ou coordenador tem uma certa abertura para com os funcionários e assim as informações poderem ser passadas com mais eficiência.

$\mathrm{Na}$ questão da "promoção de eventos e atividades de integração", a soma daqueles que concordam totalmente e parcialmente é $64,7 \%$, demonstrando que o hospital promove eventos e atividades para a integração dos funcionários. Entretanto, a soma dos que discordam parcial ou totalmente é 32,35\% sendo assim uma porcentagem significativa e que pode ser devido a estes funcionários não serem contemplados com estas ações, ou confundirem com ações que o hospital realiza para os pacientes.

Em relação ao tratamento com os pacientes os dados revelam que os funcionários procuram tratar os pacientes de forma humanizada, respeitosa e atenciosa, pois foram $52,78 \%$ que responderam concordar totalmente e 33,33\% que responderam concordar parcialmente. Com isto mostra a disponibilidade dos funcionários em se comprometerem com um atendimento humanizado, independente de suas funções.

"Funcionários treinados e capacitados" apresentou que $47,06 \%$ concordam parcialmente que os funcionários são treinados, capacitados e sensibilizados à oferecerem um atendimento humanizado. Percebe-se, então, que é preciso investir mais em treinamento e capacitação para os funcionários do hospital, pois assim prestarão um serviço mais humanizado.

Se tratando da prestação do serviço pelo funcionário mostrou que $88,89 \%$ dos funcionários concordam totalmente que procuram em suas funções ajudar a melhorar e a humanizar a prestação de serviço ao paciente. Portanto, mostra o esforço do funcionário em realizar o atendimento de forma mais humana, independente de suas atribuições e tarefas.

Quanto ao "orgulho de trabalhar na Instituição", a grande parte dos funcionários, $82,86 \%$, concordam totalmente que sentem orgulho em trabalhar no hospital, sendo assim um ponto favorável a implementação de ações do Endomarketing na instituição, pois com funcionários assim, sentindo-se orgulhosos em trabalhar no hospital, o nível de envolvimento e comprometimento será maior.

Na questão referente "à satisfação do trabalho realizado no hospital", a pesquisa mostrou que $91,67 \%$ gostam do trabalho que faz no hospital. Já 2,78\% discordam totalmente podendo ser que estejam em trabalhos que não são do agrado do funcionário, daí é importante ressaltar que os funcionários devem estar adequados a função que realmente sabem fazer.

Em "Recomendação do hospital a terceiros" $91,67 \%$ dos que responderam concordam totalmente em recomendar o hospital a um amigo ou familiar, o que mostra a confiança dos funcionários em relação aos serviços prestados pelo hospital.

$\mathrm{Na}$ "utilização dos serviços do hospital pelo funcionário", a pesquisa revelou que os funcionários, em sua maioria, 91,67\%, utilizariam os serviços do hospital que trabalham, revelando que são serviços bem prestados e confiáveis.

No questionamento acerca do tratamento aos funcionários pelo hospital foi revelado, através da porcentagem das respostas que 50\% concordam parcialmente com a forma que são tratados pela organização e que favoreçam a um atendimento e serviço humanizado. Diante deste exposto, é interessante ressaltar que mesmo sendo bem tratados pela organização, os funcionários requerem uma melhoria na atenção dada a eles e que esta possa favorecer a humanização no atendimento e serviço prestado ao cliente externo (paciente). Já uma pequena porcentagem, 2,78\% discordam totalmente do tratamento dado pela organização, o que não deixa de ser importante pois todos precisam receber um tratamento adequado e que tenha o objetivo de humanizar a prestação de serviço, pois todos os funcionários são importantes na empresa e 
para a empresa, principalmente na hora de prestar um serviço humanizado.

\subsection{DIFICULDADES PARA A MOTIVAÇÃO E COMPROMETIMENTO DOS FUNCIONÁRIOS A PRESTAR UM ATENDIMENTO HUMANIZADO}

A pesquisa revela, no gráfico acima, quais as dificuldades encontradas pelos funcionários para um comprometimento e motivação na FAP para um atendimento humanizado. Diante do exposto, é notório que $22 \%$ dos funcionários reclamaram baixos salários como um fator que dificulta o comprometimento e motivação, confirmando o que revela os dados dos resultados anteriores, quando reclamam dos salários. Além disto, 17\% mostraram-se insatisfeitos quanto ao reconhecimento e valorização que demonstram não ter no hospital em relação aos funcionários. Um outro fator que dificulta é a alta demanda de usuários, representando $2 \%$ das respostas, com isto fica difícil um atendimento mais humanizado pois aliado a alta demanda de usuários está o reduzido número de funcionários que na pesquisa representa $2 \%$ das respostas. Um ponto importante revelado na pesquisa é a ausência de uma educação continuada e permanente, representando 14\% das respostas e com isto é interessante realizar as ações de endomarketing favorecendo esta educação e por conseqüência um atendimento mais humanizado.

Gráfico 01: Dificuldade encontrada pelos funcionários em se comprometerem e se motivarem para um atendimento mais humanizado

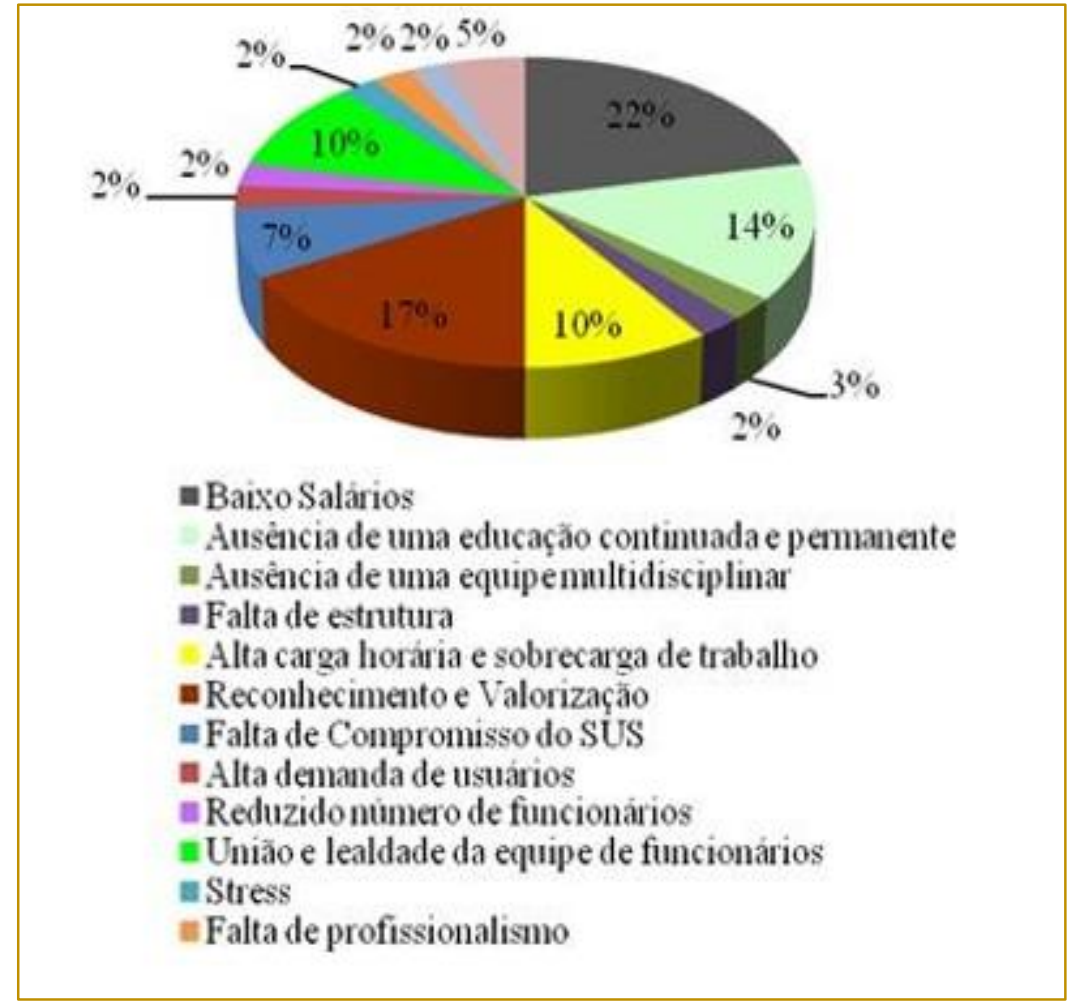

Fonte: Pesquisa 2011 


\section{CONSIDERAÇÕES FINAIS}

O trabalho realizado, a partir de sua fundamentação teórica, abriu e ampliou entendimento e conhecimentos para a ferramenta de Endomarketing que tem suas ações voltadas para o cliente interno (funcionário) de uma organização. Baseado nisto, a organização hospitalar pode utilizar-se destas ações para proporcionar um serviço humanizado, proposto pelo Ministério da Saúde do Brasil no PNHAH, à população. A Humanização proposta pelo PNHAH favorece a instituição fazendo-a crescer; ao paciente que receberá um tratamento digno, atencioso e humano; e ao funcionário, este fundamental devido ser responsável direto pelo atendimento, concedendo um trabalho digno e um ambiente mais humano e agradável. Por isto é que relacionam-se as ações de Endomarketing visando a motivação e o comprometimento dos funcionários e assim haver um atendimento atencioso e um ambiente agradável.

A pesquisa desenvolvida entre os funcionários do Hospital da FAP, em Campina Grande, revela que boa parte deles, embora se sintam bem em trabalhar nesta organização, sentem falta de ações de valorização e reconhecimento por parte da alta gerência. Diante disto, o que se sugere é que a instituição busque adotar práticas e ações de Endomarketing para que haja meios de reconhecimento e valorização para os funcionários que vão desde simples e necessários elogios até mesmo aumento de salário ou gratificações. Além disto, notou-se a falta de uma política ou programa de incentivos para os funcionários prestarem um serviço humanizado.

Outro fator importante e enriquecedor detectado neste trabalho é que a comunicação interna, descendente e ascendente, não é tão eficiente como deveria ser, acarretando, por vezes, falta de informação da parte dos funcionários. Trabalhar a comunicação interna, ajuda o hospital, em se tratando de diretoria e chefia, a aproximar-se mais do funcionário para que este se sinta valorizado e reconhecido, além de estar informado dos objetivos e metas da organização.

$\mathrm{Na}$ análise dos resultados foi visto que maior parte dos colaboradores do hospital são do sexo feminino e pela aplicação da pesquisa percebeu-se que a maior parte eram enfermeiros ou técnicos de enfermagem o que enriqueceu o trabalho, pois são funções que estão diretamente ligadas ao paciente, o qual busca ser atendido de forma mais digna e humana. Aqui não se fala de um assistencialismo, piedade ou caridade para com o paciente, mas trata-se de oferecer a ele um atendimento digno e humano para que este saia satisfeito com a organização e diante disto possa recomendá-la a outras pessoas e, portanto, todos saírem ganhando.

Por o Endormarketing tratar diretamente com o cliente interno e por este ser fundamental para o funcionamento da organização hospitalar, cabe a alta gerência ou diretoria, primeiramente aceitar que é necessário haver uma mudança na cultura organizacional voltada para a humanização, pois na pesquisa percebeu-se que estes valores não são passados de forma eficaz para os funcionários, ou não têm tanta importância para a instituição. Além disto, é interessante trabalhar ações como cursos de capacitação, campanhas de integração entre os funcionários para que aja também um ambiente saudável e agradável motivando assim os colaboradores para prestar um serviço humanizado se comprometendo com os objetivos e metas da organização.

Outro ponto importante que se pode perceber é que os funcionários reclamaram uma sobrecarga de trabalho, reduzido numero de funcionários e alta demanda de pacientes para serem atendidos. Diante deste fato, pode-se pensar em contratar novos funcionários, entretanto por se tratar de uma instituição que depende do Sistema Único de Saúde e de doações de terceiros encontra dificuldades para contratação de novos funcionários. O que se sugere então é a realização de ações visando uma melhor qualidade de vida no trabalho, revendo a pesada carga horária e aliviando tensões dos funcionários.

Por fim, sugere que sejam realizadas ações dentro do hospital interagindo com todos os departamentos, pois mesmo que haja departamentos que não estão diretamente ligados aos pacientes, mas estes também são necessários na prestação do serviço de saúde de forma humana. É mostrar ao funcionário que ele é importante no que faz e que deixando de realizar a tarefa ou mesmo fazendo-a de forma errada prejudica o dia-a-dia do hospital e assim afetando, direta ou indiretamente, a prestação de um serviço humanizado.

Logo, faz-se necessário investir um pouco mais nos recursos humanos do hospital, pois eles são fundamentais na organização, e 
então dispensando recursos financeiros e estruturais. Além de que, com funcionários comprometidos, envolvidos e motivados o hospital possa se encaminhar para receber o certificado de Acreditação Hospitalar que é um sistema de avaliação da qualidade dos serviços de saúde prestados por instituições e

\section{REFERENCIAS}

[1]. ANDRADE, Luciene Miranda de. et al. Atendimento humanizado nos serviços de emergência hospitalar na percepção do acompanhante. Revista Eletrônica de Enfermagem [online], 2009. Disponível em: $<$ http://www.fen.ufg.br/revista/v11/n1/pdf/v11n1a19 .pdf>. Acesso em: 22 set. 2011.

[2]. BEKIN, Saul Faingaus. Endomarketing: como praticá-lo com sucesso. São Paulo: Prentice Hall, 2004.

[3]. BRASIL. Ministério da Saúde. Secretaria de Assistência à Saúde. Programa Nacional de Humanização da Assistência Hospitalar. Brasília, DF, 2001. 60p.

[4]. BRUM, Analisa de Medeiros. Endomarketing de $A$ a $Z$ : como alinhar 0 pensamento das pessoas à estratégia da empresa. São Paulo: Integrare Editora, 1994.

[5]. CERQUEIRA, Wilson. Endomarketing Educação e cultura para qualidade. Rio de Janeiro, Editora Qualitymark, 2002.

[6]. DESLANDES, Suely F. Análise do discurso oficial sobre a humanização da assistência hospitalar. Rio de Janeiro, vol.9, ㄲ‥1, 2004. Disponível em: <http://www.scielo.br/scielo.php?script=sci_arttext \&pid=S1413-81232004000100002 >. Acesso em: 17 ago. 2011. que abrange desde estrutura física até mesmo no compromisso da direção com a organização. Então, utilizando-se do Endomarketing para motivar e comprometer os funcionários, que assim ajudarão no crescimento da instituição e um feedback positivo dos clientes externos.

[7]. FERNANDES, Marina Viana et al. ENDOMARKETING - UMA POSSIBILIDADE NOS SERVIÇOS DE SAÚDE. Disponível em: <http://www.ccs.uel.br/espacoparasaude/v3n2/doc lendomkt.htm>. Acesso em: 27 out. 2011.

[8]. MARTINS, Maria Cezira Fantini Nogueira. Humanização na Saúde. São Paulo, 200_. Disponível em: <http://www.portalhumaniza.org.br> Acesso em: 17 ago 2011.

[9]. SILVEIRA, Renata Medeiros; TÓFANI, Flávio. Endomarketing: ferramenta de gestão para motivas e conquistar o cliente interno. Belo Horizonte, 2007.

[10]. TERENCE, Ana Cláudia Fernandes; FILHO, Edmundo Escrivão. Abordagem quantitativa, qualitativa e a utilização da pesquisa-ação nos estudos organizacionais. Fortaleza, 2006.

[11]. VERGARA, Sylvia Constant. Projetos e Relatórios de Pesquisa em Administração. 4. ed. São Paulo: Atlas, 2003.

[12]. WEIRICH, Claci Fátima et al. ENDOMARKETING: ensaio sobre possibilidade de inovação na gestão em enfermagem. Brasília, DF, 2004. Disponível em:

<http://www.scielo.br/pdf/reben/v57n6/a26.pdf>. Acesso em: 22 set. 2011. 


\section{Eapíllo 9}

\section{FATORES ESTRESSORES NO AMBIENTE EDUCACIONAL - UM ESTUDO EM UM CMEI}

\section{Flavio Mudesto \\ Eduarda De Biase Ferrari Gomes \\ Simone de Souza Christo \\ Virgínia de Paula Batista Carvalho}

Resumo: Este artigo teve por objetivo identificar os principais fatores causadores de estresse em profissionais da educação. Para embasar teoricamente o estudo foi realizada uma pesquisa bibliográfica, onde foram abordados conceitos de estresse no ambiente de trabalho (ANGERAMI \& CAMELO, 2008), bem como suas principais causas, consequências e efeitos, dentro e fora do ambiente profissional (SADIR \& LIPP, 2009; GASPARINI, BARRETO \& ASSUNÇÃO, 2006). Para legitimar empiricamente a investigação, foi realizado um estudo de caso em um CMEI - Centro Municipal de Educação Infantil, localizado na cidade de Vitória, capital do estado do Espírito Santo, por meio da aplicação de um questionário composto por perguntas fechadas. O questionário abordou os principais estressores, ou seja, os principais fatores causadores de estresse na prática da vida dos profissionais da educação (PASCHOAL \& THAMOYO, 2005; CARLOTTO, 2002; MARTINS, 2007). Os resultados mostraram que os principais fatores causadores de estresse, na visão dos respondentes, são de natureza comportamental e organizacional, relacionados com falta de cooperação, organização e planejamento. Os resultados encontrados corroboraram com a teoria proposta pelos autores Carlotto (2002) e Martins (2007). 


\section{INTRODUÇÃO}

O estresse no ambiente de trabalho tem sido objeto de atenção nas últimas décadas em virtude de sua influência na vida dos trabalhadores modernos. As transformações ocorridas no mundo pós-moderno e a velocidade em que as mesmas ocorrem, têm proporcionado mudanças no ambiente, na organização e na forma do trabalho (SILVA, apud ANGERAMI \& CAMELO, 2008). O desenvolvimento tecnológico das últimas décadas foi benéfico, mas tem deixado a humanidade mais suscetível a problemas físicos e emocionais. O trabalho tem sido um importante fator gerador de estresse, o que possibilita um desequilíbrio emocional e fisiológico do organismo (ANGERAMI \& CAMELO, 2008).

Existe um contra censo nas organizações em esforçar-se pela eficiência e pela produtividade. Este fator, mesmo que importante para as organizações têm proporcionado prejuízo às relações de trabalho e aumento dos problemas de saúde nos trabalhadores (CAMPELLO, 2004).

Neste contexto, a sociedade, os pais e a escola têm delimitado parâmetros e exigências aos professores, e estes tem sentido a necessidade de se manterem atualizados para atenderem a esta demanda, causando sentimentos de impotência, desejo de ausentar-se de tudo, culpa, cansaço, irritabilidade, nervosismo, desgaste físico e mental. O desencadeamento destes sentimentos frequentes são as causas da vulnerabilidade de professores ao estresse (MARTINS, 2007).

Como todos os trabalhadores, os professores também têm sofrido com esse problema, pois o tipo de atividade desenvolvido por esses profissionais possibilita o surgimento do estresse e até mesmo de distúrbios psicossociais. Além disso, fatores diversos como atividades de planejamento, reuniões com pais e colegas, baixa remuneração, dupla jornada, problemas com alunos e pais e outros, podem contribuir para o surgimento do estresse entre os profissionais da educação (URBANETTO, et al, 2013).

Esse estudo visa identificar possíveis fatores causadores do estresse nos profissionais inseridos no processo de ensino em uma CMEI no Município de Vitória-ES. Em decorrência do objetivo anunciado, a presente pesquisa analisa os conceitos a respeito do estresse bem como os fatores provocadores destes, que norteiam esta pesquisa.

A escolha desse município se dá devido a sua importância como capital do Espírito Santo, por possuir uma vasta rede de ensino formada por 48 Centros Municipais de Educação Infantil (CMEIS), 53 Escolas Municipais de Ensino Fundamental (EMEFS) (VITÓRIA, 2014).

A pesquisa envolve uma revisão bibliográfica em que se discutem as principais causas do estresse em trabalhadores e em professores de uma CMEl do município de Vitória. Posteriormente é apresentada a metodologia utilizada nessa pesquisa e os resultados obtidos mediante a aplicação de um questionário. Em seguida, são apresentadas algumas considerações sobre a pesquisa, proporcionando uma reflexão a respeito dos fatores estressantes no ambiente de trabalho dos profissionais da educação.

\section{ESTRESSE}

O Estresse no ambiente de trabalho tem sido apontado como uma das maiores causas de absenteísmo e também de problemas físicos e emocionais em trabalhadores de diversos setores da economia, sem distinção de níveis de escolaridade, de raça, de credo, de gênero ou qualquer outra (ANGERAMI \& CAMELO, 2008).

Os fatores ocasionadores de estresse são chamados de estressores. Dentre eles existem os estressores organizacionais que podem ser entendidos como "fatores no trabalho que excedem a capacidade de enfrentamento do indivíduo" (PASCHOAL \& THAMOYO, 2005, p.173). Estudos demonstram que fatores externos como condições do trabalho e fatores relacionados às exigências físicas e mentais da atividade exercida podem ser considerados como estressores responsáveis pelo estresse decorrente do trabalho. Além dos fatores externos, as particularidades do indivíduo são também fatores que contribuem para o surgimento do estresse. Suas expectativas, motivações e valores pessoais podem entrar em conflito com os da organização, ocasionando assim uma possibilidade de surgimento do estresse. (SADIR \& LIPP, 2009)

O estresse por si só é uma experiência desagradável, pois é um estado de tensão fisiológica, relacionado às demandas do ambiente. O estresse ocupacional é mais agravante porque é associado a "sentimentos de hostilidade, tensão, ansiedade, frustração e 
depressão, desencadeados por estressores localizados no ambiente de trabalho" (REIS, et al, 2006 apud URBANETTO, et al, 2013).

O estresse quando presente na sociedade torna apreensivas as pessoas envolvidas no processo organizacional devido às suas consequências para a saúde e na qualidade de vida em nível pessoal. O excedente do estresse pode causar descontentamentos, desgaste físico e/ou mental, gerando envelhecimento precoce e uma série de doenças e até a morte. Tal desgaste conduz para uma situação de danos ao organismo do indivíduo que prejudicam o desempenho e as atividades diárias, gerando desconfortos, cansaço e diminuindo seu ritmo e capacidade de manter uma vida equilibrada e saudável (LIPP, 1998).

Além desses fatores, as mudanças realizadas na política governamental na área da educação, que visam trazer benefícios à sociedade, têm acarretado na massificação da mão de obra nas escolas por meio da intensificação do trabalho dos professores, trazendo consequência à saúde dos mesmos (ASSUNÇÃO \& OLIVEIRA, 2009).

As mudanças ocorridas no setor educacional do Brasil fizeram com que o papel do professor extrapolasse à sala de aula, já que o mesmo se envolve em atividades como participação na gestão escolar e interlocutor junto às famílias de seus alunos. Além disso, espera-se que o professor esteja sempre preparado para atender às demandas dos alunos, da escola e das instâncias superiores como Secretarias de Educação. Para isso, os professores buscam qualificar-se por meio de cursos e seminários que muitas vezes são realizados em horários alternativos ao horário do trabalho, levando o mesmo a uma ampliação de sua jornada de trabalho (GASPARINI, BARRETO \& ASSUNÇÃO, 2005) o que pode acarretar no surgimento do estresse, já que o profissional não consegue atender a contento seus compromissos profissionais, familiares e pessoais.

Dessa forma, é importante conhecer as possíveis causas do estresse, ou ainda os fatores que podem ser considerados estressantes para que se trabalhe na atenuação dos mesmos, visando evitar o surgimento da síndrome nos colaboradores da organização.

Duas consequências do estresse são discutidas no próximo tópico, com destaque para as consequências pessoal e institucional, sendo que esta última é o ponto chave desta pesquisa que visa identificar os fatores de estresse em profissionais da educação no ambiente de uma CMEI.

\subsection{AS CONSEQUÊNCIAS DO ESTRESSE}

- Consequência pessoal: Os malefícios causados pelo estresse têm levado pesquisadores a estudarem os fatores precipitantes do estresse na sociedade moderna. Sabe-se que o estresse tem várias etiologias, tanto em fatores externos criadores de tensões patológicas, como fontes internas capazes de atuarem como geradores de estados tencionais significativos (SADIR \& LIPP, 2009). Estes estados tencionais refletem no organismo do sexo feminino através de alguns sintomas específicos, tais como: dor pélvica, dor nos seios, espinhas ou pele ressecada, cólicas menstruais, TPM (tensão pré-menstrual), dificuldade para amamentar, perda da sensibilidade e vontade sexual, medo e ansiedade, preocupação constante, queda da auto-estima, ciúmes excessivos, dependência emocional. (LIPP 2002, apud MARTINS 2007). Em pesquisa similar, Silva e Carlotto (2003), identificaram a tendência do abandono da profissão e até mesmo a exaustão emocional entre os profissionais de educação.

- Consequência Institucional: Podemos considerar como custo para as instituições o presenteísmo, ou seja, o indivíduo está presente, mas não desenvolve uma ação que configure uma produtividade adequada. Existe ainda o absenteísmo ou a ausência do colaborador no ambiente de trabalho que provoca problemas como desorganização das atividades, queda na qualidade dos serviços prestados, limitação de desempenho e até mesmo obstáculos para os gestores. Quando os trabalhadores começam a faltar, as instituições têm que arcar com custos de substituição do profissional que faltou, há ainda no caso das escolas o prejuízo para os alunos que perdem por não haver uma constância nas aulas. Os efeitos na produtividade das equipes é fator que causa perdas em toda a organização, pois cada equipe tem uma função que está ligada e depende de certa forma do trabalho de outra equipe. Turnover é outro fator que gera custos de treinamento de novos colaboradores causando atrasos no desenvolvimento das atividades das instituições (GASPARINI, BARRETO \& ASSUNÇÃO, 2006). 


\subsection{O ESTRESSE E O AMBIENTE DE TRABALHO}

O ambiente de trabalho e os equipamentos repercutem na qualidade de vida dos colaboradores levando à satisfação ou insatisfação, a qual, por sua vez, é causa de tensão e irritabilidade, tendo como consequência o estresse. No tocante à realidade educacional nacional brasileira, geralmente estes aspectos são muito precários, não tendo este colaborador a possibilidade de desenvolver suas tarefas de modo totalmente planejado e com um alto índice de aproveitamento das partes envolvidas como os educadores e alunos. Um fator decisivo para o desenvolvimento do estresse são as relações interpessoais que por sua vez, deixa o individuo transparecer todo o seu descontentamento ao ambiente que está inserido (CARLOTTO, 2002).

Estresse ocupacional é designado por Martins (2007) como um termo que relaciona o estresse com o lugar das ocupações profissionais. Muitas das atividades desenvolvidas pelos professores são fontes de estresse como o ensino, as relações com o grupo e com os gestores, atividades administrativas que podem ser fatores de estresse que causam um desequilíbrio entre as demandas percebidas do ambiente e as habilidades próprias de cada indivíduo para enfrentá-lo. Assim, McGrath (1976, apud MARTINS, 2007) circunscreveu o estresse ocupacional ao desequilíbrio significativo que o profissional da educação percebe entre algumas pretensões imperiosas do trabalho e as suas aptidões de resposta, em condições que 0 insucesso na satisfação dessas exigências é percebido como podendo ocasionar consequências negativas (MARTINS, 2007).

É necessário se fazer uma reflexão sobre o local onde é realizado todo processo de produção de atividades, onde o fazer acontece. Um olhar para o escola organizacional em relação à qualidade de vida foi elaborado por Limongi (2011), onde relata que:

A análise de fenômenos específicos do trabalho, como saúde, segurança, motivação, adaptação de expectativas a condicionantes gerais, entre inúmeros outros, limita a compreensão da investigação. A rigor, qualidade de vida no trabalho envolve uma dimensão específica do local onde as relações de produção ocorrem (LIMONGI, 2011, p.26).

Caldas (2007, p.74) em sua pesquisa relata sobre o comprometimento e desmotivação com o trabalho educativo. O autor faz alguns questionamentos como "[...] o que é ou como se identifica o comprometimento com o trabalho educativo? Como se estrutura este compromisso, como se mantém e em que medida ele contém elementos de resistência no sentido transformador?" Estas questões nortearam a pesquisa para esclarecer a relação dos educadores(as) com o seu trabalho. Neste sentido uma reflexão sobre as condições no ambiente de trabalho é necessário para que estes questionamentos sejam respondidos. O autor aborda sobre a importância das relações que se estabelecem entre as pessoas durante a realização do trabalho no ambiente educacional citando que alguns avanços foram alcançados como a eleição democrática de diretores, a implantação do conselho escola, mas estes fatores não esgotam o:

"[...] complexo movimento de construção de relações mais democráticas e solidárias no interior das práticas escolares, sempre tensionadas entre as determinações de uma sociedade voltada para a competitividade individual e a fragmentação e necessidade derivada da própria natureza do trabalho educativo de construir um processo coletivo e cooperativo de trabalho (CALDAS, 2007, p.84).

O estudo científico dos métodos é fator fundamental para que o cientista faça suas considerações sobre o objeto de estudo. Para tanto, o próximo tópico refere-se quanto a metodologia.

\section{METODOLOGIA}

Metodologia pressupõe a realização de uma ideia ou projeto guiando-se por indagações da verdade baseado na realidade(HENRIQUES e MEDEIROS, 2003).

Vergara (2004), classifica as ferramentas que devem ser utilizadas em uma pesquisa metodológica: quanto à natureza, aos fins e aos meios.

Nesse aspecto, nessa pesquisa quanto à natureza, foi realizada uma pesquisa do tipo qualitativa, quanto aos fins, uma pesquisa do tipo descritiva, pois visa descrever as características do fenômeno estudado. Quanto aos meios, classifica-se como pesquisa de 
estudo de caso, de campo e levantamento. Estudo de caso pelo fato de ser de cunho descritivo e sem intervenção sobre a situação pesquisada.

O Centro Educacional "Alpha" foi inaugurado em 2002 e está localizado no Bairro Morro do Quadro no município de Vitória-ES. A escola possui 437 alunos em 06 meses e 6 anos de idade, sendo 210 alunos no turno matutino e 227 alunos no turno vespertino e está instalado em um prédio de 03 pavimentos com salas de aula, sala de Informática, cozinha e refeitório, uma pequena biblioteca possuindo uma estrutura física adequada para atendimento à crianças de idade pré-escolar (VITÓRIA, 2014). Possui 125 servidores diretos entre equipe administrativa, suporte operacional e professores propriamente ditos divididos entre os turnos matutino e vespertino. Além disso, há 15 servidores de empresas terceirizadas atuando na limpeza e conservação, portaria e preparo das refeições servidas aos alunos. Por ser um dos maiores CMEIS do município de Vitória, o Centro Educacional "Alpha" se constitui como uma importante referência de estudo e pesquisa do tema abordado, oferecendo uma referência para análise dos outros CMEIS do município e também do enfrentamento do problema objeto dessa pesquisa.

\subsection{MÉTODO DE COLETA DE DADOS}

O instrumento utilizado de coleta de dados foi um questionário construído para este estudo, constituído de uma parte preliminar que visava coletar dados pessoais e outra constituída por uma escala Likert com 5 pontos dividido por uma lista de 13 fontes de perguntas fechadas relativas à possíveis fontes de estresse no trabalho tomando como base a pesquisa de Sadir \& Lipp (2009).

Foi inserido um espaço opcional para que participante escrevesse uma fonte observada por ele. Neste espaço foi relacionado pelos respondentes 5 fontes os quais são: falta de compromisso com o trabalho, intolerância, fofoca, atribuições invertidas ou não cumpridas por quem convém fazê-las e muito choro, que não foram repetidas e não serão discutidas aqui, mas podem ser postos em análise e discutidas em outra pesquisa.

O questionário foi aplicado a 60 funcionários no horário matutino, ou seja, $50 \%$ do efetivo, por entender ser esta uma amostra de valor relevante para coletas de dados. O retorno dos questionários foi de $24,40 \%$ do total distribuídos. Os questionários foram analisados e os resultados estão indicados na próxima seção.

\section{RESULTADOS DA PESQUISA}

O foco desta pesquisa esta ancorado nos profissionais inseridos no processo de educação no ambiente de uma CMEI. A amostra da presente pesquisa conforme 0 quadro 1 que foi inserido no questionário para coleta de dados pessoais, foi constituída por 24 adultos respondentes, com $50 \%$ entre 18 e 39 anos de idade e outros 50\% entre 39 e 60 anos de idade. Quanto ao tempo de experiência na função, 58\% estão entre 0 a 9,9 anos e o restante $42 \%$ entre 10 e mais de 25 anos de experiência, sendo que 63\% trabalha em tempo integral. Todos estão inseridos no Centro Educacional "Alpha" no Município de Vitória-ES, sendo 88\% professores e assistentes de educação.

Quadro 1

\begin{tabular}{|c|c|c|c|c|c|}
\hline Função & Professor & $\begin{array}{l}\text { Assistente de } \\
\text { educação }\end{array}$ & $\begin{array}{l}\text { Técnico em } \\
\text { função } \\
\text { pedagógica }\end{array}$ & $\begin{array}{l}\text { Auxiliar de } \\
\text { serviços }\end{array}$ & $\begin{array}{l}\text { Assistente } \\
\text { administrativo }\end{array}$ \\
\hline Faixa etária - Idade & 18 a 29 anos & 30 a 39 anos & 40 a 49 anos & 50 a 59 anos & Mais de 60 \\
\hline Sexo & Masculino & Feminino & & & \\
\hline Tempo na função & 0 a 4,9 anos & 5 a 9,9 anos & 10 a 19,9 anos & 20 a 24,9 anos & Mais de 25 \\
\hline Período de trabalho & Integral & Parcial & & & \\
\hline
\end{tabular}

Os participantes marcaram quais fontes possuíam no trabalho, assim como a intensidade em que as percebiam. A escala de Likert de cinco pontos foi construída da seguinte forma: foi atribuído 1 ponto para "discordo totalmente", 2 pontos para "discordo", 3 pontos para "nem concordo nem discordo", 4 pontos para "concordo" e 5 
pontos para "concordo totalmente" sendo que foi somado os pontos de cada fonte $e$ relacionados de uma maior pontuação para uma menor pontuação como indicado no quadro 2 a seguir:

Quadro 2 - Soma dos pontos

\begin{tabular}{|l|c|}
\hline \multicolumn{1}{|c|}{ Fontes de estresse no trabalho } & $\begin{array}{c}\text { Soma dos } \\
\text { pontos }\end{array}$ \\
\hline Falta de cooperação & 102 \\
\hline Pessoas desorganizadas ou sem preparo & 99 \\
\hline Falta de planejamento & 96 \\
\hline Conflitos de interesses e valores & 96 \\
\hline Dificuldades interpessoais & 91 \\
\hline Ruídos no ambiente de trabalho & 91 \\
\hline Falta de reconhecimento do funcionário & 90 \\
\hline Problemas com recursos para trabalho & 90 \\
\hline Classes numerosas & 82 \\
\hline Excesso de atividades & 81 \\
\hline Indisciplina dos alunos & 80 \\
\hline Problemas com os gestores & 76 \\
\hline Dificuldade em lidar com cobranças & 67 \\
\hline
\end{tabular}

Fonte: Dados da pesquisa, 2015

Conforme pode ser visto no quadro 2, as maiores pontuações foram dadas a fatores que tem relação a estrutura de grupos e equipes de trabalho e suas atitudes em relacionamentos interpessoais, ou seja, o trabalho, as atividades em si não é fator preocupante de estresse, mas o maior problema está na atitude e no espírito de cooperação que depende das pessoas. Foi discutido neste trabalho, os três primeiros itens relacionados no quadro 2.

A maior pontuação foi dada à falta de cooperação, onde $37,5 \%$ dos respondentes indicaram concordo, 45,8\% marcaram concordo totalmente, $4 \%$ marcaram discordo e nenhum dos participantes marcou discordo totalmente. É imperativo que nas organizações exista a cooperação entre os grupos e dentro das equipes de trabalho. Cooperação tem uma conexão com a colaboração entre indivíduos tendo os mesmos objetivos, utilizando para isto métodos mais ou menos consensuais. A cooperação opõe-se, de certa forma, à colaboração e mesmo à competição. Contudo, as pessoas dentro de um grupo de trabalho tende muitas vezes à competição com outros do mesmo grupo, e isto impede a cooperação.
Ainda que a maior parte dos membros de um grupo possa ser beneficiada por meio da cooperação de todos, o interesse por parte de cada indivíduo em particular, pode tomar direção e sentido contrário. Cooperação pressupõe também que os indivíduos se preocupem com os outros pensando no coletivo (CHIAVENATO, 2005).

"Pessoas desorganizadas ou sem preparo" está em segundo lugar como fator causador de estresse com 37,5\% dos respondentes marcando concordo e 45,8\% indicando concordo totalmente, $8,3 \%$ marcaram discordo e $4 \%$ dos participantes marcou "discordo totalmente". Isto tem relação com ambientes confusos, com objetos espalhados causando estresse devido à falta de coesão entre as pessoas que trabalham juntas. Dentro de uma equipe de trabalho existe compartilhamento de informações, de materiais, equipamentos que são utilizados por todos do grupo. Como existe a falta de preparo por parte de alguns, isto é causador de stress devido não haver consenso entre os membros da equipe. Um ambiente escolar organizado, especialmente voltado para a educação infantil, pressupõe uma série 
de atividades e requisitos que, se observados, possibilitarão uma prática pedagógica mais salutar e eficaz.

O fator que vem em terceiro lugar é a falta de planejamento com 33,3\% dos respondentes marcando concordo e $41,6 \%$ indicando concordo totalmente, $8,3 \%$ marcaram discordo e $4 \%$ dos participantes marcaram "discordo totalmente". Para realizar qualquer atividade é necessário traçar uma metodologia que permita avaliar os caminhos a serem seguidos, vislumbrar e construir um referencial, estruturando a via adequada para se chegar ao objetivo e repensar todos os procedimentos a que o planejamento se destina. Comporta-se como um processo de argumentação e discussão do que não está acabado e ainda não é concreto que escolhe e organiza ações, antecipando os resultados esperados. Esta argumentação destina-se na direção em alcançar alguns objetivos prédefinidos (MAXIMIANO, 2000).

Conforme Robbins, Judge e Sobral (2010), o estresse apresenta diversos e variados sintomas entre os quais estão a pressão alta, úlceras, irritabilidade, dificuldade de tomar decisão dentre outros sintomas que podem ser resumidos em físicos, psicológicos e comportamentais. O estresse pode trazer tanto benefícios quanto malefícios, dependendo da sua intensidade e isto afeta diretamente o desempenho do funcionário. Para algumas pessoas um nível baixo de estresse pode ajudar nas tarefas diárias, mas em um nível duradouro e constante pode conduzir a uma queda no rendimento.

\section{CONSIDERAÇÕES FINAIS}

Tendo em vista a compreensão do estresse no ambiente escolar, a presente pesquisa buscou como objetivo principal identificar os possíveis fatores que podem proporcionar estresse nos profissionais da educação. O questionário apresentado contém fatores diversos relacionados à estrutura e materiais disponíveis para o trabalho e também relacionados ao desenvolvimento pessoal e interpessoal do trabalhador.

O referencial teórico apresentado corrobora com esta pesquisa, pois os resultados mostram que fatores comportamentais como relações interpessoais designado por Carlotto (2002) e relações com o grupo e com os gestores abordado por Martins (2007) são os maiores causadores de estresse, fatores estes materializados em falta de cooperação alavancados neste estudo. Apesar da visão destes dois autores colaborar com esta pesquisa, se contrapõe a ela Campello (2004), Urbanetto, et all (2013), Sadir e Lipp (2009) que formulam fatores estressores inerentes às atividades e questões institucionais como pressão para a produtividade, baixa remuneração, problemas com alunos e conflitos com os objetivos da organização.

Para Barnard (1971) as organizações são constituídas por grupos de pessoas num sistema de cooperação que se acha implícito no ajuntamento de duas ou mais pessoas. A cooperação tem a sua origem na necessidade de um indivíduo cumprir certas metas que não pode, por diversas razões, realizar sozinho. Cada pessoa pode contribuir para o alcance dos objetivos da organização, mas em cada pessoa deve haver uma disposição para cooperar.

Resignação do comportamento pessoal, abandono da ação pessoal, significa disposição no presente contexto. O resultado produzido por esta ação é uma construção de parâmetros que visa o crescimento coletivo e o seu fim último é a disposição indispensável para este avanço em conjunto. Todo este fazer deve ser de forma sustentável, sem o qual não haveria contribuição para a cooperação. Estas multiplicidades de ideias nestas relações não poderiam ser coordenadas sem uma disposição em fazer do que é próprio e particular uma contribuição para um sistema impessoal de ações (BERNARD, 1971).

Os resultados da pesquisa ainda mostram o fator falta de planejamento como importante fator estressante. Este pode ter uma abordagem por parte da gestão na adoção e definição de metas para a organização, estabelecer as estratégias para o alcance das mesmas e ainda estabelecer um conjunto de planos para integrar e coordenar as atividades.

Altas performance pode ser atingidas por meio de equipes, superando as pessoas que atuam sozinhas, especialmente quando o trabalho exige "[...] múltiplas habilidades, capacidade de julgamento e experiências diversas [...]" (KATZENBACH e SMITH, 1994, p.3). Examinando as equipes, é mais provável que se possa compreender melhor seu funcionamento. Os seus diálogos e narrativas revelam suas realizações melhor do que qualquer comentário abstrato. As equipes devem ter objetivos claros de performance para se alcançar o máximo de cada uma, pois 
seus participantes estão compromissados com a obtenção de resultados tangíveis. Equipes exigem interações entre as responsabilidades individuais e responsabilidade mútua e requerem muito tempo de convívio para que este processo se torne realidade. Os grupos jamais se tornarão uma equipe sem que estes assumam uma postura no sentido de superar restrições impostas por fronteiras individuais, funcionais e hierárquicas (KATZENBACH e SMITH, 1994).

Como limitação da pesquisa, destaca-se a não contribuição total dos funcionários na devolução dos questionários, fato relevante que reflete os resultados desta pesquisa da

\section{REFERÊNCIAS}

[1] Angerami, E. L. S, Camelo S. H. H. Riscos Psicossociais no Trabalho Que Podem Levar Ao Estresse: Uma Análise da Literatura. Ciência,Cuidado e Saúde 2008.

[2] Assunção, A. A. \& Oliveira, D. A. Intensificação do trabalho e saúde dos professores. Educ. Soc., Campinas, vol 30, n. 107, p. 349-372, maio/ago. 2009.

[3] Barnard, C. I. Funções do Executivo. São Paulo, Ed. Atlas, 1971.

[4] Caldas, A. R. Desistência e resistência no trabalho docente: um estudo das professoras e professores do ensino fundamental da Rede Municipal de Educação de Curitiba. 2007. 173 f. Tese (Doutorado em Educação) - Universidade Federal do Paraná, Curitiba, 2007.

[5] Campello, J.C., Cargas de trabalho e evidências de seu impacto sobre a saúde de trabalhadores em bancos: estudo de caso em quatro instituições financeiras em Porto Alegre. Trabalho de conclusão de curso de Mestrado da Universidade Federal do Rio Grande de Sul. 2004.

[6] Carlotto, M. S. A Síndrome de Burnout e o trabalho docente. Psicologia em Estudo, Maringa.2002.

[7] Chiavenato, I. Comportamento Organiacional: A Dinâmica do Sucesso das Organizações. 2. Ed - Rio de Janeiro,: Elsevier, 2005.

[8] Gasparini, S. M; Barreto, S. M; Assuncao, A. Á. O Professor, as Condições de Trabalho e os Efeitos Sobre Sua Saúde. Educ. Pesqui.[online]. 2005, vol.31, n.2, pp. 189-199. ISSN 1517-9702.

[9] Prevalência de transtornos mentais comuns em professores da rede municipal de Belo Horizonte, Minas Gerais, Brasil. Caderno de Saúde Pública. Rio de Janeiro, 2006. p. 2679-2691. falta de cooperação nas relações de trabalho deste grupo.

Da mesma forma, não foi possível fazer o mesmo levantamento em outra CMEl do mesmo município localizado em região diferente, para fazer as correlações possíveis. Fica a sugestão de replicar a pesquisa, visando fazer um diagnóstico mais acurado da problemática levantada nesse trabalho.

No entanto, apesar das limitações, percebe-se a suscetibilidade dos profissionais da educação em desenvolverem o estresse emocional em decorrência de sua atividade profissional, e que se devem proporcionar meios para diminuição da incidência desse problema no ambiente escolar.

[10] Henriques, A.; Medeiros, J B. Monografia no curso de Direito: Trabalho de Conclusão de Curso. $3^{\underline{a}}$ ed. São Paulo: Atlas, 2003.

[11] Katzenbach, J. R.; Smith, Douglas K. A Força e o poder das equipes. 1994.

[12] Limongi, A. C. Qualidade de vida no trabalho - QVT - : conceitos e práticas nas empresas da sociedade pós-industrial $-2^{2}$ ed. -7 . Reimpr. São Paulo : Atlas,2011

[13] Lipp, M.E.N. (Org.). (1998). Como Enfrentar o Stress. 5. ed. São Paulo: Ícone.

[14] Martins, M. G. T. Sintomas de estres em professores brasileiros. Revista Lusófona de Educação, 2007, 10, 109-128.

[15] Maximiniano, Antonio Cesar Amaru. Introduçãoà Administração. 5a․ Ed. Ver. E ampl. São Paulo: Atlas, 2000

[16] Paschoal, T.; Tamoyo, A. Impacto dos Valores Laborais e da Interferência Família Trabalho no Estresse Ocupacional. Universidade de Brasília, Psicologia: Teoria e Pesquisa. Mai-Ago 2005, Vol. 21 n. 2, pp. 173-180.

[17] ROBBINS, S. P.; JUDGE, T. A.; SOBRAL, F. Comportamento Organizacional - teoria e prática no contexto brasileiro. 14 edição, São Paulo: Pearson Prentice Hall, 2010.

[18] Sadir, M; Lipp, M. As fontes de stress no trabalho. Revista de Psicologia da IMED, Campinas - SP. 2009, p.114-126.

[19] Urbanetto, J. S. et al. Estresse no trabalho segundo o Modelo Demanda-Controle e distúrbios psíquicos menores em trabalhadores de enfermagem. Revista da Escola de Enfermagem da USP, Brasil, v. 47, n. 5, p. 1180-1186, mar. 2013. ISSN 1980-220X.

[20] Vergara, Sylvia Constant. Métodos de pesquisa em administração. São Paulo: Atlas, 2004. 
[21] Vitória, Prefeitura Municipal de, disponível em $<$ http://www.vitoria.es.gov.br/

prefeitura/educacaoinfantil>. Acesso em 21 de agosto de 2014.
[22] Vitória, Prefeitura Municipal de, Disponível em <http://www.vitoria.es.gov.br/ prefeitura/ensinofundamental> Acesso em 21 de Agosto de 2014. 


\section{ANEXOS:}

\section{QUESTIONÁRIO APRESENTADO AOS ENTREVISTADOS}

Questionário de pesquisa para disciplina de Recursos Humanos do curso de Pós Graduação Lato Sensu em Gestão Estratégica de Negócios, do Instituto Federal do Espírito Santo, Campus Guarapari.

\section{FATORES POTENCIAIS DE ESTRESSE NO AMBIENTE DE TRABALHO}

Para cada um dos itens abaixo, marque a opção pontuando sua opinião que vai de uma menor concordância (discordo totalmente) para uma maior concordância (concordo totalmente).

\begin{tabular}{|c|c|c|c|c|c|}
\hline Fontes de estresse no trabalho & $\begin{array}{l}\text { Discordo } \\
\text { Totalmente }\end{array}$ & Discordo & $\begin{array}{l}\text { Nem } \\
\text { concordo nem } \\
\text { discordo }\end{array}$ & Concordo & $\begin{array}{l}\text { Concordo } \\
\text { totalmente }\end{array}$ \\
\hline \multicolumn{6}{|l|}{ Excesso de atividades } \\
\hline \multicolumn{6}{|l|}{ Conflitos de interesses e valores } \\
\hline \multicolumn{6}{|l|}{ Dificuldades interpessoais } \\
\hline \multicolumn{6}{|l|}{ Ruídos no ambiente de trabalho } \\
\hline \multicolumn{6}{|l|}{$\begin{array}{l}\text { Dificuldade em lidar com } \\
\text { cobranças }\end{array}$} \\
\hline \multicolumn{6}{|l|}{$\begin{array}{l}\text { Pessoas desorganizadas ou sem } \\
\text { preparo }\end{array}$} \\
\hline \multicolumn{6}{|l|}{ Falta de planejamento } \\
\hline \multicolumn{6}{|l|}{ Falta de cooperação } \\
\hline \multicolumn{6}{|l|}{$\begin{array}{l}\text { Falta de reconhecimento do } \\
\text { funcionário }\end{array}$} \\
\hline \multicolumn{6}{|l|}{ Indisciplina dos alunos } \\
\hline \multicolumn{6}{|l|}{$\begin{array}{c}\text { Problemas com recursos para } \\
\text { trabalho }\end{array}$} \\
\hline \multicolumn{6}{|l|}{ Problemas com os gestores } \\
\hline Classes numerosas & & & & & \\
\hline
\end{tabular}




\section{Gapítulo 10}

\section{UMA ANÁLISE CRÍTICA DA CONSTRUÇÃO DA ESCALA DE ENVOLVIMENTO COM O TRABALHO}

\section{Bárbara Helena Giovannini Pinto}

Eric David Cohen

Resumo: Este artigo analisa as técnicas empíricas utilizadas na construção de teorias da área de Administração, com foco nas técnicas confirmatórias. A replicação da escala de envolvimento de Lodahl e Kejner foi testada e verificada a sua validade, frente aos dados coletados. A partir de uma perspectiva metodológica comum, emergem questionamentos em relação à escala analisada, posto que não se apresentou uma justificativa de mudança em relação à estrutura conceitual original, sendo utilizada - de forma inadequada - a técnica exploratória (em vez da técnica confirmatória). Esta pesquisa corrobora a necessidade de aderência aos métodos confirmatórios, tanto para os pesquisadores quanto para os revisores de artigos científicos, para justificar possíveis revisões das teorias ou para indicar modificações nos construtos por meio de índices de ajuste dos modelos.

Palavras Chave: Escalas de mensuração; Validação de escalas; Análise fatorial confirmatória; Construção de teoria; Métodos quantitativos 


\section{INTRODUÇÃO}

O trabalho é a atividade por meio da qual o ser humano produz sua própria existência. Tal definição serve, ainda, como referência para discutir o sistema capitalista de produção.

No âmbito da Revolução Industrial, a sociedade tinha relações de trabalho pautadas pela agricultura e subsistência, normalmente restritas ao âmbito familiar, com uma economia baseada em trocas de produtos ou serviços. A identidade daquela sociedade era pautada pela profissão, que geralmente passava de geração em geração, inclusive com os sobrenomes que assim conferiam as atividades laborais (BRANDÃO, 2009). A sociedade não permitia uma flexibilização nas relações de poder, trazendo uma sociedade engessada hierarquicamente.

O sentido dado pelo trabalho e da relação entre o trabalho e a sociedade vem sendo radicalmente alterado. Uma mudança importante neste processo foi a divisão do trabalho e o advento das linhas de produção, em que cada indivíduo tinha como responsabilidade a realização de tarefas parciais, através do trabalho repetitivo e tarefas pouco motivadores, pelo qual o trabalhador era remunerado de acordo com o que a empresa considerava justo.

Um novo marco na história do trabalho e da construção social ocorre com o processo de globalização, que possibilitou conexões de negócios a nível mundial, encurtando as distâncias físicas, mas ao mesmo tempo aumentando a carga de trabalho, que antes era localizado nas fábricas e escritórios, e vem se modificando com a introdução de novas tecnologias, trazendo em seu bojo a necessidade de tomada de decisões rápidas e precisas em todos os níveis hierárquicos e especialidades profissionais (PEREIRA,2003).

Com isso, surge a necessidade de discutir a relação de trabalho com a sociedade como um todo, bem como em relação à forma com que o trabalho influencia o indivíduo, podendo completa-lo, atender suas necessidades básicas, ou mesmo trazer efeitos indesejados como a perda da saúde ou da qualidade de vida. Neste trabalho, discutimos a questão do envolvimento com o trabalho, que foi originalmente definido como a intensidade com que o desempenho do indivíduo no trabalho afeta a sua autoestima, com o objetivo de pesquisar o conceito à luz da sua sustentação teórica, consideradas as diversas opiniões de autores importantes sobre o assunto, seguida da operacionalização e validação da escala de envolvimento com o trabalho clássica de Lodahl e Kejner (1965).

O envolvimento do indivíduo ocorre quando nada mais parece importar, a ponto de perder a noção do tempo. Neste caso, o indivíduo tem a energia focada em suas metas de produção, que prevalecem em relação a outros processos racionais ou emocionais, frente aos compromissos assumidos com a organização. Este estado de espírito portando leva ao enfoque, fazendo com que as horas passem rapidamente, denotando assim um alto grau de envolvimento com o trabalho (CSIKSZENTMIHALYI, 1999).

O envolvimento com o trabalho é considerado um dos principais vínculos afetivos do indivíduo com suas atividades laborais. Para alcançar esse grau de envolvimento, são necessárias três condições: as pessoas precisam acreditar que podem controlar as atividades de suas vidas; que possuem uma visão positiva de si mesmas, acreditando no trabalho que podem entregar; e visualizam no trabalho um meio de crescer e satisfazer suas necessidades psicológicas (SIQUEIRA e GOMIDE, 2004).

Este estado de envolvimento traz consequências positivas tanto para o indivíduo, quanto para a organização, levando (para o indivíduo) à satisfação de fazer parte de um grupo, e vivenciar uma sensação agradável em conseguir atingir metas pessoas e profissionais, bem como conseguir ver o resultado positivo de seu trabalho através da atividade, e proporcionando à organização um diferencial competitivo, que auxilia na conquista de mercados (SIQUEIRA, 1995).

\section{REVISÃO DA LITERATURA}

O envolvimento com o trabalho foi pesquisado tanto por psicólogos como McGregor e Allport, como por sociólogos como Hughes e Dubin (LODAHL e KEJNER, 1965). Estas áreas de conhecimento se preocupavam com questões especificas: os psicólogos focavam nas condições da organização que conduzem ao envolvimento enquanto significado do trabalho, ao passo que os sociólogos se preocupavam com os aspectos relacionados à socialização e a incorporação das pessoas em trabalhos relevantes, normas e valores.

Numa evolução teórica importante, Dubin (1961) propôs que as teorias da motivação não eram adequadas para explicar a organização, 
pois não levavam em conta os aspectos motivacionais. Este autor passou a analisar as normas sociais e os valores, levando a determinados modos específicos de comportamento.

Segundo esta teoria, as estruturas sociais e a sustentação da motivação deveriam ser consideradas de forma conjunta. $O$ autor constatou que as pessoas internalizam valores, normas, objetivos e comportamentos familiares, que guiam os indivíduos para atividades futuras. Isto implica que as pessoas buscam dentro de suas personalidades segundo formas pré-estabelecidas de realizações de atividades, que explicam e definem o comportamento. Contudo, as pessoas passam a aprender o sistema motivacional da empresa, considerando-as mais adequadas para o desempenho laboral do que estes elementos pessoas. Decorre deste fato que a intensidade com que o indivíduo foi socializado pela organização levará à intensidade do envolvimento com o trabalho (DUBIN, 1961).

As evoluções teóricas subsequentes levam à proposição de que o trabalho exerce uma forte influência na formação da imagem da pessoa, levando à definição do envolvimento com o trabalho, que postula a existência de uma relação com a internalização de valores positivos do trabalho, e com a importância do trabalho no valor do indivíduo (LODAHL e KEJNER, 1965). Assim, o indivíduo envolvido aprecia valores, habilidades, expectativas comportamentais e conhecimento social da organização, ao assumi-la e se ver como um membro participante dela (LOUIS, 1980).

Nesta mesma linha, Allport (1947) já havia identificado uma linha de pensamento equivalente, ao postular que o envolvimento poderia ser definido pela situação de busca pelo status no trabalho.

Da mesma forma, French e Kahn (1962) analisaram o efeito do envolvimento do trabalho na autoestima. Estes autores acreditam que a performance no trabalho é um ponto central para o indivíduo, e que o ego do indivíduo estaria conectado com o envolvimento e com o desempenho no trabalho.

Uma nova conceitualização levou à proposição de consideração do elemento da "moral", segundo o qual o indivíduo coloca seu trabalho com elevada importância para si próprio, para a organização e para a sociedade, não tolerando erros ou problemas de desempenho. Consequentemente, o trabalho é uma parte muito importante na vida, e afeta sobremaneira a personalidade do colaborador (GUION, 1958).

Outros pesquisadores acreditavam que a identificação com o trabalho, com o grau de importância do trabalho para a pessoa e a própria identidade seriam manifestações deste envolvimento, permitindo definir o conceito desta maneira (LAWLER e HALL, 1970).

A definição de Kanungo (1979) consolida as ideias precedentes, postulando que o envolvimento com o trabalho reflete não apenas o estado psicológico do indivíduo, mas também circunstâncias antecedentes e consequentes desse estado, o que evidencia a profusão de conceitos relacionados ao assunto, alguns dos quais vem sendo trabalhados na academia.

Autores especializados na pesquisa do envolvimento com o trabalho indicam determinadas características inerentes ao tema, mas que entretanto não fazem parte da sua definição central. Por exemplo, Brown (1996) identificou três categorias: antecedentes; correlacionados e consequências, que estão ilustradas na figura 1. 
Figura 1: Consequentes e antecedentes do envolvimento com o trabalho

\begin{tabular}{|c|c|c|}
\hline Antecedentes: & Correlacionados: & Consequência: \\
\hline Variáveis de personalidade & Variáveis demográficas & Comportamento no trabalho \\
\hline Endosso da ética no trabalho & Idade & e resultados \\
\hline Posição de controle & Estabilidade na Organização & Esforço \\
\hline Autoestima & Nivel educacional & Performance \\
\hline Necessidade de crescimento & Gênero & Absenteismo \\
\hline Motivação Interna & $\begin{array}{l}\text { Salário } \\
\text { Estado civil }\end{array}$ & Turnover \\
\hline Caracteristicas do trabalho & & Atitudes no trabalho \\
\hline Autonomia & Outras correlações & Satisfação no trabalho (geral) \\
\hline Habilidades variadas & Compromisso com a carreira & Satisfação no trabalho \\
\hline Identidade com as tarefas & Envolvimento com o trabalho (amplo) & (especifico) \\
\hline Feedback & & Satisfação do trabalho do \\
\hline Nivel hierárquico & $\uparrow$ & supervisor \\
\hline Identidade com a significância & & Satisfação do trabalho \\
\hline Potencial motivador & & com colegas de trabalho \\
\hline Desafio & & Promoção \\
\hline Identidade com a complexidade & & Salário \\
\hline Superiores & & Efeitos Colaterais \\
\hline Consideração & & Conflitos com a familia \\
\hline Participação & $\downarrow$ & Estresse \\
\hline Comunicação & & Doenças com causas \\
\hline & ENVOLVIMENTO COM OTRABALHO & somáticas \\
\hline Fator percepção & & Satisfação de vida \\
\hline Ambiguidade & & \\
\hline Conflito de papêis & & \\
\hline
\end{tabular}

Para Brown (1996), o envolvimento com o trabalho é um fator de grande importância na vida das pessoas, uma vez que as atividades laborais consomem uma grande proporção do tempo. Neste contexto, os indivíduos podem ser estimulados ou alienados emocionalmente e mentalmente com o seu trabalho.

O estado de envolvimento implica num positivo e relativo estado de engajamento em todos os aspectos que representam o indivíduo no trabalho. Já o estado de alienação implica em uma perda de individualidade e separação das perspectivas do colaborador, com as perspectivas do ambiente de trabalho. Assim, envolvimento e alienação, são antagônicos; as pessoas envolvem-se mais quando percebem o potencial que essas atividades tem de satisfazer suas necessidades psicológicas (KANUNGO, 1982).

Csikszentmihalyi (1999) corrobora este entendimento, postulando que as pessoas entram em estado de fluxo, nos momentos em que o que se sente, se deseja e se pensa se harmoniza, e que ocorrem quando se exigem metas que pedem respostas apropriadas.

Desta forma, o indivíduo consegue vivenciar uma sensação de plena realização com sua capacidade de atingir objetivos profissionais e pessoais, ao visualizar o resultado conquistado e orgulhando-se com o nível de entrega. Apoiado emocionalmente no lado pessoal e profissional, sente-se envolvido. Assim, através das suas atividades laborais, o indivíduo contribui de forma potencial com os objetivos organizacionais. O envolvimento com o trabalho, assim, pode ser considerado um dos principais vínculos afetivos entre 0 colaborador e sua atividade laboral (SIQUEIRA e GOMIDE JR., 2004).

\subsection{ESCALA DE ENVOLVIMENTO COM O TRABALHO DE LODAHL E KEJNER (1965)}

Para mensurar o envolvimento com trabalho, Lodahl e Kejner (1965) utilizaram como base a técnica de Edwards e Kilpatrick, utilizando inicialmente 110 itens. Após eliminação dos itens redundantes, a quantidade de itens ficou em 87; estes foram preparados para a apresentação de julgadores experientes.

O grupo de especialistas era composto de onze psicólogos, três sociólogos e oito estudantes de relações humanas. O grupo descartou 47 itens, deixando o questionário com 40 itens (LODAHL e KEJNER, 1965). 
Figura 2: Escala de envolvimento com o trabalho de Lodahl e Kejner (1965)

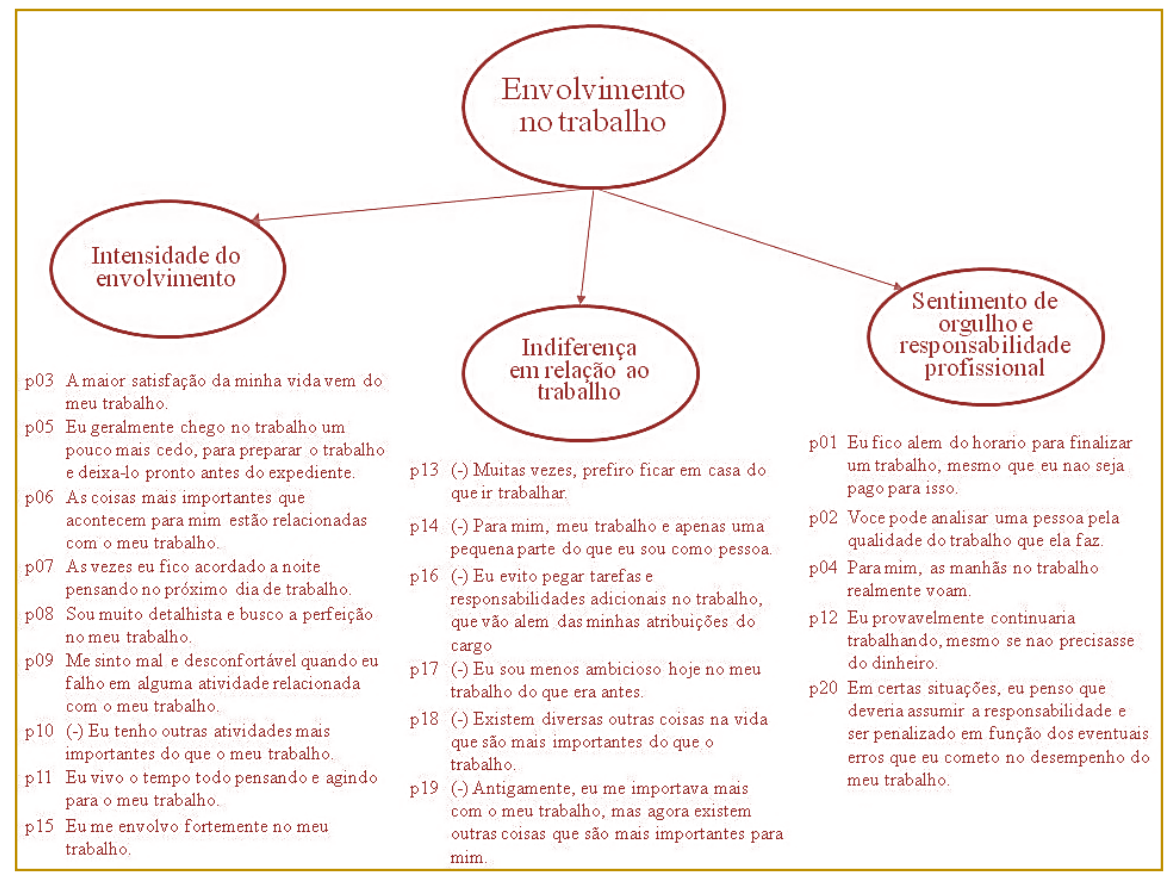

O trabalho de Lodahl e Kejner (1965) consistiu da aplicação deste questionário a um grupo de 137 enfermeiras, e um grupo de 70 engenheiros, que responderam as perguntas utilizando uma escala Likert de 4 pontos (1 concordo totalmente; 2 - concordo; 3 discordo; 4 - discordo totalmente).

\section{PROCEDIMENTOS METODOLÓGICOS}

A natureza da pesquisa é quantitativa, através de um estudo de caso que visa esclarecer uma decisão ou um conjunto de decisões: o motivo pelo qual foram tomadas, como foram implementadas e com quais resultados, de tal forma a verificar a real aplicabilidade do conceito (SCHRAMM, 1971).

A pesquisa se caracteriza como sendo descritiva, por envolver levantamento bibliográfico dos conceitos em questão, e pela aplicação de um questionário num ambiente real, a fim de verificar os resultados obtidos através da análise do nível de envolvimento dos colaboradores da empresa pesquisada (SILVA; MENEZES, 2005).

No caso presente, a coleta de dados se deu através da aplicação do questionário completo do trabalho original de Lodahl e Kejner (1965), aplicando-o a uma empresa multinacional da linha branca, em suas diversas áreas de atuação e com pessoas de diferentes idades, sexo, e hierarquia $(\mathrm{N}=204)$.

$\mathrm{Na}$ sequência, a partir dos conceitos levantados no referencial teórico, buscou-se verificar se o trabalho de Lodahl e Kejner (1965) pode ser utilizado como referência para estudos de envolvimento no trabalho, através das conexões entre a teoria destes autores, bem como suas suposições em relação à escala citada no contexto brasileiro. O focos principais da abordagem é realizar uma análise crítica desta escala, e de seu significado (SILVA \& MENEZES, 2005).

A técnica analítica utilizada para validar o modelo conceitual, as relações entre os fatores, a dimensionalidade, e a validade dos construtos é a análise fatorial confirmatória (PETT; LACKEY; SULLIVAN, 2003). Um pressuposto desta técnica é que a escala já tenha passado pelas etapas de construção e refinamento, bem como pela verificação empírica da estrutura conceitual que culmina com a construção da teoria. Assim, a replicação da escala leva em conta as propriedades psicométricas, apoiando-se na teoria existente (HAIR JR. et al., 2009; KLINE, 2010).

O primeiro teste da escala de Lodahl e Kejner (1965) não produziu resultados estatísticos, por não ser possível a convergência do modelo. Ademais, verificou-se uma correlação 
elevada entre os fatores, indicando que eles poderão estar medindo conceitos semelhantes. Conclui-se, assim, que a escala original de Lodahl e Kejner (1965) não pôde ser confirmada empiricamente, corroborando o questionamento de autores como Reeve e Smith (2001) e Salek e Hosek (1976) em relação à performance insatisfatória da escala.

Frente a esta questão, e em linha com os argumentos apresentados por Reeve e Smith (2001), decidiu-se testar uma escala bidimensional, na qual se elimina o fator F3 (justificando-se por conta das cargas não significantes dos indicadores p07 e p20, bem como pela correlação elevada entre F2 e F3, e os elevados índices de modificação correspondentes).

O teste deste modelo bidimensional apresenta excelentes índices de ajuste: $\mathrm{CFI}=1$; RMSEA $=0 ; \mathrm{Cl}=0,021 ; \mathrm{SRMR}=0,052 ; \mathrm{GFI}=0,998$, $\square 2 /$ df igual a 17,6 , e cargas fatoriais significantes.

Figura 3: Escala refinada de envolvimento com o trabalho

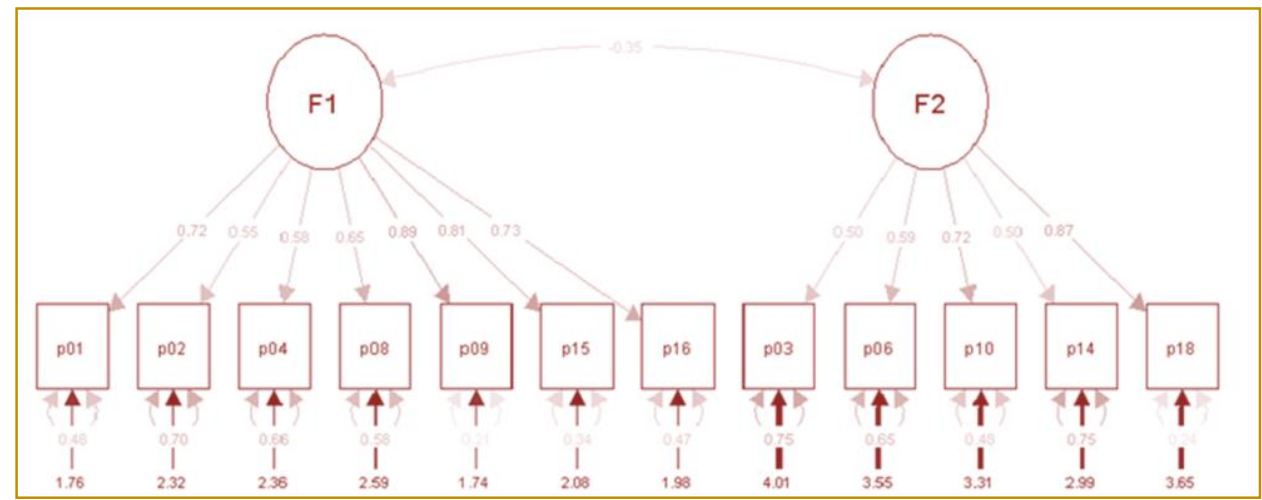

\subsection{VALIDADE CONVERGENTE, DISCRIMINANTE E DE CRITÉRIO}

Em seguida, analisou-se a validade convergente do modelo da figura 3. A variância média extraída (VME) do fator F1 é igual a 0,5090, e a confiabilidade composta (CC) é 0,8761; ambos se encontram dentro dos parâmetros recomendados de VME $(\geq 0,5)$ e CC $(\geq 0,7)$ (HAIR et al., 2009).

Por sua vez, o fator F2 tem VME $=0,4244$ e $\mathrm{CC}=0,7783$. Neste caso, a retirada dos indicadores p03 e p14 faria aumentar a validade convergente (VME $=0,5413$, dentro dos parâmetros recomendados). Se, por um lado, a eliminação dos itens com cargas fatoriais baixas fará com que a VME e a validade discriminante aumentem, por outro lado perde-se na validade de conteúdo e na capacidade de generalização (sendo recomendável, nesta situação, uma nova coleta de dados para validação da amostra).

Ora analisando a validade discriminante do modelo, calculou-se primeiramente o valor do $\chi$ para o modelo livre, e fixou-se a correlação entre os fatores F1 e F2 no valor unitário, no segundo modelo. Os $\chi$ calculados são, respectivamente, 41,67 e 227,84, permitindo rejeitar a hipótese nula de que a correlação entre os fatores é igual a um.

Por fim, analisou-se a validade de critério, por meio da inclusão da variável "relacionamento com o gestor", que é dependente das variáveis exógenas F1 e F2.

Os índices de ajuste do modelo estrutural são equivalentes aos do modelo de mensuração, levando-se à aceitação da hipótese de que uma elevação nos valores da importância do trabalho, ou nos valores de orgulho e responsabilidade profissional, levará a uma elevação (mesmo se diminuta) do relacionamento com o gestor, conferindo assim validade de critério à escala.

Vale notar que, quando se testa o modelo através da técnica confirmatória, a retirada de variáveis significa que o modelo conceitual está sendo adaptado ou ajustado aos dados, sendo recomendada a coleta de uma nova amostra, para fins de validação da escala (HINKIN, 1995; 1998). Na verdade, a questão relevante seria compreender se existe alguma questão relacionada com a validade de face dos itens retirados, ou se a elaboração do questionário não levou em conta o repertório 
adequado ao público-alvo. Sugere-se, neste sentido, que em pesquisas futuras se realize uma revisão e teste destes itens.

Os resultados apresentados nos levam a concluir que o modelo testado, fundamentado na teoria de Lodahl e Kejner (1965), após ter recebido críticas de diversos autores como Siqueira (2008), Saleh e Hosek (1976), e Reeve e Smith (2001), não pôde ser confirmado através da análise fatorial confirmatória. De maneira distinta a outros trabalhos que versam sobre o mesmo tema, o teste empírico empregou a técnica confirmatória, utilizando os procedimentos recomendados na literatura.

Quanto às conclusões para a teoria e para a prática de desenvolvimento e teste da escala, considera-se, inicialmente, que o trabalho de Lodahl e Kejner (1965) já havia sido criticado por Reeve e Smith (2001) e Saleh e Hosek (1976), em vista do fato de que o conteúdo dos itens estava relacionado com outros conceitos estranhos ao construto Envolvimento com o trabalho. Por conta disso, a escala não continuou a ser utilizada nas pesquisas internacionais.

Quanto ao ponto de vista do conteúdo (envolvimento com o trabalho), o trabalho aponta que a escala de Lodahl e Kejner (1965) não pôde ser replicada com três dimensões. Já do ponto de vista do método de validação de escalas, a análise fatorial confirmatória revela-se adequada para o teste de escalas, permitindo rejeitar 0 modelo original por considera-lo inadequado.

\section{CONCLUSÕES E CONSIDERAÇÕES FINAIS}

O presente trabalho analisa a relevância do envolvimento com o trabalho, que faz com que a pessoa se sinta parte de um grupo e consiga satisfazer suas atividades psicológicas com as suas funções, fazendo com que renda mais e melhor para a instituição que está trabalhando.

A pesquisa deixa claro que existem diversos significados para o envolvimento com 0 trabalho, por isso é necessário aprofundar no desenvolvimento teórico, focando no estudo para que se tenha um diagnóstico correto e objetivo, livres de conceitos contraditórios e com unicidade dos conceitos.

O enfoque da pesquisa girou em torno das ideias de Lodahl e Kejner (1985), e de autores que tenham pensamentos na mesma linha de desenvolvimento. Através do trabalho realizado por estes autores, foi possível mensurar e quantificar o envolvimento no trabalho em uma multinacional de grande porte. A utilização desse método permitiu testar empiricamente a eficiência desta escala de mensuração, que pode ser utilizada como referência no assunto, sendo possível a sua aplicação em locais laborais brasileiros.

O estudo levou à realização de um estudo de caso sobre envolvimento com o trabalho numa multinacional americana, utilizando a escala original de Lodahl e Kejner (1985). Do ponto de vista do conteúdo, o trabalho apresentou um conjunto de procedimentos empíricos que possibilitam verificar o ajuste do modelo conceitual frente aos dados coletados, bem como confirmar hipóteses relacionadas aos fatores subjacentes e a dimensionalidade do modelo.

O uso da técnica analítica adequada, a análise fatorial confirmatória, permite comparar os resultados da replicação da escala frente ao contexto pesquisado, a partir de uma perspectiva metodológica comum, evidenciando assim as situações em que se apresentam diferenças de conceitos que possam vir a decorrer de diferenças culturais. Com isso, é possível identificar se ocorrem problemas de interpretação, bem como questões relacionadas com a validade de face da escala, de forma a ajudar na elaboração do questionário, frente ao repertório adequado ao público pesquisado.

Já do ponto de vista do método de validação de escalas, o trabalho apresenta procedimentos indicados para a situação na qual a escala replicada não tenha mantido a mesma estrutura fatorial da escala original, em virtude da utilização indevida da técnica exploratória - caracterizando, desta forma, o que Bido (2014) denominou "destruição da teoria".

Através do uso adequado das técnicas analíticas, são apresentadas linhas de ação que propõem e justificam a revisão do referencial teórico, ou que podem apontar para modificações nos construtos teóricos, por meio de ajustes nos itens para depurar a escala.

Cabe observar que a técnica confirmatória permite analisar se os itens da escala capturam "espaços irrelevantes" do construto, causando uma contaminação da escala de mensuração. Neste sentido, podem ser indicadas modificações significativas na escala existente, ou o desenvolvimento de uma nova escala. 
Conclui-se que a escala de Lodahl e Kejner (1965) (que havia recebido criticas por diversos autores, como Siqueira (2008), Saleh e Hosek (1976), e Reeve e Smith (2001)) não pôde ser confirmada através da técnica confirmatória. Em conclusão, o presente estudo aponta para uma linha de trabalho de

\section{REFERÊNCIAS}

[1] Allport, G. W. The psychology of participation. Psychological Review. Estados Unidos, 1947

[2] Bido, D. Escalas como ferramentas de diagnóstico e gestão: que peso dar aos dados (análise fatorial exploratória) e que peso dar à teoria e pesquisas anteriores (análise fatorial confirmatória)? Apresentação oral no Painel Paralelo EPQ (P-EPQ4) - EnANPAD em 16/09/2014

[3] Bido, D.; Ribeiro, D.; Cohen, E. Aplicações da Análise Fatorial Exploratória à pesquisa na área de Produção e Operações: um estudo em publicações nacionais e internacionais. Artigo apresentado no XIX Simpósio de Administração da Produção, Logística e Operações Internacionais, EAESP - Fundação Getulio Vargas, SP, 2016

[4] Brandão, M. A. Uma contribuição do debate sobre a formação do empresariado industrial no Brasil: de lavoratori na Itália a padrone em Ribeirão Preto (1890 - 1930). Franca, 2009.

[5] Brown, S. P. A meta-analysis and review of organizational research on job involvement. Psychological Bulletin. Washington, DC, 1996.

[6] Brown, S. P. A meta-analysis and review of organizational research on job involvement. Psychological Bulletin. Washington, DC, 1996

[7] Csikszentmihalyi, M. A descoberta do fluxo: a psicologia do envolvimento com a vida cotidiana. Rio de janeiro, 1999.

[8] Dubin R. Industrial workers worlds: A study of the "central life interests" of industrial workers. Social Problems, 1995.

[9] French, J. R. P. ; Kahn, R. A programmatic approach to studying the industrial environment and mental health. Journal of Social Issues, 1962.

[10] Giovannini, B. Uma análise crítica da construção de escalas de envolvimento com o trabalho, Trabalho de conclusão de curso da Faculdade de Ciências Aplicadas da UNICAMP, Limeira, 2016

[11] Guion, R. Industrial morale - The problem of terminology. Personal Psychology, 1958.

[12] Hair Jr., J., Gabriel, M., Patel, V. Amos Covariance-based structural equation modeling (CB-SEM): Guidelines on its application as a marketing research tool, REMark - Revista Brasileira de Marketing, Edição Especial Vol. 13, n. 2., 2014 validação de escalas de Gestão Organizacional, verificando se elas possam ter sido modificadas sem estas fossem justificadas, e preconiza a validação empírica do modelo teórico através de técnicas confirmatórias.

[13] Hair, J. Jr. et al. Análise multivariada de dados. 6 ed. Porto Alegre: Bookman. 2009

[14] Hinkin, T. A brief tutorial on the development of measures for use in survey questionnaires. Organizational Research Methods, v.21, n.5, p.967-988, 1995

[15] Hinkin, T., A brief tutorial on the development of measures for use in survey questionnaires. Organizational Research Methods, 1 (1), 104-121, 1998

[16] Hinkin, T.; Tracey, J.; Enz, C. Scale construction: developing reliable and valid measurement instruments [Electronic version]. Retrieved March 22, 2017 from Cornell University site: http://scholarship.sha.cornell.edu/articles/613, 1997

[17] Kanungo, R. N. Measurement of job and work involvement. Journal of applied Psychology, 1982

[18] Kanungo, R. N. The concepts of alienation and involvement revisited. Psychological Bulletin, 1979

[19] Kline, R. Principles and practice of structural equation modeling. 3 ed. New York: Guilford Press, 2010

[20] Lawler, E. E.; Hall, D. T. Relationship of job characteristics to job involvement, satisfaction, and intrinsic motivation. Journal of applied Psychology, 1970

[21] Lodahl, T. M.; Kejner, M. The definition and measurement of job involvement. Journal of applied psychology, 1965.

[22] Lodahl, T.; Kejner, M. The definition and measurement of job involvement. Journal of Applied Psychology, 49, 24-33, 1965

[23] Louis, M. R. Surprise and sense making. What newcomers experience in entering unfomiliar organizational settings, 1980.

[24] Pereira, F. P. Os sentidos do trabalho e a importância da resiliência nas organizações. São Paulo, 2003.

[25] Aquino, A.R.; Almeida, J.R. Senna ,M. L. G. S. ;V. A. Dutra;Martins, T.P. Indicadores de desenvolvimento sustentável: uma visão acadêmica. Rio de Janeiro: Rede Sirius; OUERJ, 2014. 
[26] Bógus, L.M.M.; Pasternak, S. São Paulo na transição demográfica. In Bógus, L.M.M.; Pasternak, S.(org.). São Paulo: transformações na ordem urbana. 1. ed. Rio de Janeiro: Letra Capital, 2015.

[27] Cano, W. e Semeghini, U. C. Diagnóstico do setor de serviços: documento básico. In: CANO, W. (Coord.). São Paulo no limiar do século XXI: diagnósticos setoriais da economia paulista, setores de indústria e serviços. São Paulo: Fundação Seade, 1992. V. 3

[28] Central Inteligence Agency (CIA). The World Factbook. 2014.Disponível em https://www.cia.gov/library/publications/download/d ownload-2014. Acesso em 10/06/2016.

[29] Gaspar, R.C.; Aparício, C.A.P.; Bessa, V.C. A Metrópole de São Paulo: desenvolvimento econômico recente e configuração interna. In: BÓGUS, L.M.M.; Pasternak, S.(org.). São Paulo: transformações na ordem urbana. 1. ed. Rio de Janeiro: Letra Capital, 2015.

[30] Instituto de Pesquisa Econômica Aplicada (IPEA); Programa das Nações Unidas para o desenvolvimento (PNUD); fundação João Pinheiro (FJP). Atlas brasil. Disponível em: http://www.atlasbrasil.org.br/2013/ . Acesso em: 08/03/2016

[31] Instituto de Pesquisa Econômica Aplicada (IPEA ). Nota técnica de apoio ao lançamento do relatório de desenvolvimento humano 2010 "A verdadeira riqueza das nações": O novo IDH. 2010, $11 \mathrm{pg}$.

[32] Programa das Nações Unidas Para o Desenvolvimento (PNUD). Relatório do desenvolvimento Humano 2010 (RDH 2010) . A verdadeira riqueza das nações: vias para o desenvolvimento humano. 2010, anual, 253 pg.

[33] SCHUMPETER, J.L. Teoria do desenvolvimento econômico. São Paulo : Abril Cultural, 2 ed.,1985.

[34] Sen, Amartya. As pessoas em primeiro lugar: a ética do desenvolvimento e os problemas do mundo globalizado. São Paulo: Companhia das Letras, 2010.

[35] Desenvolvimento como liberdade. Tradução: Laura Teixeira Motta. São Paulo: Companhia das Letras: 2000.

[36] Sepe, P.M; Maciel, Y. R.; Costa, F. C.; Risette, M. C. ; Akamine, T. Caracterizando a interação sociedade-natureza- o uso de indicadores ambientais como subsídio às políticas públicas de meio ambiente: a experiência da cidade de São Paulo. Secretaria Municipal do Verde e Meio Ambiente - Prefeitura do Município de São Paulo/Brasil, 2008.

[37] Sert. Secretaria do Emprego e Relações do Trabalho (SERT) do Estado de São Paulo. Boletim Foco 2011. Região Metropolitana de São Paulo, 2012. Disponível em: http://www.seade.gov.br/projetos/simtrabalho. Acesso em: 01/09/2016.

[38] UL HAQ, M. Reflections on human development.Londo, Oxford University Press, 1995.OCORRÊNCI AS DE RETORNO PARA TROCA APÓS AS AÇÕESOCORRÊNCI AS DE RETORNO PARA TROCA APÓS AS AÇÕESAS

[39] , C.; SMITH, C. Refining Lodahl and Kejner's Job Involvement Scale with a Convergent Evidence Approach: Applying Multiple Methods to Multiple Samples. Organizational Research Methods, Vol. 4 No. 2, Sage Publications, Inc., p. 91 111,2001

[40] Saleh, S. D.; Hosek, J. Job involvement: Concepts and measurements. Academy of Management Journal, 1976.

[41] Schramm, W. Notes on cases studies of instructional media projects. Washington, DC, 1971.

[42] Silva, E. L.; Menezes, E. M. Metodologia de pesquisa e elaboração de dissertação. Florianópolis, 2005

[43] Siqueira, M. (ED.). Novas Medidas do Comportamento Organizacional: ferramentas de diagnóstico e de gestão. Porto Alegre: Artmed, 2014

[44] Siqueira, M. M. M. Antecedentes de comportamentos de cidadania organizacional: análise de um modelo pós-cognitivo. Brasília, 1995.

[45] Siqueira, M. M. M. Medidas do comportamento organizacional: Ferramentas de diagnóstico e de gestão. Porto Alegre, 2008

[46] Siqueira, M. M. M.; Gomide S. Jr. Vínculos do indivíduo com o trabalho e com a organização. Psicologia, organizações e trabalho no Brasil. Porto Alegre, 2004.

[47] Siqueira, M. Medidas do comportamento organizacional: Ferramentas de diagnóstico e de gestão. Mirlene Maria Matias Siqueira (org.). Porto Alegre: Artmed, 2008

[48] Weber, M. The protestant ethic and the spirit of capitalism. New York, 1958.

[49] Yin, R. K. Estudo de caso: planejamento e métodos. Porto Alegre, 2001 


\section{Bapítulo 11}

\section{PROFISSIONAIS DE SAÚDE: FENÔMENO BULLYING}

\section{Amanda Raquel Franca Filgueiras D'Amorim}

Ramon Schnayder de França Filgueiras D`Amorim

Luciene Laranjeira Diniz.

Angélica Carina de Andrade Farias

Adriana Costa Cavalcanti

\section{Carlos Rubens Moreira da Silva}

Resumo: Sabe-se que o índice de violência entre crianças e adolescentes cresceu consideravelmente nos últimos anos. Frente a essa problemática, atualmente, encontram-se com frequência na imprensa escrita e falada, fatos sobre as ondas de violência ocorridas. O presente trabalho constitui-se em uma pesquisa bibliográfica, que teve como objetivo, a proposta de ações educativas para os docentes da área de Saúde, sobre o fenômeno Bullying. O bullying é definido como um fenômeno devastador podendo vir a afetar a autoestima e a saúde mental das pessoas. Geralmente, ocorre quando o adolescente é mais suscetível ou vulnerável às agressões verbais ou morais que Ihes causam angústia e dor, principalmente, quando ocorrido em ambiente escolar, traduzindo-se como uma forma de exclusão social. Ele pode desencadear alguns problemas de saúde como anorexia, bulimia, depressão, ansiedade e suicídio. Pelo fato do bullying não ser abordado nos cursos de formação, específicos para os professores, há uma consequente falta de preparo para identificar, diagnosticar e desenvolver estratégias pedagógicas para enfrentar esse problema. Desse modo, desenvolveu-se esse estudo que resultou na construção de ações educativas envolvendo o fenômeno. Ressalta-se ainda que é indispensável que os educadores sejam capacitados de maneira, a saberem lidar e ou evitarem o bullying para que assim, consigam auxiliar o indivíduo e a família

Palavras-chave: Educação, Violência, Saúde. 


\section{INTRODUÇÃO}

Sabe-se que a violência, importante e crescente no mundo, é um problema de saúde pública, trazendo graves conseqüências, tanto individuais quanto sociais. A violência na escola, com as suas especificidades, é parte integrante do fenômeno Bullying e, não será facilmente compreendida se ignorarmos os laços que os ligam.

Neste mesmo pensamento, é importante ressaltar que existe um tipo de violência desenvolvida por transtorno mental $e$ denominado Bullying o que Fante (2016) define como um conjunto de reações agressivas, intencionais que ocorra de forma repetitiva entre crianças sem motivos evidentes ocasionando dor, sofrimento, angústia, dentre outros; e, que muitas vezes, é comparada como 'brincadeiras da idade', no qual poderá trazer danos psicológicos de tamanhos irreparáveis, incalculáveis às suas vítimas, uma vez que tem um poder destrutivo. Ao longo do tempo, esses conflitos podem ser represados de forma que o organismo somatize, na presença ou não desses agressores, reações bioquímicas descompensadas, funcionamento anormal da mente, sintomas psicossomáticos e reações características de estresse.

O bullying deve estar ligado à humanidade desde a época da pré-história, por ser um problema do ser humano imaturo. É também, um problema mundial, encontrado em todo lugar, bem como em qualquer escola, não estando restrito a nenhum tipo específico de instituição: primária ou secundária, pública ou privada, rural ou urbana, em qualquer país (BALLONE, 2015).

Conforme Fante (2016), o bullying é considerado um Transtorno de personalidade, no qual prevalece o psicológico, trazendo assim, dificuldade no tratamento por não depender de interação medicamentosa e sim, de apoio psicológico.

O termo bullying não existe na língua portuguesa, portanto, expressa todas as situações e ações que podem estar presentes em nosso cotidiano como: colocar apelidos, ofender, zoar, gozar, encarnar, sacanear, humilhar, fazer sofrer, discriminar, excluir, isolar, ignorar, intimidar, perseguir, assediar, aterrorizar, amedrontar, tiranizar, dominar, agredir, bater, chutar, empurrar, ferir, roubar, quebrar os pertences, entre outros. Resumindo, abrange todas as formas de atitudes agressivas, por um ou mais estudantes contra outro (s), que ocorrem sem motivação evidente, de forma repetitiva e intencional, causando dor e angústia, sendo executadas dentro de uma relação desigual de poder (ABRAPIA, 2017).

O bullying pode ocorrer em situações envolvendo a escola ou faculdade/universidade, local de trabalho, vizinhos e muitos outros. Caracteriza-se de acordo com a atuação dos alunos, ou seja, os papéis que eles venham representar. Considerando a necessidade de caracterização dos alunos que se envolvem em comportamentos desse fenômeno, existem diferentes tipos de envolvimento, especificamente enquanto agressores, vítimas ou vítimas-agressivas (ABRAPIA, 2017; SEIXAS, 2005).

Uma pesquisa realizada em um colégio da Grã Bretanha, registrou que em uma totalidade de $47 \%$ dos alunos entrevistados - sendo $37 \%$ dos alunos do primeiro grau e $10 \%$ do segundo grau - admitiram ter sofrido bullying, pelo menos, uma vez por semana (ABRAPIA, 2017).

Outro levantamento que ocorreu no ano de 2002, envolvendo 5.875 estudantes de $5^{\underline{a}}$ a $8^{\text {a }}$ séries, de onze escolas localizadas no município do Rio de Janeiro, revelou que $40,5 \%$ desses alunos admitiram ter estado diretamente envolvidos em atos de bullying, naquele ano, sendo 16,9\% alvos, 10,9\% alvos/autores e $12,7 \%$ autores de bullying. A grande predominância ocorre entre meninos, por estarem mais envolvidos, tanto como autores, quanto como alvos. Já entre as meninas, há menor prevalência, mas também ocorre, embora de forma prática de exclusão ou difamação (ABRAPIA, 2017).

As situações pelas quais passam as crianças que sofrem com o Bullying, ocasionarão conseqüências nefastas, pois as mesmas poderão crescer com sentimentos negativos, especialmente com baixa auto-estima, podendo tornar-se adultos com sérios problemas de relacionamento e também, poderão assumir um comportamento agressivo, e em casos extremos, poderão até tentar ou cometer suicídio. Tudo isso depende de características individuais, de suas relações com os meios em que vivem, em especial, as famílias. Poderão não superar, parcial ou totalmente, os traumas sofridos na escola (ABRAPIA, 2017).

Para aqueles que são autores do bullying 
poderão levar para a vida adulta o mesmo comportamento anti-social, adotando atitudes agressivas no seio familiar (violência doméstica) ou no ambiente de trabalho. Diversos países vêm desenvolvendo estudos nos quais demonstram a possibilidade de que aqueles que praticam o bullying - na época da escola - venham a se envolver, mais tarde, em atos de delinqüência ou de criminalidade. As testemunhas, sob tensão, também são afetadas, tornando-se inseguras e temerosas de que possam ser as próximas vítimas (ABRAPIA, 2017).

Frente à realidade penosa do Bullying nas escolas, pela sua alta incidência, pelas conseqüências que podem ser geradas a partir desta prática, e ainda, pela falta de conhecimento do assunto, por parte dos profissionais que atuam nas escolas observadas por Azevêdo (2007), vê-se a necessidade da interação dentre estes profissionais, buscando difundir o conhecimento acerca do Bullying. Ao contrário do que se possa pensar, o Bullying não é um problema apenas de profissionais da educação, mas é um problema também, dos profissionais de saúde, da segurança pública, da sociedade como um todo. E, é somente pensando na assistência integralizada que se poderá prevenir suas conseqüências.

Percebe-se, pois, que a literatura é escassa, dessa forma, as informações sobre o fenômeno bullying não são bem difundidas. Isso dificulta o conhecimento dos profissionais da saúde/enfermeiros e sua atuação inserida no Programa Saúde da Família no sentido de promover e prevenir o fenômeno.

Diante desse contexto o estudo tem como objetivo elaborar uma cartilha educativa sobre o fenômeno Bullying para profissionais de educação e saúde.

\section{CONSIDERAÇÕES METODOLÓGICAS}

Trata-se de uma pesquisa bibliográfica que segundo Fachini (2016) refere-se à pesquisa bibliográfica como à união de informações, conhecimentos humanos agrupados nas obras, e tem como base principal, conduzir o leitor a determinado assunto e a posterior elaboração, produção, colecionamento, arquivamento, reprodução, utilização e comunicação das informações coletadas para o desempenho da pesquisa.

Para elaboração da cartilha, foi realizado um levantamento bibliográfico através de livros didáticos voltados à temática, bem como em sites de busca, como Biblioteca Virtual de Saúde, Scielo, Google, utilizando-se como descritores: "educação"; "violência"; "enfermagem". Foram também utilizadas, como fontes valiosas de pesquisa, as revistas científicas de veiculação impressa. Após este levantamento, os textos foram selecionados, agrupados e analisados, de forma a permitir uma adequada apreensão de seu conteúdo.

Finalmente, procedeu-se a construção da cartilha informativa, lançando-se mão do referencial científico analisado, bem como dos dados disponibilizados pela pesquisa de Azevêdo (2007), que delineiam as áreas de fragilidades de profissionais de educação quanto ao conhecimento sobre a Síndrome de Bullying.

\section{PESQUISANDO A LITERATURA}

\subsection{O FENÔMENO BULLYING}

O bullying é traduzido no inglês de valentão, brigão, mas seu termo bullying significa todas as formas e atitudes agressivas, intencionais e repetidas, sem motivação evidente, provocadas por um ou mais estudantes contra outro(s), causando dor e angústia numa relação desigual de poder.

Foi na Suécia, em meados dos anos 70 , que surgiu um interesse por parte da sociedade em pesquisar sobre os problemas desencadeados entre o agressor e a vítima do Bullying, daí então, foram iniciados os estudos por parte desse fenômeno (FANTE, 2016).

O Bullying sempre existiu, mas por falta de conhecimento, e por esses comportamentos agressivos, não serem reconhecidos, valorizados e tidos como naturais, eram habitualmente ignorados, tanto pelos professores quanto pelos pais, mas é a partir da década de 90 que este fenômeno ganha relevância e destaque, sendo estudado e discutido por parte de seus pesquisadores. Esta denominação foi originada numa dificuldade em traduzir para variadas línguas e hoje, é adotada universalmente como Bullying (LOPES NETO, 2015; SEIXAS, 2005).

A primeira pessoa a desenvolver questionários de investigação nas escolas foi o pesquisador Dan Olweus da universidade de Bergen. Ele utilizou questionários aplicados aos alunos com o objetivo de detectar o problema de maneira específica e diferenciando das 
brincadeiras e gozações normais entre os pares; desenvolveu essa pesquisa mesmo sem o apoio das escolas, e que hoje vem repercutindo muito o seu trabalho (FANTE, 2016).

Atualmente, um dos problemas de saúde que mais vem aumentando, tanto pelo número de pessoas afetadas, quanto pela incapacitação, pela mortalidade, e pelos custos envolvidos no seu controle e no tratamento de suas complicações, é o Bullying; acomete tanto homens quanto mulheres, mostrado-se mais prevalente no sexo masculino com uma freqüência muito maior, tanto como autores quanto como alvos. Já entre as meninas, embora com menor freqüência, o Bullying também ocorre e caracteriza-se, principalmente, como prática de exclusão ou difamação (BALLONE, 2015).

Uma pesquisa foi realizada em 1970, pelo professor da Universidade de Bergen na Noruega, Dan Olweus, cujo estudo fundamentava-se em investigar, no âmbito escolar, os problemas de agressões e vítimas, mesmo sem o interesse das instituições de ensino sobre o assunto. $O$ interesse por parte das instituições somente foi despertado na década de 1980, posterior a um suicídio, nele contendo três meninos entre dez e catorze anos de idade, ocorrido naquele país em 1983. Vários estudos estão sendo realizados no Brasil desde então, em escolas públicas no intuito de reduzir e combater comportamentos agressivos (ABRAPIA, 2017; FANTE, 2016).

Fante (2016) define o bullying como um fenômeno violento e não, como brincadeiras próprias de criança que acontecem esporadicamente. É um fenômeno que acontece em qualquer escola, que propicia uma vida de sofrimento e dor para uns e de conformismos para outros. A autora ainda refere que danos físicos, morais e materiais, insultos, apelidos cruéis, gozações que magoam profundamente, ameaças, acusações injustas, atuação de grupos que hostilizam a vida de muitos alunos levando-o à exclusão, são algumas das condutas observadas em relação ao bullying escolar.

Para Piedra et al (2016), o bullying pode se apresentar de várias formas:1) Violência física: as agressões podem ser apresentadas por diversas formas (empurrões, socos, pontapés, agressões com objetos, entre outros); 2) Violência verbal: refere-se a insultos, colocar alcunhas, ridicularizar, responder com maus modos, fazer comentários racistas); 3)
Violência psicológica: é realizada através de ações dirigidas a mirar a auto-estima do indivíduo e fomentar a sua sensação de insegurança e temor; 4) Violência social: dá-se, principalmente, na forma de manifestação/disseminação de rumores desqualificantes e humillantes que ocasionam sua exclusão e, conseqüentemente, o isolamento do grupo; 5) Violência indireta: quando a agressão é induzida a um terceiro; 6) Abusos sexuais: ocorre na forma de intimidações e vexames.

Quanto a sua classificação existem três tipos: a testemunha/ expectador, a vítima/alvo e o autor/agressor. O expectador/testemunha é aquela pessoa que diante de uma situação presenciada, não interfere. Essa omissão deve-se ao fato de não saberem como agir, e por descrerem nas atitudes da escola, sendo assim, tornam-se inseguros, temerosos, sentem medo de sofrer represálias ou, ao contrário, sentem prazer com o sofrimento da vítima e por isso, não têm coragem de assumir a identidade de agressor (LOPES NETO, 2015; PIEDRA et al., 2016).

O bullying pode ser classificado também, de acordo como eles reagem: auxiliares (participam ativamente da agressão), incentivadores (provocam e estimulam o autor), observadores (só observam ou afastam-se) ou defensores (protegem o alvo ou chamam um adulto para interromper a agressão (BALLONE, 2015).

Outro tipo de pessoa envolvida, é o autor/agressor, produz-se por atitudes agressivas contra os colegas, acreditando que o uso de comportamentos agressivos leva a caminhos para obterem a popularidade e o poder e, por isso, tornam-se autores de bullying; essas pessoas são, freqüentemente, antipáticas, arrogantes e desagradáveis (BALLONE, 2015).

Algumas condições podem favorecer o desenvolvimento da agressividade nas crianças e adolescentes, sejam elas familiares, por uma desestruturação familiar, um relacionamento afetivo improdutivo, o acúmulo de tolerância extrapolado e a prática de maustratos físicos ou explosões emocionais, como forma de afirmação de poder dos pais; e individuais que, de certa forma, contribuem para adoção de comportamentos agressivos: hiperatividade, impulsividade, distúrbios comportamentais, dificuldades de atenção, baixa inteligência e desempenho escolar deficiente (LOPES NETO, 2015). 
Lopes Neto (2015) ressalta que o autor de bullying é uma pessoa tipicamente popular; com tendência a envolver-se numa variedade de comportamentos anti-sociais, mostra-se agressivo, inclusive com os adultos; é impulsivo; vê sua agressividade como qualidade; tem opiniões positivas sobre si mesmo; é geralmente mais forte que seu alvo; sente prazer e satisfação em dominar, controlar e causar danos e sofrimentos a outros. Não mostram contentamento com a escola e a família, são pessoas mais propensas ao absenteísmo e à evasão escolar e têm uma tendência maior para apresentarem comportamentos de risco (consumir tabaco, álcool ou outras drogas, portar armas, brigar, etc). As crianças e adolescentes adquirem atitudes anti-sociais antes da puberdade e por longo tempo, é por isso que as possibilidades são maiores nesta fase. Enfim, o último tipo é a vítima/alvo, que diferente do outro lado, costuma ser a pessoa mais frágil, diferente em suas atitudes e na sua forma de pensar em relação ao modelinho culturalmente imposto ao grupo etário em questão, os traços, que podem ser: físico (uso de óculos, apresenta alguma deficiência, não ser tão bonitinho, ser negro, gordinho, tem poucos amigos, dentre outros) Ou emocional, como é o caso da timidez, do isolamento, retraimento, geralmente, é pouco sociável, passível, inseguro e desesperançado quanto à possibilidade de adequação ao grupo, entre outros) (BALLONE, 2015).

Para todos que estão envolvidos com o Bullying, suas conseqüências podem ser físicas e/ou emocionais de curto e longo prazo, nos quais podem causar dificuldades acadêmicas, sociais, emocionais e legais. Quanto mais nova for a criança e, freqüentemente, agressiva, serão mais propensas a risco e irão apresentar, problemas associados a comportamentos anti-sociais, sofrerem depressão e baixa auto-estima quando adultos apresentarão perda de oportunidades, tipo, instabilidade no trabalho e relacionamentos afetivos pouco duradouros (LOPES NETO, 2015).

Deve-se ter o cuidado com a forma silenciosa com que as conseqüências podem afetar e perdurar por boa parte da vida do indivíduo, sem esquecer que elas afetam a todos, mas a maior prejudicada é a vítima. Esta desenvolve dificuldade relacional e de insegurança podendo tornar-se uma pessoa apática, retraída e indefesa aos ataques extremos. Pode ainda, apresentar em casos mais simples, um quadro de neuroses, como a fobia social, e em casos mais graves, desencadear psicoses e dependendo da intensidade dos maus-tratos sofridos, tende à depressão, homicídio e ou suicídio (SILVA, 2016).

Outro fato importante a destacar é a negação ou indiferença por parte da direção e dos professores, podendo gerar desestímulo e sensação de que não há preocupação pela segurança dos alunos. A relação familiar também pode ser seriamente comprometida, visto que a criança ou adolescente pode sentirse traído, caso entenda que seus pais não estejam acreditando em seus relatos ou quando suas ações não se mostram efetivas (LOPES NETO, 2015).

Para os agressores, as suas futuras relações irão ser baseadas nos modelos que sempre Ihes trouxe resultados, que é o caso da exigência-obediência pela força e agressão. Muitos deles tendem à delinqüência, criminalidade, por apresentarem uma afetividade fechada, e isto, de certa forma, afeta toda a sociedade (SILVA, 2016).

Enfim, seja como for tais ações: vítima, agressor, ou até mesmo expectador, marcam, deixam cicatrizes inaudíveis em curto prazo, mas dependendo do nível e magnitude da experiência, causam desde frustrações, comportamentos desajustados, até mesmo, atitudes sociopatas (SILVA, 2016).

\subsection{COMO EVITAR OU MINIMIZAR FENÔMENO}

Um fator fundamental é o envolvimento de professores, funcionários, pais e alunos para uma possível implementação de projetos de redução do bullying. A participação de todos visa estabelecer normas, diretrizes e ações lógicas. A que se deve a prioridade dessas ações, é à conscientização geral, o apoio às vítimas de bullying, fazendo com que se sintam protegidas, e à conscientização dos agressores sobre a incorreção de seus atos e a garantia de um ambiente escolar sadio e seguro (LOPES NETO, 2015).

Por este fenômeno ser complexo e de difícil resolutividade, merece assim, um trabalho continuado. No que tange a ações e que devem ser seguidas em todos os momentos da vida escolar, devemos expor que elas são relativamente simples e de baixo custo, podendo ser incluídas no cotidiano das escolas (LOPES NETO, 2015). 
O que se deve investir é na melhoria da relação professor-aluno, uma vez que este se sente como algo abrasador, do tipo professor forte e aluno fraco, mas esta forma de pensar e de agir precisa ser desenraizada das práticas educativas.

Uma das formas intervencionistas que os professores poderiam não dar tanta importância, pelo fato de serem atitudes consideradas aparentemente banais e sem maiores conseqüências, tidas em pleno século vinte e um, são atitudes simples, afetuosas e que expressam respeito, que podem produzir efeitos positivos, aliviando inclusive, conflitos comuns a essa fase da vida dos adolescentes (MARRIEL et al, 2016).

Quanto ao profissional de enfermagem focaliza o fenômeno Bullying como um elemento negativo, desarticulador em potencial a desequilibrar o ritmo de vida do jovem, contudo, a enfermagem encontra-se em vias de preocupação diante da atenção primária à saúde para com seu objeto de cuidado, o cliente, mas também acha-se extramente necessário de sê-lo indentificado e erradicado. Para tanto o enfermeiro dotado de olhar holístico entremeando o saber prático e teórico, encontra-se amplamente capacitado para lidar com mais este impecilho na otimização da qualidade de vida (OLIVEIRA et al., 2016).

Baseado nisso, observamos a utilização das ações de enfermagem com abordagens diversificadas para escolher a ação mais apropriada à determinado caso, em quaisquer desequilíbrios desencadeados pelo Bullying. Ainda mais, a enfermagem ampara o adolescente num compromisso que tem de salvaguardar o bem estar do próximo e/ou em prol da comunidade, refletindo numa respectiva melhora na qualidade de vida da população e em especial do adolescente (OLIVEIRA et al., 2016 ; BRASIL, 2001).

Para tanto, o enfermeiro dotado de olhar holístico, entremeando saber prático e teórico, encontra-se amplamente capacitado para lidar com mais este empecilho na otimização da qualidade de vida (OLIVEIRA et al., 2016).

Portanto, no compromisso que a enfermagem tem com a promoção à saúde do adolescente nos inúmeros espaços de atuação, cabe-lhe ainda, em suas ações junto a eles, basear-se nos princípios da articulação interinstitucional, da interdisciplinaridade, da instrumentalidade de ações, de capacitação e mobilização para a construção de práticas emancipatórias (OLIVEIRA et al., 2016; BRASIL, 2001).

O profissional da saúde, nesse aspecto da violência, tem função importante no que diz respeito à prevenção, entendendo-se a necessidade de agir, não apenas no tratamento das conseqüências da violência. Então, a saúde deve ter como instrumento, investir em informações para uma melhor elaboração das políticas públicas. O profissional como formador de opinião pública deve propor mudanças de comportamento de risco, sua atuação junto aos professores, famílias, pode intermediar na resolução de conflitos, potencializando o papel de cada membro e ajudando-os a quebrar as personagens, vítimas ou agressores e isto se deve ao fato de que ninguém nasce violento, mas sim, aprende. Em suma, o profissional de saúde é um indutor de atitudes e comportamentos saudáveis e sua capacidade de formar opiniões o coloca em posição de destaque para que, junto da população, possa fortalecê-la e torná-la mais segura e harmoniosa (PHEBO, 2016).

Não obstante, quanto aos serviços de saúde e seu acesso, a escola deveria oferecer e/ou facilitar este acesso aluno-família-funcionário ao serviço de saúde. Além disso, a escola juntamente com os serviços de saúde poderia disponibilizar-se a treinar funcionários, para identificar alunos, que estejam sofrendo perseguições, ou que apresentem chances de desenvolver comportamento de risco, sendo imediatamente referidos a programas e serviços preventivos. E assim, os serviços de saúde poderiam avaliar a magnitude dos acidentes e violências no ambiente escolar. Recomenda-se o desenvolvimento e implementação de planos de emergência para a avaliação, conduta e referência de alunos ou funcionários em situação de emergência (LIBERAL et al., 2015).

Considerando os diversos aspectos inerentes à significatividade dessa síndrome, reconhecendo a complexidade do seu sistema psíquico e somático, os professores/indivíduo/comunidade/

necessitam de informações complementares dos profissionais de saúde sobre o controle, a prevenção e as suas complicações. Situações rotineiramente repetidas podem criar zonas doentias da mente (vírus psíquico), local onde aprisionam as emoções humanas incapacitando as suas vítimas de obterem suas habilidades, sejam elas de autodefesa ou 
socialização, prejudicando assim, no seu desenvolvimento sócio-educacional contribuindo para seu isolamento (FANTE, 2016).

Diante de tais colocações e entendendo a necessidade de uma atuação adequada do enfermeiro, nos Programas Saúde da Família, no que se refere à saúde mental vejo a importância deste em contribuir como educadora e dizimadora da Atenção Básica da Saúde sobre o conhecimento do fenômeno Bullying para com os professores, e ao mesmo tempo, servindo de instrumento de orientação sobre esta Síndrome.

Diante dos resultados encontrados, neste estudo, pretende-se buscar alternativas em direção à melhoria da qualidade de vida dos alunos, das possíveis vítimas, agressores, testemunhas e também dos profissionais de saúde, em contrapartida, sua possível divulgação.

\section{CONSIDERAÇÕES FINAIS}

O fenômeno Bullying é um tipo de violência, em especial, sofrido nas escolas e compreendese assim, como ações do tipo que colocam apelidos, ofendem, encarnam, humilham, discriminam, excluem, ignoram, intimidam,

\section{REFERÊNCIAS}

[1] Abrapia. (2017) Disponível em: < www.bullying.com.br/BConceituacao21.htm>.

Acesso em: 20 março 2017.

[2] Azevêdo, Suely Aragão. (2007). Conhecimento de profissionais de educação do ensino fundamental a respeito do fenômeno Bullying. 61 f. Monografia (Graduação em enfermagem) - Faculdade de enfermagem Nova Esperança, João Pessoa .

[3] Ballone, G. J. (2015) Violência e Agressão da Criança e do Adolescente. Disponível em: $<$ www. virtualpsy.locaweb.com.br/index. php?sec=2 0\&art=63>. Acesso em: 28 maio 2017.

[4] Brasil, Ministério da Saúde. (2001). Adolescer: compreender, atuar e acolher. Projeto Acolher. Brasília, DF.

[5] Fachin, O. (2016).Fundamentos de metodologia. São Paulo: Atlas.

[6] Fante, C. (2016). Fenômeno Bullying: como prevenir a violência nas escolas e educar para a paz. 2. ed. Campinas, SP: Versus.

[7] Liberal, Edson Ferreira et al. (2015). Safe school. J. Pediatr. (Rio J.), Porto Alegre, v. 81, n. 5.

Disponíve perseguem, agridem, roubam, quebram pertences, dentre outros.

Deve-se então, preocupar-nos em criar estratégias de prevenção, já que as escolas são espaços favoráveis para a promoção da saúde, conceitos de segurança, ambos interrelacionados, pois são nas unidades escolares, em que há momento de formação da cultura, comportamentos e atitudes envolventes, onde devem ser constantemente abordados temas relativos à saúde e à segurança.

O resultado do estudo gerou uma cartilha educativa que vem esclarecer de uma forma objetiva, sucinta e clara, os casos de violência. No decorrer da revisão bibliográfica, foi observado que alguns autores consideram que as crianças fazem brincadeiras inofensivas e utilizam-se de palavras e de comportamentos não adequados durante suas brincadeiras, e isto nem sempre pode ser caracterizado como bullying.

A observação constante e a parceria entre escola, família e serviços de saúde são cruciais para a possível eliminação de tais comportamentos.

$<$ http://www.scielo.br/scielo.php?script=sci_arttext \&pid $=$ S0021-

$75572005000700005 \& \operatorname{lng}=e n \& n r m=i s o>$. Acesso em: 07 Dec 2015. doi: 10.1590/S002175572005000700005

[8] Lopes Neto, Aramis A. (2015). Bullying: aggressive behavior among students. J. Pediatr. (Rio de J.)., Porto Alegre, v. 81, n. 5. Disponível em: $<$ http://www.scielo.br/scielo.php?script=sci_arttext \&pid $=$ S0021

$75572005000700006 \& \operatorname{lng}=e n \& n r m=i s o>$. Acesso em: 28 mai. 2017. Pré-publicação.

[9] Marriel, Lucimar Câmara. (2016).Violência escolar e auto-estima de adolescentes. Cadernos de Pesquisa, v. 36, n. 127, p. 35-50, jan./abr.

[10] Oliveira, Agnes Schutz de; Antônio, Priscila da Silva. (2016). Sentimentos Do Adolescente Relacionados ao Fenômeno Bullying: possibilidades para a assistencia de enfermagem nesse contexto. Revista Eletrônica de Enfermagem, v.08, n.01, p.3041. Disponível em: <http:// www.fen.ufg.br/revista/revista8_1/original_04.htm > . Acesso em: 25 set. 2016.

[11] Phebo, Luciana. (2016). Violência como uma questão de Saúde. Disponível em: 
$<$ http://www.comunidadesegura.org/?q=pt/node/33 4>. Acesso em: 10 jun. 2016

[12] Piedra, R. Rodriguez; Lago, A. Soane; Massa, J. L. Pedreira .(2016). Crianças contra crianças: o bullying, uma perturbação emergente. An Pediatr (ed. port.);1(2):101-4. Disponível em: </http://www.aeped.es/anales/portugues/vol1n2/8artigo-especial-criancas.pdf.> Acesso em: 07 out. 2016

[13] Seixas, Sônia Raquel. (2005) Violência escolar: Metodologias de identificação dos alunos agressores e/ou vítimas. Análise Psicológica, v. 2, n. (XXIII), p. 97-100.

[14] Silva, Geane de Jesus (março 2016). Bullying: quando a escola não é um paraíso. Artigo publicado na edição no 364 do jornal Mundo Jovem, páginas 2 e 3. Disponível em: <http://www.mundojovem.pucrs.br/bullying.php $>$. Acesso em: 19 nov. 2016. 


\section{Gapítulo 12}

A AVALIACÃO DE DESEMPENHO INDIVIDUAL POR MÚLTIPLAS FONTES, UM ESTUDO SOB O VIÉS DAS RACIONALIDADES INSTRUMENTAL E SUBSTANTIVA

Getulio de Azevedo Ramos Junior,

Fernando de Oliveira Vieira

Resumo: As práticas de avaliação de desempenho não são novas. $O$ ato de avalizar é uma característica humana e uma constante que se reflete nas organizações. No Centro de Desenvolvimento da Tecnologia Nuclear a avaliação do desempenho individual dos servidores ativos é realizada desde 1987. Em junho de 2015 foi implantado o modelo de avaliação por múltiplas fontes utilizando o Sistema de Desempenho Individual - SDI. O presente trabalho verifica se o modelo abrange aspectos da racionalidade instrumental e substantiva, segundo a abordagem de Guerreiro Ramos e se a finalidade da avaliação é vista da mesma forma pelos servidores e pelos gerentes. Também é feita uma comparação da visão da área técnica versus área administrativa. Usa a metodologia quali-quantitativa e, tem como instrumento de pesquisa um questionário com vinte e duas questões onde são abordados aspectos da racionalidade instrumental e substantiva.

Palavras-Chave: Avaliação de Desempenho; Racionalidade Instrumental; Racionalidade Substantiva; Gestão de Pessoas; 


\section{INTRODUÇÃO}

As práticas da Avaliação de Desempenho não são novas, desde que um homem deu um emprego ao outro, seu trabalho passou a ser avaliado. $O$ ato de avaliar é uma característica humana e uma constante que se reflete nas organizações. Chefias e servidores, formal ou informalmente, implícita ou explicitamente, se avaliam mutuamente. Sendo as chefias responsáveis pela gestão de sua equipe, é inerente a suas atribuições o acompanhamento e gerenciamento do desempenho de seus subordinados para a valorização de sua força de trabalho. A avaliação de desempenho ocupa um papel cada vez mais relevante no serviço público federal e a proposta é que se procure identificar os fatores que impactam no desempenho dos servidores, de forma a permitir que as instituições elevem os padrões de desempenho institucional, segundo os paradigmas da administração pública visando o alcance dos resultados e o atendimento satisfatório do cidadão. Segundo Vroom (1997) a avaliação de desempenho é uma questão importante e relevante na medida em que se trata de um processo destinado a alinhar os objetivos dos gerentes e de seus subordinados diretos. Vroom tem uma visão mais voltada para a racionalidade instrumental.

A avaliação de desempenho pode ser vista como um instrumento de racionalização do trabalho. Para Guerreiro Ramos (2009), no serviço público a racionalização se manifesta através da burocracia onde predomina o interesse universal sobre o interesse particular. Segundo ele, a abordagem por uma racionalização substantiva seria mais adequada, uma vez que leva em consideração os interesses da empresa e do trabalhador. A avaliação de desempenho sob o viés da racionalidade instrumental e substantiva é abordada nesse trabalho.

Nesse contexto a preocupação é verificar se o Sistema de Desempenho Individual - SDI implantado no Centro de Desenvolvimento da Tecnologia Nuclear - CDTN contempla os aspectos da racionalidade instrumental $e$ substantiva, segundo a proposta de Guerreiro Ramos e se a finalidade da avaliação é vista da mesma forma pelos servidores e pelos gerentes, investigando se os Plano de Trabalho Individual estão levando em consideração as necessidades da empresa e dos servidores, sob o viés da racionalidade instrumental e da substantividade, como definido por Guerreiro Ramos e as expectativas dos servidores quanto ao propósito da avaliação de múltiplas fontes, comparando com a visão das chefias.

\section{A AVALIAÇÃO DE DESEMPENHO}

A Avaliação do Desempenho é um procedimento que avalia e estimula o potencial dos funcionários na empresa. Seu caráter é fundamentalmente orientativo, uma vez que redireciona os desvios, aponta para as dificuldades e promove incentivos em relação aos pontos fortes.

Ela deve ser entendida como um processo de comparação entre o resultado efetivo e o resultado esperado do trabalho de uma pessoa em uma organização, segundo critérios e medidas pré definidos. Sua aplicação é relevante na mensuração e monitoramento do resultado do trabalho das pessoas, podendo inclusive alimentar outros processos de recursos humanos, como a capacitação e a gestão de desempenho, servindo como base para a tomada de inúmeras decisões sobre carreira e remuneração.

Como ferramenta de controle social, a Avaliação Individual de Desempenho precisa estar envolta por uma carga moral e ideológica suficientemente capaz de legitimar o seu uso e minimizar a resistência natural a que está sujeita. Desta forma ela se apresenta como uma ferramenta para fornecer "feedback" aos funcionários sobre o seu desempenho, também como um estímulo para a melhoria do desempenho e produtividade das pessoas e das equipes e, ainda, como um meio de tornar mais justo o pagamento de recompensas.

Em Vroom (1977) encontramos que os planos formais de avaliação de desempenho são elaborados para:

Fornecerem julgamentos sistemáticos que justificam aumentos salariais, promoções, transferências e às vezes rebaixamentos e demissões.

Dar um feedback ao servidor de como ele está se saindo na opinião do chefe.

Usados como base para instrução e aconselhamento do indivíduo por seu superior. 


\subsection{AVALIAÇÃO DE DESEMPENHO DO CDTN}

\subsubsection{HISTÓRICO DO CDTN}

O CDTN tem sua origem na Escola de Engenharia da Universidade Federal de Minas Gerais - UFMG, onde foi criado, em 1952, com o nome de Instituto de Pesquisas Radioativas IPR. Suas atividades iniciais incluíam a pesquisa de ocorrências minerais radioativas, estudos no campo da física nuclear, da metalurgia e de materiais de interesse nuclear. Em 1960, inaugura-se, neste Instituto o Reator de pesquisa TRIGA ( Training Research /sotope General Atomic) Mark 1, com a finalidade de pesquisa, de produção de radioisótopos e treinamento.

O IPR passou a integrar o Plano Nacional de Energia Nuclear em 1965, a partir da assinatura de convênio entre a UFMG e a CNEN.

Em 1972 o IPR é transferido para a Companhia Brasileira de Tecnologia Nuclear - CBTN, onde além das pesquisas foram agregadas atividades de desenvolvimento da tecnologia nuclear.
Em 1974 o IPR é incorporado pelas Empresas Nucleares Brasileiras S/A - NUCLEBRÁS, passando a absorver tecnologia nuclear do acordo Brasil/Alemanha. Teve seu nome alterado para CDTN - Centro de Desenvolvimento da Tecnologia Nuclear.

Em 1988, com a extinção da NUCLEBRÁS, voltou a fazer parte da CNEN, e ter uma atuação mais voltada para P\&D e formação especializada na área nuclear e em áreas correlatas.

Em 2003, o CDTN iniciou o Programa de Pósgraduação, em nível de mestrado, e, em 2010, o de doutorado, de significante relevância para a formação de novas gerações de pesquisadores.

O quadro 1 abaixo mostra os marcos legais da avaliação de desempenho no serviço público, mostrando que é antiga a questão do desempenho dos servidores. $\mathrm{Na}$ Administração Pública Federal brasileira, desde 1995 foram implementadas políticas de remuneração diferenciadas com base em desempenho. (BRASIL, 1995)

Quadro 1 - Marcos Legais da Avaliação de Desempenho no Serviço Público

\begin{tabular}{|c|l|}
\hline 1960 & Lei no 3.780 - Critérios para promoção na carreira \\
\hline 1970 & Lei no 5.645 - Progressão funcional por mérito e antiguidade \\
\hline 1977 & Decreto no 80.602 - Progressão funcional mediante avaliação \\
\hline 1980 & Decreto no 84.664 - Institui critérios de avaliação para progressão e promoção \\
\hline 1990 & Lei no 8.112 - Institui o regime jurídico dos servidores \\
\hline 1995 & MP no 1.548 - Cria a gratificação de desempenho e produtividade \\
\hline 2008 & Lei no 11.784 - Institui a nova sistemática para AD \\
\hline 2010 & Decreto no 7.133 - Critérios e procedimentos gerais de AD \\
\hline
\end{tabular}

Fonte: Manual de Orientação para Gestão do Desempenho - Ministério do Planejamento, Orçamento e Gestão Secretaria de Gestão Pública.

Entretanto, a avaliação de desempenho periódica do servidor público federal foi introduzida na Constituição pela EC no 19/98, em seu artigo 41 com a seguinte redação:

Art. 41. São estáveis após três anos de efetivo exercício os servidores nomeados para cargo de provimento efetivo em virtude de concurso público.

§ 1ㅇ O servidor público estável só perderá o cargo:

I - em virtude de sentença judicial transitada em julgado;

II - mediante processo administrativo em que Ihe seja assegurada ampla defesa;
III - mediante procedimento de avaliação periódica de desempenho na forma de lei complementar, assegurada ampla defesa.

que é interpretada como uma ameaça a estabilidade do servidor.

A situação muda novamente com a Lei no. 11.784/2008 que estabelece a avaliação por múltiplas fontes, ou seja, $360^{\circ}$. Nessa avaliação os fatores de desempenho são avaliados pela chefia em relação aos subordinados, pelos subordinados em relação às chefias, pelos pares e também é feita uma autoavaliação. Ainda segundo a Lei no 11.784/2008, a avaliação de desempenho 
objetiva promover a melhoria da qualificação dos serviços públicos e subsidiar a política de gestão de pessoas, principalmente quanto à capacitação, desenvolvimento no cargo ou na carreira, remuneração e movimentação de pessoal (incisos I e II do caput do art. 140).

O modelo de avaliação por múltiplas fontes foi implementado no Centro de Desenvolvimento da Tecnologia Nuclear - CDTN/CNEN em junho de 2015 e é uma experiência nova na instituição.

\subsubsection{O SISTEMA DE DESEMPENHO INDIVIDUAL-SDI}

Através do Artigo 19 da Medida Provisória no 2.150-40 foi criada a Gratificação de Desempenho de Atividade de Ciência e Tecnologia - GDACT, devida aos ocupantes dos cargos efetivos das Careiras de Pesquisa, Desenvolvimento Tecnológico e Gestão, Planejamento e Infraestrutura em Ciência e Tecnologia, que para o recebimento pelo servidor, este deverá passar pela avaliação individual de desempenho.

Por meio da Portaria no 051, de 24 de setembro de 2001, o Presidente da Comissão nacional de Energia Nuclear aprovou o Sistema Gestor de Desempenho - SGD, que instituiu a metodologia para a avaliação de desempenho individual e institucional, com vistas à concessão da Gratificação de Desempenho de Atividade de ciência e Tecnologia - GDACT.

O Sistema Gestor de Desempenho, visando atender o disposto no parágrafo $2^{\circ}$ do Art. 20 da MP 2.229-43 e ainda o constante nos parágrafos $2^{\circ}, 3^{\circ}$ e $4^{\circ}$ do Art. $1^{\circ}$ do Decreto $n^{\circ}$ 3.762, está dividido nas seguintes fases, de conformidade com o Art. 4음 MP 2.150-40:

I - Compromisso de Trabalho Anual - CTA

II - Acompanhamento e Renegociação do Compromisso de Trabalho Anual - ARCTA

III - Avaliação de Desempenho Individual - ADI

IV - Resultado Final - RF

V - Comentários

VI - Plano de Desenvolvimento de Melhorias PDM

Em cada uma das fases do SDI, é fundamental que o gestor de avaliação e servidor avaliado, conjuntamente, observem analisem e definam as ações e diretrizes a serem cumpridas durante o processo, de forma a permitir que o resultado do desempenho do servidor, bem como os resultados alcançados pela Unidade de Avaliação sejam os melhores possíveis, sem que haja prejuízos significativos para nenhuma das partes.

O gestor de avaliação é o responsável pela definição / negociação do plano de trabalho individual - PTI, acompanhamento e avaliação do desempenho individual dos servidores que compõem uma Unidade de Avaliação, que pode ser uma divisão, um serviço ou um setor de trabalho não previsto no organograma do CDTN.

O servidor é avaliado pelo gestor de avaliação da unidade administrativa onde tenha permanecido por maior tempo, durante o período de avaliação. Caso o servidor tenha permanecido em cada unidade de avaliação por um período igual, o mesmo será avaliado pelo gestor daquela unidade onde esteja lotado na época da avaliação.

A indicação dos servidores que serão os gestores de avaliação e dos seus respectivos substitutos, é feita pelo Diretor do CDTN.

O PTI é a fase inicial do SDI e nele são definidas as etapas/sub-etapas e/ ou atividades, preferencialmente com indicadores de atingimento, que compõem o rol de tarefas a serem desenvolvidas pelo servidor, por exercício, sujeitas ao acompanhamento frequente e renegociação, se for o caso. Para cada etapa/sub-etapas e/ou atividades incluída no PTI, deverão ser definidos os seguintes itens: a) correspondência com o Plano de Trabalho do CDTN; b) pontuação esperada para a execução total e no prazo determinado, para cada semestre do exercício (Jan/Jun e Jul/Dez); período de tempo, em meses, para cada execução.

Deverão ser definidos também seis (6) Fatores de Desempenho, entre os vinte e quatro (24) possibilidades, que apresentem importância para o cumprimento das tarefas negociadas e a esses deverão ser atribuídos pesos, que somados, totalizem dezoito (18) pontos.

O Acompanhamento e Renegociação do Compromisso de Trabalho Anual - ARCTA compõem a segunda fase do SDI, sem periodicidade definida, e, quando necessário, poderá ocorrer mais de uma vez e em qualquer época. O acompanhamento é a observação, a análise e a orientação do desempenho do servidor, que pode desencadear ou não ações corretivas, a fim de que não haja prejuízo no desempenho do servidor. Já a renegociação é a alteração do PTI, em consequência de interferências verificadas que venham a 
impossibilitar a conclusão das tarefas negociadas.

Atendendo ao que dispõe o Art. 8 do Decreto $\mathrm{n}$ - 3.762, a ADI é realizada semestralmente, sendo a primeira referente ao período de janeiro a junho e a segunda de julho a dezembro, e os processamentos são realizados nos meses subsequentes aos das realizações, ocorrendo, respectivamente, em julho e janeiro.

\subsubsection{O FUNCIONAMENTO DO SISTEMA DE DESEMPENHO INDIVIDUAL - SDI}

Em função do novo cenário, decidiu-se pela implantação de um moderno sistema de gestão de desempenho.

O Sistema Desempenho individual - SDI foi criado com dois objetivos: o primeiro, de complementar o planejamento da CNEN, permitindo a formalização da interface das atividades dos servidores com o Plano de Trabalho Institucional e deste com o Plano Plurianual; o segundo, de instrumentalizar os gerentes com uma ferramenta para gestão de pessoas e resultados.

Para atender a clientela visada, gestores e colaboradores das 11 unidades da CNEN em 7 Estados, foi necessário criar uma estratégia de ações que permitisse a participação de todos no processo de construção do SDI. Para isso, o Fórum de Recursos Humanos da CNEN, composto por representante das unidades, concebeu a metodologia do SDI, com uma visão inovadora e respeitando as diretrizes legais.

O SDI é um sistema informatizado, utilizado via INTRANET, por 2.600 servidores lotados em 11 unidades localizadas em Pernambuco, Ceará, Goiás, Distrito Federal, Minas Gerais, Rio de janeiro (Capital e Angra dos Reis) e São Paulo.

Embora idealmente a avaliação de desempenho possa ter sido pensada numa forma de assegurar a eficiência do serviço público, existem preocupações como observadas em Caldas, 2011 que sugere a existência de interesses obscuros que podem interferir na avaliação.

\subsubsection{CONSIDERAÇÕES SOBRE A AVALIAÇÃO DE DESEMPENHO}

A avaliação periódica de desempenho, no plano ideal, caracteriza-se como uma importante ferramenta de aprimoramento dos recursos humanos da Administração Pública. Se efetivamente, não existissem interesses obscuros quanto à institucionalização de tal procedimento, certamente, com uma outra abordagem, o serviço público sairia ganhando no pós-reforma administrativa de 1998, dando um salto na busca pela eficiência. (CALDAS, 2011)

Também Edmir Netto de Araújo manifesta preocupação ao lecionar sobre a avaliação periódica de desempenho ao observar: "Seu objetivo é avaliar periodicamente, por critérios técnicos e supostamente objetivos, as condições de aptidão, desenvolvimento funcional e a eficiência dos serviços realizados pelo servidor."

"O perigo é que tais critérios objetivos se transformem em subjetivos, pessoais ou políticos, como tantas vezes já se viu em procedimentos de avaliação para promoções realizados pela Administração." (ARAÚJO, 2005)

O "perigo" apontado por Araújo (2005) é real e ocorre na prática. Pinto e Behr (2015, p.807) revelam que na universidade estudada, a avaliação está diretamente relacionada à proximidade da chefia imediata com seus subordinados, apesar desse aspecto não ser aprovado pelos servidores. Os servidores acreditam que a nota na avaliação de desempenho pode ser fruto de uma competição na disputa por um melhor relacionamento interpessoal com a chefia imediata. Isso foge completamente da racionalidade defendida ao implementar uma avaliação de desempenho. Em uma avaliação subjetiva, um servidor pode ser avaliado de forma mais rígida, de acordo com o relacionamento com o avaliador.

Por outro lado, a avaliação de desempenho pode ser constrangedora, devendo ponderar se vale a pena praticá-la.

Esse sistema alimenta o desempenho a curto prazo, aniquila o planejamento a longo prazo, introduz o medo, demole o espírito de equipe, fomenta a rivalidade e a política. Deixa as pessoas amargas, oprimidas, machucadas, esgotadas, desoladas, desesperadas, abatidas, sentindo-se inferiores, algumas até deprimidas, incapacitadas para o trabalho depois de conhecerem sua avaliação, sem compreender por que são inferiores. É injusto, pois atribuir aos membros de um grupo diferenças que podem ser totalmente devidas ao sistema em que trabalham. (DEMING, 1990, p. 76) 
Levando em conta as ponderações de Deming (1990) deve-se estabelecer, com clareza, os objetivos da avaliação de desempenho e, no caso de avaliação por pares, manter o sigilo na avaliação visando a não desagregação da equipe e, no caso de perseguições procurar conciliar os interesses.

A partir da década de 1970, teve início nos EUA e na Inglaterra uma tendência a transferir práticas gerenciais do setor privado para a administração pública, fornecendo as bases para o modelo gerencial de administração, que também ficou conhecido como Nova Administração Pública. Tal modelo fortaleceuse na década de 1980, sendo adotado por governos de muitos países, com o objetivo de aumentar a eficiência do Estado. Seguindo os pressupostos neoliberais, a Nova Administração Pública propõe a transferência e adaptação de ideias, valores e práticas do setor privado para o setor público (PAULA, 2005). Desde então tem-se procurado consolidar vários sistemas de avaliação para os mais diversos fins, tais como: aprovação em estágio probatório, progressão funcional e promoção e pagamento de gratificações de desempenho.

\section{CONCEITOS DE RACIONALIDADE INSTRUMENTAL E RACIONALIDADE SUBSTANTIVA}

Guerreiro Ramos (2009) mostra a evolução da Organização Racional do Trabalho desde a sociedade pré-letrada em que o trabalho era orientado pela tradição e pelo costume e não existia a ideia do lucro.

$\mathrm{Na}$ antiguidade $\mathrm{O}$ trabalho torna-se desprezível, sendo a vida ociosa das classes sociais superiores, bem evidente. Assim, não se desenvolveu nem a técnica do trabalho, nem o maquinismo.

$\mathrm{Na}$ idade média, embora se proclamasse a dignidade do trabalho, no plano social ocorria o contrário, mantendo os mesmos preconceitos da idade antiga.

Os sistemas de racionalização iniciaram em Taylor (1856-1915), mas não surgiram de repente. Sendo um resultado de um processo gradativo e lento.

\section{No sentido antigo}

[...] a razão era entendida como força ativa na psique humana que habilita o indivíduo a distinguir entre o bem e o mal, entre 0 conhecimento falso e o verdadeiro e, assim, a ordenar sua vida pessoal e social. Mais ainda, a vida da razão na psique humana era encarada como uma realidade que resistia à sua própria redução a um fenômeno histórico ou social. (GUERREIRO RAMOS, 1989, p. 2-3)

Mas esse conceito foi mudado ao longo da história e Hobbes, 1974, p.45 define a razão como uma capacidade que o indivíduo adquire "pelo esforço" e que o habilita a nada mais do que fazer o "cálculo utilitário de consequências" (HOBBES, 1974, p. 41). Esse conceito vem sendo empregado de forma enganadora sendo que a "racionalidade assume com frequência conotações antiéticas relativamente aos propósitos fundamentais da existência humana." (RAMOS, 1983, p. 3)

Tragtenberg (1974, p.19) estuda o aparecimento das teorias administrativas de acordo com as determinações econômicassociais existentes em cada época. Analisa questões para explicar a irrupção e predominância de certas teorias da administração em um dado momento histórico onde reflete 0 interesse das classes dominantes, assumindo a partir daí um caráter ideológico. Procurando traduzir esse conceito, Tragtenberg, procura responder e entender dentro da Teoria da Administração o porquê da preocupação com o nível de conhecimento instrumental e o conhecimento humano ficam limitado as partes passiveis de controle.

Preocupa-se ainda com o surgimento das Teorias de Taylor-Fayol, na medida em que a passagem do vapor à eletricidade contribuiu para formação da ideologia administrativa de acumulação bem como a ideia de como o capitalismo de organização encontrou em Mayo sua ideologia administrativa explicita. (p. 20)

Segundo Tragtenberg (1974, p.28) a burocracia pressupõe, pelo menos, o espírito corporativo, tendo em vista que o estado com seu formalismo pode opor o interesse como instrumento as corporações (interesses privados). A burocracia, além de ser um instrumento das classes dominantes tem efeitos de permanência subsistindo com nível relativo de autonomia encontrando nas lideranças sindicais e estados socialistas. Entende que a burocracia hegemônica é incapaz de vencer o antagonismo das corporações, mas tem sua razão de ser, uma vez que une os aspectos formais e reais no nível do poder real e absoluto. De acordo com Tragtenberg a ideologia da burocracia aparece quando se dá a divisão dos 
funcionários como portadores de símbolos, uniformes e signos.

Conforme Guerreiro Ramos (2009, p. 118) no serviço público a racionalização se manifesta através da burocracia onde predomina o interesse universal sobre o interesse particular.

Existe aqui uma convergência de pensamentos com relação a burocracia, que se traduz numa realidade instrumental, que cumpre o seu papel por algum tempo, mas que é incompleta segundo Guerreiro Ramos e Tragtenberg.

A racionalidade substantiva sustenta que 0 lugar adequado à razão é a psique humana. Nessa conformidade, a psique humana deve ser considerada o ponto de referência para a ordenação da vida social, tanto quanto para a conceituação da ciência social em geral, da qual o estudo sistemático da organização constitui domínio particular. (GUERREIRO RAMOS, 1989, p. 27)

Guerreiro Ramos sugere partir para a abordagem substantiva, que leva os interesses do trabalhador em consideração.

\subsection{RACIONALIDADE INSTRUMENTAL}

Em sua obra, Economia e sociedade, Max Weber (1922) apresenta rudimentos do que hoje é o conceito de racionalidade. Apresenta quatro tipos de ação social: racional no tocante a fins, racional no tocante a valores, a afetiva e a tradicional.

Para Mannheim (1962) a Instrumentalidade é "A organização da atividade dos membros da sociedade em função de finalidades objetivas". Quando os atos são articulados ou relacionados com outros elementos para lograr um objetivo, é dito que é funcionalmente racional.

A partir dos trabalhos de Guerreiro Ramos e de Habermas, Serva (1997) define a ação racional instrumental e seus elementos constitutivos.

Ação baseada no cálculo, orientada para o alcance de metas técnicas ou de finalidades ligadas a interesses econômicos ou de poder social, através da maximização dos recursos disponíveis. São seus elementos constitutivos:

cálculo - projeção utilitária das consequências dos atos humanos;

fins - metas de natureza técnica, econômica ou política (aumento de poder);

maximização dos recursos - busca da eficiência e da eficácia máximas, sem questionamento ético, no tratamento de recursos disponíveis, quer sejam humanos, materiais, financeiros, técnicos, energéticos ou ainda, de tempo;

êxito, resultados - o alcance, em si mesmo, de padrões, níveis, estágios, situações, que são considerados como vitoriosa face a processos competitivos numa sociedade capitalista;

desempenho - performance individual elevada na realização de atividades, centrada na utilidade;

utilidade - dimensão econômica considerada na base das interações como um valor generalizado;

rentabilidade - medida de retomo econômico dos êxitos e dos resultados esperados;

estratégia interpessoal - aqui entendida como influência planejada sobre outrem, a partir da antecipação das reações prováveis desse outrem a determinados estímulos e ações, visando atingir seus pontos fracos.

(SERVA, 1997, p. 22 - 23)

\subsection{RACIONALIDADE SUBSTANTIVA}

Substantividade é "um ato de pensamento que revele percepção inteligente das inter-relações dos acontecimentos de uma determinada situação". (MANNHEIM, 1962)

Em Serva (1997), baseado nos estudos de Guerreiro Ramos e Habermas, a ação racional substantiva fica definida como sendo:

Ação orientada para duas dimensões: na dimensão individual, que se refere à autorealização, compreendida como concretização de potencialidades e satisfação; na dimensão grupal, que se refere ao entendimento, nas direções das responsabilidade e satisfação sociais. Por conseguinte, os elementos constituídos da ação racional substantiva são:

autorealização - processos de concretização do potencial inato do indivíduo, complementados pela satisfação;

entendimento - ações pelas quais se estabelecem acordos e consensos racionais, mediadas pela comunicação livre, e que coordenam atividades comuns sob a égide da responsabilidade e satisfação sociais;

julgamento ético - deliberação baseada em juízos de valor (bom, mau, verdadeiro, falso, certo, errado etc.), que se processa através do debate racional sobre as pretensões de 
validez emitidas pelos indivíduos nas interações;

autenticidade - integridade, honestidade e franqueza dos indivíduos nas interações;

valores emancipatórios - aqui se destacam os valores de mudança e aperfeiçoamento do social nas direções do bem-estar coletivo, da solidariedade, do respeito à individualidade, da liberdade e do comprometimento, presentes nos indivíduos e no contexto normativo do grupo;

autonomia - condição plena dos indivíduos para poderem agir e expressarem-se livremente nas interações.

(SERVA, 1997, p. 22)

\subsection{RACIONALIDADE INSTRUMENTAL} VERSUS RACIONALIDADE SUBSTANTIVA
O quadro 2, a seguir, apresenta as características das racionalidades substantiva e instrumental nos diversos processos organizacionais, e como a racionalidade substantiva leva em conta os aspectos humanos em uma organização, preocupandose com o indivíduo e não apenas com êxito, resultados ou desempenho. Ao valorizar a autorealização, a racionalidade substantiva acaba por conter a racionalidade puramente instrumental. Criticar a racionalidade instrumental e chamar a atenção para a existência da racionalidade substantiva, apenas supondo a possibilidade de aplicação desta última nas organizações, ao nosso ver não é o bastante. Se quisermos que o pensamento de Guerreiro Ramos dê frutos, temos que fazer avançar a teoria e impulsionar a prática. (SERVA, 1997)

Quadro 2 - Análise das racionalidades nos processos organizacionais

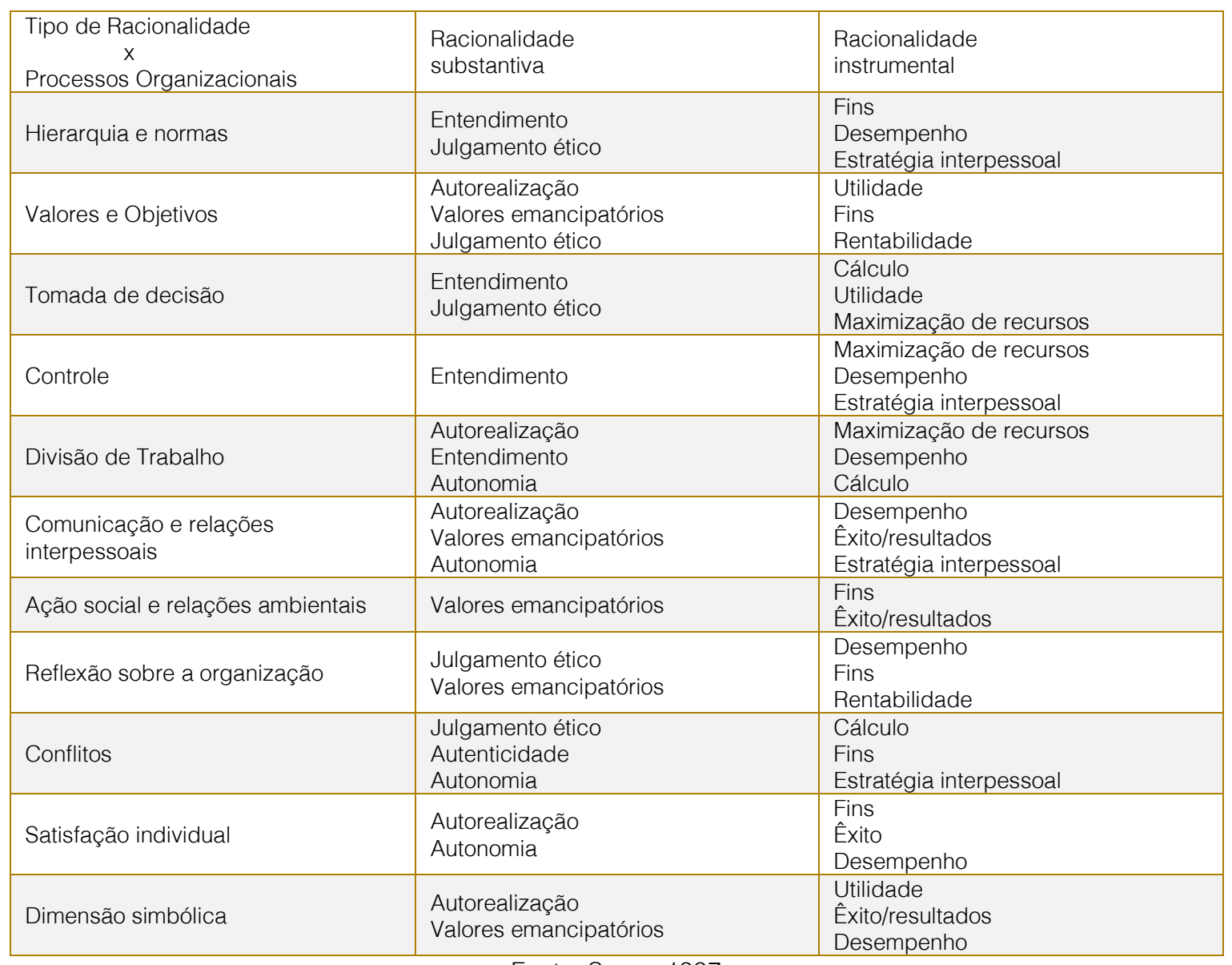

Fonte: Serva, 1997

Segundo ele a teoria da vida humana associada é substantiva quando a razão no sentido substantivo, é sua principal categoria de análise, ela é formal quando a razão, no sentido funcional, é sua principal categoria de análise. Quando a teoria substantiva é entendida como ordenativa, passa ser uma teoria normativa. Já quando a razão funcional 
é apenas uma definição ou uma elaboração lógica, a teoria formal é nominalista. Para ele os conceitos da teoria substantiva são conhecimentos derivados do e no processo de realidade e os conceitos da teoria formal são apenas instrumentos convencionais de linguagem que descrevem procedimentos operacionais.

Continuando, na segunda distinção a teoria substantiva da vida humana associada é algo que existe há muito tempo e seus elementos sistêmicos podem ser encontrados nos trabalhos dos pensadores de todos os tempos, harmonizados ao significado de que o senso comum atribui a razão.

Quanto a terceira distinção é de que a teoria substantiva, tal como concebida, envolve uma superordenação ética da teoria política.

\section{Quadro 3 - Teoria da Vida Humana Associada}

\begin{tabular}{|c|c|}
\hline Formal & Substantiva \\
\hline $\begin{array}{l}\text { Os critérios para ordenação das associações } \\
\text { humanas são dados socialmente. }\end{array}$ & $\begin{array}{l}\text { Os critérios para a ordenação das associações } \\
\text { humanas são racionais, isto é, evidentes por si } \\
\text { mesmos ao senso comum individual, } \\
\text { independentemente de qualquer processo } \\
\text { particular de socialização. }\end{array}$ \\
\hline $\begin{array}{l}\text { Uma condição fundamental da ordem social é que } \\
\text { a economia se transforme num sistema } \\
\text { autorregulado. }\end{array}$ & $\begin{array}{l}\text { Uma condição fundamental da rodem social é a } \\
\text { regulação política da economia. }\end{array}$ \\
\hline $\begin{array}{l}\text { O sentido da história das associações humanas é } \\
\text { livre do conceito de valor: há uma dicotomia entre } \\
\text { valores e fatos. }\end{array}$ & $\begin{array}{l}\text { O estudo cientifico das associações humanas é } \\
\text { normativo: a dicotomia entre valores e fatos é falsa, } \\
\text { na prática, e, em teoria, tende a produzir uma } \\
\text { análise defectiva. }\end{array}$ \\
\hline $\begin{array}{l}\text { O sentido da história pode ser captado pelo } \\
\text { conhecimento, que se revela através de uma séria } \\
\text { de determinados estados empírico-temporais. }\end{array}$ & $\begin{array}{l}\text { A história torna-se significante para o homem } \\
\text { através do método paradigmático de auto } \\
\text { interpretação da comunidade organizada. Seu } \\
\text { sentido não pode ser captado por categorias } \\
\text { serialistas do pensamento. }\end{array}$ \\
\hline $\begin{array}{l}\text { A ciência natural fornece o paradigma teórico } \\
\text { para a correta focalização de todos os assuntos e } \\
\text { questões suscitadas pela realidade. }\end{array}$ & $\begin{array}{l}\text { O estudo cientifico adequado das associações } \\
\text { humanas é um tipo de investigação em si mesmo, } \\
\text { distinto da ciência dos fenômenos naturais, e mais } \\
\text { abrangente que esta }\end{array}$ \\
\hline
\end{tabular}

Fonte: Guerreiro Ramos (1989, p. 29)

O pensamento de Guerreiro Ramos é no sentido de que a ideia de uma ciência social tendo como base a presunção de que o indivíduo é fundamentalmente um ser social, e que suas virtudes dever ser avaliadas segundo critérios socialmente estabelecidos.

Segundo Guerreiro Ramos, na ciência social moderna ao desdobrar-se como uma associação puramente natural, gera os padrões da existência humana em seu conjunto. Para ele essa transavaliação do social, de que a moderna ciência social é resultado, ocorreu nos três últimos séculos da história.

Para Guerreiro Ramos, é o sentimento que o homem tem de pertencer à sociedade que constitui o fundamento da conduta moral, sendo que a simpatia a sensitividade do indivíduo em relação à aprovação e censura dos outros desempenha um papel fundamental no desenvolvimento de seu senso moral.

\section{METODOLOGIA}

Neste trabalho será feita uma pesquisa qualitativa que, segundo Strauss e Corbin (1990) pode ser usada em ocasiões em que pouco se sabe sobre o tema ou para obter novas perspectivas sobre questões sobre as quais se sabe muito.

Será aplicado o questionário mostrado, uma vez que este instrumento de pesquisa permite atingir uma grande quantidade de servidores. Além disso, o questionário “... garante o anonimato e pode conter questões para atender às finalidades específicas de uma 
pesquisa. Aplicada criteriosamente, esta técnica apresenta elevada confiabilidade", segundo Barbosa (1998, p.2).

A parte inicial do questionário, embora garanta o anonimato, colhe informações que permitirão estratificar os resultados, mostrando diversas perspectivas sobre o assunto estudado.

Seguindo a orientação de Gray (2012, p. 291) "Todos os questionários, sejam em papel, por e-mail ou na internet, precisam ser testados cuidadosamente por meio de um piloto antes de serem disseminados a um público mais amplo.", o questionário será aplicado a 3 chefes e 7 servidores subordinados, selecionados aleatoriamente, para comprovar o bom entendimento das perguntas. Esse cuidado será tomado, uma vez que foram introduzidas novas questões, além das propostas por Oliveira (2014).

Após breve apresentação são apresentados os objetivos geral e específicos do trabalho, a questão de pesquisa e a relevância. É feita a delimitação da pesquisa e um pequeno histórico do Centro de Desenvolvimento da Tecnologia Nuclear.

Com a revisão da literatura será feita uma pesquisa qualitativa (GRAY, 2012) para estabelecer os conceitos da racionalidade e da substantividade, em Guerreiro Ramos e seus seguidores, e os demais conceitos pertinentes, tais como: avaliação de desempenho, para permitir avaliar os Planos de Trabalho Individuais segundo esses

\section{REFERENCIAS}

[1]. ARAÚJO, E. N. Curso de Direito Administrativo. São Paulo: Saraiva, 2005.

[2]. BERGAMINI, C. W.; BERALDO, D. G. R. Avaliação de desempenho humano na empresa. São Paulo: Atlas, 1988

[3]. BRASIL. Decreto-Lei no. 8691, de 28 de julho de 1993. Dispõe sobre o Plano de Carreiras para a área de Ciência e Tecnologia da Administração Federal Direta, das Autarquias e das Fundações Federais e dá outras providências. Diário Oficial, Brasília, n. 143, 29 julho 1993. p. 10709-10712, Seção I.

[4]. BRASIL. Plano Diretor da Reforma do Estado. [S.I.]. 1995.

[5]. BRASIL. Lei no. 9638, de 20 de maio de 1998. Cria a Gratificação de Desempenho de Atividade de Ciência e Tecnologia - GDCT, e dá conceitos. É feito um histórico da implantação da avaliação de desempenho na CNEN/CDTN e outro da criação da Gratificação de Desempenho de Atividade de Ciência e Tecnologia - GDACT.

Será descrito o Sistema de Desempenho Individual - SDI e proposto questionário usando a escala Likert (1932) para verificar a expectativa dos servidores quanto aos resultados da avaliação de desempenho e verificar se os servidores estão envolvidos na elaboração dos Planos de Trabalho Individual - PTI.

Em pesquisa limitada aos servidores do CDTN será feito um levantamento das avaliações efetuadas dentro do SDI e um questionário será enviado para se avaliar as visões de chefes e subordinados da avaliação praticada. Verificar os aspectos de racionalidade instrumental e substantiva presentes.

\section{CONCLUSÕES}

O trabalho permitirá reflexões sobre a avaliação de desempenho, bem como formas de aperfeiçoar o processo de avaliação através dos resultados a serem obtidos. Analisar as contribuições que poderão advir para o aprimoramento do desempenho Institucional à luz das considerações de Guerreiro Ramos, com isso os procedimentos poderão tornar-se mais eficientes, procurando um equilíbrio entre os objetivos da empresa e dos servidores.

outras providências. Diário Oficial, Brasília, v. 21, p. 1-2, maio 1998

[6]. BRASIL. Lei No. 9647, de 26 de maio de 1998. Cria a Gratificação de Desempenho de Atividade de Ciência e Tecnologia - GDCT para os ocupantes dos cargos efetivos de nível intermediário da carreira de Gestão, Planejamento e Infraestrutura em C\&T. Diário Oficial, Brasília, n. n. 99, p. 5-6, maio 1998.

[7]. CALDAS, I. L. D. A. A avaliação periódica de desempenho do servidor público estável. Efeitos do princípio de eficiência sobre o desempenho do servidor público. Âmbito Jurídico, Rio Grande, v. XIV, n. 87, abr 2011. Disponível em: $<\mathrm{http}: / /$ www.ambito-

juridico.com.br/site/index.php?n_link=revista_artigo s_leitura\&artigo_id=9259>. Acesso em: 03 mar 2015. 
[8]. CENTRO DE DESENVOLVIMENTO DA TECNOLOGIA NUCLEAR. História do CDTN. Site do Centro de Desenvolvimento da Tecnologia Nuclear - CDTN, 2015. Disponível em: <www.cdtn.br/ocdtn>. Acesso em: 20 jul. 2015.

[9]. DEMING, W. E. Qualidade: a revolução da administração. Tradução de Clave Comunicações e Recursos Humanos. Rio de Janeiro: MarquesSaraiva, 1990

[10]. GUERREIRO RAMOS, A. A nova ciência das organizações - uma reconceituação da riqueza das nações. 2ª . ed. Rio de Janeiro: FGV, 1989.

[11]. GUERREIRO RAMOS, A. Uma introdução ao histórico da organização racional do trabalho. Brasília: Artes Gráficas e Editora Pontual Ltda, 2009. Disponível em: $<$ http://www.cfa.org.br/servicos/publicacoes/livroguerreiro-ramos/Guerreiro\%20Ramos.pdf>. Acesso em: 08 abr. 2015.
[12]. MANNHEIM, K. O homem e a sociedade: estudos sobre a estrutura social moderna. Rio de Janeiro: Zahar Editores, 1962.

[13]. PAULA, A. P. P. Por uma nova gestão pública: limites e potencialidade da experiência contemporânea. Rio de Janeiro: FGV, 2005.

[14]. PINTO, J. D. F.; BEHR, R. R. Contradições na avaliação de desempenho dos servidores técnico-administrativos em educação na universidade pública. Cad. EBAPE.BR

[15]. SERVA, M. Racionalidade Substantiva Demonstrada na Prática Administrativa. Revista de Administração de Empresas, São Paulo, v. 37 n. 2, p. 18-30, Abr./Jun. 1997.

[16]. TRAGTENBERG, M. Burocracia e Ideologia. São Paulo: Ática, 1974.

[17]. VROOM, V. H. Gestão de pessoas, não de pessoal. Tradução de Priscilla Martins Celeste Ana Beatriz Rodrigues. Rio de Janeiro: Campus, 1997 


\section{Capítulo 13}

\section{A “CO-OPETICÃO" NA CAPACITACÃO PROFISSIONAL: EXEMPLOS DA INDÚSTRIA DE PETRÓLEO NO BRASIL}

\section{Renata Pereira Gonçalves Ribeiro}

Júlio César de Faria Alvim Wasserman

Evandro La Macchia

Resumo: O termo "co-opetição", voltado para capacitação profissional, é a junção da cooperação e da competição, e designa entre outros aspectos, a união de esforços de todos os envolvidos, como alunos, professores, corpo administrativo, instituições parceiras, laboratórios e centros de pesquisa e inovação, na busca por melhores aplicações no mercado de trabalho. Este artigo teve como objetivo debater, através de levantamento teórico e exemplos existentes na indústria de petróleo e gás ( $P \& G$ ) no Brasil, a importância da co-opetição na capacitação profissional. Foi possível confirmar que estas são necessidades essenciais para atender à crescente demandante por mão de obra especializada nesta indústria.

Palavras-chave: cooperação e competição; parcerias estratégicas; capacitação; indústria de petróleo e gás (P\&G). 


\section{INTRODUÇÃO}

\subsection{CONTEXTUALIZAÇÃO DA INDÚSTRIA DE PETRÓLEO E GÁS}

O petróleo, na sua forma de óleo e gás, foi responsável por $57 \%$ da oferta global de energia em 2012, no mundo (BP, 2013). Isto se justifica pelo mesmo ser uma fonte com alto espectro de mobilidade e uso, tendo capacidade de alimentar nossos sistemas de transporte, indústria petroquímica, geração de energia elétrica, siderurgia e agricultura. O petróleo ainda ilumina, aquece e resfria residências, hospitais, estabelecimentos comerciais e escritórios. No Brasil, do ponto de vista de sua matriz de oferta primária de energia, é destaque a participação de fontes renováveis, $46 \%$ da produção (dados de 2012), segundo o Balanço de Energia Nacional 2013 (BEN, 2013). Notamos, porém, que o óleo e o gás natural participaram com $51,5 \%$ da matriz energética em 2012, ou seja, apesar de termos umas das maiores porcentagens de energia renovável do mundo, mais da metade da produção brasileira é de petróleo, o que nos faz dependentes deste recurso.

De acordo com o relatório World Energy Outlook 2013, da Agência Internacional de Energia (IEA, 2013), no ano de 2035, a indústria $P \& G$ será responsável pelo suprimento de $50,5 \%$ de toda a necessidade primária de energia de nosso mundo. O relatório destaca ainda que se somado ao carvão, outro combustível não renovável e de origem fóssil, em $2035,76 \%$ da demanda de energia primária mundial será formada pelos três energéticos, petróleo, gás natural e carvão. Para o Brasil, a Agência (IEA, 2013) no seu cenário New Policies, projeta que no ano de 2035 o petróleo ainda será o responsável por $50,4 \%$ do suprimento total da demanda de energia primária brasileira, sendo 34,4\% na forma de petróleo e $16,0 \%$ na forma de gás, situação esta muito similar às previsões da Agência para o mundo como um todo.

Traduzindo-se em volumes, a IEA indica no seu cenário central, que a produção de óleo no Brasil crescerá de 2,2 milhões de barris dia em 2012, para 4,1 milhões de barris dia em 2020 e 6 milhões de barris por dia em 2035 sendo o crescimento do consumo de energia primária no país entre $56 \%$ e $88 \%$ dependendo do cenário adotado pela agencia. Este potencial de crescimento está baseado nas descobertas de hidrocarbonetos nos reservatórios do présal no litoral brasileiro. Considerando que os reservatórios do pré-sal estão localizados em águas profundas, deve ser levada em conta a complexidade do desenvolvimento das referidas descobertas bem como a escala de investimentos requeridos (IEA, 2013). Este cenário de produção não se confirmará se não forem atendidos, dentre outros requisitos, a disponibilidade de recursos financeiros, a disponibilidade de tecnologias, a capacidade de suprimento da indústria nacional e a capacitação da mão de obra.

Para suprir a demanda por mão de obra qualificada, dentre outros aspectos, o Brasil necessita de maior competitividade $e$ cooperação para desenvolver profissionais capazes de lidar com os desafios da indústria de P\&G. Para Nalebuff e Brandenburger (2006, p.22), criadores da abordagem "co-opetição", as instituições de capacitação para a execução de um trabalho, devem buscar constantes parcerias, nacionais e internacionais, em diferentes áreas, para que possam aplicar teorias, trabalhar coletivamente, e gerar maior interação entre os públicos interessados, deve ainda, ser capaz de promover a troca de conhecimentos e experiências, e também desenvolver habilidades profissionais que consequentemente reflitam no desempenho do individuo no ambiente de trabalho, como afirmam Arvanitis e Woerter (2009).

\subsection{A ABORDAGEM DA "CO-OPETIÇÃO" NA CAPACITAÇÃO PROFISSIONAL}

A "co-opetição" une competição e cooperação, esses dois fatores juntos, de acordo com Nalebuff e Brandenburger (1996), são determinantes para o sucesso das instituições prestadores de serviços de capacitação. Sejam elas o modelo que for, necessariamente precisam atentar para os seus públicos interessados, e expandir a gestão, os métodos e as parcerias, em constante consonância com as demandas do mercado de trabalho, onde a interação para a criação e aplicação do conhecimento, é o que produzirá e proporcionará o crescimento em todos os aspectos, incluindo o individuo, empresas e sociedade (Nonaka et al. 2000). Para Arvanitis e Woerter (2009), as interações e o trabalho colaborativo entre instituições, geram inovação e são capazes de transferir conhecimento e tecnologia com maior agilidade.

Paula (2004) segue com o pensamento de que é imprescindível a busca constante por 
parcerias entre instituições que capacitam para o mercado de trabalho, com o objetivo de desenvolver novas tecnologias. A produção compartilhada é influenciada por diversos conhecimentos e habilidades, por esta razão deve ser construída com o envolvimento das partes interessadas (CRICHTON, 2009). Nalebuff e Brandenburget (1996, p.35) apresentam um "exercício que constitui um input essencial no processo de geração de novas estratégias" e possibilita buscar constantes aprimoramentos no que denominam rede de valores e relacionamento com os principais públicos interessados, como apresentada na figura 01.

Figura 01: Rede de Valores para uma Instituição de Capacitação

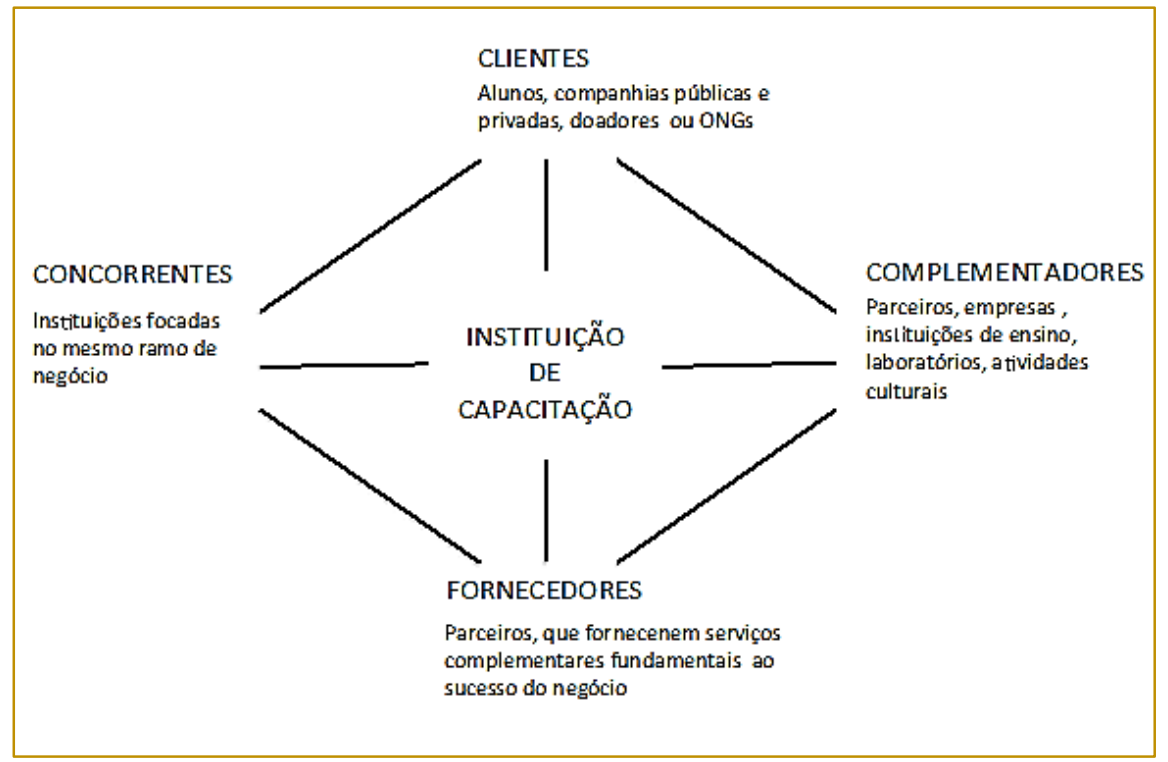

Fonte: Adaptado de NALEBUFF E BRANDENBURGER, 1996.

\subsection{RETENÇÃO E APLICAÇÃO DE CONHECIMENTOS NA CAPACITAÇÃO PROFISSIONAL}

Costa (2009, p.48), aponta o Brasil como um país privilegiado por seus variados recursos naturais e "atualmente mais ainda pelo hidrocarboneto", porém, afirma o autor, que é ilusão apontar o País como rico, devido à ausência de desenvolvimento industrial em escala, capaz de suportar a demanda. O autor exemplifica o Japão, onde "o desenvolvimento é acelerado por conta da evolução da força de trabalho, mediante rápido aumento da educação geral e níveis de capacitação especializada". Desta forma, a transmissão do saber enfatiza a conversão de conhecimentos, com interação entre o conhecimento tácito e o conhecimento explícito, tendo por objetivo o desenvolvimento de habilidades que agregam um maior compartilhamento de experiências aos métodos tradicionais de aprendizagem, conforme mostra a figura 02, de acordo com Nonaka e Konno (1998, p.43). Para Paula (2004), os princípios da espiral da conversão do conhecimento devem ser elementos estratégicos das instituições capacitadoras, pois visam proporcionar aos alunos, equilíbrio entre a teoria e a prática, onde a retenção e aplicação do conhecimento são recursos indispensáveis, e devem refletir no ambiente profissional. 
Figura 02: Espiral da Evolução da Conversão do Conhecimento (1998).

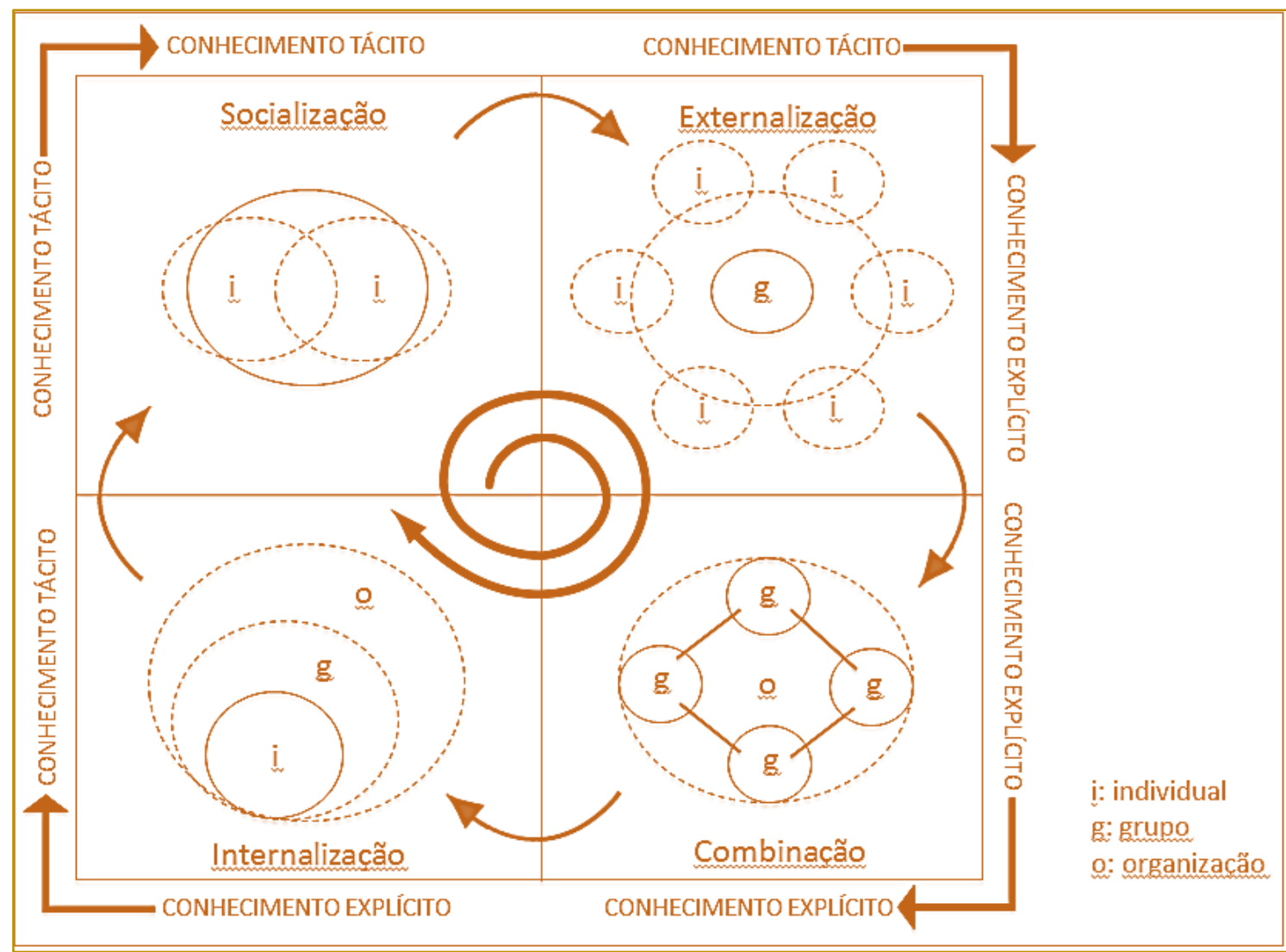

Fonte: adaptado de Nonaka; Konno, 1998, p.43

Para Nonaka e Takeuchi (1997) a geração de inovações representa um conjunto de conhecimentos e aptidões, capazes de desenvolver novos produtos, processos e serviços e melhorar os já existentes de forma mais eficiente e eficaz. No sentido da teoria do conhecimento ou da epistemologia, as experiências sensoriais e empíricas são as maiores geradoras de conhecimento por indução. Assim, pode-se afirmar que a eficácia utilizando jogos de decisão tácita resulta em desenvolvimento e melhoria das capacidades humanas, e está cada vez mais introduzida em ambientes de ensino e aprendizagem. O desenvolvimento de equipes utilizando as decisões tácitas eleva os indicadores de segurança e melhora o desempenho industrial. (CRICHTON, 2009).

\subsection{CAPACITAÇÃO PROFISSIONAL PARA O SÉCULO XXI}

Freire (2001) enfatiza que o educador deve ter habilidades de testemunhar aos educandos, dando-Ihes provas concretas e irrefutáveis de suas opiniões. Da mesma forma, o processo de aprendizagem do aluno adulto deve conter os modelos e métodos de ensino onde as habilidades individuais são investigadas e aproveitadas (YOSHIMOTO, INENAGA, YAMADA,2007). Os métodos de educação voltados para o adulto têm sido amplamente discutidos nos ambientes de ensino corporativo, pois tem promovido a conscientização, favorecendo aos educadores e educandos, explorar o melhor de seus esforços acadêmicos. (COOKE, 2010).

De acordo com Cotten (2001), muitas empresas apontam a capcitação como um investimento necessário, e não como algo que contribua somente na geração de receita. Nessas organizações, os profissionais são treinados porque precisam de habilidades específicas, seja por necessidade de mudança de comportamento ou por capacitação obrigatória exigida pela legislação, o que ocorre em áreas especificas como segurança e meio ambiente (MAGALHÃES, 2006). Dentro desta perspectiva, os quatro pilares da educação 
definidos pela (UNESCO, 1998, p.101) propõem, conforme a seguir, 0 desenvolvimento profissional, observando o contexto, sua história e tradições, onde as diversas formas de aprendizagem, como a capacidade de comunicar, de trabalhar com os outros, de gerir e de resolver conflitos, são fundamentais, como apresenta a figura 03 e definições a seguir.

Figura 03: Os Quatro Pilares da Unesco Necessários à Educação do Século XXI.

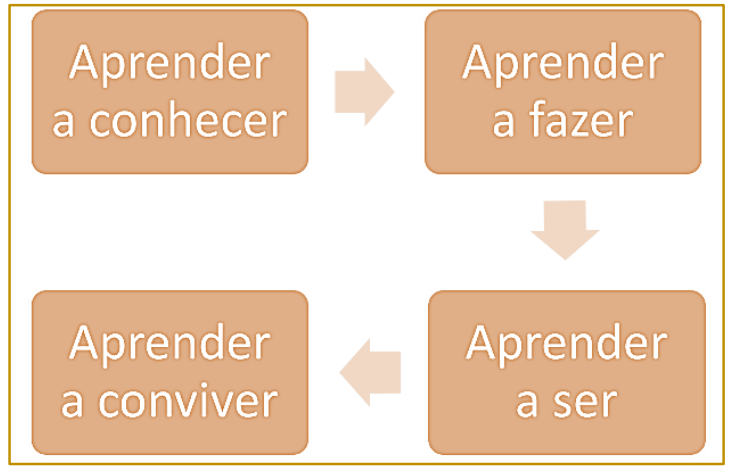

Fonte: Elaborado pela autora

- Aprender a conhecer, combinando uma cultura geral, suficientemente vasta, com a possibilidade de trabalhar em profundidade um pequeno número de matérias. O que também significa: aprender a aprender, para beneficiar-se das oportunidades oferecidas pela educação ao longo de toda a vida;

- Aprender a fazer, a fim de adquirir, não somente uma qualificação profissional, mas, de uma maneira mais ampla, competências que tornem a pessoa apta a enfrentar numerosas situações e a trabalhar em equipe. Mas também aprender a fazer, no âmbito das diversas experiências sociais ou de trabalho que se oferecem aos jovens e adolescentes, quer espontaneamente, fruto do contexto local ou nacional, quer formalmente, graças ao desenvolvimento do ensino alternado com o trabalho;

- Aprender a viver juntos desenvolvendo a compreensão do outro e a percepção das interdependências — realizar projetos comuns e preparar-se para gerir conflitos - no respeito pelos valores do pluralismo, da compreensão mútua e da paz;

- Aprender a ser, para melhor desenvolver a sua personalidade e estar à altura de agir com cada vez maior capacidade de autonomia, de discernimento e de responsabilidade pessoal. Para isso, não negligenciar na educação nenhuma das potencialidades de cada indivíduo: memória, raciocínio, sentido estético, capacidades físicas, aptidão para comunicar-se e etc.

Ainda no contexto de repensar os rumos da capacitação profissional, Barbieri et al (2010, p.148) enfatizam o conceito de inovação sustentável como um fator também importante para alcançar o desenvolvimento eficiente. Os autores definem "organizações inovadoras sustentáveis" como aquelas que inovam considerando as três dimensões da sustentabilidade: dimensão social, com a preocupação nos impactos sociais das inovações nas comunidades humanas dentro e fora da organização, tais como desemprego, exclusão social, pobreza, diversidade organizacional, etc.; dimensão ambiental, com a preocupação nos impactos ambientais pelo uso de recursos naturais e pelas emissões de poluentes; e, dimensão econômica, com a preocupação na eficiência econômica, sem a qual as empresas não se perpetuariam. A figura 04 demonstra esta interação simultânea entre as três dimensões. 
Figura 04: Interação das Dimensões Social, Ambiental e Econômica.

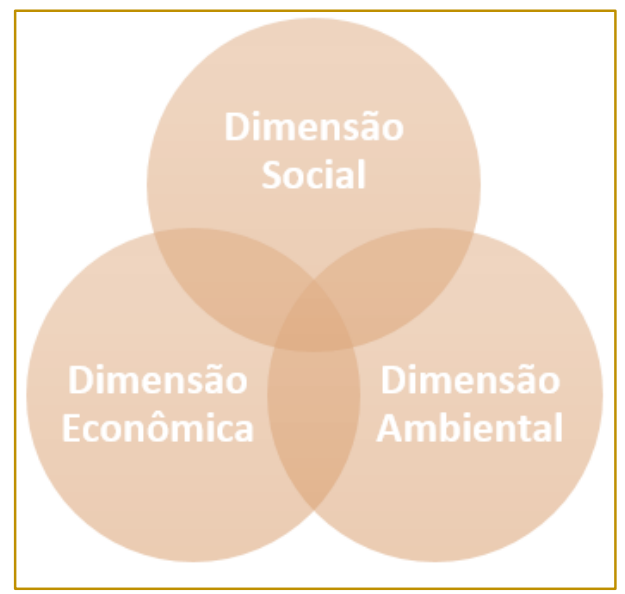

Fonte: Elaborado pela autora

O modo de conceber, abordar e, principalmente, de utilizar a inovação sustentável, seja nas empresas, nas instituições de governo, ou no meio acadêmico marcaram as ultimas décadas do século passado. Inovar de forma sustentável, harmonizando os aspectos sociais, ambientais e econômicos, se tornou fundamental para a formação profissional (GIAMBIAGI, BARROS 2009). As sociedades passaram a demandar em escalas maiores, pessoas capazes de questionar e explorar contextos complexos. Kilimnik, Sant'anna e Luz (2004), classificam o desenvolvimento de competências focadas em inovação sustentável uma decorrência de fatores como os processos de reestruturação produtiva em curso.

Vieira (2012) destaca as instituições de capacitação que consideram a autoresponsabilidade dos alunos e conscientização de seus papeis na promoção da sustentabilidade, preservação do meio ambiente e na boa utilização dos recursos tecnológicos. Como afirma CAPES (2005), o projeto pedagógico de qualquer instituição focada na capacitação profissional, deve ser construído de forma compartilhada, possibilitando o processo de inovação para o ambiente de trabalho. Neste contexto, a capacitação profissional para século XXI demanda uma organização capaz de explorar conhecimentos existentes e criar novos conhecimentos, não apenas pelo conjunto de tecnologias que detém, mas também pela gestão e sua capacidade de aprimorar todo esse conhecimento circulante. (NONAKA, TOYAMA, NAGATA, 2000).

\section{EXEMPLOS DE "CO-OPETIÇÃO" NA INDÚSTRIA DE O\&G NO BRASIL}

Foram selecionados alguns exemplos de instituições existentes, para conhecimento de suas funções e discussão de como a abordagem da "co-opetição se aplicada na capacitação profissional. Os exemplos deste estudo são, o IBP, o Parque tecnológico da UFRJ, o Senai e o PRH da ANP.

\subsection{O IBP}

Desde a sua fundação em 1957, o IBP construiu reconhecida credibilidade junto à sociedade e ao governo, não apenas por seu singular conhecimento técnico, mas também por fomentar as discussões de grandes temas afins para a constante estruturação do setor. É uma organização sem fins lucrativos, tem a missão de promover o desenvolvimento do setor nacional de petróleo e gás, visando uma indústria competitiva, sustentável ética e socialmente responsável. Seus objetivos contemplam a melhoria do ambiente regulatório, a disseminação de informações, a promoção do desenvolvimento e a preocupação com o tema Saúde, Meio Ambiente e Segurança (SMS). Seu estatuto pressagia a capacitação, aferição e suporte às empresas produtoras e distribuidoras de petróleo e gás que atuam no território nacional e dedica seus esforços para a elaboração de estudos e propostas concretas em prol do desenvolvimento ambiental, desenvolvimento sustentável e crescimento técnico e tecnológico, buscando associar maior eficiência e equilíbrio entre os interesses social, econômico e ambiental. 
Ribeiro (2014) apresenta o resultado de uma pesquisa com ex-alunos e professores de 17 turmas de pós-graduação realizadas pelo IBP no período de 2009 a 2012, onde se mostra fundamental aos programas de capacitação profissional, a interação através do trabalho compartilhado, envolvendo diversos aspectos, como inovação, participação das empresas, métodos didáticos, ferramentas de simulação, entre outros. Neste sentido, vale destacar o entendimento Sveiby (1998), para o que poderá ser explorado em programas de capacitação de forma a compatibilizar os objetivos, o conteúdo programático e as dinâmicas, através de cooperação entre todas as partes envolvidas.

\subsection{PROGRAMA DE RECURSOS HUMANOS DA ANP}

O Programa de Recursos Humanos da Agência Nacional do Petróleo, Gás Natural e Biocombustíveis (PRH-ANP) é uma iniciativa da ANP, que tem como finalidade promover a regulação, a contratação e a fiscalização das atividades econômicas integrantes da indústria do petróleo, gás natural e biocombustíveis. O Programa foi criado em 1999, e inicialmente, financiado integralmente com recursos orçamentários próprios da ANP. A partir de 2000, passou a receber apoio financeiro do Fundo Setorial de Petróleo e Gás Natural CTPETRO, através de recursos oriundos da parcela dos royalties destinada ao Ministério da Ciência, Tecnologia e Inovação - MCTI. Hoje em dia, os recursos para sua manutenção são obtidos por meio dos recursos da cláusula de Pesquisa e Desenvolvimento - P\&D, prevista nos contratos de concessão, para exploração e produção de P\&G.

Dentre as atribuições previstas pela Lei do Petróleo no 9.478/97, no art. 8으, inciso X, é de responsabilidade da ANP estimular a pesquisa e adoção de novas tecnologias na exploração, produção, transporte, refino e processamento de petróleo, gás natural, seus derivados e biocombustíveis. Esta atividade é considerada de grande relevância e destaque no que diz respeito a qualificação da mão de obra para atendimento à crescente demanda de conteúdo local, gerada pela expansão das atividades petrolíferas no Brasil, que teve seu início a partir do final da década de 1990. Neste contexto, diante da importância de promover a capacitação dos profissionais para atender aos novos desafios tecnológicos e regulatórios da indústria de $P \& G$, a Agência tomou a iniciativa de estimular e induzir a formação e especialização de graduandos, mestrandos e doutorandos interessados em atuar no setor, onde é oferecido recursos financeiros, na forma de bolsas de estudos e taxa de bancada, a programas de formação de recursos humanos realizados por universidades e instituições de ensino e pesquisa do país.

\subsection{PARQUE TECNOLÓGICO DA UFRJ}

O parque tecnológico da UFRJ foi inaugurado em 2003 é um complexo de grandes, médias e pequenas empresas que desenvolvem pesquisa e inovação, em especial na área de energia. Seus laboratórios são compartilhados com a academia e centros de pesquisa de empresas. São laboratórios que desenvolvem projetos conjuntos voltados para a aplicação imediata ao setor produtivo. O parque é um exemplo de cooperação e competição através de redes colaborativas. Vale enfatizar, que diante dos inúmeros desafios que a educação de qualidade demanda, é imprescindível superar a visão ingênua da realidade e oportunizar um diálogo entre a academia, a empresa, o governo e a sociedade, que inclua a cooperação, união, organização e solução dos problemas reais.

O complexo tem como definição promover a cultura da inovação e aumento da competitividade das empresas, além de estimular as interações entre as universidades, empresas e instituições tecnológicas. Para Rodriguez, Dahlman e Salmi (2008), o conhecimento ocupa um lugar especial nos complexos produtivos e no crescimento das economias, onde $\mathrm{o}$ desenvolvimento tecnológico, associado a programas de educação continuada podem fortalecer as bases científica e de inovação. Argumentam os autores que inúmeras oportunidades são adiadas ou desperdiçadas por ineficiências e negligências ocorridas nos sistemas de ensino.

\subsection{SENAI}

O Serviço Nacional de Aprendizagem (SENAI), foi criado em 1942, com o propósito de apoiar a capacitação profissional no Brasil, foi inspirado em outras iniciativas já existentes, públicas e privadas, voltadas para 0 desenvolvimento industrial. O SENAI faz parte de uma composição de instituições que 
trabalham em prol do avanço industrial em áreas específicas. Desde a sua fundação em 1942, a instituição já disponibilizou ao mercado de trabalho mais de 55 milhões de profissionais com alguma capacitação. Seus diversos programas, que compõem 28 segmentos industriais, incluem 0 ensino técnico, graduação e especialização, além de cursos para reciclagem profissional. No ano de 2014 o SENAI registra 2,5 milhões de matrículas distribuídas em mais de 3 mil cursos de capacitação. As iniciativas do SENAI são trabalhadas em conjunto com as indústrias e têm como missão promover a educação profissional e tecnológica, a inovação e a transferência de tecnologias industriais para elevar a competividade da indústria.

\section{METODOLOGIA DA PESQUISA}

Este estudo tem abordagem teórica, visto que fez uso de coleta de evidências de registros e documentos, e também empírica, pelos fatores observacionais. A abordagem teórica trouxe como principal relevância, a hipótese da "coopetição", que busca assegurar o sucesso de qualquer negócio, em especial na capacitação profissional. Aliada a esta teoria, também foi explorado o conceito da espiral da conversão do conhecimento tácito e explícito e outros fatores como qualidade e métodos de ensino. A experiência exploratória desta pesquisa utilizou informações existentes nos sites oficiais de cada instituição pesquisada, além de publicações sobre elas.

\section{CONCLUSÃO}

A conclusão propõe compreender o propósito fundamental deste estudo, que é o de levantar a discussão para a expansão da cooperação e competição para a capacitação de profissionais na indústria de O\&G no Brasil. Quanto ao objetivo desta pesquisa, onde buscou-se debater a importância da coopetição na capacitação profissional, através de levantamento teórico, e também apresentar exemplos de instituições e programas existentes na indústria de petróleo e gás no Brasil, considera-se atendido, uma vez que o estudo explora uma reflexão do tema proposto e apresenta dados e informações relevantes ao entendimento do objeto de estudo. Como retratado na literatura fundamentada desta investigação, existem métodos e teorias voltadas para a aquisição do conhecimento que poderão auxiliar na capacitação de profissionais. A revisão bibliográfica buscou também fundamentar a importância de valores globais, necessários ao desenvolvimento adequado para o século XXI.

A competitividade somada a cooperação, podem desenvolver indivíduos, sociedades e economias, historicamente, esses dois componentes juntos foram capazes de transformar estilos e filosofias de vida, e também contribuíram fortemente para a evolução tecnológica ao longo dos tempos. A necessidade de desenvolver pessoas para atender demandas no mercado de trabalho pode ser o maior gargalo dos países com grandes potencias de desenvolvimento, pois apresentam recursos naturais em abundancia e recursos humanos disponíveis, porém, não capacitados para suprir tais desafios, na velocidade e eficiência necessárias. Neste sentido, se faz fundamental refletir sobre as diferentes possibilidades de "co-operar", buscando eficiência nas parcerias e políticas públicas, foco na aplicação, trabalho conjunto com as empresas do setor a ser capacitado, entre outros aspectos.

Recomenda-se para estudos futuros o desenvolvimento de uma metodologia que estimule as instituições, e também, todos os interessados na capacitação de profissionais e se desenvolverem a partir de um pensamento de "co-operação, onde empresas, universidades e instituições especializadas, nacionais e internacionais, desenvolvam conjuntamente programas focados no desenvolvimento técnico e gerencial dos profissionais. 


\section{REFERÊNCIAS}

[1]. ANDREWS, J.; HARRIS, M. Postgraduate study and managers' subsequent work experience: an exploratory evaluation. Assessment \& Evaluation in Higher Education. Vol. 34, No. 4, August, 2009.

[2]. ARVANITIS, S.; WOERTER, M. Firms' transfer strategies with universities and the relationship with firms' innovation performance. Industrial and Corporate Change, Oxford University - v.18, N.6, p. 1067-1106, june 2009.

[3]. BARBIERI, C.; VASCONCELOS, I.; ANDREASSI, V.; FLÁVIO, C. Inovação e Sustentabilidade: Novos Modelos e Proposições. RAE • São Paulo, v. 50 n. 2 abr./jun. 2010, p 146154.

[4]. BOMFIN, D. Pedagogia no Treinamento Correntes Pedagógicas no Treinamento Empresarial. Rio de Janeiro: Qualitymark, 1995, $164 f$.

[5]. BP: 2013. BP Statistical Review of World Energy. www.bp.com. Acesso em 11/04/2014.

[6]. BOOTH, W.; COLOMB, G.; WILLIANS, J. A Arte da Pesquisa. Tradução de Vera Maria Marques. 2.ed. São Paulo: 2008.

[7]. CHOPRA, D. A Alma da Liderança. Tradução de Rosana Watson. Rio de Janeiro: Rocco, 2011.

[8]. COHENDET, P.; STEINMUELLER, W. The Condification of Knowledge: a Conceptual and Empirical Exploration. Industrial and Corpoate Change, Oxford University, v.9, n.2, p. 195-209, 2000.

[9]. COOKE, A. Becoming an Andragogical Librarian: Using Library Instruction as a Tool to Combat Library Anxiety and Empower Adult Learners. Taylor \& Francis Group, New Jersey, p.208-227, 2010

[10]. CORDEIRO, A. Modelo de avaliação dos cursos de uma instituição de ensino superior privada para utilização dentro do processo de planejamento operacional da corporação - o caso Unisuam. UFF, 2008. 260f.

[11]. COTTEN, W. B. Transforming traditional training methods to meet the needs of a modern industry. Journal of Petroleum Technology, v.53, n.2, Feb, p.54-58. 2001.

[12]. CRICHTON, T. Improving team effectiveness using tactical decision games.Safety Science, v.47, n.3, p.330-336. 2009.

[13]. DINSMORE, C.; NETO S. Gerenciamento de projetos e o fator humano. $2^{2}$ edição 2012, editora Qualitymark.

[14]. GIAMBIAGI, F.; BARROS, O. (Organizadores). Brasil pós-crise. Agenda para a próxima década. Rio de Janeiro: Elsevier, 2009.
[15]. Gil, A. Como elaborar projetos de pesquisa. 4 ed. São Paulo: Atlas, 2009.

[16]. GUIMARÃES, J. O emprego do modelo pedagógico balanceado no programa de gestão do conhecimento: Um estudo de caso. UFF, 2008,135f.

[17]. IEA, World Energy Outlook 2013. International Energy Agency. Paris, França, 2013.

[18]. KILIMNIK, Z.; SANT'ANNA, A.; LUZ, T. Competências Profissionais e Modernidade Organizacional: Coerência ou Contradição? RAE Publicações, Minas Gerais, v.44, Edição Especial, abril-dezembro 2004.

[19]. Knowles, M. S. The modern practice of adult education: From pedagogy to andragogy. Englewood Cliffs: Prentice Hall/Cambridge.1980.

[20]. MAGALHÃES, A. A Educação Ambiental para os Trabalhadores como Instrumento de Gestão para o Licenciamento Ambiental em Atividades de Exploração e Produção de Petróleo Offfshore. UFF, 2006. $95 f$.

[21]. MARCONI, M.; LAKATOS, E. Metodologia do trabalho científico - Procedimentos Básicos, Pesquisa Bibliográfica, projeto e relatório, Publicações e Trabalhos Científicos. 7.ed. São Paulo: Atlas, 2010.

[22]. MME: Ministério de Minas e Energia. BEN 2013, Balanço Energético Nacional 2013. www.mme.gov.br. Acesso em 11/04/2014.

[23]. NONAKA, I.; KONNO, N. The Concept of "Ba": Building a Foundation for Knowledge Creation. California Management Review, vol.40, n 3, p.40-54. 1998.

[24]. NONAKA, I.; REINMOELLER, P.; SENOO, D. European Management Journal. Vol 16 No 6 December 1998.

[25]. NONAKA, I.; TAKEUCHI, H. Criação de conhecimento na empresa: Como as empresas japonesas geram a dinâmica da inovação. Rio de Janeiro: Elsevier -Campus, 1997. 14 ed.

[26]. NONAKA, I.; TOYAMA, R.;, NAGATA, A. A Firm as a knowledge-creating entity: $A$ new perspective on the theory of the firm. Industrial and Corporate Change, v.9, n.1, p.1-20. 2000.

[27]. O'DONNELL, D. Dealing with staff recruitment, retention, and training in the oil and gas business. First Break, v.24, n.7, p.77-81.2006.

[28]. PARASURAMAN, A; ZEITHAML, V.A; BERRY, L. A conceptual model of service quality of and its implication for future reserch. Jornal of Marketing. 1985.

[29]. PAULA, A. Critérios de Excelência do prêmio nacional de qualidade como instrumento de gestão para empresas das incubadoras tecnológicas do Estado do Rio de Janeiro. UFF, 2004, $115 f$. 
[30]. Plano Nacional de Pós-Graduação - PNPG 2005-2010 / Ministério da Educação. Brasília: CAPES, 2005.

[31]. PLANO DE NEGÓCIOS E GESTÃO 2013$2017 . \quad$ http://www.petrobras.com.br/pt/quemsomos/estrategia-corporativa/plano-de-negocios.

[32]. PONTES, A. A motivação dos professores como fator de melhoria dos serviços educacionais: Estudo de caso do segmento educacional superior privado de Juiz de Fora, Minas Gerais. UFF, 2009, $118 f$.

[33]. Programa de Mobilização da Indústria Nacional de Petróleo e Gás Natural (Prominp). 8oㅡ Encontro Nacional do Prominp (2011).

[34]. RIBEIRO, R.P.G. Análise da Efetividade dos Cursos de Pós-graduação do IBP e seu Impacto na Indústria de Petróleo no Brasil. UFF, 2014, $136 f$.

[35]. RODRIGUEZ, A.; DAHLMAN. C.; SALMI, J. Conhecimento e Inovação para a Competitividade.
Banco Mundial. Tradução de Confederação Nacional da Indústria. Brasília: CNI, 2008.

[36]. RODRIGUEZ, M.V.R. (ORGANIZADOR). Gestão do Conhecimento e Inovação nas Empresas. Rio de Janeiro: Qualitymark, 2011.

[37]. UNESCO. Educação - Um Tesouro a Descobrir: Relatório para a UNESCO da Comissão Internacional sobre Educação para o Século XXI, CORTEZ, 1998.

[38]. VIEIRA, A. Análise Crítica da Educação a Distância: Estudo de Caso no Mercado Segurador. 2012. $153 f$.

[39]. YERGIN, D. O Petróleo: Uma História de Ganância, Dinheiro e Poder. São Paulo: Scritta, 1994.

[40]. YOSHIMOTO, K.; INENAGA, Y.; YAMADA, $H$. Pedagogy and Andragogy in Higher Education A Comparison between Germany, the UK and Japan. European Journal of Education, USA, vol. 42, No. 1, P. 75-98, may 2007. 


\section{Gapítulo 14}

ANÁLISE DA CONTRIBUIÇÃO DA CAPACITAÇÃO DO
FISCAL DE CONTRATO NA ADMINISTRAÇÃO PÚBLICA

Juliana Cristina da Silva de França Barboza

Marcelo Gonçalves do Amaral

Sheila Serafim da Silva

Resumo: A Lei no 8.666/93 institui normas para licitações e contratos da Administração Pública. Todavia, a fiscalização de contratos e licitações, em alguns casos, enfrentam problemas devido à má execução em virtude do desconhecimento ou ausência de procedimentos adequados nas organizações públicas. Assim, esse estudo teve como objetivo analisar a importância da capacitação dos fiscais de contratos de terceirização para o exercício da função, a partir da seguinte questãoproblema: ações de capacitação podem contribuir para a melhoria do processo de fiscalização de contratos? O estudo teve como objeto de estudo uma Instituição Pública de Ensino Superior no Estado do Rio de Janeiro, com sede na cidade de Niterói. Levantou-se a opinião dos fiscais de contrato da Instituição e realizou-se uma pesquisa documental junto ao setor de contratos e legislações pertinentes. Os resultados destacaram a importância do papel do fiscal de contratos administrativos de terceirização de mão de obra e como ações de capacitação podem contribuir para a melhoria do processo de fiscalização e, ainda, apontou fragilidades no que se refere à execução e necessidade de treinamento dos fiscais de contrato. A pesquisa indicou limitações e proposições para avanços em novos estudos.

Palavras-chave: Gestão de contratos, Fiscalização, Capacitação de Servidos Públicos. 


\section{INTRODUÇÃO}

A terceirização de serviços de atividades consideradas acessórias é uma prática comum na Administração Pública, inclusive nas universidades públicas. Com a promulgação do Decreto Lei oㅡ 200 de 1967, foi prevista a possibilidade de a Administração desobrigar-se da realização material de atividades executivas, recorrendo, sempre que possível, à execução indireta, mediante contrato.

Com o advento, na década de 90, do Plano Diretor de Reforma do Aparelho do Estado e, posteriormente, do Decreto № 2.271/97, que impediu a realização de concursos para cargos extintos, ganhou força a contratação desses serviços por meio de empresas terceirizadas. Assim coube à Administração o dever de fiscalizar e acompanhar a prestação de serviços. Em se tratando da fiscalização de contratos com alocação de mão de obra deve ser feito não só o monitoramento da execução contratual, mas também a verificação do cumprimento pela empresa contratada dos direitos trabalhistas, o que torna mais complexa a atividade.

Segundo Marinho (2012), a função de fiscalização de contratos é uma atividade que requer conhecimento e constante atualização dos agentes públicos, tendo em vista que a não conformidade na verificação dos documentos ou o descumprimento das diversas práticas aplicáveis no acompanhamento da execução do instrumento contratual podem levar à responsabilização da Administração Pública, implicando em prejuízos ao erário, além da responsabilização civil do servidor.

A partir disso, é importante que o fiscal de contratos ao assumir essa função tenha conhecimento de suas responsabilidades e de como deve efetivamente desempenhá-la. É importante também que o fiscal detenha conhecimento técnico do objeto que irá fiscalizar, uma vez que o desconhecimento do servidor acerca das exigências legais pertinentes ao contrato sob sua supervisão pode trazer eventuais responsabilizações.

A relevância do tema justifica-se pelo fato da sociedade atual privilegiar o conhecimento e o aperfeiçoamento constante. Por conta disso, muitas empresas têm investido em treinamento e capacitação em busca de uma gestão contemporânea. Na Administração Pública, os servidores devem ser capacitados para atender as demandas crescentes da população por serviços públicos mais eficientes e pelo bom uso dos recursos públicos.

Diante disso, surge a seguinte questãoproblema: ações de capacitação podem contribuir para a melhoria do processo de fiscalização de contratos? Para responder essa questão, o estudo terá como objetivo analisar a importância do papel de fiscal de contratos de serviços contínuos com terceirização de mão de obra e verificar como ações de capacitação podem contribuir para uma fiscalização de contratos mais eficiente.

Os sujeitos da pesquisa são fiscais de contrato de terceirização de mão de obra de uma Instituição Pública localizada no Estado do Rio de Janeiro, sendo este o objeto de investigação. No que diz respeito ao aspecto temporal, a pesquisa englobou somente os contratos em andamento que envolve terceirização de mão de obra celebrados entre a instituição estudada e as empresas prestadoras de serviço. No presente, encontram-se vigentes 14 contratos, sendo eles para prestação de serviços agropecuários, copeiragem, limpeza, apoio administrativo e técnico, vigia, vigilância armada, condução de veículos, processamento de alimentos e distribuição nos restaurantes universitários, manutenção predial, manutenção de áreas verdes, entrega motorizada e auxílio operacional em arquivos e bibliotecas.

\section{REVISÃO DE LITERATURA}

\subsection{FISCALIZAÇÃO DE CONTRATOS}

Para que um contrato administrativo seja executado de modo satisfatório e tenha seu objeto plenamente atendido, é necessário que ele seja monitorado pela Administração. A Lei Federal no 8.666/93, Lei Geral de Licitações e Contratos, previu esta necessidade e por este motivo em seu artigo 67 impôs a Administração Pública que seja designado um representante para acompanhar e fiscalizar o desenvolvimento dos contratos celebrados com particulares (CASTRO, 2010), como se pode observar no trecho a seguir:

Art. 67. A execução do contrato deverá ser acompanhada e fiscalizada por um representante da Administração especialmente designado, permitida a contratação de terceiros para assisti-lo e subsidiá-lo de informações pertinentes a essa atribuição. 
$\S 1^{\circ}$ O representante da Administração anotará em registro próprio todas as ocorrências relacionadas com a execução do contrato, determinando o que for necessário à regularização das faltas ou defeitos observados.

§ำ As decisões e providências que ultrapassarem a competência do representante deverão ser solicitadas a seus superiores em tempo hábil para a adoção das medidas convenientes (BRASIL, 1993).

Assim, é função do fiscal acompanhar e fiscalizar a execução do contrato, anotando em registro próprio todas as ocorrências observadas, tais como falhas, atrasos, inadimplemento, descumprimento de cláusulas contratuais, bem como orientações repassadas à contratada para que esta se adeque aos termos do contrato. Havendo reincidência de faltas ou inadimplementos que possam vir a ser penalizados ou, até mesmo, gerar a rescisão do contrato, deve o fiscal informar a autoridade competente, para que este tome as medidas que o caso requer.

É grande a responsabilidade do fiscal e vai além de uma prerrogativa da Administração Pública. Fiscalizar um contrato é ao mesmo tempo um poder e um dever e não cabe, neste caso, juízo de oportunidade ou conveniência. De acordo com Almeida (2009), a administração possui o poder-dever de fiscalizar a execução dos contratos nos moldes do Artigo 58 da Lei no 8.666/93. Dessa forma, visando atender ao interesse público, a Administração deve fiscalizar a execução do contrato durante todo seu curso, sendo tal atribuição um dever, e não uma faculdade.

Justen Filho (2009), em seu livro Comentários à Lei de Licitações e Contratos Administrativos, afirma que "o regime de Direito Administrativo atribui à Administração o poder-dever de fiscalizar a execução do contrato [...] O dispositivo deve ser interpretado no sentido de que a fiscalização pela Administração não é mera faculdade assegurada a ela. Trata-se de um dever, a ser exercitado para melhor realizar os interesses fundamentais. Parte-se do pressuposto, inclusive, de que a fiscalização induz o contratado a executar de modo mais perfeito os deveres a ele impostos".

Na mesma linha, Furtado (2013) defende que em decorrência da supremacia do interesse público, não pode a Administração ficar inerte, aguardando que o contratado cumpra todas as obrigações contratuais, muito menos esperar o fim do termo de contrato para verificar se seu objetivo foi efetivamente alcançado. É dever da Administração durante a própria execução do contrato verificar se o contratado está cumprindo as etapas e fases do contrato. Segundo o autor, essa forma de agir preventivamente traz benefícios para a Administração.

Verifica-se aí a importância do papel do fiscal, que deve acompanhar a execução e tomar as providências necessárias para o cumprimento das condições contratuais estabelecidas. O Tribunal de Contas da União, em um de seus acórdãos, manifestou-se acerca do assunto:

Somente por meio do acompanhamento e da fiscalização da execução do contrato, tem a Administração oportunidade de verificar tempestivamente o cumprimento, por parte do contratado, das obrigações acordadas e impor a adoção de medidas corretivas no tempo oportuno, caso sejam identificadas falhas na implementação do ajuste. Trata-se de dever da Administração, ao qual não pode se furtar de exercer. (Acórdão no 540/2008, Plenário).

Segundo Almeida (2009) a fiscalização contratual constitui-se em um dos mais relevantes temas da gestão pública contemporânea no Brasil e a considera o "Calcanhar de Aquiles" da execução dos contratos administrativos. Para o autor não são raros os casos em que boas licitações e bons contratos são perdidos em seus fins por causa de deficiências na fiscalização ou mesmo pela ausência desta.

Assim, entende-se que a responsabilidade do fiscal de contrato é tão importante quanto à de uma comissão de licitação, o que implica na necessidade de capacitação dos servidores para que tenham condições de cumprir a função que lhes é submetida.

Em se tratando de contratos de prestação de serviços com dedicação exclusiva de mão de obra a preocupação deve ser ainda maior, pois além de verificar a correta execução do contrato e agir em tempo oportuno, o fiscal deve certificar-se de que os direitos trabalhistas dos empregados terceirizados estão sendo cumpridos pela contratada, tendo em vista que há um entendimento pacificado pelo Tribunal Superior do Trabalho (TST) de que o tomador de serviços pode ser responsabilizado subsidiariamente quando o fiscal é omisso e não cumpre o seu papel.

Em virtude de uma Ação Declaratória de Constitucionalidade (ADC 16-DF) ajuizada no Supremo Tribunal Federal, a Súmula 331 
ganhou uma nova redação, sendo alterado o item IV e inseridos os itens $\mathrm{V}$ e VI. No julgamento, o plenário do STF julgou constitucional o artigo 71 da Lei ำ 8.666/93 que prevê que a inadimplência de empresas contratadas pelo Poder Público em relação aos encargos trabalhistas, fiscais e comerciais não transfere para a Administração Pública a responsabilidade por seu pagamento. Entretanto, enfatizou que o Estado tem responsabilidade quando comprovada a omissão da Administração em relação à fiscalização contratual.

Santos (2014) destaca que o entendimento do STF é de que nem sempre se dará a transferência da responsabilidade do pagamento dos encargos trabalhistas à Administração Pública por inadimplência da empresa contratada. Contudo, "eventual omissão da Administração Pública na obrigação de fiscalizar o contrato pode gerar responsabilidade". Apenas foi afastada a aplicação direta da responsabilidade subsidiária, como vinha sendo feito pela Justiça do Trabalho. A correta fiscalização continua sendo a principal defesa dos órgãos e entidades públicas contra débitos trabalhistas vinculados aos seus contratos administrativos (ALMEIDA, 2011).

\subsection{ATRIBUIÇÕES E RESPONSABILIDADES DOS FISCAIS DE CONTRATOS}

A Lei no 8.666/93 não definiu claramente quais são as atribuições do fiscal de contrato. Entretanto, o Ministério do Planejamento, Orçamento e Gestão editou a Instrução Normativa n-02/2008, que dispõe sobre regras e diretrizes para a contratação de serviços, continuados ou não.

Em seus artigos 31 a 35, a instrução traz importantes diretrizes para o servidor que for nomeado para fiscalizar a execução do contrato. Tais diretrizes devem ser lidas em conjunto com o Anexo IV - Guia de Fiscalização dos Contratos de Prestação de Serviços com Dedicação Exclusiva de Mão de Obra, que traz orientações para proceder no momento em que a prestação de serviços é iniciada, medidas que devem ser tomadas antes do pagamento da fatura, ações para fiscalização diária (SANTOS, 2014).

Esse instrumento ao estabelecer as diretrizes que devem ser seguidas para 0 acompanhamento dos contratos firmados entre órgãos ou entidades que integram a
Administração Pública e empresas terceirizadas, contribui para melhor atuação dos fiscais dos contratos, conforme Marinho (2012).

\subsection{CAPACITAÇÃO DE SERVIDORES PARA A MELHORIA DO PROCESSO DE FISCALIZAÇÃO}

A Lei Federal no 8.666/93, não expressa claramente qual deve ser o perfil dos fiscais de contratos e suas atribuições. Contudo, a fiscalização de contratos constitui-se em uma atividade importante na execução dos contratos e, por isso, o ordenador de despesas deve incorporar à gestão uma cultura de fiscalização adequada, na qual o servidor designado e capacitado conjugue seu conhecimento profissional a necessária postura quando do exercício da fiscalização de contratos administrativos (ALMEIDA, 2011).

Assim, entende-se que é papel da Administração capacitar e preparar os fiscais de contratos, dando a esses profissionais o conhecimento e as habilidades necessárias ao desenvolvimento das atividades inerentes a função, para que se tenha um processo de fiscalização mais eficiente.

Segundo o exposto no Decreto 5.707/2006, que institui a Política e as Diretrizes para o Desenvolvimento de Pessoal da administração pública federal direta, autárquica e fundacional, e regulamenta dispositivos da Lei no 8.112/1990, entende-se por capacitação o "processo permanente e deliberado de aprendizagem, com o propósito de contribuir para o desenvolvimento de competências institucionais por meio do desenvolvimento de competências individuais".

Ainda de acordo com o Decreto no 5.707/2006, em seu $3^{\circ}$ artigo, incisos I e II, deve ser incentivado e apoiado "o servidor público em suas iniciativas de capacitação voltadas para o desenvolvimento das competências institucionais e individuais" e assegurado "o acesso dos servidores a eventos de capacitação interna ou externamente ao seu local de trabalho".

\section{PROCEDIMENTOS METODOLÓGICOS}

Este estudo trata-se de uma pesquisa descritiva, pois pretende analisar a importância de capacitação de fiscais de contrato administrativo de terceirização, por meio do levantamento de opinião. 
Para a execução da pesquisa, adotou-se o procedimento técnico pesquisa documental com consulta a contratos feitos pela instituição em análise que envolve a prestação de serviços com alocação exclusiva de mão de obra, bem como as legislações específicas voltadas a área de contratos, fiscalização e capacitação de servidores. Fez-se um levantamento por meio da interrogação direta junto a servidores que exercem a função de fiscal de contrato.

A amostra deste estudo compreende 13 de 18 servidores que desempenham a função de fiscal de contratos de serviços continuados com terceirização de mão de obra que estão em andamento na instituição no ano de 2015.

Adotou-se um questionário como instrumento de coleta de dados, com o objetivo de identificar a opinião dos fiscais de contratos acerca da necessidade de adquirir conhecimentos para o exercício desta função, além de buscar identificar se os mesmos conhecem a legislação que trata da contratação de serviços na Administração Pública e se durante a prática da fiscalização eles buscam atender as exigências legais. $O$ questionário foi elaborado a partir da revisão de literatura e baseado no modelo aplicado por Marinho (2012), com questões fechadas em sua maioria, dividido em três blocos.

\section{APRESENTAÇÃO E DISCUSSÃO DOS RESULTADOS}

Com os resultados do primeiro bloco pôde-se perceber que em relação ao gênero, 61,54\% dos entrevistados pertencem ao sexo masculino, enquanto $38,46 \%$ são do sexo feminino. Sobre o nível de escolaridade pôdese identificar: 69,23\% (Especialização lato sensu ou Mestrado) e 30,77\% (nível médio). Esse resultado pode ser apontado como um fator importante para a pesquisa, tendo em vista que a qualificação profissional contribui positivamente para o desempenho do servidor. Sobre o tempo em que atuam como fiscais de contrato, $61,54 \%$ exercem esta função há mais de três anos. Entretanto, embora estejam exercendo a função por um tempo considerável, a maior parte dos entrevistados relatou conhecer pouco a legislação que trata da contratação de serviços terceirizados na Administração Pública.

Quanto à quantidade de contratos sob sua supervisão a maioria (84,62\%) fiscaliza somente um contrato. É importante destacar que não há limitação legal quanto o número de contratos que cada servidor pode assumir como fiscal. Contudo, não é recomendável que este quantitativo exceda um contrato por servidor, de modo a garantir a efetiva fiscalização contratual, o cumprimento, por parte do contratado, das obrigações acordadas e impor a adoção de medidas corretivas no tempo oportuno, caso sejam identificadas falhas, conforme orientação do TCU por meio do Acórdão no 540/2008-P.

O segundo bloco buscou verificar se o participante conhecia as atribuições inerentes à função de fiscal de contrato, conforme recomenda a legislação específica que regulamenta a contratação de serviços na Administração. As ações descritas foram extraídas do Guia de Fiscalização de Contratos, anexo da Instrução Normativa no 02/2008.

As questões deveriam ser assinaladas conforme a seguinte escala: [1] Nunca, [2] Raramente, [3] Eventualmente, [4] Frequentemente e [5] Sempre. A Tabela 1 apresenta a frequência relativa das variáveis estudadas (razão entre a frequência absoluta e o número total de observações). 
Tabela 1- Incidência de respostas de acordo com a escala de frequência - Questões 2.1 a 2.9

\begin{tabular}{|c|c|c|c|c|c|c|}
\hline & \multirow{2}{*}{ Variáveis } & \multicolumn{5}{|c|}{ Escala de Frequência (\%) } \\
\hline & & {$[1]$} & {$[2]$} & [3] & [4] & {$[5]$} \\
\hline 2.1 & $\begin{array}{c}\text { Mantém arquivo organizado contendo todas as } \\
\text { comunicações realizadas com o preposto ou diretamente com } \\
\text { a empresa contratada. }\end{array}$ & 7,69 & 7,69 & 7,69 & 38,46 & 38,46 \\
\hline 2.2 & $\begin{array}{l}\text { Mantém listagem atualizada contendo nome, função e local } \\
\text { de trabalho dos terceirizados. }\end{array}$ & 0,00 & 0,00 & 15,38 & 23,08 & 61,54 \\
\hline 2.3 & $\begin{array}{l}\text { Verifica se o número de terceirizados por função coincide } \\
\text { com o previsto no contrato administrativo. }\end{array}$ & 0,00 & 0,00 & 7,69 & 30,77 & 61,54 \\
\hline 2.4 & $\begin{array}{l}\text { Confere a documentação que acompanha a nota fiscal antes } \\
\qquad \text { de atestá-la. }\end{array}$ & 0,00 & 7,69 & 0,00 & 38,46 & 53,85 \\
\hline 2.5 & $\begin{array}{l}\text { Costuma verificar se a empresa contratada está pagando } \\
\text { regularmente os salários e benefícios aos seus funcionários. }\end{array}$ & 0,00 & 0,00 & 7,69 & 23,08 & 69,23 \\
\hline 2.6 & $\begin{array}{l}\text { Dirige-se diretamente ao terceirizado, determinando } \\
\text { alterações na prestação do serviço. }\end{array}$ & 15,38 & 7,69 & 30,77 & 7,69 & 38,46 \\
\hline 2.7 & $\begin{array}{c}\text { Dirige-se formalmente ao preposto da empresa, } \\
\text { recomendando medidas saneadoras referentes à faltas e/ou } \\
\text { ocorrências observadas. }\end{array}$ & 7,69 & 0,00 & 0,00 & 38,46 & 53,85 \\
\hline 2.8 & $\begin{array}{l}\text { Registra em documento próprio as irregularidades } \\
\text { encontradas e as providências determinadas, decorrentes do } \\
\text { descumprimento das obrigações pactuadas em contrato. }\end{array}$ & 7,69 & 15,38 & 7,69 & 30,77 & 38,46 \\
\hline 2.9 & $\begin{array}{c}\text { Acompanha e controla a vigência do contrato e posteriores } \\
\text { termos aditivos. }\end{array}$ & 0,00 & 0,00 & 7,69 & 30,77 & 61,54 \\
\hline
\end{tabular}

\section{Fonte: Resultados da pesquisa.}

Com base nas informações apresentadas, algumas considerações podem ser feitas: em geral, os servidores adotam medidas que estão em conformidade com as atribuições de um fiscal de contratos. Cerca de $80 \%$ dos fiscais informou que sempre ou frequentemente mantém listagem atualizada contendo nome, função e local de trabalho dos terceirizados; 92,31\% verificam sempre ou frequentemente se o número de terceirizados por função coincide com o previsto no contrato, bem como acompanham e controlam o prazo de vigência contratual.

Outro ponto positivo está no fato de mais de 92\% verificar sempre ou frequentemente se a empresa paga regularmente o salário e os benefícios de seus funcionários. $\bigcirc$ não cumprimento das normas trabalhistas pode gerar a responsabilidade subsidiária da Administração. É dever do fiscal verificar se os direitos trabalhistas dos empregados estão sendo respeitados. A fiscalização eficiente diminui os riscos inerentes a fiscalização, especialmente os decorrentes do descumprimento pela contratada das obrigações trabalhistas e previdenciárias. Conforme Santos (2014) ressalta, a responsabilização somente se dá mediante a ausência ou negligência da fiscalização.

Entretanto, algumas fragilidades despertam a atenção. Embora seja um percentual pequeno, $15,38 \%$ dos entrevistados revelaram nunca ou raramente manter arquivo contendo as comunicações com o preposto ou diretamente com a contratada. É comum durante a prestação do serviço, a comunicação verbal do problema ocorrido. É importante, no entanto, informar por escrito as falhas ocorridas durante a execução contratual. O registro dessas ocorrências comprovará irregularidades e legitimará a aplicação de sanções, caso os problemas encontrados não sejam solucionados pela empresa.

Também chama atenção o fato de cerca de $70 \%$ dos entrevistados terem dito que se dirigem diretamente ao terceirizado quando a Instrução Normativa no 02/2008, diz expressamente em seu Guia de Fiscalização que devem ser evitadas ordens diretas aos terceirizados e que as solicitações de serviços, reclamações e cobranças devem ser dirigidas ao preposto. Tal constatação corrobora com o relato dos fiscais que disseram conhecer pouco a legislação. Neste sentido, a capacitação pode ser uma oportunidade para 
orientar os fiscais de contratos de terceirização sobre aquilo que eles podem e devem fazer.

Destaca-se também o fato de $23,07 \%$ dos fiscais nunca ou raramente registrarem em documento próprio as irregularidades encontradas e as providências determinadas. De acordo com o §1ํ, do artigo 67 da Lei de Licitações e Contratos, o fiscal tem a obrigação de anotar em livro próprio todas as ocorrências verificadas durante a execução contratual e determinar o que for necessário para a regularização das faltas. Contudo, conforme se verifica a prática de registro de ocorrências ainda não está plenamente estabelecida.

A Tabela 2 apresenta o percentual de incidência das respostas obtidas nas questões 3.1 a 3.6 do terceiro bloco do questionário.

Tabela 2: Incidência de respostas de acordo com a escala de frequência - Questões 3.1 a 3.6

\begin{tabular}{|c|c|c|c|c|c|c|}
\hline & \multirow{2}{*}{ Variáveis } & \multicolumn{5}{|c|}{ Escala de Frequência (\%) } \\
\hline & & {$[1]$} & {$[2]$} & [3] & [4] & {$[5]$} \\
\hline 3.1 & $\begin{array}{c}\text { A instituição oferece oportunidade de aprendizagem e fornece } \\
\text { meios para o desenvolvimento de competências. }\end{array}$ & 15,38 & 53,85 & 15,38 & 7,69 & 7,69 \\
\hline 3.2 & $\begin{array}{c}\text { Participa de eventos externos (cursos, palestras, congressos) } \\
\text { voltados à fiscalização de contratos. }\end{array}$ & 61,54 & 23,08 & 15,38 & 0,00 & 0,00 \\
\hline 3.3 & $\begin{array}{l}\text { Participa de programas internos de treinamento voltados à } \\
\text { fiscalização de contratos }\end{array}$ & 76,92 & 23,08 & 0,00 & 0,00 & 0,00 \\
\hline 3.4 & $\begin{array}{l}\text { Ao desempenhar a função de fiscal minhas decisões são } \\
\text { baseadas em experiências vividas e intuição. }\end{array}$ & 15,38 & 7,69 & 23,08 & 30,77 & 23,08 \\
\hline 3.5 & $\begin{array}{l}\text { Ao desempenhar a função de fiscal minhas decisões são } \\
\text { baseadas no meu conhecimento técnico. }\end{array}$ & 15,38 & 7,69 & 15,38 & 38,46 & 23,08 \\
\hline 3.6 & $\begin{array}{l}\text { Durante a tarefa de fiscalização, quando tenho dúvidas busco } \\
\text { informações no setor de contratos da instituição. }\end{array}$ & 7,69 & 7,69 & 15,38 & 23,08 & 46,15 \\
\hline
\end{tabular}

Fonte: Resultados da pesquisa.

Analisando os dados, na variável "A instituição oferece oportunidade de aprendizagem e fornece meios para o desenvolvimento de competências" (questão 3.1) apenas 7,69\% dos profissionais que atuam na fiscalização de contratos acreditam que a instituição sempre oferece oportunidades de aprendizado. $\mathrm{Na}$ opinião dos fiscais a instituição não promove, de forma contínua, oportunidades de aprendizagem.

Os resultados obtidos nas questões 3.2 e 3.3 demonstram que é necessário o desenvolvimento de ações que propiciem a capacitação dos servidores designados como fiscais de contratos. Tal necessidade revela-se considerando que $61,54 \%$ disseram nunca ter participado de eventos externos voltados à fiscalização de contratos e 76,92\% nunca ter participado de programas internos de treinamento voltados à fiscalização de contratos, o que contraria o disposto no inciso II, do artigo $3^{\circ}$ do Decreto 5.707/2006.

Nas variáveis 3.4 e 3.5 , cujo objetivo foi descobrir como se dava a tomada de decisão do fiscal, $53,85 \%$ dos servidores disseram que tomam decisões baseados na experiência e na intuição para resolverem as dificuldades encontradas no dia a dia.

Ao mesmo tempo, 61,54\% dos entrevistados disse que suas decisões são baseadas em seu conhecimento técnico. Esses resultados vão de encontro ao que afirma Almeida (2011), para ele devem ser conjugados os conhecimentos profissionais do servidor com a adequada capacitação para o exercício da fiscalização de contratos administrativos. O conhecimento acumulado durante a prática de fiscalização tem sido utilizado como recurso na rotina dos servidores. Entretanto, conforme já constatado anteriormente, é baixa a oferta pela instituição de meios de aprendizagem voltados a fiscalização.

Sobre a assessoria realizada pelo setor de contratos da instituição, 69,23\% dos agentes respondeu que sempre ou frequentemente dirige-se ao departamento para esclarecimentos de dúvidas. Essa troca de informações deveria mais ser constante, uma vez que compete ao setor, entre outras atribuições, controlar e executar as atividades 
inerentes à gestão dos contratos administrativos; arquivar os processos administrativos e de pagamento referentes aos contratos; encaminhar as notas fiscais, após ateste do fiscal, para pagamento; bem como auxiliar o fiscal com instruções pertinentes a execução e fiscalização contratual.

Foram feitas ainda duas questões abertas. $\mathrm{Na}$ primeira, quando questionados se haviam recebido algum tipo de capacitação ao serem nomeados para exercer a função de fiscal, a totalidade dos entrevistados respondeu que não houve qualquer tipo de treinamento ou instrução para a função, reforçando a constatação de que a instituição não proporciona meios de aprendizagem no campo da fiscalização de contratos. Já quando questionados se a capacitação poderia contribuir para a melhoria do processo de fiscalização, todos os participantes da pesquisa responderam positivamente. Tal resultado demonstra 0 interesse dos participantes em receber orientações que possam auxiliá-los no desempenho da função.

Por fim, os fiscais foram confrontados com uma lista na qual deveriam apontar o principal desafio que mais interfere na fiscalização de contratos. Houve um empate nos resultados, $38,46 \%$ dos participantes assinalaram a opção "dificuldades para conciliar a função de fiscal de contratos com outras atribuições da sua rotina de trabalho como agente público". Outros 38,46\% escolheram "falta de treinamento e capacitação adequada para o exercício da função de fiscal" como item de preocupação.

As outras opções da lista foram menos citadas pelos entrevistados. Entretanto, não são consideradas menos importantes, também representam pontos de atenção a ser considerados pela instituição. Um dos entrevistados apontou como dificuldade o relacionamento com a empresa contratada. Outros dois indicaram como principal desafio o desconhecimento acerca da legislação que trata do tema. Ao desconhecer o conteúdo da lei, tais entrevistados demonstram não estarem aptos a desempenhar as atividades de fiscalização nos moldes legalmente estabelecidos. A frequência das respostas encontra-se na Tabela 3.

Tabela 3 - Frequência do principal desafio que mais interfere na fiscalização de contratos

\begin{tabular}{|l|c|c|}
\hline $\begin{array}{l}\text { Dificuldades para conciliar a função de fiscal de contratos com outras atribuições da sua } \\
\text { rotina de trabalho como agente público. }\end{array}$ & 5 & 38,46 \\
\hline Desconhecimento acerca das cláusulas constantes no instrumento contratual. & 0 & 0,00 \\
\hline Desconhecimento acerca da legislação que trata do tema. & 2 & 15,38 \\
\hline Falta de capacitação e treinamento adequado para o exercício da função de fiscal. & 5 & 38,46 \\
\hline $\begin{array}{l}\text { Dificuldades relacionadas à empresa contratada: desorganização, descumprimento das } \\
\text { obrigações contratuais, relacionamento com o preposto. }\end{array}$ & 1 & 7,69 \\
\hline Outros (Especificar). & 0 & 0,00 \\
\hline Total & 13 & 100,00 \\
\hline
\end{tabular}

Fonte: Resultados da pesquisa.

O levantamento de campo realizado permitiu a pesquisadora obter importantes respostas para a pesquisa, permitiu identificar a opinião dos fiscais acerca da necessidade de adquirir capacitação, verificar se há na instituição a disponibilização de meios para aprendizagem, conhecer as principais dificuldades enfrentadas no exercício da função.

\section{CONSIDERAÇÕES FINAIS}

A presente pesquisa objetivou discutir sobre a importância do papel do fiscal de contratos administrativos de terceirização de mão de obra e como ações de capacitação poderiam contribuir para a melhoria do processo de fiscalização. Foi buscado, para tanto, na legislação em vigor e na literatura os principais aspectos relacionados ao assunto em estudo. Pode-se dizer que os objetivos propostos foram atendidos. Contudo, verificou-se que há poucos trabalhos que abordem especificamente a fiscalização de contratos de cessão de mão de obra, embora Almeida (2009) diga que a fiscalização contratual 
constitui-se em um dos mais relevantes temas da gestão pública contemporânea no Brasil.

Após leitura das normas, orientações do Tribunal de Contas, livros e artigos sobre o tema, percebeu-se que a tarefa de fiscalização exige um elevado nível de responsabilidade e cabe ao órgão público preparar o servidor para desempenhá-la.

Nesse sentido, devem ser desenvolvidas pelas entidades públicas ações que visem a capacitação efetiva dos fiscais de contratos, devendo ser estimulada a capacitação periódica do servidor, para que este possa cumprir seu papel com mais segurança e de acordo com as normas legais, para que se atualize acerca das normas e responsabilidades pertinentes a função, para que domine os principais procedimentos envolvidos e também para que haja a troca de experiências.

Em relação à instituição em análise, por meio do levantamento de campo podem ser constatadas algumas fragilidades no processo de fiscalização, tais como o desconhecimento de parte dos servidores acerca da legislação, a falta de registro das ocorrências em livro próprio das irregularidades cometidas pelo contratado e das medidas tomadas, a comunicação direta de fiscais com os funcionários das empresas contratadas.

Os resultados obtidos sinalizam a necessidade de que sejam desenvolvidas ações de capacitação por parte da instituição, proporcionando meios de processos de aprendizagem voltados à fiscalização de contrato administrativo de terceirização, o que pode modificar comportamentos e ajudar na transmissão de informações aos fiscais para que possam desempenhar corretamente a função que thes é encarregada. Com base nos dados, pode-se dizer que as fragilidades apontadas pelos fiscais na pesquisa de campo poderiam ser amenizadas se houvesse na instituição um processo contínuo e permanente de capacitação específica voltada à legislação e outros aspectos relacionados ao tema fiscalização de contratos.
A partir dos resultados dessa pesquisa, podese pensar na elaboração de um plano de treinamento adequado as reais necessidades dos fiscais, tendo em vista que se o treinando percebe que o treinamento não obterá resultado satisfatório, pouco se pode esperar como resultado do programa de capacitação. Além disso, a realização do levantamento poderá subsidiar a inclusão no Programa de Capacitação Anual da instituição de cursos específicos voltados ao dia a dia do fiscal de contratos.

É preciso salientar que não foi possível o aplicar questionário junto à totalidade dos fiscais, o que pode ser considerada uma limitação do trabalho. Seria importante ouvir a opinião daqueles que não puderam participar da pesquisa, para que seja possível fazer generalizações mais adequadas. Da mesma forma a pesquisa poderia ser ampliada e incluir outras partes envolvidas, como os gestores dos contratos, prestadores de serviço e usuários dos serviços.

Esta pesquisa não esgota o tema em sua totalidade, futuros estudos podem ampliar e aprofundar os resultados obtidos. Por isso sugere-se: expandir os estudos acerca da capacitação de fiscais de contratos terceirizados no serviço público, uma vez que o tema ainda é pouco explorado; replicar em outros tipos de contratos ou em outras instituições públicas a metodologia desenvolvida nesta pesquisa, para ampliar a validade da mesma e por fim, verificar a possibilidade de normatizar por meio de guias explicativos e manuais de apoio os principais procedimentos de fiscalização, baseados na legislação e em experiências práticas.

Por meio da pesquisa, verificou-se que alguns órgãos editaram manuais de fiscalização, com um roteiro de como, quando e de que forma agir para realizar um acompanhamento eficiente da execução do contrato. Entretanto, ainda não é uma realidade nas instituições públicas de ensino superior. 


\section{REFERÊNCIAS}

[1]. ALMEIDA, Carlos Wellington Leite. Fiscalização contratual: "Calcanhar de Aquiles" da execução dos contratos administrativos. Revista do Tribunal de Contas, Brasília, n. 114, p. 53-62, jan./abr. 2009.

[2]. Liquidação de despesa e aplicação de penalidades: momentos essenciais da fiscalização de contratos administrativos. Revista do Tribunal de Contas, Brasília, n. 120, p.26-38, jan./abr. 2011.

[3]. BRASIL. Constituição (1988). Constituição da República Federativa do Brasil. Disponível em: $<$ http://www.planalto.gov.br/ccivil_03/Constituicao/ Constituicao.htm>. Acesso em: 01 set. 2015.

[4]. Decreto $\mathrm{n}$-5.707, de 23 de fevereiro de 2006. Institui a Política e as Diretrizes para o Desenvolvimento de Pessoal da administração pública federal direta, autárquica e fundacional, e regulamenta dispositivos da Lei no 8.112, de 11 de dezembro de 1990. Brasília, DF, 23 fev. 2006. Disponível em: $<$ http://www.planalto.gov.br/ccivil_03/_Ato20042006/2006/Decreto/D5707.htm>. Acesso em: 25 set. 2015.

[5]. Lei no 8.666, de 21 de junho de 1993. Regulamenta o inciso XXI, da Constituição Federal, institui normas para licitação e contratos da Administração Pública e dá outras providências. Diário Oficial [da] República Federativa do Brasil, Brasília, DF, 22 jun. 1993. Disponível em: <http://www.planalto.gov.br/ccivil_03/Leis/L8666co ns.htm>. Acesso em: 01 set. 2015.

[6]. Lei $n$ ํ. 11.091, de 12 de janeiro de 2005. Dispõe sobre a estruturação do Plano de Carreira dos Cargos Técnico-Administrativos em Educação, no âmbito das Instituições Federais de Ensino vinculadas ao Ministério da Educação, e dá outras providências. Brasília, DF, 12 jan. 2005. Disponível <http://www.planalto.gov.br/ccivil_03/_ato20042006/2005/lei/l11091.htm>. Acesso em: 01 out. 2015.

[7]. Ministério do Planejamento, Orçamento e Gestão. Secretaria de Logística e Tecnologia da Informação. Instrução Normativa no 02 , de 30 de abril de 2008. Dispõe sobre regras e diretrizes para a contratação de serviços, continuados ou não. Disponível em: <http://www.comprasnet.gov.br/legislacao/in/in02_ 30042008.htm>. Acesso em: 10 set. 2015.

[8]. Tribunal de Contas. Acórdão no 540/2008. Plenário. Ministro Relator: Guilherme Palmeira. Brasília, 02 de abril de 2008. Disponível em:

<http://www.lexml.gov.br/urn/urn:lex:br:tribunal.cont as.uniao; plenario:acordao:2008-04-02;540>. Acesso em: 11 set. 2015

[9]. Tribunal Superior do Trabalho. Súmula 331 - TST. Contrato de prestação de serviços. Legalidade (nova redação do item IV e inseridos os itens V e VI à redação) - Res. 174/2011, DEJT divulgado em 27, 30 e 31.05.2011. Disponível em:

<http://www3.tst.jus.br/jurisprudencia/Sumulas_co m_indice/Sumulas_Ind_301_350.html>. Acesso em: 10 set. 2015 .

[10]. CASTRO, Ana Célia Bastos de. Obrigações trabalhistas em contratos de terceirização na administração pública: o caso do Centro de Pesquisas Aggeu Magalhães. 2010. 95 f. Dissertação (Mestrado Profissional em Saúde Pública) Fundação Oswaldo Cruz, Recife, 2010.

[11]. FILHO, Marçal Justen. Comentários à Lei de Licitações e Contratos Administrativos. 13.ed. São Paulo: Dialética, 2009.

[12]. FURTADO, Lucas Rocha. Curso de Direito Administrativo. 4.ed. revista e atualizada. Belo Horizonte: Fórum, 2013.

[13]. GIL, Antônio Carlos. Como elaborar Projetos de Pesquisa. 4.ed. São Paulo: Atlas, 2002.

[14]. MARCONI, Marina de Andrade; LAKATOS, Eva Maria. Fundamentos de Metodologia Científica. 5.ed. São Paulo: Atlas, 2003.

[15]. MARINHO, Rita de Cássia Pinto. A implementação de procedimentos de controle como estratégia de disseminação do conhecimento e instrumento para atingir eficiência na fiscalização de contratos de serviços terceirizados em uma universidade pública. 2012. 176 f. Dissertação (Mestrado Profissional em Sistemas de Gestão) Universidade Federal Fluminense, Niterói, 2012.

[16]. SANTOS, Lucimar Rizzo Lopes dos. Gestão e Fiscalização de Contratos Administrativos. ENAP Escola Nacional de Administração Pública, Brasília, 2014.

[17]. VERGARA, Sylvia Constant. Projetos e Relatórios de Pesquisa em Administração. 14.ed. São Paulo: Atlas, 2013.

[18]. VIEIRA, Antonieta Pereira; VIEIRA, Henrique Pereira; FURTADO, Madeline Rocha Furtado; FURTADO, Monique Rafaella Rocha. Gestão de Contratos de Terceirização na Administração Pública. 5.ed. revista e ampliada. Belo Horizonte: Fórum, 2013. 


\section{Bapítulo 15}

\section{PROGRAMACÃO \\ NEUROLINGUISTICA \\ PNL: \\ $U M$ \\ DIFERENCIAL PARA FORMAÇÃO DE GESTORES}

\section{Henrique Martins Galvão \\ Hilquias Gabriel Capucho \\ Luciani Vieira Gomes Alvareli}

Resumo: O ambiente organizacional sofre constantes influências externas e necessita mudar com grande rapidez, exigindo a aprendizagem em diferentes habilidades, seja no nível técnico, no relacionamento interpessoal ou nas execuções com excelência. O líder ou gestor na organização pode exercer influência direta sobre seus liderados, em todas as ações ou na busca de resultados, sempre empregando alguma estratégia. O presente estudo foca na Programação Neurolinguística - PNL desenvolvida a partir dos estudos de Richard Bandler e John Grinder, como forma de codificar e identificar sistemas representacionais do comportamento humano. A PNL é uma ferramenta que auxilia o gestor na aplicação em grupos de colaboradores, visando maior autoconhecimento, comunicação eficaz, melhoria na aceitação pessoal, rápida aprendizagem, avaliação de estados emocionais e comportamentais, expressados pela comunicação verbal ou não verbal. Os resultados apontaram para uma visão diferenciada sobre a relação líder e liderados e conhecimento das técnicas de PNL. A pesquisa realizada com voluntários de diferentes áreas de trabalho mostrou que dentre os sistemas representacionais, houve prevalência do perfil cinestésico, com menor incidência do perfil visual e nenhuma do perfil auditivo. Com base nos resultados foi possivel aferir que a PNL facilita o líder na identificação de potenciais gestores no seu grupo de colaboradores.

Palavras-chave: Líder. Liderança. Programação Neurolinguística. Sistemas representacionais. Gestores. 


\section{INTRODUÇÃO}

No contexto social e cultural considera-se que a comunicação e a atitude das pessoas não possuem, na maioria das vezes, os mesmos sinais abrangidos pelos sistemas representacionais, tais como: visual, auditivo e cinestésico. Tal situação encontrada criam dificuldades na compreensão mútua e completa de uma mensagem, bem como afetam a eficácia da comunicação. No âmbito empresarial, a falta de informação, a pouca experiência, a limitação linguística, o envolvimento emocional e as convicções e interesses, também podem impedir que a comunicação alcance seu objetivo. Nesses casos, o gerenciamento de tarefas envolvendo, por exemplo, planejamento, organização, delegação de poder e controle administrativo, serão afetados, principalmente na relação entre o líder e o liderado. Logo, a compreensão completa do processo de comunicação entre líder e liderado será possível quando houver consciência no modo como o outro se comporta ou atua. Observa-se que a eficiência desse processo está na maneira como o indivíduo formula os pensamentos e por quais canais recebe a mensagem.

A posição de liderança ocupada em qualquer área organizacional depende necessariamente da confiança e da clareza na comunicação. Assim, considera-se como dever do locutor (líder ou gestor) saber claramente quais são os pensamentos, as imagens $e$ os sentimentos que deseja transmitir, e qual o modelo de sinalização irá utilizar, identificando no receptor (liderado) a capacidade receptiva adequada para 0 modelo que será empregado.

Nesse contexto, insere-se a Programação Neurolinguística - PNL, campo de estudo que em linhas gerais traz a combinação da ciência da comunicação e da psicoterapia. A PNL foi desenvolvida por Richard Bandler e John Grinder, sendo que a formação de ambos denota a sua origem. Bandler buscava fundamentação para alicerçar suas teorias na comparação do cérebro humano com um computador (hardware), Enquanto Grinder pesquisava a linguagem verbal e corporal buscando revelar a gramática oculta do pensamento e ação. Os trabalhos de Grinder vislumbravam a mente humana como um conjunto de programas (softwares) inseridos através de inputs sensoriais. Os trabalhos sobre PNL de Bandler e Grinder são frequentemente utilizados como prática no meio empresarial e contribuíram para se transformar num modelo eficaz de comunicação interpessoal, assim como para o desenvolvimento de liderança (JOEY e YAZDANIFARD, 2015; GOLD, THORPE e MUMFORD, 2010; KONG, 2011).

Diante do exposto, o presente estudo visa explorar autores que colaboraram com pesquisas na área da PNL, e como suas técnicas contribuíram na orientação pessoal, intelectual e de negócios, principalmente no gerenciamento e liderança. As qualidades da informação no processo de comunicação são decisivas para trabalhar metas desejadas com exatidão e definir a melhor estratégia para sua realização. Para tanto, buscou-se identificar conceitos de liderança com ênfase na teoria de traços da personalidade, a qual considera uma pessoa quando nasce com determinados traços será um líder (ROBBINS, 2005; VERGARA, 2012). Dessa forma, a indagação motivadora para o estudo é norteada pela seguinte questão de pesquisa: Seria possível que através das técnicas da PNL um indivíduo que não se encaixa no contexto da teoria dos traços da personalidade, conseguiria ser um líder eficaz de excelência que desenvolve e transforma seus liderados e ao mesmo tempo cria um novo conceito para esse processo de gestão?

\section{REVISÃO DA LITERATURA}

\subsection{A MUDANÇA QUE VEM DE DENTRO}

O ambiente organizacional busca se adequar às constantes e rápidas transformações ambientais. Como resposta, as organizações detectam a necessidade de mudanças, elaboram e implementam estratégias, procuram desenvolver capacidades de aprender diferentes habilidades para encontrar melhores soluções e executar atividades com excelência (KONG, 2011). As empresas estão mudando seus ambientes, modificam a estrutura organizacional e buscam transforma-se para o aprendizado. Mediante à isso, cada vez mais os indivíduos devem ser capazes de se desenvolverem e aprimorarem as suas capacidades para fazer melhor uso do aprendizado, de modo aproveitar ao máximo o seu potencial. Métodos passados já não são eficientes neste novo ambiente (KNIGHT, 1997). A ideia de "faça o que você sempre fez, e continuará conseguindo o que sempre conseguiu!" não é mais a chave que abrirá caminhos para o futuro. Na verdade trata-se de uma "chave" 
dentro de cada indivíduo, apesar de desfragmentada da capacidade individual de se administrar seus pensamentos, conflitos e experiências (KNIGHT, 1997, p.3).

É importante ressaltar que o líder ou gestor da organização exerce influência direta sobre o ambiente e as pessoas. Para comandar uma equipe, o líder precisa saber extrair as interrelações estabelecidas, atuar com a sinergia necessária para a obtenção de resultados mais eficazes. Ao conhecer os seus padrões internos, o líder tende à influenciar a vivência e as experiências de seus liderados. Embora a mudança venha de dentro, ou seja, das atitudes diante das experiências acumuladas, dependerá muito mais da capacidade do líder em alcançar o nível de excelência em tudo o que pensa, fala e faz (NOVO, CHERNICHARO E BARRADAS, 2009, p.3).

A influência do líder está atrelada diretamente no desempenho das equipes, e consequentemente ao sucesso das organizações. Conforme Lacomnbe (2005, p. 204), o líder é aquele que exerce a ação, agindo no sentido de influenciar o comportamento e a mentalidade de outras pessoas em prol da realização de objetivos, cuja atuação é vista como sendo o processo social por meio da liderança (MAXIMIANO, 2000). Os estudos sobre a liderança nas organizações focam na sua finalidade seja como função ou tarefa, destinada a direcionar esforços da equipe e induzir pessoas a atingir resultados, bem como analisam as diferentes características e papéis do líder. Embora exista uma variedade de tipos de liderança e que dificulta estabelecer precisamente o que faz um líder, observa-se que por meio da liderança, as pessoas se mantem unidas mesmo sem estarem fisicamente próximas, sendo necessário defender valores coletivamente, numa relação de influência recíproca (LACOMBE, 2005; MAXIMIANO, 2000; ROBBINS, 2005).

O comportamento de liderar é significativo, pois envolve múltiplas funções como, por exemplo, planejar, comunicar, informar, direcionar, controlar e delegar. Liderar tem um aspecto relacional, na essência visa orientar um grupo na direção a determinados objetivos ou metas previamente estabelecidas. Sendo a liderança um processo de influência, é necessário que o líder modifique intencionalmente o comportamento de outras pessoas, o que é possível através do modo como usa o seu poder ou autoridade
(MAXIMIANO, 2000; $\quad$ SILVA, 2001; MINTZBERG, 2010).

Visto de outa forma, a capacidade de liderança não estaria tipicamente vinculado a um papel gerencial. Para Cotrim et al. (2010, p. 113), os indivíduos apresentam características de aprender, inventar, perceber, interpretar, comunicar o que percebeu, e também podem transformar a si mesmo e modificar o que está ao seu redor. Apesar do perfil de líder não ser vinculado estritamente à função gerencial no sentido formal, considera-se primordial que o líder é aquele indivíduo visto como o principal responsável pela realização dos objetivos e cumprimento das metas organizacionais. O líder na organização tem a autoridade para se relacionar com seus liderados, bem como capaz de desenvolver habilidades para fazer uso da autoridade, cujo exercício se torna reconhecido e legitimado com base em normas estabelecidas pela organização (MAXIMIANO, 2000; SILVA, 2001).

Várias teorias e estudos sobre liderança se enquadram no campo da abordagem comportamentalista e têm sido desenvolvidos de modo a compreender o papel do líder na organização como processo de gerenciamento. Estudos realizados na Universidade de Michigan em 1947, conduzidos por Rensis Likert, enfatizaram o comportamento da liderança centrada no trabalho (tarefas) e centrada nas pessoas, em ambos os casos o objetivo consistia em avaliar o comportamento dos liderados diante da eficácia quando submetidos ao tipo de comportamento do líder (SILVA, 2001). Quando centrado no trabalho, o comportamento do líder tende enfocar na forte supervisão para aumento do desempenho dos liderados, enquanto o comportamento do líder centrado nas pessoas, busca a orientação de desenvolvimento eficaz de grupos associando com as necessidades, crescimento pessoal e profissional dos colaboradores. Likert também identificou quatro tipos básicos de estilos de liderança que se relacionam a um modelo continuum caracterizados como: autoritário, baseado na coerção e decisões centralizadas com ênfase em punições; benevolente, com poucas interações e uso de punições; consultivo, clima de confiança com interação moderada e algumas decisões pelo grupo, e; participativo, com confiança completa e envolvimento participativo do grupo com atribuição de responsabilidades.

De modo semelhante aos estudos de Rensis Likert, na Universidade de Ohio são 
desenvolvidos os trabalhos de E. A. Fleishman com enfoque para "consideração" e "estrutura de iniciação". A primeira se preocupa com as pessoas e no relacionamento interno, permeada por confiança mútua e a segunda enfatiza a atuação do líder com a estrutura de atividades claramente definidas e canais de comunicação formais. Ambas variam entre baixa e alta intensidade, combinando o modo como a liderança é exercida (ROBBINS, 2005; SILVA, 2001).

Também, os estudos de Likert influenciaram Robert R. Blake e Jane S. Mouton, os quais propuseram o grid de liderança ou grade gerencial relacionando o comportamento do líder com pessoas e com a produção, porém variando numa matriz de nove pontos nos eixos $x$ e $y$, situando o perfil do líder em cinco estilos: empobrecido, quando nem foca nas pessoas e nem na produção; autoritário, percebido como aquele fortemente interessado com a produção e menos com o grupo; clube de campo, caracterizado como liderança paternalista e bem estar do grupo, e; eficaz, quando a liderança é percebida tanto pelo empenho no relacionamento de confiança com o grupo quanto com os recursos necessários para alcançar resultados (MAXIMIANO, 2000; SILVA, 2001; ROBBINS, 2005).

Dentre as abordagens que tratam do comportamento do líder, destaca-se o trabalho de Robert Tannenbaum e Warren H. Schmidt, os pesquisadores sugerem que $\mathrm{O}$ comportamento do líder pode variar de diferentes formas, em que o uso da autoridade foca numa determinada situação como sendo autoritária, ou seja, a tomada de decisão é centrada no chefe e migrando gradualmente para as tomadas de decisões centradas no grupo, caracterizada pelo estilo participativo das decisões (SILVA, 2001).

O papel da liderança que aproxima o líder da função de atender expectativas de grupos de colaboradores tem como proposta os estudos de Robert J. House e Terrence Mitchell, estabelecendo a atuação do líder em tornar claro o que deve ser feito, entendido como o caminho, e as recompensas que as pessoas desejam, portanto, visto como meta. Assim, o modelo caminho-meta define: a liderança diretiva, quando visa esquemas de trabalho, padrões de desempenho e as expectativas de desempenho das pessoas; liderança de apoio, aquela que busca a melhoria de relacionamentos interpessoais, gera apoio, se torna acessível e amigável; liderança participativa, caracterizada pelo envolvimento das pessoas ao trabalho e elaboram opiniões sobre o trabalho; e, liderança orientada para a realização, quando desenvolve a confiança mútua, encorajando as pessoas para a melhoria de desempenho e fortalecendo motivações para alcance de metas (SILVA 2001).

Conforme Robbins (2005), um dos mais importantes estudos que vem conquistando adeptos é a teoria situacional desenvolvida por Paul Hersey e Ken Blanchard, pois está centrada sobre os liderados. Os pesquisados argumentam que a ênfase nos liderados é alcançada em razão da eficácia do líder, ou seja, os resultados alcançados dependem das ações dos liderados. Para o caso dos liderados serem incapazes ou se sentirem desmotivados para realizar uma determinada atividade, o líder estará atento para orientar sua equipe, poderá utilizar suas habilidades para apoiar e participar juntamente com os seus liderados, compensando as limitações e capacidades dos membros da sua equipe. De outro modo, conforme Silva (2001), quando os indivíduos têm maturidade psicológica ou disposição, bem como de maturidade de trabalho, levando-se em conta a sua capacidade técnica não haveria necessidade da habilidade de direção da liderança. Além disso, a liderança situacional não pressupõe um único estilo que seja melhor para influenciar os indivíduos na organização.

Nesse âmbito, a maioria dos estilos se enquadra ao modelo de liderança transacional orientado na direção das metas com papéis definidos e exigências no cumprimento de tarefas, por exemplo, como fazem uso da autoridade do cargo para troca de recompensas pelo esforço do funcionário, se possuem menos interesse na inspiração e motivação, focando no desempenho constante e onde o líder tem o perfil de negociador manipulativo. No entanto, Daft (2008) e Robbins (2005), destacam que as respostas às pressões do ambiente externo colocam a liderança na condução das mudanças dentro das organizações. Neste caso, o estilo de liderança é aquele que promove adaptação e inovação continuadas baseada na liderança transformacional. Para que isso aconteça os funcionários deverão estar dispostos na dedicação de tempo e esforço para atingir as novas metas (DAFT, 2008). Num primeiro momento, a organização deve reconhecer a necessidade de mudança, posteriormente a liderança cria visão compartilhada e, 
finalmente, institui as mudanças. Para tanto, o líder transformacional é aquele que desempenha o papel como agente de renovação e de mudança, conduzindo os funcionários na preparação, comunicando e desenvolvendo a aceitação para o entendimento da mudança, assim como promovendo $\mathrm{O}$ engajamento $\mathrm{e}$ comprometimento na discussão e resolução dos problemas, das dúvidas, no estabelecimento de feedbacks dos empregados, em que visem a institucionalização do processo de mudança. O processo de mudança tende a ser visto como menos ameaçador e não como algo novo, mas como necessário e fundamental para a continuidade dos negócios (DAFT, 2008; MAXIMIANO, 2009).

Nos vários estudos sobre liderança, perfil do líder é visto como necessário para influenciar grupos ao alcance de resultados, mas que dependem da identificação de alguns traços que determinam a capacidade do exercício da liderança. A teoria dos traços da liderança auxilia na identificação dos líderes dos nãolíderes: ambição e energia; desejo de liderar; honestidade e integridade; autoconfiança e estabilidade emocional; inteligência; monitoramento e conhecimentos relevantes para o trabalho (ROBBINS, 2005). Para essa teoria, o líder exercerá influência sobre os indivíduos e grupos, ou seja, se o indivíduo nascesse com determinados traços sejam estes traços sociais, físicos, intelectuais ou de personalidade (VERGARA 2012, p. 75), assim quem nasce com estes traços seria líder. Para Vergara (2012, p. 17), as pesquisas acerca de descobrir os possíveis traços de liderança não foram contundentes e não explorou todas as circunstâncias, muito embora difícil de serem abrangidas.

Todavia, Robbins (2005) destaca que quando um indivíduo apresenta determinados traços pode-se prever o surgimento da liderança e distinguindo entre líderes e não líderes, ou seja, líderes eficazes e eficientes. No tocante a isso, será que a aparência, a estatura, a energia ou a força física realmente implicam na posição de liderança?

Tratando-se de liderança, os seres humanos provaram sua capacidade de mudar a si mesmo e o ambiente em que vivem. Mediante a isso, o fato é que a Programação Neurolinguística será capaz de defender por meio de técnicas para compreensão de padrões de comportamento e que podem ser modificados, ou seja, reprogramados.

\subsection{PROGRAMAÇÃO NEUROLINGUÍSTICA -} $\mathrm{PNL}$

A PNL nasceu nos Estados Unidos na década de 70, como um misto de ciência da comunicação e psicoterapia. Seus idealizadores foram Richard Bandler, um expert em computação e lógica, que na época estudava psicologia na Universidade da Califórnia, em Santa Cruz, e John Grinder que era professor de linguística na mesma universidade. Bandler era matemático, pósgraduado em psicologia e computação, enquanto Grinder graduou-se em linguística, especializando-se em sintaxe e na teoria da gramática transformacional de Noam Chomsky. Bandler buscava fundamentação para alicerçar suas teorias na comparação do cérebro humano com um computador (hardware). Grinder pesquisava acerca de linguagem verbal e corporal buscando revelar a gramática oculta do pensamento e ação, vislumbrando a mente humana como um conjunto de programas (software) inseridos ali através de inputs sensoriais (AZEVEDO, 2006 p. 34). Ao descobrirem tamanha semelhança acerca deste assunto, combinaram os conhecimentos em computação e linguística com intuito de desenvolver uma linguagem de mudança. Munidos de objetivos comuns sobre tal assunto, deram início ao projeto "Programação NeuroLinguística", cujo principal objetivo era programar ou reprogramar o cérebro humano, utilizando-se códigos verbais e não verbais (AZEVEDO, 2006 p. 35).

A partir de então, a PNL logo se expandiu para além do campo da comunicação e da terapia e começou a ser utilizada em diferentes campos, sempre buscando através da modelagem a excelência nos resultados. Nesse sentido, pode-se observar que em todas as ações, metas ou busca de resultados, sempre é empregada alguma estratégia, algo que dirija o comportamento para um determinado fim (ROBBINS, 2005). Para cada caso, os padrões de pensamentos são orientados por crenças, valores e convicções.

Assim, a PNL (Programação Neurolinguística) se constitui na ferramenta que faz com que estas estratégias venham à tona, através da modelagem, trabalhando os processos conscientes e principalmente os inconscientes, a fim de se reproduzir o mesmo resultado de excelência, além de poder se ensinar a outros para que possam continuadamente alcançar os resultados almejados. Desta forma, Harry (1996, p. 6) 
afirma que a PNL diz respeito "ao modo como os indivíduos vitoriosos em diferentes campos de atividade obtêm resultados valiosos e como seu pensamento e comportamento bemsucedidos podem ser imitados". Portanto, a PNL trata daquilo que acontece quando pensamos e do efeito do pensamento sobre o comportamento, nosso e dos demais.

A utilização da PNL contribui para que a pessoa aprenda a comunicar-se externa e internamente, de forma que possa fazer diferença entre resultados medíocres de excelentes. Para tal, é necessário entender o funcionamento do mais notável órgão do corpo humano, o cérebro. Passos (1997, p. 6) observa que cérebro humano possui milhões de recursos, mas não vem com "nenhum folheto de explicação de seu funcionamento", no entanto a PNL pretende ser o manual de instruções. Conforme Passos (1997), alguns autores definem a PNL como uma janela pela qual o homem pode atingir a excelência pessoal através dos propósitos, pensamentos e dos efeitos sobre seu comportamento. Cada indivíduo possui o seu cérebro, e consequentemente sua maneira de ver, sentir e ouvir o mundo a seu redor, logo cada um tem suas experiências subjetivas e utilizam dos seus recursos internos para dar significado aos acontecimentos externos. As técnicas de PNL disponibilizam ferramentas, conceitos e pressupostos que visam explicar cada momento dessa relação entre o indivíduo e seu mundo. Assim, a PNL torna-se uma importante ferramenta de autoconhecimento, de acordo com Rodrigues (2010, p. 51):

A PNL não se constitui de uma técnica de cura de perturbação mental, mas sim de intervenção cuja finalidade principal é ajudar o crescimento pessoal e facilitar o encontro do indivíduo com a autenticidade de sua existência, de forma a assumi-la e a projetá-la mais livremente no mundo.

O ser humano é um ser social, e depende da inter-relação com outros indivíduos como aspecto de sobrevivência; a PNL torna-se modelo de estudo interdisciplinar, podendo ser aplicado em diferentes áreas da comunicação interpessoal, seja na família, educação e psicologia. Enfim, a PNL estuda a estrutura e a organização dos processos do pensamento, a obtenção de informações através dos cincos sentidos (ver, ouvir, cheirar, sentir e degustar). Além disso, a PNL passa a ser vista como arte e ciência (HARRY, 1996).
A PNL busca mudanças no comportamento humano, por meio do maior autoconhecimento, comunicação mais eficaz, melhora na aceitação pessoal, aprendizagem mais rápida, e uma vida mais harmoniosa em comunidade. Conhecendo como o cérebro ("Neuro") funciona, busca-se a melhor maneira para se criar pensamentos, estado emocional e comportamento ("Linguagem"), sendo possível direcionar tais elementos para o caminho mais curto e assertivo da excelência (JOEY e YAZDANIFARD, 2015; HARRY, 1996).

Nos estudos da PNL a linguagem dos sentidos se destaca como sistemas representacionais. Para tanto, a linguagem que utilizamos para comunicação nos dá pistas da maneira que pensamos. Em PNL, as palavras são conhecidas como predicados. O que você acredita sobre o que vê, ouve e sente baseiase em sua experiência de uma vida inteira, que filtra todas as informações que chegam pelos sentidos (HARRY, 1996 p. 20). Nesse caso, os principais canais de receptividade do ser humano são: Visual, Auditivo, Cinestésico, Olfativo e Gustativo.

Ao usarmos nossos sentidos para captar dados ou informações do meio ambiente que nos cerca, estamos primeiro nos comunicando com nós mesmos, isso influenciará na maneira da construção do nosso pensamento e das nossas atitudes. Conforme Mancilha (2010, p. 2), "quando pensamos, "representamos" a informação para nós mesmos, internamente". A PNL denomina nossos sentidos de Sistemas Representacionais, pois fazemos uso dos nossos sistemas representacionais o tempo todo, mas tendemos a usar alguns mais do que outros. Por exemplo, muitas pessoas usam o sistema auditivo para conversar consigo mesmas, essa é uma maneira de pensar (MANCILHA, 2010).

Segundo Passos (1997), se pensarmos no meio social, na cultura ou na educação, esses exercerão influência direta na nossa programação cerebral ou na maneira de construção de nossos pensamentos. Dessa forma, antes mesmo de tornamos realidade a informação captada através de um de nossos sentidos, nosso cérebro procura por padrões já estabelecidos ou alguma experiência fragmentada e toda informação prévia recebe interferência na forma de percepção da experiência atual, numa relação de causa e efeito e que vinculam aos inputs, cujas informações exercerão influências no modo como o indivíduo forma o pensamento. 
Os sentidos são os principais caminhos de coletas de informações, mas os inputs (entradas) mais importantes são o visual, auditivo e cinestésico, e suas causas implicam diretamente na formação do pensamento e na atitude do indivíduo. O sistema representacional do homem é visível através da linguagem corporal, ou seja, manifesta-se na postura, tom de voz, padrão respiratório e movimento dos olhos. As palavras não são inventadas no ato da fala, já fazem parte de experiências anteriores. Dessa forma, é possível saber como as pessoas pensam enquanto falam (PASSOS, 1997, p. 26-27).

A seguir, observa-se cada padrão e seu manifesto: Visual - O sistema visual é utilizado para as imagens internas, "sonhar acordado" e imaginação (MANCILHA, 2010, p. 3). Algumas das características de um indivíduo "visual" são ser direto, objetivo e franco. Frequentemente ele necessita reproduzir um filme que construiu na sua cabeça. Sendo assim, pensar em imagens, representam as ideias, lembranças e fantasias como imagens mentais. Para esse indivíduo, o tipo de comportamento específico é utilizar palavras ou frases que representem estado visual. Para Kluczny et al. (1996, p. 8) indivíduos visuais frequentemente representam suas ideias da seguinte forma: "Eu vejo bem o que você diz, isto parece bem, a ideia não ficou bem clara para mim". O indivíduo visual precisa ver para crer, ele cria uma conexão direta com o cérebro através de imagens da mesma forma que capta informações do mundo exterior (Imagem + Sentimento). Observar como o indivíduo se expressa e responder com a mesma sintonia trará a confiança para o indivíduo visual, melhorando seus resultados.

No segundo sentido o Auditivo - caracteriza-se como ouvir música internamente, conversar consigo mesmo e ouvir as vozes de outras pessoas (MANCILHA, 2010, p.3). São sinais de indivíduos calados, detalhistas introvertidos, bons ouvintes, auditivos geralmente funcionam na velocidade do som, conversa com ele mesmo antes de tomar uma decisão. Para Passos (1997, p. 28), indivíduos auditivos utilizam um vocabulário com predominância auditivo: "Isso não me soa bem, escuta, eu disse duas palavras". O indivíduo auditivo precisa de algo que fale com ele ou para ele, a conexão é estabelecida entre os sons e os pensamentos, sons + sentimento, este canal é preferencial para captar as informações do mundo interior, formular pensamentos e atitudes excelentes.
No terceiro sentido o Cinestésico - verificamse características do indivíduo com a necessidade de sentir algo como na frase "Eu quero provar um sapato. Pega algum bem macio de couro flexível" (SANTOS, 2010, p. 130). O indivíduo costuma ser emotivo, empático, afetivo, sociável e extrovertido. Nesses casos, os indivíduos cinestésicos usam padrões de comunicação voltados ao sentimento, por meio deste também é o seu principal meio de aprendizado e captação de dados do mundo externo. De um modo geral as frases mais usadas por estes indivíduos segundo Kluczny et. al. (1996, p. 9) são: "Eu peguei a situação controlada, você sentiu o problema, eu tenho a sensação de que isso é bom". Usando tais padrões, este indivíduo passa a ter um comportamento típico do mesmo, e opta por tomada de decisões baseadas no que ele está sentindo no momento. Cada indivíduo tem um canal mais apurado do que outros, e de forma individual capta a realidade e as transforma em sentido. Segundo Spritzer (1993 p. 97), quando percebemos a realidade, agimos através de nossos órgãos dos sentidos. Dessa maneira, em nosso cérebro, as experiências são codificadas em pequenos pedaços de imagens, sons, sensações e sentimentos, cujos resultados variam conforme cada experiência e podem ser utilizados mais de um sentido.

Na PLN, as pessoas não são rotuladas. Partese do princípio de estudar e entender as experiências subjetivas, a forma como cada pessoa experimenta o mundo em cada momento, em cada experiência. Diante disso, podemos também fazer uso de linguagens não verbais. Para Kluczny et al. (1996), palavras e ou frases não se constituem como única forma geral de comunicação. O corpo também "fala", a linguagem corporal contribui para o modelo ou padrão de pensamento do indivíduo. Tudo está interligado, cérebro e corpo, em uma só sintonia, comunicando-se com o mundo externo (KLUCZNY et al. 1996, p. 15). Por isso, é possível dizer que quanto mais intensamente a pessoa reflete sobre um acontecimento ou um fato, mais estará envolvendo-se de maneira emocional e neurológica, e isso influenciará diretamente a forma de manifesto em suas atitudes verbais e não verbais. Desse modo, a postura do indivíduo passa a ser elemento essencial na identificação do tipo de sistema representacional do mesmo. Kluczny et al. (1996, p. 16-17) postulou uma lista de elementos referentes à postura dos indivíduos, 
segundo cada sistema representacional, conforme Tabela 1 a seguir:

Tabela 1: Sistemas representacionais do individuo

\begin{tabular}{|c|c|c|}
\hline Indivíduos visuais & Indivíduos Auditivos & Indivíduos Cinestésicos \\
\hline $\begin{array}{l}\text { Representam-se por uma postura } \\
\text { mais reclinada, tronco para frente } \\
\text { e a cabeça e ombros também } \\
\text { ficam eretos. A respiração não é } \\
\text { profunda se localiza no alto do } \\
\text { tórax, o tom de voz pode ser mais } \\
\text { alto assim como a velocidade da } \\
\text { fala é mais rápida. Gesticula na } \\
\text { altura dos olhos e aponta com os } \\
\text { mesmos. }\end{array}$ & $\begin{array}{l}\text { A cabeça é inclinada mais para frente, } \\
\text { algumas vezes inclinada lateralmente, } \\
\text { esticando um lado do ouvido mais para } \\
\text { frente (em direção à fonte auditiva } \\
\text { interna), os ombros ligeiramente } \\
\text { puxados para cima, braços geralmente } \\
\text { cruzados. Respiração no centro do tórax } \\
\text { na área do diafragma, sobrancelhas } \\
\text { franzem ligeiramente, varia a tonalidade } \\
\text { e velocidade da fala. Gesticulam com } \\
\text { frequência e na frente do tórax, além de } \\
\text { tocar na barba, lábios ou nas } \\
\text { bochechas. }\end{array}$ & $\begin{array}{l}\text { Postura marcada pela } \\
\text { cabeça e ombros baixos, } \\
\text { respiração localizada no } \\
\text { abdômen, voz ligada no } \\
\text { mesmo ritmo respiratório, e } \\
\text { se apresenta mais grave com } \\
\text { fala mais lenta. Tocam com } \\
\text { frequência no abdômen, peito } \\
\text { e coração, e gesticulam } \\
\text { frente ao abdômen, como se } \\
\text { cada palavra fosse seguida } \\
\text { de um sentimento. }\end{array}$ \\
\hline
\end{tabular}

Fonte: adaptado com base em Kluczny et al. (1996)

Atentar-se a essa riqueza de detalhes, às linguagens não verbais, será o diferencial no reconhecimento do tipo representacional do indivíduo, sendo fator determinante para a comunicação e o estabelecimento da confiança no ambiente organizacional. Numa empresa as inter-relações ocorrem de maneira dinâmica. Contudo, de maneira geral torna-se necessário estabelecer uma relação de confiança, não importa onde o indivíduo atue, seja na educação, saúde ou como gestor de empresas, diariamente é preciso se relacionar e se comunicar com pessoas nos mais diferentes segmentos da sociedade (KLUCZNY et al., 1996, p. 57). Atualmente para a carreira profissional mais do que ser um grande profissional, é preciso conquistar a excelência em trabalhar com pessoas (OLIVEIRA, 2010, p. 171). Na PNL, um pressuposto básico da esfera de comunicação é estabelecer confiança, respeito mútuo entre as partes envolvidas, que se denomina rapport. Estabelecer esse fenômeno que se assemelha à empatia é uma forma mais eficaz e primordial na comunicação.

Conforme descreve Mancilha (2010, p. 20), rapport ou empatia acontece quando você equipara o comportamento, o pensamento e o nível de energia da outra pessoa, em outras palavras, quando você a está encontrando no modelo de mundo dela. Dessa forma, o rapport acontece naturalmente quando as pessoas tomam consciência um do outro e começam a se comunicar. É como uma dança na qual uma pessoa conduz e a outra segue. Pessoas em rapport têm uma maneira cooperativa e harmoniosa de estarem juntas, prevalece o senso de reconhecimento mútuo e sabem que está bem, sem saber quem elas são. Em suma o fato de estabelecer rapport (empatia) está ligado em se fazer uma aliança, uma ligação que beira a intimidade, sintonia e confiança.

Sendo assim, o conhecimento da existência de partes comportamentais inconscientes pode ser usado de forma consciente na formação ou manutenção de um relacionamento de confiança, principalmente no ambiente de empresa. Além disso, a PNL apresenta técnicas de espelhamento que auxiliam em um clima comunicativo de confiança organizacional.

$\mathrm{Na}$ pesquisa conduzida por Al Khuja, Adomaitiene e Giedraitis (2016), concluíram que a adoção de um programa de neurolinguística como ferramenta de gestão, propicia maior desempenho nas tarefas e desempenho contextual significativo, elevando positivamente para a produtividade de uma empresa. Consideraram que o estabelecimento de crenças tem relação positiva para introduzir a PNL. Assim quando adotada, a PNL pode dar uma perspectiva flexível positiva com base em uma atitude de "posso-faço" em vez de se concentrar em problemas na realização de tarefas no local de trabalho ou em outro lugar. Portanto, os autores consideram ser altamente recomendado introduzir pressupostos de PNL na cultura geral de uma empresa para que os funcionários possam se concentrar mais em ser flexível e ver os problemas como desafios. 


\section{METODOLOGIA DA PESQUISA}

Para o desenvolvimento desse estudo, baseou-se na pesquisa de caráter exploratório, suportada por pesquisa de levantamento bibliográfico, com o intuito de revisar e filtrar algumas teorias e informações sobre liderança de PNL. Conforme Gil (2007), a pesquisa do tipo exploratória propicia familiaridade com o problema, além de considerar os vários aspectos relacionados ao fenômeno de estudo. Ainda, segundo Gil (2007, p.71), a pesquisa bibliográfica é desenvolvida a partir de material já elaborado, constituído principalmente de livros e artigos científicos. A principal vantagem da pesquisa bibliográfica reside no fato de permitir ao investigador a cobertura de uma gama de fenômenos muito mais ampla do que aquela que poderia pesquisar diretamente. Como caráter comparativo entre teoria e prática, o estudo se caracteriza como pesquisa qualitativa. Segundo Godoy (1995, p. 1), a pesquisa qualitativa ocupa um reconhecido lugar entre as várias possibilidades de se estudar os fenômenos que envolvem os seres humanos e suas intrincadas relações sociais, estabelecidas em diversos ambientes, principais nos ambientes organizacionais. Para atender aos objetivos foi realizada aplicação de técnica PNL com um pequeno grupo de voluntários.

\subsection{ETAPAS DA PESQUISA}

Aos cinco voluntários submetidos aos testes, foram utilizadas como critério de escolha para a amostra as diferentes áreas de atuação em que estão inseridos no mercado de trabalho, em que não exercerem nenhum posto de liderança, eles têm suas identidades mantidas em sigilo. Para identificarmos cada um nesse estudo utilizaram-se letras do alfabeto para o nome, sexo, profissão e idade. Sendo assim, os voluntários ficaram identificados como:

Voluntario A sexo masculino estagiário, 25 anos; B sexo masculino, Operador de Maquinas, 26 anos; C sexo masculino, estagiário, 21 anos; D sexo masculino mecânico de manutenção, 22 anos; $\mathrm{E}$ sexo feminino, estagiária, 20 anos, ambos estão em período final de graduação em uma instituição de ensino superior do estado de São Paulo.

Os cinco participantes da pesquisa foram, primeiramente, submetidos a um teste escrito, um questionário com 21 perguntas, dividido em 3 blocos com sete perguntas fechadas, com respostas diretas "sim" ou "não". A segunda parte da atividade constitui-se num pequeno relato em que o participante foi orientado a descrever uma memória de sua infância, podendo ser uma lembrança de um acontecimento ou a descrição de um local que frequentava. O objetivo da primeira parte do teste escrito foi coletar dados dos canais representativos atuante no participante. O objetivo da aplicação do questionário foi tentar identificar por qual canal representacional o voluntário se identifica (visual, auditivo e cinestésico). Sendo assim, de acordo com a maior quantidade de afirmações, obteve-se um primeiro parâmetro que caracteriza o voluntário. Na segunda parte, a aplicação da redação tinha o objetivo de identificar e contar o número de palavras utilizadas (em PNL as palavras são definidas como Predicatos) que, via de regra, denotam características visuais, auditivas e cinestésicas. Essas auxiliam o pesquisador a identificar qual estado ou canal o participante utilizou para construir seu texto. Os dois parâmetros foram comparados para avaliar possíveis incongruências entre as duas partes. Como critério comparativo ao questionário, outro meio de coleta de dados foi aplicado aos participantes em três etapas, uma amostra na prática de atividades onde se demanda habilidades de cunho visual, auditivo ou cinestésico.

A primeira etapa, de cunho visual: Disponibilizando ao voluntario um bloco $\angle E G O$ como modelo com três cores diferentes, a instrução era montar a mesma figura e sequência de cores com as peças que thes foram entregues. Nesta mesma etapa, avaliouse também o canal cinestésico já que para a PNL o indivíduo cinestésico precisa tocar os objetos, o voluntario que pegou ou simplesmente tocou o modelo the foi atribuído uma nota a este teste para caráter de desempate. Para a terceira etapa de cunho auditivo, três vozes de apresentadores de TV de sexo masculino e de origens nacional e famosos, os quais foram colocados para a audição dos voluntários, a instrução é dizer se conhece ou não a aquela voz e identificá-la pelo nome, atribuindo acerto ou erro.

\section{ANÁLISE DOS DADOS}

Com base nos dados obtidos pós a aplicação dos testes em uma pesquisa de caráter qualitativa cada indivíduo apresentou os seguintes resultados: Individuo A obteve $40 \%$ de canal auditivo, $20 \%$ de canal visual e $40 \%$ 
de canal cinestésico atuante, quando submetido ao teste auditivo alcançou $67 \%$ de acerto contra $33 \%$ de erros, o teste visual onde a média foi de 8 segundos para montagens do bloco seguindo o modelo proposto, A conseguiu a bater exatamente a média, não toucou o modelo de bloco antes ou depois de realizar a montagem fator que não caracterizou o canal cinestésico e por motivos desconhecidos não concluiu o teste escrito com a redação proposta para medir o números de palavras visuais, auditivas e cinestésicas utilizadas na construção do texto. Com base nos dados colhidos pela pesquisa qualitativa e com fundamento nas pesquisas realizadas acerca de PNL, pode conclui que o indivíduo A possui o canal predominante auditivo, fato que foi provado pelo bom desempenho no teste auditivo e por descartar a hipótese de ser cinestésico e visual nos demais testes. Alinhado aos resultados suponha-se que, dentro de uma organização ao indivíduo $A$ seria recomendável um posto de trabalho onde a característica seja ouvir pessoas e descrever com detalhes alguma atividade ou relatórios já que as pessoas dotadas do canal auditivo são detalhistas, caladas e bons ouvintes.

O indivíduo B obteve 36\% no canal auditivo, $28 \%$ para o visual e $36 \%$ cinestésico, ao passo que foi submetido ao teste auditivo proporcionou $67 \%$ de erros contra apenas 33\% de acertos, finalizou o teste visual/cinestésico em 11 segundos, 3 segundos acima da média obtida, não tocou o bloco modelo durante ou ao termino do teste, ao anualizar o texto proposto no teste escrito por ele foi possível perceber que este indivíduo utilizou de palavras de cunho cinestésico narrando uma situação que marcou com aflição um momento em sua vida. Com base nos dados obtidos acima pode se concluir que B é cinestésico, pois não apresentou um bom resultado no teste auditivo descartando tal hipótese, embora completasse o teste de montagem dos blocos com o tempo acima da média, o indivíduo B demostrou necessidade de mais tempo com as peças em mão para tomar a decisão de onde colocá-las. Sendo assim ao indivíduo B recomenta-se uma possível atividade em que tenha que se tocar com frequência determinados produtos, ou testalos, assim como é possível potencializar o aprendizado ou a capacitação deste se utilizando de artifícios que possam estimular esse canal.

Ao indivíduo C ficaram atribuídos $28 \%$ auditivo, $36 \%$ visual e $36 \%$ cinestésico, alcançou $67 \%$ de acertos no teste auditivo e errou apenas em $33 \%$, obteve um ótimo tempo no teste visual e ficou abaixo da média com 6 segundos, não tocou o bloco modelo durante a aplicação do teste, ao analisar a narrativa do indivíduo C notou-se que a construção de seu texto se fez com palavras de cunho visual, onde contou uma experiência de aprendizagem em sua infância utilizando-se de visão para a mesma , portanto considerou-se este indivíduo como visual, embora tenha obtido bom rendimento no teste auditivo, seu desempenho se mostrou ainda melhor no teste visual e esta hipótese se consolidou com a leitura e interpretação de seu texto. Sendo assim C caracteriza-se como visual, e poderia ser dentro de uma organização, um candidato excelente para atividade de demandem metas, que sejam claras e objetivas, já que tais características são presentes em pessoas visuais.

Indivíduo D após ser submetidos aos testes mostrou-se $23 \%$ auditivo, $31 \%$ visual e $46 \%$ cinestésico, com resultado do teste visual alcançou apenas 33\% de acertos e errou $67 \%$ da resposta. No teste visual conseguiu a marca de 6 segundos do tempo de montagem ficando abaixo da média, dos participantes foi o único a tocar o modelo ao termino da montagem, como resultado desta ação destacou o canal cinestésico atuante, ao ser analisado a construção do texto esta hipótese foi confirmada, pois se utilizou de palavras com "sentir cheiro" e "comida deliciosa" a fim de narrar uma lembrança de infância cheia de sensações em determinada parte de sua vida. Desta forma pode-se dizer com base nos dados obtidos e segundos estudos realizados por outros autores acerca das características de indivíduos cinestésicos, que D se apresenta com todos os resultados o canal cinestésico atuante. Sendo assim D se encaixa em um mesmo conjunto de atividades determinadas a $\mathrm{B}$, que possui o mesmo canal cinestésico.

Por último, o indivíduo E obteve 41\% auditivo, $30 \%$ visual e $29 \%$ cinestésico, no teste auditivo não chegou a um satisfatório com apenas 33\% de acertos e errou em $67 \%$ as resposta. Quando submetido ao teste visual, finalizou o tempo de montagem 2 segundos acima da média, não tocou em nenhum momento o bloco modelo o que descaracterizou uma possível atuação do canal cinestésico. Com base nos dados do texto escrito por $E$, este deixou aparente por meio das palavras "perto", "família" e "Almoço" que se orientou do canal cinestésico para formar pensamentos e construir uma narrativa a uma lembrança de 
alguma parte de sua infância. Sendo assim embora $\mathrm{E}$ apresentou no teste escrito uma tendência ao canal auditivo, não obteve um bom desempenho no teste auditivo proposto, a hipótese de ser visual não se concretizou ao terminar acima do tempo médio de montagem, onde não se mostrou ser indivíduo direto e ter objetividade, a análise do texto deixou aparente um canal cinestésico atuante que se pode confirmar ao se comparar o tempo em que $\mathrm{E}$ ficou com as peças leitivogo para a montagem em mãos, resultando em um tempo final acima da média. Portanto, identifica-se o indivíduo E como cinestésico, e a ele cabem as mesmas orientações de atividades propostas a $B$ e $D$ que possuem as mesmas características e canais atuantes.

Quadro 1 - Traços comportamentais baseados na PNL

\begin{tabular}{|c|c|c|c|c|c|c|c|c|}
\hline \multirow[b]{2}{*}{ Indíviduo } & \multicolumn{3}{|c|}{ Questionário } & \multirow{2}{*}{$\begin{array}{c}\text { Teste Redação } \\
\text { Predomínio: auditivo, } \\
\text { visual e cinestésico }\end{array}$} & \multirow{2}{*}{\begin{tabular}{|l|} 
Bloco Lego \\
Montagem: tempo
\end{tabular}} & \multicolumn{2}{|c|}{ Teste Auditivo } & \multirow[t]{2}{*}{ Característia PNL } \\
\hline & $\begin{array}{c}\text { Canal } \\
\text { Auditivo }\end{array}$ & $\begin{array}{l}\text { Canal } \\
\text { Visual }\end{array}$ & $\begin{array}{c}\text { Canal } \\
\text { Cinestésico }\end{array}$ & & & Acerto & Erro & \\
\hline $\mathbf{A}$ & $40 \%$ & $20 \%$ & $40 \%$ & Não concluído & 8" (seg.) sem tocar & $67 \%$ & $33 \%$ & Auditivo \\
\hline B & $36 \%$ & $28 \%$ & $36 \%$ & Cinestésico & 11" (seg.) sem tocar & $33 \%$ & $67 \%$ & Cinestésico \\
\hline $\mathbf{C}$ & $28 \%$ & $36 \%$ & $36 \%$ & Visual & $<6$ " (seg.) sem tocar & $67 \%$ & $33 \%$ & Visual \\
\hline D & $23 \%$ & $31 \%$ & $46 \%$ & Cinestésico & 6" (seg.) tocou & $33 \%$ & $67 \%$ & Cinestésico \\
\hline $\mathbf{E}$ & $41 \%$ & $30 \%$ & $29 \%$ & Cinestésico & $>6 "$ (seg.) sem tocar & $33 \%$ & $67 \%$ & Cinestésico \\
\hline
\end{tabular}

Fonte: resultados da pesquisa

Mediante aos resultados apresentados e conforme revisão da literatura sobre o perfil de liderança e a PNL que alicerçou a realização da pesquisa pôde-se considerar que o pensamento e atitudes do ser humano dentro de sua esfera de percepções e orientação, a tomada de decisões de cada indivíduo foi posto à frente de afirmações que desenhavam um perfil para um canal representacional atuante. Assim, em sua grande maioria ficou subdivididos entre dois canais, fato que realçou a necessidade de recorrer a vários mecanismos ou meios de coleta de dados. A comparação entre os parâmetros obtidos desenharam um possível perfil dos indivíduos que ao longo da pesquisa foram se confirmando mediante resultados nos testes práticos, chegando a um resultado onde se sustenta a teoria de que os indivíduos se utilizam de experiências anteriores, e tem preferência por certas possibilidades de orientação, dentro de um canal atuante seja visual, auditivo ou cinestésico. Embora, considerando as limitações de pesquisa, a aplicação e os resultados permitiram confrontar a teoria esta levantada por Bandler e Grinder (1970), em que o equilíbrio e também as combinações das possibilidades refletiram nos resultados finais, observando-se que apesar do grupo participante ser restrito a cinco participantes, verificou-se que os indivíduos com características de representação visual A e $C$, se orientaram desse canal para tomada de decisão, conforme teste visual. Assim, como resultado, obtiveram o tempo médio padrão ou mesmo abaixo do estabelecido no teste, caracterizando os indivíduos A e C "perfeccionistas" (detalhista, exigente ou rigoroso) em relação aos demais voluntários $B$, $\mathrm{D}$ e $\mathrm{E}$, os quais mostram usar canal cinestésico atuante. Esses indivíduos obtiveram tempo médio acima do padrão de montagem e em suas redações fizeram alusão a experiências gravadas em memorias sobre fortes sensações, leva a supor que estavam conversando consigo mesmas enquanto seguram o bloco e mediante ao que sentiam tomavam uma decisão de onde colocar a peça.

\section{CONCLUSÃO}

Quando Richard Bandler e John Grinder combinaram ciência da comunicação e psicoterapia em (1970) deram vida à Programação Neurolinguística (PNL), uma ferramenta com técnicas que contribuíram na orientação pessoal, intelectual e de negócios, principalmente no gerenciamento e liderança, em que a qualidade da informação é decisiva para trabalhar metas desejadas com exatidão e definir a melhor estratégia para sua realização. Alguns autores afirmam que uma pessoa que nasce com determinados traços (teoria dos traços de personalidade/liderança) específicos será sempre um líder. Porém, a teoria de autodesenvolvimento e autoconhecimento da PNL demonstra que, se 
uma pessoa sempre repete determinadas ações com excelência então existe uma estrutura, se há uma estrutura tem um padrão, que pode ser inconsciente e com os conhecimentos em PNL é possível que esta estrutura venha à tona. Esse pensamento foi trabalhado ao longo desse estudo e sintetizado a partir das ideias de que todos têm comportamentos excelentes ou que podem realizar mudanças para a excelência, mas considera primordialmente que a chave está dentro de cada indivíduo, ou seja, precisa ser desfragmentada pela capacidade individual de se administrar seus pensamentos, conflitos e experiências. O PNL contribui para que a pessoa aprenda a comunicar-se externa e internamente, de modo que faça a diferença, pois ao se conhecer como o cérebro funciona, pode-se escolher a melhor maneira para criar pensamentos, lidar com seu estado emocional e comportamentos, sendo possível direcionar tais elementos para o caminho mais curto e assertivo da excelência.

Mais do que ser um grande profissional, é preciso conquistar a excelência em trabalhar com pessoas, desenvolvendo nelas habilidades. Isso pode acontecer em toda sua plenitude quando se utiliza a PNL, pois um pressuposto básico da esfera de comunicação é estabelecer confiança, respeito mútuo entre as partes envolvidas, que se denomina rapport. Destaca-se que imagem que as pessoas mais devem apreciar são elas mesmas.

Dessa forma, com base na referencial teórico que respaldou a aplicação dos testes utilizado para alicerçar o terreno do conhecimento acerca do comportamento humano, fundamentou-se uma ideia que responde à pergunta que originou este artigo, todos

\section{REFERÊNCIAS}

[1]. AZEVEDO Regina Maria de. Programação Neurolinguística: Transformação e Persuasão no Meta Modelo. 2006. 187 f. Dissertação (Mestrado em Ciências da Comunicação) - Escola de Comunicações e Artes, universidade de São Paulo, São Paulo, 2006. Disponível em: http://www.teses.usp.br/teses/disponiveis/27/27142 /tde-01122006-173633/pt-br.php. Acesso em: 15 fev. 2016.

[2]. COSTA, Henrique Sergi Gutierrez da. Negociando para o sucesso. Curitiba: Ibpex, 2008.

[3]. COTRIM, Gilberto e Fernandes, Mirna. Fundamentos da Filosofia. São Paulo: Saraiva, 2010. podem alcançar posição de liderança, dentro da sua esfera de percepção do mundo, todos são únicos dentro de sua plenitude de valores, crenças e experiências. Por isso, pode-se afirmar que, ao se utilizar as técnicas, fruto de estudo da PNL, o gestor estará trabalhando aspectos de liderança, buscando desenvolver nos seus liderados a auto liderança ou seja o colaborador torna-se gestor de seus próprios serviços. Desta forma vislumbra-se uma ideia diferenciada a respeito de gestão de pessoas, tal ideia pode ser desenhada em uma equação simples: "Técnica+Motivação=Satisfação", ou seja, quando se conhece qual o canal representacional pelo qual o indivíduo se orienta, o gestor tem em mãos a Técnica deste indivíduo, pois conhece em outro nível as suas possíveis competências, dotado dessa técnica pode-se orientá-lo a exercer atividades onde essa técnica ou canal atuante seja correlato, resultando na motivação. $O$ indivíduo que possui habilidade certa, estando no lugar certo trará resultados e se sentirá motivado em explorar ainda mais seu potencial. A satisfação é consequência, indivíduo com habilidades certas nas atividades onde possa empregar tais habilidade estará satisfeito em fazer parte da equipe, do projeto em dar o melhor de si em resultados sólidos e duradouros.

Sendo assim considerou-se que os objetivos de estudo foram alcançados. Contudo, recomenda-se novos estudos, mais aprofundados e com um número maior de pessoas, se fazem necessários a fim de se consolidar a hipótese de que é possível a identificação do canal representacional pelo qual o indivíduo se orienta para tomar decisões.

[4]. DAFT, Richard. Organizações - teoria e projetos. $2^{a}$. Ed. São Paulo: Cengage Learning, 2008.

[5]. GIL, Atonio Carlos. Como elaborar Projetos de pesquisa. São Paulo: Atlas, 2007.

[6]. GODOY, Arilda Schmidt. Pesquisa qualitativa: tipos fundamentais. Revista de Administração de empresas, v. 35, n. 3, p. 20-29, 1995.

[7]. THORPE, Richard. Gower handbook of leadership and management development. Chapter 17 - Neurolinguistic Programming for Leaders and 
Managers. In: Gower Handbook of Leadership and Management Development, fifth edition (2010),

[8]. HARRY, Alder. 1996. A ciência e a arte de conseguir o que quer. Rio de Janeiro: Record, 1996.

[9]. KNIGHT, Sue. A programação Neurolinguistica e o sucessos nos negócios. São Paulo: Ediouro,1997.

[10]. KONG, Eric. Developing human capital through neuro-linguistic programming. In: Proceedings of the 8th International Conference on Intellectual Capital, Knowledge Management and Organisational Learning (ICICKM 2011). Academic Publishing, 2011. p. 319-325.

[11]. KLUCZNY, Johann e Texeira, A. Elson. Programação neurolinguística; guia básico para pessoas e empresas. São Paulo: Marron books, 1996.

[12]. KHUJA, Hateem AL et al. The influence of neuro-linguistic programming (nlp) awareness and practices on the individual work performance of lithuanian students. European Journal of Business and Social Sciences, v. 5, n. 09, p. 49-66, 2016.

[13]. JOEY, Lim; YAZDANIFARD, Rashad. Can Neuro-Linguistic Programming (NLP) be used as contemporary and effective skill for an exceptional manager in an organization?. International Journal of Management, Accounting and Economics, v. 2, n. 5 , p. 456-465, 2015.

[14]. LACOMBE, Francisco. Recursos Humanos: princípios e tendências. São Paulo : Saraiva, 2005.

[15]. MANCILHA, Jairo. 2010. Programação NeuroLinguistica aplicada ao ensino ea aprendizagem. 2010.
[16]. MAXIMIANO, Antonio Cesar Amaru. Introdução à Administração. São Paulo: Atlas, 2000.

[17]. Teoria Geral da Administração. São Paulo: Atlas, 2009.

[18]. MINTZBERG, Henry. Managing: desvendando o dia a dia da gestão. Porto Alegre: Bookman, 2010. 304 p.

[19]. NOVO, Damaris Vieira et al. Liderança de Equipes. Rio de Janeiro: FGV, 2009.

[20]. PASSOS, Terezinha. Reaprendendo a viver. Petrópolis: Vozes, 1997.

[21]. ROBBINS, Stephen Paul. Fundamentos do comportamento organizacional. São Paulo: Pearson Prentice Hall, 2005.

[22]. RODRIGUES, Davi. Dicas e estratégias de Programação Neurolinguistica que podem mudar sua vida. In: FURLAN, Jô; SITA, Mauricio. Ser mais com PLN. São Paulo: Ser mais, 2010.

[23]. SANTOS, Eliane. Vejo, escuto e sinto. In: FURLAN, Jô; SITA, Mauricio. Ser mais com PLN Dr. São Paulo: Ser mais, 2010.

[24]. SILVA, Reinaldo O. da. Teorias da Administração. São Paulo: Pioneira-Thomson Learning, 2001.

[25]. SPRITZER, Dr. Nelson. Pensamento \& Mudança. Porto Alegre: L\&PM, 1993.

[26]. VERGARA, Silvia Constant. Gestão de Pessoas. São Paulo: Atlas, 2012. 


\section{Gapítulo 16}

\section{O PAPEL DA GESTÃO DE PESSOAS MEDIANTE A URGENCIA DE QUALIFICAÇ̃OO DA MÃO DE OBRA UTILIZADA NO TURISMO E A OPORTUNIDADE OFERECIDA PELOS MEGAEVENTOS}

\section{Marcia Assunção Alves Barbosa}

\section{Leandro Souza Moura}

Resumo: A inserção do país no calendário dos grandes eventos, aliado a questões internas associadas à política e à economia, somadas a discussões nas esferas das políticas de educação e das relações de emprego sempre acabam envolvendo a reflexão com relação ao papel da gestão de pessoas. Do ponto de vista do turismo, a gestão de pessoas deve ser contextualizada com relação aos potenciais benefícios econômicos e sociais, aos estabelecimentos que atuam direta ou indiretamente na operação e no suporte das operações associadas à atividade turística, e aos milhares de trabalhadores que visualizam nessa atividade boas oportunidades de emprego. Assim, a qualificação dos trabalhadores é fundamental para que não se perca a oportunidade de desenvolvimento econômico e social pelo incremento no turismo gerado pela realização de grandes eventos. O Brasil como país sede da última Copa do Mundo FIFA, que ocorreu em 2014 e futuramente das Olímpiadas de 2016 encontra-se em um momento crucial onde é fundamental planejamento e capacitação da população para que tais eventos perpetuem um legado positivo após sua realização. O essencial neste momento é que o Brasil volte seus esforços e crie projetos que capacitem os profissionais de turismo, com o objetivo de melhorar a qualidade dos serviços prestados nas mais diversas áreas para que este legado seja positivo e que o desenvolvimento econômico do país através da atividade turística possa ser aproveitado durante os anos seguintes. 


\section{INTRODUÇÃO}

A inserção do país no calendário dos grandes eventos, aliado a questões internas associadas à política e à economia, somadas a discussões nas esferas das políticas de educação e das relações de emprego sempre acabam envolvendo a reflexão com relação ao papel da gestão de pessoas. Sarsur (2010) argumenta que a gestão de recursos humanos, em sua prática diária, representa o elo entre três dimensões: (1) a realidade política, econômica e social; (2) a organização na qual se encontra inserida e suas peculiaridades e; (3) Os indivíduos que nela trabalham, cada qual com características próprias. Desse modo, entende-se que, do ponto de vista do turismo, a gestão de pessoas deve ser contextualizada com relação aos potenciais benefícios econômicos e sociais, aos estabelecimentos que atuam direta ou indiretamente na operação e no suporte das operações associadas à atividade turística, e aos milhares de trabalhadores que visualizam nessa atividade boas oportunidades de emprego. Assim, a qualificação dos trabalhadores é fundamental para que não se perca a oportunidade de desenvolvimento econômico e social pelo incremento no turismo gerado pela realização de grandes eventos.

Os eventos, além de fazerem parte da própria transformação da humanidade no decorrer da história (Nakane, Vieira, Rios, 2012), para Getz (2008) "são um importante motivador do turismo, e figura proeminente nos planos de desenvolvimento e marketing da maioria dos destinos". Por ser uma atividade de caráter múltiplo e complexo, o turismo necessita fundamentalmente de estudos com o objetivo de melhorar a compreensão de seus aspectos e evolução sejam feitos (Milito, Marques, Alexandre, 2013). Estima-se que os benefícios da realização de um evento possam ser absorvidos tanto a curto como em longo prazo (Tavares 2011). Um turista satisfeito com os serviços prestados propaga uma imagem positiva do lugar e incita a vinda de outros turistas.

O Brasil como país sede da última Copa do Mundo FIFA, que ocorreu em 2014 e futuramente das Olímpiadas de 2016 encontrase em um momento crucial onde é fundamental planejamento e capacitação da população para que tais eventos perpetuem um legado positivo após sua realização. $O$ comportamento, exigências e preferências dos turistas têm mudado com o passar dos anos, bem como o próprio turismo em si. E é diante de tais mudanças, que se faz necessária uma qualificação do profissional de turismo, focando a prestação de um serviço com primor. Para isso, Ruschmann (apud PAIXÃO e GÂNDARA, 2004.) sugere "que se capacitem os recursos humanos". O crescimento da sociedade a partir da realização de megaeventos esportivos acontece, segundo Horne (2007), devido a três fatores: a criação e disseminação de novas tecnologias de comunicação em massa, o interesse das grandes empresas em patrocinar estes eventos e a possibilidade do megaevento ser utilizado para promoção, divulgação e venda de produtos das grandes empresas.

\section{O TURISTA DE EVENTOS ESPORTIVOS E O DESAFIO DA CAPACITAÇÃO PROFISSIONAL DOS TRABALHADORES DO TURISMO}

Com relação ao turista de eventos, alguns autores (BRITTO e FONTES, 2002; SANTOS e SOUZA, 2012) argumentam que ele busca desfrutar da sua estadia com qualidade e conforto, sendo rigoroso com o serviço que deseja receber, e via de regra, pagam um valor diário consideravelmente maior que um turista de lazer. Falando especificamente sobre o turista de eventos esportivos, Ishy (1998) afirma que ele carrega consigo a necessidade de manifestar a paixão reprimida em seu subconsciente, exaltar seu ídolo no esporte além de usufruir de momentos em que poderá se divertir ao ar livre, afastando-se então de um cotidiano atribulado e ter seu tempo de lazer.

O Ministério do Turismo, no Plano Nacional de Turismo 2013-2016 destaca, entre seus objetivos, a capacitação e qualificação profissional dos gestores de turismo através da criação de ferramentas pedagógicas e tecnológicas para melhorias e atualização de métodos profissionais em diversas áreas do conhecimento. O objetivo da intervenção é "melhorar a qualidade dos serviços prestados ao turista e aumentar a empregabilidade e a competência dos profissionais por meio da qualificação." (BRASIL, 2015a). No tocante à qualificação do trabalhador, Rodrigues (1999) destaca, entre outras coisas, a necessidade de incentivar e desenvolver programas de capacitação no setor governamental municipal e no empresarial, de treinar os recursos humanos locais para o gerenciamento e posições de liderança e de aumentar o status dos recursos humanos em todos os níveis, pois de acordo com o referido autor, a promoção de um sentido de orgulho no trabalho e de 
cuidados para o destino e para a comunidade são essenciais para 0 desenvolvimento turístico. Sendo assim, se por um lado o governo e as empresas têm interesse no desenvolvimento econômico que a prática do turismo de eventos pode proporcionar, por outro lado, para que tal objetivo se realize, o governo e as empresas têm que auxiliar na capacitação profissional.

\section{MEGAEVENTOS NO BRASIL E AS INTERVENÇÕES DO GOVERNO E DA INICIATIVA PRIVADA PARA QUALIFICAR A MÃO DE OBRA PROFISSIONAL}

A experiência do país na realização de grandes eventos vinha se sedimentando. Em termos de eventos com visibilidade internacional, o carnaval é provavelmente a experiência mais significativa do país, mas o ano de 1984 marcou o primeiro Rock in Rio, que já teve edições fora do país, grandes nomes da música mundial, como Luciano Pavarotti e Frank Sinatra, assim como astros da música pop internacional como Michael Jackson, Madona e Paul Mc McCartney já se apresentaram em grandes estádios do país como o Maracanã. Em 1950 o país já havia sediado uma Copa do Mundo de Futebol, mas em termos de grandiosidade e complexidade nada se compara à Copa do Mundo FIFA 2014 e às Olimpíadas de 2016. O Brasil é o primeiro país da América do Sul a sediar os Jogos Olímpicos e Paraolímpicos. O interesse dos países em sediar eventos desse porte é enorme devido a gama de benefícios que podem ser gerados em longo prazo.

De acordo com Milito, Marques e Alexandre (2013) os megaeventos se apresentam como uma forma de atrair a demanda turística internacional e gerar desenvolvimento econômico para a região onde eles são realizados, pois em prol do evento há uma transformação da infraestrutura local e é propagada uma imagem turística do destino em questão em âmbito global. Tavares (2011) destaca que alguns benefícios ocorrem no longo prazo tendo em vista que a promoção de uma cidade ou região como destino turístico fomenta o incremento de gastos turísticos.

No que se refere a projetos desenvolvidos para capacitação profissional, D'Ailto e Noronha (2008) citam como exemplo um que foi desenvolvido em dezembro de 2005, pela Confederação Brasileira de Remo (CBR), denominado Programa de Voluntários da CBR. Esse programa tinha como objetivo principal o desenvolvimento e integração de pessoas, com foco na gestão de recursos humanos, dando prioridade à capacitação específica e ao treinamento para as funções pertinentes às competições de Remo dos Jogos Panamericanos. A missão da CBR para este programa foi de garantir a assimilação da ideologia, dos valores e das metas da Confederação por meio do treino adequado, sempre visando o desenvolvimento total do indivíduo. Na visão da entidade, "a preparação específica do voluntário técnico para atuar na modalidade foi considerada necessária e fundamental para o sucesso do evento na modalidade remo." (D'Aiuto e Noronha, 2008). O desafio da qualidade por sua vez, conforme Paixão e Gândara (2004), é algo complicado tendo em vista que o consumidor está sempre à procura do deslumbre através dos serviços prestados. E no que diz respeito ao turismo, a qualidade na prestação de serviços também depende da qualidade dos equipamentos turísticos, do apoio à infraestrutura e da conexão entre o turista e o núcleo receptor.

O Ministério do Turismo (BRASIL, 2014) por sua vez promove duas ações estratégicas para capacitação profissional: uma para a estruturação da Política Nacional de Qualificação Profissional do Turismo e outra relativa a ações complementares de qualificação.

A Política Nacional de Qualificação Profissional do Turismo visa majorar a escolaridade média dos trabalhadores, além de viabilizar a entrada de jovens no mercado de trabalho, desenvolvendo suas capacidades. Esse Programa tem como objetivos:

- Baixar a taxa de rotatividade para garantir retorno no processo de qualificação e manutenção de investimentos em formação;

- - Inserir maior número de jovens no setor;

- - Aumentar os anos de formação formal média dos trabalhadores do setor;

- Elevar o nível de qualificação profissional dos trabalhadores do setor;

- - Promover, em parceria com o setor privado, a formação continuada e progressiva dos trabalhadores.

O Ministério do Turismo acredita que, atingindo tais objetivos haverá uma melhoria na qualidade dos serviços prestados e, consequentemente na empregabilidade da 
população brasileira. Já as ações complementares, estão voltadas para cursos nos seguintes campos:

- - Transportes de passageiros: taxistas, motoristas e cobradores de ônibus e motoristas de agências locadoras de veículos.

- $\quad$ - Alimentação fora do lar: vendedores de área de circulação turística (quiosques de praias, feiras, baianas, ambulantes de alimentos, atendentes de bares e cafés de aeroportos, rodoviárias e portos) e permissionários de mercado público.

- - Atendimento turístico: atendentes de Centro de Atendimento Turístico - CAT e de atrativos turísticos naturais e culturais.

- - Gestão: empresários e gerentes de empreendimentos turísticos (segmento de Meios de hospedagem e Alimentos e bebidas).

- - Segurança pública (policial militar, policial civil, bombeiro, guarda municipal e salva-vidas).

Além das ações citadas anteriormente, o Ministério do Turismo juntamente com o Ministério da Educação desenvolveram, em 2011 o Programa Nacional de Acesso ao Ensino Técnico e Emprego, mais conhecido por PRONATEC. O objetivo principal é "expandir, interiorizar e democratizar a oferta de cursos de Educação Profissional e Tecnológica (EPT) para a população brasileira". O projeto prevê a oferta de oito milhões de vagas no decorrer de quatro anos (BRASIL, 2015b). O programa divide-se em quatro linhas de ação: PRONATEC Turismo Cidadão; PRONATEC Turismo na Empresa; PRONATEC Turismo Social e; PRONATEC Turismo e Desenvolvimento Local. Paixão e Gândara (2004) destacam que a primazia com que o profissional executa seus serviços no turismo advém, muitas vezes, de atributos que este aprende, aperfeiçoa e desenvolve em cursos técnicos, profissionais e superiores na área. O especialista, quando bem capacitado em seus cursos, adquire uma visão mais ampla do setor e consegue compreender melhor as exigências do mercado, consequentemente ampliando suas chances de ser absorvido por ele (PAIXÃO e GÂNDARA, 2004).

Uma pesquisa sobre a demanda turística internacional durante a Copa do Mundo FIFA 2014 (BRASIL, 2014) abordou aspectos como o perfil do visitante, caracterização da viagem, satisfação com a viagem e intenção de retorno.
Neste documento, na avaliação sobre os serviços turísticos, apesar de boa parte dos serviços turísticos terem recebido uma nota acima de 90.0 o tópico de "Atendimento no seu idioma" recebeu uma nota 58,9, consideravelmente inferior aos demais aspectos avaliados. Esse fato registra que ainda há uma falta de qualificação no fornecimento de um serviço mais personalizado ao turista, fator que influencia também em seu retorno, pois um turista satisfeito e bem atendido tende a propagar uma imagem positiva do país, retornar e gastar mais, fazendo com que novos empregos sejam criados e a comunidade local desfrute de uma renda e bem-estar maior (PAIXÃO e GÂNDARA, 2004).

\section{CONSIDERAÇÕES FINAIS}

As oportunidades de sediar eventos deste porte já foram dadas ao Brasil e, diante das pesquisas feitas com base na realização destes megaeventos em outros países, é possível estudar os pontos fracos e fortes, positivos e negativos no quesito de prestação de serviços voltado ao público destinado a prestigiar tais espetáculos. Como visto anteriormente, o Plano Nacional de Turismo 2013-2016 visa melhorias significativas na economia a partir principalmente da realização destes eventos. Contudo, é fundamental a preparação dos profissionais e a qualificação da mão-de-obra local para que, a partir do fluxo de turistas gerado, esse crescimento venha ser real.

Além disso, para que os impactos na economia estendam-se para além do período de realização dos Jogos Olímpicos e da Copa do Mundo, a experiência vivenciada pelo turista deve ser positiva, afim de que este dissemine uma imagem positiva do país para aqueles que o cercam. A imagem passada pelo turista sobre a sua experiência para outras pessoas de seu convívio social pode estimular a vinda destes que, além da exposição mundial gerada pelos megaeventos e de todo o marketing internacional que isso proporciona, poderá contar também com a avaliação de pessoas próximas, o que aumenta muito a confiança do turista em potencial para que ele se torne um turista efetivo.

O essencial neste momento é que o Brasil volte seus esforços e crie projetos que capacitem os profissionais de turismo, com o objetivo de melhorar a qualidade dos serviços prestados nas mais diversas áreas para que este legado 
seja positivo e que o desenvolvimento econômico do país através da atividade

\section{REFERÊNCIAS}

[1]. BRASIL. Ministério do Turismo. Estudo da Demanda Turística Internacional durante a Copa do Mundo da FIFA 2014. Brasília, ago. 2014. Disponível em:

http://www.dadosefatos.turismo.gov.br/export/sites/ default/dadosefatos/outros_estudos/downloads_out rosestudos/Estudo_da_Demanda_Internacional__Brasil_-_Copa_2014_1.pdf. Acesso em 20/06/2015

[2]. Plano Nacional de Turismo 20132016. Disponível em: www.turismo.gov.br. Acesso em 05/07/2015a.

[3]. PRONATEC Turismo. Disponível em: http://pronatec.turismo.gov.br/pronatec. html. Acesso em 05/07/2015b.

[4]. BRITTO, Janaina. FONTES, Nena. Estratégias para Eventos: Uma Ótica do Marketing e Do Turismo. São Paulo: Ed. ALEPH (Série Turismo), 2002.

[5]. D’AILTO, Andréa; NORONHA, Júlio. O programa de gestão de voluntários técnicos do Remo para os Jogos Pan-americanos Rio 2007. IN: DA COSTA et al (Ed.). Legados de Megaeventos Esportivos. Brasília: Ministério do Esporte, 2008.

[6]. GETZ, Donald. Event tourism: Definition, evolution, and research. Tourism Management, $v$. 29, p. 403-428, 2008.

[7]. HORNE, J. The Four 'Knows' of Sports Mega-Events. Leisure Studies, vol. 26, n. 1, p. 81-96, 2007.

[8]. ISHY, Morupi. Turismo e megaeventos esportivos. Revista Turismo em Análise, São Paulo, v. 9, n. 2, nov. 1998

[9]. MILITO, Marcelo Chiarelli; MARQUES, Sérgio; ALEXANDRE, Mauro Lemuel. Percepção do turística possa ser aproveitado durante os anos seguintes.

Residente em Relação a Turismo e Megaevento: análise bibliométrica de periódicos internacionais e latino-americanos. Turismo em análise, São Paulo, v.24, n.3, p. 482-502, Dezembro 2013

[10]. NAKANE, Andréa; VIEIRA, Francisco de Canindé gentil; RIOS, Gleiva Félix de Araújo. Voluntariado: A Essência da Hospitalidade como Fator crucial para Elevada Performance dos Megaeventos Esportivos no Brasil. TURyDES: Revista de investigacion en turismo y desarrollo local. v.5 n. 12. Jun./Jul. 2012. Disponível em http://www.eumed.net/rev/turydes /12/nvr.pdf

[11]. PAIXÃO, Dario Luiz Dias; GÂNDARA, José Manoel Gonçalves. A Relação entre Formação de Recursos Humanos e o Desenvolvimento Sustentável do Turismo: uma análise da educação turística na cidade de Curitiba/PR. Anais do V Seminário Internacional de Turismo. Curitiba: UnicenP, 2004

[12]. RODRIGUES, Adyr. Turismo e Espaço. 2ed. São Paulo: Ed. HUCITEC, 1999.

[13]. SANTOS, Rodrigo Amado dos; SOUZA, Norma de Sitta. Eventos Esportivos e Turismo: Definição de Mercado e Perspectivas de Atuação. Revista Científica Eletrônica de Turismo. Ano IX, n. 16, Jan. 2012

[14]. SARSUR, Amyra Moyzes. Empregabilidade como uma "Nova" Gestão de Recursos Humanos. IN: BITENCOURT, Claudia (org.). Gestão Contemporânea de Pessoas: novas práticas, conceitos tradicionais. 2ed. Porto Alegra: Bookman, 2010.

[15]. TAVARES, Otávio. Megaeventos Esportivos. Movimento, Porto Alegre, v. 17, n.3, p.11-35, jul./set. 2011. 


\section{Capítulo 17}

IMPACTOS DA CRISE ECONÔMICA BRASILEIRA NA GESTÃO DE RECURSOS HUMANOS: UM ESTUDO EM HOSPITAIS DO INTERIOR DE MINAS GERAIS

\section{Matheus Toledo Cupertino}

Junio Vasconcelos Soares

Patrícia Souza Luz, Fritz

Resumo: O Brasil atravessa uma grave crise econômica que afeta diretamente as organizações. Diante deste cenário de fortes pressões sobre as empresas, esta pesquisa teve como objetivo compreender os impactos causados pela atual crise nas organizações hospitalares, em especial no que se refere à Gestão de Recursos Humanos (GRH), utilizando como objeto de análise três hospitais da cidade de Muriaé, situada no interior do Estado de Minas Gerais. O estudo revelou que os impactos foram com relação a movimentações de pessoal e a gratificações salariais e revelou ainda que as organizações adotaram uma postura proativa diante da situação a fim de conscientizar suas equipes a ajudar a empresa a superar o difícil momento.

Palavras chave: Crise econômica. Gestão de Recursos Humanos. Impactos na GRH. Gestão Hospitalar. Gestão de Pessoas. 


\section{INTRODUÇÃO}

A crise econômica que o Brasil atravessa é um dos assuntos mais comentados, se não o mais, dos últimos tempos. Quedas de investimentos no país e falhas no sistema político são alguns dos fatores apontados como causas do fenômeno. Cunha et al (2015) atribuem também a sequência de aumentos dos juros que acabaram freando o consumo, derrubando o emprego e a renda disponíveis e realimentando o ciclo de crise, aprofundando ainda mais a recessão.

O reflexo foi imediato nas empresas e nos indicadores econômicos nacionais: a atividade produtiva decresceu, o Produto Interno Bruto (PIB) também, assim como aumentaram as demissões e caiu o nível de emprego. Para diminuir o impacto deste cenário, as empresas foram desafiadas a rever seus processos e estruturas e a reduzirem seus custos, bem como a estimularem suas equipes a, mais do que nunca, vestirem a camisa da empresa e ajudá-la a sobreviver num cenário tão desfavorável. Assim, o presente artigo pretende entender melhor os impactos causados pela atual crise econômica nas organizações, em especial no que se refere à Gestão de Recursos Humanos (GRH), utilizando como objeto de análise três hospitais situados na cidade de Muriaé, interior do Estado de Minas Gerais. Ademais, o estudo guiou-se pelos seguintes objetivos:

- identificar os impactos da atual crise econômica na GRH dos hospitais muriaeenses; e

- identificar, de acordo com a análise do discurso dos gestores de Recursos Humanos $(\mathrm{RH})$ das instituições, as principais medidas tomadas pelos hospitais para sobreviver neste cenário e para conscientizar seus funcionários. A escolha do segmento hospitalar para a realização da pesquisa justifica-se por este ter sido afetado pela crise econômica, visto que com o aumento do desemprego, inúmeras pessoas perderam o acesso a benefícios que estavam atrelados a seus empregos, como o convênio médico, o que diminuiu, de certa forma, o acesso e a demanda por serviços de saúde. Em um contexto mais local, no ano de 2016 um convênio médico da cidade de Muriaé foi à falência, deixando na mão um grande número de usuários.

Espera-se que a pesquisa agregue conhecimentos ao campo de estudos da Gestão Empresarial e da Gestão de RH, que possa auxiliar na compreensão dos impactos da crise mediante uma análise da realidade e ainda que auxilie gestores de $\mathrm{RH}$ a tomarem decisões adequadas para $\mathrm{O}$ momento em questão.

\section{REFERENCIAL TEÓRICO}

\subsection{A CRISE ECONÔMICA E AS ORGANIZAÇÕES}

De acordo com o dicionário Michaelis Online, crise é: "[...] conjuntura desfavorável; situação anormal e grave; conflito, tensão, transtorno [...]" e é nesta situação que a economia brasileira se encontra desde 2014. O país passa por um momento político delicado, que afeta diretamente sua imagem e o faz perder credibilidade perante investidores internacionais, além de modificar o ciclo regular dos negócios públicos e privados.

Para Pires (2016), é possível afirmar que essa crise teve como causas dois grandes períodos:

- o primeiro período foi marcado por um conjunto de políticas que não se mostraram suficientes para sustentar o crescimento econômico que a economia havia apresentado até 2011;

- o segundo período se refere ao enorme conjunto de choques negativos que começaram a atingir o país desde 2014.

De acordo com o mesmo autor, tais choques foram: os termos de troca, a crise hídrica, o realinhamento de preços monitorados, os desinvestimentos da Petrobrás e a depreciação da taxa de câmbio. Cunha et al (2015) acrescentam também o aumento da inflação, que desencadeou uma forte pressão sobre os preços ao consumidor, afetando o poder de compra dos assalariados. "Na sequência desses choques, vários outros efeitos secundários aprofundaram a recessão como o aumento da taxa de juros, aumento do desemprego, a queda da renda, a contração do mercado de crédito e a redução dos investimentos públicos" (PIRES, 2016, p. 249).

Todos estes fatores influenciaram diretamente os principais agentes econômicos: as empresas. Sgarbossa, Lopes e Kemper (2016), afirmam que os impactos decorrentes da crise econômica na produção industrial surgiram por meio das vias comerciais e creditícias, pois a falta de crédito veio com o enfraquecimento dos mercados financeiros e com isto, a indisponibilidade de aquisição de grandes empréstimos destinados à produção afetou o nível de investimento na economia 
brasileira, bem como as expectativas dos agentes.

Este cenário exigiu dos gestores empresariais a adoção imediata de medidas para sobrevivência das organizações. Em períodos de crise é necessário criar novas oportunidades e repensar estratégias.

Para reduzir custos e manter a competitividade em tempos difíceis, as organizações contam com alternativas como revisão de contratos com fornecedores, venda de ativos e redução do quadro de pessoal. Sgarbossa, Lopes e Kemper (2016) realizaram pesquisa junto a gestores de 35 empresas e constataram que para eles, a principal forma de sair da crise é reduzir custos, seguida de investir em novidades. No entanto, uma parcela também afirmou acreditar que aumentar a produção ou demitir são soluções. Contudo, esta última foi a alternativa mais utilizada pelas organizações brasileiras para sobreviverem em meio a crise econômica em questão.

Como se não bastassem os impactos nas estruturas financeira e produtiva, as organizações também foram afetadas na estrutura humana. Grandes foram os números de demissões e cortes de pessoal realizados pelas empresas e anunciados pela mídia em geral. O resultado é visível na Relação Anual de Informações Sociais (RAIS) 2015. De acordo com o documento do Ministério do Trabalho, o número de empregos formais em dezembro/2015 sofreu uma queda de 3,05\% em relação ao mesmo período em 2014, o que correspondeu, em termos absolutos, a uma perda de 1.510.703 (um milhão, quinhentos e dez mil, setecentos e três) postos de trabalho. Em decorrência, o contingente de vínculos formais no Brasil caiu de 49,6 milhões para 48,1 milhões. Consoante Tonelli (2000), a demissão e seu corolário imediato - o desemprego - têm sido vistos como inevitáveis diante dos ajustes necessários à sobrevivência das empresas.

Pires (2016) acredita que o triênio 2014/2015/2016 representa a mais grave recessão que atingiu o Brasil. Em suma, diante de um cenário tão desfavorável, as organizações saíram de seu curso regular e perderam competitividade.

\subsection{A GESTÃO DE RECURSOS HUMANOS}

A área de Recursos Humanos, um dos departamentos organizacionais mais conhecidos, é responsável por todas as atividades que envolvem o elemento humano nas organizações, como recrutamento e seleção (R\&S) e administração de cargos e salários, entre outras. Porém, as funções deste departamento se modificaram ao longo dos anos, conforme evoluiu a teoria administrativa e o pensamento sobre o papel do homem nas organizações. Wood Jr, Tonelli e Cooke (2011) apresentam uma análise histórica dessa evolução no Brasil nos últimos 60 anos divididos em dois períodos, os quais denominaram Colonização e Neocolonização da $\mathrm{GRH}$. As principais mudanças ocorridas na $\mathrm{GRH}$ em cada período, de acordo com a análise dos autores, são apresentadas na figura a seguir:

Figura 1 - Principais mudanças ocorridas na GRH nos períodos de Colonização e de Neocolonização

\begin{tabular}{|c|l|}
\hline \multicolumn{1}{|c|}{ Período } & \multicolumn{1}{|c|}{ Principais mudanças } \\
\hline Colonização da GRH (1950-1980) & $\begin{array}{l}\text { Introdução de princípios de divisão do trabalho } \\
\text { Introdução de valores relacionados à meritocracia } \\
\text { Introdução de práticas de GRH, tais como } \\
\text { recrutamento, seleção, treinamento e } \\
\text { desenvolvimento }\end{array}$ \\
\hline Neocolonização da GRH (1980-2010) & $\begin{array}{l}\text { Busca de um melhor alinhamento da GRH com os } \\
\text { objetivos empresariais } \\
\text { Adoção intensiva de novos modelos e práticas } \\
\text { Adoção de uma nova retórica }\end{array}$ \\
\hline
\end{tabular}

Fonte: Adaptado de Wood Jr, Tonelli e Cooke (2011, p. 234 e 236). 
Em sua obra, Souza (2016) também faz uma contextualização da função $\mathrm{RH}$ nas organizações e aponta as evoluções ao longo dos anos. A visão inicial do elemento humano nas organizações foi marcada por uma concepção robótica e mecanicista. Os primeiros formuladores de teorias em Administração acreditavam que as pessoas eram meros repetidores de tarefas, as quais deviam ser executadas dentro de padrões de tempo e qualidade predeterminados e aceitáveis, desconsiderando a subjetividade e a fragilidade humanas. Com o passar do tempo, o advento da globalização e suas influências no universo organizacional, mudanças foram necessárias.

O aumento na instabilidade ambiental e, particularmente, o acirramento da competição colocaram a questão da mudança como central para a sobrevivência das organizações. O foco passou a ser mudar para criar uma performance competitiva (WOOD JR, 2009, p. 264).

Não obstante, as rápidas mudanças advindas com a globalização também afetaram a função $\mathrm{RH}$. Com a chegada de novos estudiosos ao meio organizacional e suas pesquisas, a concepção mecanicista inicial foi sendo, aos poucos, deixada de lado e construtos como motivação e satisfação no ambiente de trabalho passaram a ser considerados. Estes estudos marcaram o início do empoderamento do homem, também entendido como a valorização de suas características pessoais e percepção destas como vantagem competitiva para as organizações e marcaram o início de uma nova fase, agora estratégica, para o departamento de $\mathrm{RH}$. Além das atividades tradicionais do departamento, falam-se agora também em gestão de carreiras, treinamento e desenvolvimento (T\&D), avaliação de desempenho, coaching e benefícios.

O papel estratégico a ser desempenhado passa a ser repensar as atividades próprias da área de RH em termos estratégicos, ou seja, de forma a integrar os objetivos de longo prazo da organização, as variáveis relevantes do ambiente e as necessidades decorrentes em termos de pessoas (LACOMBE; TONELLI, 2001, p. 159).

Em síntese, a nova função $\mathrm{RH}$ agora integra a cúpula das organizações e representa vantagem competitiva para elas. Este departamento tornou-se ainda um alocador de muito capital financeiro, visto que aumentaram as remunerações com bônus por mérito e conhecimento. Fischer (1998, p. 126), argumenta que o modelo de $\mathrm{RH}$ estratégico tem como objetivo principal "superar a visão técnica, tornando os mecanismos de gestão de pessoas alinhados à estratégia de negócio da empresa [...] fazendo com que a visão de Recursos Humanos interfira na definição da estratégia negocial".

\section{METODOLOGIA}

De acordo com as definições de Gil (2008), esta pesquisa se caracteriza como descritiva quanto aos objetivos e como estudo de campo quanto aos procedimentos técnicos.

Utilizou-se como objetos de análise hospitais da cidade de Muriaé - MG, representados por seus gestores de Recursos Humanos. A cidade conta atualmente com quatro hospitais e o estudo visou atingir todos os estabelecimentos guiando-se pelo critério de disponibilidade dos hospitais em participar da pesquisa, no entanto, 1 (um) dos hospitais não pôde participar, portanto a pesquisa foi realizada com gestores de $\mathrm{RH}$ em três hospitais, a fim de captar a percepção dos mesmos sobre o impacto da atual crise em seus respectivos estabelecimentos.

Foram coletados dados primários a partir de entrevistas semiestruturadas com roteiro criado exclusivamente para atender aos objetivos do estudo e as mesmas, após gravadas em dispositivo portátil, foram transcritas e analisadas sob a técnica de Análise de Conteúdo. Souza (2014, p. 243) define a Análise de Conteúdo como "técnica de tratamento dos conteúdos veiculados por meio de documentos escritos, em discursos mais espontâneos ou em discursos provocados [...]" e o mesmo autor esforça-se na definição e caracterização da técnica como "uma estratégia privilegiada de tratamento de dados, graças ao seu grau de sistematização".

De forma a manter a confidencialidade, os hospitais serão doravante chamados de $\mathrm{H} 1$, $\mathrm{H} 2$ e $\mathrm{H} 3$ e seus respectivos gestores de Recursos Humanos, de GRH1, GRH2 e GRH3.

\section{RESULTADOS E DISCUSSÃO}

Os gestores de $\mathrm{RH}$ foram questionados sobre os impactos causados pela atual crise econômica na Gestão de Recursos Humanos dos hospitais e o apontamento inicial de todos eles foi com relação às movimentações de 
pessoal. No entanto, o fato ocorreu de formas diferentes em cada instituição.

Os gestores de $\mathrm{H} 1$ e $\mathrm{H} 3$ afirmaram que a crise não afetou o quadro de pessoal a ponto de requerer redução, mas manutenção. A situação fez com que as instituições tivessem que cancelar projetos de ampliação do quadro e trabalhar com equipes mais enxutas, conforme declararam os gestores:

A crise não afetou a gente numa situação de a gente ter que diminuir despesas com pessoal, mas sim de abrir novas vagas, entendeu? $O$ leque de possibilidades para " $N$ " setores aqui de a gente dar uma melhorada em alguns processos que às vezes demandam de mais mão de obra não pôde continuar com andamento, teve que cessar mesmo justamente por causa desses problemas financeiros. (GRH1)

Nós não tivemos um impacto porque nós não desligamos ninguém, claro que também começamos a fazer uma análise mais consciente dos nossos recursos, a questão de evitar desperdícios e trabalhar com a equipe o momento de crise. Os desligamentos que a gente faz são por questões de competências, de parte comportamental que às vezes acontece e aí sim nós tivemos alguns cargos que não foram repostos. Fomos mais conscientes com relação à abertura de processos seletivos, trabalhando com a equipe mais enxuta, revendo processos pra gente poder ver o que é possível fazer. (GRH3)

Todavia, pode-se inferir que neste sentido $\mathrm{H} 1$ foi mais impactado, pois no momento demandava de aumento do quadro de pessoal, conforme apontou GRH1:

Um setor que às vezes a gente quer implantar um processo igual a gente tá num processo de acreditação, a gente demanda às vezes de mais pessoal. A gente já tem uma base pronta pra o assistencial, a gente está buscando acreditação que é a melhoria de processos e dentro dessa melhoria de processos a gente demanda de mais pessoal, mas a gente não pode, então a gente estar escasso nisso acaba que sobrecarrega os que já estão aqui. (GRH1)

Verifica-se que o impacto foi o mesmo em ambas as instituições hospitalares e que os gestores afirmaram que o mesmo se deveu a fatores financeiros, no entanto, com causas diferentes em cada instituição. GRH1 explicou:

Se o governo não tem verba, ele não repassa pro hospital e, se repassa, ele não repassa tudo, entendeu? Então vamos dizer, os hospitais eles faturam (faturar que eu digo = eles produzem) e não têm o recurso pra bancar aquele custo que ele já teve, tanto fixo quanto variável. Então isso não sobra na questão do investimento pra gente poder melhorar algumas coisas aqui dentro na questão de pessoal. (GRH1)

Para GRH3, a causa está ligada à mudança de perfil dos clientes, os pacientes:

É claro que o cenário impactou e não só impactou na questão de Recursos Humanos, impactou porque os nossos clientes que tinham convênio também migraram para o SUS. Então a gente teve bastante pessoas que tinham convênio e pela crise acabaram indo para o SUS e isso compromete a receita do hospital, porque o convênio, a saúde suplementar, a gente recebe um valor maior do que o próprio SUS que é um pacote. (GRH3)

Já no caso de H2, seu gestor de Recursos Humanos foi incisivo ao dizer:

Não. A crise não chegou a afetar a área da saúde a nível de contratação e demissão. Foi aleatório: se tiveram duas ou três demissões num mês, tiveram duas ou três contratações. Certo? Mas isso não por conta da crise, por conta do quadro de funcionários mesmo, por conta da ética do profissional dentro do estabelecimento. (GRH2)

As diferentes percepções dos gestores podem estar ligadas às situações específicas de cada uma de suas organizações, pois os hospitais estudados trabalham tanto com atendimentos gratuitos - via Sistema Único de Saúde (SUS) - quanto particulares, cujos pagamentos a eles pelos serviços prestados se dão de formas diferentes. Salienta-se também que as proporções de cada tipo de atendimento variam de hospital para hospital.

A figura abaixo mostra o contingente de empregados de cada hospital ao final dos exercícios de 2014, 2015 e 2016: 
Figura 2 - Contingente de empregados de cada hospital ao final dos exercícios de 2014, 2015 e 2016

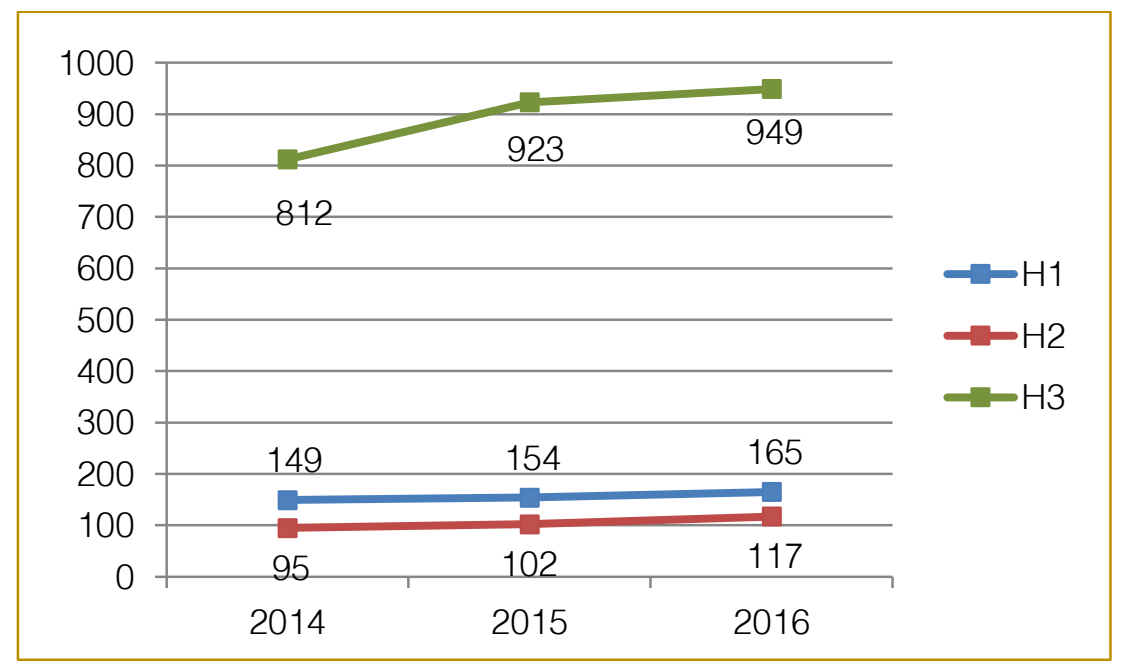

Fonte: Os autores.

Pochmann (2009), averiguando outro período de crise, apontou que diante da queda na expansão da produção, as demissões cresceram acima das contratações, fazendo com que trabalhadores perdessem empregos e que os novos ingressantes no mercado de trabalho não tivessem possibilidades de trabalhar. O fato se repetiu na atual crise com os hospitais estudados, como corroboram os dados apresentados anteriormente.

Ainda com relação às movimentações de pessoal, GRH3 acrescentou:

Como a gente está num momento de crise, de retração, a gente está contratando menos, então a gente está mandando menos pessoas ir embora porque as pessoas estão mais comprometidas. (GRH3)

É interessante relacionar a fala de GRH3 com o estudo de caso realizado por Rezende (2016) em uma empresa de grande porte abordando o comprometimento organizacional no contexto de crise econômica atravessada pelo Brasil. A pesquisa mostrou que mesmo num contexto de instabilidade econômica que afetou diretamente a organização estudada, os executivos demonstraram atitudes engajadas de comprometimento e perceberam diferentes formas de comprometimento em suas equipes.

Ao serem questionados sobre impactos relacionados a questões salariais e de benefícios oferecidos pela empresa, se algum teve que ser cancelado ou suspenso, os gestores de Recursos Humanos de $\mathrm{H} 1$ e $\mathrm{H} 2$ afirmaram que não houve impactos, pois esta questão é definida junto aos sindicatos.
Benefício não, porque a maioria, a questão dos benefícios da empresa eles já são estipulados, já são assegurados por acordo coletivo e registrados junto ao Ministério do Trabalho, então não tem como muito fugir à regra. $(\mathrm{GRH} 1)$

A gente tem por ano aqui, todo ano a gente tem um acordo coletivo firmado entre o órgão de saúde com o sindicato, ou seja, todo mês de fevereiro do ano existe um acordo coletivo onde faz essa interligação com o sindicato estipulando um aumento de salário. Certo? (GRH2)

Todavia, GRH1 comentou sobre gratificações definidas pela empresa sem intermédio sindical:

O que acontece na situação de salários é que realmente devido se a gente não está podendo contratar a gente também não está podendo melhorar o que a gente já tem aqui, entendeu? A gente até pede a compreensão de alguns funcionários [...] só que nessa situação acaba que a gente realmente é afetado e a gente não tem como fazer essa melhoria porque não existe um peso de duas medidas, se a gente trabalhar num reconhecimento aqui horizontal, várias pessoas, não vai ser um ou outro, vão ter um leque de profissionais que vão ter acesso a este tipo de gratificação dentro da remuneração e a gente não tá podendo ter essa despesa no momento, entendeu? (GRH1)

GRH3 não apontou impactos com relação a salários, afirmou apenas que no período a empresa suspendeu um de seus benefícios, mas que a causa não foi relacionada à crise. 
Contudo, subentende-se que a mesma também tem seus salários definidos com 0 apoio do sindicato.

É comum que momentos difíceis também interfiram no clima organizacional e que nestes momentos, as organizações busquem ampliar a sinergia entre suas equipes para, com o apoio de todos, superar o momento. Algumas das instituições pesquisadas tiveram esta preocupação. Em H1, aproveitou-se da fase de busca por acreditação pela qual a empresa passava para aplicar ferramentas de qualidade com o objetivo de obter ganhos de produtividade:

Então, igual eu te falei, a gente está numa fase de acreditação [...] aí dentro dessa fase de acreditação, a gente está trabalhando na questão da melhoria contínua pra gente adquirir selo de qualidade e tudo mais e dentro disso há e até foi aplicada uma ferramenta que pra muitos é lúdica mas que funciona, que é a ferramenta 5S pra gente trabalhar entre os funcionários e dentro disso aí envolve até o próprio autoconhecimento do funcionário aqui dentro pra ele saber qual a importância dele aqui dentro, pra ele comprar a causa também, entendeu? (GRH1)

H3 mostrou-se precocemente preocupada em alertar seus funcionários:

Logo que ela começou, então a gente já teve essa preocupação no início da crise, de trazer alguém aqui pra falar sobre isso [...] e falou da importância de a gente estar valorizando porque quem está fora está querendo entrar e quem está dentro tinha que segurar o seu trabalho. E como segurar, ne? Colaborando com a empresa. É apagando uma luz, é não gastando copo descartável... parte de Enfermagem: material, luvas ne, toda essa parte. Então assim, todo mundo cooperando pra que a gente não precisasse de mexer no que é mais importante pra empresa que são as pessoas. (GRH3)

\section{E comemorou:}

E nós conseguimos! A gente não precisou até o momento de mandar ninguém embora, nós não tivemos nenhum desligamento por crise. (GRH3)

H3 também buscou apoio dos gestores departamentais e encontrou nas reuniões de rotina outra alternativa para conscientizar seus empregados:

[...] nós precisamos de disseminar essa consciência e aí como? Trazendo reportagens, mostrando o que está acontecendo. Nós temos reuniões de gestores aqui [...] então a gente pede pra que eles nessas reuniões, trabalhem esse tema com suas equipes e é muito interessante porque eles sabem ne, às vezes não ligam, mas quando você conversa [...] então aí a gente pega e tenta "linkar" com a importância ne, o que ele tem, a importância dele estar aqui dentro, de ser uma empresa que honra com compromissos [...]. A gente precisa de criar a consciência no colaborador.

Já em H2 não se percebeu muita preocupação, afirmando o gestor apenas que:

Uma vez por mês a gente tem uma reunião informando os indicadores da empresa, de todos os setores. Entendeu? O que teve de receita no mês e o que teve de despesa. Em cima destes formulários é feito um plano de ação tentando reverter o quadro. Entendeu? (GRH2)

Percebeu-se que embora os hospitais tenham agido proativamente diante da situação, as formas de conscientização apresentaram diferentes níveis de intensidade em cada um deles. Este fato também pode estar relacionado a características específicas de cada hospital como a política de gastos, visto que $\mathrm{H} 3$ contratou um palestrante externo e que $\mathrm{H} 1$ e $\mathrm{H} 2$ se aproveitaram de eventos atuais e cotidianos (processo de acreditação e reunião mensal, respectivamente) para conscientizar seus funcionários.

Finalmente, acrescenta-se uma afirmação interessante de GRH3, que ao concluir seu discurso sobre o momento que requer ampliação da sinergia entre a equipe, apontou, excentricamente, um impacto positivo da crise:

Tudo tem pontos bons e pontos ruins, esse é um ponto que favorece, se a gente sabe trabalhar esses pontos dentro da empresa, então a gente tem a ganhar, então como a gente tinha essa situação ne, a nossa rotatividade está muito menor, depois que a gente teve a crise a gente está com uma rotatividade muito menor, eu estou tendo muito menos substituição. E é o momento de trabalhar isto, as pessoas estão sensíveis para isso e a gente não pode perder, é um momento que você tem e ele não volta, entendeu? Então você tem que aproveitar. Porque quando você cria o hábito, você tem que criar o hábito e aí vira rotina, aí pode vir, pode estar ótimo que ele vai estar mantendo aquela conduta, aquela atividade dele. (GRH3) 


\section{CONSIDERAÇÕES FINAIS}

O presente estudo buscou compreender os impactos causados pela atual crise econômica nas organizações hospitalares, em especial no que se refere à sua Gestão de Recursos Humanos.

Pode-se afirmar que o objetivo foi alcançado em sua integralidade. O estudo sobre o impacto da atual crise na GRH dos hospitais da cidade de Muriaé - MG revelou que os impactos foram com relação a movimentações de pessoal - sendo este o maior - pois as organizações tiveram que deixar de contratar novos funcionários e trabalhar com equipes reduzidas; e com relação a gratificações salariais, que tiveram de ser paralisadas por escassez de recursos financeiros.

O estudo revelou também que as organizações adotaram uma postura proativa diante da situação a fim de conscientizar suas equipes a ajudar a empresa a superar o momento, informando seus funcionários sobre a

\section{REFERENCIAS}

[1]. Cunha, J. S.; Andrade, M.; Lopes, C.; Nascimento, M.; Valverde, T. Crise mundial e a trajetória do rasil, entre 2008 e 2015. Cadernos do CEAS (online), n. 234, p. 4-46, 2015. Disponível em: $<$ https://cadernosdoceas.ucsal.br/index.php/cader nosdoceas/article/view/12>. Acesso em 02/04/2017.

[2]. Fischer, A. L. A constituição do modelo competitivo de gestão de pessoas no Brasil: um estudo sobre as empresas consideradas exemplares. 1998. 391 p. Tese (Doutorado em Administração). Faculdade de Economia, Administração e Contabilidade da Universidade de São Paulo. Disponível em: <http://www.teses.usp.br/teses/disponiveis/12/1213 2/tde-03042009-125228/pt-br.php >. Acesso em 28/04/2017.

[3]. Gil, A. C. Como elaborar projetos de pesquisa. 4. ed. São Paulo: Atlas, 2008.

[4]. Lacombe, B. M. B.; Tonelli, M. J. O discurso e a prática: o que nos dizem os especialistas e o que nos mostram as práticas das empresas sobre os modelos de Gestão de Recursos Humanos. Revista de Administração Contemporânea (online), n. 2, p. 157-174, 2001. Disponível em: $<$ http://www.scielo.br/scielo.php?script=sci_arttext \&pid=S1415-65552001000200008>. Acesso em 02/05/2017. importância dessa postura para a manutenção de seus próprios empregos.

Cabe ressaltar aqui que o presente estudo restringiu-se apenas ao setor de Recursos Humanos de hospitais da cidade de Muriaé MG, sugerem-se como propostas para estudos futuros analisar o impacto da crise nos demais setores organizacionais, de forma a entender os impactos e influências da mesma em cada setor.

Embora se tenha buscado por bibliografia nas principais bases de dados nacionais, ressaltase como uma fragilidade do estudo o fato de o mesmo abordar um tema recente e sobre o qual não há muitas publicações, assim, espera-se ter contribuído com o preenchimento desta lacuna e ainda incentivar pesquisadores a desenvolver outros estudos sobre o assunto, a fim de prover informações mais concisas, que auxiliem gestores organizacionais a desenvolverem e implementarem estratégias de sobrevivência organizacional em tempos de crise econômica.

[5]. Michaelis Online. Crise. Disponível em: $<$ http://michaelis.uol.com.br/busca? $r=0 \& f=0 \& t=0 \& p$ alavra=crise $>$. Acesso em 24/04/2017.

[6]. Ministério do Trabalho. RAIS - 2015. Disponível em: $<$ http://pdet.mte.gov.br/rais?view=default $>$. Acesso em 25/05/2017.

[7]. Pires, M. C. C. Política econômica e estabilização: uma breve análise da recessão brasileira. Brazilian Keynesian Review (online), n. 2, p. 247-251, 2016. Disponível em: <http://www.akb.org.br/revista/index.php/BKR/articl e/view/87 > . Acesso em 03/05/2017.

[8]. Pochmann, M. O trabalho na crise econômica no Brasil: primeiros sinais. Estudos Avançados (online), n. 66, p. 41-52, 2009. Disponível em: $<$ http://www.scielo.br/scielo.php?script=sci_arttext $\& p i d=S 0103-40142009000200004>$. Acesso em 30/03/2017

[9]. Rezende, W. A. Identificando padrões de comprometimento do profissional em situação de crise econonõmica do mercado brasileiro: estudo de caso de uma empresa de varejo no Estado do RJ. 2016. 87 p. Dissertação (Mestrado em Sistemas de Gestão). Universidade Federal Fluminense. Disponível em: <http://www.repositorio.uff.br/jspui/handle/1/638>. Acesso em 25/05/2017. 
[10]. Sgarbossa, L.; Lopes, I. D.; Kemper, R. O impacto da crise brasileira na região oeste de Santa Catarina. Revista Tecnológica (online), n. 2, p. 271292, 2016. Disponível em <http://www.uceff.edu.br/revista/index.php/revista/a rticle/view/163/154>. Acesso em 04/05/2017.

[11]. Souza, E. M. Metodologias e analíticas qualitativas em pesquisa organizacional: uma abordagem teórico conceitual. Disponível em: <http://repositorio.ufes.br/handle/10/774/browse?ty pe $=$ title\&sort_by $=1 \&$ order $=$ ASC\&rpp $=20 \&$ etal $=$ $1 \&$ null=\&offset=0 $>$. Acesso em 30/03/2017.

[12]. Souza, M. Z. A. Gestão de pessoas: uma vantagem competitiva?. 1. ed. Rio de Janeiro: FGV, 2016.
[13]. Tonelli, M. J. Demissão: causas, efeitos e alternativas para empresa e indivíduo. Revista de Administração de Empresas (online), n. 4, p. 103108, 2000.

[14]. Wood JR, T. Mudança organizacional. 5. ed. São Paulo: Atlas, 2009.

[15]. Wood JR, T; Tonelli, M. J.; Cooke B. Colonização e Neocolonização da Gestão de Recursos Humanos no Brasil (1950-2010). Revista de Administração de Empresas - RAE (online), n. 3, p. 232-243, 2011. Disponível em: <http://rae.fgv.br/rae/vol51-num32011/colonizacao-neocolonizacao-gestaorecursos-humanos-no-brasil-1950-2010>. Acesso em 02/05/2017. 


\section{Capítulo 18}

\section{GESTÃO DE PESSOAS EM UNIDADES ESCOLARES DO MUNICIPIO DE IÚLIO DE CASTILHOS, RS: ESTUDO DE CASO COMPARATIVO ENTRE ESCOLAS PÚBLICA E PRIVADA.}

\section{Ana Paula Fernandes}

Katia da Motta Fronquetti

\section{Camila Coletto}

\section{Siomara Cristina Broch}

Resumo: A ideia de que cada grupo e organização possui uma estrutura diferenciada, levou ao propósito desta pesquisa que tem como meta fazer uma análise comparativa entre os profissionais de instituições de ensino pública e privada. A análise irá basear-se em fundamentos teóricos da área de gestão de pessoas com pesquisa bibliográfica e pesquisa de campo através de um instrumento aplicado em duas escolas do município de Júlio de Castilhos. Os pontos observados serão quanto à avaliação dos profissionais atuantes de ambas as instituições, no que se referem à remuneração, promoções, relacionamento com colegas de trabalho, planos de carreira e como avaliam a comunicação no ambiente de trabalho.

Palavras Chave: Gestão de Pessoas - Ensino Público e Pri - Profissionais 


\section{INTRODUÇÃO}

O mundo contemporâneo baseia-se, cada vez mais em aspectos de diferenciação de um individuo em relação ao outro. Possuir conhecimento, habilidades e atitude, não é suficiente, as empresas buscam profissionais diferenciados, que conseguem por si próprios tomar atitudes e resolver problemas, com agilidade e eficiência.

Os profissionais, em sua maioria, preocupam-se com a estabilidade no trabalho, o reconhecimento por seu desempenho e a remuneração. Não sendo o bastante também anseiam por promoções e recompensas, porém nem todos estabelecem planos de carreira para o decorrer de sua vida profissional.

A estagnação e o desinteresse após alguns anos de trabalho geram alta rotatividade nas organizações, pois o colaborador deixa de contribuir com o desenvolvimento da corporação. A alta rotatividade de docentes nas instituições de ensino, tem se tornado fator preocupante para a gestão escolar. Para Schuh e Costa, A rotatividade, certamente possui uma relação estreita com a motivação, já que os estudos citados demonstram que os fatores como a remuneração, o reconhecimento, a relação interpessoal no trabalho e a previsão de ascensão na carreira, podem levar a dois caminhos: ao descontentamento, quando não correspondido os anseios do funcionário e consequentemente o seu desligamento da empresa ou, a motivação, quando satisfeitas as suas pretensões podendo, quiçá, reter talentos por muitos anos (SCHUH e COSTA, 2012, p.21).

A necessidade dos profissionais estarem sempre em busca de novas bases de instruções que auxiliem na aprendizagem de práticas que tragam retorno as organizações, representa uma troca com a empresa, que precisará encontrar programas e ferramentas de gestão capazes de incorporar todos os colaboradores ao sistema organizacional, proporcionando condições favoráveis de convívio, comunicação e participação para melhores índices de desempenho profissional e retenção de capital humano.

Inicialmente, neste texto, será apresentada uma breve revisão bibliográfica apontando fundamentos teóricos acerca da gestão de pessoa. A partir disso, com base em dados de duas escolas do município de Júlio de Castilhos, o objetivo da pesquisa foi realizar uma análise comparativa entre os profissionais de instituições de ensino pública e privada, ambas de ensino fundamental, abordando aspectos referentes a sua satisfação profissional, remuneração, relacionamento com os demais colaboradores e as oportunidades de formação e crescimento dentro da organização que atuam.

\section{REFERENCIAL TEÓRICO}

Nesse capítulo será demonstrado os autores e teorias que serviram de base para o desenvolvimento dessa pesquisa.

\subsection{GESTÃO DE PESSOAS}

O mundo moderno, busca cada vez mais por adequar a gestão à identidade da empresa, através de uma administração focada no individuo, enquanto ser único e dotado de competências natas e/ou adquiridas. Esse diferencial, se bem desenvolvido no colaborador, pode ser o ponto forte da organização em relação às outras, pois a empresa que souber utilizar o capital humano em prol de sua caminhada rumo a uma trajetória de crescimento, com a tendência de avanços e proposição de novas possibilidades gerenciais, bem como inovações, juntamente com outros diferenciais organizacionais, alcançará seu objetivo.

A área de gestão de pessoas é quem fomenta - desenvolvimento profissional, analisa desempenhos, resolve conflitos e planeja cargos, os modelos de gestão que envolvem "áreas- chaves para a determinação de políticas de gestão de pessoas: grau de influência do empregado (participação), o fluxo de $\mathrm{RH}$ (recrutamento, utilização e demissão), o sistema de recompensas, e os sistemas de trabalho (organização do trabalho)" (Lacombe e Tonelli, 2001). Diretamente ligado a gestão de pessoas encontra-se a cultura organizacional, que "são fenômenos coletivos fundamentados na construção da realidade, em que as percepções, conhecimentos e os juízos sobre eventos, interagem para conferir significado as manifestações de cultura" (Barreto et al., 2013), ou seja, a cultura organizacional nasce a partir das convicções de cada integrante da organização, e por isso é responsável pela qualidade de vida no trabalho.

Diante disso, um ponto importante para as organizações está no bom relacionamento 
interno entre todos os setores e/ou departamentos que compõem a empresa estando atrelado ao perfil de profissionais que a organização atrai, desenvolve e retém. Há alguns anos atrás, as empresas focavam sua atenção nos acionistas, consumidores e fornecedores, porém com o passar dos anos foi-se percebendo que os colaboradores são o elemento chave para os resultados positivos da organização. Corroborando com estas colocações, destaca-se a relevância de subsistemas qualificados dentro das empresas, proporcionando um desenvolvimento sistêmico com foco em posicionamentos estratégicas.

A qualidade nos processos pode ser observada com base na satisfação dos colaboradores e no crescimento da produtividade que pode ser individual ou em equipe e, "os programas devem levar em consideração que o desempenho individual, grupal ou setorial deve ser avaliado e recompensado de acordo com o desempenho da empresa" (Veriano e Martins, 2004, p.25).

A avaliação de desempenho estará atenta ao comportamento dos colaboradores, aos fatores motivacionais, produtividade em equipe e grupal, se há necessidade de efetuar programas de treinamento, e também redefinir os objetivos e padrões de trabalho desejados para que o empregador e empregado alcancem a melhora do desempenho pretendida. Segundo Periard (2011) "este método é importante também, para eliminar achismos e palpites quando da avaliação de um funcionário. É um meio de obter informações reais e avaliar de perto as implicações de uma possível mudança". Desse modo, essa análise confrontará informações do passado e da atualidade, a fim de verificar a relação das vantagens e desvantagens apresentadas por cada colaborador.

Um fato significante para o desenvolvimento e produtividade dos colaboradores é a comunicação eficaz. Kunsch, diz que,

A questão da comunicação humana nas organizações deva em futuro próximo vir a ocupar novos espaços tanto no meio acadêmico como também nas práticas cotidianas face a urgência das novas demandas sociais dos trabalhadores e a necessidade de se buscar novos aportes teóricos para reflexão de uma problemática muito presente na atualidade no ambiente empresarial (KUNSCH, 2012, p. 273).

Os colaboradores de uma organização mantém a comunicação entre si, cabendo agestão de pessoas analisar, é a qualidade dessa comunicação, principalmente, a que é direcionada aos empregados. A clareza na comunicação é um fator fundamental, pois é através dela que haverá um forte engajamento dos colaboradores com as metas, objetivos e valores da organização. Conforme Filho e Blikstein;

No mundo empresarial contemporâneo a capacidade de se comunicar bem é considerada uma habilidade valiosa. Os fatores para essa valorização são muitos: complexidade social crescente, maciça presença de novos meios de comunicação, equipes de trabalho que mudam a cada projeto, maior contato entre pessoas de diferentes áreas, necessidade de solução de conflitos em ambientes com grande diversidade e muito estresse (FILHO E BLIKSTEIN, 2013, p. 28).

Um método de comunicação de qualidade e transparência facilita e aumenta o número de contribuições em todos os segmentos e processos dentro da empresa. O diálogo, quando eficaz, promove aumento significativo na produtividade, além de manter o bom relacionamento entre o público interno e externo de uma organização, este sendo resultado visível do trabalho em equipe.

O trabalho em uma corporação depende do bom funcionamento de todo sistema envolvido nos processos. Cada setor/departamento tem suas particularidades e sua importância frente ao conjunto de ações e decisões definidas pela empresa. Com base em estudos das últimas décadas as corporações tem se preocupado em reter seu capital humano, e para isso tem elaborado planos de carreira que vão além do tradicional. Compreende-se por plano de carreira tradicional "uma promessa feita pela organização ao indivíduo, na qual o mérito, a diligência e a autodisciplina seriam recompensados com o progresso contínuo numa trajetória desenhada à semelhança de uma escada" (SILVA, 2012, p.91). Um plano de carreira criteriosamente planejado trará benefícios para os profissionais e para a empresa. O profissional percorrerá o caminho da sabedoria e da experiência que irá ajuda-lo a avaliar suas habilidades e seus pontos fracos, colocandoo a disposição em busca de mais 
conhecimento e qualificação para agregar valor a sua bagagem profissional.

\section{METODOLOGIA}

A pesquisa bibliográfica na área de gestão de pessoas serviu como sustentação teórica para a fundamentação da pesquisa de campo. Com base na teoria, a coleta de informações "permite analisar o dado concreto, deduzindo do mesmo os elementos constantes, abstratos e gerais" (MARCONI E LAKATOS, 2011, p. 92).

Assim, foi aplicado um instrumento de coleta de dados em duas escolas situadas no município de Júlio de Castilhos, RS. A seleção das duas instituições de ensino pesquisadas teve como critérios, ambas atuarem no ensino fundamental, sendo a primeira do setor privado e a segunda do setor público, o que veio ao encontro do propósito da pesquisa de comparar a percepção dos profissionais do setor de ensino de mesma área de atuação.

A pesquisa contou com a opinião de 10(dez) colaboradores de cada instituição, totalizando uma amostra de 20 (vinte) pessoas pesquisadas. Entre os colaboradores pesquisados na instituição de ensino privada teve-se a opinião de 5 (cinco) funcionários e 5 (cinco) docentes, dos 32 (trinta e dois) profissionais que compõem o quadro funcional da instituição. Quanto à instituição de ensino pública, participaram da pesquisa
2 (dois) funcionários e 8(oito) docentes, dos 55(cinquenta e cinco) profissionais que compõem o quadro funcional da instituição. As amostras mantiveram a proporção dos segmentos de funcionários e docentes das respectivas instituições.

O instrumento de pesquisa utilizado foi um levantamento de dados elaborado pela MACROPLAN (2006), entidade que realiza pesquisas sociais, estratégicas, de gestão e políticas públicas. Ele foi adaptado conforme as variáveis de interesse na investigação proposta.

\subsection{ANÁLISE DOS RESULTADOS}

Esta pesquisa se propõe a fazer uma análise comparativa entre os profissionais de instituições de ensino pública e privada, através do levantamento da percepção dos profissionais de ensino. Os pontos observados foram quanto à opinião e avaliação efetuadas pelos profissionais atuantes de ambas as instituições.

Os dados da pesquisa são apresentados em gráficos de barras com o propósito de facilitar a visualização e entendimento dos resultados encontrados e a sua análise.

No Gráfico 1 constam as opiniões dos 10 (dez) profissionais das instituição de ensino privada pesquisados.

Gráfico 1 - Instituição de Ensino Privada

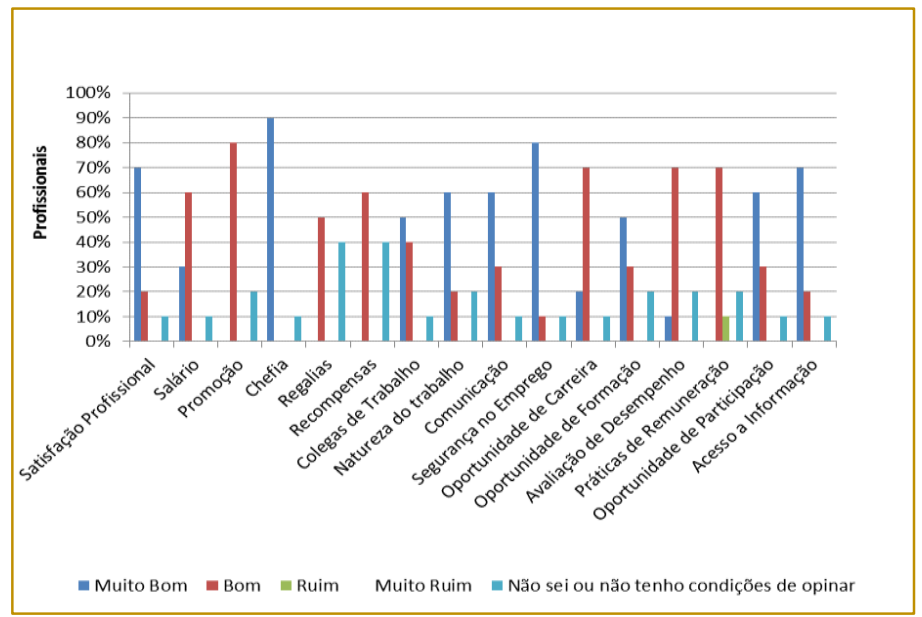

Fonte: Dados da pesquisa

Pelo gráfico 1 pode-se observar que os funcionários da Instituição de ensino privada pesquisada tem opinião positiva na maioria dos itens pesquisados. Especialmente na 
Satisfação Profissional, Chefia, Segurança no Emprego e Acesso à Informação 90\% dos respondentes consideraram Muito Bom ou Bom, com predominância do conceito máximo que a pesquisa sugere. Quanto a Satisfação Profissional, $70 \%$ dos colaboradores pesquisados avaliaram o item como Muito Bom e 20\% como Bom, ou seja, 90\% consideraram-se satisfeitos com a profissão que exercem. Outro item com quase a totalidade de aprovação foi o da Chefia, conceituado como Muito Bom por 90\% dos colaboradores participantes. A Segurança no Emprego foi qualificada por $80 \%$ das pessoas pesquisadas na instituição como Muito Bom e 10\% como Bom. Já o item Acesso a Informação foi avaliado como Muito Bom por $70 \%$ dos pesquisados e por 20\% como Bom.

Em avaliação positiva também estão os itens Salário, Colegas de Trabalho, Comunicação, Oportunidade de Carreira, Oportunidade de
Participação, Oportunidade de Formação, Avaliação de Desempenho e Natureza do Trabalho, em que apontam 90\%, 90\%, 90\%, $90 \%, 90 \%, 80 \%, 80 \%$ e $80 \%$ entre opiniões de Muito Bom e Bom.

Referente às classificações consideradas negativas atribuídas pelos funcionários da instituição de ensino privada, apresentou-se a avaliação Muito Ruim no item Regalias, por $10 \%$ dos colaboradores pesquisados e $40 \%$ não opinaram; os outros 50\% acham Bom. Também no item Práticas de Remuneração, conceituada como Ruim por $10 \%$ dos colaboradores pesquisados e 20\% não opinaram; os outros $80 \%$ acham Bom. O conceito Não sei ou não tenho condições de opinar foi utilizado em todos os itens por no mínimo 10\% dos profissionais pesquisados.

\section{Gráfico 2 - Instituição de Ensino Pública}

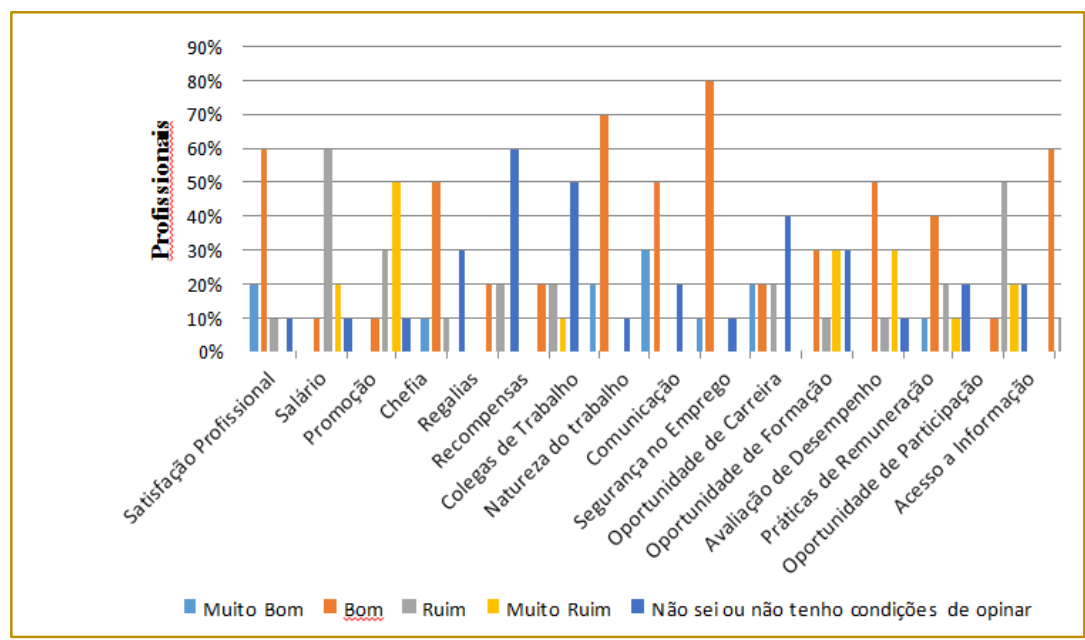

Fonte: Dados da pesquisa

No gráfico 2 estão os dados coletados somente na instituição de ensino pública, que tiveram opiniões variadas em grande parte dos itens. Inicialmente o que chama a atenção é que, nesta instituição, nenhum dos itens teve avaliação predominante Muito Bom. Inclusive a avaliação Muito Bom não esteve presente na maioria das opiniões dos participantes da instituição pública, variando entre $10 \%$ a $30 \%$ os profissionais que utilizaram essa classificação nos itens Satisfação Profissional, Colegas de Trabalho, Natureza do Trabalho, Comunicação, Segurança no Emprego, Avaliação de
Desempenho e Acesso a Informação. Os itens Colega de Trabalho, Natureza do Trabalho, Comunicação e Acesso a Informação foram avaliados como Muito Bom ou Bom pelas pessoas pesquisadas, respectivamente, com 90\%, $80 \%, 90 \%$ e $90 \%$, sendo os únicos itens que não tiveram opinião Ruim ou Muito Ruim. Já os itens Satisfação Profissional e Oportunidade de Participação, ambos foram conceituados como Bom por 60\% dos colaboradores pesquisados, sendo que $20 \%$ consideraram Muito Bom o item Satisfação Profissional. 
Em termos de itens considerados negativos para a instituição pública, destacam-se o Salário, considerado Ruim por 60\% e Muito Ruim por $20 \%$ das pessoas pesquisadas, o item Promoção classificado como Ruim por $30 \%$ e Muito Ruim por $50 \%$ dos colaboradores pesquisados e 0 item Práticas de Remuneração classificado como Ruim por $50 \%$ e Muito Ruim por $20 \%$ dos respondentes. Considerando a classificação Não sei ou não tenho condições de opinar teve seus maiores percentuais nos itens Regalias, com a opinião de $60 \%$ dos colaboradores e no item Recompensas, classificado por $50 \%$ das pessoas pesquisadas.

O contraste entre as opiniões dos profissionais do setor público e privado é visível em algumas variáveis, principalmente em termos de salário que é a grande insatisfação dos profissionais do setor de ensino público e também em termos de oportunidades de carreira, já que o servidor público encontra-se limitado a um plano de carreira, enquanto os profissionais do setor privado têm muitas possibilidades de crescimento dentro da organização. Essas variáveis em conjunto com as demais, que apresentam menores índices de insatisfação, influenciam o desempenho dos profissionais e podem ser fatores de desmotivação profissional.

Com o objetivo de realizar o comparativo proposto pela pesquisa entre as duas instituições de ensino, privada e pública, selecionou-se as variáveis (ou itens) que apresentaram maiores discrepâncias de resultados apresentados anteriormente nos gráficos 1 e 2 para análises individuais.

A primeira variável a ser analisada é a Variável Salário exibida no gráfico 3.

\section{Gráfico 3 - Variável Salário}

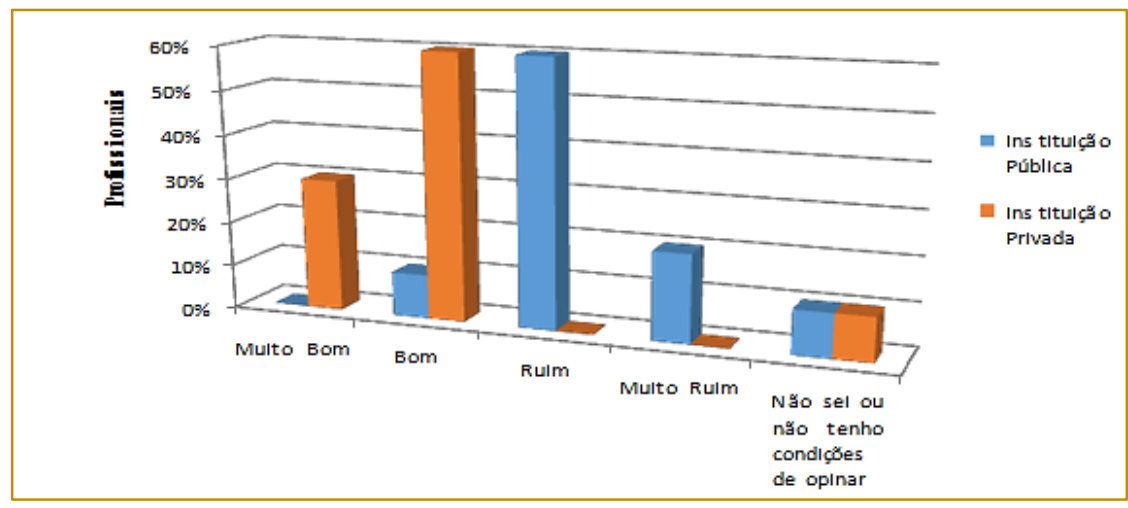

A Variável Salário obteve 30\% dos colaboradores da instituição privada classificando- a como Muito Bom e 60\% como Bom, em contrapartida, a classificação Muito Bom não foi mencionada pelos colaboradores da instituição pública que classificaram como Bom, Ruim e Muito Ruim, com 10\%, 60\% e $20 \%$, respectivamente. Não opinaram 10\% dos colaboradores da instituição privada e também da instituição pública. A Variável Salário é uma das que apresenta maior contraste entre as classificações dos profissionais, pois enquanto $90 \%$ dos profissionais do setor privado se consideram satisfeitos com seu retorno financeiro, $80 \%$ dos profissionais do setor público estão descontentes com sua remuneração, deixando evidente que apesar da estabilidade no emprego, consideram que suas atividades estão sendo desvalorizadas em termos financeiros. 
.Gráfico 4 - Variável Promoção

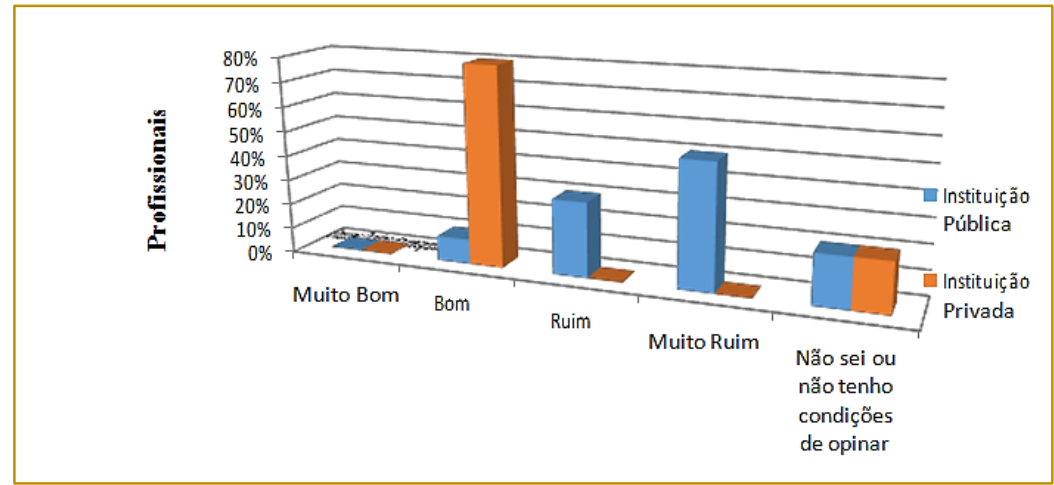

Fonte: Dados da pesquisa

No Gráfico 4 apresenta-se a Variáve/ Promoção que mostra grande aceitação por parte dos colaboradores da instituição privada, pois $80 \%$ dos profissionais pesquisados a classificaram como Bom. $\mathrm{Na}$ mesma proporção, também $80 \%$ dos profissionais pesquisados na instituição pública a classificaram como Ruim e Muito Ruim, retratando mais uma vez a dissonância de opiniões entre o Setor Público e o Setor Privado.

\section{Gráfico 5 - Variável Segurança no Emprego}

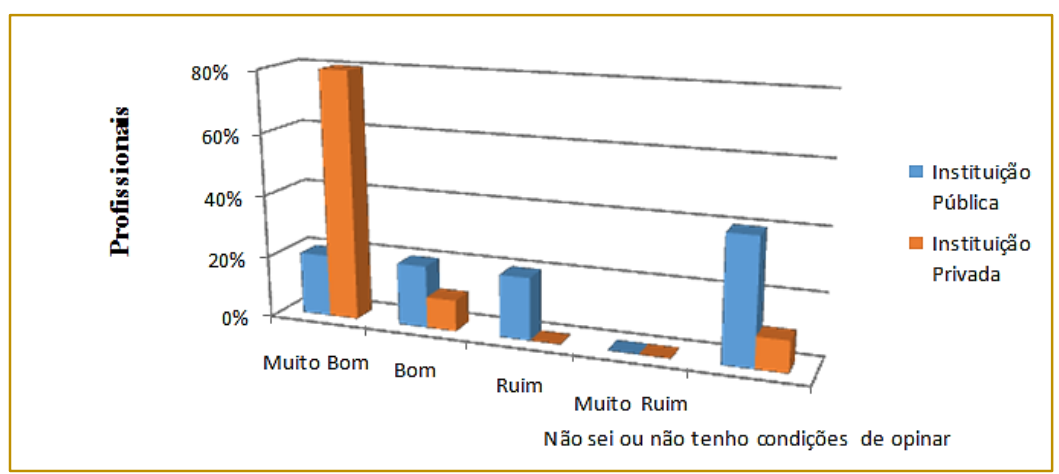

Fonte: Dados da pesquisa

O Gráfico 5 expõe dados da Variável Segurança no Emprego que mostra uma concentração de opiniões por parte dos profissionais da instituição privada, onde $80 \%$ das pessoas a conceituam como Muito Bom. A diversidade de opiniões fica a critério dos profissionais da instituição pública em que $60 \%$ dos colaboradores dividem opiniões e a avaliam como Muito Bom, Bom e Ruim enquanto $40 \%$ dos profissionais participantes da pesquisa não souberam ou não tiveram condições de opinar. 
Gráfico 6 - Variável Oportunidade de Carreira

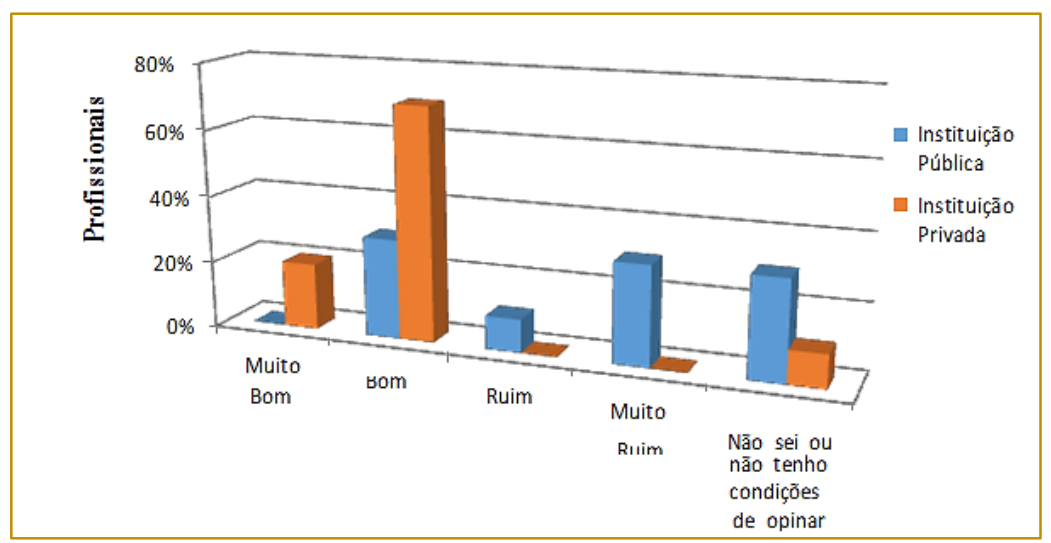

Fonte: Dados da pesquisa

O Gráfico 6 apresenta a Variável Oportunidade de Carreira considerada positiva, estando dividida entre os conceitos Muito Bom e Bom atribuídos por $90 \%$ dos profissionais participantes da pesquisa na instituição privada. Os colaboradores participantes na instituição pública apenas não utilizaram o conceito Muito bom para esta variável, ficando então assim divididos: $30 \%$ consideraram Bom, 10\% consideraram Ruim, $30 \%$ consideraram Muito Ruim e $30 \%$ das pessoas não souberam ou não tiveram condições de opinar.

Gráfico 7 - Variável Avaliação de Desempenho

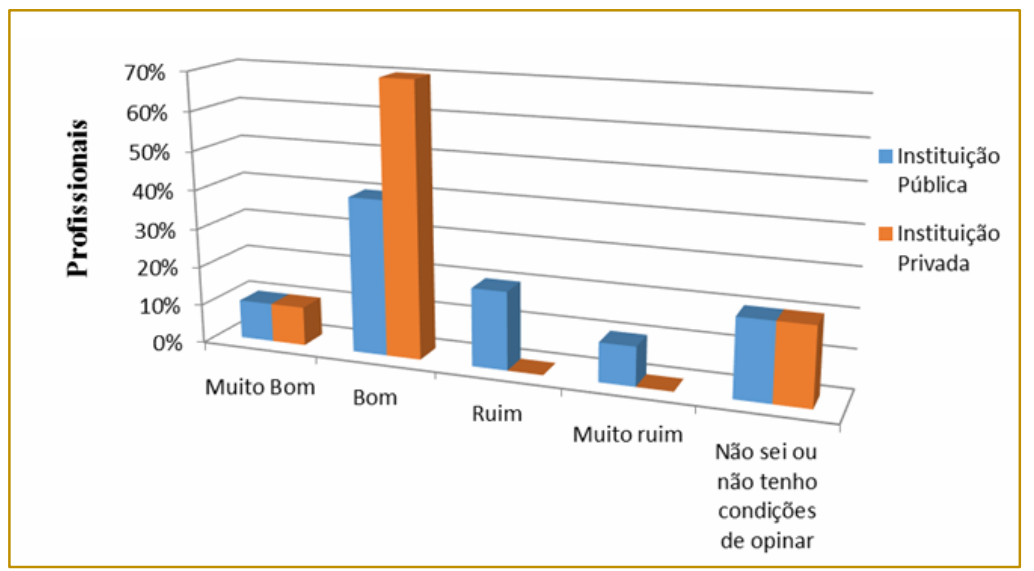

Fonte: Dados da pesquisa

O Gráfico 7 mostra a Variável Avaliação de Desempenho onde expõe que os profissionais da instituição privada estão favoráveis aos métodos aplicados na instituição para verificação de desempenho dos profissionais atuantes, porém nem todos da instituição pública apoiam a metodologia utilizada na Avaliação de Desempenho e isso é perceptível no gráfico 7 , que retrata a diversidade de opiniões dos profissionais da área pública por utilizarem as cinco classificações sugeridas pela pesquisa, tendo um número maior (40\%) que concentraram-se no conceito Bom.

\section{CONSIDERAÇÕES FINAIS}

A partir da análise de dados da pesquisa, percebe-se que as opiniões dos colaboradores da instituição privada apresentaram maior consonância a cada item classificado, concentrando suas avaliações, em sua maioria, nos itens Muito Bom e Bom, 
enquanto os profissionais da instituição de ensino pública dispuseram de pareceres pouco concentrados. Essa diferença nas respostas do setor público se deve a maior liberdade de expressão dos profissionais, que se expõem sem receio de serem perseguidos profissionalmente ou mesmo demitidos.

Com base no levantamento de informações efetuados na pesquisa, observou-se que os itens com avaliação mais alta, Muito Bom, no setor privado foram: Satisfação Profissional, Chefia, Segurança no Trabalho e Acesso a Informação, com 70\%, 90\%, 80\% e 70\%, respectivamente. Já os itens Regalias e Práticas de Remuneração apresentaram avaliações Ruim e Muito Ruim, sendo 10\% e $10 \%$, respectivamente.

O setor público apresentou maior satisfação, Muito Bom e Bom, nos itens Satisfação Profissional, 80\%, Colegas de Trabalho, 90\%, Natureza do Trabalho, 80\%, Comunicação, 90\%, e Acesso a Informação, 90\%. Nos itens com maior insatisfação, estão o Salário, Promoção e Práticas de Remuneração, respectivamente, com $80 \%$, $80 \%$ e $70 \%$.

Em um comparativo entre as duas instituições pesquisadas referente aos itens utilizados na pesquisa, constatou-se que alguns itens tiveram a mesma proporção de profissionais, público e privado, os avaliando como Muito Bom e Bom, sendo eles: Colegas de Trabalho, Comunicação, Acesso a Informação, 90\% e Natureza do Trabalho, ambas com $80 \%$. A pesquisa ainda possui a classificação Não sei ou Não Tenho Condições

\section{REFERÊNCIAS}

[1] Barreto, Leilianne M. T. S. et al. Cultura Organizacional e Liderança: Uma Relação Possível? R. Adm., v. 48, n.1, jan/fev/mar, São Paulo (RAUSP), 2013.

[2] Filho, Antonio G., Blikstein, Izidoro. Comunicação Assertiva e o Relacionamento nas Empresas. GV Executivo, v.12, n.2, jul/dez, 2013.

[3] Lacombi, Beatriz M. B. e Tonelli, Maria J. O discurso e a prática: o que nos dizem os especialistas e o que nos mostram as práticas das empresas sobre o modelo de gestão de Recursos Humanos. Rev. Adm. Contemp. [online], v.5, n.2, ISSN 1982-7849, 2001.

[4] Kunsch, Margarida M. K. As dimensões Humanas Instrumental e Estratégica da Comunicação Organizacional: recorte de um estudo aplicado no segmento corporativo. Ver. Bras. Ciênc. Comum. V.35, n.2, ISSN 1809-5844, de Opinar que teve seus maiores índices nos itens Regalias e Recompensas, ambas com 40\% na instituição de ensino privada e a instituição de ensino pública indicou os maiores índices nos itens Regalias, 60\%, Recompensas, 50\% e Segurança no Trabalho com $40 \%$.

As conclusões do estudo qualitativo e comparativo levam a afirmar que mesmo em setores diferentes, público e privado, os profissionais da área de ensino demonstram algumas semelhanças em seus pareceres e têm necessidade de uma gestão de pessoas de qualidade para que possam expor suas prioridades e/ou insatisfações que impeçam um melhor desempenho de suas atividades. A criação de programas da área de gestão de pessoas voltados à motivação dos profissionais poderá ajuda-los a se realizarem novamente em sua profissão. Isso pode ser feito com melhores recompensas, melhores métodos de avaliação de desempenho, oportunidades de carreira, práticas de remuneração, promoções e salário, o qual obteve $80 \%$ de reprovação na instituição pública, que os estimularão a desempenhar o trabalho com mais afinco, proporcionando um ambiente acolhedor, trazendo bem estar ao profissional e se tornando atrativo as pessoas.

A elaboração de políticas de gestão concentradas na valorização e autonomia do profissional poderá transformar a base de um ciclo que tem se mostrado vicioso e que a partir de pequenas mudanças proporcionará um novo futuro para as organizações e consequentemente, melhores profissionais.

2012

[5] Macroplan e lets. O Rio tem Futuro!? Pesquisa qualitativa e de opinião - relatório preliminar de pesquisa - Rio de Janeiro, 2006

[6] Marconi, Marina A. e Lakatos, Eva M. Metodologia Científica: Ciência e Conhecimento Científico, Métodos Científicos, Teoria, Hipóteses e Variáveis e Metodologia Jurídica. 6aㅡ ed., São Paulo, 2011.

[7] Marconi, Marina A. e Lakatos, Eva M. Técnicas de Pesquisa: Planejamento e Execução de Pesquisas, Amostragens e Técnicas de Pesquisa e Elaboração, Análise e Interpretação de Dados. 7ª ed., São Paulo, 2010.

[8] Martins, Sérgio S. e Veriano, Carlos E. A Remuneração Flexível como Componente da Gestão de Salários. Rae, v.44, ed. Especial Minas Gerais, 2004. 
[9] Paschoal, Tatiane et al. Bem-Estar no Trabalho: Relações com Estilos de Liderança e Suporte para Ascensão, Promoção e Salários. Anpad, RAC, v.16, n.5, art.6, set/out, Rio de Janeiro, 2012.

[10] Periard, Gustavo. Avaliação de Desempenho - O que é e como funciona. SA Sobre Administração. Julho de 2011. Disponível em: www.sobreadministração.com/avaliação-dedesempenho-o-que-e-e-como-funciona/

[11] Schuh, André S. e Costa, Pedro A. A
Relação entre a Motivação e a Rotatividade no Emprego: Um a Percepção dos Funcionários da UERGS. Universidade Federal do Rio Grande do Sul. Escola de Administração. Curso de Especialização em Gestão Pública UAB, 2012.

[12] Silva, Rosangela V. A. Trajetórias Profissionais de Executivas aos Postos de Alto Escalão: Fatores-Chave, Barreiras, Inibidores de Ascensão e Estratégias de Enfrentamento. FGV, EBAPE, RJ, 2012.7 


\section{Capítulo 19}

PLANO DE AÇÃO PARA MINIMIZAR O ABSENTEISMO NA ATENCÃO AMBULATORIAL DE UM HOSPITAL UNIVERSITÁRIO DA REGIÃO METROPOLITANA II, NA CIDADE NITERÓI-RJ.

\section{Waldir Viana das Neves Junior}

\section{Christina Souto Nicolau das Neves}

Resumo: O presente relatório técnico teve como objetivo elaborar um plano de ação a ser implantado em um Hospital Universitário, na cidade de Niterói-RJ, visando diminuir o índice de absenteísmo de pacientes agendados para consultas ambulatoriais. Inicialmente foi apresentado o caso, com a identificação do problema e suas consequências. Em seguida foi apresentada a base teórica que subsidiou a elaboração do plano de ação e por fim, a apresentação do plano de ação. Esperase que a definição e priorização de atividades e tarefas antes mesmo de colocadas em prática, garantam mais assertividade e correção prévia dos problemas identificados, e que o plano de ação depois de efetivado produza efeitos para diminuir o índice de absenteísmo no serviço ambulatorial neste Hospital Universitário.

Palavras-chave: Gestão ambulatorial; Absenteísmo; Hospital Universitário. 


\section{1 - INTRODUÇÃO}

O desafio pela estruturação de um sistema público de saúde no Brasil, de acesso universal, com cobertura integral e qualidade faz parte dos propósitos e conquistas de uma nação que alimentou os valores da equidade e da democracia. O Sistema Único de Saúde (SUS) é a manifestação, no campo da saúde, do desejo de um país justo e do compromisso com a cidadania (MENDES, 2011).

$\mathrm{Na}$ atualidade, os serviços de saúde devem estar comprometidos com a qualidade das ações institucionais ofertadas. Todavia, as pressões da sociedade, os altos custos da assistência bem como a necessidade de promover a equidade de acesso aos recursos estão direcionando os esforços das instituições públicas no sentido de buscar evidências objetivas de que os serviços de saúde estão sendo providos efetiva e eficientemente, por modelos de gestão adequados que aperfeiçoem os recursos aplicados, trazendo melhora da produtividade e satisfação para todos os cidadãos de uma Região de Saúde (RS), e os respectivos participantes das ações e serviços de saúde (NEVES, 2004).

Com tudo, o não comparecimento dos usuários às consultas, exames, procedimentos e terapias agendados em ambulatórios no SUS, tem comprometido o atendimento à demanda. Monitorar esses dados é imprescindível, pois ações podem ser executadas para reduzir o impacto do absenteísmo nos serviços ambulatoriais (UNA-SUS, 2017).

Os Hospitais Universitários (HU) são organizações complexas onde convivem diversos processos e atividades associados à atenção à saúde propriamente dita as questões essencialmente administrativas e àquelas relacionadas ao ensino e à pesquisa. O desafio nestas instituições é alcançar maiores níveis de eficiência com os recursos institucionais e evoluir de organizações centradas nos profissionais e serviços a organizações centradas nos usuários, sendo estes, objetivos importantes a serem considerados (BRASIL, 2013).

\section{2 - APRESENTAÇÃO DO CASO}

O Hospital Universitário apresentado neste caso caracteriza-se por ser um espaço de produção, transformação e difusão do conhecimento mediante a prática do ensino, pesquisa e extensão, ou seja, enquanto hospital escola o HU conta com cursos de graduação, pós-graduação, residência médica e multiprofissional.

Este HU é totalmente integrado ao SUS, sendo referência na prestação de assistência médico-hospitalar de média e alta complexidade da Região Metropolitana II, formada pelos municípios Niterói, São Gonçalo, Itaboraí, Tanguá, Rio Bonito, Silva Jardim e Maricá, o que corresponde a 6,2\% da área do Estado do Rio de Janeiro, sendo que $12,07 \%$ da população total do estado do Rio de Janeiro, o que significa aproximadamente dois milhões de habitantes (SES, 2012).

Classificado como hospital de médio porte, atualmente conta com 282 leitos, abrigando em suas dependências as enfermarias de Clínica Médica, Clínica Cirúrgica, Obstetrícia, Pediatria, Oftalmologia, Centro de Diálise, Hematologia, Otorrinolaringologia, Unidade de Terapia Intensiva Adulta, Unidade Coronariana, UTI Neonatal e Centro Cirúrgico. Possui laboratório de análises clínicas, Serviço de Nutrição e Dietética, Farmácia, Banco de Sangue, Unidade de Anatomia Patológica, o Núcleo de Processamento de Dados, a Administração e a Unidade de Imagem e Métodos Gráficos e Diagnósticos que comportam os serviços Complementares e Diagnósticos.

Além desses, apresenta um complexo ambulatorial com 82 consultórios que além de ofertar apenas aos usuários do SUS (não atende usuários de planos de saúde ou particular) especialidades médicas, como enfermagem, nutrição, psicologia, serviço social, farmácia, fonoaudiologia e fisioterapia, disponibiliza exames diagnósticos complementares, procedimentos de média e alta complexidade e a orientação terapêutica de pacientes, configurando-se como a principal porta de entrada do HU.

Cabe ressaltar que o principal acesso ao atendimento sistemático no HU é por meio do serviço ambulatorial regulado pela Central de Regulação Municipal da cidade de Niterói-RJ.

Dessa forma, o usuário tem sua marcação realizada por meio da Unidade Básica de Saúde (UBS) mais próxima da sua residência, de forma obrigatória, pois o ótimo manejo das consultas ambulatoriais de atenção especializada precisa do envolvimento do gestor e deste nível de atenção, que na organização assistencial do SUS configura-se como a "porta de acesso ao sistema". 
O aumento da demanda por ações e serviços hospitalares, a maior complexidade dos processos assistenciais e a necessidade de gerir as informações assistenciais têm demandado do HU a organização de uma estrutura que ordene e coordene as atividades que ocorrem em torno da assistência médica, com a finalidade de facilitar o acesso da população aos recursos disponíveis, mantendo os princípios básicos de equidade e racionalização da utilização dos mesmos e garantindo a articulação do conjunto da organização junto ao paciente e seu processo assistencial.

Recentemente, o HU institucionalizou um grupo de trabalho para sistematizar as diretrizes e normas de funcionamento do complexo ambulatorial, considerando a necessidade de reavaliação dos processos de trabalho e fluxos ambulatoriais já existentes; a adaptação do perfil assistencial; a implantação das linhas de cuidados; e a necessidade de ajustes nos processos de marcação de consultas, buscando coordenar as atividades ambulatoriais com maior qualidade.

Uma situação-problema que compromete a qualidade que se busca na gestão do complexo ambulatorial é o não comparecimento dos pacientes às consultas agendadas, identificados no sistema de informação oficial do HU. Nos anos de 2015 e 2016 foram agendados 357.251 consultas e procedimentos ambulatoriais, sendo que destes, 100.757 não foram realizados devido ao não comparecimento dos pacientes, ou seja, em média $28,20 \%$ dos pacientes agendados faltam ao atendimento ambulatorial no HU, conforme demonstrado no gráfico 1.

Gráfico 1 - Faltas em Consultas Agendadas e Procedimentos Ambulatoriais no HU nos anos 2015 e 2016.

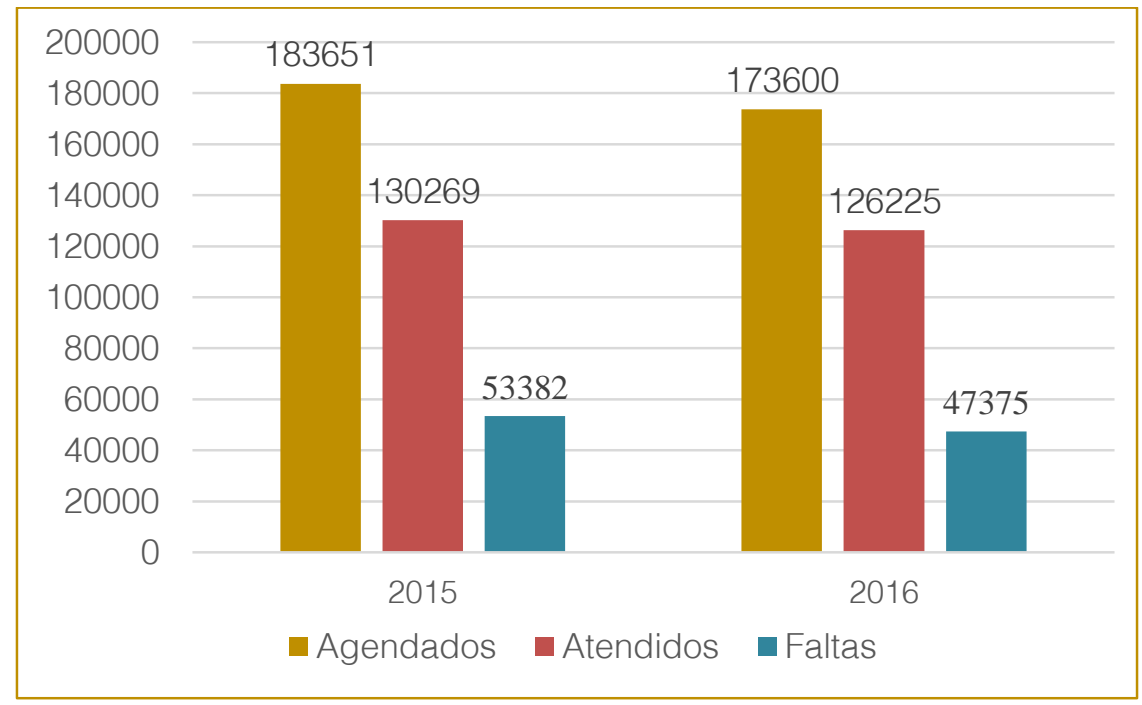

Fonte: Criado e elaborado pelos autores (2017).

Além de deixar de oferecer atendimento ao paciente previamente agendado, esse número de faltas traz prejuízo ao HU na medida em que todas as rotinas hospitalares preestabelecidas são disponibilizadas (prontuários, vagas, materiais cirúrgicos, estruturas físicas e os recursos humanos) diariamente para atender a demanda.

Desta forma, este relatório técnico buscou propor um plano de ação para minimizar o problema identificado. Para alcançar este objetivo houve a necessidade de levantar informações sobre o quantitativo de faltas em consultas e procedimentos ambulatoriais agendados no $\mathrm{HU}$, e realizar pesquisa bibliográfica sobre o tema, para identificar ações efetivas em outros serviços ambulatoriais que proporcionaram a minimização do absenteísmo.

\section{3 - REFERENCIAL TEÓRICO}

O termo absenteísmo ambulatorial é definido como "[...] o não comparecimento do paciente 
a um procedimento previamente agendado em unidade de saúde, sem nenhuma notificação." (OLíMPIO et al. 2016, p. 19). Os serviços de saúde especializados não realizados representam uma chance perdida de ofertar assistência a outro usuário que necessita de atenção a sua saúde e também perda de recursos administrativos, financeiros e sociais que foram disponibilizados para a realização do serviço.

O absenteísmo em consulta ambulatorial é uma ocorrência comum no Brasil e em outros países, variando de $10 \%$ até $41,3 \%$ e $20 \%$ até $36,4 \%$, respectivamente. (OLíMPIO et al., 2016).

As relações de causa/efeito do absenteísmo abrangem todos os atores envolvidos (trabalhadores, gestão e usuários), sendo as causas relacionadas com o serviço e gestão, passíveis de correções mediante readequação do processo de trabalho das equipes, por terem maior governabilidade e serem os responsáveis pela indução da política de regulação (RONALD et al., 2013).

Izecksohn e Ferreira (2014) identificaram um percentual de absenteísmo de 48,9\% em consultas ambulatoriais dos usuários acompanhados pela Estratégia Saúde da Família (ESF) no bairro Manguinhos, Rio de Janeiro. Entre os motivos citados, pelos autores, para as faltas às consultas, destacaram-se a distância entre a data do agendamento e a consulta, esquecimento, dificuldade de liberação do trabalho e de locomoção, paternidade, melhora do sintoma que ocasionou o agendamento e atendimento médico prévio sem que seja agendado, além de relatos do usuário não ter sido avisado da marcação.

"As causas do absenteísmo em atendimento ambulatorial devem ser estudadas individualmente em cada especialidade, haja vista que podem existir fatores específicos como gravidade da doença, disponibilidade de profissionais e equipamentos, entre outros fatores." (OLíMPIO et al., 2016, p. 31). Para o autor, a falta de transporte, dificuldades de locomoção, insatisfação com o atendimento anterior, demora no atendimento e abandono do local, seriam outros fatores inerentes do absenteísmo.

A Universidade Federal de Pernambuco (UFPE), integrante da Rede UNA-SUS universidade aberta do SUS, e a Coordenação Geral de Regulação e Avaliação (CGRA) do Ministério da Saúde destacam no Programa de
Qualificação para Profissionais de Regulação do SUS que:

O absenteísmo pode ter como causas a Indicação desnecessária do procedimento; Agendamento do procedimento em um estabelecimento muito distante ou desconhecido do usuário; Agendamento realizado "em cima da hora" ou não avisado "em tempo" ao usuário; Falta de condições econômicas por parte do usuário para o deslocamento necessário; Ausência de transporte especial para a locomoção do usuário; Ocorrência de imprevistos que impossibilitam a ida do usuário ao estabelecimento executante; Escolha do local, data e hora do agendamento realizada sem a aprovação do usuário; Descompromisso do usuário com a própria oferta e/ou com a sua saúde; Impossibilidade de realizar os "preparos" necessários para a realização de alguns procedimentos; Falta ao trabalho do profissional, falta momentânea de insumos, greves, fechamento imprevisto do estabelecimento executante etc. (UNA-SUS, 2017, [s.p]).

O desperdício financeiro é um fato no âmbito da saúde pública decorrente do absenteísmo. No Reino Unido afere-se perda de £ 900 milhões/ano. No Brasil, a Secretaria Municipal de Saúde de Uberlândia/MG, após colocar em prática a organização de um sistema eletrônico de agendamento único e oferta de telefones para cancelamentos, acabou com as agendas independentes, estimando um valor não concretizado em repasses pelo SUS equivalente a $\mathrm{R} \$ 1,1$ milhoes (OLíMPIO et al., 2016).

Outras consequências, como o adiamento das necessidades de cuidados, aumento da insatisfação com o serviço e aumento do tempo de espera para marcar a consulta, afetam diretamente ao usuário do serviço saúde. Em relação à gestão destes serviços, é gerado crescimento da demanda reprimida, desequilíbrio na oferta de serviços; aumento dos custos assistenciais, desperdício dos serviços desde a consulta do médico da atenção básica; o retrabalho do marcador e nova visita do agente comunitário de saúde para entrega do agendamento (CAVALCANTE, 2013, p. 76).

Ronald et al. (2013) apresentam a relação entre o absenteísmo e a proporção de visitas domiciliares realizadas pelos agentes de saúde. Nos períodos em que foi apresentada maior média de visitas observou-se declínios 
no absenteísmo do bairro do Roger no Distrito Sanitário IV, em João Pessoa, capital do estado da Paraíba. Ou seja, na medida em que se aumenta o número de visitas produz-se um menor número de absenteísmo.

Outro ponto identificado na pesquisa de Ronald et al (2013, p.77) diz respeito à percepção dos usuários quanto ao absenteísmo, conforme relato de um dos usuários, "Minha consulta foi marcada num dia de sexta-feira à tarde. Sou cabelereiro... é o dia e horário que tenho mais clientes, não posso sair do salão." Fica a evidência de que há necessidades de visitas domiciliares sistemáticas pelos agentes de saúde para se evitar o desperdício de trabalho, o agravamento dos problemas de saúde dos usuários e o absenteísmo.

Izecksohn e Ferreira (2014) destacam a percepção do usuário quanto à importância de comparecer ou não às consultas agendadas. Os entrevistados afirmaram não terem sido ouvidos sobre o melhor dia ou período para agendamento, sendo desconsiderados, inclusive, seus horários de trabalho, conforme relato dos usuários "[...] não, ela marcou e pronto [...]" (IZEKSOHN E FERREIRA, 2014, p. 238), o mesmo foi evidenciado por outro usuário que respondeu: "[...] não, se eles me dessem eu gostaria, mas não dá não [...]" (IZEKSOHN E FERREIRA, 2014, p. 238).

Estudos relacionados à percepção do usuário nas consultas ainda são poucos no Brasil, e estes, são necessários para complementar e identificar as razões do absenteísmo ambulatorial. Entre estes estudos, ações alternativas como agendas fechadas, com turnos predeterminados por ciclo de vida ou comorbidades, ou unidades que não trabalham com horário estendido já foram pensadas para minimizar as faltas às consultas, com alguns resultados pouco expressivos, o que reforça a necessidade de se entender a percepção do usuário (IZECKSOHN E FERREIRA, 2014).

A correção do problema merece atenção dos administradores já que entre as causas encontram-se aquelas ligadas a fatores socioeconômicos e comportamentais, necessitando de um trabalho multiprofissional de maneira eficaz nos serviços saúde, para compreender as causas e as consequências, permitindo assim, a elaboração de planejamentos que levem á correção ou minimização do absenteísmo.

Para Canelada et al. (2013), ações de gestão da agenda e do trabalho em rede, desenvolvidos através do contato com os usuários agendados para confirmação de presença em consultas especializadas e exames com maior demanda; reuniões com os colegiados gestores municipais e do ambulatório, para apresentação dos agendamentos, da taxa de absenteísmo, entre outros indicadores, visando pactuações e corresponsabilidade entre os serviços, possibilitou a diminuição do percentual de faltas (taxa de absenteísmo) entre 2 e 4\%.

Para Gonçalves et al. (2015), a realização de palestras sobre saúde bucal, educação permanente nas reuniões de equipe, capacitação dos Agentes Comunitários de Saúde (ACS), participação em grupos terapêuticos, parcerias entre Equipe de Saúde Bucal (ESB) e equipamentos sociais da comunidade, levaram à diminuição das faltas em $66,6 \%$ e o caráter motivador das oficinas possibilitou a reflexão crítica para o redirecionamento da prática em saúde.

Desta forma, espera-se que a definição e priorização de atividades e tarefas antes mesmo de colocadas em prática, garantam mais assertividade e correção prévia dos problemas identificados, e que um plano de ação depois de efetivado produza efeitos para diminuir o índice de absenteísmo no serviço ambulatorial do HU apresentado.

Por tanto, a ferramenta de gestão utilizada para organizar e colocar em prática o plano de ação foi o sistema 5W2H. Para Silva et al.(2013), esta ferramenta foi criada por profissionais da indústria automobilística do Japão como uma ferramenta auxiliar de planejamento, com perguntas e atividades pré-estabelecidas, para serem desenvolvidas com a maior compreensão possível, conforme demonstrado no quadro 1. 
Quadro 1 - Elaboração do Plano de Ação - Metodologia 5W2H

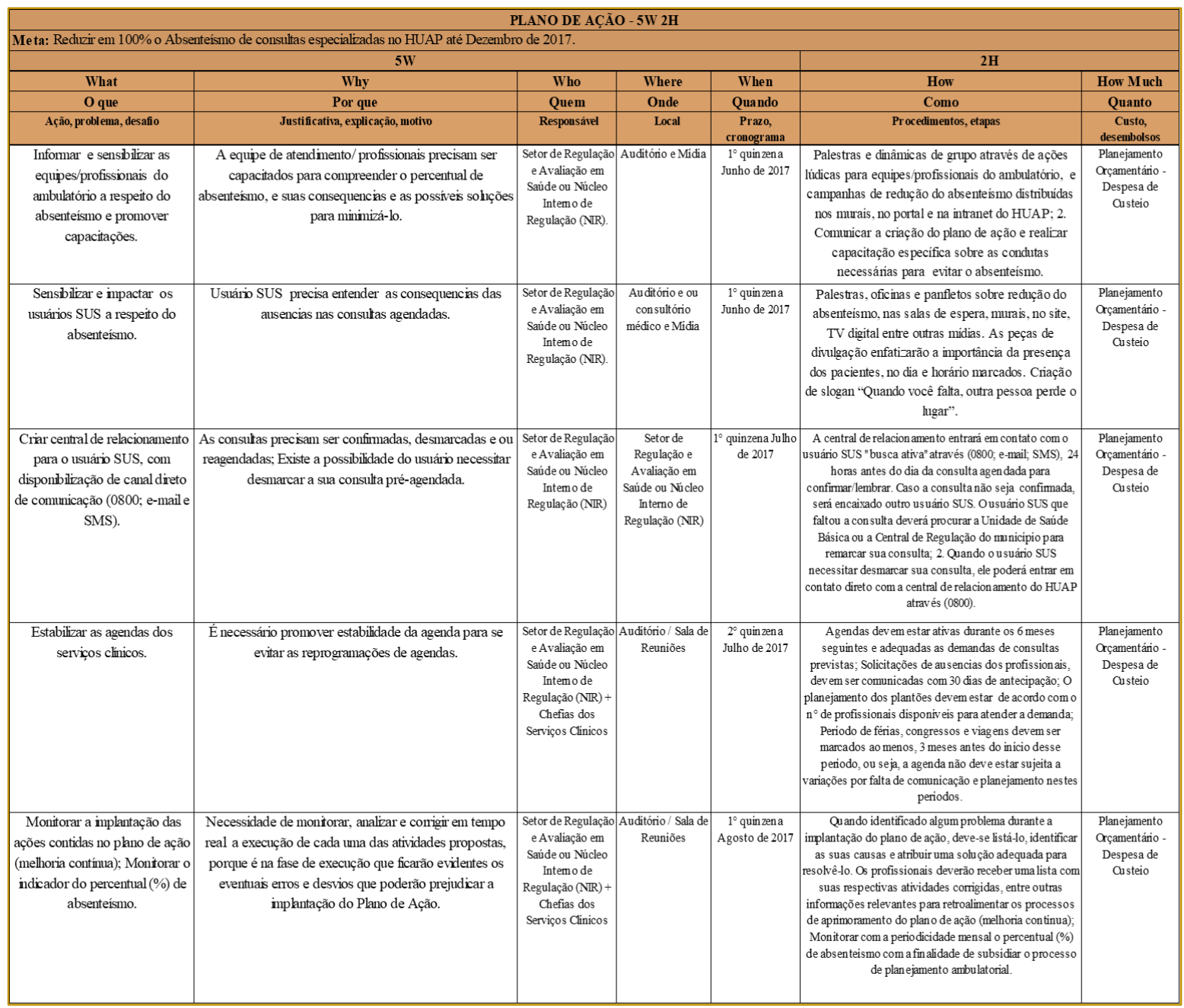

Fonte: Criado e elaborado pelos autores (2017).

\section{5 - CONCLUSÃO}

Esse estudo buscou discutir a importância do absenteísmo em um Hospital Universitário, na cidade de Niterói-RJ propondo ao final um plano de ação capaz de reverter ou minimizar a ausência de pacientes agendados para consultas ambulatoriais

O absenteísmo ambulatorial, caracterizado como a falta do paciente a um serviço de saúde previamente agendado, sem nenhuma notificação é fato que ocorre no Brasil e em outros países como afirmado por Olímpio et al (2016). Este acontecimento, segundo Ronald et al, abrange todos os atores envolvidos (trabalhadores, gestores e usuários).
$\mathrm{Na}$ instituição apresentada foram identificados 100.757 faltas, nos anos de 2015 e 2016, o que corresponde a $28,20 \%$ de falta entre os pacientes agendados, gerando prejuízos ao hospital na medida em que todas as rotinas hospitalares preestabelecidas são disponibilizadas (prontuários, vagas, materiais cirúrgicos, estruturas físicas e os recursos humanos) diariamente para atender a demanda, além de deixar de oferecer atendimento a outros pacientes que poderiam estar utilizando estas vagas, ocasionando o desperdício dos recursos institucionais (financeiros), corroborando com os estudos de Olímpio et al (2016). 
Desta forma, ao versar sobre absenteísmo foi apresentado, segundo Izecksohn e Ferreira, suas causas - relacionadas com o serviço, a gestão e a percepção do usuário - como por exemplo, falta ao trabalho do profissional, falta momentânea de insumos e ocorrência de imprevistos que impossibilitam a ida do usuário ao ambulatório, ou seja, dificuldade da liberação do trabalho e também de locomoção, paternidade, distância da data do agendamento e da consulta, esquecimento do usuário, melhoria do sintoma e falta de aviso para lembrar o usuário de sua consulta.

Olímpio et al (2016), complementa os estudos de Izecksohn e Ferreira apontando como causas fatores específicos como a gravidade da doença, óbitos do paciente, a não disponibilidade de profissionais e equipamentos, insatisfação do atendimento anterior, demora e abandono do local de atendimento. Como também, apresentou as consequências do absenteísmo, ou seja, perda de recursos administrativos, financeiros e sociais que foram disponibilizados para a realização do serviço ambulatorial.

Cavalcante (2016), acrescenta os estudos de Olímpio et al (2016), outras consequências do absenteísmo, como por exemplo, o adiamento das necessidades de cuidados que o usuário necessita, crescimento da demanda reprimida, desiquilíbrio na oferta de serviços, aumento dos custos assistenciais, desperdícios dos serviços da atenção básica, e o retrabalho na marcação da consulta através de agentes comunitários.

Ronald et al(2016), verificou que o aumento da visita do agente comunitário produz um menor número de absenteísmo. Desta forma os autores citados acima apontam as causas e as consequências do absenteísmo, havendo uma complementação entre as afirmações evidenciadas.

Diante do exposto, apresentaram-se as ações corretivas realizadas para diminuição do absenteísmo através do trabalho em equipe multiprofissional focadas na qualidade dos serviços, da gestão e do usuário, ou seja, na conduta dos profissionais, na adequação da estrutura física, na padronização dos processos e principalmente os de comunicação, motivado pelos estudos dos autores Ronald et al. (2013), Canelada et al. (2014) e Gonçalves C.A et al. (2015) apresentados no referencial teórico.

Assim, constatou-se que através do conhecimento das causas e das consequências elencadas pelos autores e as ações sugeridas por eles, foi possível dimensionar o absenteísmo e elaborar um plano de ação para o $\mathrm{HU}$, estruturado com a intenção de diminuir o índice de absenteísmo nos serviços de saúde da instituição pesquisada, possibilitando aos gestores a tomada de decisões que favoreçam a correção ou minimização do absenteísmo, evitando assim o desperdício de recursos institucionais e a insatisfação do usuário.

Deste modo, a elaboração do plano, iniciou-se a partir da institucionalização de um grupo de trabalho para sistematizar as diretrizes e normas do funcionamento ambulatorial do $\mathrm{HU}$ para coordenar os processos de trabalho com maior qualidade, reavaliando fluxos ambulatoriais e a necessidade de ajustes nos processos de marcação de consultas.

Isto posto, o plano de ação foi baseado na metodologia $5 \mathrm{~W} 2 \mathrm{H}$, com definições de atividades, responsabilidades, prazos e a maneira como implantá-las para o aprimoramento do acesso dos usuários do SUS aos serviços ambulatoriais do HU.

Desta forma, o plano estabeleceu ações para informação, sensibilização e capacitação das equipes/profissionais do ambulatório a respeito do absenteísmo, para compreensão do problema existente, suas consequências e possíveis soluções para minimizá-lo; a sensibilização dos usuários a respeito do absenteísmo, para compreensão das consequências geradas pelas faltas; a criação de central de relacionamento através de um canal direto de comunicação (0800; e-mail e SMS), para reagendamento do serviço; a estabilização das agendas dos serviços clínicos, para evitar reprogramações de agendas e por fim, o monitoramento da implantação das ações contidas no plano de ação, para analisar e corrigir em tempo real a execução de cada uma das atividades propostas, objetivando assim a melhoria contínua do serviço.

As ações elencadas acima, propostas no plano de ação, também foram observadas nos estudos de Ronald et al. (2013), Canelada et al. (2014) e Gonçalves C.A et al. (2015) auxiliando como referência para elaboração do plano proposto neste estudo.

Por tanto, espera-se que a definição e priorização de atividades e tarefas antes mesmo de colocadas em prática, garantam mais assertividade e correção prévia dos problemas identificados e que o plano de ação 
após sua efetivação, produza efeitos para diminuir o índice de absenteísmo no serviço ambulatorial do HU, ou seja, o absenteísmo é passível de correção quando há a realização de ações efetivas e eficazes ocasionando o aperfeiçoamento da oferta do serviço e a sua efetividade aos usuários do SUS.

Apesar desse estudo não esgotar a identificação de causas/consequências

\section{REFERÊNCIAS}

[1]. BRASIL. Ministério da Saúde. Secretaria de Atenção à Saúde. Portaria $n^{\circ} 3.390$, de 30 de dezembro de 2013. Institui a Política Nacional de Atenção Hospitalar (PNHOSP) no âmbito do Sistema Único de Saúde (SUS), estabelecendo-se as diretrizes para a organização do componente hospitalar da Rede de Atenção à Saúde (RAS). Diário Oficial [da República Federativa do Brasil], Brasília, DF, n. 253, 31 de dezembro de 2013. Seção 1, p. 54-57.

[2]. CANELADA, Haline Fernanda; LEVORATO, Cleice Daiana; CORTE, Rachel da Silveira; DINIZ, Emanuela dos Santos. Redução do Absenteísmo Através da Gestão da Agenda e do Trabalho em Rede. In: Anais do Congresso Internacional de Humanidades \& Humanização em Saúde [= Blucher Medical Proceedings, n. 2, v.1]. São Paulo: Editora Blucher, 2014. ISSN 2357-7282.

[3]. CAVALCANTI, Ronald Pereira; CAVALCANTI, Jaqueline Cristina Mota; SERRANO, Rossana Maria Souto Maior; SANTANA Paulo Roberto de. Absenteísmo de consultas especializadas no sistema de saúde público: relação entre causas e o processo de trabalho de equipe de saúde da família, João Pessoa - PB, Brasil. Tempus Actas de Saúde Coletiva. 2013;7(2): 63-84. Disponível em: <http:// dx.doi.org/10.18569/tempus.v7i2.1344> [Acesso em 10 mar 2016].

[4]. GIANNOTTI, E. M. A organização de processos regulatórios na gestão municipal de saúde e suas implicações no acesso aos serviços: Um estudo de caso do município de Guarulhos. (Dissertação). São Paulo: Faculdade de Saúde Pública da USP, 2013.

[5]. GONÇALVES et al., Estratégias para o enfrentamento do absenteísmo em consultas odontológicas nas Unidades de Saúde da Família de um município de grande porte: uma pesquisaação Ciência \& Saúde Coletiva, 20(2):449-460, 2015

[6]. IZECKSOHN MMV, Ferreira JT. Falta às consultas médicas agendadas: percepções dos usuários acompanhados pela Estratégia Saúde da Família, Manguinhos, Rio de Janeiro. Rev Bras Med Fam Comunidade. 2014;9(32):235-241. Disponível geradoras do absenteísmo, nem tão pouco evidenciar todas as possibilidades de intervenção/ação frente a esse problema, ficou visível a necessidade da implementação do plano de ação para redução do absenteísmo no HU. Dessa forma, sugere-se o aprofundamento do tema em relação ao impacto causado pelo absenteísmo aos usuários do SUS.

em: $\quad$ <http://dx.doi.org/10.5712/rbmfc9(32)960>. Acesso em 10 mar 2016.

[7]. MENDES, Eugênio Vilaça. As redes de atenção à saúde. Brasília: Organização PanAmericana da Saúde, 2011.

[8]. MISOCZKY, Maria Ceci Araújo. Planejamento e programação na administração pública - 2. ed. - Florianópolis: Departamento de Ciências da Administração.

[9]. NEVES, Waldir Viana Jr. Gestão Hospitalar: programa brasileiro de acreditação e sistemas de indicadores. Dissertação de mestrado, Universidade Federal Fluminense, Niterói, RJ, Brasil, 2004. Disponível: http://www.bdtd.ndc.uff.br/tde_busca/arquivo.phd? cod arquivo $=1841$.

[10]. OLÍMPIO, Nogueira Bittar; MAGALHÃES, Adriana; MARTINES, Claudio; FELIZOLA, Nadja; FALCÃO, Lilian. Absenteísmo em atendimento ambulatorial de especialidades no estado de São Paulo, 2016. Artigo - BEPA 2016; 13(152):19-32

[11]. RONALD et al. Absenteísmo de consultas especializadas no sistema de saúde público: relação entre causas e o processo de trabalho de equipes de saúde da família, João Pessoa - PB, Brasil. Rev Tempus Actas Saúde Coletivas, 2013.

[12]. SECRETARIA ESTADUAL DE SAÚDE DO ESTADO DO RIO DE JANEIRO. Atualização do Plano Diretor de Regionalização. Secretaria Estadual de Saúde do Estado do Rio de Janeiro, 2012.

[13]. SILVA, A. O.; RORATTO, L.; SERVAT, M. E.; DORNELES, L.; POLACINSKI, E. Gestão da Qualidade: Aplicação da ferramenta $5 \mathrm{~W} 2 \mathrm{H}$ como plano de ação para projeto de abertura de uma empresa. 2013. Disponível em: <http://www.fahor.com.br/publicacoes/sief/2013/ge stao_de_qualidade.pdf> Acesso em: 5 jun., 2017.

[14]. UNA-SUS. Programa de Qualificação para Profissionais de Regulação do Sistema Único de Saúde. Disponível em: $<$ http://www.unasus.gov.br/page/cursosabertos/programa-de-qualificacao-regulacao-dosus>. Acesso em 20 fev., 2017. 


\section{Gapítulo 20}

\section{CULTURA E MUDANCA ORGANIZACIONAL: UM ESTUDO NO HOSPITAL DE TRAUMA - PB}

\section{Amanda Raquel Franca Filgueiras D'Amorim}

Ramon Schnayder de França Filgueiras D`Amorim

Luciene Laranjeira Diniz.

Angélica Carina de Andrade Farias

Adriana Costa Cavalcanti

\section{Odaelson Antônio Clementino da Silva}

Resumo: Cultura organizacional define comportamentos específicos que direcionam a maneira como as pessoas agem, seus valores, normas, crenças e costumes que muitas vezes se traduzem em condutas desajustadas produzindo efeitos adversos ao sucesso da organização. O presente estudo tem como objetivo analisar a mudança na cultura organizacional do Hospital Estadual de Emergência e Trauma Senador Humberto Lucena, após a chegada da organização social Cruz Vermelha, bem como a postura dos servidores às mudanças implementadas. A pesquisa tem por intuito ajudar a entender como aspectos da cultura organizacional são relevantes para o gerenciamento do Hospital de Trauma referente à sua manutenção em nível de organização pública de saúde. Sendo a cultura organizacional uma ferramenta fundamental na administração de um hospital, por permitir ao gestor encontrar uma identidade coletiva na organização e possibilitar mecanismos hábeis de comunicação para seus colaboradores, ela também disponibiliza informações necessárias para sua contribuição com o desempenho organizacional. Este trabalho mostrou que a comunicação no processo de mudança organizacional, em certos momentos, influência negativamente no desenvolvimento da organização na busca de seus objetivos, e que para as organizações alcançarem um grau de eficácia é necessária mudança no processo da análise e tratamento das informações (comunicação).

Palavras-chave: Cultura Organizacional; Mudança; Hospital de Trauma 


\section{INTRODUÇÃO}

A realidade organizacional traz consigo a necessidade de adaptação constante, onde mesmo líderes do mercado precisam mudar melhorar, e inovar. Tais fatores de mudança mexem com a cultura da organização, que deve enfatizar as características e comportamentos para sua sobrevivência. Tal mudança é primordial para a sobrevivência na sociedade atual pelo fato de uma das grandes características do mundo moderno ser o fenômeno da mudança. Mudança essa que traz transformações que ocorrem nos campos da política, economia, tecnologia entre outras áreas. Mudar hoje é uma questão de sobrevivência (KISIL, PUPO, 1998).

Para que as organizações implementem essa mudança é necessário conhecer e considerar a cultura organizacional para absorção dessas novas tecnologias. Nesse contexto de mudança, emerge uma organização moderna, apoiada nas tecnologias da informação, atuando em rede e fundamentada na informação. Essas mudanças visam melhorar a eficiência das empresas, que, por sua vez, buscam resultados mais satisfatórios e maior poder de competitividade em um mercado globalizado, o que exige uma gestão estratégica eficiente, visto que uma instituição bem organizada é um dos componentes fundamentais para a prestação de um bom serviço e, portanto, para qualquer nível de melhoria, tanto no que se refere à disponibilização de tratamentos adequados eficientes, quanto ao atendimento efetivo a toda sociedade (FERREIRA et al, 2008).

Neste contexto os gestores públicos são exigidos para atuar em uma nova perspectiva gerencial que acarrete numa mudança na cultura da organização que possibilite a mesma atuar com mais eficiência e eficácia para atender às novas demandas da sociedade. É bem verdade que os ambientes e instituições públicas tenham um setor grau de estabilidade deslumbramos novas demandas da sociedade que evoluem em termos qualitativos e quantitativos o que nos faz manifestar-se sobre disposição do Estado por mudanças visando a sua adaptação a nova realidade que vivemos de inovação (BEGUE, 2012).

Assim, não estão fora deste contexto às instituições públicas hospitalares, visto que uma instituição bem organizada é um dos componentes fundamentais para a prestação de um bom serviço a sociedade. A cultura organizacional é uma ferramenta fundamental na administração de um hospital, pois permite ao gestor encontrar uma identidade coletiva, na organização possibilitando mecanismos hábeis de comunicação para seus colaboradores as informações que eles precisam para contribuir com o desempenho organizacional (SENHORAS, 2007). Vários fatores são críticos para garantir o sucesso efetivação de uma nova cultura organizacional em uma instituição de saúde entre eles esta a comunicação que deve ser garantida pelo compartilhamento de informações um espaço de participação.

As questões culturais podem inúmeras vezes transforma-se em problemas para a mudança em qualquer organização. Desta forma nossa pesquisa se propõe a elucidar as questões: como se percebe os aspectos de mudança e cultura organizacional no Hospital Estadual de Emergência e Trauma Senador Humberto Lucena após a chegada da organização social Cruz Vermelha? Qual a postura dos gestores e servidores com relação às mudanças que foram implementadas? Até que ponto a cultura organizacional melhorou o desenvolvimento da instituição?

Mediante a problemática evidenciada o presente estudo tem como objetivo analisar a mudança na cultura organizacional do Hospital Estadual de Emergência e Trauma Senador Humberto Lucena, após a chegada da organização social Cruz Vermelha bem como postura dos servidores as mudanças implementadas. Essa pesquisa ajudará entender como aspectos da cultura organizacional são relevantes para o gerenciamento de uma organização hospitalar.

A pesquisa também poderá auxiliar os membros da própria organização a compreender o papel dos valores realmente prezados e instigados na organização, bem como enxergar que contribuições poderão dar para garantir uma boa prestação de serviço à sociedade. As discussões sobre a cultura hospitalar é um elemento estratégico para os gestores, pois a preocupação com a cultura organizacional esta associada ao aperfeiçoamento e desenvolvimento dos processos em uma instituição hospitalar (SENHORAS, 2007). 


\section{CULTURA E MUDANÇA ORGANIZACIONAL}

A cultura organizacional é um conjunto de premissas que um grupo aprendeu a aceitar, como resultado da solução de problemas de adaptação ao ambiente e de integração interna. Essas premissas funcionam suficientemente bem para serem consideradas válidas e podem ser ensinadas a novos integrantes como sendo a forma correta de perceber e sentir-se em relação a esses problemas de adaptação externa e integração. Ferreira et al (2008). Tagliapietra e Bertolini (2007, p. 90) nos esclarecem que a cultura é representada por "[...] comportamentos que identificam o modo como determinado grupo social estabelece normas de conduta que irá orientar o comportamento das pessoas no trabalho, na comunidade e na família". A cultura organizacional tem sido colocada por diversos autores como importante aspecto da análise organizacional, capaz de oferecer informações importantes para uma compreensão ampliada do comportamento da organização (SARAIVA, 2002). Neste sentido, a cultura é representada por modelos mentais consolidados durante determinado período. A cultura organizacional define comportamentos específicos que direcionam a maneira como as pessoas devem agir, como as decisões são tomadas pelos administradores, qual o estilo de liderança adotado Ferreira et al (2008).

Para atender as novas demandas da sociedade, Bresser Pereira (1997 apud Saraiva, 2002) sustenta que o novo papel do Estado é o de facilitar a competitividade internacional, o que pode ser conseguido mediante melhoria dos seus sistemas de gestão para uma ação mais efetiva e eficiente em benefício da sociedade. A nova administração pública deve busca desenvolver nos funcionários um compromisso com a construção de uma sociedade mais preparada para enfrentar as novas demandas contextualizadas em uma era de mudanças nas organizações que para Cesar (2006 apud Ferretti et al, 2012, p.6) é representada por rupturas de forma irreversível, de estados estabelecidos, especialmente quando tais mudanças estão relacionadas com mudança de padrões culturais. Para a autora, a tecnologia é apontada como geradora de mudanças do sistema de produção e organização do trabalho e o desempenho dos gestores frente à situação de mudança é identificado como responsável pela origem das crises organizacionais. Um dos grandes marcos do mundo contemporâneo é o fenômeno da Mudança. Mudança que resulta das varias transformações que se dão nas áreas da política, econômico, tecnológico e filosófico. Mudar passa a ser palavra de ordem para a sobrevivência organizacional (KISIL; PUPO, 1998).

De maneira que mudança implica entender que: mudar é um processo que envolve pessoas, organizações e sistemas sociais; mudar requer que se conheça a razão de mudar e as forças desestabilizadoras do atual; mudar exige conhecer o que se quer mudar; mudar significa que se conheça de onde se está partindo e aonde se quer chegar; mudar exige organizar e gerenciar o processo de mudança e mudar exige de quem tem autoridade à decisão de muda (KISIL; PUPO, 1998).

\section{GESTÃO EM SAÚDE}

O contexto atual conjuntura em uma população está cada vez mais consciente de seus direitos e vários setores da sociedade começam a despertar e toma consciência, e "reivindica" por melhores serviços e transparência nas ações das instituições públicas. Como afirma Gonçalves et al. (2008, p. 10) "Em meio ao movimento da descentralização, a população de países como Brasil e Uruguai rumam em direção à mobilização e à reivindicação por melhores serviços públicos prestados".

$\mathrm{Na}$ atualidade, um dos diferenciais que conferem êxito às organizações é o desenvolvimento de suas atividades fundamentada na boa prestação de bons serviços de maneira a atender as demandas da sociedade. Essa realidade exige dos gestores uma nova perspectiva gerencial voltada não só as esferas econômicas e políticas, mas também para a gestão eficiente.

Nessa conjuntura, as instituições hospitalares, enquanto entidades ligadas diretamente à saúde e ao bem-estar social, precisam atentar ao gerenciamento adequado de seus serviços. Na gestão da saúde da população há uma necessidade de aplicar uma nova prática de gestão (uma nova postura) que na qual os servidores e gestores devem ser unir, e trabalhar em equipe, para desenvolvermos um bom serviço, visando o tão desejado comprometimento com a máquina pública, com os projetos, as ações, as metas, os prazos, além da cooperação e integração entre as secretarias e órgãos públicos, 
qualificando sempre os serviços públicos para o bom atendimento à população.

A Administração Pública precisa inovar-se. A sua operacionalidade no caso dos serviços que devem assegurar o direito à saúde é insatisfatória e não garante a efetividade do direito à saúde. É necessário promover uma reforma no seu interior, adotando-se novos marcos legais condizentes com as atuais necessidades da população em relação aos serviços públicos. (SANTOS. 2010, p.84)

A qualidade na prestação dos serviços com e eficiência são desafios que devem ser seguidos, de forma continua, pelos gestores públicos, pois a implantação de um novo plano de gerenciamento de um hospital precisa ser compreendida por todos. Através do trabalho em conjunto esforços coletivos, a uma grande necessidade de comunicação para que haja a busca pelo aprendizado e o aprimoramento contínuo na prática de novos padrões de conduta (SENHORAS, 2007).

O desenvolvimento de um processo de comunicação de qualidade, com nível de ruído quase inexistente é de grande importância para o crescimento da organização, uma vez que possibilita aos colaboradores e os gestores um entendimento comum das suas respectivas responsabilidades e dos padrões de desempenho que a organização espera obter deles. O processo de comunicação tem interferido no processo de mudança em virtude que nem todos da organização estão recebendo as informações e não estão compreendendo o processo de mudança. "A comunicação, portanto, é uma pilastra de aprendizagem para a coordenação cultural, de onde decorre a funcionalidade maior ou menor para a diminuição de custos de transação dentro da organização hospitalar" (SENHORAS, 2007, p.51).

\section{ORGANIZAÇÃO PÚBLICA: O HOSPITAL DE TRAUMA}

O Hospital Estadual de Emergência e Trauma Senador Humberto Lucena foi fundado em 2001 a partir da Lei Estadual № 6.746, de 09 de junho de 1999. O complexo hospitalar dispõe de uma estrutura moderna e arrojada e tem com finalidade específica operacionalizar a gestão e execução das atividades e dos serviços de saúde de urgência e emergência em trauma. O Hospital está capacitado para prestar assistência médica na área de traumatologia, queimados e outros serviços de urgência e emergência clínico-cirúrgica, de baixa, média e alta complexidade (HETSHL, 2014).

O Hospital está sendo administrado em uma gestão pactuada entre a Cruz Vermelha e o Governo do Estado. A mudança na administração do Hospital de Trauma foi anunciada pelo Governador no dia 6 de julho de 2011. Sobre os servidores e médicos que atuam na unidade: estes foram contratados pela Cruz Vermelha, passando a ser celetistas (CLT), e sendo que as parcerias com as cooperativas médicas continuam existindo (HETSHL, 2014).

A Cruz Vermelha é a maior instituição humanitária do mundo. Está presente em mais de 190 países, inclusive no Brasil. Em nosso País, encontra-se representado por um órgão nacional e por filiais estaduais e municipais. A Diretoria Nacional, sabedora do ambiente de constantes mudanças econômicas, políticas e sociais, seja por fatores oriundos da globalização, sejam por circunstâncias próprias da cultura brasileira, e do papel do Estado repensando sua atuação e o perfil de desempenho administrativo de suas estruturas, oferece ao segmento da Saúde instrumentos de apoio, planejamento, gestão e produção de serviços estruturados em modelos de organização, como forma de adequação às necessidades destes novos cenários, onde a saúde esta sendo tomada rapidamente pelos exigentes padrões de qualidade já comuns em outros setores. É reconhecida pelo governo brasileiro como sociedade de socorro voluntário, autônoma, auxiliar dos poderes públicos e, em particular, dos serviços militares de saúde, bem como única Sociedade Nacional da Cruz Vermelha autorizada a exercer suas atividades em todo o território brasileiro. (HETSH, 2014).

\section{PROCEDIMENTOS METODOLÓGICOS 5.1 MÉTODO}

Este estudo caracteriza-se como exploratório descritivo. Segundo Gil (1987, p. 46), a pesquisa descritiva é um dos métodos mais utilizados por pesquisadores sociais preocupados com a atuação prática. Ela permite caracterizar determinada população ou fenômeno e/ou estabelecer relações entre variáveis, além de possibilitar a explicação das relações de causa e efeito, ou seja, analisa o papel das variáveis que, de certa forma, influenciam ou causam o aparecimento dos 
fenômenos, sem manipulá-las (GIL, 1987; BOYD e WESTFALL, 1989; OLIVEIRA, 1997).

\subsection{NATUREZA}

De natureza qualitativa o estudo busca uma melhor compreensão particular daquilo que é estudado e tem sua principal atenção na centralização no especifico, com o objetivo da compreensão e não a explicação dos fenômenos preocupa-se em analisar e interpretar os dados em seu conteúdo psicossocial. Considera que há uma relação dinâmica entre o mundo real e o sujeito, isto é, um vínculo indissociável entre o mundo objetivo e a subjetividade do sujeito que não pode ser traduzido em números. Na pesquisa qualitativa, a interpretação dos fenômenos e a atribuição de significados são fundamentais. É descritiva e não requer utilização de métodos e técnicas estatísticas. O pesquisador, considerado instrumento chave, tende a analisar seus dados indutivamente, no ambiente natural (PRODANOV, FREITAS 2013).

\subsection{PARTICIPANTES}

Segundo o autor Vergara (2008) o universo pode ser considerado como um conjunto de elementos formados pelas empresas, produtos e pessoas que possuem as características que estarão no objeto de estudo. Nesse sentido o universo foram os servidores do Hospital de Trauma. Cabe ressaltar que conhecer as características que compõem a cultura organizacional da de uma instituição como o hospital de trauma é de grande relevância acadêmica para dar suporte a estudos posteriores mais aprofundados, pois estudar a cultura de uma organização requer um trabalho minucioso principalmente porque esta varia de acordo com cada instituição.

Com relação à amostra, Maconi e Lakatos (2007) a definem como uma parcela da população selecionada a partir do universo escolhido. Neste estudo, foi aplicado o critério não probabilístico por acessibilidade que é aquela em que a seleção dos elementos da população para compor a amostra depende ao menos em parte do julgamento do pesquisador ou do entrevistador no campo (OLIVEIRA, 2001 apud MATTAR, 2001, p. 132).

A amostra utilizada compõe-se de servidores do hospital de trauma sendo representadas por 50 indivíduos de diversos setores, onde todos são servidores que trabalham na instituição a mais de 5 anos.

\subsection{INSTRUMENTO DE PESQUISA}

O instrumento de pesquisa utilizado para analisar a mudança na cultura organizacional do Hospital Estadual de Emergência e Trauma Senador Humberto Lucena, após a chegada da organização social Cruz Vermelha bem como postura dos servidores as mudanças implementadas fora um roteiro de entrevista semi-estruturado aplicado junto aos servidores.

De acordo com Prodanov e Freitas (2013) a entrevista que é a obtenção de informações de um entrevistado sobre determinado assunto ou problema. Para o cumprimento do objetivo do estudo buscou-se conhecer a literatura referente à cultural mudança organizacional, bem como processo de comunicação e adotou os autores que segue no quadro, associandoos com as questões de pesquisa e suas variáveis. 
Quadro 1. Questões e Autores utilizados nas questões da entrevista.

\begin{tabular}{|c|c|c|}
\hline $\begin{array}{c}\text { Variável de } \\
\text { pesquisa }\end{array}$ & Questões do Instrumento de pesquisa & Autores \\
\hline Cultura & $\begin{array}{l}\text { Quais as reações das pessoas a essas mudanças que estão sendo } \\
\text { implementadas? } \\
\text { Quais os objetivos alcançados com a mudança já implementas? } \\
\text { Até que ponto a cultura existente na empresa contribui para o bom } \\
\text { andamento da mesma? E ate que ponto atrapalha? } \\
\text { Houve satisfação com as mudanças que ocorreram na instituição? }\end{array}$ & $\begin{array}{c}\text { Souza, } \\
2008, \\
\text { begue, } \\
2012\end{array}$ \\
\hline Mudança & $\begin{array}{l}\text { O que está mudando no Hospital de Trauma a partir do momento em } \\
\text { que passou a ser administrada pela organização social Cruz } \\
\text { Vermelha? } \\
\text { Qual o objetivo das mudanças na organização? } \\
\text { Quais campanhas estão sendo implementadas na organização? E } \\
\text { como estão sendo implementada? } \\
\text { As campanhas desenvolvidas dentro do Hospital qual o seu } \\
\text { objetivo? } \\
\text { Há resistência a mudanças, a que se deve essa resistência? } \\
\text { Sabemos que a sociedade está em constantes transformações. Você } \\
\text { tem percebido mudanças nas decisões estratégias da organização } \\
\text { por influencia dessas mudanças externas à organização? } \\
\text { A mudança ocorre com um processo de assimilação e crítica? Ou } \\
\text { seja, o que está sendo implantado na Organização passou por um } \\
\text { processo de adaptação? } \\
\text { O que culminou o processo de mudança adotado na Organização? } \\
\text { Qual foi o fato do contexto nacional ou internacional determinante } \\
\text { para esse processo? }\end{array}$ & $\begin{array}{c}\text { Begue, } \\
2012, \\
\text { Kisil, pupo, } \\
1998\end{array}$ \\
\hline $\begin{array}{l}\text { Processo de } \\
\text { comunicação }\end{array}$ & $\begin{array}{l}\text { O processo de comunicação para a mudança foi planejado pela } \\
\text { organização? } \\
\text { Houve melhorar efetividade na comunicação? } \\
\text { O processo de comunicação Ele é eficaz? } \\
\text { O processo de comunicação tem auxiliado ou interferido no êxito da } \\
\text { mudança? }\end{array}$ & $\begin{array}{c}\text { Begue, } \\
2012, \\
\text { senhoras, } \\
2007\end{array}$ \\
\hline
\end{tabular}

\subsection{PROCEDIMENTOS}

Considerando que o presente estudo foi desenvolvido no contexto organizacional do Hospital de Trauma, fez-se necessário obedecer aos trâmites éticos e burocráticos da instituição para a pesquisa científica. Tal prática possibilitou uma clara apresentação dos objetivos bem como da aprovação e apoio da referida instituição. Após a elaboração do instrumento de coleta dos dados, contataramse servidores da instituição para a elaboração da pesquisa. Sequencialmente, foi realizada a entrevista semi-estruturado aplicação foi realizada de forma individual.

\section{RESULTADOS}

\subsection{MUDANÇA E CULTURA ORGANIZACIONAL ASPECTOS OBSERVADOS}

As mudanças identificadas estão relacionadas à forma de realizar os procedimentos no hospital, visando mais eficiência, eficácia e efetividade organizacionais. Estas mudanças estão ocorrendo por meio da implantação de programas e campanhas. Como diz o (RESPONDENTE 1) "varias coisas estão acontecendo no hospital varias mudanças como reformas mudanças e procedimentos é umas campanhas que estão divulgando nos setores"

Para (RESPONDENTE 2) a principal mudança no seu setor foi a forma de identifica o paciente que chegar ao seu setor "antes se o paciente chegasse inconsciente no meu setor ficava difícil identificá-lo de maneira correta pois varias vezes as fichas acabam se misturando. Agora cada paciente vem com uma pulseira de identificação que facilita meu trabalho".

Uma das mudanças relatadas pelo respondente 2 faz parte de varias mudanças que vem ocorrendo na instituição essa em especial tem o objetivo de identificar os pacientes corretamente, pois falhas de identificação dos pacientes podem causar erros graves como a administração de medicamentos e cirurgias em pacientes errados. 


\subsection{ETAPAS DAS MUDANÇAS}

A qualidade e Excelência em atendimento é a busca contínua pela qualidade e hoje em dia, é indiscutível que a excelência no atendimento ao cliente (paciente) é um dos maiores diferenciais do mercado e o fator principal para o crescimento e desenvolvimento de toda organização. O (RESPONDENTE 3) nos esclareceu que varias etapas estão sendo desenvolvidas na organização " $A$ primeira mudança que ocorreu o hospital foi à forma que a gente fazia a identificação dos pacientes que agora esta bem melhor, depois foi à comunicação entre profissionais que pouco existia e agora melhorou um pouco, outra coisa que melhorou foi à segurança de medicações que esta bem mais rigorosa antes não tinha muito controle".

Para o (RESPONDENTE 4) que trabalha no bloco cirúrgico a mudança aconteceu foi "agora antes da cirurgia realizar uma revisão do início do procedimento cirúrgico, para garantir que se trata do paciente certo, cirurgia e parte do corpo certa antes isso pouco ocorria".

Para o (RESPONDENTE 5) que trabalhar na higienização do hospital uma etapa fundamental foi "hoje a uma conscientização maior dos funcionários em descarta o lixo no lugar adequando e manter o seu setor limpo isso tem ajudado muito meu trabalho".

Reduzir o risco de infecções hospitalares e fundamental para os cuidados a saúde. Diversos. Respondentes afirmaram hoje existe muita conscientização por parte dos colaboradores do hospital sobre medidas que podem ser tomadas para sua prevenção de infecção hospitalar. A higiene das mãos, de acordo com as diretrizes atuais da Organização mundial da saúde é uma medida primária preventiva fundamental $(\mathrm{O}$ RESPONDENTE 7) diz "eu não tinha o habito de lava as mãos antes dos procedimentos. Depois das orientações que recebi sei da importância desse procedimento".

Para os (RESPONDENTES 6, 8, 9 10, 12 e 14) a principal mudança foi em relação às campanhas que a organização implementou na organização. Para o (RESPONDENTE 6) foi muito importante as palestras e serviços oferecidos pela organização "fiquei muito feliz, pois participei de varias palestras sobre pressão arterial, pois tenho pressão alta" (RESPONDENTE 8) importante foi a "gostei muito da orientação nutricional, da ginástica laboral e diversas outras que participei me sentir valorizado".

A partir das respostas dos colaboradores observamos que o Hospital lançou varias a campanhas com a finalidade de melhora a qualidade de vida dos seus colaboradores. Para (RESPONDENTE 14) que é coordenador de um dos setores do hospital "Com 0 desenvolvimento dessa campanha, o hospital pretende aumentar a satisfação dos funcionários e aumenta a autoestima deles".

De acordo com um dos coordenadores, as campanhas desenvolvidas dentro do Hospital servem para aproximar e valorizar todos os servidores da Instituição: "É nosso dever contribuir para a cidadania dos nossos servidores".

O tema "Qualidade de vida no trabalho" vem se tornando cada vez mais uma preocupação para a Administração Pública e empresas, devido à ligação que existe entre condições adequadas para realização de um trabalho e produtividade, podendo se destacar por vários itens que formam um conjunto de fatores que interferem no desempenho dos funcionários. Para França (2007, p.168 apud Albuquerque, 2014) "No trabalho a qualidade de vida representa a necessidade de valorização das condições de trabalho, da definição de procedimentos da tarefa em si, do cuidado com o ambiente físico e dos bons relacionamentos". A gestão da qualidade vida nas organizações depende fundamentalmente da otimização do potencial humano, isto é, depende de quão bem as pessoas se sentem trabalhando na organização.

\subsection{POSTURA DOS SERVIDORES FRENTE ÀS MUDANÇAS}

As reações tem sido as mais diversas. Existe ressentimento dos colaboradores que resistem às propostas de mudança. Como diz (RESPONDENTE 19) "essas mudanças só vieram para arruma mais trabalho mim agora tenho que verificar isso aquilo tenho trabalho em dobro não gosto dessa cruz vermelha"

Outros colaboradores ignoram a mudança e fingem que nada está acontecendo. (RESPONDENTE 16) afirma que "Isso não vai da em nada, não resolver nada eu mesmo não vou colabora com nada, não vejo sentido nisso tudo".

Porém, boa parte dos colaboradores acredita e aceita a mudança com bons olhos e acreditar 
no sucesso da organização. O (RESPONDENTE 20) diz "já estava na dessas mudanças trabalho nesse hospital a mais de 5 anos e estou muito satisfeito e ansioso com rodas as mudanças que estão ocorrendo". O que chama atenção em relação à postura dos servidores e que vários servidores se referem que as mudanças ocorrem sem que a informação não chegar de forma correta para todos. Para o (RESPONDENTE 13) "as mudanças não atingiram todos os funcionários principalmente para aqueles que trabalham a noite há uma grande falha no processo de comunicação dentro da organização, visto que as informações não são repassadas para todos os colaboradores, dificultando integração dos mesmos".

O (RESPONDENTE 23) nos diz "só fico sabendo o que acontece pelos corredores (o famoso rádio peão ou corredor) ". O (RESPONDENTE 27) "o que ocorre com a informação principalmente pra quem trabalhar a noite e que na verdade são poucas as informações, e quando existem são ruim".

O (RESPONDENTE 30) diz que "a comunicação é tão falha gera um grande problema de comunicação entre as entre as equipes que acarretam na execução das tarefas de forma diferente".

Nada adianta ter um processo de comunicação muito elaborado, mas de difícil entendimento, desta forma o colaborador não vai compreender o que está sendo transmitido e ocorrerá uma série de desentendimentos e enganos, que por usa vez irão influenciar negativamente no processo de mudança na organização. "É primordial ressaltar que o sucesso da organização de aprendizagem é dependente da integração sistêmica das pessoas por meio da criação de canais confiáveis de comunicação" (SENHORAS, 2007, p.51). O processo de comunicação na instituição não é eficaz, pois a comunicação é ineficiente e muitas vezes inexistente.

\subsection{SATISFAÇÃO FRENTE ÀS MUDANÇAS}

A uma grande satisfação dos colaboradores, como dos pacientes e o melhor uso do aparelho público da instituição. É o que mostra uma pesquisa interna realizada no Hospital, a pesquisa revela que $97 \%$ dos usuários internados na instituição estão satisfeitos com o atendimento da unidade de saúde. Os números foram obtidos a partir de um questionário, aplicado na instituição, que verificou o grau de satisfação com os serviços. O (RESPONDENTE 33) está muito satisfeito com as mudanças "estou muito satisfeito com as mudanças e melhorias após a chegada da cruz vermelha antes não recebia um salário bem baixo agora esta bem melhor, alem disso minha carteira foi assinada tenho direito a férias e outros e benefícios". O trabalho que vem sendo realizado mensalmente na organização tem o objetivo corrigir falhas e intensificar a excelência na gestão e no atendimento.

\subsection{ASSIMILAÇÃO AO PROCESSO DE MUDANÇA}

O (RESPONDENTE 34) afirma "as mudanças tem sido muito boas para todos pacientes e funcionários aos poucos estamos compreendendo a importância dessas mudanças". Afirma o (RESPONDENTE 14) que é coordenador de um dos setores do hospital diz que "o hospital vem promovendo a melhoria contínua dos serviços de saúde e a melhoria no desempenho de todos os colaboradores da instituição isso vem facilitando a compreensão de todas as mudanças"

Durante processo de mudança no hospital houve grande assimilação às mudanças. A mudança de comportamento dos de grande parte dos servidores demonstra isso. O que tem ajudado essa assimilação são as palestras e orientações que o hospital vem realizando, e verdade que existem algumas falhas, mas de modo geral os colaboradores estão satisfeitos.

\section{SUGESTÕES E PROPOSTAS}

Diante do exposto e de nossas análises e sabendo que a cultura organizacional define comportamentos específicos que direcionam a maneira como as pessoas devem agir, como as decisões são tomadas pelos administradores, como os processos organizacionais são conduzidos, qual o estilo de liderança adotado, entre outras, infere-se que a cultura interna a organização pesquisada vem vários sérios problemas no que diz respeito à comunicação interna.

De modo geral, podemos observar que uma falha nas informações que são repassadas aos todos colaboradores. O sistema de informação e comunicação não esta atendendo de forma adequada todos os funcionários no tocante à informação precisa. 
O que nos remete a inferir que as deficiências encontradas durante a pesquisa se devem ao fato das organizações, e não só esta, tentarem encontrar formulas mágicas para solução de seus problemas como nos afirma Soto (2002, p. 260):

[...] A administração para muitas empresas consiste não em procurar o melhor para elas por intermédio de seu pessoal, mas em ler o novo livro da moda ou contratar um consulto de renome para que aplique o remédio para sua organização. Tudo sem saber que soluções únicas e personalidades se encontram na própria organização [...].

Como enfatiza Soto, os administradores pensam encontrar com facilidade métodos ou metodologias para aplicação de tecnologias com promessas de mudanças de inovação; fórmulas mágicas e instantâneas de sucesso. Esse pensamento se caracteriza como um tipo de cultura organizacional ou podemos chamar de "modismos gerenciais". Essas valorações de novas tecnologias introduzem climas favoráveis de "modismos tecnológicos". Esses modelos milagrosos quando não atingem o sucesso esperado acarretam vários problemas insatisfação, desmotivação, frustração assim aumentando o grau de resistência à mudança.

Como sugestão para que as instituições possam obter suporte para melhoria no processo de decisão, é necessário que o sistema de informação (comunicação) possa atender as principais necessidades de informacionais dos usuários. 0 desenvolvimento de um sistema de informação deverá passar primeiro pela identificação das reais necessidades de cada setor, devendo ser reunida de forma ordenada, e para que isso ocorra será necessária à ocorrência de mudanças no processo de comunicação.

\section{CONSIDERAÇÕES FINAIS}

O estudo apresentou conceitos sobre a cultura e mudança organizacional e sua importância para as instituições hospitalares. O grande desafio da gestão é garantir um processo coordenado e planejado de mudança. Pois implantações de uma nova cultura e programas de qualidade em grandes empresas falhavam por não terem sido precedidas ou acompanhadas de mudanças culturais bem planejadas. Essa pesquisa teve como objetivo analisar a mudança na cultura organizacional do Hospital Estadual de Emergência e Trauma Senador Humberto
Lucena, após a chegada da organização Social Cruz Vermelha bem como postura dos servidores as mudanças implementadas. Ao analisamos a mudança na cultura organizacional da organização e qual a postura dos gestores e servidores com relação às mudanças que foram implementadas observamos a falta de um engajamento e comprometimento de alguns profissionais com a organização. Mas a grande maioria dos respondentes de nossa pesquisa se demonstra satisfeito com as mudanças e com muitas expectativas para 0 futuro da organização.

Durante as mudanças podem ocorrer fatores imprevistos e emergentes que não forma previamente planejados que podem gerar resultados insatisfatórios e consequentemente o insucesso das mudanças. É importante, portanto, que as organizações deem mais atenção à preparação dos funcionários visando uma melhor aceitação as mudanças.

O que pudemos inferir da análise de nossas observações, da aplicação das entrevistas, e considerando que um bom sistema de comunicação pode ser um fator decisivo para - estabelecimento de uma mudança organizacional, verificou-se que a instituição pesquisada tem um sistema de comunicação com algumas falhas, mas que pode melhora a partir da sugestão dos próprios colaboradores que identificaram esse problema. Para que haja uma boa comunicação, precisamos ouvir ativamente e consequentemente, compreender o significado da comunicação. Desse modo, evitam-se os ruídos, que impedem que a mensagem seja transmitida de maneira clara.

Os objetivos alcançados com as mudanças implementadas na organização se relacionam ao fato de que o Hospital de Trauma de João Pessoa acabou sendo indicado para certificado de Acreditação. O Hospital é o primeiro hospital público da Paraíba e o quarto do Nordeste a conquistar a indicação para receber o certificado de Acreditação. A certificação atesta a qualidade dos serviços prestados, garantindo maior transparência e eficiência no atendimento médico. Com o recebimento do selo de Acreditação, o Hospital de Trauma de João Pessoa entra na lista dos grandes hospitais do Brasil, que possuem esse certificado.

Essa pesquisa permitiu uma melhor compreensão da cultura organizacional e da 
sua relevância para um bom desenvolvimento de uma organização hospitalar.

Sendo assim, este trabalho mostrou que a comunicação no processo de mudança organizacional, em certos momentos, influência negativamente no desenvolvimento da organização na busca de seus objetivos, e para as organizações alcançarem um grau de

\section{REFERÊNCIAS}

[1] Bergue, Sandro Trescastro. Cultura e Mudança organizacional. Departamento de Ciências da Administração / UFSC; [Brasília]: CAPES: UAB, 2010.106p.

[2] Boyd, H.; Westfall, R. Pesquisa Mercadológica. 5. ed., Rio de Janeiro: Fundação Getúlio Vargas, 1982

[3] Ferreira, Josivaldo Soares. Dantas, Cristiana da Silva. Veloso, Jardel Gonzaga. Fidelis, Marli Batista. Fernandes, Emmanuel Silva. Léllis, Jimmy de Almeida. Uma Análise do Binômio Cultura / Tecnologia Através do Uso do SIG: um estudo de caso no segmento eletroeletrônico. III Congresso de Pesquisa e Inovação da Rede Norte Nordeste de Educação Tecnológica Fortaleza - CE - 2008.

[4] Ferretti, Renata. Tres, Guilherme Smaniotto. Louzada, Sergio Vinicius. A Implantação do Modelo Gerencial na Administração Pública Brasileira e a Resistência à Mudança: A Análise da Implantação do Processo Judicial Eletrônico no Tribunal Regional do Trabalho na Cidade de São Paulo. Encontro de Administração Pública e Governo. Salvador $\backslash$ BA. 18 a 20 de novembro de 2012. Disponível em < http://www.anpad.org.br/diversos/trabalhos/EnAPG/ enapg_2012/2012_EnAPG155.pdf> acesso em 15 de outubro de 2014.

[5] Gil, A. C. Como elaborar projetos de pesquisa. São Paulo: Atlas, 1987

[6] Gonçalves, Andréa de Oliveira. Gonçalves, Rodrigo de Souza, Weffort, Elionor Farah Jreige. Tipologias de Comunidades Participativas na América Latina: o Caso dos Conselhos de Saúde de Montevidéu (Uruguai) e Porto Alegre (Brasil). Cadernos Prolam/USP (ano 8 - vol. 1 - 2008), p. 9 39. Disponível em < http://www.usp.br/prolam/downloads/2008_1_1.pdf > acesso em 04 de setembro de 2014.

[7] Hetshl. Hospital Estadual de Emergência e Trauma Senador Humberto Lucena. Apresenta informações sobre a organização social Cruz vermelha. Disponível em < http://hospitaldetrauma.pb.gov.br/cruz-vermelhabrasileira/saude-publica-e-a-cruz-vermelhabrasileira> acesso em 27 de março de 2014.

[8] Kisil, Marcos. Pupo, Tânia Regina Gasparini Botelho. Gestão da Mudança Organizacional. São Paulo: Faculdade de Saúde Pública da Universidade de São Paulo, 1998. (Série eficácia é necessária mudança no processo da análise e tratamento das informações (comunicação).

De maneira que mudança implica entender que: mudar é um processo que envolve pessoas, organizações e sistemas sociais; e tudo isso resultará num diferencial de qualidade e eficiência na organização.

Saúde \& Cidadania). Disponível em < http://www.saude.sc.gov.br/gestores/sala_de_leitur a/saude_e_cidadania/ed_04/index.html> acesso em 20 de março de 2014.

[9] Marconi, Mariana de Andrade. Lakatos, Evan Maria. Fundamentos de Metodologia Cientifica. 6 ed. São Paulo: atlas 2008.

[10] Mattos, Lissandra Kerppers. As Mudanças Organizacionais e Seus Gestores nas Empresas na Era da Informação. Dissertação de mestrado apresentada a Escola Brasileira de Administração Pública e de Empresas como requisito parcial para obtenção de Título Mestre em Administração Pública pela Fundação Getulio Vargas, Centro de Formação Acadêmica e Pesquisa. Disponível em < http://bibliotecadigital.fgv.br/dspace/bitstream/han dle/10438/3671/Lissandra.pdf?sequence=1 > acesso em 10 de setembro de 2014

[11] Oliveira, Tânia Modesto Veludo de. Amostragem não probabilística: Adequação de Situações para uso e Limitações de amostras por Conveniência, Julgamento e Quotas. Administração On Line. Volume 2 - Número 3 (julho/agosto/setembro - 2001) disponível em < http://www.fecap.br/adm_online/art23/tania2.htm> acesso em 20 de outubro de 2014.

[12] Oliveira, S. L. Tratado de metodologia científica: projetos de pesquisa, TGI, TCC, monografias, dissertações e teses. São Paulo: Pioneira, 1997.

[13] Prodanov, Cleber Cristiano. Metodologia do Trabalho Científico [recurso eletrônico]: métodos e técnicas da pesquisa e do trabalho acadêmico / Cleber Cristiano Prodanov, Ernani Cesar de Freitas. - 2. ed. - Novo Hamburgo: Feevale, 2013.

[14] Saraiva, Luiz Alex Silva. Cultura Organizacional em Ambiente Burocrático. RAC, v. 6, n. 1, Jan./Abr. 2002: 187-207.

[15] Santos, Lenir. Administração pública e a gestão da saúde in Gestão Pública e Relação Público Privado na Saúde/ Nelson Rodrigues dos Santos e Paulo Duarte de Carvalho Amarante (Organizadores) - Rio de Janeiro: Cebes, 2010. $324 p$

[16] Senhoras, Elói Martins. A cultura na organização hospitalar e as políticas culturais de coordenação de comunicação e aprendizagem. RECIIS - R. Eletr. de Com. Inf. Inov. Saúde. Rio de Janeiro, v.1, n.1, p.45-55, jan.-jun., 2007. Disponível 
em

http://www.reciis.icict.fiocruz.br/index.php/reciis/arti cle/viewFile/45/55> acesso em 05 de setembro de 2014.

[17] Soto, Eduardo. Comportamento Organizacional: o impacto das emoções. São Paulo: Pioneira Thomson Learning, 2002.

[18] Souza, Alan Araújo Monteiro de. A influência da cultura organizacional no gerenciamento eletrônico de documentos [manuscrito]: o caso da Diretoria Jurídica do Banco do Brasil. - 2008. $168 \mathrm{f}$

[19] Tagliapietra, Odacir Miguel, Bertolini, Geysler Rogis Flor. Cultura Nacional e Cultura Organizacional. Ciências Sociais em Perspectiva (6) 10: 89 - $981^{\circ}$ ㅇ sem. 2007

[20] Vergara, Sylvia Constant. Projetos e Relatórios de Pesquisa em Administração. 2 ed. São Paulo:Atlas, 1998. 


\section{Gapítulo 21}

\section{ESTUDO SOBRE A GESTÃO SUCESSÓRIA NA ADMINISTRACÃO PÚBLICA ESTADUAL COM BASE NO CAPITAL INTELECTUAL/HUMANO}

\section{Thiago Couto Lage \\ Branca Regina Cantisano dos Santos e Silva Riscado Terra \\ Ricardo Miyashita}

Dércio Santiago da Silva Junior

Resumo: O tema deste trabalho é a gestão sucessória nas empresas, tendo como foco a implementação desse processo nas unidades organizacionais que compõem a Administração Pública. De acordo com a literatura, a sucessão planejada é amplamente adotada nas empresas privadas, o mesmo não ocorrendo no âmbito das organizações públicas. A pesquisa explora assuntos correlatos ao tema central de um ponto de vista teórico, tais como inovação organizacional, gestão do conhecimento, ativos intangíveis, capital intelectual e capital humano. Apresenta recorte empírico correspondente a investigação junto a unidades organizacionais da administração direta do Poder Executivo do Governo do Estado do Rio de Janeiro com o objetivo de saber como os gestores públicos deste ambiente percebem e vivenciam o processo de gestão sucessória. Conclui que a gestão sucessória é prática fundamental para assegurar a qualidade dos serviços públicos oferecidos à população, especialmente no cenário brasileiro, e que a adoção e difusão de políticas de planejamento sucessório contribui para o enfrentamento dos atuais desafios do setor público. Por outro lado, conclui que no setor público o planejamento sucessório depende de cultura organizacional e que este é um processo ainda incipiente na estrutura governamental do Estado do Rio de Janeiro, perspectiva que pode ser estendida a outras administrações públicas do Brasil. 


\section{CONTEXTO DO PROBLEMA}

O setor público possui natureza reconhecidamente distinta da natureza do setor privado. A iniciativa privada preza por interesses de indivíduos e grupos, pautandose pelas leis do mercado, enquanto o setor público, visando à preservação do bem público e ao bem-estar da coletividade, pautase pelas normas legais institucionalizadas pelo Estado.

Uma área importante de estudo é compreender como as instituições públicas lidam com o seu capital intelectual e humano, que inclui conhecimentos, qualificações, competências coletivas, aptidões, experiências, criatividade, capacidade de inovação, motivação e formação profissional dos trabalhadores, potencialmente identificados, medidos e desenvolvidos (OREJA e PRIETO, 1998).

Uma iniciativa muito importante dentro deste contexto é a adoção do planejamento sucessório. A matéria já é bastante presente no cotidiano das empresas privadas, onde sistemas de gestão sucessória vêm sendo amplamente implementados. No setor público, entretanto, esta é uma preocupação apenas recente, sinalizando que programas de gestão sucessória são ainda muito pouco utilizados no âmbito administrativo (WILKERSON, 2007).

Isso pode ser explicado pela influência política a que este setor está sujeito. Muitos cargos de chefia na administração pública são preenchidos por indicação política, não levando em consideração elementos do capital humano que podem tornar-se um diferencial na escolha de um gestor para assumir posições estratégicas. Em consequência, essas posições acabam ocupadas por gestores que não possuem competências técnicas e gerenciais, além de conhecimento específico da área onde irão atuar, principalmente por não terem sido capacitados para esse fim.

Este trabalho trata da gestão sucessória na administração pública, tendo como foco órgãos da administração direta do Poder Executivo do Governo do Estado do Rio de Janeiro.

\section{OBJETIVOS}

O objetivo geral da pesquisa é analisar o planejamento sucessório nas organizações e seus benefícios.

São objetivos específicos: i) reunir conhecimentos associados ao tema central, como inovação e inovação no setor público, gestão do conhecimento, ativos intangíveis, capital intelectual e capital humano; ii) refletir sobre as questões que envolvem a gestão sucessória no setor público, bem como os modelos sugeridos pela literatura neste âmbito; e iii) verificar de que forma a administração direta do Poder Executivo do Estado do Rio de Janeiro lida com o processo de gestão sucessória.

\section{REVISÃO DA LITERATURA}

\subsection{ATIVOS INTANGÍVEIS, CAPITAL INTELECTUAL E CAPITAL HUMANO}

Apesar da importância dos bens físicos imobilizados - até a década de 1980, a grande preocupação no mundo dos negócios era como avaliar o ativo tangível das empresas com a globalização, desregulamentação da economia, avanços tecnológicos e o aumento da disponibilidade de tecnologias da informação, particularmente a internet, cresceu a importância dos ativos intangíveis para as organizações na formação de valor agregado e como importante diferencial competitivo (LEV, 2001).

Tal perspectiva também se justifica mediante normas internacionais e nacionais de contabilidade - dentre as quais a International Accouting Standard (IAS) 38, a Lei no 11.638, de 2007, e o Procedimento Técnico CPC 04 (R1), de 2010, - que não só reconhecem a importância dos ativos intangíveis como estabelecem que eles devem ser identificados e divulgados no Balanço Patrimonial das empresas (BP).

Grande parte da literatura refere-se a ativos intangíveis como capital intelectual, frequentemente utilizando essas expressões como sinônimas. Nesta pesquisa, contudo, toma-se o capital intelectual como um dentre outros ativos intangíveis - de acordo com Antunes e Martins (2005), na Ciência Contábil, o capital intelectual integra o rol dos ativos intangíveis.

O capital intelectual está diretamente ligado aos elementos intangíveis resultantes das atividades e práticas administrativas 
desenvolvidas pelas organizações para se adaptarem e atuarem na denominada "sociedade do conhecimento". Os intangíveis surgem principalmente em função das revoluções nas áreas da tecnologia da informação e das telecomunicações, que, por sua vez, também propiciaram as condições atuais dessa nova sociedade (ANTUNES e MARTINS, 2005).

Para outros autores como Stewart (2002a), Oreja e Prieto (1998) e Edvinsson e Malone (1998) o capital intelectual seria basicamente composto pelo capital humano, pelo capital estrutural e capital de clientes ou relacional, suas mais dimensões representativas na relação com a capacidade inovadora da empresa.

A presença do capital humano em todas as classificações mencionadas denota a importância desse elemento, tal qual ocorreu na época dos primeiros estudos sobre capital intelectual, que se desenvolveram a partir de reflexões acerca do papel desempenhado pelo capital humano nas organizações (ANTUNES, 2000). Contudo, capital intelectual e capital humano, embora intimamente relacionados, não são coincidentes. Segundo Khang (2014), em termos gerais, o capital humano refere-se a recursos humanos ou capacidades humanas que produzem renda monetária e psíquica futura. Enquanto o capital intelectual está centrado no investimento no negócio e na produção de fontes intangíveis de valor futuro, o capital humano foca naquilo que os indivíduos possuem e no investimento em suas capacidades próprias para produzir valor futuro.

\subsection{GESTÃO SUCESSÓRIA}

O tema sucessão vem se inserindo fortemente nos debates da administração e gestão de empresas, seja no cenário mundial ou no brasileiro, especialmente em relação às empresas privadas (OLIVEIRA e BERNARDON, 2008). Sua relevância justificase porque a própria sobrevivência das empresas depende de dispor de pessoas em todos os níveis organizacionais preparadas para assumir as posições críticas abertas pelo crescimento do negócio ou pela saída de seus atuais ocupantes (OHTSUKI, 2013).

O processo sucessório tem sido mais estudado no âmbito das empresas familiares, organizações tidas como de dinâmica diferenciada por envolver membros de uma mesma família participando da propriedade e/ou direção (LEONE, 2004). Nesse contexto, a sucessão, ligada ao fator hereditário, é definida como um rito de transferência do poder e do capital entre a atual geração dirigente e a que virá dirigir. Ou seja, o processo sucessório dá-se quando uma geração da mesma família abre espaço à preparação da outra para assumir o comando (LEONE, 2004).

De modo geral, verifica-se que o evento sucessório nas organizações ocorre independentemente de ter sido ou não planejado, não estando necessariamente sujeito a qualquer definição ou ações prévias tampouco à explicitação de critérios para a tomada de decisão referente a potenciais sucessores. Nesses casos, a sucessão pode ser considerada um evento pontual, episódico (FERREIRA, 2015).

Contudo, idealmente, a sucessão precisa ser definida com antecedência (permitindo ao sucessor receber treinamento adequado e conhecimentos necessários ao negócio), estar diretamente ligada à estratégia da empresa e ocorrer de forma gradativa e planejada. (OLIVEIRA e BERNARDON, 2008; LEONE, 2004). Por seus efeitos na organização, e para a elaboração ou implantação de estratégias explícitas, esse processo é parte de uma mudança, e, por isso, tem de ser planejado (LEONE, 2004).

De acordo com Mehrabani e Mohamad (2011), o planejamento sucessório é um plano que corresponde a um esforço adequado para o enfrentamento das mudanças no ambiente organizacional, particularmente quanto ao que a empresa projeta para o futuro em relação a seus colaboradores, que pode mudar por razões tais como aposentadorias, promoções, doença grave, morte ou qualquer saída voluntária de um empregado para seguir carreira em outro lugar.

Para Ferreira (2015), esse planejamento decorre, invariavelmente, de ações deliberadas e anteriores ao evento propriamente dito, pois é condicionado à interrelação estabelecida, ou a ser estabelecida, entre o ocupante da posição e o(s) potencial(ais) ou eventual(ais) candidato(s) sucessor ou sucessores - seja no curto, médio ou longo prazo.

Embora a proliferação de estudos sobre gestão sucessória no setor privado tenha criado um significativo corpo teórico, existe uma lacuna de análises sobre o tema no setor 
público. Apenas recentemente o processo sucessório tem sido focado por esse setor, bem como os riscos da não adequação desse processo ou sua ausência (WILKERSON, 2007).

Conforme já mencionado, o setor público possui características que o distinguem singularmente do segmento privado. Em relação à força de trabalho, notadamente a maior flexibilidade do setor privado sobre o público no recrutamento de profissionais e lideranças para contratação (LUNA, 2012).

No Brasil, empresas públicas e órgãos da administração pública estão sujeitos ao provimento de pessoal mediante a realização de concursos públicos para contratar profissionais, sendo que todo esse processo deve respeitar os princípios que norteiam esse tipo de contratação, quais sejam, universalidade de acesso e uso de critérios abrangentes e impessoais (FARO e DINIZ, 2012).

No Brasil, Faro e Diniz (2012) apontam a perda de um líder em razão de sua aposentadoria como uma ruptura na continuidade da gestão. Mesmo mediante a identificação de um sucessor por cada líder anos antes de sua aposentadoria, persistem dúvidas tais como se - líder a se aposentar seria a melhor pessoa para escolher seu sucessor, se ele possui as habilidades necessárias para tanto e desenvolver seu sucessor e se existiriam interesses não meritórios nesse processo. Rupturas menores na continuidade da gestão também contribuiriam para a necessidade de implementação da gestão sucessória no serviço público, pois não se sabe exatamente quando e em que proporção elas ocorrerão, tais como pedido de demissão por parte do líder, necessidade de demissão por parte da organização, transferência do líder para outra área ou outra empresa e crescimento orgânico do negócio.

Lynn (2001) pontua ainda os impedimentos em levar a sério os esforços de sucessão no setor público, que incluiriam questões de escopo, o confronto entre substituição versus posicionamento e a ausência de técnicas de planejamento em face de limitações políticas, dentre outras. Soma-se a isso, o fato de a janela de oportunidades ser muitas vezes de curta duração para a gestão de nomeados políticos, afetando o desenvolvimento de estratégias de sucessão no serviço público.

Em parceria com a empresa PwC, a Companhia de Energia Elétrica de Minas
Gerais (CEMIG), empresa de economia mista atuante no setor de energia elétrica brasileira, implementou um modelo de gestão sucessória com foco na preparação de lideranças futuras para a ocupação de posições-chave - na época, o público mais crítico para o planejamento da sucessão - com vistas ao provimento de maior capacidade da organização para enfrentar os desafios de seu ambiente de negócios por meio da gestão de seu capital humano (FARO e DINIZ, 2012).

De acordo com Faro e Diniz (2012), a CEMIG partiu de algumas premissas na implantação do modelo de gestão sucessória que adotou. Uma delas foi a integração do modelo às políticas de recursos humanos já implantadas na organização, buscando com isso a valorização dos instrumentos já utilizados na gestão de pessoas. Não por acaso, o modelo baseou-se no alinhamento estratégico entre a área de recursos humanos (agente coordenador do processo) e o desenvolvimento de lideranças. Outra foi a opção da organização por uma elevada transparência em termos de divulgação do programa e dos resultados da aplicação de testes ou entrevistas, o que ressalta a importância da comunicação. Uma terceira foi a ênfase na estruturação de um sistema efetivo de governança, a fim de que o programa fosse bem-sucedido, e para a qual contribuiu a formação de comitês de sucessão formados por superintendentes com o papel de validar e ajustar as análises de potencial dos candidatos, decidir sobre quais seriam os potenciais sucessores e sugerir ações para a sua preparação (FARO e DINIZ, 2012).

Com base nessas premissas, a CEMIG procedeu ao diagnóstico das lacunas de competências da organização e do nível de prontidão dos gestores para assumir postos de comando e desenvolveu um mapeamento que identificou quantos líderes deixariam a organização nos próximos anos por conta de aposentadorias, bem como que competências a empresa perderia com isso (FARO e DINIZ, 2012).

O modelo de gestão sucessória adotado na CEMIG é composto por cinco etapas. A primeira corresponde à identificação das posições-chave em função da estratégia da organização, sendo que, na CEMIG, essas posições corresponderam aos cargos de liderança, quais sejam, gerentes, superintendentes e executivos (FARO e DINIZ, 2012). A segunda etapa contempla a identificação da criticidade das posições- 
chave por meio do mapeamento do risco de descontinuidade. Identificadas as posiçõeschave críticas, a terceira etapa prevê o mapeamento do potencial dos profissionais que demonstram interesse em se desenvolver na carreira gerencial, os denominados potenciais sucessores, em quantidade equivalente a três vezes a necessidade de reposição. Em seguida, na quarta etapa, são planejadas e executadas ações para que esses potenciais sucessores sejam preparados para o futuro, ou seja, para o momento em que, surgindo a necessidade de reposição, estejam prontos para assumir as cadeiras vagas. A quinta e última etapa do modelo corresponde à decisão de quem será o sucessor, dado que um banco de possíveis sucessores foi formado (FARO e DINIZ, 2012).

A Figura 1 ilustra as etapas deste modelo.

Figura 1 - Etapas do modelo de gestão sucessória da CEMIG

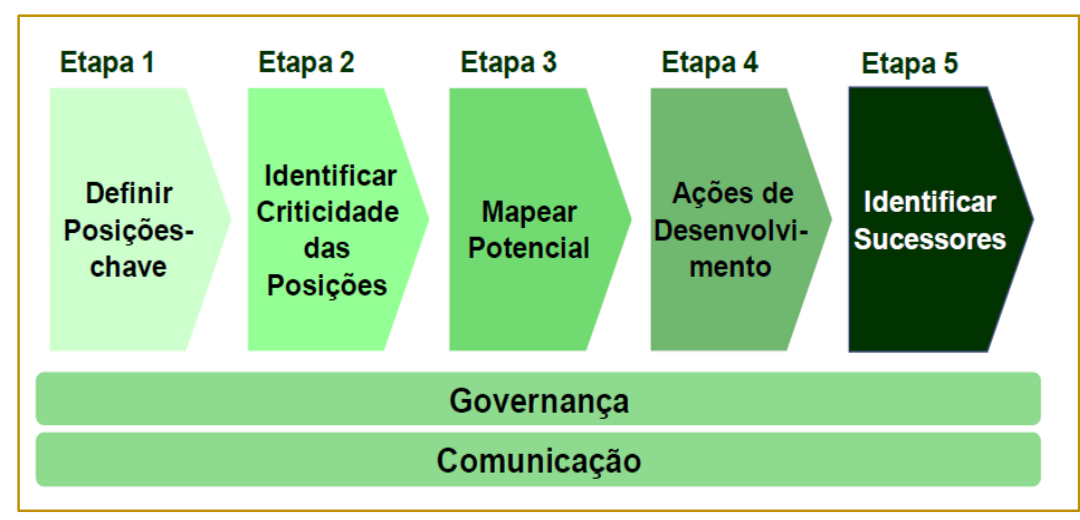

Fonte: FARO e DINIZ (2012).

\section{METODOLOGIA}

Tendo como fundamento os principais conteúdos analisados na revisão de literatura, o método empregado nessa pesquisa é o hipotético-dedutivo, aquele que deduz alguma coisa a partir da formulação de hipóteses que são testadas, buscando relações causais entre elementos (VERGARA, 2013).

Como instrumento de coleta de dados, adotouse a técnica da observação não participante que de acordo com Marconi e Lakatos (2003) utiliza os sentidos na obtenção de determinados aspectos da realidade, além propiciar o exame de fatos ou fenômenos que se deseja estudar.

O universo da pesquisa corresponde ao conjunto dos 29 órgãos que integram a estrutura da administração direta do Estado do Rio de Janeiro, quais sejam: Governadoria e Vice-Governadoria do Estado, 25 secretarias de Estado e ainda a Procuradoria e a Defensoria Geral do Estado, conforme detalhado no Quadro 1 
Quadro 1 - Estrutura do Poder Executivo do Estado do Rio de Janeiro

\begin{tabular}{|c|c|}
\hline Governadoria do Estado & Secretaria de Estado de Transportes - SETRANS \\
\hline Vice-Governadoria do Estado & Secretaria de Estado de Ambiente - SEA \\
\hline Secretaria de Estado da Casa Civil - CASACIVIL & $\begin{array}{l}\text { Secretaria de Estado de Agricultura e Pecuária - } \\
\text { SEAPEC }\end{array}$ \\
\hline Secretaria de Estado de Governo - SEGOV & $\begin{array}{l}\text { Secretaria de Estado de Desenvolvimento regional, } \\
\text { Abastecimento e Pesca - SEDRAP }\end{array}$ \\
\hline $\begin{array}{l}\text { Secretaria de Estado de Planejamento e Gestão - } \\
\text { SEPLAG }\end{array}$ & Secretaria de Estado de Trabalho e Renda - SETRAB \\
\hline Secretaria de Estado de Fazenda - SEFAZ & Secretaria de Estado de Cultura - SEC \\
\hline $\begin{array}{l}\text { Secretaria de Estado de Desenvolvimento } \\
\text { Econômico, Energia, Indústria e Serviços - SEDEIS }\end{array}$ & $\begin{array}{l}\text { Secretaria de Estado de Assistência Social e Direitos } \\
\text { Humanos - SEASDH }\end{array}$ \\
\hline Secretaria de Estado de Obras - SEOBRAS & $\begin{array}{l}\text { Secretaria de Estado de Esporte, Lazer e Juventude - } \\
\text { SEELJE }\end{array}$ \\
\hline Secretaria de Estado de Segurança - SESEG & Secretaria de Estado de Turismo - SETUR \\
\hline $\begin{array}{l}\text { Secretaria de Estado de Administração Penitenciária } \\
\text { - SEAP }\end{array}$ & $\begin{array}{l}\text { Secretaria de Estado de Envelhecimento Saudável e } \\
\text { Qualidade de Vida - SEESQV }\end{array}$ \\
\hline Secretaria de Estado de Saúde - SES & $\begin{array}{l}\text { Secretaria de Estado de Proteção e Defesa do } \\
\text { Consumidor - SEPROCON }\end{array}$ \\
\hline Secretaria de Estado de Defesa Civil - SEDEC & $\begin{array}{l}\text { Secretaria de Estado de Proteção à Dependência } \\
\text { Química - SEPREDEQ }\end{array}$ \\
\hline Secretaria de Estado de Educação - SEEDUC & Procuradoria Geral do Estado - PGE \\
\hline $\begin{array}{l}\text { Secretaria de Estado de Ciência, Tecnologia e } \\
\text { Inovação - SECTI }\end{array}$ & Defensoria Pública Geral do Estado - DPGE \\
\hline Secretaria de Estado de Habitação - SEH & \\
\hline
\end{tabular}

Fonte: GOVERNO DO ESTADO DO RIO DE JANEIRO (2016).

A amostra onde a entrevista foi aplicada é composta por sete das 25 secretarias do governo do Estado do Rio de Janeiro. Essa amostra foi escolhida a partir de fácil do acesso do pesquisador aos responsáveis pelos setores que poderiam contribuir com a pesquisa. São elas: a Secretaria de Estado da Fazenda (SEFAZ); a Secretaria de Estado de Assistência Social e Direitos Humanos (SEASDH); a Secretaria de Estado de Planejamento e Gestão (SEPLAG); a Secretaria de Estado de Prevenção à Dependência Química (SEPREDEQ); a Secretaria de Estado de Administração Penitenciária (SEAP); a Secretaria de Estado de Esporte e Lazer (SEELJE) e a Secretaria de Estado de Ciência, Tecnologia e Inovação (SECTI).

Quarenta gestores públicos dessas secretarias, com cargos em comissão de chefia, concursados e não concursados, e responsáveis por equipes dentro de suas unidades organizacionais, foram os sujeitos da pesquisa. Eles forneceram os dados necessários para que o estudo se desenvolvesse.

A entrevista seguiu um roteiro previamente estruturado de nove perguntas. Elaboradas a partir da teoria abordada na primeira parte deste trabalho, elas tiveram a intenção de traçar um panorama sobre como ocorre o processo sucessório nas sete secretarias envolvidas na pesquisa, incluindo preparação e escolha de sucessores para cargos de chefia. O Quadro 2 mostra a definição dos cargos em comissão de chefia dos servidores concursados e não concursados entrevistados.

Este estudo adotou os tratamentos quantitativo e qualitativo na análise dos dados coletados. Os dados coletados foram primeiro organizados com o programa MS Excel e posteriormente exportados para o programa de análise estatística Statistical Package for the Social Sciences (SPSS), versão 22 para Windows. As variáveis qualitativas estudadas foram caracterizadas através de frequências 
absolutas e relativas em percentuais. Para avaliar a opinião dos inquiridos sobre os vários aspectos em estudo, em algumas questões foi apresentada a opção de resposta em escala de Likert de cinco pontos ordinais com a seguinte codificação: 1 = Sem importância; 2 = Não muito importante; 3 = Um pouco importante; 4 = Muito importante; $5=$ Extremamente importante.
$\mathrm{Na}$ análise dessas questões, as frequências das respostas foram apresentadas em percentuais, bem como calculadas as médias das pontuações correspondentes a cada questão. Essas pontuações médias podem variar de 1 a 5 , sendo que quanto maior a pontuação média, maior é a importância atribuída ao aspeto avaliado. Foram utilizadas as seguintes siglas: ' $M$ ' para média, 'DP' para desvio-padrão e 'N' para dimensão da amostra.

Quadro 2 - Definição dos cargos em comissão de chefia

\begin{tabular}{|c|c|c|}
\hline \multicolumn{3}{|l|}{ Secretaria de Estado da Fazenda } \\
\hline Cargos Entrevistados: & Concursados & Não Concursados \\
\hline Supervisores de Auditoria & \begin{tabular}{l|l}
7 \\
\end{tabular} & - \\
\hline Coordenadores de Auditoria & 6 & - \\
\hline Diretores de Departamentos de Contabilidade & 4 & - \\
\hline Auditor Geral do Estado & 1 & - \\
\hline Superintendentes de Contabilidade & 1 & - \\
\hline Superintendentes de Auditoria & 6 & - \\
\hline \multicolumn{3}{|c|}{ Secretaria de Estado de Assistência Social e Direitos Humanos } \\
\hline Cargos Entrevistados: & Concursados & Não Concursados \\
\hline Diretor Geral de Administração e Finanças & \begin{tabular}{|l|}
- \\
\end{tabular} & 1 \\
\hline Superintendente de Contratos & - & 1 \\
\hline Coordenador de Contabilidade & 1 & - \\
\hline Supervisor de Auditoria & 1 & - \\
\hline Assessora Departamento Financeiro & - & 1 \\
\hline Superintendente de Controle Interno & 1 & - \\
\hline Superintendente de Politicas Emergencias & - & 1 \\
\hline \multicolumn{3}{|l|}{ Secretaria de Estado de Planejamento e Gestão } \\
\hline Cargos Entrevistados: & Concursados & Não Concursados \\
\hline Superintendente Setorial de Gestão de Pessoas & \begin{tabular}{|l|l}
1 &
\end{tabular} & - \\
\hline \multicolumn{3}{|c|}{ Secretaria de Estado de Prevenção a Dependência Química } \\
\hline Cargos Entrevistados: & Concursados & Não Concursados \\
\hline Diretor Geral de Administração e Finanças & \begin{tabular}{|l|l}
- & \\
\end{tabular} & 1 \\
\hline Coordenador Setorial de Auditoria & 1 & - \\
\hline \multicolumn{3}{|c|}{ Secretaria de Estado de Administração Penitenciária } \\
\hline Cargos Entrevistados: & Concursados & Não Concursados \\
\hline Coordenador de Auditoria & 1 & - \\
\hline \multicolumn{3}{|l|}{ Secretaria de Estado de Esporte e Lazer } \\
\hline Cargos Entrevistados: & Concursados & Não Concursados \\
\hline Diretor Geral de Administração e Finanças & \begin{tabular}{|l|l|}
- & \\
\end{tabular} & 1 \\
\hline Coordenador Setorial de Auditoria & 1 & - \\
\hline Diretor de Tecnologia da Informação & - & 1 \\
\hline \multicolumn{3}{|c|}{ Secretaria de Estado de Ciência Tecnologia e Inovação } \\
\hline Cargos Entrevistados: & Concursados & Não Concursados \\
\hline Assessor Chefe & \begin{tabular}{l|l}
1 \\
\end{tabular} & - \\
\hline Total de Cargos & 33 & 7 \\
\hline
\end{tabular}




\section{APRESENTAÇÃO DOS RESULTADOS}

No presente tópico são apresentados os resultados obtidos com as entrevistas feitas com os gestores concursados e não concursados, e responsáveis por equipes dentro de suas unidades organizacionais.

Questão 1: Existência de uma política de gestão sucessória na unidade organizacional

Nenhum dos entrevistados disse existir qualquer tipo de política de gestão sucessória formalizada e em efetivo funcionamento em suas unidades organizacionais. Esse resultado invalidou a questão de número 2.

Questão 3: Existência de algum movimento interno no sentido da elaboração de política de gestão sucessória

Todos os entrevistados afirmaram não haver qualquer tipo de movimento de grupos internos para a adoção de uma política de gestão sucessória em qualquer das unidades organizacionais.

Questão 4: Importância do planejamento sucessório na unidade organizacional

Apesar da constatação da ausência de planejamento sucessório em suas unidades organizacionais, todos os gestores públicos reconheceram a sua importância. Nenhum deles apontou as opções 'sem importância', 'não muito importante' e 'um pouco importante' da escala de Likert empregada. Os respondentes consideram que o planejamento da gestão sucessória em sua unidade é muito importante $(55.0 \%)$ ou extremamente importante (45.0\%).
Questão 5: Razões para a realização de planejamento sucessório na unidade organizacional

Quanto às razões que seriam levadas em conta para se realizar um planejamento sucessório na unidade organizacional, a mais apontada foi "melhorar ou manter o desempenho operacional", pois teve a pontuação média mais elevada $(\mathrm{M}=4.4$; $\mathrm{DP}=$ 0.7 ), sendo considerada 'muito importante' por $50.0 \%$ dos respondentes ou 'extremamente importante' por $42.5 \%$ dos respondentes. "Dar continuidade a algum projeto ou atividade" foi a proposição que apareceu em seguida, com pontuação média de $\mathrm{M}=4.3 ; \mathrm{DP}=0.7$.

Outra proposição ressaltada pelos gestores foi "substituir adequadamente funcionários-chave da organização que possuem características difíceis de substituir" com pontuação média de $\mathrm{M}=4.1 ; \mathrm{DP}=0.9$. Na sequência, aparece a proposição "adaptar a organização às mudanças do ambiente" ( $\mathrm{M}=4.0$; $\mathrm{DP}=0.9)$. Ambas tiveram pontuação média superior a 4 e foram consideradas 'muito importantes' ou 'extremamente importantes' por mais de $70 \%$ dos respondentes, indicando a relevância destes dois aspetos para a realização do planejamento sucessório na unidade organizacional. A proposição menos apontada foi "reduzir a rotatividade dos funcionários" (M = 3.3; $\mathrm{DP}=1.3$ ). Este aspecto foi considerado 'muito importante' ou 'extremamente importante' por apenas $42.5 \%$ dos entrevistados.

A Tabela 1 resume esses resultados.

Tabela 1 - Razões para a realização de planejamento sucessório na unidade

\begin{tabular}{|c|c|c|c|c|c|c|}
\hline QUESTÕES & 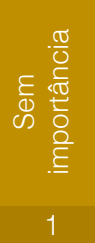 & 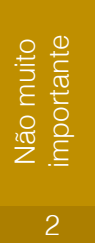 & 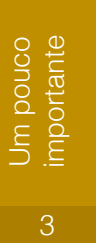 & 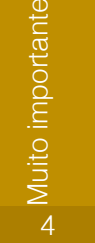 & 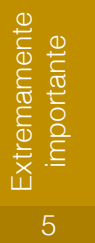 & $\begin{array}{c}\text { Média } \\
\text { (DP) }\end{array}$ \\
\hline Dar continuidade a algum projeto ou atividade & - & $2.5 \%$ & $7.5 \%$ & $52.5 \%$ & $37.5 \%$ & $4.3(0.7)$ \\
\hline Melhorar ou manter o desempenho operacional & - & & $7.5 \%$ & $50.0 \%$ & $42.5 \%$ & $4.4(0.6)$ \\
\hline Reduzir a rotatividade dos funcionários & $12.5 \%$ & $10.0 \%$ & $35.0 \%$ & $20.0 \%$ & $22.5 \%$ & $3.3(1.3)$ \\
\hline Adaptar a organização às mudanças do ambiente & - & $5.0 \%$ & $25.0 \%$ & $40.0 \%$ & $30.0 \%$ & $4.0(0.9)$ \\
\hline $\begin{array}{c}\text { Substituir adequadamente funcionários chave da } \\
\text { organização que possuem características difíceis } \\
\text { de substituir }\end{array}$ & - & $7.5 \%$ & $17.5 \%$ & $37.5 \%$ & $37.5 \%$ & $4.1(0.9)$ \\
\hline
\end{tabular}


Questão 6: Atividades para desenvolver potenciais candidatos a cargos de chefia

Indagou-se aos participantes que atividades poderiam ser realizadas com a finalidade de desenvolver potenciais candidatos a assumir caros de chefia. As sete proposições sugeridas foram consideradas importantes pelos respondentes.

Destacaram-se com pontuação de respostas médias mais elevadas e maiores percentagens de respostas 'muito importante' ou 'extremamente importante', "realizar treinamentos para os candidatos chave" ( $M=$
4.5; DP = 0.6), "orientar os candidatos chave" $(\mathrm{M}=4.3$; $\mathrm{DP}=0.7)$ e "desenvolver planos de carreira" ( $M=4.3$; $D P=0.9)$.

O aspeto menos valorizado foi "promover a rotação em várias áreas de trabalho para os candidatos chave" ( $\mathrm{M}=3.9 ; \mathrm{DP}=1.0)$. Mesmo assim, essa proposição teve pontuação média elevada, sendo considerada 'muito importante' ou 'extremamente importante' por $62.5 \%$ dos respondentes.

A Tabela 2 ilustra esses achados.

Tabela 2 - Atividades de desenvolvimento de potenciais candidatos a cargos de chefia

\begin{tabular}{|c|c|c|c|c|c|c|}
\hline QUESTÕES & 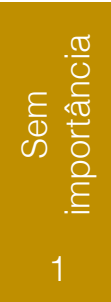 & 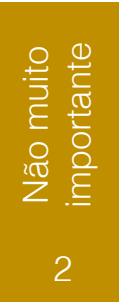 & 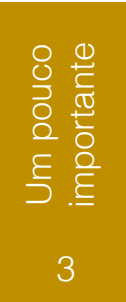 & 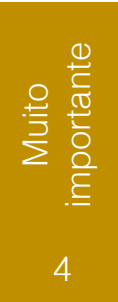 & 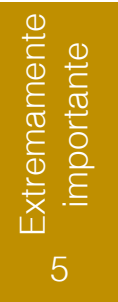 & $\begin{array}{l}\text { Média } \\
(\mathrm{DP})\end{array}$ \\
\hline Orientar os candidatos chave & - & $2.5 \%$ & $10.0 \%$ & $47.5 \%$ & $40.0 \%$ & $4.3(0.7)$ \\
\hline $\begin{array}{l}\text { Avaliar anualmente o desempenho dos } \\
\text { candidatos chave }\end{array}$ & - & $7.5 \%$ & $10.0 \%$ & $55.0 \%$ & $27.5 \%$ & $4.0(0.8)$ \\
\hline $\begin{array}{l}\text { Promover a rotação em várias áreas de } \\
\text { trabalho para os candidatos chave }\end{array}$ & - & $10.0 \%$ & $27.5 \%$ & $27.5 \%$ & $35.0 \%$ & $3.9(1.0)$ \\
\hline $\begin{array}{l}\text { Realizar treinamentos para os candidatos } \\
\text { chave }\end{array}$ & - & - & $5.0 \%$ & $40.0 \%$ & $55.0 \%$ & $4.5(0.6)$ \\
\hline Desenvolver Planos de Carreira & $2.5 \%$ & $2.5 \%$ & $10.0 \%$ & $32.5 \%$ & $52.5 \%$ & $4.3(0.9)$ \\
\hline $\begin{array}{l}\text { Desenvolver uma lista de habilidades } \\
\text { organizacionais }\end{array}$ & - & - & $22.5 \%$ & $50.0 \%$ & $27.5 \%$ & $4.1(0.7)$ \\
\hline $\begin{array}{l}\text { Desenvolver um plano formal de } \\
\text { competências essenciais }\end{array}$ & - & $5.0 \%$ & $12.5 \%$ & $55.0 \%$ & $27.5 \%$ & $4.1(0.8)$ \\
\hline
\end{tabular}

Questão 7: Importância dos critérios existentes na literatura para a realização do processo de gestão sucessória

Com base na literatura estudada, foram apresentados 18 critérios para a realização da gestão sucessória, elencados a partir dos elementos do capital humano presentes nos modelos de mensuração do capital intelectual e nos modelos de planejamento sucessório. Indagou-se aos respondentes qual o grau de importância de cada um deles.

Todos os critérios apresentados foram considerados importantes. Todos tiveram pontuação média de resposta maior do que 3.6. As variáveis 'muito importante' e 'extremamente importante' foram superiores a $50 \%$. Por outro lado, os critérios menos valorizados foram a "experiência profissional pregressa" ( $M=3.6$; $\mathrm{DP}=0.8)$, "formação acadêmica" $(M=3.7 ; \mathrm{DP}=0.9)$ e "avaliação de desempenho" ( $\mathrm{M}=4.0 ; \mathrm{DP}=0.8)$.

Todos os outros critérios tiveram pontuação média de resposta maior do que 4 e elevadas percentagens de respostas 'muito importante' e 'extremamente importante'. Os que tiveram pontuações médias mais elevadas foram: "compromisso" ( $\mathrm{M}=4.8$; DP = 0.5), "atitude" $(\mathrm{M}=4.7 ; \mathrm{DP}=0.6)$, "trabalho em equipe" $(\mathrm{M}=$ 4.7; $\mathrm{DP}=0.5)$, "liderança" $(M=4.7 ; \mathrm{DP}=0.5)$, "geração de resultados" $(M=4.6$; $D P=0.5)$, "postura profissional" $(\mathrm{M}=4.6 ; \mathrm{DP}=0.7) \mathrm{e}$ 
"motivação" (M = 4.6; DP = 0.5). A Tabela 3

mostra esses resultados.

Tabela 3 - Importância de critérios no desenvolvimento da gestão sucessória

\begin{tabular}{|c|c|c|c|c|c|c|}
\hline QUESTÕES & 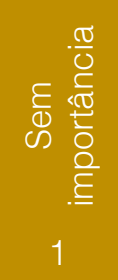 & 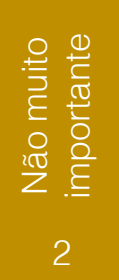 & 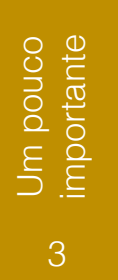 & 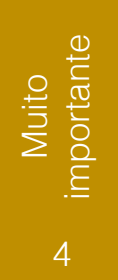 & 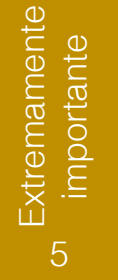 & $\begin{array}{l}\text { Média } \\
(\mathrm{DP})\end{array}$ \\
\hline Avaliação de Desempenho & - & $2.5 \%$ & $22.5 \%$ & $47.5 \%$ & $27.5 \%$ & $4.0(0.8)$ \\
\hline Experiência Profissional Pregressa & - & $10.0 \%$ & $32.5 \%$ & $45.0 \%$ & $12.5 \%$ & $3.6(0.8)$ \\
\hline Formação Acadêmica & $5.0 \%$ & $2.5 \%$ & $20.0 \%$ & $60.0 \%$ & $12.5 \%$ & $3.7(0.9)$ \\
\hline Motivação & - & - & $2.5 \%$ & $32.5 \%$ & $65.0 \%$ & $4.6(0.5)$ \\
\hline Liderança & - & - & - & $32.5 \%$ & $67.5 \%$ & $4.7(0.5)$ \\
\hline Facilidade de Comunicação & - & - & $10.0 \%$ & $37.5 \%$ & $52.5 \%$ & $4.4(0.7)$ \\
\hline Capacidade de Inovar & - & - & $12.5 \%$ & $47.5 \%$ & $40.0 \%$ & $4.3(0.7)$ \\
\hline Trabalho em equipe & - & - & $2.5 \%$ & $25.0 \%$ & $72.5 \%$ & $4.7(0.5)$ \\
\hline Flexibilidade & - & - & $12.5 \%$ & $55.0 \%$ & $32.5 \%$ & $4.2(0.6)$ \\
\hline Dinamismo & - & - & $10.0 \%$ & $47.5 \%$ & $42.5 \%$ & $4.3(0.7)$ \\
\hline Lealdade com a Instituição & - & $2.5 \%$ & $7.5 \%$ & $27.5 \%$ & $62.5 \%$ & $4.5(0.8)$ \\
\hline Compromisso & - & - & $2.5 \%$ & $20.0 \%$ & $77.5 \%$ & $4.8(0.5)$ \\
\hline Atitude & - & - & $5.0 \%$ & $25.0 \%$ & $70.0 \%$ & $4.7(0.6)$ \\
\hline Postura Profissional & - & $2.5 \%$ & $2.5 \%$ & $27.5 \%$ & $67.5 \%$ & $4.6(0.7)$ \\
\hline $\begin{array}{l}\text { Capacidade de aplicar normas e } \\
\text { procedimentos }\end{array}$ & - & - & $12.5 \%$ & $45.0 \%$ & $42.5 \%$ & $4.3(0.7)$ \\
\hline Geração de resultados & - & - & $2.5 \%$ & $37.5 \%$ & $60.0 \%$ & $4.6(0.5)$ \\
\hline Autodesenvolvimento & - & - & $5.0 \%$ & $50.0 \%$ & $45.0 \%$ & $4.4(0.6)$ \\
\hline Visão Sistêmica & - & - & $5.0 \%$ & $40.0 \%$ & $55.0 \%$ & $4.5(0.6)$ \\
\hline
\end{tabular}

Questão 8: Candidato ideal para assumir posições-chave

Quando questionados sobre qual o tipo ideal de candidato para ocupar posições-chave na unidade organizacional, a grande maioria dos entrevistados (95.0\%) referiu que o ideal seria um candidato interno. Apenas dois (5.0\%) dos 40 inquiridos referiram que 0 ideal seria um candidato externo.

Questão 9: Pesquisa de candidatos externos para assumir posições-chave

Dos dois entrevistados que mencionaram que o candidato ideal deveria ser externo, um afirmou que a pesquisa para a assunção de posições-chave deveria ser desenvolvida internamente e outro respondeu que ela deveria ser desenvolvida em nível local. Nenhuma das outras alternativas sugeridas pelo pesquisador (regional ou nacional) foi referida.

\section{ANÁLISE DOS RESULTADOS}

Inicialmente, é preciso destacar que há um vínculo de afetividade do servidor, especialmente do servidor concursado, com a administração pública que precisa ser considerado por reverberar em diferentes situações. O servidor concursado possui um 
vínculo de permanência no serviço público, e, quando possuidor de um cargo em comissão, fica, em geral, lotado em secretarias com carreiras estruturadas, menos suscetíveis a mudanças organizacionais oriundas de questões políticas. Em sua grande maioria, os servidores concursados são técnicos e escolhem seus sucessores entre os integrantes da própria carreira.

Todos os entrevistados (servidores concursados ou não) reconhecem a importância do planejamento sucessório nas unidades organizacionais do governo, muito embora seja visível a fragilidade dessa iniciativa num contexto em que não há vínculos com a administração. Apesar desse reconhecimento, os relatos apontam para a não existência de programas formais de gestão sucessória em suas unidades organizacionais. Alguns gestores, inclusive, principalmente o de secretarias que possuem servidores de carreira, admitiram o emprego de métodos informais na escolha de seus sucessores, adotando critérios pessoais (alguns valorizam experiência e tempo de casa e outros o desempenho) não compartilhados com a sua equipe e não amplamente divulgados, posicionamento condizente com concepções ultrapassadas, baseadas em questões subjetivas e metodologias inconsistentes ao invés do foco em habilidades e talentos.

Todos os entrevistados confirmaram a ausência de qualquer movimento interno em curso em suas unidades no sentido formalizar - processo de gestão sucessória, que possibilitaria não apenas a construção de etapas e critérios mais consistentes como também maior transparência no processo. Ficou nítida também a falta de assessoramento na implementação de qualquer política de gestão de pessoas, inclusive o planejamento sucessório.

Todos os gestores entrevistados reconheceram os benefícios que o planejamento sucessório pode levar a suas unidades organizacionais. Eles acreditam que esse processo pode contribuir principalmente para melhorar ou manter o desempenho operacional da unidade e dar continuidade aos projetos e atividades com curso. O resultado é particularmente sensível junto a gestores de secretarias que realizam trabalhos sociais que impactam diretamente a vida da sociedade e precisam ser continuados e melhorados mesmo no caso de troca de comando.
Outra questão mencionada pelos gestores entrevistados é a possibilidade que o planejamento sucessório oferece em relação à reposição adequada de funcionários-chave da unidade por outros que possuam características de difícil substituição, numa clara demonstração de conhecimento sobre uma das características essenciais dos programas de gestão sucessória: colocar a pessoa certa no lugar certo.

Essas caraterísticas foram apontadas por esses gestores mediante a apresentação de alguns critérios de elegibilidade, elencados a partir das variáveis do capital humano presentes nos modelos contábeis score cards (placares) de valoração de ativos intangíveis e em modelos de gestão sucessória propostos na literatura. Independentemente da Secretaria a que pertencem, para os entrevistados, os critérios mais valorizados em um eventual processo de sucessão em suas unidades foram compromisso, atitude, trabalho em equipe, liderança, geração de resultados, postura profissional e motivação, resultado que denota preocupação com a presença de caraterísticas que podem contribuir para a eficiência da gestão como um todo, fazendo com que a administração pública cumpra o seu papel perante a sociedade.

Indagou-se aos entrevistados que atividades poderiam ser realizadas no desenvolvimento dessas caraterísticas em relação aos potenciais candidatos-chave a uma posição sujeita à sucessão. Treinamentos, orientação e aconselhamentos foram citados, evidenciando mais uma vez a preocupação dos gestores em garantir que seu sucessor tenha o perfil necessário e condizente com a vaga.

No caso estudado, cabe a indagar se não existiriam planos de carreira capazes de preparar sucessores para cargos estratégicos na estrutura da administração direta do Governo do Estado do Rio de Janeiro. Verificou-se a inexistência de preocupação com planos de carreira principalmente junto aos gestores de secretarias que não possuem carreiras estruturadas. Nessas secretarias, a rotatividade de gestores é muito grande devido, sobretudo, às mudanças no governo. Daí a inexistência de planos de carreira por não se tratarem de servidores efetivos. A constante mudança no quadro político gera incertezas quanto à continuidade de projetos e atividades em que os gestores então engajados. Alguns gestores relataram que essas incertezas fazem com que suas próprias 
funções na área pública tenham de ser divididas com atividades particulares.

Os planos de carreira existem para os servidores concursados. Os gestores entrevistados nas secretarias com esse perfil de servidor relataram que os planos de carreira dão segurança para o servidor seguir em sua carreira. Eles são avaliados periodicamente e isso pode contribuir para o melhor desempenho de suas funções. Em ambos os casos, no entanto, inexistem planos de carreira que, deliberadamente, se voltem à preparação de sucessores, situação que é compatível com o modelo de gestão sucessória adotado na CEMIG. De acordo com Faro e Diniz (2012), o foco da gestão sucessória naquela organização foi a identificação de potenciais sucessores para serem desenvolvidos, e não políticas de remuneração e carreira.

Por outro lado, pôde-se perceber uma preocupação por parte dos gestores entrevistados com o desenvolvimento profissional de suas equipes. Nas secretarias sem carreiras estruturadas, onde prevalecem indicações políticas para os cargos, houve comentários sobre a falta qualificação técnica do corpo funcional das equipes. Alguns gestores admitiram que quando assumiram seus postos não conheciam detalhes da vaga tampouco a cultura da organização e as atividades a serem realizadas, principalmente por não terem recebido qualquer treinamento ou orientação; tiveram de aprender na rotina de suas funções. Tal situação evidencia a existência de gestores sem o perfil adequado para a vaga que assumiram, o que dificulta o andamento das atividades dentro das secretarias. Alguns gestores relataram a falta de interesse dos próprios funcionários em realizar treinamentos devido à grande rotatividade no corpo funcional nessas secretarias.

Nas secretarias com carreiras estruturadas, onde os servidores públicos são concursados, a incidência de treinamento é frequente, conforme relatos dos gestores. Quando esses servidores entram em exercício e assumem suas funções são realizados treinamentos e cursos de ambientação. A grande maioria dos gestores que assumem os cargos de chefia é composta por servidores da própria casa, técnicos, com experiência na função e conhecimento da cultura da unidade organizacional.

Quando interrogados sobre qual seria o perfil de candidato ideal em uma eventual sucessão, a maioria absoluta dos gestores optou pela escolha de um candidato interno, argumentando este que é concursado, técnico, conhece a cultura da organização, o que o credenciaria para a realização das atividades nas secretarias, sendo, portanto, os mais indicados no momento da escolha para a sucessão.

Nas secretarias menos politizadas a busca pelo candidato interno é uma prática recorrente; existe a preocupação de buscar servidores da própria carreira do gestor para assumir sua posição. Já nas secretarias mais suscetíveis à interferência política em suas gestões, apesar do alto percentual de resposta dos gestores de que buscariam um candidato interno para realizar qualquer tipo de sucessão dentro de suas equipes, as questões políticas podem interferir nessa escolha. Alguns gestores relataram que com a sua saída sequer são consultados sobre a questão da sucessão, e candidatos externos entram para assumir as funções. Nesse caso, a cultura organizacional não valoriza a "prata da casa".

A grande questão que perpassou praticamente todas as respostas do roteiro de perguntas proposto nas entrevistas foi a interferência política. A impressão dominante é de que a administração pública utiliza os cargos em comissão de chefia para atender interesses políticos. Muitas vezes, como relatado abertamente pelos gestores das secretarias em estudo, esses cargos são preenchidos por indicações de deputados em troca de apoio político. É chamada a "barganha política", que, na verdade, não é uma prática exclusiva da administração estadual do Rio de Janeiro, uma vez que amplamente utilizada na administração pública brasileira e mesmo nas organizações públicas internacionais.

Isso ficou evidente, por exemplo, na inquirição a gestores de secretarias sem servidores de carreira ou efetivos. Constatou-se a sua insegurança no desempenho de suas funções, uma vez que conhecem e estão acostumados com a cultura das frequentes exonerações advindas com a troca de comando do governo. De acordo com esses gestores, isso causa desestímulo na demonstração de suas competências, pois eles têm a consciência de que mesmo realizando bons trabalhos sempre haverá quebra de continuidade para atender as indicações políticas.

Houve relatos de situações nesse sentido, quando, mesmo realizando trabalhos 
importantes e considerados excelentes, os gestores foram exonerados devido a trocas políticas do governo. Houve relatos também de que até mesmo a falta de interesse da administração pública em implementar qualquer inovação em termos de gestão de pessoas, aí incluído o planejamento sucessório, é uma consequência da interferência na utilização de cargos para atender interesses políticos da própria administração.

Percebe-se nitidamente que nessas secretarias não existe interesse na implementação de qualquer política de gestão de pessoas, muito embora alguns de seus gestores tenham demonstrado vontade de operar mudanças em suas unidades com o objetivo de melhorar a gestão pública, caso da implementação do planejamento sucessório. Apesar de compartilharem com colegas concursados dos benefícios desse processo, eles demonstraram que o constante rompimento na continuidade de suas gestões por questões políticas criam barreiras e diminuem o ímpeto de implementar essas mudanças.

O mesmo não ocorre nas secretarias que possuem servidores concursados e efetivos, com carreiras consolidadas, nas quais a influência do ambiente político externo é menor, não prevalecendo a força política nas indicações para cargos de liderança. Para os gestores dessas secretarias, programas que capacitem as pessoas como o de gestão sucessória são bem vindos, pois valorizam o pessoal interno.

\section{CONCLUSÕES}

Este trabalho dedicou-se ao tema gestão sucessória nas empresas, tendo como foco a sua implementação nas unidades organizacionais da administração pública. $\mathrm{O}$ principal objetivo foi analisar a existência ou não desse processo nas empresas públicas, bem como identificar os seus benefícios, caso houvesse ou viesse a ser implantado, sob o ponto de vista da literatura científica sobre o tema e sob a ótica de servidores efetivos e não efetivos da administração direta. Com isso, objetivou-se analisar o planejamento sucessório nas organizações e seus benefícios e especificamente reunir conhecimentos associados ao tema e refletir sobre as questões que envolvem a gestão sucessória no setor público, além de verificar de que forma a administração direta do Poder
Executivo do Estado do Rio de Janeiro lida com o processo de gestão sucessória.

Reconhece-se que o método escolhido para a realização do estudo de campo apresentou certas limitações. A principal delas, o foco em sete secretarias de Estado, isentando outras secretarias e demais órgãos que compõem a administração direta do governo estadual do Rio de Janeiro do processo investigativo. Nesse sentido, os resultados da pesquisa limitaram-se à amostra selecionada, refletindo apenas a percepção de uma parcela dos integrantes das sete secretarias envolvidas no estudo, não abrangendo outras camadas populacionais da estrutura do governo.

Nas conclusões sobre a pesquisa de campo, é preciso considerar o vínculo de efetividade dos servidores, especialmente os concursados, com a administração pública. Na avaliação geral, observou-se que esse vínculo foi determinante para a formação de algumas visões sobre gestão sucessória, expressas nas respostas desses servidores, por exemplo, quanto à escolha de sucessores de carreira entre os integrantes da própria Secretaria.

Especialmente por seus benefícios, todos os entrevistados reconheceram a importância do planejamento sucessório nas unidades organizacionais da estrutura direta do Poder Executivo do Governo do Estado, muito embora tenham admitido não haver qualquer iniciativa formal nessa direção (por meio de programas e ações), o que indica uma falta de comprometimento das lideranças governamentais no que concerne à implementação do planejamento sucessório. Nesse sentido, pode-se inferir que o processo não é efetivamente implantado nas estruturas do Governo do Estado do Rio de Janeiro por falta de apoio dos gestores estratégicos da própria Administração.

Duas outras hipóteses mencionadas na pesquisa foram confirmadas frente a esta realidade. A primeira hipótese, de que no setor público, a implementação de processos sucessórios planejados depende fundamentalmente de uma cultura organizacional voltada para este fim, que, somada à atuação do setor de recursos humanos na gestão de pessoas, pode promover sistematicamente a identificação, seleção e formação de candidatos com alto potencial de liderança para assumir posiçõeschave. A segunda hipótese, de que os processos sucessórios são incipientes no interior das unidades organizacionais no 
núcleo do Governo do Estado do Rio de Janeiro. Esta constatação acrescida da própria escassez de relatos junto à literatura sobre a adoção e implementação de gestão sucessória em outros organismos públicos no Brasil, permite inferir que o mesmo ocorre na administração pública do País.

Verificou-se que a interferência política na gestão pública é um elemento que efetivamente obsta a efetivação de processos inovadores como o planejamento sucessório nas secretarias pesquisadas. De fato, suplantar efeitos e consequências de

\section{REFERÊNCIAS}

[1]. ANTUNES, M.T.P.; MARTINS, E. Gerenciando o Capital Intelectual: uma abordagem empírica baseada na Controladoria de grandes empresas brasileiras. IX Congresso Internacional de Custos, Florianópolis, 28 a 30 de novembro de 2005.

[2]. EDVINSSON, L.; MALONE, M. Capital Intelectual: descobrindo o valor real de sua empresa pela identificação de seus valores internos. São Paulo: Makron Books, 1998.

[3]. FARO, E.; DINIZ, R. Gestão sucessória: identificando e construindo os talentos do futuro - o caso CEMIG. V Congresso Consad de Gestão Pública, Brasília, 04 a 06 de junho de 2012.

[4]. FERREIRA, M.A.A. Processo Sucessório em Organizações Brasileiras: um estudo com uso de Ground Theory. 2015. 275 f. Tese (Doutorado em Administração) - Faculdade de Economia, Administração e Contabilidade, Universidade de São Paulo, 2015.

[5]. GOVERNO DO ESTADO DO RIO DE JANEIRO. Estrutura do Governo. Disponível em: http://www.rj.gov.br/ Acesso em: 15 jan. 2016.

[6]. IRFS Foundation. IAS 38 Ativos Intangíveis. 2011. Disponível em: http://www.ifrs.org/IFRSs/IFRStechnical-summaries/Documents/IAS38.pdf Acesso em: 15 de set. 2015 .

[7]. KAHNG, L. The taxation of intellectual capital. Florida Law Review, vol. 66, pp. 2.229-2.277, 2014.

[8]. LEONE, N.M.C.P.G. O processo sucessório em empresas familiares. O exemplo dos comerciantes e o processo no Saara. Revista Organizações \& Sociedade, vol. 11, n. 24, pp. 149172, Salvador, 2004

[9]. LEV, B. Intangibles: management, measurement, and reporting. Washington: Brookings Institution Press, 2001.

[10]. LUNA, G. Planning for an American Higher Education Leadership Crises: the succession issue indicações políticas para cargos de gestão é um dos desafios da administração pública em geral. Para enfrentá-lo, assim como a outros atuais desafios do setor público, a adoção e a difusão de políticas de gestão sucessória podem ser uma via consistente, outra hipótese aventada na pesquisa. Por meio do processo de planejamento sucessório, é possível identificar e preparar funcionários com potencial de talento e liderança para a assunção de posições críticas nas unidades organizacionais, de modo a alcançar excelência e preservar o oferecimento de serviços de qualidade à população.

for administrators. International Leadership Journal, vol. 4, issue 1, pp. 56-79, Trenton, Thomas Edison State University, winter 2012.

[11]. LYNN, D.B. Succession management strategies in public sector organizations: building leadership capital. Review of Public Personnel Administration, vol. 21, n. 2, pp. 114-132, Summer 2001.

[12]. MEHRABANI, S.E; MOHAMAD, N.A. Succession Planning: a necessary process in today's organization. International Journal of $e$ Education, e-Business, e-Management and eLearning, vol. 1, n. 5, pp. 371-377, December 2011.

[13]. OHTSUKI, C.H. Como as Organizações Brasileiras Identificam Pessoas Aptas a Assumir Atribuições e Responsabilidades no Contexto do Processo Sucessório: um estudo de caso. 2013. 123 f. Dissertação (Mestrado em Administração) Faculdade de Economia, Administração e Contabilidade, Universidade de São Paulo, 2013.

[14]. OHTSUKI, C.H. Como as Organizações Brasileiras Identificam Pessoas Aptas a Assumir Atribuições e Responsabilidades no Contexto do Processo Sucessório: um estudo de caso. 2013. 123 f. Dissertação (Mestrado em Administração) Faculdade de Economia, Administração e Contabilidade, Universidade de São Paulo, 2013.

[15]. OLIVEIRA, L.R.; BERNARDON, R.A. Instrumento para avaliação de diretrizes estratégicas de sucessão empresarial. Revista Gestão e Planejamento, vol. 9, n. 2, pp. 141-158, Salvador, julho/dezembro de 2008.

[16]. OREJA, C.M.; PRIETO, T.C. Indicadores de Capital Intelectual aplicados a la actividad investigadora y de gestión del conocimiento en las Universidades y Centros Públicos de Investigación de la Comunidad de Madrid. In: MODREGO, A. (coord). Capital Intelectual y Produción Científica. Madrid: Dirección General de Investigación. 
Consejería de Educación. Comunidad de Madrid, 1998.

[17]. VERGARA, S.C. Projetos e Relatórios de Pesquisa em Administração. São Paulo: Atlas, 2013.
[18]. WILKERSON, B. Effective Succession Planning in the Public Sector. Chicago: Watson Wyatt, 2007. 


\section{Gapítulo 22}

\section{AUTONOMIA FINANCEIRA NO CONTEXTO DO MERCADO DE TRABALHO EM CRISE: EXPECTATIVAS DE UNIVERSITÁRIOS DA GERAÇÃO Y}

\section{Thaís Andrade Damasceno \\ Maria de Lurdes Costa Domingos \\ Helenna Barreto Magdalena \\ Luana Camargo Carrilho}

Resumo: Este artigo objetiva explorar a percepção do universitário da geração Y em busca da autonomia financeira num mercado de trabalho em crise. Foi realizada uma pesquisa exploratória, com enfoque qualitativo, estabelecendo-se três indicadores investigativos: mercado de trabalho em crise, autonomia financeira e geração Y. A revisão bibliográfica serviu de base para a delimitação de indicadores alinhados aos objetivos do trabalho e às questões investigativas no campo. Adicionalmente, foi elaborada uma lista com a caracterização da Geração Y, aplicada numa amostra de jovens universitários. Os resultados permitiram a definição de nove categorias temáticas, submetidos à análise de conteúdo. Observando o critério de categorização semântica, nas grades de análise destacaram-se: a insuficiência do diploma universitário para o estabelecimento no mercado de trabalho, o aumento das exigências para se manter trabalhando, a crise econômica acentuando a crise da juventude e a falta de identificação com as características da denominada geração Y. Conclui-se que os jovens da geração $Y$ enfrentam uma crise dupla, em relação à sua identidade pessoal e laboral. Neste quesito, a formação mostra-se insuficiente para a desejada autonomia financeira, a falta de oportunidades se apresenta como um impacto sentido por esses jovens e a não identificação com as características atribuídas à eles é representada por uma porcentagem significativa. Futuros estudos, necessários em vista da importância que possuem os jovens da geração $Y$ no mercado de trabalho, devem aprofundar os resultados obtidos nas categorias temáticas levantadas neste estudo. 


\section{INTRODUÇÃO}

A partir de 2014, um cenário de crise na economia foi se instaurando no Brasil, a qual corroborou com impactos negativos e danosos no mercado de trabalho, com uma potente elevação do desemprego, aumento da informalidade, diminuição da renda real $e$ aumento da concentração da renda de trabalho. Inicia-se então um novo contexto, com decorrências deletérias sobre o mercado de trabalho no país (CACCIAMALI; TATEI, 2016), que atinge de maneira particular os jovens, cujo diploma demora cada vez mais para garantir-lhe um futuro empregatício (ANDRADE, 2010).

A crise econômica afeta a dinâmica dos empregos e desempregos. Cacciamali e Tatei (2016) observaram que o produto interno brasileiro de 2010 foi elevado em 7,5\%, sem que a inflação registrasse altas significativas, em vista da recuperação do consumo e investimento, demonstrando a acelerada recuperação pós-crise 2008 dos Estados Unidos, que teve repercussão mundial. Em ratificação, o período que seguiu de 2010-013, teve um número de novos empregos formais ainda maior do que entre 2004-2008, o que contribuiu para a impressão de que a economia estava sob total controle. No entanto, em 2015, como consequência da perda de apoio político gerado por denúncias de corrupção, houve redução da arrecadação e elevação das despesas públicas e da inflação, produzindo um quadro de profunda desaceleração econômica que, por sua vez, influenciou o mercado de trabalho em aspectos tais como a elevação do índice de desemprego e a redução da renda real do trabalho.

Diante deste contexto, o presente estudo tem a intenção de explorar a percepção do universitário da geração $Y$ que almeja a autonomia financeira e se depara com um mercado de trabalho economicamente em decadência. Para tal exploração é relevante reconhecer que o jovem é parte essencial na continuidade da evolução econômica do país. Muito possivelmente, a entrada em um mercado de trabalho em crise acarretará impactos nesses sujeitos e isso tenderá a refletir no seu desempenho profissional, pelo menos, durante as fases iniciais de suas carreiras (SÁ; LEMOS; CAVAZOTTE, 2014).

Analisar os efeitos da crise sobre o ingresso no mercado de trabalho, estabelecer paralelos entre o mercado em crise e a autonomia financeira e refletir sobre a interpretação do jovem da Geração Y sobre si mesmo no contexto laboral, são objetivos desta pesquisa. Além da primeira parte que inclui esta introdução, a segunda parte deste estudo discute o mercado de trabalho em crise, a autonomia financeira e a geração $\mathrm{Y}$. $\mathrm{Na}$ terceira parte, está exposta a metodologia, com uma pesquisa realizada com jovens universitários pertencentes à geração $Y$.

\section{FUNDAMENTAÇÃO TEÓRICA}

\subsection{O MERCADO DE TRABALHO EM CRISE}

Entre 2015 e 2016, o número de indivíduos desocupados no Brasil saltou de 7.934 milhões para 11.089 milhões, acrescendo aos gastos públicos, dentre outros custos, o pagamento do seguro desemprego. Segundo o Cadastro Geral de Empregados e Desempregados (Caged), 1,6 milhão de postos de trabalho formais foram perdidos no ano de 2015, número este que equivale ao total de postos criados no período correspondente de 20122014. Esta situação gerou uma crise de significados e colocou em cheque o próprio diploma universitário, como será discutido neste item.

\subsubsection{CRISE DE SIGNIFICADOS NA EVOLUÇÃO DO CONCEITO DE TRABALHO}

Lobato (2004) destaca o feudalismo como último estágio nas construções précapitalistas. Servos mantinham uma relação de dependência com seus senhores, trabalhando em troca da terra que cultivavam e onde residiam. Para o autor, nessa relação, o trabalho assume o significado de algo penoso e cansativo e, no âmbito psicológico, a simbolização de riqueza e sucesso. Consequentemente, assumia um lugar de obrigatoriedade que trazia consigo a insegurança, o isolamento e a ansiedade, atingindo assim a esfera pessoal da vida de todos. Noutro estudo, Teixeira (2002) afirma que o ingresso no mercado de trabalho prevê a superação das próprias inseguranças. $\mathrm{Na}$ oposição entre estas pesquisas, estabelece-se um paradoxo entre a insegurança gerada pela obrigatoriedade do trabalho e seu enfrentamento para assumir uma posição no mercado.

Avançando historicamente, a Revolução Industrial alterou a conceitualização, natureza e ordenações do trabalho, como ação em prol 
da produtividade e geração de lucros, desenvolvidas principalmente institucionalmente. Os trabalhadores se encontravam obrigados a trabalhar sem posse de matéria-prima e ferramentas, fato que esvaia o significado de realização no trabalho, rotulado como desgaste físico-moral. $\mathrm{Na}$ Terceira Revolução Industrial, embora o fazer intelectual tenha surgido como uma nova forma de trabalho, adventos tecnológicos tornam-se responsáveis pela redução da oferta empregatícia e aumento do índice de desemprego. (LOBATO, 2004)

\subsubsection{CRISE NO MERCADO DE TRABALHO PARA O JOVEM: O DIPLOMA UNIVERSITÁRIO EM QUESTÃO}

A entrada no mercado de trabalho pode gerar o vislumbre de uma autonomia financeira. No entanto, recém-formados deparam-se com a dificuldade de ingressar efetivamente na profissão para a qual investiram anos de educação. Há algumas décadas consideravase o diploma universitário como praticamente uma garantia de emprego. Hoje, as fronteiras entre profissões têm se esvanecido e a colocação no mercado de trabalho já independe somente da formação em nível superior, porque pode incluir a capacidade de utilizar conhecimentos e habilidades tanto profissionais, como pessoais para o desenvolvimento de atividades e solução de problemas em diversas áreas da atuação profissional. (TEIXEIRA, 2002)

Sobre a insuficiência do diploma universitário na conquista de um espaço dentro do mercado de trabalho, Teixeira acrescenta que as experiências dentro das universidades não conduzem a uma identidade, dentro das possibilidades de uma profissão, que auxilie o estudante, enquanto futuro profissional, na escolha entre as áreas compostas por seus interesses específicos. Lobato (2004) afirma que a realidade do mercado é incondizível com a teoria acadêmica. O fato do diploma não ser suficiente para se firmar profissionalmente, gera o retorno às universidades em busca de mais conhecimento. Esta continuidade nos estudos é percebida como uma exigência para a entrada no mercado de trabalho (TEIXEIRA, 2002; ANDRADE, 2010; LACHTIM; SOARES, 2011), com os jovens à espera de adentrar a profissão que reúna a realização pessoal e a autonomia financeira (ANDRADE, 2010).

Lachtim e Soares (2011) observam que a manutenção nos estudos é um escape ao que denominaram "fantasma da inutilidade", indicando que os jovens sentem-se culpados por não alcançar o mercado, vivido como um sofrimento.

Lobato (2004, p. 51) entende o trabalho como estruturante da subjetividade humana, sendo fundamental à vida como fonte de identidade $e$ forma de sobrevivência. Ele afirma que não encontrar trabalho provoca um luto angustiante. O estudo é, então, uma atividade substitutiva para essa falta. A associação envolve "um novo conjunto de competências e expectativas a serem cumpridas para um profissional manter sua colocação no mercado". No entanto, não há uma garantia total, já que há que se considerar o contexto.

Teixeira (2002, p. 37) afirma que a taxa de baixo crescimento econômico está associada à taxa de desemprego elevada. Ainda que o número de profissionais com diploma universitário seja crescente, o desemprego afeta a "elaboração de um plano profissional em função das expectativas futuras". Pode-se inferir, que o alinhamento entre desemprego e baixo crescimento aplica-se à época atual se consideramos estes dois indicadores como correlacionados entre si.

As rápidas transformações ocorridas no mercado de trabalho o caracterizam como altamente complexo e competitivo, em função de determinantes históricos e da evolução da sociedade, demandando constantes atualizações não só profissionais, como pessoais por parte dos jovens. Para Lipkin e Perrymore (2010), a geração Y é composta por um amplo número desses jovens e há necessidade que o mercado se adeque a uma ética de trabalho que os considere. Isto exige a integração entre a vida profissional e pessoal, e paralelamente, o reconhecimento e respeito às ideias deles, inclusive considerando a maneira como eles vivenciam o trabalho. (SILVA; SOBROSA; DALAGASPERINA, 2016) Acerca da aproximação entre as vidas pessoais e profissionais, Andrade (2010) diz que a integração dessas dimensões facilitará o exercício da profissão permanente.

Lachtim e Soares (2011) afirmam que a taxa de desemprego nos jovens é maior do que nos adultos. Assim, se o trabalho é tido como a principal preocupação para a inserção no mundo adulto, é gerada uma expectativa de alta capacitação e desempenho em variadas atividades, de uma maior qualificação para que ele não seja descartável. 


\subsection{A AUTONOMIA FINANCEIRA PARA O JOVEM}

Em busca do conceito clássico de autonomia, pode-se recorrer ao dicionário de filosofia de Abbagnano (2007). A entrada de "autonomia" no dicionário traz como definição primeira a concepção de Kant acerca do assunto, que contrasta com a noção de heteronomia enquanto faculdade de desejar:

(...) [é designada como] a independência da vontade em relação a qualquer desejo ou objeto de desejo e a sua capacidade de determinar-se em conformidade com uma lei própria, que é a da razão. Kant contrapõe a A. à heteronomia, em que a vontade é determinada pelos objetos da faculdade de desejar. Os ideais morais de felicidade ou perfeição supõem a heteronomia da vontade porque supõem que ela seja determinada pelo desejo de alcançá-los e não por uma lei sua. A independência da vontade em relação a qualquer objeto desejado é a liberdade no sentido negativo, ao passo que a sua legislação própria (como "razão prática") é a liberdade no sentido positivo. (ABBAGNANO, 2007, p. 97)

Trazendo essa noção para o contexto do jovem adulto, pode-se pensar que um dos marcos para a saída da adolescência e o devir adulto é justamente a busca pela autonomia e independência. A saída da casa dos pais seria o primeiro passo, de acordo com o percurso esperado do desenvolvimento, principalmente se levarmos em conta a geração anterior, em que os jovens saíam da escola, se empregavam e se casavam. Entretanto, nos dias de hoje, a entrada no mercado de trabalho é instável, contribuindo para que muitos jovens na atualidade estendam a permanência na casa dos pais, invistam mais tempo aos estudos com o apoio da família e, consequentemente, deixem para mais tarde a construção do seu próprio arranjo familiar. Esse fenômeno é observado em grande parte em jovens da classe média. (BAADER, 2013)

$O$ adiamento e a reconhecida necessidade de maiores especializações fazem com que a autonomia se torne um objetivo a ser alcançado em longo prazo, o que pode vir a causar conflitos, caso se confirme a tendência imediatista dos atuais jovens adultos. Por um lado, esses indivíduos desejam a autonomia imediatamente. Por outro, o caminho que normalmente seguem para atingir a realização do seu desejo faz com que essa conquista seja gradual.

Segundo Teixeira (2002), os jovens que nunca trabalharam veem a entrada no mercado de trabalho como uma forma de conseguir a própria autonomia e independência do âmbito familiar. Embora a permanência tardia na casa dos pais seja uma tendência, mais cedo ou mais tarde, eles optam por levar uma vida mais independente, adquirindo seus próprios valores. Nesse contexto, uma das formas de consolidação da autonomia do jovem adulto seria a entrada na Universidade, uma vez que o diploma tende a ser visto como um facilitador para uma entrada no mercado de trabalho.

A ressalva deste pensamento reside, porém, sobre o fato de que nem todos os jovens passam pelos mesmos rituais de desenvolvimento da sociedade capitalista na transição para a vida adulta. Dependendo da classe social e da condição econômica do grupo ao qual pertencem, por exemplo, pode haver uma dicotomia na relação que eles atribuem à autonomia e sua entrada no mercado de trabalho. Teixeira comenta que a forma pela qual o jovem vivenciará a conquista de se tornar autônomo e os primeiros passos de sua carreira estarão vinculados ao contexto em que ele está inserido e que não há, necessariamente, uma cronologia nas fases que atravessa:

Estas tarefas não são necessariamente experimentadas ao mesmo tempo, e enquanto alguns jovens já vivenciaram alguma delas, outros ainda demorarão a vivenciá-las ou talvez nem cheguem a experimentá-las todas. De qualquer forma, elas compõem um conjunto de transições culturalmente esperadas que terminam por orientar, em maior ou menor grau, os projetos de vida dos jovens adultos. (TEIXEIRA, 2002, p. 13)

Nesse âmbito, uma das relevantes diferenças sobre a visão de autonomia entre os jovens pode ser constatada na análise de Branco (2005) da pesquisa "Perfis da Juventude Brasileira", em que se observa que jovens de baixa renda compreendem que a realização laboral tem como principal função o suprimento das necessidades pré-existentes em seu ambiente familiar, seguido de independência, crescimento e autorrealização. Em contrapartida, jovens de rendas maiores apontam que $O$ ato de trabalhar remete primeiramente à independência, seguido de crescimento, autorrealização e necessidade. Conclui-se que a necessidade dos jovens de 
zonas periféricas adentrarem mais cedo o mercado, em grande parte em subempregos, faz diferença. A primazia de ser autônomo é muito mais comum entre os jovens mais abastados, cujo primeiro contato é, na maioria das vezes, realizado através de estágios, usufruindo, portanto, de mais tempo para o preparo de melhores chances no mercado de trabalho, o que thes permite mais liberdade de escolha. (LACHTIM; SOARES, 2011)

Fica claro que pensar a autonomia, quando relacionada aos jovens, ainda encontra emendas no que se refere à situação econômica desses indivíduos. Quando considerados os jovens de classe média/alta, pode-se dizer que as ideias normalmente discorridas sobre o assunto se aplicam com mais fidedignidade, principalmente pela maior facilidade de acesso à universidade, considerada o primeiro passo da busca consolidada pela autonomia. Já com os indivíduos menos favorecidos economicamente, a autonomia não ocupa o primeiro plano e, portanto, fica mais propícia a interferências de outras questões sociais e familiares que se mostram prioritárias.

\subsection{QUESTÕES GERACIONAIS E O JOVEM ADULTO DA GERAÇÃO Y}

Há uma discussão teórico-metodológica sobre as questões geracionais em curso, que caracteriza a geração $X$ e a geração $Y$ a partir de um recorte delimitado num período de tempo, onde as vivências históricas, sociais, econômicas, políticas e laborais são relativas a um determinado modo de compartilhar experiências:

Segundo as teorias sobre gerações, pessoas nascidas num mesmo período compartilham experiências de vida históricas e sociais, e essa vivência comum afetaria, de forma similar, seu padrão de resposta a situações, seus valores e suas crenças sobre as organizações, sobre sua ética de trabalho, bem como as razões pelas quais trabalham, suas aspirações na vida profissional e seu comportamento no trabalho. (SÁ; LEMOS; CAVAZOTTE, 2014, p. 10)

Entendendo que a geração $X$ compreende aqueles nascidos entre 1960 e 1980, Sá, Lemos e Cavazotte (2014) estabelecem algumas características generalizadoras para este grupo: são pacientes e conservadores, uma vez que não vivenciaram as constantes transformações científico-tecnológicas; entendem que o dever e o trabalho vêm antes do prazer; a segurança no trabalho e a estabilidade financeira são fundamentais; aspiram ao crescimento vertical na empresa; atribuem elevada importância aos títulos dos cargos; se sujeitam à empresa demandando que essa gerencie e ofereça treinamento, desenvolvimento da carreira, assim como conduza um plano de carreira estruturado.

Ainda segundo as autoras, a geração $\mathrm{Y}$, também denominada de Geração Milênio, de iGeração ou Geração da internet é composta por indivíduos que nasceram entre os anos de 1980 e o ano 2000. São jovens inseridos em uma cultura imediatista desenhada por incessantes transformações técnicocientíficas; baixa tolerância à frustração; audácia em correr riscos e enfrentar novos desafios no âmbito do trabalho buscando satisfação, status e reconhecimento; demandam, frequentemente, por feedbacks de seus superiores e/ou chefes; a segurança financeira e a remuneração não são objetivos primordiais, visto que de modo holístico, prezam o ambiente, o perfil ético da empresa, o bom relacionamento com a equipe de trabalho, a autonomia para o desenvolvimento pessoal e a flexibilidade no que tange aos dias e horários de trabalho; são impulsionados pela motivação externa, pois sustentam o seu desejo a partir do outro; tendem a serem impacientes, hedonistas, multitalentosos; ansiosos, ambiciosos, criativos, exigentes e são socialmente conscientes (SILVA; SOBROSA; DALAGASPERINA, 2016).

Nesse sentido, a geração $Y$ pode ser considerada individualista, uma vez que sua vida pessoal tende a se sobrepor aos demais aspectos, sejam eles sociais ou ligados a carreira. Além disso, são marcados por opiniões e comportamentos apoiados na constante busca por autonomia. A preocupação com os outros, acima do que sentem ser e a conjugação das habilidades tradicionais com as tecnologias de sua época são novas características dos jovens (BAADER, 2013).

Por outro lado, é inegável a influência dos meios tecnológicos que surgem caracterizando cada geração, além das mudanças inevitáveis de valores de um recorte comparado a outro, anterior. A consequente emergência de um conflito dialético entre o novo e o velho no momento em que diferentes gerações convivem no mesmo espaço de trabalho é inevitável (SÁ; LEMOS; CAVAZOTTE, 2014). Apesar da importância 
das peculiaridades geracionais, é indispensável questionar o corte cronológico feito para identificar cada geração.

No cenário brasileiro, propício à diversidade, criar generalizações que se ajustem satisfatoriamente a todos os indivíduos, mesmo com a restrição de faixa etária é tarefa complexa. No âmbito profissional e financeiro, isso fica claro na comparação de visões entre jovens de diferentes classes sociais quando questionados sobre a necessidade do trabalho: entre outras coisas, para os mais abastados, o trabalho serve para garantir manutenção de privilégios socioeconômicos; para os jovens periféricos, a função é de garantir a sobrevivência. (LACHTIM; SOARES, 2011)

Portanto, é impossível afirmar que existe uma homogeneidade nas caracterizações de um grupo geracional. Um jovem pertencente à geração $Y$ não compartilhará necessariamente todas as peculiaridades com todos os membros de sua geração e nem terá apenas características típicas de seu recorte, podendo também identificar-se com atributos de gerações antecedentes. (SÁ; LEMOS; CAVAZOTTE, 2014)

Outro fator relevante dessa discussão é compreender que a geração $Y$ se encaixa, hoje, na categoria de jovens adultos e sobre eles pairam questões que não eram comuns em gerações passadas: as novas condições e fatores da transição para a idade adulta. A título de elucidação, cabe uma rápida definição do conceito de jovens adultos: são, convencionalmente, aqueles que estão dentro da faixa etária de 22 a 35 anos. Também podem ser definidos como todos os que estão saindo da adolescência e ingressando no mercado de trabalho, incluindo aqueles que já estão firmando suas posições sociais (LOBATO, 2004).

$\mathrm{Na}$ transição para a idade adulta, cabe dar ênfase à família como uma forte rede de apoio financeiro e emocional que se estende até o subjetivo momento em que os filhos estarão preparados para a vida adulta, o que não se via com muita frequência nos jovens adultos da geração X. Essa maturidade, no entanto, não se mostra mais tão ligada a fatores como o cargo ocupado no trabalho ou a algum novo vínculo familiar, mas se aproxima do desenvolvimento psicológico satisfatório em relação à autonomia pessoal. A família brasileira atual tende a investir muito mais tempo na formação intelectual de seus filhos, o que, somado à instabilidade do mercado de trabalho para aqueles que estão ingressando, atrasa a saída da casa dos pais e a formação de uma nova família para esses jovens. (ANDRADE, 2010)

Dessa forma, a geração $Y$ se mostra fértil para diversas análises que podem abranger desde os fatores que determinam essa geração, como a avalanche informacional das últimas décadas, até questões como influências familiares, a transição para novas etapas de suas vidas. O cenário brasileiro, e a novidade do tema em particular, propiciam grande diversidade de questões, fato que contribui para traçados inesgotáveis acerca desta geração.

\section{METODOLOGIA}

Minayo (2001) destaca que na pesquisa qualitativa, opção deste estudo, os valores, atitudes, crenças, motivos, aspirações e significados oferecem uma maior profundidade, o que permite a compreensão de fenômenos irreduzíveis à operacionalização de variáveis.

Para iniciar a delimitação do perfil dos entrevistados, seguiu-se a classificação do Instituto Brasileiro de Geografia e Estatística IBGE, em que o jovem está na faixa etária entre 15 e 24 anos, sendo 18 a idade estimada para a finalização do ensino médio e início da graduação. Por esse motivo, do universo de participantes entre 18 e 24 anos, a amostra compreendeu nove estudantes universitários com idade entre 20 e 23 anos, do curso de psicologia de uma instituição privada na zona norte da cidade do Rio de Janeiro. A escolha aleatória dos participantes exigia apenas que o jovem cursasse a formação superior sem vínculo empregatício. Fez-se uso de redes sociais como Facebook e WhatsApp para constituir a amostra. A tabela 1 explicita o perfil desses jovens: 
Tabela 1 - Perfis dos entrevistados

\begin{tabular}{|c|c|c|}
\hline Participante & \multicolumn{2}{|c|}{ Sexo } \\
\hline P1 & Masculino & 20 \\
\hline P2 & Feminino & 21 \\
\hline P3 & Feminino & 21 \\
\hline P4 & Feminino & 21 \\
\hline P5 & Feminino & 21 \\
\hline P6 & Feminino & 21 \\
\hline P7 & Masculino & 22 \\
\hline P8 & Masculino & 22 \\
\hline 9 & Feminino & 23 \\
\hline
\end{tabular}

Fonte: Elaboração dos autores.

Os sujeitos foram submetidos a entrevistas semiestruturadas, com dez perguntas abertas. A realização das entrevistas, feitas ao longo de duas semanas, tiveram duração média de uma hora. Os dados não foram gravados, mas registrados no ato da interação. $\mathrm{Na}$ aplicação das entrevistas percebeu-se a necessidade de acrescentar perguntas para auxiliar a compreensão do enunciado, bem como instigar respostas mais amplas, tendo a preocupação de não induzir a investigação. Foram feitas as seguintes perguntas, divididas por categorias e metas, conforme tabela 2:

Tabela 2 - Indicadores, objetivos e questões selecionadas

\begin{tabular}{|c|c|c|}
\hline Indicadores & Objetivo & Questões \\
\hline $\begin{array}{l}\text { Mercado de } \\
\text { trabalho em crise }\end{array}$ & $\begin{array}{l}\text { Entender os efeitos da crise } \\
\text { sobre a entrada no mercado } \\
\text { de trabalho. }\end{array}$ & $\begin{array}{l}\text { Qual a sua percepção sobre o mercado de trabalho em } \\
\text { crise? } \\
\text { Qual a sua percepção sobre a relação entre ter um } \\
\text { diploma universitário e entrar no mercado de trabalho? } \\
\text { Em sua opinião, a crise afeta a entrada do jovem no } \\
\text { mercado de trabalho? Por quê? }\end{array}$ \\
\hline $\begin{array}{l}\text { Autonomia } \\
\text { financeira }\end{array}$ & $\begin{array}{l}\text { Tecer a relação entre a } \\
\text { autonomia financeira do } \\
\text { jovem e o mercado de } \\
\text { trabalho em crise. }\end{array}$ & $\begin{array}{l}\text { Para você, o que é autonomia financeira? } \\
\text { Como você acha que o jovem interpreta a autonomia } \\
\text { financeira? } \\
\text { Você vê relação entre mercado de trabalho e autonomia } \\
\text { financeira? Qual? Por quê? } \\
\text { Há relação entre crise e autonomia financeira? Qual ou } \\
\text { quais? }\end{array}$ \\
\hline Geração Y & $\begin{array}{l}\text { Compreender como o jovem } \\
\text { da Geração Y interpreta a si } \\
\text { mesmo. }\end{array}$ & $\begin{array}{l}\text { Qual a sua visão sobre o que é ser jovem? } \\
\text { Você sabe o que é a Geração Y? } \\
\text { Você se identifica com as características da Geração Y? }\end{array}$ \\
\hline
\end{tabular}

Fonte: Elaboração dos autores. 
Para a décima questão, que investigava a caracterização da Geração Y, foi incluída uma lista com dez itens formulada a partir do artigo "Expectativas de Carreira na Contemporaneidade: O que Querem os Jovens
Profissionais?" (SÁ, LEMOS E CAVAZOTTE, 2014). Era solicitado aos participantes que comentassem se identificavam-se ou não com os itens da lista (tabela 3) e os motivos para tais.

\section{Tabela 3 - Caracterização da Geração Y}

\begin{tabular}{l} 
Autoconfiantes e otimistas sobre o futuro. \\
\hline Necessitam de constantes feedbacks. \\
\hline $\begin{array}{l}\text { Sua motivação está relacionada ao fator financeiro, mas também ao relacionamento com o gestor, ao } \\
\text { desenvolvimento pessoal e ao ambiente de trabalho. }\end{array}$ \\
\hline $\begin{array}{l}\text { Suas expectativas não são de longo prazo, priorizando menos a segurança no trabalho e ansiando por } \\
\text { novos desafios. }\end{array}$ \\
\hline São impacientes, apesar de tolerantes com erros. \\
\hline $\begin{array}{l}\text { Anseiam por flexibilidade quanto aos dias e aos horários de trabalho, menos formalismos e rigidez quanto } \\
\text { à vestimenta profissional e ao local de trabalho, maior tempo livre e mais acesso às mídias digitais. }\end{array}$ \\
\hline $\begin{array}{l}\text { Valorizam a integração entre a vida profissional e a pessoal, acreditando não poder ter uma separação } \\
\text { entre ambas. }\end{array}$ \\
\hline Preferem atuar em empresas-modelo em termos de ética e de responsabilidade social. \\
\hline Maior desejo por status e por autonomia no trabalho. \\
\hline Ambiciosos, centrados na carreira e inclinados a apreciar papéis e metas de trabalho desafiadoras. \\
\hline \multicolumn{1}{|c|}{ Fonte: Adaptada de Sá, Lemos e Cavazotte (2014). } \\
\hline
\end{tabular}

Na tabela 3, acima, as frases incluíam mais de uma característica, fato que, por vezes, contaminava os resultados com o surgimento de respostas negativas e positivas do participante numa mesma sentença. Um exemplo pode ser visto na afirmativa 1, que diz que os membros da geração $Y$ são autoconfiantes e otimistas sobre o futuro. O informante P1 disse concordar com o fato de que compartilha com seus contemporâneos o traço da autoconfiança, mas discordou sobre ser otimista em relação ao futuro. Para resolver este problema, foi criada uma nova enumeração para fins analíticos (tabela 4) com características separadas e enumeração distinta. Além disso, alguns entrevistados apontaram na sentença (e) uma questão que não estava prevista na lista e que foi adicionada à pesquisa. 
Tabela 4 - Nova enumeração das características

Características da maneira como foram apresentadas aos entrevistados
Nova enumeração para fins analíticos

\begin{tabular}{|c|c|}
\hline \multirow{2}{*}{$\begin{array}{l}\text { Autoconfiantes e otimistas sobre o } \\
\text { futuro. }\end{array}$} & A1. Autoconfiantes \\
\hline & A2. Otimistas sobre o futuro \\
\hline Necessitam de constantes feedbacks. & B1. Necessitam de constantes feedbacks \\
\hline \multirow{4}{*}{$\begin{array}{l}\text { Sua motivação está relacionada ao } \\
\text { fator financeiro, mas também ao } \\
\text { relacionamento com o gestor, ao } \\
\text { desenvolvimento pessoal e ao } \\
\text { ambiente de trabalho. }\end{array}$} & C1. Sua motivação está relacionada ao fator financeiro \\
\hline & $\begin{array}{l}\text { C2. Sua motivação está relacionada ao relacionamento com o } \\
\text { gestor }\end{array}$ \\
\hline & C3. Sua motivação está relacionada ao desenvolvimento pessoal \\
\hline & C4. Sua motivação está relacionada ao ambiente de trabalho \\
\hline \multirow{3}{*}{$\begin{array}{l}\text { Suas expectativas não são de longo } \\
\text { prazo, priorizando menos a segurança } \\
\text { no trabalho e ansiando por novos } \\
\text { desafios. }\end{array}$} & D1. Suas expectativas não são de longo prazo \\
\hline & D2. Priorizam menos a segurança no trabalho \\
\hline & D3. Anseiam por novos desafios \\
\hline \multirow{3}{*}{$\begin{array}{l}\text { São impacientes, apesar de tolerantes } \\
\text { com erros. }\end{array}$} & E1. São impacientes \\
\hline & E2. São tolerantes com os próprios erros \\
\hline & E3. São tolerantes com erros alheios \\
\hline \multirow{4}{*}{$\begin{array}{l}\text { Anseiam por flexibilidade quanto aos } \\
\text { dias e aos horários de trabalho, menos } \\
\text { formalismos e rigidez quanto à } \\
\text { vestimenta profissional e ao local de } \\
\text { trabalho, maior tempo livre e mais } \\
\text { acesso às mídias digitais. }\end{array}$} & $\begin{array}{l}\text { F1. Anseiam por flexibilidade quanto aos dias e aos horários de } \\
\text { trabalho }\end{array}$ \\
\hline & $\begin{array}{l}\text { F2. Anseiam por menos formalismos e rigidez quanto à vestimenta } \\
\text { profissional e ao local de trabalho }\end{array}$ \\
\hline & F3. Anseiam por maior tempo livre \\
\hline & F4. Anseiam por mais acesso às mídias digitais \\
\hline $\begin{array}{l}\text { Valorizam a integração entre a vida } \\
\text { profissional e a pessoal, acreditando } \\
\text { não poder ter uma separação entre } \\
\text { ambas. }\end{array}$ & $\begin{array}{l}\text { G1. Valorizam a integração entre a vida profissional e a pessoal, } \\
\text { acreditando não poder ter uma separação entre ambas. }\end{array}$ \\
\hline $\begin{array}{l}\text { Preferem atuar em empresas-modelo } \\
\text { em termos de ética e de } \\
\text { responsabilidade social. }\end{array}$ & $\begin{array}{l}\text { H1. Preferem atuar em empresas-modelo em termos de ética e de } \\
\text { responsabilidade social. }\end{array}$ \\
\hline \multirow{2}{*}{$\begin{array}{l}\text { Maior desejo por status e por } \\
\text { autonomia no trabalho. }\end{array}$} & 11. Maior desejo por status \\
\hline & 12. Maior desejo por autonomia no trabalho \\
\hline \multirow{3}{*}{$\begin{array}{l}\text { Ambiciosos, centrados na carreira e } \\
\text { inclinados a apreciar papéis e metas } \\
\text { de trabalho desafiadoras. }\end{array}$} & J1. Ambiciosos \\
\hline & J2. Centrados na carreira \\
\hline & J3. Inclinados a apreciar papéis e metas de trabalho desafiadoras \\
\hline
\end{tabular}

Fonte: Elaboração dos autores.

\subsection{ANÁLISE DOS RESULTADOS}

Os dados coletados foram submetidos à análise de conteúdo. Observou-se o critério de categorização semântica, de categorias temáticas, para justapor as percepções dos participantes em nove grades de análise (BARDIN, 2011), conforme exposto a seguir: 


\subsubsection{O DIPLOMA UNIVERSITÁRIO E A ENTRADA NO MERCADO DE TRABALHO}

As expectativas, salientadas nas falas de P2 e P5, acerca do diploma universitário, questionam e pensam na significação da serventia deste certificado, o que coincide com o que Teixeira (2002) retratou, acerca das dificuldades encontradas pelos recémformados ao ingressarem, efetivamente, na profissão escolhida para sua graduação. O autor discute o esvanecimento de sentido que outrora se atribuiu ao diploma. Em vez de ser um diferencial e uma garantia de permanência numa vaga, seu valor precisa ser ressignificado por esses jovens, conforme mostram os recortes abaixo:

Eu não acho que tenha relação porque o diploma, às vezes, não significa nada. Tem muita gente que muitas vezes tem o diploma e não está conseguindo se colocar no mercado de trabalho. (P2)

Eu acho que as pessoas procuram ter um diploma para ser um diferencial, mas felizmente por causa da facilidade de se entrar na faculdade, o diploma acaba não sendo um diferencial. (P5)

Devido à insuficiência do diploma na conquista de um espaço no mercado de trabalho, traçando um paralelo com Lobato (2014), tal situação fomenta uma busca incessável por especializações e uma maior qualificação. Por conseguinte, o jovem retorna às universidades e ao prolongamento dos estudos, o que para o mercado de trabalho, parece ser mais uma nova exigência.

- as pessoas precisam ser cada vez melhores, se aperfeiçoando cada vez mais. (P6)

- se você não buscar se especializar e buscar cursos, você acaba desempregado ou aceitando qualquer emprego. (P9)

A complexidade e competitividade do mercado de trabalho $e$ as rápidas transformações, exigentes de constantes atualizações profissionais e pessoais são percebidas pelos jovens (P6, P7) quando fazem alusão à continuidade dos estudos associada à exigência para a entrada e permanência no mercado de trabalho (ANDRADE, 2010; LACHTIM; SOARES, 2011; SOBROSA; CAMERIM; SANTOS; DIAS, 2012).

\subsubsection{A CRISE E A ENTRADA DO JOVEM NO} MERCADO DE TRABALHO

O trabalho pode ser análogo a um nó, à medida que "amarra" a identidade e a sobrevivência, estruturando a subjetividade humana numa falta constante. A falta do trabalho, ou seja, não estar empregado, provoca um luto angustiante no sujeito. (LOBATO, 2004). Pode-se, nesta questão, traçar um paralelo com a crise, que, segundo Teixeira (2002), abala a construção de um plano profissional, dado que a instabilidade no mercado juntamente com a taxa de baixo crescimento econômico, deixam em suspenso tal concretude.

Diante deste crítico panorama, com a entrada no mercado de trabalho dificultada, percebeuse que a aproximação entre a vida pessoal e profissional, como tratado por Andrade (2010), também será afetada, visto que impossibilitará, em muitos casos, a proximidade da formação com a realização pessoal.

Por causa da disparidade da taxa de desemprego dos jovens, quando comparadas às dos adultos, o trabalho assume uma relevância crucial para 0 jovem. Estar empregado seria a ratificação de sua inserção no mundo adulto. No entanto, uma expectativa de elevada capacitação, bem como de um exímio desempenho em distintas atividades (LACHTIM; SOARES, 2011), pode ser percebida como desanimadora porque ele não percebe garantias no investimento para permanecer trabalhando quando algo dá errado:

- eu vejo muito o meu irmão. Ele trabalha há muito tempo com telemarketing em empresa grande e mesmo ele sendo despedido, ele não consegue voltar a trabalhar, tanto que ele e a namorada foram mandados embora e nenhum dos dois voltaram a trabalhar. Eles tentaram em outra área e também não conseguiram. Na área deles, que deveria ser mais fácil não tem, fora então... (P7)

\subsubsection{A AUTONOMIA FINANCEIRA}

Dos nove participantes da amostra, sete associaram a conquista da autonomia financeira à independência que um sujeito tem em relação a terceiros:

Você não depender de outra pessoa para pagar suas contas, é conseguir se manter. (P9) 
- gerenciar o meu próprio dinheiro independentemente dos outros... (P4)

- se sustentar sem depender de terceiros. (P2)

A independência econômica, para Teixeira (2002), é compreendida como uma renda mensal capaz de suprir as necessidades básicas de alimentação, vestuário, moradia, lazer e saúde; de forma a não depender de terceiros. Estes aspectos também foram valorizados pelos entrevistados. O sujeito P1 ilustra esta posição de maneira clara:

É você ter casa própria, um trabalho que lucre com ele porque senão você vai ficar devendo e isso não é autonomia financeira. No que eu falei sobre o trabalho que gere lucro, seria conseguir pagar contas, necessidades básicas e um excedente para usar com lazer e tal. (P1)

\subsubsection{O JOVEM E A AUTONOMIA FINANCEIRA}

A questão específica da autonomia financeira do jovem merece destaque. Baader (2013) ressalta que um dos marcos da passagem da adolescência para "adultez jovem", consiste na busca por autonomia e independência, exemplificadas nos seguintes relatos:

- Acho que pro jovem seria simplesmente ter um trabalho e se bancar. Só pagar os estudos e pronto. Eles vêm só uma parte do conjunto, porque não é só isso, quem paga as contas da casa ainda são os pais... (P1).

- Como uma forma de conseguir se libertar dos pais, talvez. Uma forma de comprar o que quiser sem ter que pedir permissão ou pedir dinheiro. (P5)

Acho uma virada importante, uma passagem da vida adolescente para adulta, onde ele consegue se manter sozinho. (P9)

Assim, para esses jovens, a conquista da autonomia é realizada por intermédio da atividade laboral. Nesse sentido, acreditam que o trabalho possibilitaria o sustento de si próprio, bem como permitiria uma maior liberdade da dependência financeira de seus pais.

\subsubsection{O MERCADO DE TRABALHO E A AUTONOMIA FINANCEIRA}

No discurso de quase metade dos entrevistados, a autonomia financeira é um produto do trabalho, fato que é um divisor entre a dependência e a independência na relação com a família e com a própria inserção do sujeito no mercado de trabalho.

Pra você ter autonomia financeira, você precisa de um trabalho porque se outra pessoa banca você, não é autonomia. (P1)

- Se tu não trabalha, você não tem dinheiro. E portanto, não tem autonomia financeira. (P3)

- Para conseguir autonomia no mínimo estável é necessário que você esteja no mercado de trabalho, que é onde possuem melhores oportunidades na maioria das vezes é onde nosso mundo circula, nós estamos dentro do mercado de trabalho infelizmente. (P6)

- Quando se está inserido no mercado de trabalho, se recebe pelos serviços prestados, consequentemente consumando a autonomia financeira. (P8)

Estas questões são valorizadas por Teixeira (2002) quando destaca que para o jovem o ingresso no mercado de trabalho faz com que ele vislumbre o alcance da própria autonomia financeira.

\subsubsection{A CRISE E A AUTONOMIA FINANCEIRA}

A falta de autonomia financeira apareceu associada à crise econômica da atualidade no discurso de um dos participantes. Ele explica que hoje é mais complicado alcançar a autonomia financeira, uma vez que para conseguir isto 0 sujeito necessita estar empregado. Nas palavras de P7, "a crise aumenta" impossibilitando muitos jovens de ingressarem no mercado de trabalho e galgarem à autonomia desejada:

- - Aumenta a crise, as pessoas são mandadas embora, as pessoas querem voltar pro mercado de trabalho, tem pessoas querendo entrar no mercado de trabalho e nem todo mundo entra. (P7)

A concepção sobre a existência de uma crise para o jovem que procura emprego parece ser uma constante (TEIXEIRA, 2002), que somada à crise financeira atual ganha proporções 
elevadas e anuncia-se aumentada (CACCIAMALI; TATEI, 2016), provocando ainda mais incerteza sobre o futuro (ANDRADE, 2010).

\subsubsection{O SER JOVEM}

A juventude foi associada ao ciclo do desenvolvimento pelos entrevistados. Andrade (2010), possibilita pensar sobre o contexto do jovem na saída da adolescência para o devir adulto, em que um dos marcos é justamente a busca pela autonomia e independência. Isso fica evidente nas falas de alguns entrevistados:

- Eu acho que é mais a fase que você está saindo da adolescência. Que você está se tornando mais independente. Que você está tentando estabelecer uma carreira, pensar mais na sua vida de adulto. (P5)

- $\quad$ aí depois quando você cresce e atinge a maioridade, tem outras questões tipo "você precisa trabalhar, você precisa estudar, precisa conseguir a sua autonomia". Então assim, é muita coisa para pouco tempo, acho. Não, que... a experiência em si é interessante, mas ao mesmo tempo eu acho desafiadora... (P7)

Esses relatos, remetendo a Andrade (2010), revelam a importância dada à transição da adolescência para a idade adulta, onde há a ratificação da identidade pessoal e social que a posteriori culminará num estatuto social de adulto à medida em que os papéis profissionais e familiares forem sendo exercidos (P5). A autora denominará de "adulto emergente" o que consiste justamente a transição da adolescência para a fase adulta como propiciadora de novos desafios vivenciados pelo jovem (P7).

Baader (2013) pontua que o jovem sobrepõe o sentimento à visibilidade, ou seja, precisa da aceitação do outro. A preocupação de tornarse visível com o "ser aceito por um grupo" e com o "reconhecimento" foi mapeada neste trabalho.

- é sempre estar buscando ser aceito por um grupo, mercado de trabalho e pais, é estar sempre buscando esse reconhecimento. (P9)

\subsubsection{GERAÇÃO Y}

Pôde-se observar, ao contrário do que é definido pela literatura sobre os Yrs acerca da homogeneidade do recorte geracional, que isso não acontece. Cada geração ultrapassa e dialoga com características que vão além daquelas atribuídas a um recorte cronológico. Fechar uma geração numa caracterização pode ter um caráter limitador à medida que um jovem da geração $Y$ pode não se identificar com todas as características que supostamente o definiria (SÁ; LEMOS; CAVAZOTTE, 2014), conforme observado nas falas dos entrevistados:

- muitas vezes acho que essa geração se perde um pouco e esquece das coisas boas que eram na época do orelhão. E muitas vezes as relações acabam sendo superficiais; se importando muito mais com like do que com a presença física. (P6)

- É uma geração mediadora entre o século passado e o atual, tendo em sua história tanto vivência de uma sociedade mais antiga quanto da moderna... (P8)

É possível que o jovem da geração $Y$ não compartilhe com toda a caracterização de seu recorte geracional, assim como pode identificar-se com características de gerações anteriores: ilustrado por P6 ao se remeter à época dos orelhões e por P8 ao qualificar como "mediadora" a geração $Y$ à medida que atribui a esta o caráter de intercessão entre o novo e o velho.

\subsubsection{CARACTERIZAÇÃO DA GERAÇÃO Y}

A maioria dos entrevistados desconhece o termo "geração Y", precisando ver a lista de características (tabela 2) antes de se identificar e tecer comentários com alguma delas. Apenas uma das entrevistadas se identificou com a característica imediatista dessa geração (SÁ; LEMOS; CAVAZOTTE, 2014) antes da lista ser apresentada:

- E o imediatismo também é uma coisa que eu me identifico muito. Eu não gosto de esperar, eu gosto muito das coisas na hora que eu preciso, tenho dificuldade de esperar e isso é uma coisa que eu vejo muito presente na nossa geração. (P5)

Verificou-se que nem sempre o jovem universitário se identifica com a caracterização 
da Geração Y. Os atributos a ela dirigidos pode ser fruto de um discurso do mercado ou restrito ao campo acadêmico. Percebendo isto, a lista foi-lhes apresentada com a nova divisão (tabela 4), contabilizando um total de 215 respostas. O informante 9 não respondeu à frase (E3). Desse número, aproximadamente $71,6 \%$ foram de respostas que concordavam com as sentenças generalizadoras a respeito da geração $Y$ e aproximadamente $28,4 \%$ de discordaram. Em nenhuma característica foi obtido resultado categórico de respostas positivas ou negativas. Abaixo, na tabela 5, encontra-se o resultado em percentual e em números absolutos de adesão ou rejeição de cada característica.

Tabela 5 - Resultados de concordância e discordância de cada característica

\begin{tabular}{|c|c|c|c|c|c|c|c|c|c|c|c|c|c|c|}
\hline & \multicolumn{2}{|c|}{ Conc. } & \multicolumn{2}{|c|}{ Disc. } & & \multicolumn{2}{|c|}{ Conc. } & \multicolumn{2}{|c|}{ Disc. } & & \multicolumn{2}{|c|}{ Conc. } & \multicolumn{2}{|c|}{ Disc. } \\
\hline & N.A & $\%$ & N.A & $\%$ & & N.A & $\%$ & N.A & $\%$ & & N.A & $\%$ & N.A & $\%$ \\
\hline A1 & 3 & $33 \%$ & 6 & $67 \%$ & D2 & 3 & $33 \%$ & 6 & $67 \%$ & $F 4$ & 7 & $78 \%$ & 2 & $22 \%$ \\
\hline A2 & 4 & $44 \%$ & 5 & $66 \%$ & D3 & 4 & $44 \%$ & 5 & $66 \%$ & G1 & 5 & $66 \%$ & 4 & $44 \%$ \\
\hline$B 1$ & 7 & $78 \%$ & 2 & $22 \%$ & E1 & 7 & $78 \%$ & 2 & $22 \%$ & $H 1$ & 8 & $89 \%$ & 1 & $11 \%$ \\
\hline C1 & 8 & $89 \%$ & 1 & $11 \%$ & E2 & 4 & $44 \%$ & 5 & $66 \%$ & 11 & 8 & $89 \%$ & 1 & $11 \%$ \\
\hline C2 & 8 & $89 \%$ & 1 & $11 \%$ & E3 & 7 & $87,5 \%$ & 1 & $12,5 \%$ & 12 & 8 & $89 \%$ & 1 & $11 \%$ \\
\hline C3 & 8 & $89 \%$ & 1 & $11 \%$ & F1 & 7 & $78 \%$ & 2 & $22 \%$ & J1 & 8 & $89 \%$ & 1 & $11 \%$ \\
\hline C4 & 8 & $89 \%$ & 1 & $11 \%$ & $F 2$ & 6 & $67 \%$ & 3 & $33 \%$ & $\mathrm{~J} 2$ & 8 & $89 \%$ & 1 & $11 \%$ \\
\hline D1 & 4 & $44 \%$ & 5 & $66 \%$ & $F 3$ & 7 & $78 \%$ & 2 & $22 \%$ & J3 & 7 & $78 \%$ & 2 & $22 \%$ \\
\hline
\end{tabular}

Fonte: Elaboração dos autores.

Os enunciados com maior adesão pelos jovens foram: (C1), (C2), (C3), (C4), (H1), (I1), (I2), (J1) e (J2), apresentando, em cada um deles, uma aprovação de $88 \%$. Fica claro, portanto, que o novo modo de lidar com o trabalho da geração aqui em questão é mais intensificado em quesitos como o bom relacionamento com o ambiente e a equipe de trabalho, as possibilidades de desenvolvimento pessoal e a busca por empresas com engajamento ético e social, além das que oferecerem espaço para que o jovem exerça sua função de maneira autônoma. Os estudantes disseram valorizar ocupar postos que forneçam um status positivo socialmente e definiram-se como ambiciosos e focados na carreira.

No que tange à visão otimista sobre o futuro, destacaram-se: expectativas de curto prazo, busca por novos desafios em detrimento da estabilidade de carreira, tolerância com os próprios erros e a unificação entre vida pessoal e profissional. Os entrevistados se mostraram divididos entre serem identificados com as características geracionais. Os que rejeitaram a identificação se definiram próximo ao que normalmente se espera da geração X. Em números absolutos, 4 pessoas disseram concordar com os enunciados (A2), (D1), (D3), (E2), contra 5 que discordaram, 5 pessoas foram adeptas ao proposto em (G1) em contraste com 4 respostas que rejeitaram esta característica.

Finalmente, as sentenças mais rejeitadas pelos jovens foram, por empate, (A1) e (D2) recebendo, cada uma, apenas 3 concordâncias em um total de 9 respostas. Isso mostra que a autoconfiança não é assimilada com uma característica da vida desses indivíduos e que a estabilidade empregatícia, tida como típica da geração anterior, ainda é, sim, importante para a maioria dos estudantes que buscam a autonomia financeira em um cenário de crise.

\section{CONSIDERAÇÕES FINAIS}

Nesta pesquisa, foi mapeada a percepção do universitário da geração $Y$ que busca uma autonomia financeira com o mercado de trabalho em crise. Os resultados diferiram do artigo de Teixeira (2002), que afirma não haver 
associação entre as exigências do mercado e as constantes transformações no âmbito pessoal e profissional que afetam os jovens que buscam trabalho. O mapeamento mostrou que, na verdade, eles sentem que o mercado exige deles constantes aprimoramentos para ingressar e se manter no mundo laboral. Além disso, em concordância com o estudo de Sá, Lemos e Cavazotte (2014), o bom relacionamento com o ambiente e a equipe de trabalho, a busca por empresas éticas e com projetos de responsabilidade social, autonomia no exercício da função, postos que propiciam status socialmente positivo, ambição e grau elevado de importância concedido à carreira também foram sinalizados.

O trabalho é percebido pelo jovem universitário como um meio para alcançar sua autonomia financeira, além de sancionar seu ingresso no mundo adulto. As crises, incluindo a atual crise financeira, acabam por estremecer o planejamento da vida profissional dos universitários porque o mercado de trabalho não é percebido como linear e estável o suficiente para o seu crescimento. Evidenciase, neste processo, a importância conferida ao trabalho como estruturante da subjetividade humana (LOBATO, 2004).

Esses e outros apontamentos na confecção deste artigo foram possíveis devido à contribuição de autores como Lobato (2004) e Lachtim e Soares (2011) que embasaram teoricamente a questão do mercado de trabalho em crise; além de Teixeira (2002) e Baader (2014) que fundamentaram a importância da autonomia financeira para o jovem. Acerca da geração $Y$, foram relevantes os conhecimentos de Sá, Lemos e Cavazotte (2014) e Silva, Sobrosa e Dalagasperina (2016). As conexões entre esses autores, bem como a análise dos resultados obtidos com o

\section{REFERÊNCIAS}

[1]. ABBAGNANO, Nicola. Dicionário de Filosofia. São Paulo: Martins Fontes, 2007. 1026 p.

[2]. ANDRADE, Cláudia. Transição para a idade adulta: Das condições sociais às implicações psicológicas. Análise Psicológica, [s.I.], v. 28, n. 2, p.255-267, 6 dez. 2012. ISPA - Instituto Universitario. http://dx.doi.org/10.14417/ap.279. Disponível em: <http://publicacoes.ispa.pt/index.php/ap/article/vie wFile/279/pdf>. Acesso em: 23 fev. 2017.

[3]. BAADER, Karina dal Bosco. JUVENTUDE E TRABALHO: Identificação das necessidades sobre campo, possibilitaram a elucidação das questões colocadas por este estudo. No entanto, também surgiram novas indagações, principalmente acerca da generalização de aspectos característicos da geração Y. As categorias "autoconfiantes" e "priorizam menos a segurança no trabalho" se destacaram em relação às demais anunciando diferenças de atribuição que mostram o reducionismo classificatório típico de algumas investigações científicas.

Quando um número considerável de participantes não se identificou com determinadas características da Geração Y, interessantes questionamentos emergiram sobre os possíveis fatores que podem, ou não, estar coadunados com o motivo dessa rejeição. Seriam eles: Há uma contradição no que tange ao recorte geracional sobre a diferenciação entre Geração X e Geração Y? Porque os jovens universitários não se identificaram de todo com a delimitação esperada por tal recorte, reconhecendo-se em atributos de gerações anteriores? As características de identificação vieram à tona devido à crise do atual contexto socioeconômico que o Brasil se encontra, podendo ter instaurado nos jovens da geração Y um sentimento generalizado de insegurança e um certo pessimismo frente ao futuro? $O$ desejo por segurança financeira seria um reflexo desse zeitgeist?

Estas questões podem motivar futuros estudos sobre a geração aqui em análise, permitindo a previsão de, pelo menos, duas possibilidades: A) a problemática acerca do recorte geracional é limitada; e/ou B) em um cenário pós-crise, mensurar as dimensões de uma instabilidade econômica tão substancial se reflete nas expectativas e planejamentos de toda uma geração. trabalho, migração e educação. 2013. 17 f. Monografia (Especialização) - Curso de Gestão de Recursos Humanos, Universidade do Oeste de Santa Catarina, Joaçaba, 2013. Disponível em: <http://www.uniedu.sed.sc.gov.br/wpcontent/uploads/2014/04/Karina-Dal-BoscoBaader.pdf>. Acesso em: 1 mar. 2017.

[4]. BARDIN, Laurence. Análise de conteúdo. 4. ed. São Paulo: Edições 70, 2011. 280 p.

[5]. BRASIL. INSTITUTO BRASILEIRO DE GEOGRAFIA E ESTATÍSTICA. População Jovem no 
Brasil.

Disponível

em: $<$ http://www.ibge.com.br/home/estatistica/populaca o/populacao_jovem_brasil/default.shtm>. Acesso em: 21 abr. 2017.

[6]. CACCIAMALI, Maria Cristina; TATEI, Fabio. Mercado de trabalho: da euforia do ciclo expansivo e de inclusão social à frustração da recessão econômica. Estudos Avançados, [s.I.], v. 30, n. 87, p.103-121, ago. 2016. FapUNIFESP (SciELO). http://dx.doi.org/10.1590/s0103-

40142016.30870007. Disponível em: $<$ http://www.scielo.br/pdf/ea/v30n87/0103-4014-ea30-87-00103.pdf>. Acesso em: 14 mar. 2017.

[7]. LACHTIM, Sheila Aparecida Ferreira; SOARES, Cássia Baldini. Valores atribuídos ao trabalho e expectativa de futuro: como os jovens se posicionam?. Trabalho, Educação e Saúde, [s.I.], v. 9, n. 2, p.277-294, out. 2011. FapUNIFESP (SciELO). http://dx.doi.org/10.1590/s1981-

$77462011000200007 . \quad$ Disponível em: <http://www.scielo.br/pdf/tes/v9n2/07.pdf>. Acesso em: 26 fev. 2017.

[8]. LOBATO, C. R. P. S. O significado do trabalho para o adulto jovem no mundo do provisório. Revista de Psicologia da UNC, v. 1, n. 2, p. 44-53, 2004. Disponível em: <http://xa.yimg.com/kq/groups/19590703/2083563 168/name/o+significado+do+trabalho.pdf > . Acesso em: 27 fev. 2017.
[9]. MINAYO, Maria Cecília de Souza (Org.). Pesquisa Social: Teoria, método e criatividade. 18. ed. Petrópolis: Vozes, 2001.

[10]. SÁ, P. F.; LEMOS, A. H. C.; CAVAZOTTE, F. S. C. N. Expectativas de carreira na contemporaneidade: 0 que querem os jovens profissionais?. Revista ADM.MADE, v. 18, n. 2, p. 827, $2014 . \quad$ Disponível em: <http://www.spell.org.br/documentos/download/331 73>. Acesso em: 28 fev. 2017.

[11]. SILVA, J.g.; SOBROSA, G.m.r.; DALAGASPERINA, P.. Novas Gerações no Mercado de Trabalho. Mudanças - Psicologia da Saúde, [s.I.], v. 24, n. 2, p.31-38, 30 dez. 2016. Instituto Metodista de Ensino Superior. http://dx.doi.org/10.15603/2176-

1019/mud.v24n2p31-38. Disponível em: <https://www.metodista.br/revistas/revistasims/index.php/MUD/article/download/6537/5539>. Acesso em: 27 fev. 2017.

[12]. TEIXEIRA, Marco Antônio Pereira. A experiência de transição entre a universidade e o mercado de trabalho na adultez jovem. 2002. $168 \mathrm{f}$. Tese (Doutorado) - Curso de Pós-graduação em Psicologia do Desenvolvimento, Instituto de Psicologia, Universidade Federal do Rio Grande do Sul, Porto Alegre, 2002. Disponível em: <http://www.lume.ufrgs.br/bitstream/handle/10183/ 4007/000346602. pdf?sequence=1 >. Acesso em: 13 fev. 2017. 


$$
\text { Alutary }
$$




\section{LUIZ CLÁUDIO DE LIMA (ORGANIZADOR)}

PhD em Administração e Professor Titular da Universidade FUMEC. Professor do IBMEC Belo Horizonte, Empresário e Consultor Organizacional

\section{ADRIANA COSTA CAVALCANTI}

Doutoranda em Ciências da Informação pela Universidade Fernando Pessoa, Porto-Portugal. Mestre em Administração de Empresas pela Universidade de Fortaleza-UNIFOR. Graduada em Administração com especialidade em Comércio Exterior. Bolsista FUNCAP no período de Mestrado. Participante do Núcleo Estruturante da Faculdade de Baturité (NDE) e do NDE de marketing da Faculdade Tecnológica do Nordeste-FATENE. Pesquisadora e Professora de Administração e Marketing

\section{AMANDA RAQUEL DE FRANÇA FILGUEIRAS D’AMORIM}

Doutoranda em Information Sciences pela UFP (Porto). Mestra em Administração- State Labor and Society. Especialista em Gestão de Pessoas pela Universidade Cândido Mendes (RJ) em andamento. Graduada em Administração - UFPB. Atuação e experiência em Ensino, Pesquisa e Extensão. Pesquisadora/colaboradora de projetos do CNPq -Pesquisa e Extensão. Capacitação em Projetos - PMDome (PMI) São Paulo (Brasil). Pesquisadora bolsista premiada: Jovem Pesquisadora. Financiamento CNPq. Ministrante de Cursos de Capacitação para servidores e colaboradores em empresas públicas e privadas. Experiência em EAD -IFPBGraduação e Especialização- Administração Pública. Ex-professora da Universidade Federal da Paraíba- UFPB - Campus João Pessoa-PB (Substituta). Assessorou na Expansão e Relações Internacionais de Programas de MBA`s e Mestrados. Atuação por 05 anos em empresas do varejo e Assessora e Consultora Administrativa/ Gestão em empresas/ Pessoas. Docente em Pós-Graduações - (MBA`s).

\section{ANA PAULA FERNANDES}

Técnica Contábil (2009) pelo Instituto Estadual de Educação Mãe de Deus, Técnica em Secretariado ( 2012), Bacharel em Administração (2018) pelo Instituto Federal Farroupilha Campus Júlio de Castilhos. Atuou em empresa voltada ao Agronegócio familiar para implementação de softwares e atualmente é assistente comercial em empresa de grãos e insumos agrícolas.

\section{ANDRÉ FAES OLIVEIRA}

Graduando Engenharia de Produção na Universidade Estadual do Norte Fluminense (UENF).

\section{ANGÉLICA CARINA DE ANDRADE FARIAS}

Graduada em Administração pela Universidade Federal de Campina Grande. MBA em Gestão de Pessoas pela Faculdade Anglo Americano. Mestra em Administração pela Universidade Federal da Paraíba, na área de Gestão Estratégica. Experiência por nove anos nas áreas de Departamento Pessoal, Recursos Humanos, Gestão de equipes, Gestão e elaboração de Projetos, Desenvolvimento de líderes (coach) bem como todos os processos relacionados ao $\mathrm{RH}$. Atualmente professora universitária (UFCG) e das Faculdades Rebouças (CG) e Unifacisa (CG). 


\section{BARBARA GIOVANNINI}

Graduada em Gestão de Empresas pela FCA Unicamp

\section{BRANCA REGINA CANTISANO DOS SANTOS E SILVA RISCADO TERRA}

Possui graduação em Engenharia Civil pela Universidade do Estado do Rio de Janeiro - UERJ (1977), mestrado em Engenharia Civil pela Universidade Federal do Rio de Janeiro UFRJ/COPPE (1988), doutorado sanduíche pela State University of New York at Purchase SUNY (1998) e doutorado em Engenharia de Produção pela Universidade Federal do Rio de Janeiro - UFRJ/COPPE (1999). Atualmente é professora da UERJ, Visiting Professor da SUNY at Stony Brook onde concluiu o pós-doutorado em engenharia em 2006, além da Faculdade de Economia e Administração - FEA da Universidade de São Paulo - USP (2007). É líder dos grupos de pesquisa do Conselho Nacional de Desenvolvimento Científico e Tecnológico CNPq Inovação e Sociedade e Inovação na Gestão Pública.

\section{CAMILA COLETTO}

Possui Graduação em administração (2004), Mestrado em Administração (2008) e Licenciatura em Educação profissional e tecnológica (2011), pela Universidade Federal de Santa Maria. Atualmente atua como docente no Instituto Federal Farroupilha, Campus Julio de Castilhos, com experiência na área de administração, principalmente nos seguintes temas/áreas: Gestão de pessoas, empreendedorismo, planejamento estratégico. Atua/atuou em diferentes níveis de ensino: ensino médio, subsequente, tecnólogo, superior, especialização e EAD, coordenadora do curso Bacharelado em Administração.

\section{CARLOS RUBENS MOREIRA DA SILVA}

Doutorando em Ciências da Informação pela Universidade Fernando Pessoa - UFP, Porto, Portugal. Mestre em Políticas Públicas pela Universidade Estadual do Ceará. Graduado em Economia pela Universidade Federal do Ceará (1990). Auditor de Controle Interno da Controladoria e Ouvidoria Geral do Estado do Ceará - CGE. Possui experiência na área de Controladoria, com ênfase em Controle Interno e Acompanhamento da Gestão.

\section{CHRISTINA SOUTO NICOLAU DAS NEVES}

Bacharel em Administração Pública /UFF; MBA em Gestão de Recursos Humanos /UFF; Tecnóloga em Gestão de Recursos Humanos.

\section{DANTE FLÁVIO OLIVEIRA PASSOS}

Doutorando de pesquisa interdisciplinar em economia de empresas pela Università degli Stuti Internazionale di Roma-Itália, Mestre em Engenharia de Produção pela Universidade Federal da Paraíba, graduado em Administração pela Universidade Tiradentes, Professor efetivo na Universidade Estadual da Paraíba campus VII na cidade de Patos-PB, no curso de Administração, nas disciplinas de Administração da Produção I e II. Pesquisador na área do Comportamento do consumidor, Marketing da felicidade, qualidade, transporte público, estratégia competitiva em massa crítica. 


\section{DENNIS HANSON}

Professor DE na Faculdade de Engenharia da UFMS. Ex-professor DE no curso de Comunicação Visual do IFSULDEMINAS. Doutorando no programa de Meio Ambiente e Desenvolvimento Regional na Universidade Anhanguera Uniderp de Campo Grande, MS, com trabalho em andamento sobre desenvolvimento de produtos na indústria da hospitalidade. Mestrado em Engenharia de Produção com ênfase em Sistemas de Gestão com pesquisa em marketing pela Universidade Federal Fluminense (2004). Possui graduação em Comunicação pela PUC-Rio e em Administração pela Universidade Paulista São José. Tem formação técnica na área de artes visuais na Escola de Artes Visuais do Rio de Janeiro. Tem longa experiência nas áreas de Design e Gestão Empresarial. Suas áreas de interesse são: estratégia empresarial, gestão estratégica, gestão de negócios, inovação, marketing, design, design thinking, design estratégico, gestão estratégica da comunicação. É autor de artigos e trabalhos em suas áreas de interesse, com diversos trabalhos publicados. Foi sócio-diretor executivo de diversas empresas como DHC Arte \& Design (Consultoria de Marketing e Design), DR+ Comunicação Dirigida, i9Brasil (Consultoria de Marketing Direto). Foi gerente de marketing e de obras no Ponto Frio - Globex SA e gerente de cultura do Oi Futuro.

\section{DÉRCIO SANTIAGO DA SILVA JUNIOR}

Engenheiro Mecânico pela Universidade Gama Filho (1989) e Advogado pela Faculdade Moraes Junior-Mackenzie Rio (2009), mestre em Administração pelo COPPEAD/UFRJ (1996) e Doutor em Saúde Coletiva (ênfase em gestão de saúde) pelo Instituto de Medicina Social IMS/UERJ (2003). Atualmente é Professor Adjunto no Departamento de Engenharia Industrial (DEIN) da Faculdade de Engenharia (FEN) da Universidade do Estado do Rio de Janeiro (UERJ), Coordenador de Serviços Técnicos no Hospital Universitário Pedro Ernesto da UERJ e Consultor Ad-Hoc.

\section{DIEGO ALEXSANDER MOREIRA PIRES}

Graduando Engenharia de Produção na Universidade Estadual do Norte Fluminense (UENF).

\section{EDUARDA DE BIASE FERRARI GOMES}

Graduada em Administração de Empresas pela Universidade Vila Velha (2003) e Mestre em Administração pela Ufes (2008). Atuou como docente e como coordenadora adjunta do curso de Administração na Faculdade São Geraldo e como Professora Substituta do Departamento de Administração da Ufes. Possui experiência na área de Administração, com ênfase em Gestão de Pessoas. Atualmente é professora efetiva do IFES - Campus Guarapari, atuando como docente dos cursos de graduação e técnico e como Coordenadora do Curso Técnico de Administração.

\section{ERIC DAVID COHEN}

Professor do Mestrado em Administração do Centro Universitário Alves Faria

\section{ÉRIKA CAMPOS MARINHO DE G. PIRES}

Possui Graduação em Administração, pela FOCCA. Especialização em Psicopedagogia, pela UPE. Especialização em Finanças e Controladoria, pela Faveni. Mestrado em Administração. Atualmente é Professora na Universidade Estadual da Paraíba, Campus VII - Patos e Professora na Escola Técnica Estadual Prof. Célia Siqueira em PE. 


\section{EUNICE FERREIRA}

Possui graduação em Ciência Econômica pela Universidade Federal de Campina Grande (1995) e mestrado em Economia Rural [C. Grande] pela Universidade Federal da Paraíba (2000). Atualmente é professora efetiva da Universidade Estadual da Paraíba. Tem experiência na área de Economia, com ênfase em Economia, atuando principalmente nos seguintes temas: trabalho feminino, desenvolvimento econômico local e sustentável.

\section{EVANDRO LA MACCHIA}

Engenheiro Mecânico, mestre em Engenharia de Produção e doutor em Engenharia - Sistemas de Gestão Sustentáveis. Consultor em desenvolvimento de negócios, fusões, aquisições e desinvestimentos de ativos e empresas no Brasil, América Latina, Asia do Pacífico, Oceania e Europa nos segmentos de E\&P, Refino, Distribuição, Gás Natural e Energia Elétrica. Exerceu funções executivas na Shell e Portobello e de consultoria sênior na Petrobras. Coordenador e professor de cursos de especialização e pós-graduação na indústria de Petróleo e professor visitante em curso de Mestrado em Gestão e Direito do Petróleo.

\section{FERNANDO DE OLIVEIRA VIEIRA}

Graduado em Administração pela Faculdade de Ciências Contábeis e Administrativas Moraes Júnior (1990); mestrado e doutorado em Educação pela Universidade Metodista de Piracicaba (1999 e 2003). Pós-doutorado no Programa de Pós-graduação em Psicologia Social, do Trabalho e das Organizações, no Instituto de Psicologia da UnB - Universidade de Brasília (2014). Atualmente, coordena o ESCOPO - Grupo de Estudos dos Coletivos de Trabalho e das Práticas Organizacionais - www.escopo.uff.br. É pesquisador e Professor Associado do Departamento de Administração da Universidade Federal Fluminense.

\section{FLAVIO MUDESTO}

Graduado em Engenharia de Produção pela Universidade Vila Velha (2012). Especialista em Gestão Estratégica de Negócios pelo Ifes (2016). Possui experiência na área de Manutenção Industrial, com ênfase em Eletricidade.

\section{GEÓRGIA GONÇALVES}

Técnica em radiologia formada no ano 2000 pela Escola técnica federal de Santa Catarina, bacharel em administração formada em 2016 pela Uniasselvi, especialista na área de exames de mamografia, trabalho há 18 anos na área de saúde atualmente como coordenadora e supervisora de qualidade na empresa Sonitec diagnóstico por imagem em Florianópolis, Santa Catarina.

\section{GETULIO DE AZEVEDO RAMOS JUNIOR}

Possui graduação em Engenharia Metalúrgica pela Universidade Federal de Minas Gerais (1983). Atualmente é Tecnologista do Centro de Desenvolvimento da Tecnologia Nuclear. Exerce a função de Chefe do Serviço de Gestão de Pessoas. Mestre em Sistema de Gestão pela Universidade Federal Fluminense (2017).

\section{HELENNA BARRETO MAGDALENA}

Nome: Helenna Barreto Magdalena; 23 anos; estudante de Psicologia da Universidade Veiga de Almeida nono período; Estagiária de Psicologia clínica na linha Psicanalítica no Serviço de Psicologia Aplicada da Universidade Veiga de Almeida. 


\section{HELIO ALVES DA CRUZ}

Mestre em Administração. Administrador. MBA em Coaching. MBA em Gestão Empresarial. Especialista em Ensino a Distância. Experiência profissional-organizacional de 15 anos em agroindústria de grande porte em processos administrativos, logística e produção. Desde 2008, professor universitário, consultor, palestrante, treinamentos e cursos; Autor de dezenas de artigos científicos em eventos e revistas acadêmicas. Autor do Livro Entre o Oriente e o Ocidente: Representações de Lideranças - Uma Análise Organizacional, do Estilo de Vida e a Visão de Mundo (Novas Edições Acadêmicas, 2016). Empreendedor.

\section{HENRIQUE MARTINS GALVAO}

Possui graduação em Administração de Empresas, pós-graduação em Administração Contábil e Financeira, Mestrado em Administração pela PUC-SP e doutorado em Administração pela FEA-USP. Possui experiência profissional em empresas dos setores da indústria e de serviços. Atualmente, exerce as funções de coordenador no Centro Universitário Teresa D'Ávila UNIFATEA (Salesianas) e docente permanente no Programa de Pós-Graduação Mestrado Profissional em Design, Inovação e Tecnologia do UNIFATEA e docente na Faculdade de Tecnologia do Estado de São Paulo - FATEC.

\section{HILQUIAS GABRIEL CAPUCHO}

Formado em Gestão empresarial (Fatec-Cruzeiro), possui experiencia profissional em empresa do setor da industria automotiva. Atualmente é empreendedor no setor da educação esportiva, empresa onde é sócio proprietário e atua como diretor administrativo.

\section{JULIANA CRISTINA DA SILVA DE FRANÇA BARBOZA}

Graduada em Administração pelo Centro Universitário da Cidade (Univercidade) e pósgraduada em Gestão em Administração Pública pela Universidade Federal Fluminense (UFF). É servidora pública desde 2011, tendo atuado como chefe substituta da Divisão de Contratos da Pró-Reitoria de Administração da UFF. Atualmente, integra o setor financeiro do Instituto de Química da Universidade Federal do Rio de Janeiro (UFRJ).

\section{JULIO CÉSAR DE FARIA ALVIM WASSERMAN}

Oceanógrafo pela Universidade do Estado do Rio de Janeiro (1985), o pesquisador concluiu o doutorado em Oceanografia Química pela Université de Bordeaux I (França) em 1990 e um Pós-doutorado em Química Ambiental na Université de Pau et des Pays de l'Adour (França) em 1999. Atualmente é Professor Titular da Universidade Federal Fluminense e Coordenador da Rede UFF de Meio Ambiente e Desenvolvimento Sustentável, onde tem trabalhado com pesquisa aplicada a problemas ambientais e particularmente focado na dinâmica de poluentes. No escopo da REMADS-UFF tem coordenado equipes para realizar estudos de impacto ambiental, monitoramentos ambientais, e tem atuado junto a empresas e sociedade civil, buscando novas tecnologias para a solução de impactos ambientais e sustentabilidade. Publicou 85 artigos em periódicos especializados e mais de 200 trabalhos em anais de eventos. Possui 20 capítulos de livros e 4 livros editados. Possui 1 produto tecnológico registrado. Orientou 26 dissertações de mestrado e 7 teses de doutorado, além de ter orientado 24 trabalhos de iniciação científica. Atua na área de Oceanografia Química, Química de Poluentes, Gestão Ambiental e Gerenciamento Costeiro. Tem larga experiência na dinâmica de metais pesados, mas também vem estudando outros tipos de poluentes aquáticos, atmosféricos e de solos. Desde o final dos anos 1990, vem trabalhando com gestão ambiental em uma perspectiva interdisciplinar, interagindo com pesquisadores de diversas áreas, incluindo médicos, engenheiros, geógrafos e sociólogos. 


\section{JUNIO VASCONCELOS SOARES}

Mestre em Sistemas de Gestão pela UFF - RJ (2017). Especialista em Gestão de Recursos Humanos pela UCAM - RJ (2012) e em Planejamento, Implementação e Gestão da Educação à Distância pela UFF - RJ (2015). Graduado em Administração pela UNIFAMINAS - MG (2011); e em Teologia pela FABAPAR - PR (2017). Cursando Graduação em Formação Pedagógica em Matemática (R2) para não Licenciados na Universidade Cruzeiro do Sul (previsão de conclusão: fev/2019). É coordenador do curso superior em Administração da UNIFAMINAS em Muriaé - MG, onde também atua como docente. Atua ainda como docente no curso superior de administração e no curso técnico de administração (EAD) do IF Sudeste campus Muriaé MG.

\section{JUSSARA PALMEIRA DOS SANTOS}

Graduada em Administração pela Universidade Federal de Campina Grande - UFCG

\section{KATIA DA MOTTA FRONQUETTI}

Técnica em Agropecuária (2011), Bacharel em Administração (2017), pelo Instituto Federal Farroupilha Campus Júlio de Castilhos. Atualmente atua na área Administrativa no setor de transportes.

\section{LEANDRO SOUZA MOURA}

Professor do Departamento de Turismo da Universidade do Estado do Rio de Janeiro (UERJ), Doutor em Administração pela Escola Brasileira de Administração Pública e de Empresas da Fundação Getúlio Vargas (EBAPE/FGV), Mestre em Administração Pública pela Escola Brasileira de Administração Pública e de Empresas da Fundação Getúlio Vargas (EBAPE/FGV) e Bacharel em Ciências Econômicas pela Pontifícia Universidade Católica de São Paulo (PUC/SP).

\section{LUANA CAMARGO CARRILHO}

Estudante de Psicologia da Universidade Veiga de Almeida, nono período; Estagiária de Psicologia Clínica no Serviço de Psicologia Aplicada 2016-2018; Estagiária do DEGASE 2018; Monitoria da disciplina teorias comportamentais 2016; Monitoria da disciplina Psicologia e Profissão 2017.

\section{LUCIANI VIEIRA GOMES ALVARELI}

Possui Graduação em Letras com habilitação em Português e Inglês e Respectivas Literaturas (UNIFATEA), Mestrado e Doutorado em Linguística Aplicada e Estudos da Linguagem (PUCSP) .É Pró-Reitora Acadêmica do Centro Universitário Teresa D'Ávila - UNIFATEA, sendo docente permanente no Mestrado em Design, Inovação e Tecnologia - PPG-DTI e no Curso de Graduação em Letras. Professora Associada de Língua Inglesa do CEETPS - FATEC Cruzeiro - Prof. Waldomiro May - Cruzeiro - SP, sendo docente nos Cursos de Gestão Empresarial e Gestão da Produção Industrial. Atua principalmente nos seguintes temas: educação e tecnologia, formação de professores, língua inglesa, orientação de trabalhos de conclusão de curso, metodologia da pesquisa. 


\section{LUCIENE LARANJEIRA DINIZ}

Professora da Universidade Federal da Paraíba- UFPB, sendo lotada no CCHSA em regime de Dedicação exclusiva. Mestra em Engenharia de Produção pela UFPB. Bacharela em Administração com linha de formação em Cooperativismo pela UFPB/CCHSA.

\section{MARCELO GONÇALVES DO AMARAL}

Graduado em Economia pela UFRJ, mestre e doutor em Engenharia de Produção pela COPPE/UFRJ, e tem pos doutorados pela USP e pela North Carolina State University. Atuou em diversas instituições como Centro de Pesquisas de Energia Elétrica (CEPEL), Federação das Indústrias do Estado do RJ (FIRJAN) e Centro de Tecnologia Mineral (CETEM). Foi empresário e desde 2006 é professor da Universidade Federal Fluminense. Desde 2008 lidera o Triple Helix Research Group Brazil (www.triple-helix.uff.br) e publicou mais de 50 trabalhos científicos. É membro do Comitê Executivo da Triple Helix Association (THA) e pesquisa em temas relacionados à gestão da inovação.

\section{MARCIA ASSUNÇÃO ALVES BARBOSA}

Bacharel em Turismo pela Universidade do Estado do Rio de Janeiro (UERJ). Estagiária por um ano na área de turismo receptivo em um dos maiores símbolos da cidade do Rio de Janeiro, o Cristo Redentor. Participação voluntária no projeto de iniciação científica: "Jogos Olímpicos na cidade do Rio de Janeiro: Propostas e subsídios para avaliação e gestão de impactos ambientais e sociais", orientado pela Prof. Dra. Clara Lemos de Carvalho e oferecido pela UERJ. Co-autora do artigo: "Impactos e legados de megaeventos esportivos: uma análise junto as empresas organizadoras de eventos no Rio de Janeiro", apresentado no XIII Encontro Nacional de Turismo de Base Local, realizado pela Universidade Federal de Juiz de Fora. Nível avançado de inglês e intermediário em francês e espanhol.

\section{MARIA DE LURDES COSTA DOMINGOS}

Possui graduação em psicologia, Universidade Federal do Rio de Janeiro (1996), especialização em Psicologia Clínica pela Federal do Rio de Janeiro (1996), especialização em Psicologia Clínica pela Pontifícia Universidade Católica do Rio de Janeiro (PUC-RJ); mestrado em Psicossociologia de Comunidades e Ecologia Social pela Universidade Federal do Rio de Janeiro (1999) e doutorado em Psicologia Social pela Universidade do Estado do Rio de Janeiro (2007). Atualmente é docente na Universidade Veiga de Almeida (UVA). Atua como professora permanente no Laboratório de Tecnologia, Gestão de Negócios e Meio Ambiente (LATEC-UFF). Tem experiência na área de Psicologia, com ênfase em Psicologia do Trabalho e Organizacional, atuando principalmente nos seguintes temas: globalização, responsabilidade social, sustentabilidade, risco, organizações de trabalho, confiança e capital social. do Rio de Janeiro Gv (PUC-RJ); mestrado em Psicossociologia de Comunidades e Ecologia Social pela Universidade Federal do Rio de Janeiro (1999) e doutorado em Psicologia Social pela Universidade do Estado do Rio de Janeiro (2007).

\section{MARIELZA BARBOSA ALVES}

Graduada em Administração pela UFPB com mestrado em Organização e Recursos Humanos pela UFPB. Professora de Gestão de Pessoas na UFCG ministrando as disciplinas Gestão de Pessoas I e II. 


\section{MATHEUS TOLEDO CUPERTINO}

Bacharel em Administração pelo Centro Universitário FAMINAS - UNIFAMINAS (2016) e pósgraduando MBA em Gestão Empreendedora pelo Instituto Federal de Educação, Ciência e Tecnologia do Sudeste de Minas Gerais - IF Sudeste MG (conclusão prevista para julho/2018).

\section{MAURICIO SOARES DO VALE}

Arquiteto e Urbanista pela Universidade Federal do Rio de Janeiro (UFRJ); Mestrado pelo Programa de Pós-graduação em Arquitetura (PROARQ/FAU/UFRJ); Pós graduação em Engenharia de Segurança do Trabalho pela Universidade Federal Fluminense (UFF); Pós graduação em Engenharia de Petróleo e Gás Natural pela Universidade Estadual do Rio de Janeiro (UERJ).

\section{MÁYRA GABRIEL DOS SANTOS}

MBA em Gestão Pela Qualidade Total no Latec-UFF. Pós-graduação em Gestão de Arquivos pela Universidade Federal de Santa Maria. Curso de Extensão em Empreendedorismo e Inovação da UFF/EAD. Graduação em Arquivologia pela Universidade Federal Fluminense. Atualmente é arquivista no setor de óleo e gás. Tem experiência na área de Ciência da Informação, com ênfase em Arquivologia.

\section{NEIDE LÚCIA DE 0. ALMEIDA}

Doutoranda em Sistemas de Gestão da Sustentabilidade, na Universidade Federal Fluminense (UFF), é Mestre em Sistemas de Gestão, com foco na área da Responsabilidade Social Corporativa. MBA em Gestão Pela Qualidade Total no Latec-UFF, é pós-graduada em Gestão Pública Municipal, em Especialização Planejamento, Implementação e Gestão de Educação a Distância e em Marketing. É graduada em Comunicação Social, sendo bacharel em Relações Públicas. Entre 2009 e 2011, foi bolsista do Sistema Universidade Aberta do Brasil/DED/CAPES/MEC; a partir de 2012 atuou como bolsista do CEDERJ, tendo a função de Tutora do Curso Empreendedorismo e Inovação da UFF/EAD. Novamente, em 2014, atuou pela UAB como Coordenadora de Tutoria do Curso Semipresencial de Extensão "A Escola e a Cidade: políticas públicas educacionais". Atualmente é docente no MBA Executivo do Departamento de Empreendedorismo e Gestão da UFF.

\section{ODAELSON ANTÔNIO CLEMENTINO DA SILVA}

Possui graduação em administração pela Universidade Federal da Paraíba (2002), é mestre em Engenharia de Produção pela Universidade Federal da Paraíba (2007). Atua no setor operacional da Companhia de Água e Esgoto da Paraíba, e como professor da Faculdade Maurício de Nassau João Pessoa - PB com vinculo desde 2011. Atua principalmente nos seguintes temas: Gestão da qualidade e administração de serviços.

\section{PATRÍCIA SOUZA LUZ FRITZ}

Bacharel em Administração pelo Centro Universitário FAMINAS 


\section{RAMON SCHNAYDER DE FRANÇA FILGUEIRAS D’AMORIM}

Mestrando do Programa de Pós-Graduação em Engenharia de Produção - PPGEP / UFPB. Possui Pós-Graduação em Gestão de Pessoas, pela Faculdade São Francisco da Paraíba FASP (João Pessoa/PB - 2011) e Graduação em Sistemas de Telecomunicações, pelo Instituto Federal de Educação, Ciência e Tecnologia da Paraíba - IFPB (João Pessoa/PB - 2006). Atualmente é Assistente em Administração da Universidade Federal da Paraíba - UFPB (desde 2008). Possui experiência na área de Administração, Comunicação, Informática, Telecomunicações e Música.

\section{RANDES DE FARIA ENES}

Possui 25 anos de experiência em empresas nacionais e multinacionais sendo suas últimas posições como Diretor de Relacionamento e Diretor de Marketing e Inovação no segmento de Cosméticos e Oil \& Gas. Exerce suas habilidades como consultor executivo, coach e palestrante nas principais empresas do país. Possui diversas reportagens e artigos nacionais e internacionais sobre Gestão Empresarial e Espiritualidade Corporativa. Recentemente lançou seu primeiro livro: Empresa Espiritualmente Dirigida. Mestre em Sistemas de Gestão pela Qualidade Total (UFF/RJ), possui três MBAs, sendo em Organizações e Estratégia (UFF/RJ), Gestão de Negócios e Projetos (ISCTE/Lisboa) e Marketing de Varejo (FGV). Há 11 anos atua como docente na FGV em Estratégia, Gestão, Pessoas, Marketing e Vendas nos Programas de MBA, Pós-ADM, CADEMP, In Company e On-line. Possui certificação em coaching pelo PBC ${ }^{\circledR}$ Institute, é membro da ICF Global (International Coaching Federation) e da ABPMP (Association of Business Process Management Professionals).

\section{RAPHAELA MOTA LACERDA}

Possui Graduação em Administração pela Universidade Estadual da Paraíba.

\section{RENATA PEREIRA GONÇALVES RIBEIRO}

Formada em Jornalismo pela Faculdade Hélio Alonso, Pós-Graduada em Administração pelo IBMEC e com Mestrado em Sistemas de Gestão e Qualidade pela Universidade Federal Fluminense. Atuou durante 10 anos como Gerente de Cursos voltados para executivos do setor de Petróleo e Gás e atualmente é Coordenadora de Planejamento e Gestão da Gerência de Certificação do IBP. Suas experiências estão calcadas no gerenciamento e implementação de projetos educacionais gestão de relacionamento, incluindo: clientes, colaboradores, parceiros, fornecedores, fomentos, gerenciamento de treinamentos, palestras, seminários, workshops, formaturas. Elaboração de programas customizados, em diferentes soluções educacionais. Atuação comercial com ampla carteira de clientes e foco na geração de valor, através de uma visão ampla de excelência. Liderança e formação de equipes.

\section{RICARDO MIYASHITA}

Professor Associado da Faculdade de Engenharia da Universidade do Estado do Rio de Janeiro. É graduado em Engenharia de Produção pela Escola Politécnica da USP, mestre em Administração de Empresas pelo Coppead/UFRJ e doutor em Engenharia de Produção pela Coppe/UFRJ. Tem como principais linhas de pesquisa Design Thinking, Gestão da Inovação, Projeto de Produtos e Serviços, Simulação, Gestão da Saúde e Jogos de Empresa. 


\section{SAMARA PASSIG}

Bacharela em Administração - Centro Universitário Leonardo da Vinci - Uniasselvi/SC. Gerente de Atenção Básica e Diretora de Saúde na Secretaria de Saúde de Santo Amaro da Imperatriz de 2010 a 2015. Atualmente atua na Secretaria de Saúde do Estado de Santa Catarina.

\section{SHEILA SERAFIM DA SILVA}

Graduada e mestre pela Universidade Federal Fluminense, onde desenvolveu atividades de ensino, pesquisa e extensão na área de Administração. É doutoranda em Administração pela USP; assistente docente nos programas da FIA de Administração e Negócios; orientadora no programa PNAP de especialização em Gestão Pública da UFF; participante do grupo de pesquisa Laboratório de Gestão Organizacional Simulada (LAGOS-UFF) e pesquisa os temas educação executiva, metodologias ativas (em especial, jogo de empresas), Soft Skills e educação híbrida.

\section{SIMONE COSTA SILVA}

Possui Graduação em Administração pela UFRN (2004) e Mestrado em Administração com foco na área Organização e Recursos Humanos, pela UFPB (2011). Atualmente é professora da Universidade Estadual da Paraíba (UEPB), Campus VII, desde Abril de 2012 e doutoranda na Universidade Federal de Pernambuco, no Programa de Pós-graduação em Administração (PROPAD), linha de pesquisa Gestão Organizacional.

\section{SIMONE DE SOUZA CHRISTO}

Graduada em Administração de Empresas pela Facastelo (2004), Especialista em Gestão Empresarial pela São Camilo (2006) e Mestre em Administração pela Fucape (2009). Atuou como docente e como Coordenadora do Curso de Ciências Contábeis da Universidade de Vila Velha (2006 - 2010). Possui experiência na área de Administração, com ênfase em Contabilidade e Finanças. Atualmente é Professora efetiva do IFES - Campus Guarapari, atuando como Docente do Curso de Bacharelado em Administração e do Curso Técnico em Administração.

\section{SIOMARA CRISTINA BROCH}

Possui graduação em Engenharia Química (1994) e Licenciatura em Matemática (2000) pela Universidade Federal de Santa Maria (UFSM). É especialista em Engenharia de Segurança no Trabalho (1996 - UFSM) e em Estatística e Modelagem Quantitativa (2006 - UFSM), mestre em Engenharia de Produção (1998 - UFSM) e doutora em Estatística e Experimentação Agropecuária pela Universidade Federal de Lavras (UFLA) (2013). Atua como docente do Ensino Básico, Técnico e Tecnológico do Instituto Federal Farroupilha campus Júlio de Castilhos. Tem experiência docente na área de educação matemática, estatística, matemática e segurança do trabalho. Atua em pesquisa e extensão na área de Probabilidade e Estatística Aplicadas e em Educação Matemática.

\section{THAIRO TARGINO LEOPOLDINO}

Graduado em Administração de Empresas pela Universidade Federal de Campina Grande UFCG e pós-graduado em MBA em Gestão e Auditoria Hospitalar pela Faculdade Redentor RJ. 
Graduanda em Psicologia pela Universidade Veiga de Almeida (UVA). Atuou como monitora em disciplinas de Estágios Básicos e como estagiária clínica no Serviço de Psicologia Aplicada (SPA). Atualmente, dedica-se ao trabalho junto a equipe de Orientação Profissional e participa como aluna-ouvinte na disciplina de "Trabalho, Subjetividade e Contemporaneidade" do Mestrado de Administração da Universidade Federal Fluminense (UFF). Interessa-se pelos temas de Análise do Comportamento, Adolescência e Carreira.

\section{THIAGO COUTO LAGE}

Possui graduação em Ciências Contábeis pela Universidade Estácio de Sá (2011), graduação em Administração pela Universidade Estácio de Sá (2009) e Mestrado em Ciências Contábeis pela Universidade do Estado do Rio de Janeiro (2016). Atualmente é professor universitário da Faculdade São José e Auditor - Auditoria Geral do Estado Rio de Janeiro. Tem experiência na área de Administração, com ênfase em Ciências Contábeis.

\section{VIRGÍNIA DE PAULA BATISTA CARVALHO}

Graduada em Administração pelo Centro Universitário Newton Paiva (1994), especialista em Administração Pública pela Fundação João Pinheiro/MG. Mestre em Economia Empresarial pela Universidade Cândido Mendes/RJ, atuou em diversas Secretarias do Estado de Minas Gerais como Assessora, Diretora e Superintendente e como gerente administrativa da Secretaria Municipal de Educação de Guarapari. Desde 2003, vem lecionando em faculdades como Fipag, FASB, FACTEF, FANAN, Estácio de Sá, INED e Pitágoras. Na Faculdade Pitágoras, além de atuar como professora, coordenou o Núcleo de Pós-Graduação e os Cursos Superiores de Tecnologia e de Comunicação Social. Atualmente leciona no Instituto Federal do Espírito Santo - IFES - Campus Guarapari/ES como professora efetiva dos Cursos de PósGraduação, Graduação e Técnicos em Administração nas modalidades presencial e EaD, além de exercer a função de Coordenadora Geral de Ensino do campus Guarapari.

\section{WALDIR VIANA DAS NEVES JUNIOR}

Mestre em Sistemas de Gestão pela Qualidade Total na UFF/LATEC; MBA Executivo em Saúde no COPPEAD/UFRJ; Pós-graduado em Geriatria e Gerontologia / UFF; Pós-graduado em Administração Hospitalar pela Faculdade São Camilo RJ; Especialista com estudos de Extensão em Gestão em Saúde pela JOHNS HOPKINS UNIVERSITY -USA. Atua como Analista em Gestão de Saúde, no Hospital Universitário Antônio Pedro (HUAP) em Niterói, no Setor de Regulação e Avaliação em Saúde. 
Agência Brasileira do ISBN ISBN 978-85-7042-004-6

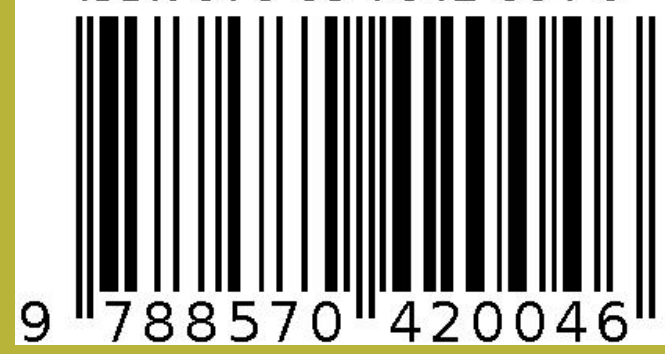

